

\section{DISCLAIMER}

This report was prepared as an account of work sponsored by an agency of the United States Government. Neither the United States Government nor any agency Thereof, nor any of their employees, makes any warranty, express or implied, or assumes any legal liability or responsibility for the accuracy, completeness, or usefulness of any information, apparatus, product, or process disclosed, or represents that its use would not infringe privately owned rights. Reference herein to any specific commercial product, process, or service by trade name, trademark, manufacturer, or otherwise does not necessarily constitute or imply its endorsement, recommendation, or favoring by the United States Government or any agency thereof. The views and opinions of authors expressed herein do not necessarily state or reflect those of the United States Government or any agency thereof. 


\section{DISCLAIMER}

Portions of this document may be illegible in electronic image products. Images are produced from the best available original document. 


\title{
SOLAR HEATING AND COOLING DEMONSTRATION
}

\section{PROJECT SUMMARIES}

\author{
MAY 1978
}

\section{U.S. DEPARTMENT OF ENERGY \\ ASSISTANT SECRETARY FOR CONSERVATION \\ AND SOLAR APPLICATIONS \\ DIVISION OF SOLAR APPLICATIONS \\ WASHINGTON, D.C. 20545}

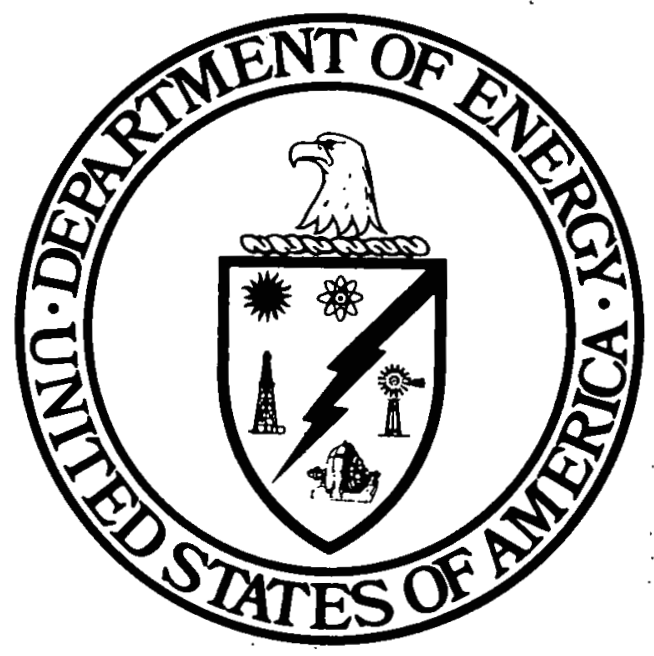

DISTRIBUTION OF THIS DOCUMENT IS UNLIMITED 


\section{NOTICE}

This report was prepared as an account of work sponsored by the United States Government. Neither the United States nor the United States Department of Energy, nor any of their employees, makes any warranty, express or implied, or assumes any legal liability or responsibility for the accuracy, completeness, or usefulness of any information, apparatus, product, or process disclosed, or represents that its use would not infringe privately owned rights. Reference herein to any specific commercial product, process, or service by trade name, mark, manufacturer, or otherwise, does not necessarily constitute or imply its endorsement, recommendation, or favoring by the United States Government or any agency thereof. The views and opinions of authors expressed herein do not necessarily state or reflect those of the United States Government or any agency thereof.

For sale by the Superintendent of Documents, U.S. Government Printing Office

Washington, D.C. 20402

Stock No. 061-000-00082-8 
TABLE OF CONTENTS

\section{FOREWORD}

INTRODUCTION

SECTION I Commercial Demonstration Program - Non-Federal Buildings

Map . . . . . . . . . . . . . . . . . . . . . . . . . . . . . . . . . . . . I-i

Index . . . . . . . . . . . . . . . . . . . . . . . . . . . . . . . . . . . I-ii

Project Summaries . . . . . . . . . . . . . . . . . . . . . . . . . . . . . . . . . I l

SECTION II Commercial Demonstration Program - Federal Buildings

Map . . . . . . . . . . . . . . . . . . . . . . . . . . . . . . . . Il-i

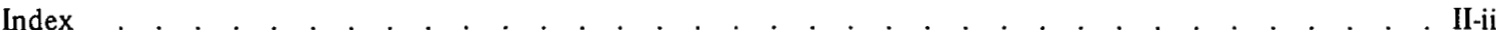

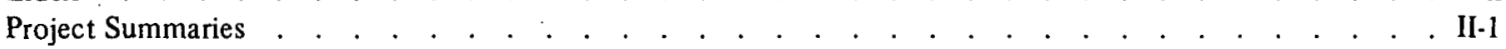

SECTION III Residential Demonstration Program - Federal Buildings

Map . . . . . . . . . . . . . . . III-1

Index . . . . . . . . . . . . . . . . . . . . . . . . . . . . . . . . . . . . . III-ii

Project Summaries _. . . . . . . . . . . . . . . . . . . . . . . . . III-

SECTION IV Residential Demonstration Program - Non-Federal Buildings

Map . . . . . . . . . IV-i

Index . . . . . . . . . . . . . . . . . . . . . . . . . . . . . . . . . . . . IV-1 
THIS PAGE

\section{WAS INTENTIONALLY LEFT BLANK}




\section{FOREWORD}

The National Program for Solar Heating and Cooling of Buildings, directed by The Department of Energy (DOE), responds to the Solar Heating and Cooling Demonstration Act of 1974 (P.L. 93-409, September 3, 1974). This Act calls for programs to develop, demonstrate, and promote the use of solar heating and cooling systems. The role of the Federal Government is to stimulate the use of solar heating and cooling equipment and to assist industry with the development of technology and the demonstration of systems.

The Federal program includes demonstrations of heating and/or combined heating and cooling systems for residential and commercial buildings. A comprehensive discussion of this program is contained in ERDA Report 76-6, dated November 1976. The report is being updated and will be redesignated DOE/CS-0007. Early solar system development relied heavily on the utilization of readily available, although not necessarily efficient, equipment with advances in technology being incorporated as they became available. The new technology being advanced by this program is directed at improving performance and reliability and reducing the cost of component and system procurement and operation. The schedule for this program following the Congressional directive in P.L. 93-409: "(b) . . to provide for the demonstration within a three-year period of the practical use of solar heating technology and to provide for the development and demonstration within a five-year period of the practical use of combined heating and cooling technology."

This report is one of two documents which contain summaries of projects that were funded by ERDA/DOE through fiscal year 1977 and conducted under the National Program for Solar Heating and Cooling of Buildings. The two documents are as follows.

\section{DOE/CS-0009 SOLAR HEATING AND COOLING DEMONSTRATION PROJECT SUMMARIES}

This document presents brief descriptive overviews of the design and operating characteristics of all commercial and Federal residential solar heating and cooling systems and of the structures themselves. Also included are available pictures of the buildings and simplified solar system diagrams. A list of non-Federal residential installations is provided.

\section{DOE/CS-0010 SOLAR HEATING AND COOLING RESEARCH AND DEVELOPMENT PROJECT SUMMARIES}

This document describes the Conservation and Solar Applications Solar Heating and Cooling Research and Development Program. It summarizes the research and development program and the projects it presently supports for further development of collectors, thermal energy storage, heat pumps and heat exchangers, solar cooling, and systems and controls. The report has two parts, an introduction and a series of project descriptions. The introduction describes the evolution of the R\&D program and outlines the present program. The second part of the report describes R\&D projects. It includes a list and summary information for all current $R \& D$ projects.

\section{NOTE:}

The information contained herein represents current plans as of November 1, 1977, and as such, is subject to change. Errors or omissions should be brought to the attention of the Demonstration Branch, Division of Solar Applications. 


\section{INTRODUCTION}

\section{SOLAR HEATING AND COOLING DEMONSTRATION PROJECT SUMMARIES}

The demonstration program includes commercial and residential-type buildings sponsored by DOE, alone, or jointly with other Federal agencies, city and state governments, and private agencies. The commercial projects include a wide variety of building types, such as: office buildings, schools, fire stations, civic centers, factories, and libraries. Residential projects include both single and multifamily dwellings of various configurations.

Approximately 200 projects will be instrumented to measure the performance of the solar systems. Analysis of the collected data will provide definitive guides for design criteria and permit realistic economic assessment of various solar systems.

The demonstrations are discussed in four sections:

SECTION I Commercial Demonstration Program - Non-Federal Buildings

SECTION II Commercial Demonstration Program - Federal Buildings

SECTION III Residential Demonstration Program - Federal Buildings

SECTION IV Residential Demonstration Program - Non-Federal Buildings

Maps showing the locations (by state) of the buildings are provided at the beginning of each section, along with an index which identifies each project and page number for the corresponding descriptive information. A map depicting the distribution of all demonstration projects is included in this introduction. The comparable map from last year's publication is also shown to depict the increase in the number of projects. The contents of this document are based on information available as of November $1,1977$.

\section{SECTION I COMMERCIAL DEMONSTRATION PROGRAM NON-FEDERAL BUILDINGS}

DOE is responsible for the management of the commercial demonstrations in non-Federal buildings. These projects are selected primarily from responses to the Program Opportunity Notice (PON). This section contains data on:

- Four early proof-of-concept experiments started in 1974 by the National Science Foundation (NSF),

- Twenty-two projects initiated by NSF,

- Thirty-two projects from PON-1,

- Seventy-four projects from PON-2, and

- Fifty projects from the Hot Water Initiative.

\section{SECTION II COMMERCIAL DEMONSTRATION PROGRAM FEDERAL BUILDINGS}

DOE is also responsible for the management of this portion of the program. Projects are selected from proposals submitted by other Federal agencies. Participating agencies include Department of Defense, Government Services Administration, Tennessee Valley Authority, United States Postal Service, Department of the Interior, National Aeronautics and Space Administration, Veteran's Administration, Department of Justice, Treasury Department, and Department of Agriculture; descriptions of their commercial projects are contained in this section. 


\section{SECTION III RESIDENTIAL DEMONSTRATION PROGRAM}

FEDERAL BUILDINGS

The Department of Defense (DOD) manages this portion of the residential program. Projects are selected by DOD at various military installations throughout the United States.

\section{SECTION IV RESIDENTIAL DEMONSTRATION PROGRAM} NON.FEDERAL BUILDINGS.

The Department of Housing and Urban Development (HUD) manages this part of the residential program. Projects are selected from responses to Request for Grant Applications (RFGA) issued by HUD. This section contains only a list of the HUD projects showing state, location, owner/builder, building type, number of units, solar application, and solar manufacturer. HUD's Cycle 1 projects are described in their document Solar Heating and Cooling Demonstration Program: a Descriptive Summary of HUD Cycle 1 Solar Residential Projects (GPO \#023-000-00338-4). Cycle 2 descriptions are also available (GPO \#023-000-00389-9) and the document for the Cycle 3 description is currently being processed by GPO. 


\section{"Distribution OF SOLAR HEATING \& COOLING DEMONSTRATION PROJECTS COMMERCIAL AND RESIDENTIAL}

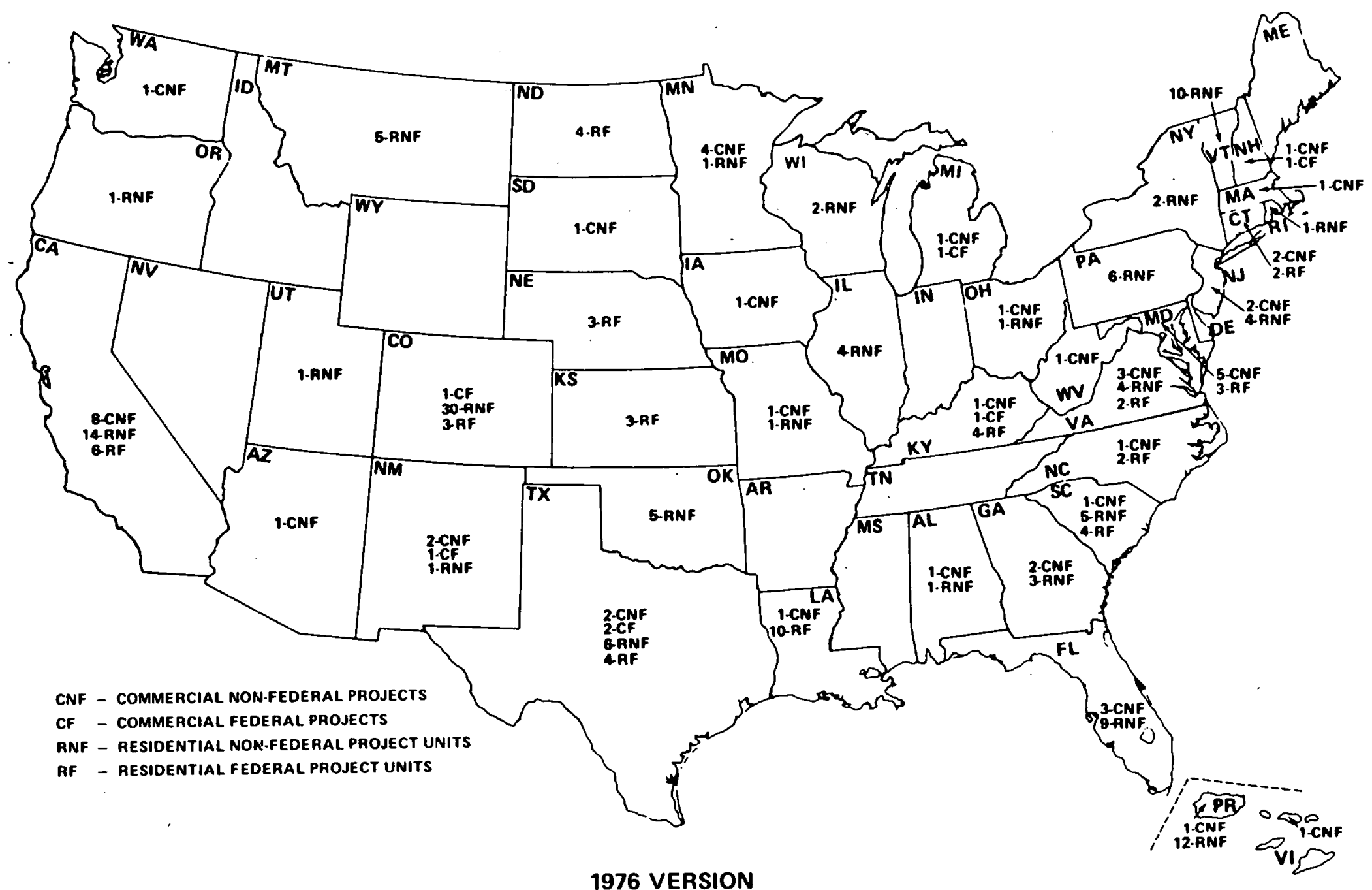




\section{DISTRIBUTION OF SOLAR HEATING \& COOLING DEMONSTRATION PROJECTS COMMERCIAL AND RESIDENTIAL}

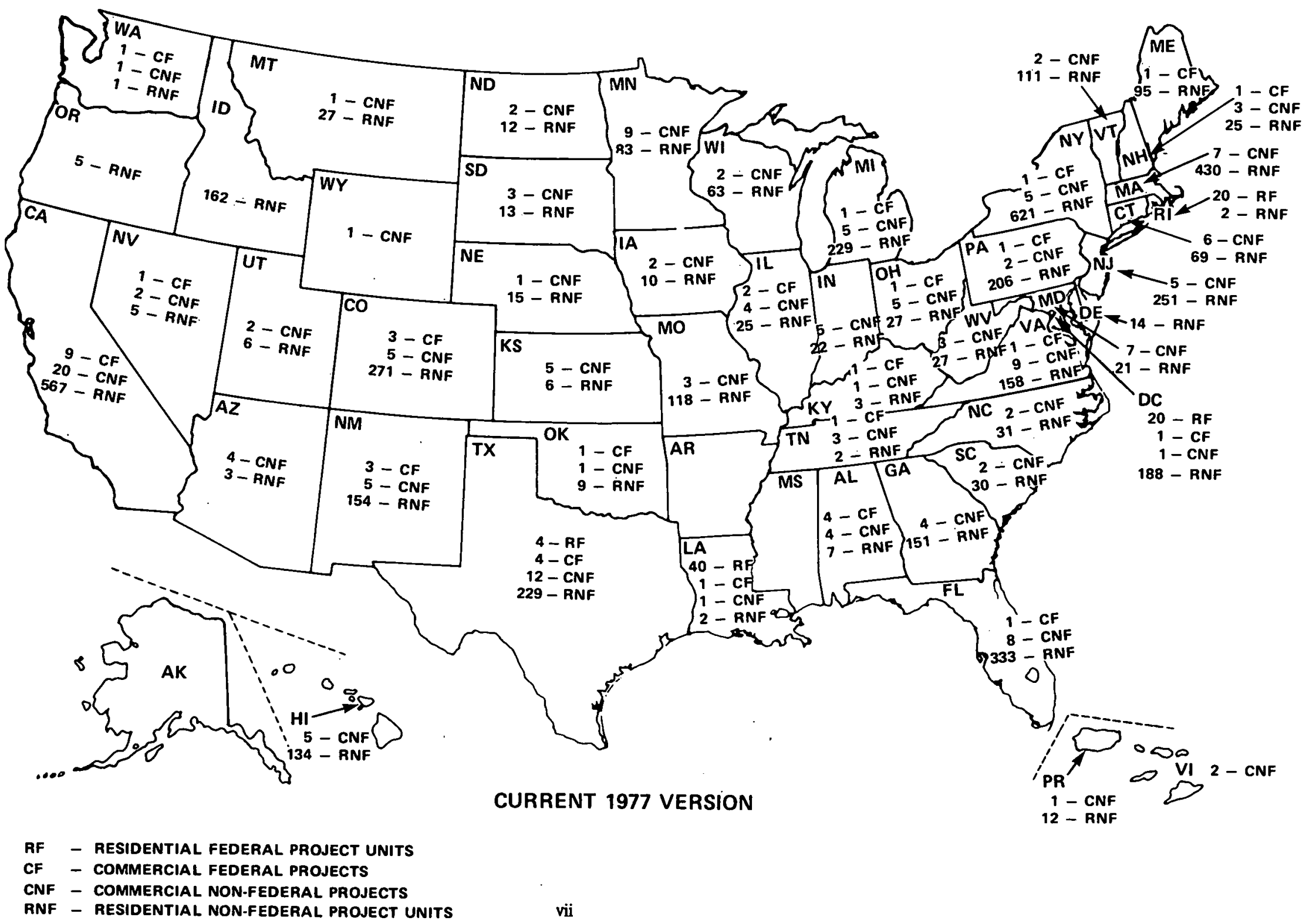




\title{
THIS PAGE
}

\section{WAS INTENTIONALLY}

\author{
LEFT BLANK
}




\section{SECTION I}

COMMERCIAL DEMONSTRATION PROGRAM NON-FEDERAL BUILDINGS 
COMMERCIAL DEMONSTRATION PROGRAM

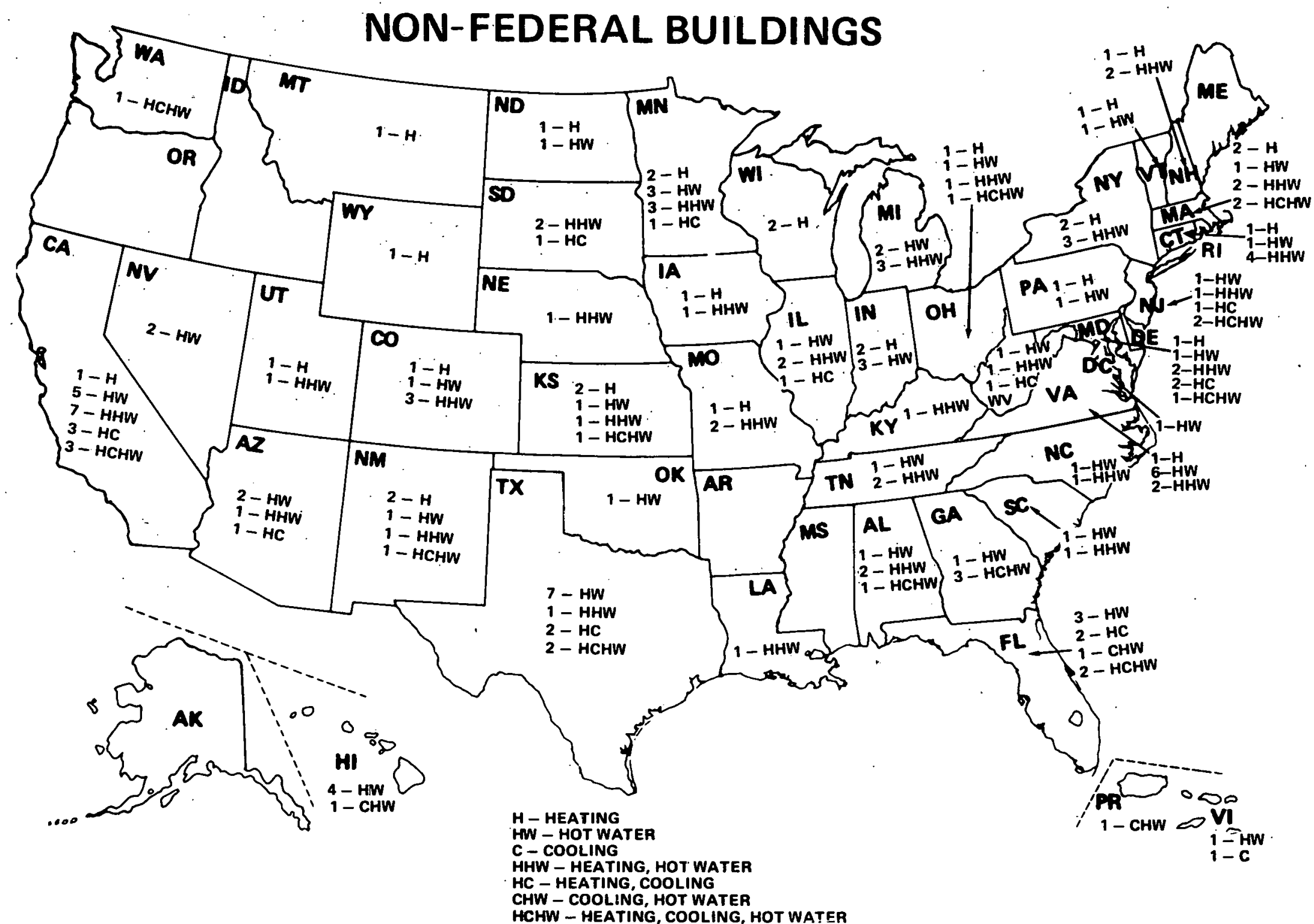




\section{SECTION I COMMERCIAL DEMONSTRATION PROGRAM NON-FEDERAL BUILDINGS}

\begin{tabular}{|c|c|c|c|c|}
\hline PAGE & STATE & LOCATION & OWNER/BUILDER & $\begin{array}{l}\text { BUILDING } \\
\text { TYPE }\end{array}$ \\
\hline $1-1$ & ALABAMA & Huntsville & City of Huntsville & $\begin{array}{l}\text { Senior Citizens } \\
\text { Center }\end{array}$ \\
\hline 1.2 & & Listerhill & $\begin{array}{l}\text { Reyuolds Metals Company, } \\
\text { Pioduct Development Division }\end{array}$ & $\begin{array}{l}\text { Industrial Shower } \\
\text { Ficility }\end{array}$ \\
\hline [.3 & & Mcbile & Travis-Braun \& Associates, Inc. & Low Rise Motel \\
\hline $\begin{array}{l}1.4 \\
1.5\end{array}$ & ARIZONA & $\begin{array}{l}\text { Montevallo } \\
\text { Phoenix }\end{array}$ & $\begin{array}{l}\text { Aiabama Power Company } \\
\text { Rodeway Inns of America \& R.V. }\end{array}$ & $\begin{array}{l}\text { Offie } \\
\text { Low Rise Motel }\end{array}$ \\
\hline l.6 & & Scoutsdale & $\begin{array}{l}\text { Development Company } \\
\text { Gily of Scottsdale. }\end{array}$ & Office \\
\hline 1.7 & & Tempe & $\begin{array}{l}\text { Tempe Union High School } \\
\text { District } 213\end{array}$ & High School \\
\hline $1-8$ & & Tucson & $\begin{array}{l}\text { Rodeway Inns of America \& R.V. } \\
\text { Development Company }\end{array}$ & Low Rise Motel \\
\hline $1+9$ & CALIFORNIA & Cerritos & $\begin{array}{l}\text { Gi:y of Cerritos/Redevelopment } \\
\text { Agency }\end{array}$ & City Hall \\
\hline $\begin{array}{l}1.10 \\
1.11\end{array}$ & & $\begin{array}{l}\text { El Toro } \\
\text { El Toro }\end{array}$ & Fredericks Deve:opment Corporstion & Apartments \\
\hline 1.12 & & Fresno & $\begin{array}{l}\text { Orange County } \\
\text { ARATEX Services, Inc. }\end{array}$ & $\begin{array}{l}\text { Worary } \\
\text { Industrial Laundry }\end{array}$ \\
\hline 1.13 & & Irvine & Itvine Unified School District & Elementary School \\
\hline $1-14$ & & Long Beact. & City of Long Beach & Fire Station \\
\hline 1.15 & & Los Angeles & City of Los Anzeles & Police Station \\
\hline$[.16$ & & Mill Valley & lris Images, Inc. & Film Laboratory \\
\hline 1.17 & & North Highlanơs & $\begin{array}{l}\text { Rodeway Inns of America \& R.V. } \\
\text { Development Company }\end{array}$ & Low Rise Motel \\
\hline 1.18 & & Orange & $\begin{array}{l}\text { Norman Brock/Ridgeline Racquet } \\
\text { Club, Inc. }\end{array}$ & Clubhouse \\
\hline $\begin{array}{l}1.19 \\
1.20\end{array}$ & & $\begin{array}{l}\text { San Diego } \\
\text { San Francisco }\end{array}$ & $\begin{array}{l}\text { San Diego Unified School District } \\
\text { Storek \& Storek }\end{array}$ & $\begin{array}{l}\text { High School } \\
\text { Office }\end{array}$ \\
\hline 1.21 & & San Jose & Oak Grove School District & Elementary School \\
\hline 1.22 & & Santa Clara & City of Santa Clara & Community Center \\
\hline 1.23 & & Santa Cléra & Renault \& Handiey & Industrial Buildings \\
\hline 1.24 & & Saratoga & $\begin{array}{l}\text { City of Saratoga/Mechanics } \\
\text { Research, Inc. }\end{array}$ & Library \\
\hline 1.25 & & South Lake Tahoe & Lake Valley Fire District & Fire Station \\
\hline $\begin{array}{l}1.26 \\
1.27\end{array}$ & & $\begin{array}{l}\text { Stanford } \\
\text { Upland }\end{array}$ & $\begin{array}{l}\text { Stanford University } \\
\text { Fredericks Development Corporation }\end{array}$ & $\begin{array}{l}\text { Food Service } \\
\text { Apartments }\end{array}$ \\
\hline 1.28 & COLORADO & Aurora & $\begin{array}{l}\text { Adams Arapahoe Joint School } \\
\text { District }\end{array}$ & Elementary School \\
\hline \multirow[t]{2}{*}{$\begin{array}{l}1.29 \\
1-30\end{array}$} & & $\begin{array}{l}\text { Boulder } \\
\text { Lakewood }\end{array}$ & $\begin{array}{l}\text { Paul Shippee } \\
\text { Jefferson County School District }\end{array}$ & $\begin{array}{l}\text { High Rise Motel } \\
\text { School for the } \\
\text { Retarded }\end{array}$ \\
\hline & & $\begin{array}{l}\text { EY: } \\
\text { - Heating }\end{array}$ & C - Cooling & Hot Water. \\
\hline
\end{tabular}

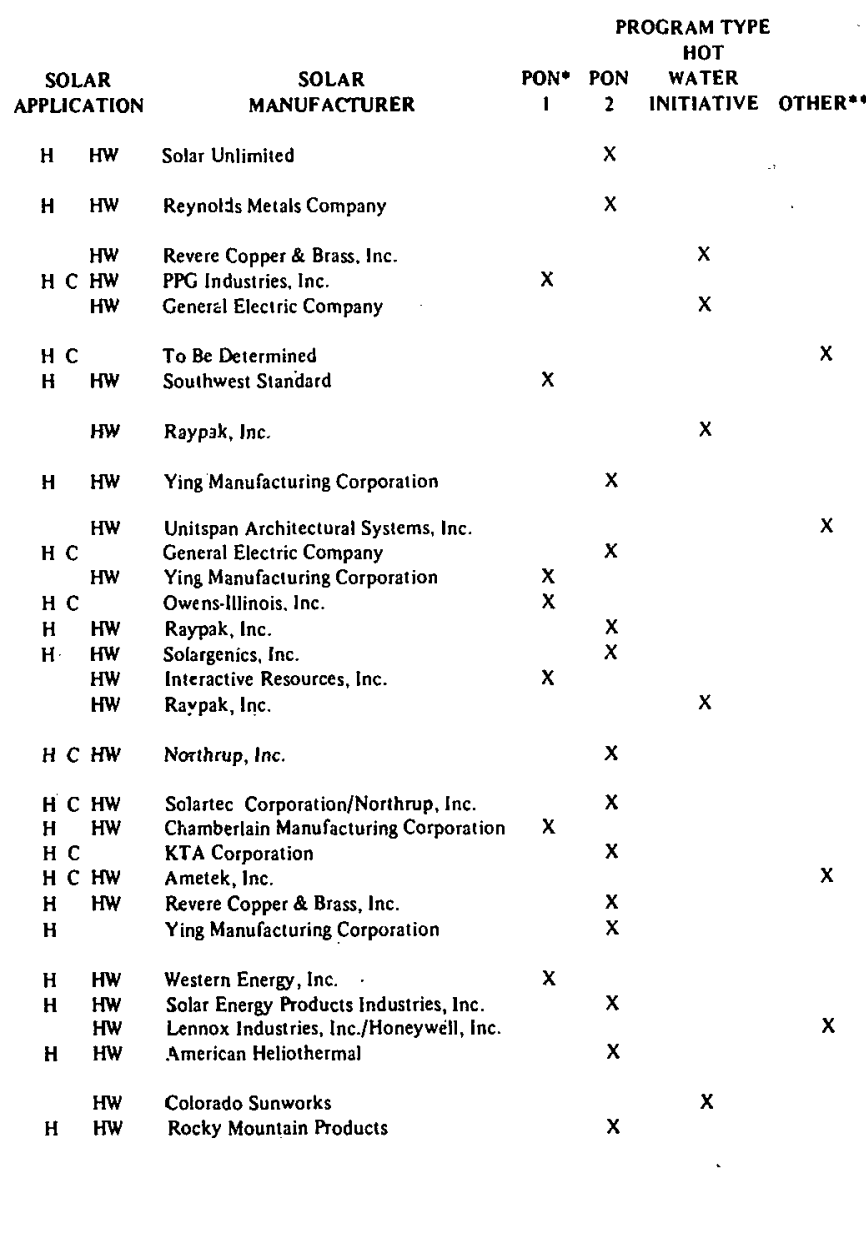

-Program Opportunity Notice (PON) Projects administered by DOE

- Includes projects initiated by the National Science Foundation 


\section{SECTION I COMMERCIAL DEMONSTRATION PROGRAM NON-FEDERAL BUILDINGS (CONTINUED)}

\begin{tabular}{|c|c|c|c|c|c|c|c|c|c|c|c|}
\hline \multirow[b]{2}{*}{ PAGE } & \multirow[b]{2}{*}{ STATE } & \multirow[b]{2}{*}{ LOCATION. } & \multirow[b]{2}{*}{ OWNER/BUILDER } & \multirow[b]{2}{*}{$\begin{array}{l}\text { BUILDING } \\
\text { TYPE }\end{array}$} & \multirow{2}{*}{\multicolumn{2}{|c|}{$\begin{array}{l}\text { SOLAR } \\
\text { APPLICATION }\end{array}$}} & \multirow[b]{2}{*}{$\begin{array}{c}\text { SOLAR } \\
\text { MANUFACTURER }\end{array}$} & \multicolumn{4}{|c|}{ PROGRAM TYPE } \\
\hline & & & & & & & & $\begin{array}{l}\text { PON* } \\
1\end{array}$ & $\begin{array}{l}\text { PON } \\
2\end{array}$ & $\begin{array}{c}\text { HOT } \\
\text { WATER } \\
\text { INITIATINE }\end{array}$ & OTHER** \\
\hline 1.31 & & Littleton & Cily of Littleton & Cily Hall & H & HW & Sunworks, Inc. & & $\mathrm{x}$ & & \\
\hline 1.32 & & Vail & Town of Vail & Bus Stop Shelter & H & & Wormser Stientific Corporation & & $\hat{x}$ & & \\
\hline 1.33 & CONNECTICUT & Branford & $\begin{array}{l}\text { John R. McColl, Jr/I } \\
\text { William H. Wade }\end{array}$ & $\begin{array}{l}\text { Cemmercial/ } \\
\text { Industrial }\end{array}$ & $\mathrm{H}$ & HW & Solaron Corporation & & $x$ & & \\
\hline 1.34 & & Danbury & Danbury Hospital & Hospital & $\mathrm{H}$ & HW & Libby-Owens-Ford Company & & $x$ & & \\
\hline $1-35$ & & East Hanford & American Molor Inns, Inc. & High Rise Molor Inn & & HW. & Sunworks. Inc. & & & $x$ & \\
\hline 1.36 & & Hamden & $\begin{array}{l}\text { Hamden Connecticut Housing } \\
\text { Authorily }\end{array}$ & $\begin{array}{l}\text { Multifamily Elderly } \\
\text { Housing }\end{array}$ & H & HW & Solar Producis Manufacturing Corporation & & & & $\mathrm{x}$ \\
\hline 1.37 & & New Hiven & Albic Booth Memorial Boys Club & $\begin{array}{l}\text { Boys Club \& Com. } \\
\text { munity Center }\end{array}$ & H & HW & Solar Heat ting Systems Corporation & & $\mathrm{x}$ & & \\
\hline 1.-38 & & Stamford & Lutz.Sotire Parnnership & Orfise & H & & Sunworks, lne. & $\mathrm{x}$ & & & \\
\hline 1.39 & DIST.OF COLUMBIA & Washington, D.C. & Marriolt Corporation & Restaurant & & HW & Sunworks, Inc. & 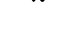 & & & $x$ \\
\hline 1.40 & FLORIDA & Brandon & Brandon Swimming Association & $\begin{array}{l}\text { Spons/Medical } \\
\text { Center }\end{array}$ & HC & HW & Revere Copper \& Brass. Inc. & & $\mathrm{x}$ & & n \\
\hline$[.41$ & & Cape Canaveral & Florida Solar Energy Center & Office & $\mathrm{HC}$ & & General Electric Company & & $x$ & & \\
\hline 1.42 & & Clermont & Days inn of American, Inc. & Low Rise Motel & & HW & Energy Systems, Inc. & & & $x$ & \\
\hline $1-43$ & & Coral Gables & Dade County & Elementary School & & HW & PPC Industries, Inc. & & & & $\mathrm{x}$ \\
\hline 1.44 & & Hallandale & $\begin{array}{l}\text { Diplomat Golf } \\
\text { \& Racquet Club }\end{array}$ & Low Rise Motel & & HW & Solar Engineering, Inc. & & & $\mathrm{x}$ & \\
\hline I.45 & & Key West & Quality Inn & $\begin{array}{l}\text { Low \& High Rise } \\
\text { Motel }\end{array}$ & & HW & Capital Solar Heating, Inc. & & & $\mathrm{x}$ & \\
\hline I.46 & & Lake Buena Vista & Reedy Creek Utilities Co., Inc. & Office & $\mathrm{HC}$ & HW & AAI Corporation & $\mathrm{x}$ & & & \\
\hline 1.47 & & Nassau County & Florida Department of Commerce & Welcome Station & H C & & Notthrup, Inc. & $\mathrm{x}$ & & & \\
\hline 1.48 & GEORGIA & Allants & City of Atlants & Elementary School & HC & HW & PPG Industries, Inc. & & & & $\mathrm{x}$ \\
\hline 1.49 & & Coilege Park & La Quinta Motor Inns, Inc. & Low Risc Motel & & HW & Revere Copper \& Brass, Inc. & & & $\mathrm{x}$ & \\
\hline 1.50 & & Dalion & $\begin{array}{l}\text { North Georgia Area Planning \& } \\
\text { Development Commission }\end{array}$ & Office & $\mathrm{HC}$ & HW & Revere Copper \& Brass, Inc. & & $\mathrm{x}$ & & \\
\hline 1.51 & & Shenandoah & Shenandoah Development Corp. & Recreational Center & H C & $\mathrm{HW}$ & Revere Copper \& Brass, Inc. & & & & $\mathrm{x}$ \\
\hline 1.52 & HAWAII & Honolulu & Airport Ramada Inn & Hotel & & HW & To Be Determined & & & & $\mathrm{x}$ \\
\hline 1.53 & & Honotulu & lolani School & School & & HW & Northrup. Inc. & & $x$ & & \\
\hline I. -54 & & Honolulu & Metropolitan YMCA & Dorm and Shower Room & & HW & Raypak, Inc. & & & $\mathrm{x}$ & \\
\hline 1.55 & & Kona & Hawaiian Pacific Resorts & High Rise Hotel & & HW & Raypak, Inc. & & & $\mathrm{x}$ & \\
\hline I.56 & & Waikoloa & E. W. Westgate Company & High Rise Hotel & & HW & Acurex/Aerotherm & & & $\mathrm{x}$ & \\
\hline 1.57 & ILUNOIS & Chicago & Museum of Science and Industry & Museum & H C & & General Electric Company & & $\mathrm{x}$ & & \\
\hline 1.58 & & Chicage & $\begin{array}{l}\text { Public Building Commission } \\
\text { of Chicago. }\end{array}$ & Office/Exhibition & $\mathrm{H}$ & HW & Chamberlain Manufacturing Corporation & & & . & $x$ \\
\hline 1.59 & & Chicago & $\begin{array}{l}\text { Rodeway Inns of America \& R.V. } \\
\text { Development Company }\end{array}$ & High Rise Hotel & & HW & Lennox Industries, Inc. & & & $\mathrm{x}$ & \\
\hline 1.60 & & St. Charles & Community Unit District 303 & High School & H & $\mathrm{HW}$ & Sunworks, Inc. & & $\mathrm{x}$ & & \\
\hline 1.61 & INDIANA & Clarksville & $\begin{array}{l}\text { Clarksville Community School } \\
\text { Corporation }\end{array}$ & Middle School & H & & Solar Development, Ine. & & $\hat{x}$ & & \\
\hline & & Heating & C - Cooling & ot Water & & & & & & & \\
\hline
\end{tabular}




\section{SECTION I COMMERCIAL DEMONSTRATION PROGRAM NON-FEDERAL BUILDINGS (CONTINUED)}

\begin{tabular}{|c|c|c|c|c|c|c|c|c|c|c|c|}
\hline \multirow[b]{2}{*}{ PAGE } & \multirow[b]{2}{*}{ STATE } & \multirow{2}{*}{ LOCATION } & \multirow[b]{2}{*}{ OWNER/BUILDER } & \multirow[b]{2}{*}{$\begin{array}{l}\text { BUILDINC } \\
\text { TYPE }\end{array}$} & \multirow{2}{*}{\multicolumn{2}{|c|}{ SOLAR }} & \multirow[b]{2}{*}{$\begin{array}{c}\text { SOLAR } \\
\text { MANUFACTURER }\end{array}$} & \multicolumn{4}{|c|}{$\begin{array}{l}\text { PROGRAM TYPE } \\
\text { HOT }\end{array}$} \\
\hline & & & & & & & & $\begin{array}{l}\text { PON* } \\
1\end{array}$ & $\underset{2}{P O N}$ & $\begin{array}{c}\text { WATER } \\
\text { INITIATIVE }\end{array}$ & OTHER ** \\
\hline 1.622 & & Gary & $\begin{array}{l}\text { InJliana Voc̈utiunal Technical } \\
\text { (:)llegc }\end{array}$ & Vocational Schoul & $\mathrm{H}$ & & Owens-IIlinois. Ine. & & $\mathrm{x}$ & & \\
\hline 1.6 .3 & & Indianapolis & La Quinta Motor Inns, Inc. & Low' Rise Motel & & HW & Lennax Industrics. Inc. & & & $\mathrm{x}$ & \\
\hline 1.64 & & Indianapolis & $\begin{array}{l}\text { Rudeway Inns of America \& R.V. } \\
\text { Develurment Company }\end{array}$ & Low Rise Motel & & $\mathrm{HW}$ & Lennex Industries. Inc. & & & $\mathrm{x}$ & \\
\hline 1.65 & & Merrillville & La Duinta Motor Inns, Inc. & Low Rise Motel & & HW & General Electric Company & & & $\mathrm{x}$ & \\
\hline 1.66 & IOWA & Marion & Narion Independent School District & Office & fi & & Hone;well. Inc./Lennox Industries. Inc. & & $\mathrm{x}$ & & \\
\hline 1.67 & & West Branch & Scattergood School & School Gymnasium & H & HW & Solarion Corporation & $\mathrm{x}$ & & & \\
\hline 1.68 & KANSAS & Gypsum & Unified Schoul District No. 306 & $\begin{array}{c}\text { Kindergarten-12th } \\
\text { Grade School }\end{array}$ & H & HW & Solar Corpuration of America & & $\mathrm{x}$ & & \\
\hline 1.69 & & Kansas City & Du Cal Invesimenis. Inc. & Warehouse/Office & $\mathrm{H}$ & & Solaton Corporation & & $\mathrm{x}$ & & \\
\hline 1.70 & & Topeka & $\begin{array}{l}\text { Kaw Valley State Bank and Trust } \\
\text { Company }\end{array}$ & Bank & 40 & $\mathrm{CHW}$ & General Electric Company & & $\mathrm{x}$ & & \\
\hline 1.71 & & Wichita & Charles F. Henning. M.D. & Medical Orfices & H & & Solar Services, Inc. & & $\mathrm{x}$ & & \\
\hline 1.72 & & Wichita & La Quinta Motor Inns. Inc. & Low Rise Motel & & HW & Lennox Industries, Inc. & & & $\mathrm{x}$ & \\
\hline 1.73 & KENTUCKY & Louisvilte & Rademaker Corporation & Office/Warehouse & H & HW & $\begin{array}{l}\text { Solaron Corpuration/Solar } \\
\text { Development, Inc. }\end{array}$ & $x$ & & & \\
\hline 1.74 & LOUISIANA & Baton Rouge & $\begin{array}{l}\text { Louisiana State University } \\
\text { \& A\&M College }\end{array}$ & Field House & $\mathrm{H}$ & HW & $\begin{array}{l}\text { Honeywell, Inc./Lennux } \\
\text { Industries, Inc. }\end{array}$ & $\mathrm{x}$ & & & \\
\hline 1.75 & MARYLAND & Annapolis & Ferguson Corporation & Motel & & HW & Southwest Ener. Tech, Inc. & $x$ & & & \\
\hline 1.76 & & Baltimore & Gily of Baltimore & Community Center & $\mathrm{H}$ & HW & InterTechnology Corporation & $x$ & & & \\
\hline 1.77 & & Baltimore & City of Baltimore & Fire Station & $\mathrm{HC}$ & $\mathrm{CHW}$ & To Be Determined & & $\mathrm{x}$ & & \\
\hline 1.78 & & Cockeysvitle & Baitimore County & Elementary School & $\mathrm{HCC}-2-10$ & & AAI Corporation & & & & $\mathrm{x}$ \\
\hline 1.79 & & Gaithersburg & $\begin{array}{l}\text { Md. National Capital Park \& } \\
\text { Planning Commission }\end{array}$ & Office & $H$ & & KTA Corporation & $x$ & & & \\
\hline 1.80 & & Germantown & Monigomery Community College & Community College & H & HW & PPG Industries, Inc. & & $\mathrm{x}$ & & \\
\hline 1.81 & & Timoniun & Baltimore County & Elernentary School & $\mathrm{HC}$ & & AAl Corporation & & & & $\mathrm{x}$ \\
\hline 1.82 & MASSACHUSETTS & Amberst & Hampshire College & College & $\mathrm{HCCO}-\mathrm{Cr}$ & $\mathrm{CHW}$ & Owens-1llinois. Inc. & & $\mathrm{x}$ & & \\
\hline 1.83 & & Boston & City of Boston & School & $\mathrm{H}$ & & General Electric Company & & & & $x$ \\
\hline 1.84 & & Boston & Children's Hospital Medical Center & Hospital & $\mathrm{H}$ & HW & General Electric Company & & $\mathrm{x}$ & & \\
\hline I.85 & & Boston & Metropolitan District Commission & Community Center & H & HW & Daystar Corporation & & $\mathrm{x}$ & & \\
\hline $\mathrm{J}-86$ & & Burlington & Technology Properties Trust & Office & $\mathrm{HCCH}-\mathrm{Cl}^{-1}$ & $\mathrm{CHW}$ & Daystar Corporation & & $\mathrm{x}$ & & \\
\hline $1-87$ & & Concord & Town of Concord & Office/Warehouse & $\mathrm{H}$ & & Sunworks. Inc. & & & & $x$ \\
\hline 1.88 & & Lenox & American Motor Inns, Inc. & Low Rise Motor Inn & & HW. & Sunworks, Inc. & & & $\mathrm{x}$ & \\
\hline 1.89 & MICHIGAN & Cedar Springs & Jordan College & Residence Hall & H & HW & PPG Industries. Inc. & & $x$ & & \\
\hline 1.90 & & Okemos & $\begin{array}{l}\text { Ingham County Board of } \\
\text { Commissioners }\end{array}$ & Health Center/Hospital & & HW & Revere Copper \& Brass. Inc. & $\mathrm{x}$ & & & \\
\hline 1.91 & & Petoskey & $\begin{array}{l}\text { Petoskey Motr:l/Leonard } \\
\text { Sieraoski, Sr. }\end{array}$ & Low Rise Mote! & & HW & Southwest Ener-Tech, Inc. & & & $\mathrm{x}$ & \\
\hline 1.92 & & Traverse City & $\begin{array}{l}\text { John O. Esslinger, M.D./ } \\
\text { Valentine Esslinger, M.D. }\end{array}$ & Medical Orfices & H & HW & Salaron Corporation & . & $\mathrm{x}$ & & \\
\hline & & $\begin{array}{l}\text { EY: } \\
\text { - Heating }\end{array}$ & C - Cooling & $V$ - Hol Water & & & & & & & \\
\hline
\end{tabular}

* Program Opportunity Notice (PON) Projects administered by DOE

**Includes projects initiated by the National Science Foundation. 


\section{SECTION I , COMMERCIAL DEMONSTRATION PROGRAM NONFEDERAL BUILDINGS (CONTINUED)}

\begin{tabular}{|c|c|c|c|c|c|c|c|c|c|c|c|}
\hline \multirow[b]{2}{*}{ PAGE } & \multirow[b]{2}{*}{ STATE } & \multirow[b]{2}{*}{ LOCATION } & \multirow[b]{2}{*}{ OWNER/BUILDER } & \multirow[b]{2}{*}{$\begin{array}{l}\text { BUILDING } \\
\text { TYPE }\end{array}$} & \multirow{2}{*}{\multicolumn{2}{|c|}{$\begin{array}{c}\text { SOLAR } \\
\text { APPLICATION }\end{array}$}} & \multirow[b]{2}{*}{$\begin{array}{l}\text { SOLAR } \\
\text { MANUFACTURER }\end{array}$} & \multirow[b]{2}{*}{$\begin{array}{l}\text { PON* } \\
. .1\end{array}$} & \multicolumn{2}{|c|}{$\begin{array}{c}\text { PROGRAM TYPE } \\
\text { HOT }\end{array}$} & \multirow{2}{*}{ OTHER } \\
\hline & & & & & & & & & $\begin{array}{c}\text { PON } \\
2\end{array}$ & $\begin{array}{l}\text { WATER } \\
\text { INITIATIVE }\end{array}$ & \\
\hline 1.93 & & Truy & Troy S'hmol Districi & Elemenlayy Schoul & $\mathrm{H}$ & IIW & Libhy.Owens.Furd Cumpany & & $x$ & & \\
\hline 1.94 & MINNESOTA & Apple Valley & Minnesolda Zoulogical Bourd & Zou Ride Sialion & $\mathrm{H}$ & HW & Lennox Industrics. Ins. & & $\hat{x}$ & & \\
\hline 1.45 & & Blowmington & $\begin{array}{l}\text { Rode way Inns of America \& R.V. } \\
\text { Develupmeni Cumpany }\end{array}$ & High Rise Holel & & Ifw & Lennoux Industrics. Irk. & & & $\mathrm{x}$ & \\
\hline $1 \cdot \% 6$ & & Bluc bijrh & Telex Communications. Ine. & Manufucturing Plant & H & & Solur Corporatimn of America & $\mathrm{x}$ & & & \\
\hline 1.97 & & Brikuklyn Center & Ossey, Schesel Districi . & Junier High School & $H$ & HW & Honcywell. Inc. & & & & $x$ \\
\hline $1.9 k$ & & Duluth & Dulultr YWCA & High Rise Hotel & & HW & Ilse Engineering. Ins. & & & $\mathrm{x}$ & \\
\hline 1.94$)$ & & Dututh & Radisson Hotel Corporation & High Rise Horel & & HW & Lennox Industries. Inc. & & & $\mathrm{x}$ & \\
\hline 1.100 & & Hibbing & Minnesola Community College & $\begin{array}{l}\text { Planetarium/Environmental } \\
\text { Science Center }\end{array}$ & H & & Sheldatl, Inc. & & $x$ & & \\
\hline 1.101 & & Minneapulis & University of Minnesota & Bookstore/Orfice & H C & & Sllclu:llul SLATS & & & & $x$ \\
\hline 1.102 & & Si. Paul & Radisson Hotel Corporation & Hotel & H & HW & $\begin{array}{l}\text { Lennox Indusirics. Inc, } \\
\text { Honeywell. Inc. }\end{array}$ & $x$ & & & \\
\hline 1.103 & MISSOURI & Columbia & Stephens College & Visitors Center & H & & $\begin{array}{l}\text { Honeywell, Inc./Lennox } \\
\text { Industries. Inc. }\end{array}$ & & $x$ & & \\
\hline 1.104 & & Kansas Cily & City of Kansas City & Fire Station & H & $\mathrm{HW}$ & Solaron Corporation & $\mathrm{x}$ & & & \\
\hline 1.105 & & St. Louis & William Tao \& Associates, Inc. & Office & H & HW & KTA Corporation & & $x$ & & \\
\hline 1.106 & MONTANA & Billings & Billings Shipping Corporation & Office & $\mathrm{H}$ & & Lennox Industries. Inc. & & $\mathrm{x}$ & & \\
\hline 1.107 & NEBRASKA & Linculn & Lincoln Housing Authority & Office & H & HW & Chamberlain Manufacturing Corporation & & $x$ & & \\
\hline 1.108 & NEVADA & Las Vegas & La Quinta Motor Inns, Inc. & Low Rise Motel & & HW & Revere Copper \& Brass. Inc. & & & $\mathrm{x}$ & \\
\hline 1.109 & & Las Vegas & Sahara Nevada Corporation & High Rise Hotel/Casino & & HW & Young Energy Systems. Inc. & & & $\mathrm{x}$ & \\
\hline 1.110 & NEW HAMPSHIRE & Durham & University of New Hampshire & Chemistry Laboratory & H & HW & Sunworks. Inc. & & $x$ & & \\
\hline 1.111 & & Jaffrey & Contemporary Systems, Inc. & Office/Manufacturing & $\mathrm{H}$ & HW & Contemporary Systems. Inc. & & $\mathrm{x}$ & & \\
\hline 1.112 & & Manchester & Kalwall Corporation & Warehouse & H & & Kalwall Corporation & $x$ & & & \\
\hline 1.113 & NEW JERSEY & Basking Ridge & Somerset County Park Commission & $\begin{array}{l}\text { Auditorium/Classrooms/ } \\
\text { Office }\end{array}$ & H C & HW & General Electric Company & & & & $x$ \\
\hline 1.114 & & Cherry Hill & Garden State Racing Association & Hotel & H & $\mathrm{HW}$ & General Electric Company & & $\mathrm{x}$ & & \\
\hline 1.115 & & Long Branch & Sea Lof & Restaurant & $\mathrm{HC}$ & HW & Owens-Illinois, Inc. & & $\mathrm{x}$ & & \\
\hline 1.116 & & Lumberton & RKL Controls, Inc. & Manufacturing & H C & & Sunworks. Inc. & $\mathrm{x}$ & & & \\
\hline $1-117$ & & Neptune & Host Motel & Low Rise Motel & & $\mathrm{HW}$ & Sunworks. Inc. & & & $\mathrm{x}$ & \\
\hline I.118 & NEW MEXICO & Albuquerque & $\begin{array}{l}\text { City of Albuquerque (Animal } \\
\text { Control Center) }\end{array}$ & Dffice/Kennel & H & HW & $\begin{array}{l}\text { Albuquerque Western Solar Industries, } \\
\text { linc. }\end{array}$ & & $\mathrm{x}$ & & \\
\hline $1-119$ & & Las Cruces & Coachlight Inn, Las Cruces Led. & Low Rise Motel & & HW & Solar Systems, Inc. & & & $x$ & \\
\hline 1.120 & & Las Cruces & New Mexico State University & Office & H C & HW & $\begin{array}{l}\text { American Heating \& Thermal/ } \\
\text { Northrup, Inc. }\end{array}$ & & & & $x$ \\
\hline 1.121 & & Nambe & Nambe Indian Pueblo & Community Center & H & & Los Alamos Scientific Laboratory & & & & $x$ \\
\hline I. 122 & & Taos & $\begin{array}{l}\text { State of New Mexico Properly } \\
\text { Control Division }\end{array}$ & Office & $\mathrm{H}$ & & $\begin{array}{l}\text { Architects Taos. } \\
\text {. }\end{array}$ & & $x$ & & \\
\hline I.123 & NEW YORK & Baliston Spa & $\begin{array}{l}\text { Ballston Spa Central School } \\
\text { District }\end{array}$ & $\begin{array}{l}\text { Middle and Elementary } \\
\text { School }\end{array}$ & H & HW & To Be Determined & & $\mathrm{x}$ & & \\
\hline I. 124 & & Bohemia & Dayton T. Brown, Inc. & Onice & $\mathrm{H}$ & & Sunworks. Inc. & & $x$ & & \\
\hline & & Heating & C-Cooling & t Water & & & , & & & & \\
\hline
\end{tabular}




\section{SECTION I COMMERCIAL DEMONSTRATION PROGRAM NON-FEDERAL BUILDINGS (CONTINUED)}

\begin{tabular}{|c|c|c|c|c|c|c|c|c|c|c|c|}
\hline \multirow[b]{2}{*}{ PAGE } & \multirow[b]{2}{*}{ STATE } & \multirow[b]{2}{*}{ LOCATION } & \multirow[b]{2}{*}{ OWNER/BUILDER } & \multirow[b]{2}{*}{$\begin{array}{l}\text { BUILDING } \\
\text { TYPE }\end{array}$} & \multirow{2}{*}{\multicolumn{2}{|c|}{$\begin{array}{c}\text { SOLAR } \\
\text { APPLICATION }\end{array}$}} & & \multicolumn{4}{|c|}{ PROGRAM TYPE } \\
\hline & & & & & & & $\begin{array}{c}\text { SOLAR } \\
\text { MANUFACTURER }\end{array}$ & $\begin{array}{l}\text { PON* } \\
1\end{array}$ & $\begin{array}{l}\text { PON } \\
2\end{array}$ & $\begin{array}{l}\text { WATER } \\
\text { INITIATIVE }\end{array}$ & OTHER** \\
\hline 1.125 & & Millbrunk & New York Bolunical Carden & Drfice/Laburatury & $\mathrm{H}$ & HW & $\begin{array}{l}\text { Chamberlain Manufacturing Corpors. } \\
\text { ivon/KTA Corporation }\end{array}$ & & $x$ & & \\
\hline 1.126 & & New Rorethelle & The City of New Renchelle & Libriry & $\mathrm{H}$ & HW & Sclar Corpuration of Ameriser & & $\mathrm{x}$ & & \\
\hline 1.127 & & Truy & Carl Grinm & Retail & H & & Lennex Industries. Iluc. & & $\mathrm{x}$ & & \\
\hline $1.12 x$ & NORTIICAROLINA & Chrrlentic & $\begin{array}{l}\text { Charlutle Memerial Hespital } \\
\text { Medical Center }\end{array}$ & $\begin{array}{l}\text { Health Center/Offitel } \\
\text { Classroum }\end{array}$ & $\mathrm{H}$ & HW & General Electric Conspiny & $\mathrm{x}$ & & & \\
\hline $1.12^{\prime \prime}$ & & Charlotte & Oiffice Parks of Charlotic, Ine. & Low Rise Motel & & HW & Energy Sysiems. Inc. & & & $x$ & \\
\hline 1.1 .30 & NORTH DAKOTA & Bismarck & Bosin Electric Power Cooperative & Office & $\mathrm{H}$ & & Sunworks. Inc. & & & & $x$ \\
\hline 1.131 & & Bismarck & Mid-State Investment Corporation & High Rise Hotcl & & $\mathrm{HW}$ & Lesnox Industries. Inc. & & & $x$ & \\
\hline 1.132 & OHIO & Columturs & Columbus Technical Institute & Offices & $\mathrm{HC}$ & & Owens-Illinois. Inc. & & $\mathrm{x}$ & & \\
\hline 1.133 & & Collumitus & Highlights for Children. Inc. & orfice & HC & $H W$ & Honeywell. Inc. & & $\mathrm{x}$ & & \\
\hline 1.134 & & Cohiunbus & $\begin{array}{l}\text { Rodeway Inns of America \& R.V. } \\
\text { Development Company }\end{array}$ & High Rise Morel & & $\mathrm{HW}$ & General Eleciric Company & & & $\mathrm{x}$ & \\
\hline 1.135 & & Dect Creck Pa:k & $\begin{array}{l}\text { Ohio Department of Natural } \\
\text { Resources }\end{array}$ & Low Rise Lodge & $\mathrm{H}$ & HW & Revere Copper \& Brass. Inc. & & & $x$ & \\
\hline 1.136 & & Troy & Troy-Miami Counly Public Libran. & Library & H & & Owens-IIlinois. Inc. & $x$ & & & \\
\hline 1.137 & OKLAHOMA & Kingston & $\begin{array}{l}\text { Oklahoma Department of Tourisu } \\
\text { and Recreation }\end{array}$ & Low Rise Hotel & & HW & Daystar Corporation & & & $\mathrm{x}$ & \\
\hline $\begin{array}{l}1.138 \\
1.139\end{array}$ & PENNSYLVANIA & $\begin{array}{l}\text { Lancaster } \\
\text { West Goshen }\end{array}$ & $\begin{array}{l}\text { American Motor Inns. Inc. } \\
\text { Bell Telephone Company of } \\
\text { Pennsylvania }\end{array}$ & $\begin{array}{l}\text { Low Rise Motor Inn } \\
\text { Office/Storage }\end{array}$ & H & HW & $\begin{array}{l}\text { Sunworks. Inc. } \\
\text { Heliotherm, Inc. }\end{array}$ & & & $\mathrm{x}$ & $\mathrm{x}$ \\
\hline 1.140 & PUERTO RICO & Cunovanas & Commonwealth of Puerto Rico & Industrial Factory & & HW & Owens-Illinois. Inc. & & & & $x$ \\
\hline $1.14 \mid$ & SOUTH CAROLINA & Anderson & Days Inn of America, Inc. & Low Rise Motel & & HW & Gulf Thermal & & & $x$ & \\
\hline 1.142 & & Greenwood & Blakedale Professional Center, toc. & office & $H$ & HW & PPC Indusıries. Inc. & $x$ & & & \\
\hline 1.143 & SOUTH DAKOTA & Aberdcen & First Baptist Church & Church & H & $\mathrm{HW}$ & Solaron Corporation & & $\mathrm{x}$ & & \\
\hline 1.144 & & Ke)stone & $\begin{array}{l}\text { National Park Service, Dept. of } \\
\text { Interior }\end{array}$ & Visitors Center & H C & & Lennox Industries, Inc. & $\mathrm{x}$ & & & \\
\hline 1.145 & & Spearfish & Spearfish School District No. 40-2 & High School & H & HW & Solaron Corporation & & $\mathrm{x}$ & & \\
\hline 1.146 & TENNESSEE & Jackson & $\begin{array}{l}\text { Coca-Cola Boclling Works of } \\
\text { Jackson, Inc. }\end{array}$ & $\begin{array}{l}\text { Soft Drink Bottling } \\
\text { Plant }\end{array}$ & H & HW & Owens-Illinois, Inc. & & $\mathrm{x}$ & & \\
\hline 1.147 & & Nashville & La Quinta Motor Inns, Inc. & Low Rise Motel & & HW & Lennox Industries, Inc. & & & $\mathrm{x}$ & \\
\hline $1.148^{\circ}$ & & Nashville & $\begin{array}{l}\text { Tennessee Building Material } \\
\text { Association }\end{array}$ & office & H & HW & Solar Unlimited Corporation & & $\mathrm{x}$ & & \\
\hline 1.149 & TEXAS & Austin & $\begin{array}{l}\text { Uoyd A. Bell/American Ornamental } \\
\text { Metal Company }\end{array}$ & Factory/Office & H C & & To Be Determined & & $\mathrm{x}$ & & \\
\hline 1.150 & & Austin & Radian Corporation & - Office/Laboratory & H C & & Northrup, Inc. & $\mathrm{x}$ & & & \\
\hline I.151 & & Beaumont & La Quinta Motor Inns, Inc. & Low Rise Motel & & HW & General Electric Company & & & $\mathrm{x}$ & \\
\hline 1.152 & & Dallas & City of Dallas & Recreation/Health Care & H C & $\mathrm{HW}$ & Honeywell, Inc. & & & & $\mathrm{x}$ \\
\hline 1. 153 & & Dallas & $\begin{array}{l}\text { Lon W. Travis/Earl E. Braun, } \\
\text { Jr. Parniership }\end{array}$ & Office & H & $\mathrm{HW}$ & Solargenics, Inc. & & $\mathbf{x}$ & & \\
\hline & & ting & Cooling & 1 Water & & & & & & & \\
\hline
\end{tabular}

-Program Opportunity Notice (PON) Projects administered by DOE. 
PROJECT INFORMATION

Owner/Builder: City of Huntsville

Contractor: Dickson Associates

Operational Date: To be determined

Total Estimated DOE Funds: $\quad \$ 121,937$

Building

Type: Senior Citizens Center

Area: 12,922 sq. ft.

Location: Huntsville, Alabama

Latitude: $34.07^{\circ} \mathrm{N}$

Climatic Data

Degree Days

Avg. Temp. $\left({ }^{\circ} \mathrm{F}\right)$

Avg. Insol. (Ly/d)

$\begin{array}{llll}\text { Heating } & 3070 & \text { Cooling } & \text { N/A } \\ \text { Winter } & 41 & \text { Summer } & 78 \\ \text { Winter } & 240 & \text { Summer } & 542\end{array}$

\section{SOLAR ENERGY SYSTEM}

Application Heating 75\% Cooling $0 \%$

Collector

Type: Liquid flat-plate

Area (sq. ft.): 1,945

Manufacturer: Solar Unlimited

\section{Storage}

Type: Fiberglas water tank (above ground)

Capacity: 4,000 gallons

Auxiliary System Type: Gas fired boiler

\section{PROJECT DESCRIPTION}

The renovation of this Center included design and installation of a mechanical system which would easily accept the solar system. The Center is located in the heart of downtown Huntsville. The site itself is level, well graded, landscaped, and tastefully planned. A stone-rimmed lagoon of clear spring water is situated immediately north of the building. The basic construction is of brick and concrete block-bearing walls with a steel bar joist roof frame and exposed cement fiber insulating roof deck with built-up bituminous roofing. Floors are standard concrete slab-on-grade construction. The solar system is designed to provide space heating and domestic water heating using the existing conventional system as the back-up system. The system includes 1945 sq. ft. of self-supporting solar collectors mounted on the southeast side of the building with a $30^{\circ}$ cant to face the collectors almost due south. The absorber plate is covered with a dual pane, low iron, tempered glass. Direct heating of the domestic water is provided through a dual wall heat exchanger
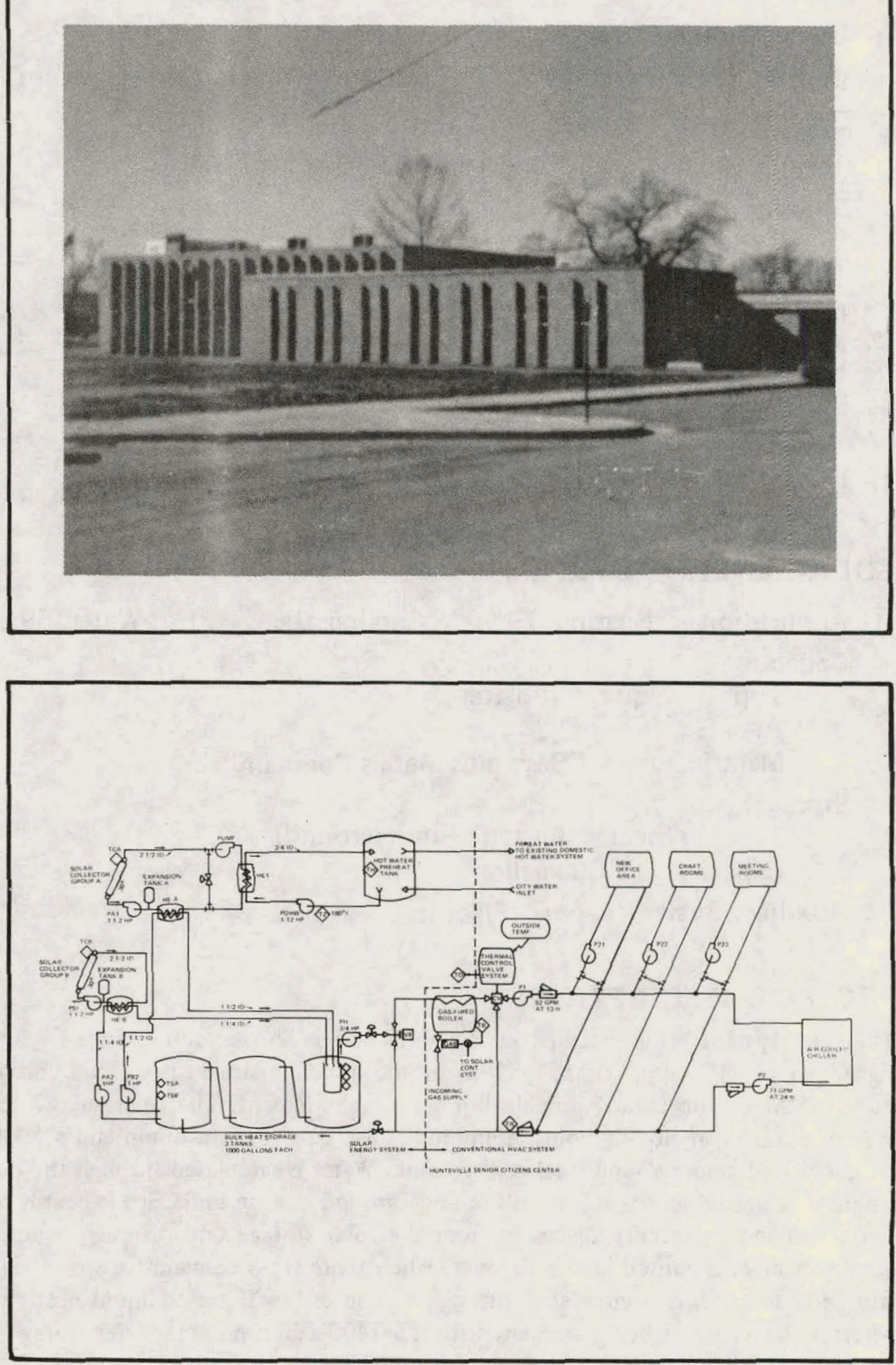


\section{PROJECT INFORMATION}

Owner/Builder: Reynolds Metals Company

Contractor: Reynolds Metals Company, Product Development Division Operational Date: January 1978

Total Estimated DOE Funds: $\quad \$ 71,916$

Building

Type: Industrial shower facility

Area: 3,842 sq. $\mathrm{ft}$.

Location: Listerhill, Alabama

Latitude: $34.65^{\circ} \mathrm{N}$

Climatic Data

Degree Days

Avg. Temp. $\left({ }^{\circ} \mathrm{F}\right.$

Heating

Winter

3302

Avg. Insol. (Ly/d)

Winter
Cooling N/A

Summer 73.2

Summer 473

\section{SOLAR ENERGY SYSTEM}

Application Heating $79 \%$

Collector

Cooling $0 \% \quad$ Hot Water $59 \%$

Type: Liquid flat-plate

Area (sq. ft.): 2,344

Manufacturer: Reynolds Metals Company

Storage

Type: Steel water tank (underground)

Capacity: 5,000 gallons

Auxiliary System Type: Electrical resistance

\section{PROJECT DESCRIPTION}

The solar system being installed at Reynolds Metals Shower and Change Facility is designed to provide approximately $79 \%$ of the annual space heating load and approximately $59 \%$ of the annual potable hot water requirement. The solar energy collection system consists of 80 Reynolds Aluminum solar collectors, a pump and a 5000-gallon unpressurized underground steel storage tank. Water is circulated through the collectors where it is heated and is stored in the underground storage tank. Space heat is provided upon demand by circulating water from the solar storage tank through a liquid-to-air heat exchanger mounted in the air duct. When there is no demand for space heat, water from the solar tank is circulated through a counterflow liquid-to-liquid heat exchanger where it heats water being circulated from a 1400-gallon potable water storage tank. A commercial fan coil is used to dump excess heat.
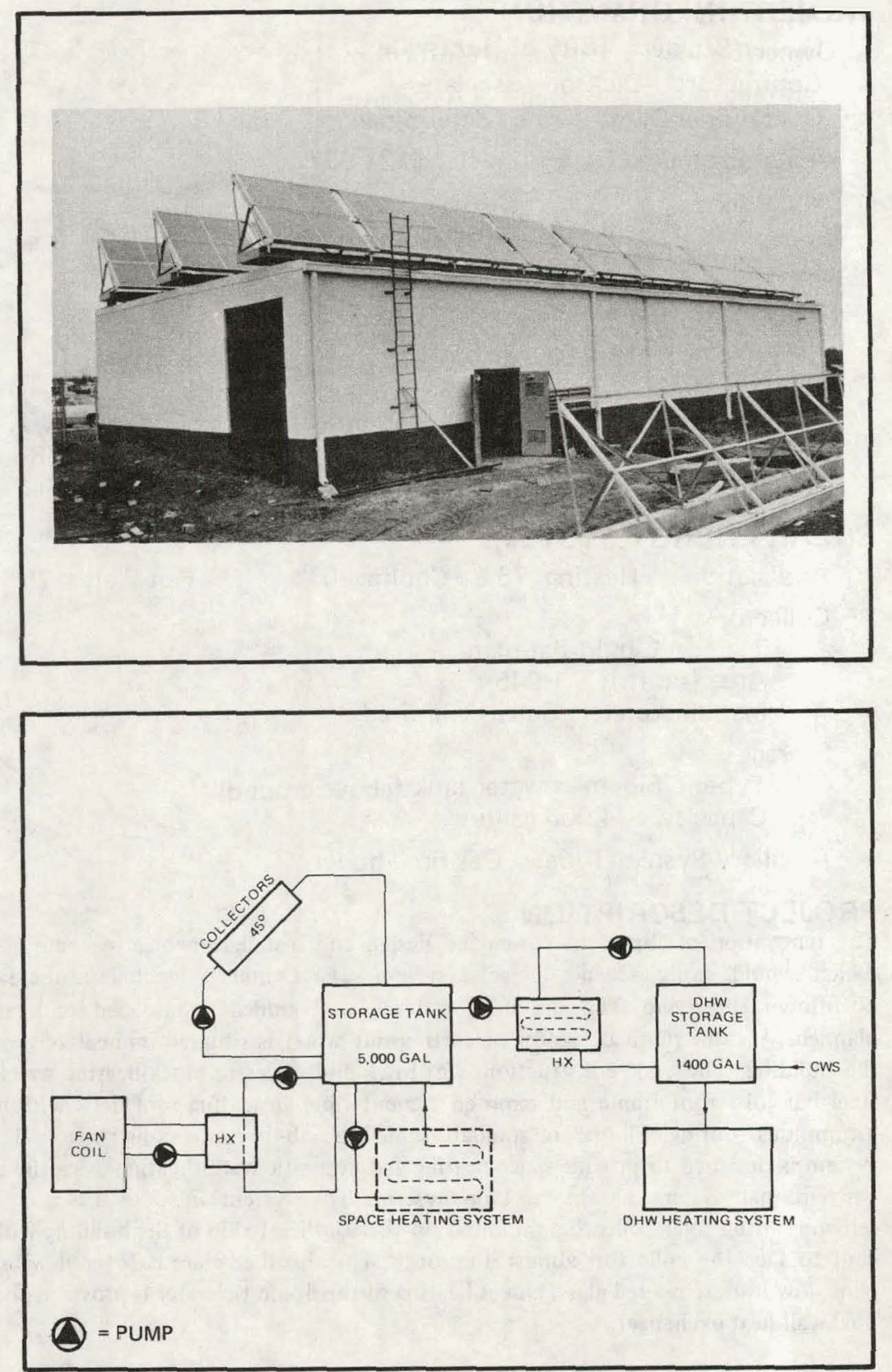


\section{PROJECT INFORMATION}

Owner/Builder: La Quinta Motor Inns, Inc.

Contractor: Travis-Braun \& Associates, Inc.

Operational Date: Mid 1978

Total Estimated DOE Funds: $\$ 39,307$

Building

Type: Low rise motel

Area: Not applicable to hot water systems

Location: Mobile, Alabama

Latitude: $30^{\circ} 4^{\prime} \mathrm{N}$

Climatic Data

$\begin{array}{lllll}\text { Degree Days } & \text { Heating } & 1600 & \text { Cooling } 2700 \\ \text { Avg. Temp. }\left({ }^{\circ} \mathrm{F}\right) & \text { Winter } & 55 & \text { Summer } & 89 \\ \text { Avg. Insol. (Ly/d) } & \text { Winter } & 250 & \text { Summer } & 525\end{array}$

\section{SOLAR ENERGY SYSTEM}

Application Heating $0 \%$ Cooling $0 \%$ Hot Water $67 \%$

Collector

Type: Liquid flat-plate

Area (sq. ft.): 2,000

Manufacturer: Revere Copper \& Brass, Inc.

Storage

Type: Steel water tank (underground)

Capacity: 1,600 gallons

Auxiliary System Type: Electric boiler

\section{PROJECT DESCRIPTION}

A drain-down system is proposed under this grant. This system is one in which, each time the water circulation pump stops, the collector fluid water drains out of and down into the protection of an enclosed space. In this proposal, this enclosed space is the mechanical room of the motel. This system is a hybrid version of a drain-down system employing a heat exchanger. By using this heat exchanger, the buildup of minerals in the solar collector is eliminated. On the solar loop of the system, a contained amount of water is employed. As this water level drops and makeup water is introduced into the system, new minerals, acids, etc., are also introduced; however, this introduction is extremely minor in comparison to the minerals which would be constantly introduced by a direct link between the storage vessel and the solar collectors.
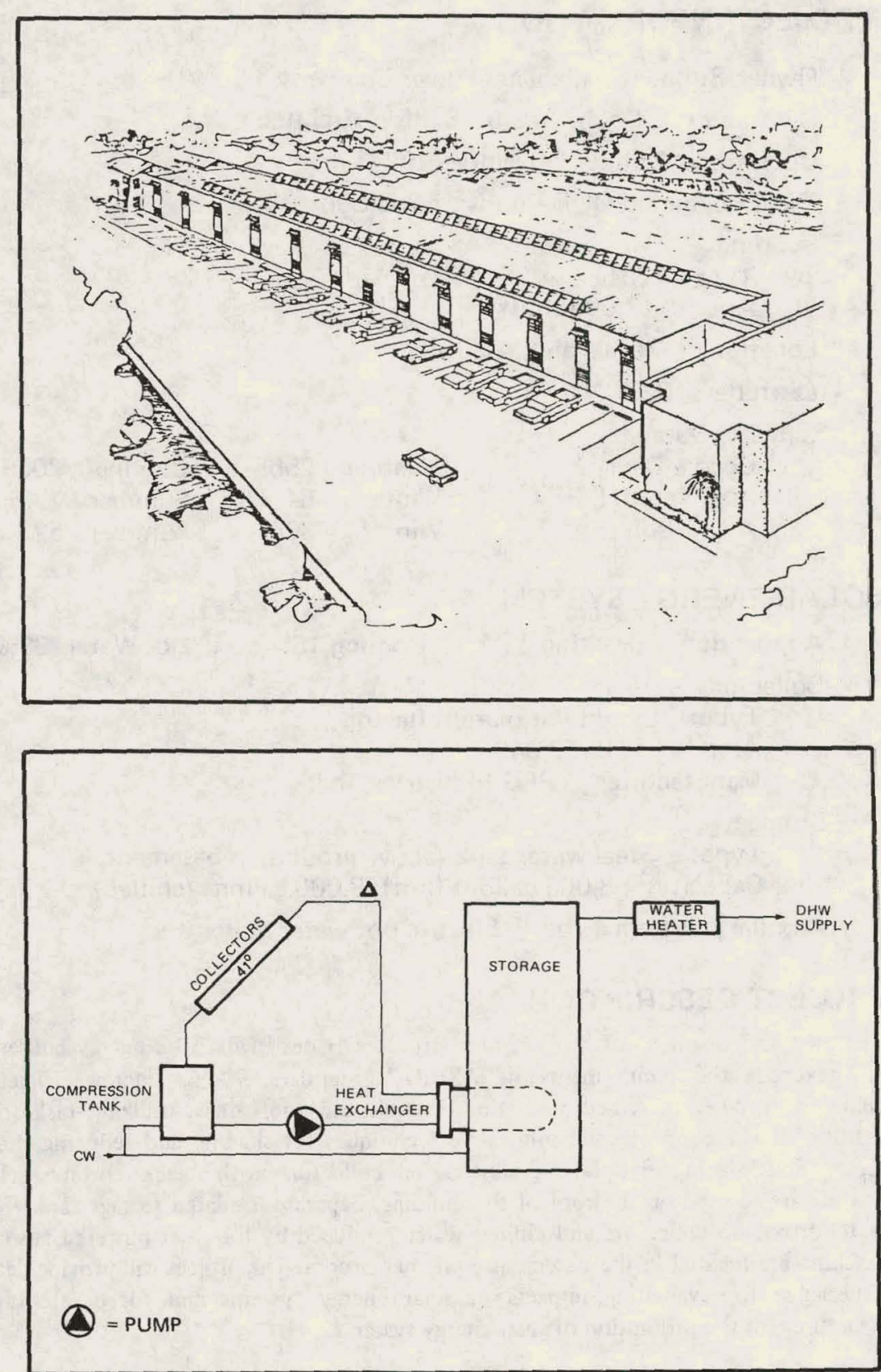


\section{PROJECT INFORMATION}

Owner/Builder: Alabama Power Company

Contractor: Cobb, Adams, Benton Architects, Inc.

Operational Date: November 1977

Total Estimated DOE Funds: $\$ 265,000$

Building

Type: Office

Area: $\quad 17,000$ sq. ft.

Location: Montevallo, Alabama

Latitude: $33.1^{\circ} \mathrm{N}$

Climatic Data

\begin{tabular}{|c|c|c|}
\hline Dearee Days & Heating & 26 \\
\hline Avg. Temp. $\left({ }^{\circ} \mathrm{F}\right)$ & Winter & \\
\hline Avg. Insol. (Ly/d) & Winter & 30 \\
\hline
\end{tabular}

Cooling 2059

Summer 77.5

Avg. Insol. (Ly/d)

Winter 304

Summer 522

\section{SOLAR ENERGY SYSTEM}

Application Heating 57\%

Cooling $18 \%$

Hot Water $38 \%$

\section{Collector}

Type: Liquid flat-plate/reflector

Area (sq. ft.): 2,340

Manufacturer: PPG Industries, Inc.

\section{Storage}

Type: Steel water tank (above ground, in basement)

Capacity: 8,000 gallons (hot); 8,000 gallons (chilled)

Auxiliary System Type: Electric hot water boiler

\section{PROJECT DESCRIPTION}

The two and one-half story triangular structure is designed to be energy conservative and exceeds the requirements of ASHRAE Standard 90-75. Energy efficiency is achieved through increased insulation in wall and roof areas, utilizing task-oriented lighting design concepts and innovative techniques for shading and reducing the glass areas. South-facing flat-plate double-glazed collectors with black chrome selective coating are located on the roof of the building. Separate insulated storage tanks for hot water from the collectors and chilled water produced by the solar powered absorption machine are located in the basement equipment room. The project will provide data and experience for evaluating impacts of solar energy systems and for developing rate structures for the promotion of solar energy systems.
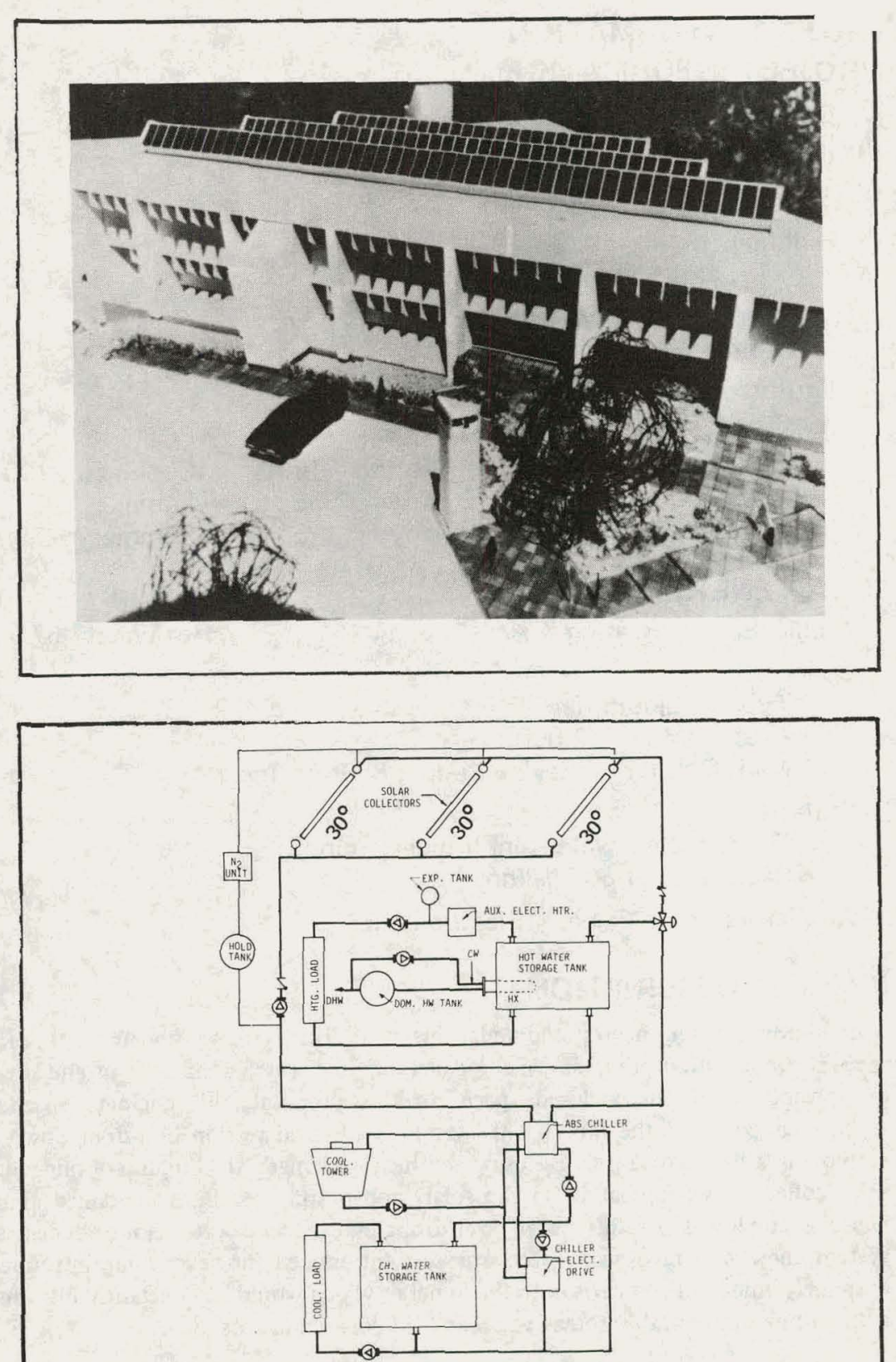


\section{PROJECT INFORMATION}

Owner/Builder: Rodeway Inns of America \& R. V. Development Company

Contractor: Charter Builders, Inc.

Operational Date: July 1978

Total Estimated DOE Funds: $\quad \$ 69,643$

Building

Type: Low rise motel

Area: Not applicable to hot water systems

Location: Phoenix, Arizona

Latitude: $33^{\circ} \mathrm{N}$

Climatic Data

$\begin{array}{lllll}\text { Degree Days } & \text { Heating } & 1093 & \text { Cooling } & 4285 \\ \text { Avg. Temp. }\left({ }^{\circ} \mathrm{F}\right) & \text { Winter } & 56 & \text { Summer } & 92 \\ \text { Avg. Insol. (Ly/d) } & \text { Winter } & 421 & \text { Summer } & 465\end{array}$

\section{SOLAR ENERGY SYSTEM}

\section{Application Heating $0 \%$ Cooling $0 \%$ Hot Water $59.5 \%$}

Collector

Type: Evacuated tubular

Area (sq. ft.): 2,500

Manufacturer: General Electric Company

\section{Storage}

Type: Insulated steel water tank

Capacity: 3,000 gallons

Auxiliary System Type: Electric boiler

\section{PROJECT DESCRIPTION}

The collectors for this system will be located on the roof of the motel. The energy collected by the collectors will be transferred to a double bundle heat exchanger via a collector loop circulating pump. Through the heat exchanger, the absorbed energy will be transferred to the storage tank via the storage loop circulating pump. Utilization of the double bundle heat exchanger eliminates the danger of ethylene glycol leakage from the solar loop to the storage tank. Energy from the storage tank is utilized for the motel potable water and laundry.
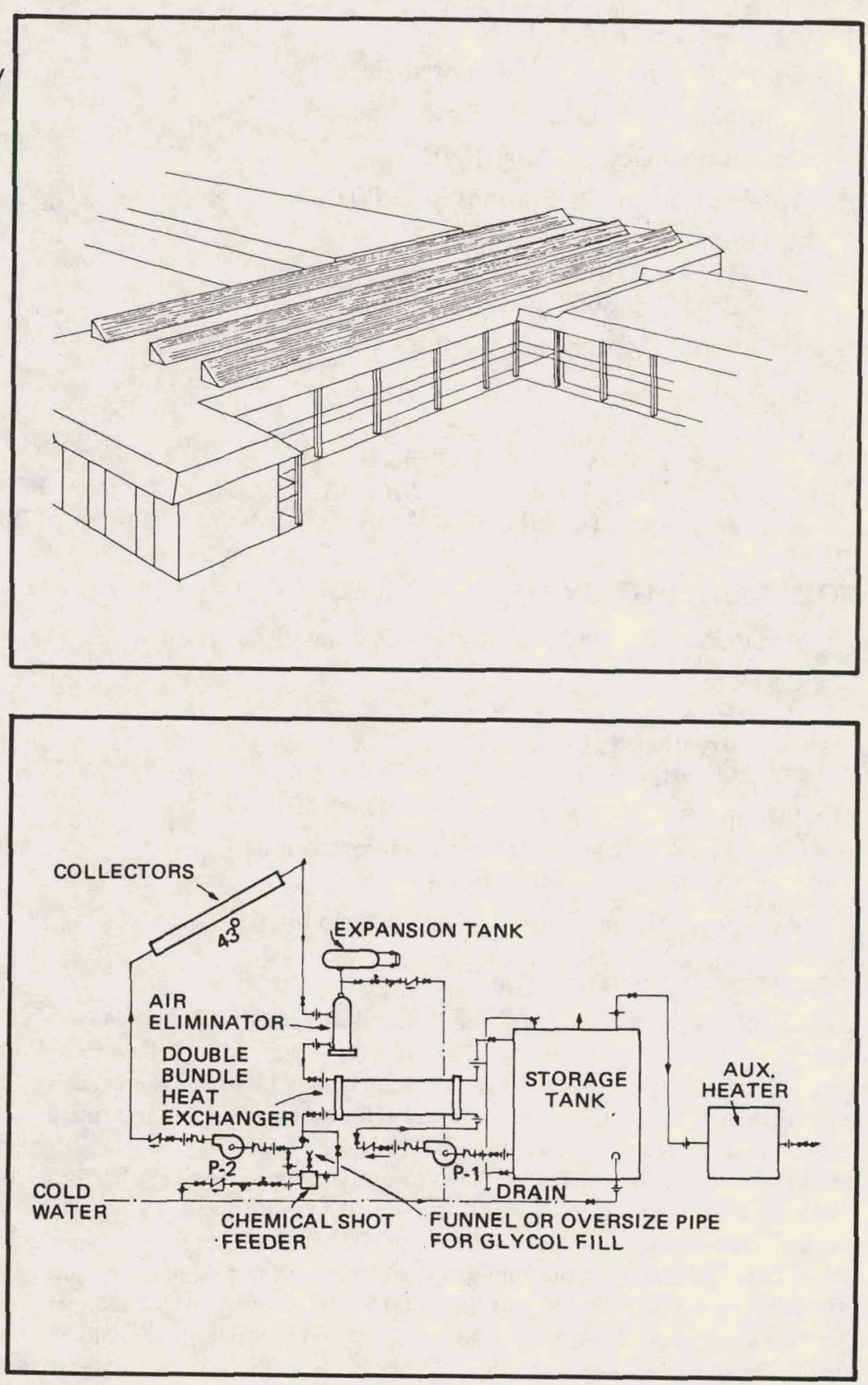


\section{PROJECT INFORMATION}

Owner/Builder: City of Scottsdale

Contractor: Sullivan \& Masson, Inc.

Operational Date: June 1978

Total Estimated DOE Funds: $\$ 200,000$

Building

Type: Office

Area: $\quad 6,850$ sq. ft.

Location: Scottsdale, Arizona

Latitude: $33^{\circ} \mathrm{N}$

Climatic Data

Degree Days

Avg. Temp. $\left({ }^{\circ} \mathrm{F}\right)$

Avg. Insol, (Ly/d)

$\begin{array}{llll}\text { Heating } & 1765 & \text { Cooling } & 4094 \\ \text { Winter } & 50 & \text { Summer } & 85 \\ \text { Winter } & 250 & \text { Summer } & 625\end{array}$

\section{SOLAR ENERGY SYSTEM}

\section{Application Heating 100\% \\ Cooling $60 \%$ Hot Water $0 \%$}

\section{Collector}

Type: Concentrating

Area (sq. ft.): 2,700

Manufacturer: To be determined

\section{Storage}

Type: Steel water tank (underground)

Capacity: 7,000 gallons

Auxiliary System Type: Electric strip heat

\section{PROJECT DESCRIPTION}

This county courthouse is a one-story stucco/block wall, insulated steel rouf faciliiy. The collectors are mounted on the flat roof at a very slight tilt angle (less than $5^{\circ}$ ) and track the sun east to west. A high limit operating aquastat detracts the collectors if a higher than desired temperature exists on the collector energy gathering and storage system. The collectors supply solar heated hot water $\left(220^{\circ} \mathrm{F}\right)$ which is piped to either the 25 -ton absorption chiller for cooling, to the hot water heating system $\left(180^{\circ} \mathrm{F}\right)$ or to the thermal storage tank. Controls to discriminate between heating and cooling, solar system or back-up system are of the automatic electronic type. All pumps are furnished with high temperature seals; piping pressure drops are kept low so that pump motors can be small. The solar system is expected to save $\$ 5000-\$ 6000$ annually, which represents $60 \%$ of the annual energy needed for heating and cooling. An economizer cycle will be retrofitted to further reduce energy consumption. Certain areas of the system are designed to accommodate a full monitoring system to be installed later.
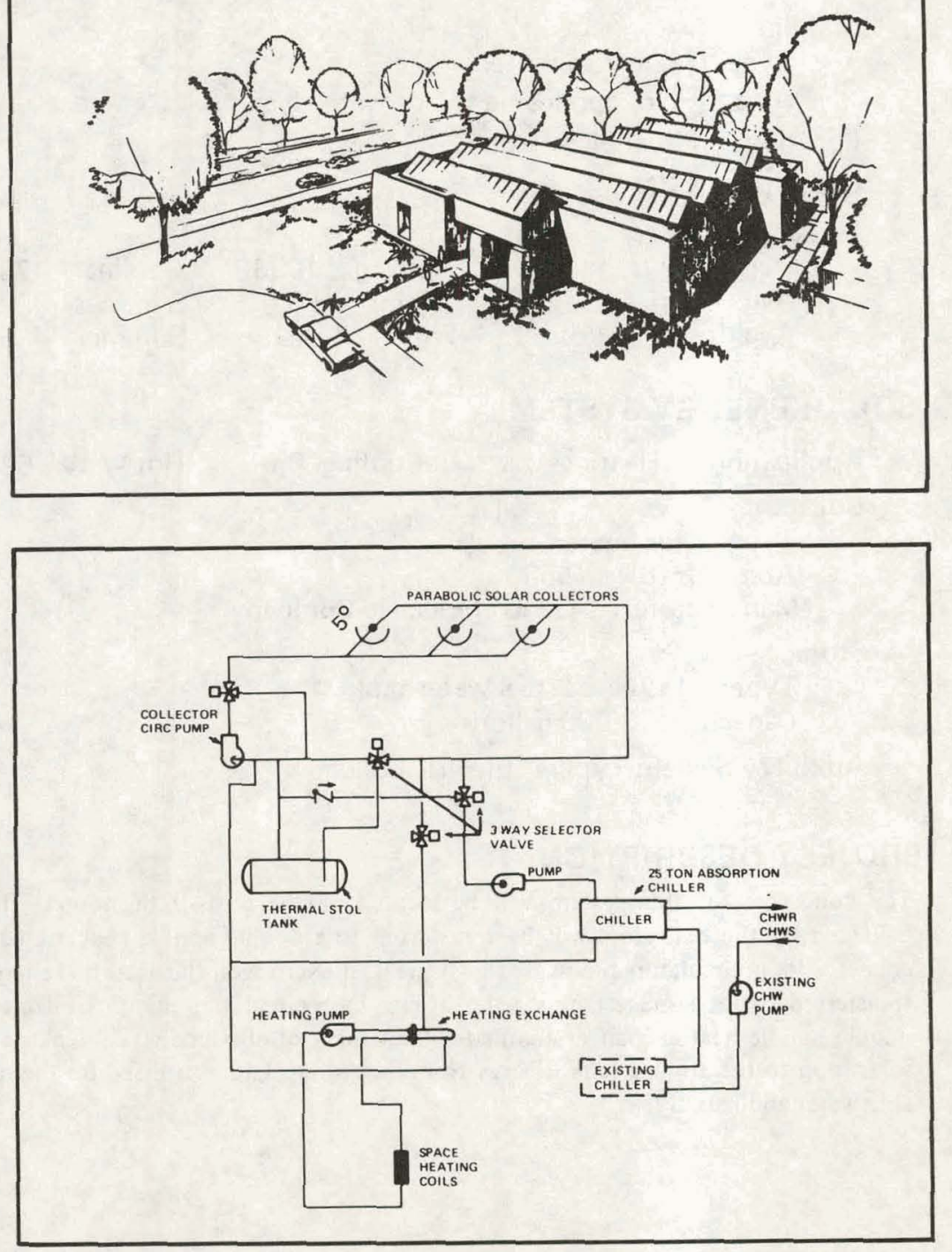


\section{PROJECT INFORMATION}

Owner/Builder: Tempe Union High School District 213

Contractor: Mardian Construction Company

Operational Date: March 1978

Total Estimated DOE Funds: $\$ 692,100$

Building

Type: High school

Area: 264,000 sq. ft.

Location: Tempe, Arizona

Latitude: $33.5^{\circ} \mathrm{N}$

Climatic Data

$\begin{array}{lllll}\text { Degree Days } & \text { Heating } & 1552 & \text { Cooling } & 3508 \\ \text { Avg. Temp. }\left({ }^{\circ} \mathrm{F}\right) & \text { Winter } & 58.5 & \text { Summer } & 81.7 \\ \text { Avg. Insol. (Ly/d) } & \text { Winter } & 280 & \text { Summer } & 750\end{array}$

Avg. Insol. (Ly/d) Winter 280 Summer 750

\section{SOLAR ENERGY SYSTEM}

Application Heating 83\% Cooling 0\% Hot Water 90\%

Collector

Type: Liquid flat-plate

Area (sq. ft): $\quad 20,000$

Manufacturer: Southwest Standard

Storage

Type: Insulated steel water tank (partially buried)

Capacity: 47,000 gallons

Auxiliary System Type: Electric

\section{PROJECT INFORMATION}

The Corona Del Sol High School has a solar system which will provide thermal energy required for space heating and hot water. Rooftop collectors face south at an angle of $32^{\circ}$ from horizontal. Additional energy conservation design features include earth berming at perimeter walls, concentration of building mass, in accordance with sun angles, extensive use of insulation throughout the facility, and use of natural landscaping surrounding the perimeter and interior court of the facility. Heated water from the buried storage tank will be pumped into heat exchangers transferring the heat energy to a four-pipe heating/cooling system and air handlers. Forced air will be discharged from the air handlers as required in various locations of the building.
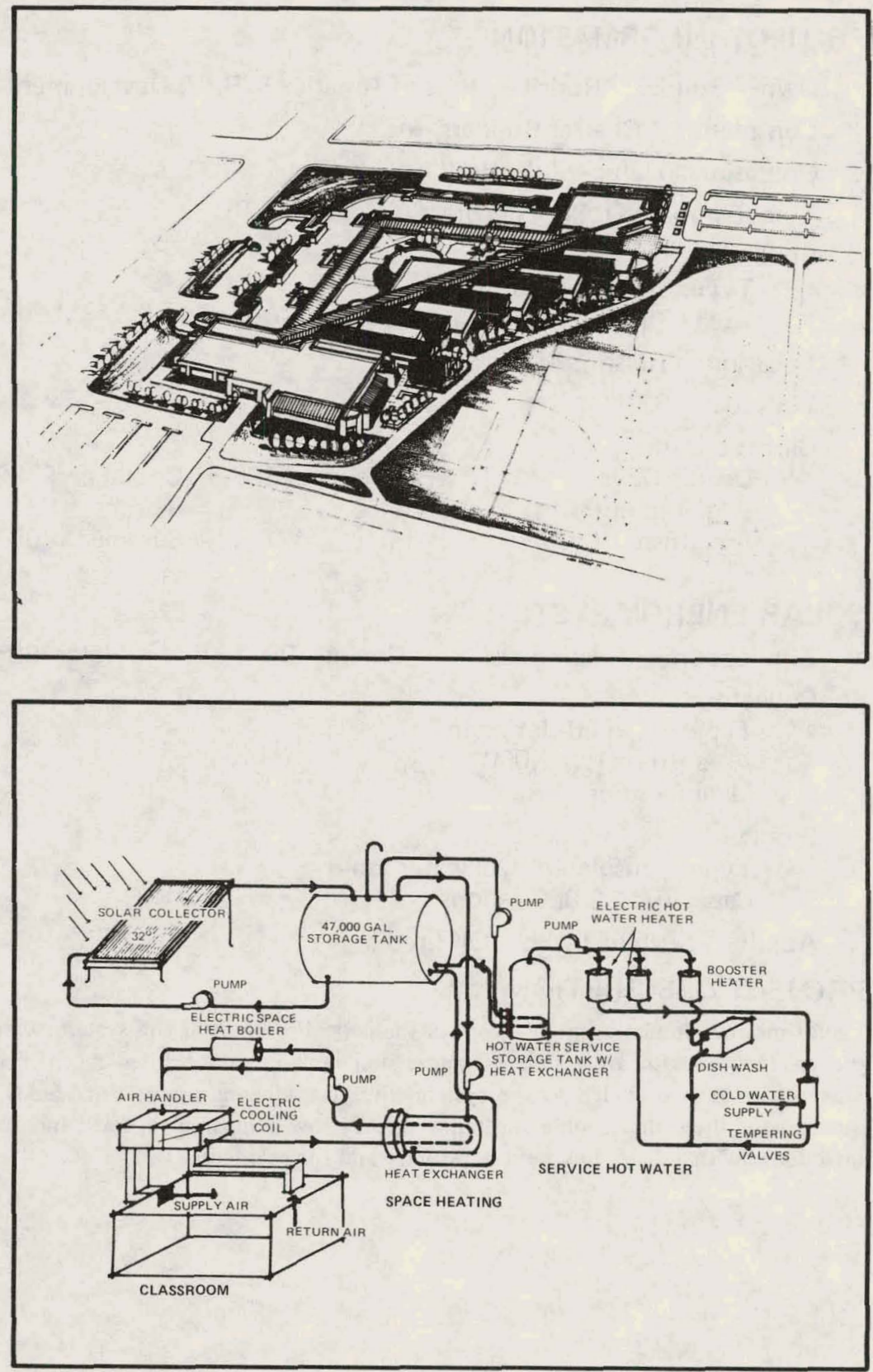


\section{PROJECT INFORMATION}

Owner/Builder: Rodeway Inns of America \& R. V. Development Company

Contractor: Charter Builders, Inc.

Operational Date: July 1978

Total Estimated DOE Funds: $\$ 43,704$

Building

Type: Low rise motel

Area: Not applicable to hot water systems

Location: Tucson, Arizona

Latitude: $33^{\circ} \mathrm{N}$

Climatic Data

Degree Days

Avg. Temp. $\left({ }^{\circ} \mathrm{F}\right)$

Heating 2226

Cooling 2592

Avg. Insol. (Ly/d)

Winter 56

Summer 92

Winter 421 Summer 465

\section{SOLAR ENERGY SYSTEM}

Application Heating $0 \%$

Hot Water $68 \%$

Collector

Type: Liquid flat-plate

Area (sq. ft.): 2,000

Manufacturer: Raypak, Inc.

\section{Storage}

Type: Insulated steel water tank

Capacity: 2,000 gallons

Auxiliary System Type: Oil fired boiler

\section{PROJECT DESCRIPTION}

Each time the circulation pump stops in the collection loop of this system, water drains out of the collector array into a compression tank in the enclosed mechanical room. Makeup water is provided to the system, thus introducing minerals and acids, but the quantity of these undesirable substances is very low compared to that which would be introduced with a direct link between storage and the solar collectors.
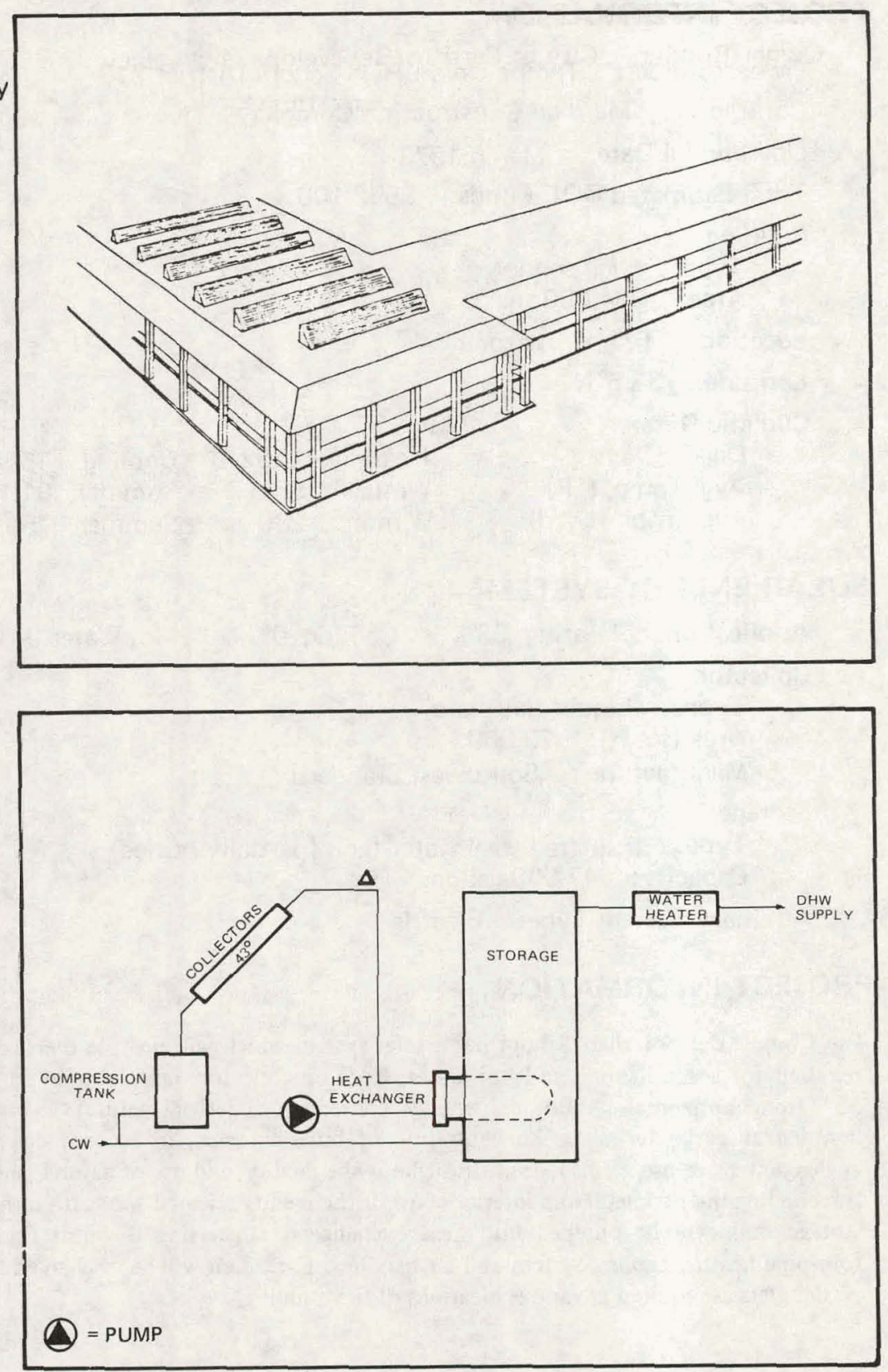


\section{PROJECT INFORMATION}

Owner/Builder: City of Cerritos/Redevelopment Agency

Contractor: Maurice H. Fleishman, Architect

Operational Date: May 1978

Total Estimated DOE Funds: $\quad \$ 40,000$

Building

Type: City Hall

Area: 51,806 sq. ft.

Location: Cerritos, California

Latitude: $33.8^{\circ} \mathrm{N}$

Climatic Data

Degree Days

Avg. Temp. $\left({ }^{\circ} \mathrm{F}\right)$

Avg. Insol. (Ly/d)

\begin{tabular}{|c|c|c|c|}
\hline Heating & 1400 & Cooling & $\mathrm{N} /$ \\
\hline Winter & 55 & Summer & 71 \\
\hline Winter & 272 & Summer & 62 \\
\hline
\end{tabular}

\section{SOLAR ENERGY SYSTEM}

Application Heating $60 \%$

Cooling $0 \%$

Hot Water $95 \%$

Collector

Type: Liquid flat-plate

Area (sq. ft.): 1,408

Manufacturer: Ying Manufacturing Corporation

Storage

Type: Insulated steel water tanks (below ground)

Capacity: 3,000 gallons

Auxiliary System Type: Gas fired boiler

\section{PROJECT DESCRIPTION}

The proposed City Hall is a three-story structure with a lower level approximately three feet below natural grade. An estimated $60 \%$ of the building's heating load will be provided by the solar system. The system utilizes the collectors to heat water which is subsequently stored in two 1500-gallon insulated storage tanks. Water from the storage tanks is used to drive heat pumps to provide building space heating. A gas fired boiler is available to provide supplemental heat to the water. Water circulating through heat exchangers in the storage tanks and then through external heat exchangers preheats incoming domestic water. The domestic hot water is stored in conventional gas fire water heaters. The air-conditioning system will be a conventionally electrically operated refrigerator plant having no relationship to the solar heating system.

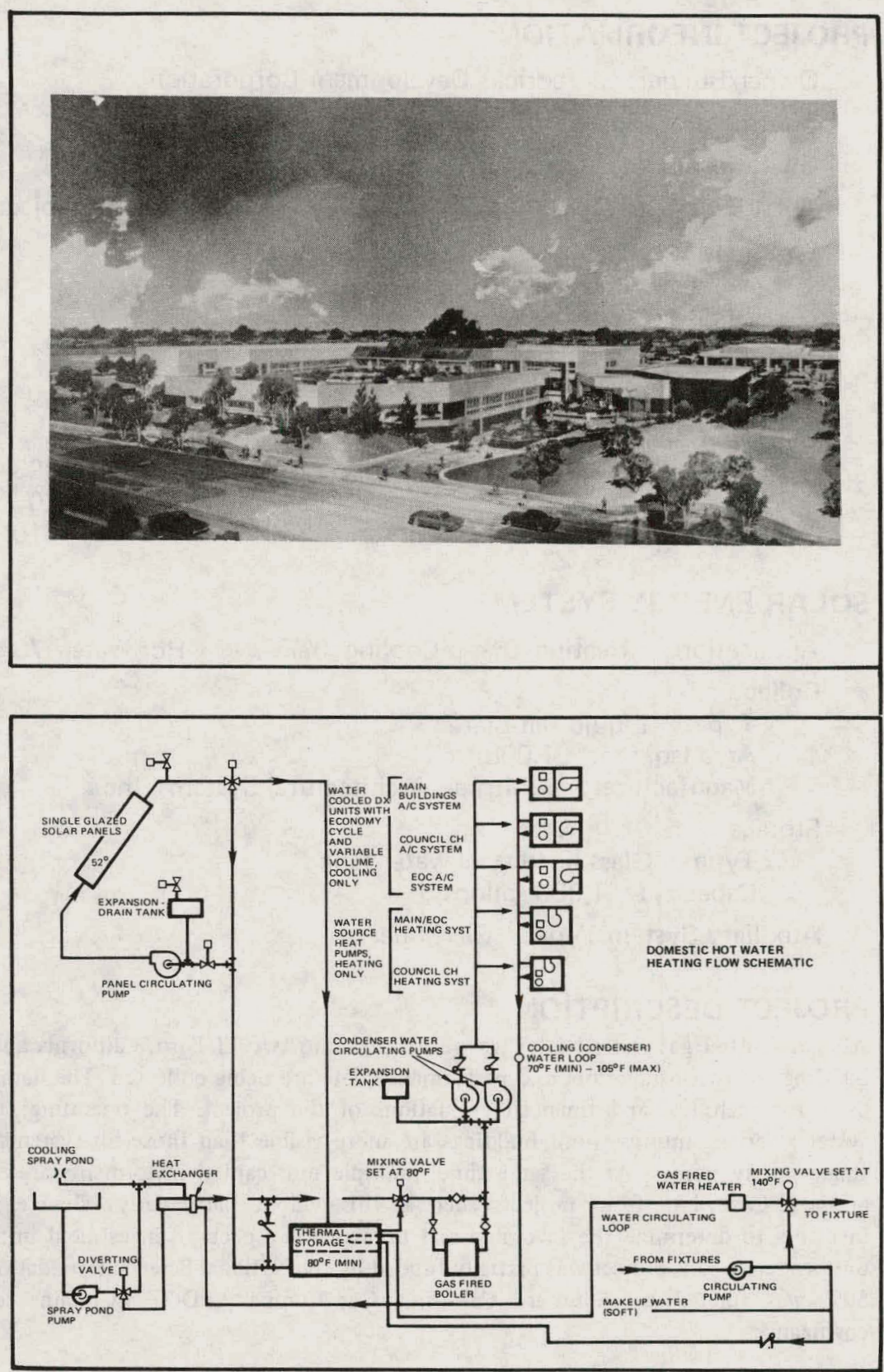




\section{PROJECT INFORMATION}

Owner/Builder: Fredricks Development Corporation

Contractor: Southern California Gas Company

Operational Date: August 1975

Total Estimated DOE Funds: $\$ 391,900$ (includes Upland Project) Building

Type: Apartments (32 units)

Area: $\quad 57,600$ sq. ft.

Location: El Toro, California

Latitude: $33.6^{\circ} \mathrm{N}$

Climatic Data

$\begin{array}{lllll}\text { Degree Days } & \text { Heating } & 1355 & \text { Cooling } & 993 \\ \text { Avg. Temp. }\left({ }^{\circ} \mathrm{F}\right) & \text { Winter } & 59.6 & \text { Summer } & 70.1 \\ \text { Avg. Insol. (Ly/d) } & \text { Winter } & 365 & \text { Summer } & 510\end{array}$

\section{SOLAR ENERGY SYSTEM}

Application Heating $0 \%$ Cooling $0 \%$ Hot Water $70 \%$

\section{Collector}

Type: Liquid flat-plate

Area (sq. ft.): 1,008

Manufacturer: Unitspan Architectural Systems, Inc.

Storage

Type: Glass lined steel water tank

Capacity: 1,200 gallons

Auxiliary System Type: Gas boiler

\section{PROJECT DESCRIPTION}

A solar-assisted gas water heater was retrofitted into two El Toro, California apartment buildings. Cost, installation, and performance data are being collected. The data will be used for technical and financial evaluations of the project. The operating costs for systems serving multiple unit buildings are more visible than those for systems serving single family homes. At the same time, multiple unit capital investments are easier to arrange. Cost data from projects such as this will be particularly valuable, helping investors to determine the favorable and unfavorable aspects of investment in multiple unit systems. This project was partially funded by the National Science Foundation. Over $50 \%$ was funded by Southern Eakifornia Gas Company. DOE maintains technical cognizance.
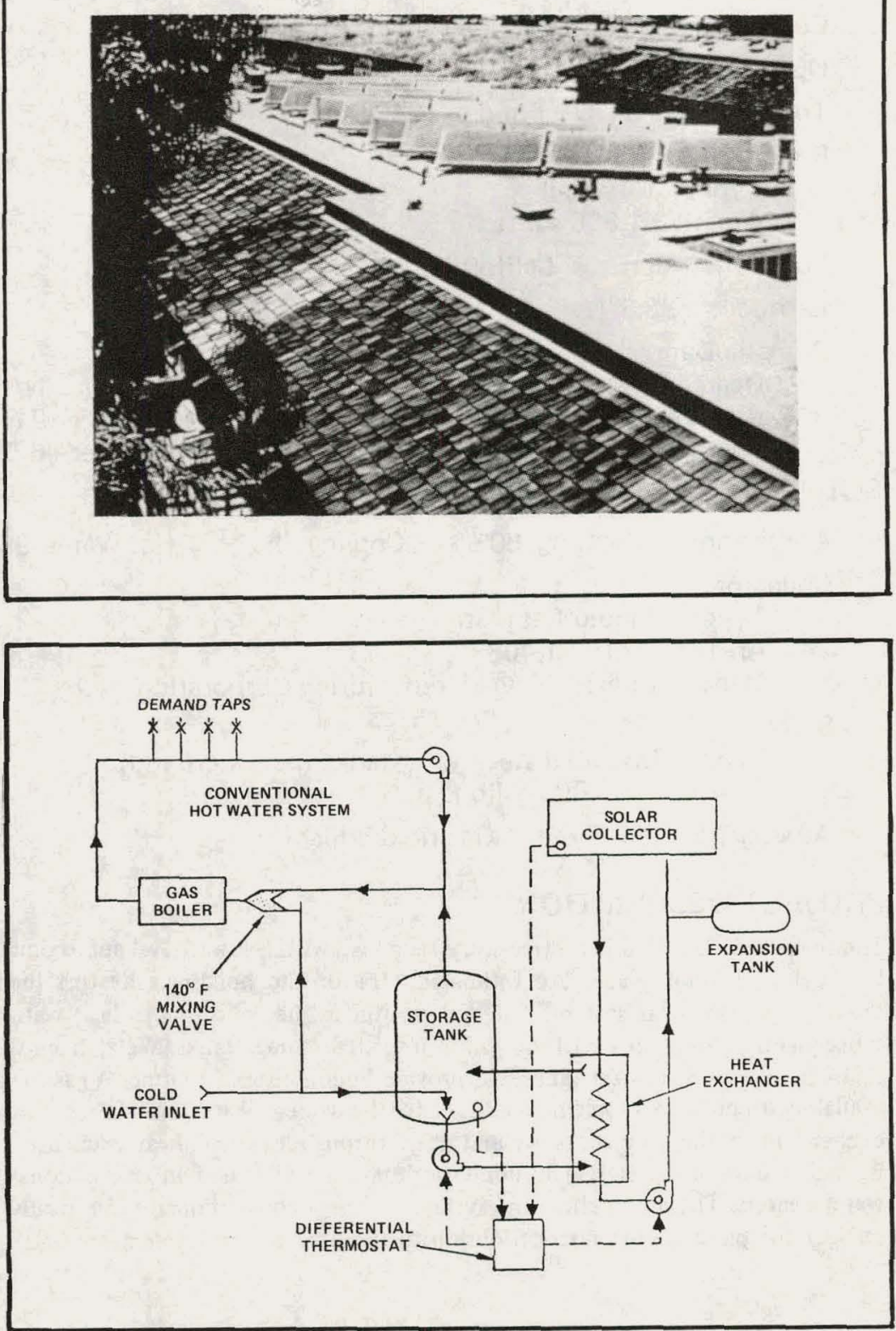


\section{JECT INFORMATION}

Owner/Builder: Orange County

Contractor: Richard Brooks, Jr. and Associates (Architect)

Operational Date: June 1979

Total Estimated DOE Funds: $\quad \$ 117,215$

Building

Type: Library

Area: 10,000 sq. ft.

Location: EI Toro, California

Latitude: $33.8^{\circ} \mathrm{N}$

Climatic Data

$\begin{array}{lllll}\text { Degree Days } & \text { Heating } & 1867 & \text { Cooling } & 759 \\ \text { Avg. Temp. }\left({ }^{\circ} \mathrm{F}\right) & \text { Winter } & 57 & \text { Summer } & 67 \\ \text { Avg. Insol. (Ly/d) } & \text { Winter } & 314 & \text { Summer } & 559\end{array}$

\section{SOLAR ENERGY SYSTEM}

Application Heating 95\% Cooling 60\% Hot Water $0 \%$

Collector

Type: Evacuated glass tubular

Area (sq. ft.): 1,500

Manufacturer: General Electric Company

Storage

Type: Insulated steel water tank (above ground)

Capacity: 1,500 gallons

Auxiliary System Type: Gas fired boiler

\section{PROJECT DESCRIPTION}

The solar system provides heating, cooling, and storage with complete flexibility in operating modes. Both heating and cooling will be provided by drawing hot water from storage. In the cooling mode the hot water will be pumped to an absorption chiller. The air distribution system consists of a single roof-mounted air handler (with hot and cold water coils) plus various fan-coil units. The collectors are flush-mounted on the shake roof with all plumbing and headers (except for valves and air vents) incorporated within the roof structure. The collector slope faces $30^{\circ}$ west of due south. Deionized water is the heat transfer fluid circulated through the collectors. Freeze protection is provided by circulation from storage, during rare periods of freezing ambient temperature. In the event of a power failure, the system automatically drains into the storage tank.
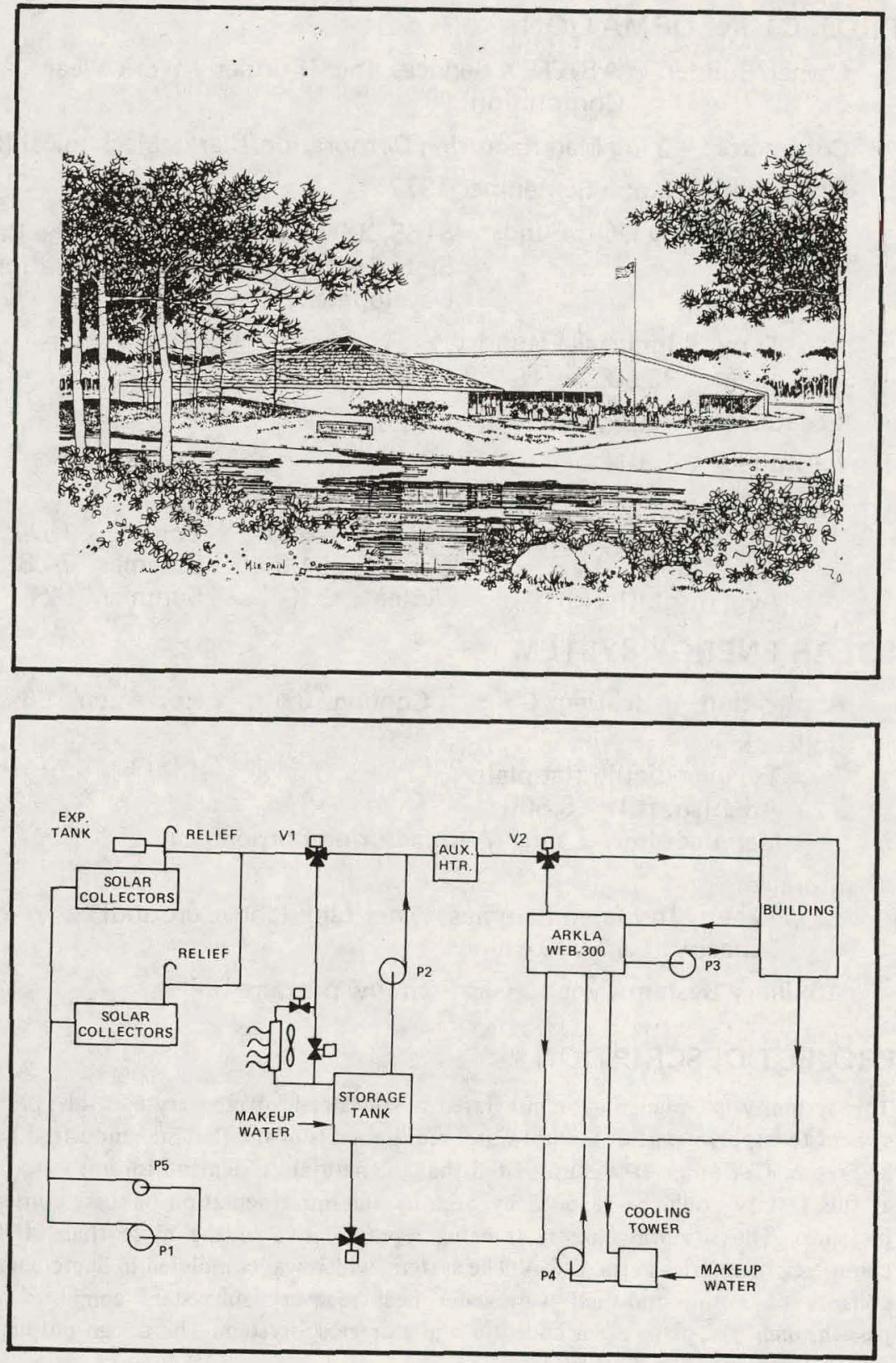


\section{PROJECT INFORMATION}

Owner/Builder: ARATEX Services, Inc. (Formerly Work Wear Corporation)

Contractor: Ying Manufacturing Corporation/Clarke Mechanical Inc.

Operational Date: September 1977

Total Estimated DOE Funds: $\$ 165,000$ (plus $\$ 17,000$ from the California State Energy Resources Conservation and Development Commission)

Building

Type: Industrial laundry

Area: 32,500 sq. ft.

Location: Fresno, California

Latitude: $36.8^{\circ} \mathrm{N}$

Climatic Data

Degree Days

Avg. Temp. $\left({ }^{\circ} \mathrm{F}\right)$

Heating 2650

Cooling 1671

Avg. Insol. (Ly/d)

Summer 74.8

Summer 621

\section{SOLAR ENERGY SYSTEM}

Application Heating $0 \%$ Cooling $0 \%$ Hot Water $56 \%$

Collector

Type: Liquid flat-plate

Area:(sq. ft.): $\quad 6,500$

Manufacturer: Ying Manufacturing Corporation

Storage

Type: Insulated fiberglas water tank (above ground)

Capacity: 12,000 gallons

Auxiliary System Type: Gas fired low pressure boiler

\section{PROJECT DESCRIPTION}

This system was designed as an integrated wastewater heat recovery and solar preheating system to supply a part of the hot water requirements of the Red Star Industrial Laundry in Fresno, California. It was estimated that the natural gas demand for hot water heating at this facility could be reduced by $56 \%$ by the implementation of these conservation measures. The site was chosen as being representative of the more than 2000 large commercial laundries in the U.S.A. The system, which was completed in September 1977, consists of a tube-and-shell wastewater heat recovery subsystem combined with a pass-through flat-plate solar collector and storage subsystem. The design output of the solar subsystem is $2 \times 10^{9} \mathrm{Btu} /$ year.
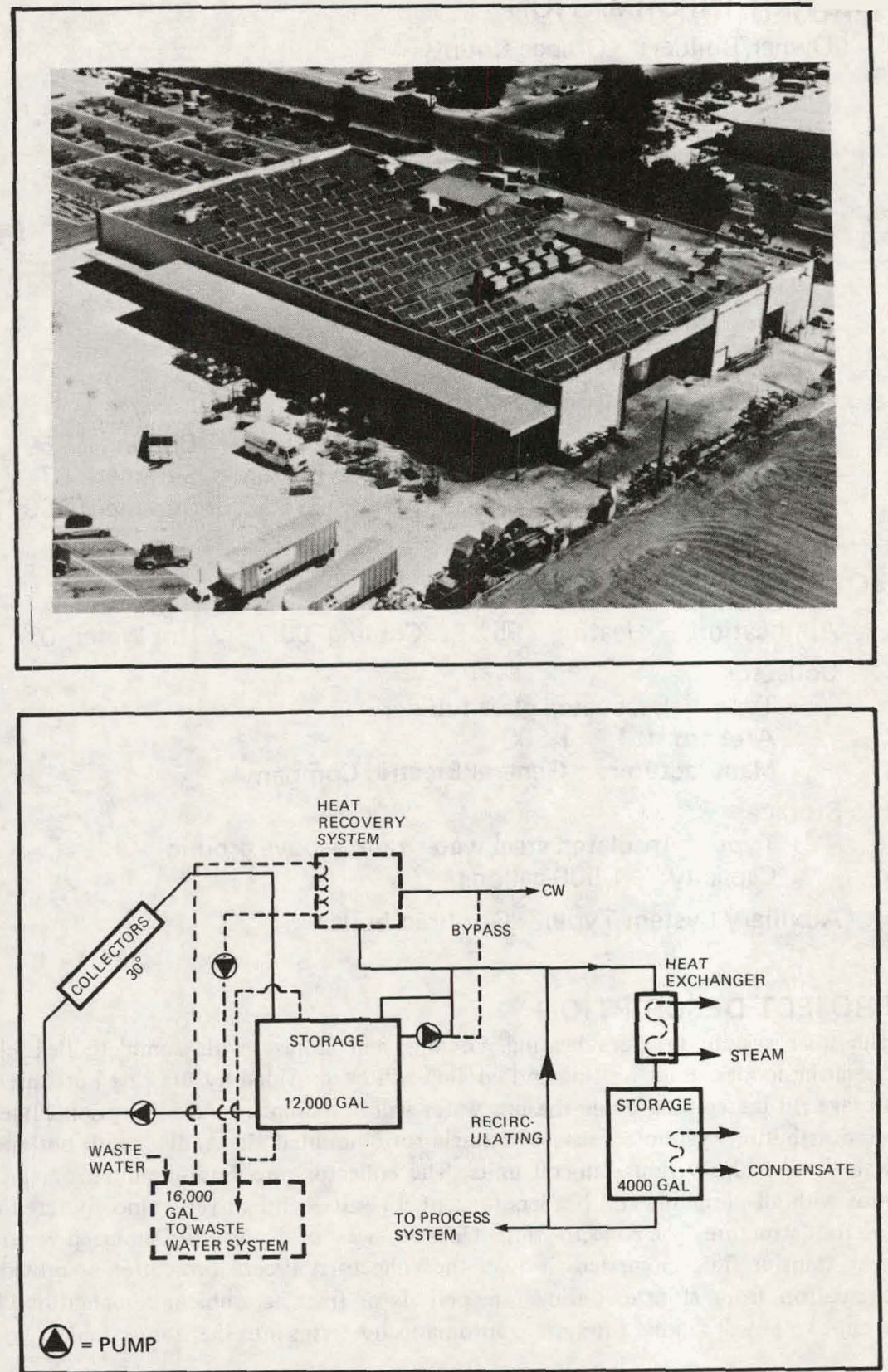


\section{PROJECT INFORMATION}

Owner/Builder: Irvine Unified School District

Contractor: United Air Conditioning

Operational Date: May 1978

Total Estimated DOE Funds: $\quad \mathbf{\$ 2 6 6 , 6 8 0}$

Building

Type: Elementary school

Area: 39,500 sq. ft.

Location: Irvine, California

Latitude: $33.6^{\circ} \mathrm{N}$

Climatic Data

$\begin{array}{lllll}\text { Degree Days } & \text { Heating } & 1355 & \text { Cooling } & 993 \\ \text { Avg. Temp. }\left({ }^{\circ} \mathrm{F}\right) & \text { Winter } & 59.6 & \text { Summer } & 70.1 \\ \text { Avg. Insol. (Ly/d) } & \text { Winter } & 365 & \text { Summer } & 510\end{array}$

\section{SOLAR ENERGY SYSTEM}

\section{Application Heating $\checkmark$}

Collector

\section{Cooling $\checkmark \quad$ Hot Water $0 \%$}

Type: Water cooled evacuated tubular

Area (sq. ft.): $\quad 5,000$

Manufacturer: Owens-Illinois, Inc.

\section{Storage}

Type: None

Capacity: Not applicable

Auxiliary System Type: Gas fired boiler

\section{PROJECT DESCRIPTION}

This project calls for retrofit solar augmentation of the heating and cooling system of the El Camino Real Elementary School. The school is an appropriate subject for the project, because it is new and has good insulation and very few windows. Solar energy is used to drive one of the school's two ARKLA 100-ton absorption chillers. Irvine is also a good location for the project. It has $70 \%$ sunshine during daylight hours, and it is warm enough that the collectors will not require drainage to prevent freezing. The system's working fluid will be demineralized water with environmentally acceptable corrosion inhibitors as the only additives. The water will be stored in a 1500-gallon above-ground storage tank. Hot water from the boiler is fed directly to fancoil units in the various zones within the building. Cool water from the chillers is provided to cooling coils located in 7 plenurns. Fresh air makeup is about $20 \%$.
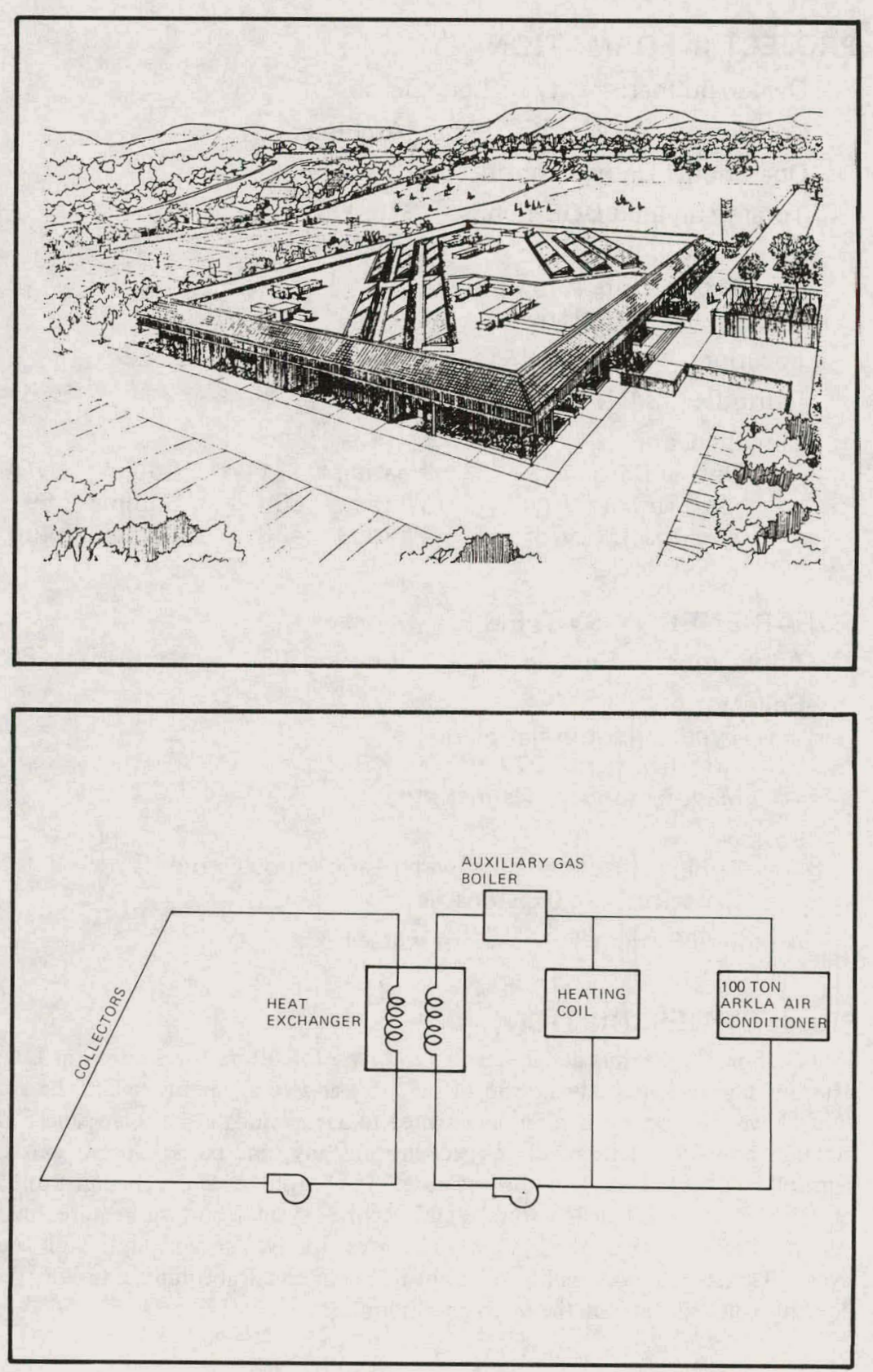


\section{PROJECT INFORMATION}

Owner/Builder: City of Long Beach

Contractor: Richard L. Poper, Architect

Operational Date: October 1978

Total Estimated DOE Funds: $\quad \$ 15,000$

Building

Type: Fire station

Area: 8,000 sq. $\mathrm{ft}$

Location: Long Beach, California

Latitude: $34^{\circ} \mathrm{N}$

Climatic Data

$\begin{array}{lllll}\text { Degree Days } & \text { Heating } & 1711 & \text { Cooling } & \text { N/A } \\ \text { Avg. Temp. }\left({ }^{\circ} \mathrm{F}\right) & \text { Winter } & 63 & \text { Summer } & 69 \\ \text { Avg. Insol. (Ly/d) } & \text { Winter } & 438 & \text { Summer } & 460\end{array}$

\section{SOLAR ENERGY SYSTEM}

Application Heating $66 \%$ Cooling $0 \%$ Hot Water $60 \%$

Collector

Type: Liquid flat-plate

Area (sq. ft.): 277

Manufacturer: Raypak, Inc.

Storage

Type: Insulated steel water tank (above ground)

Capacity: 500 gallons

Auxiliary System Type: Hot water boiler

\section{PROJECT DESCRIPTION}

Fire Station No. 21 was designed as a prototype for future fire stations in Long Beach. The building will house living and office space and an apparatus room. The area of the roof above the apparatus room is designed to accommodate the solar panels. While the system's primary function will be space heating, any time excess capacity exists, the system will be used to heat domestic hot water. The heating system will consist of $277 \mathrm{sq} . \mathrm{ft}$. of solar panels, a 500-gallon storage tank, control system, and the required distribution system. The air side of the system will consist of five fan coil units with economizer cycles. The storage tank will be adjacent to the mechanical equipment room. Pumps and controls will be located in the mechanical room.
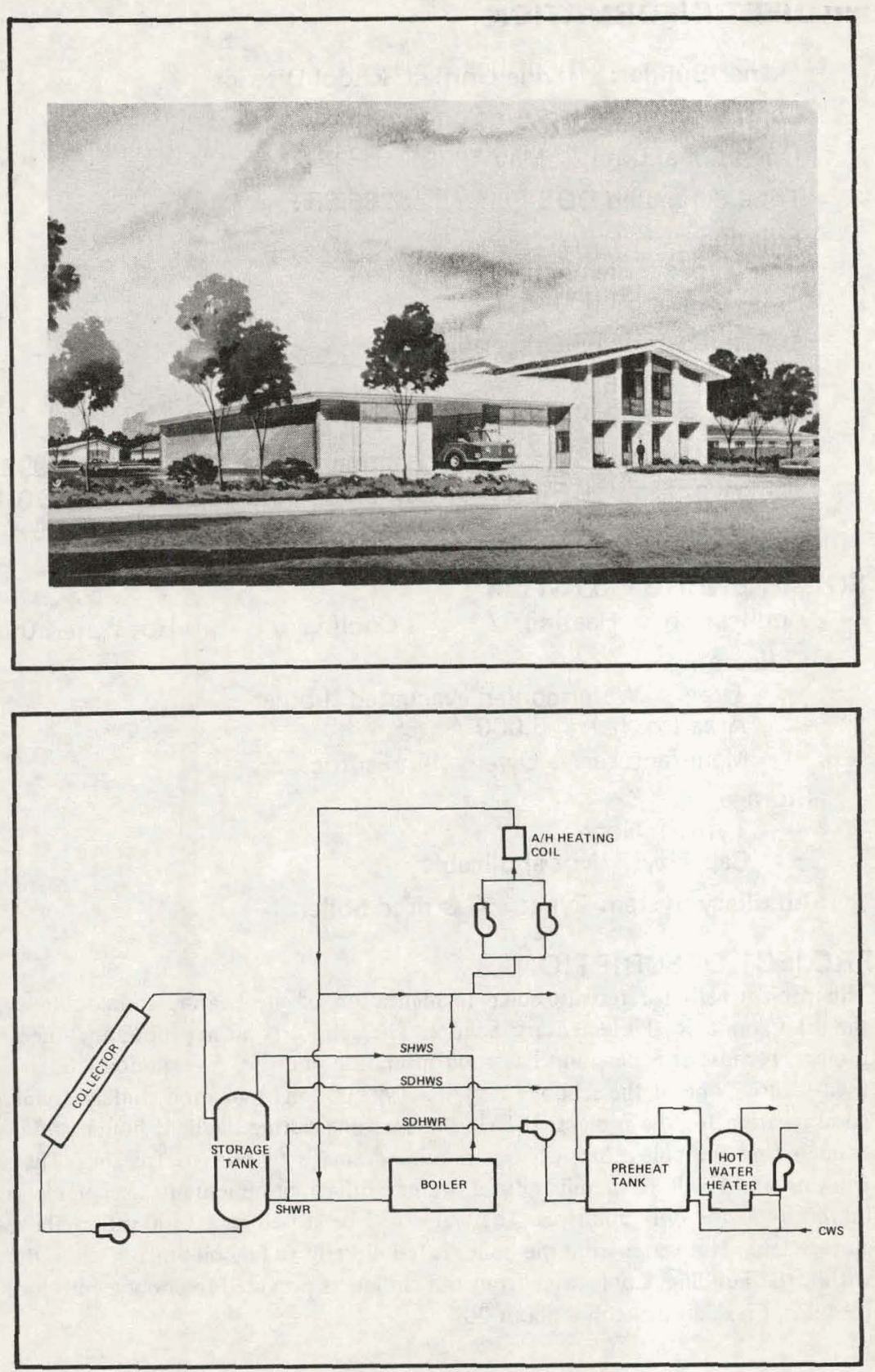


\section{PROJECT INFORMATION}

Owner/Builder: City of Los Angeles

Contractor: City of Los Angeles

Operational Date: September 1978

Total Estimated DOE Funds: $\quad \$ 230,215$

Building

Type: Police station

Area: 24,600 sq. ft.

Location: Los Angeles, California

Latitude: $\quad 34^{\circ} \mathrm{N}$

Climatic Data

$\begin{array}{lllll}\text { Degree Days } & \text { Heating } & 2061 & \text { Cooling } & \text { N/A } \\ \text { Avg. Temp. }\left({ }^{\circ} \mathrm{F}\right) & \text { Winter } & 67 & \text { Summer } & 78 \\ \text { Avg. Insol. (Ly/d) } & \text { Winter } & 260 & \text { Summer } & 606\end{array}$

\section{SOLAR ENERGY SYSTEM}

Application Heating 65\%

Collector

Type: Liquid flat-plate

Area (sq. ft.): $\quad 6,600$

Manufacturer: Solargenics, Inc.

Storage

Type: Type: Insulated glass lined steel water tanks (underground) Capacity: 16,630 gallons

Auxiliary System Type: Hydronic

\section{PROJECT DESCRIPTION}

The building selected for installation of a solar heating, hot water and off-peak cooling system is the Wilshire Division Station of the Los Angeles Police Department. The Venice Division Station is an identical building located four miles away and will be monitored for comparison purposes. The buildings are windowless, having solid concrete walls with a brick veneer. Both have a substantial hot water load, due to 24-hour occupancy with policemen using showers between shifts. The storage tanks will be mounted vertically to achieve a high degree of stratification.
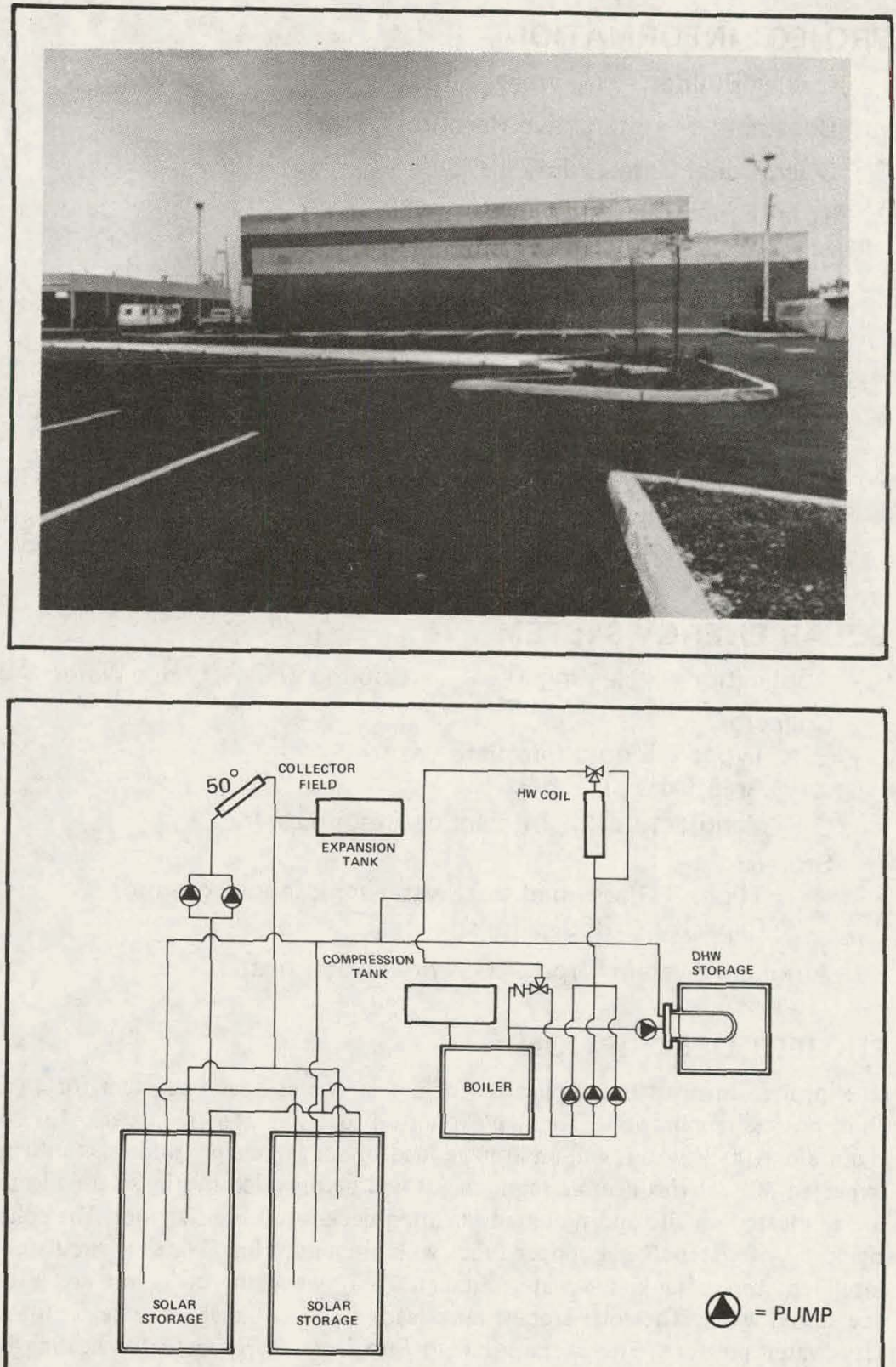


\section{PROJECT INFORMATION}

Owner/Builder: Iris Images, Inc.

Contractor: Interactive Resources, Inc.

Operational Date: July 1976

Total Estimated DOE Funds: $\$ 35,154$

Building

Type: Film laboratory

Area: 3,700 sq. ft.

Location: Mill Valley, California

Latitude: $37.9^{\circ} \mathrm{N}$

Climatic Data

$\begin{array}{lllll}\text { Degree Days } & \text { Heating } & 2970 & \text { Cooling } 530 \\ \text { Avg. Temp. }\left({ }^{\circ} \mathrm{F}\right) & \text { Winter } & 55.0 & \text { Summer } 72.2 \\ \text { Avg. Insol. (Ly/d) } & \text { Winter } & 294 & \text { Summer } & 531\end{array}$

\section{SOLAR ENERGY SYSTEM}

Application Heating $0 \%$

Collector

Type: Liquid flat-plate

Area (sq. ft.): 640

Manufacturer: Interactive Resources, Inc.

Storage

Type: Glass lined steel water tank (above ground)

Capacity: 360 gallons

Auxiliary System Type: Gas fired water heater

\section{PROJECT DESCRIPTION}

The project involves the application of a solar water heating system for an industrial film process application. The lab's photo processors require a peak 12 gallons per minute of $100^{\circ} \mathrm{F}$ water, and an average load of six gallons per minute is anticipated. An expected $59 \%$ of this heating requirement will be provided by the solar collectors which are fabricated on site and mounted on tilted decks atop the flat roof. The collectors are made up of water-cooled copper tubes with aluminum fins. Water is circulated from an insulated storage tank, the water circulates only when the collectors are warmer than the stored water. The solar storage tank feeds a conventional water heater under normal city water pressure. The average rate of auxiliary energy used for heating hot water should be no greater than $129,000,000 \mathrm{Btu} /$ month. The system has been designed to allow for public viewing without disturbing the operation of the lab.
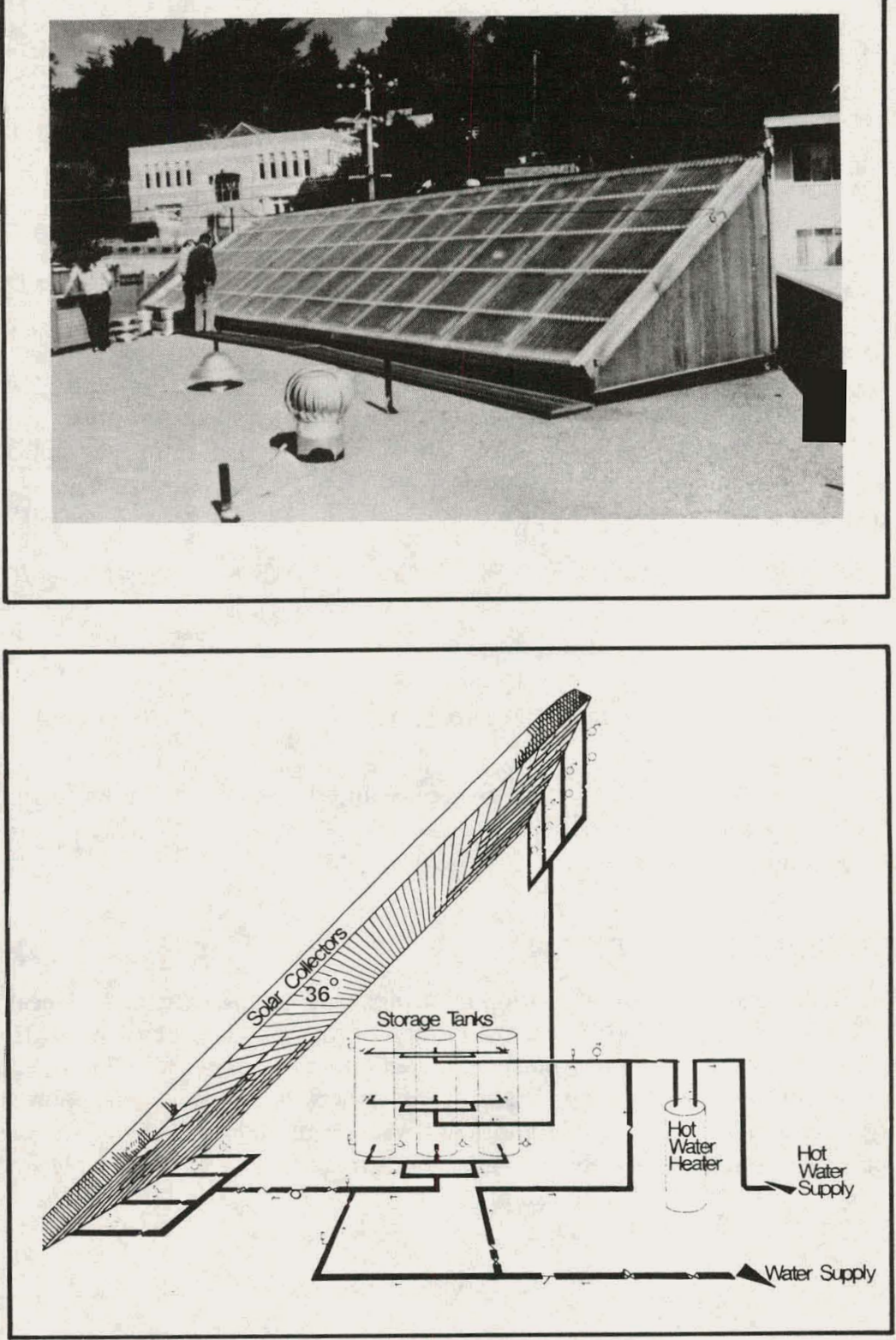
Owner/Builder: Rodeway Inns of America \& R. V. Development Company Contractor: Charter Builders, Inc.

\section{Operational Date: July 1978}

Total Estimated DOE Funds: $\quad \$ 58,922$

Building

Type: Low rise motel

Area: Not applicable to hot water systems

Location: North Highlands, California

Latitude: $39^{\circ} \mathrm{N}$

Climatic Data

$\begin{array}{lllll}\text { Degree Days } & \text { Heating } & 2971 & \text { Cooling } & 1654 \\ \text { Avg. Temp. }\left({ }^{\circ} \mathrm{F}\right) & \text { Winter } & 49.7 & \text { Summer } & 84 \\ \text { Avg. Insol. (Ly/d) } & \text { Winter } & 236 & \text { Summer } & 486\end{array}$

\section{SOLAR ENERGY SYSTEM}

Application Heating $0 \%$

Collector

Type: Liquid flat-plate

Area (sq. ft.): 3,000

Manufacturer: Raypak, Inc.

Storage

Type: Insulated steel water tank

Capacity: 2,000 gallons

Auxiliary System Type: Gas boiler

\section{PROJECT DESCRIPTION}

Each time the circulation pump stops in the collection loop of this system, water drains out of the collector array into a compression tank in the enclosed mechanical room. Makeup water is provided to the system, thus introducing minerals and acids, but the quantity of these undesirable substances is very low compared to that which would be introduced with a direct link between storage and the solar collectors.
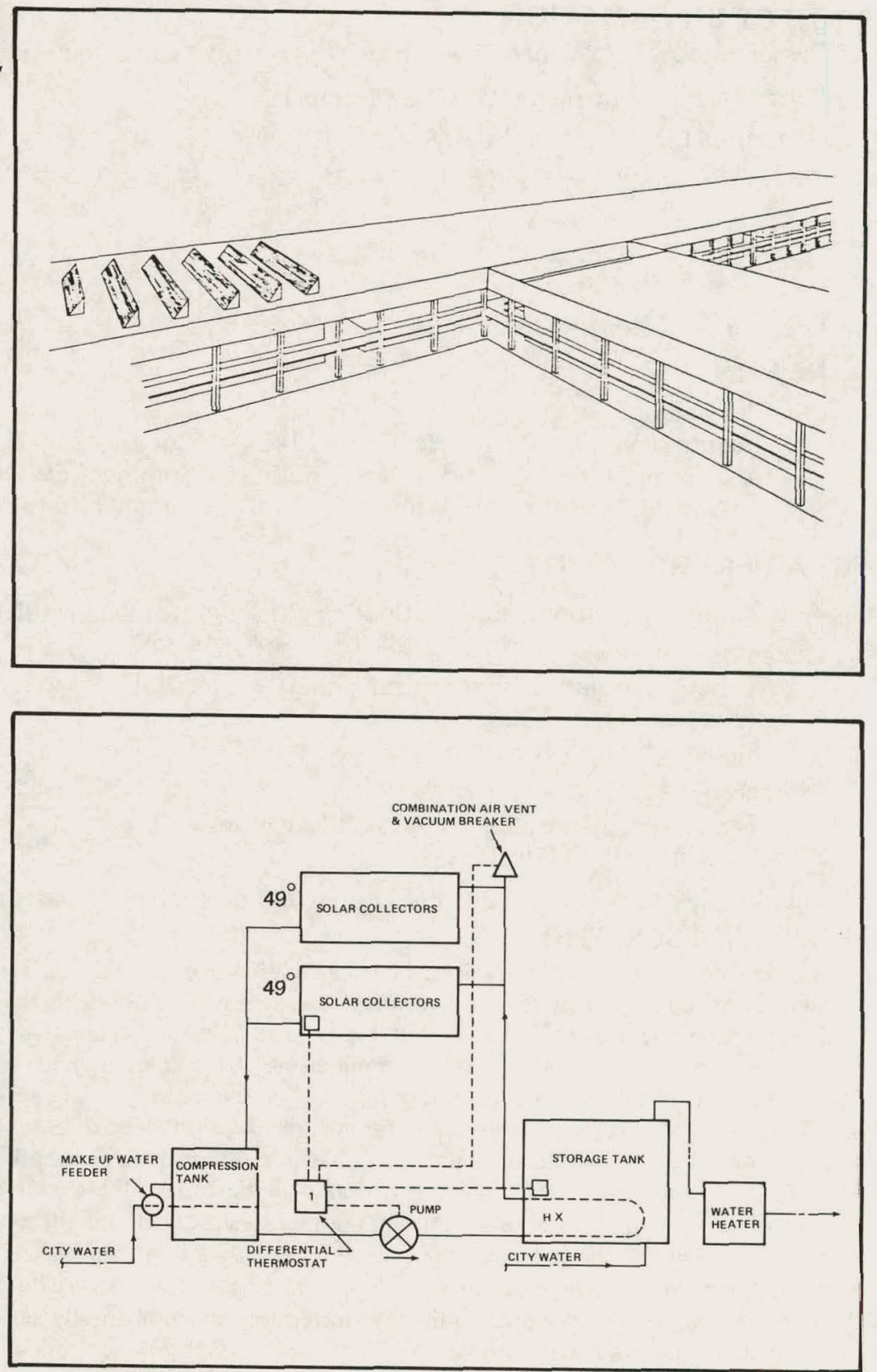


\section{PROJECT INFORMATION}

Owner/Builder: Norman Brock/Ridgeline Racquet Club, Inc.

Contractor: Controlco (HVAC contractor)

Operational Date: March 1978

Total Estimated DOE Funds: $\quad \$ 177,682$

Building

Type: Clubhouse

Area: $10,650 \mathrm{sq} . \mathrm{ft}$.

Location: Orange, California

Latitude: $34^{\circ} \mathrm{N}$

Climatic Data

Degree Days

Avg. Temp. $\left({ }^{\circ} \mathrm{F}\right)$

Avg. Insol. (Ly/d)

$\begin{array}{llll}\text { Heating } & 1245 & \text { Cooling } & 1185 \\ \text { Winter } & 60.5 & \text { Summer } & 69.1 \\ \text { Winter } & 474.8 & \text { Summer } & 543.4\end{array}$

\section{SOLAR ENERGY SYSTEM}

Application Heating 95\%

Cooling $70 \%$

Hot Water

$95 \%$

Collector

Type: Liquid tracking concentrating

Area (sq. ft.): 3,300

Manufacturer: Northrup, Inc.

Storage

Type: Insulated steel water tank (underground)

Capacity: 5,000 gallons

Auxiliary System Type: Gas fired boiler and domestic hot water heater

\section{PROJECT DESCRIPTION}

During the summer months, this solar system provides cooling through an absorption machine located in a "sheltered" room. When the system is indexed to the heating (winter) position, the solar cooling is de-activated and the collectors begin providing space heating hot water as well as providing the requirements of the domestic hot water load. Should freezing conditions occur, a sensor in the collector arrays will override the collector pump controls and circulate water through the collectors. The collector tracking motor is controlled by two silicon cells set on a base at a $60^{\circ}$ angle to one another facing the sun. When one cell receives more radiation than the other, the circuit becomes unbalanced and the driving motor operates in the appropriate direction until equilibrium is restored by pointing the cells (and the collectors) directly into the sun. The maximum expected temperature under no flow conditions will be (in steady state) the ambient temperature. This is primarily because the tracking device will automatically de-focus the collectors under no flow conditions.
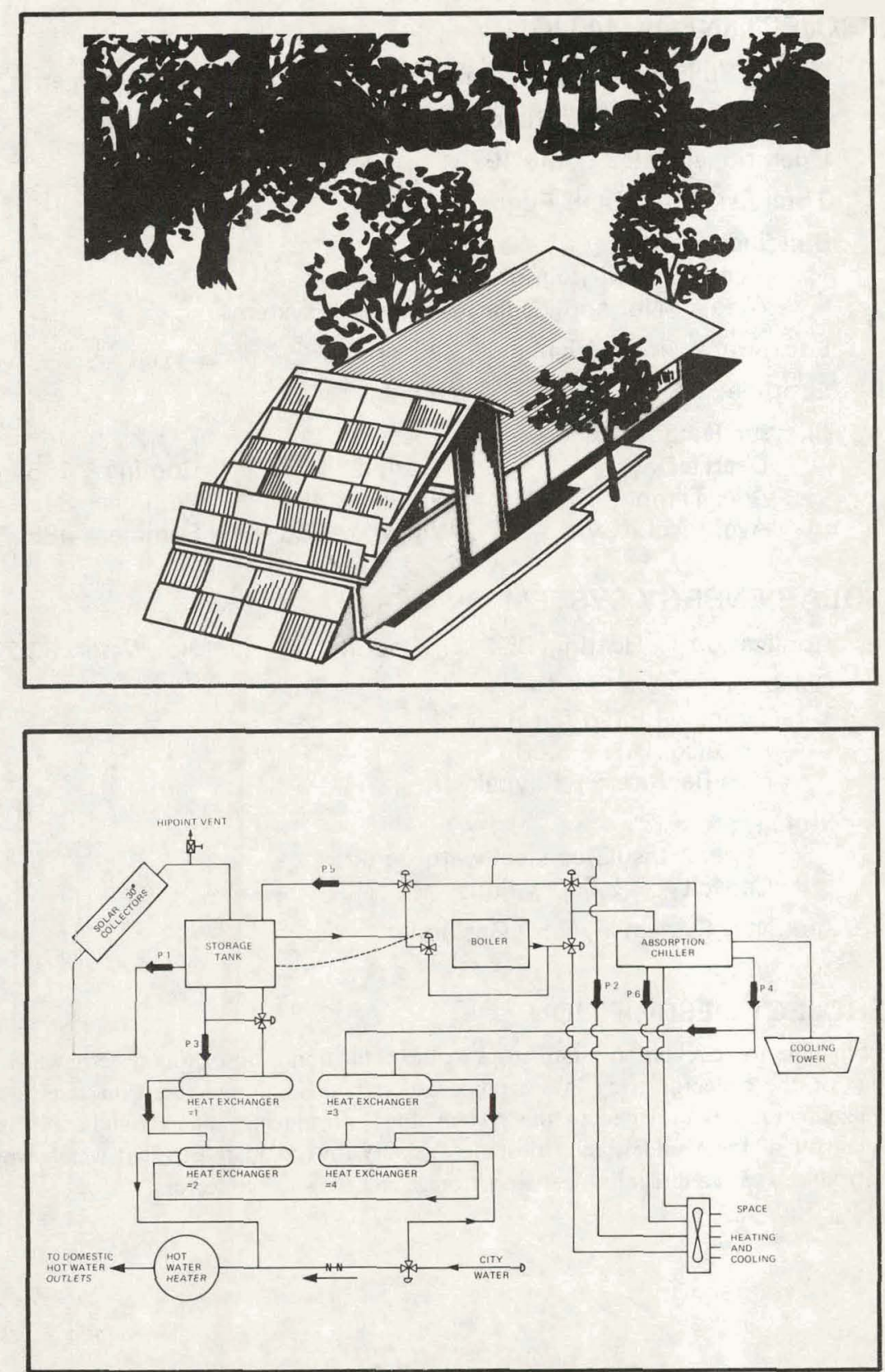


\section{PROJECT INFORMATION}

Owner/Builder: San Diego Unified School District

Contractor: Hugh Carter Engineering

Operational Date: July 1979

Total Estimated DOE Funds: $\$ 392,740$

Building

Type: High school

Area: $\quad 185,000$ sq. ft. $(40,000$ sq. ft. cooling only)

Location: San Diego, California

Latitude: $32.75^{\circ} \mathrm{N}$

Climatic Data

$\begin{array}{lllll}\text { Degree Days } & \text { Heating } & 1439 & \text { Cooling } 700 \\ \text { Avg. Temp. }\left({ }^{\circ} \mathrm{F}\right) & \text { Winter } & 55 & \text { Summer } & 71 \\ \text { Avg. Insol. (Ly/d) } & \text { Winter } & 256 & \text { Summer } & 483\end{array}$

\section{SOLAR ENERGY SYSTEM}

\section{Application Heating $75 \%$ Cooling $71 \%$ Hot Water $90 \%$}

\section{Collector}

Type: Parabolic/concentrating

Area (sq. ft.): $14,680 / 2,328$

Manufacturer: Solartec Corporation/Northrup, Inc.

\section{Storage}

Type: Insulated steel water tanks (underground)

Capacity: 99,900 gallons

Auxiliary System Type: Convertible gas and oil fired boilers, electric cooling.

\section{PROJECT DESCRIPTION}

The school site is approximately 80 acres of land typical of the Southern California coastal terrain with arrays cutting into relatively flat mesas. The solar collector field will be located on a south facing hill which forms a backdrop for the four, one-story buildings. For maximum solar augmentation of energy requirements, the mechanical design favors a central heating and cooling plant adjacent to the solar collection field. An enthalpy controlled economizer cycle will be used at each building. Air handling units with variable volume air valves for each zone will supply air for the space heating and cooling loads. A time clock control system insures that the buildings are not heated or cooled when they are vacant. A one-half to one-hour morning preheat cycle closes outside air and recirculates $100 \%$. The return air passes through the lighting units which lessens the light heat rejected to the space and reduces supply volume equipment size and operating costs. The solar panels are sized to provide an expected overall annual $70-80 \%$ thermal energy savings.

Photograph not available

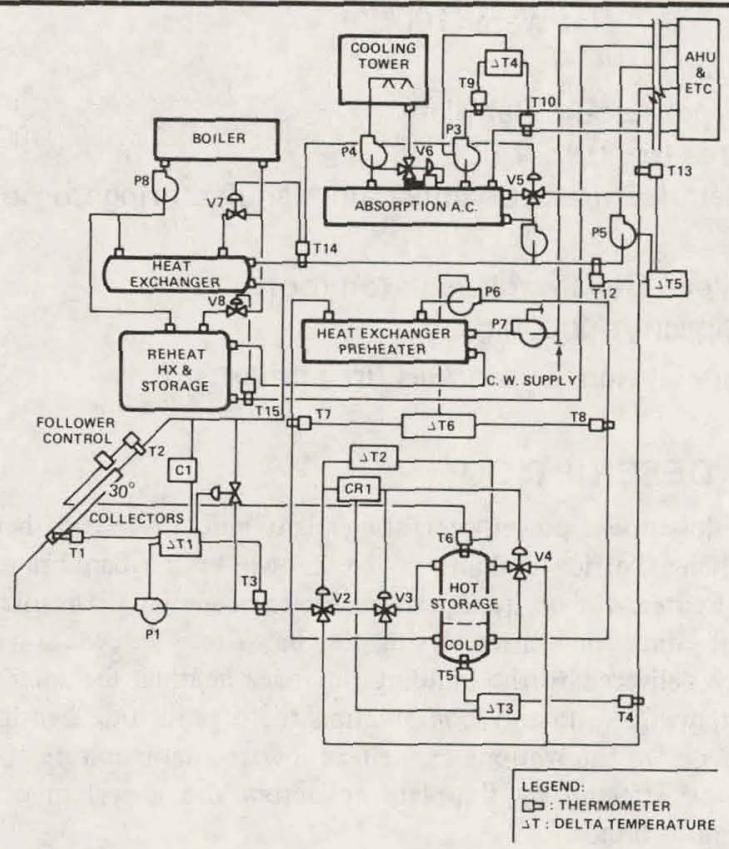




\section{PROJECT INFORMATION}

Owner/Builder: Storek \& Storek

Contractor: Berkeley Solar Group

Operational Date: October 1979

Total Estimated DOE Funds: $\$ 138,866$

Building

Type: Office

Area: $\quad 55,000$ sq. ft.

Location: San Francisco, California

Latitude: $37.5^{\circ} \mathrm{N}$

Climatic Data

$\begin{array}{lllll}\text { Degree Days } & \text { Heating } & 3200 & \text { Cooling } & 130 \\ \left.\text { Avg. Temp. ( }{ }^{\circ} \mathrm{F}\right) & \text { Winter } & 51 & \text { Summer } & 59 \\ \text { Avg. Insol. (Ly/d) } & \text { Winter } & 150 & \text { Summer } & 700\end{array}$

\section{SOLAR ENERGY SYSTEM}

Application Heating 57\% (active); $23 \%$ (passive) Cooling 0\% Hot Water $100 \%$

\section{Collector}

Type: Liquid flat-plate

Area (sq. ft.): 1,800

Manufacturer: Chamberlain Manufacturing Corporation

Storage

Type: Steel water tank (on roof)

Capacity: 3,000 gallons

Auxiliary System Type: Gas fired boiler

\section{PROJECT DESCRIPTION}

An obsolete downtown power generating plant built in 1916 is being reconstructed as an energy-efficient office building to be known as the San Francisco Environmental Center. The Center will be headquarters for environmental organizations and a public environmental education center serving the Bay Area. The windows supply 23\% of the annual energy delivered to the building for space heating, the solar collectors $57 \%$, and auxiliary systems $20 \%$. Energy conservation features include lighting, HVAC, elevator, and envelope design innovations as well as lowered temperature standards. Solar space heating will be effected by flat-plate collectors and a system of variable reflective/ absorbent window blinds.
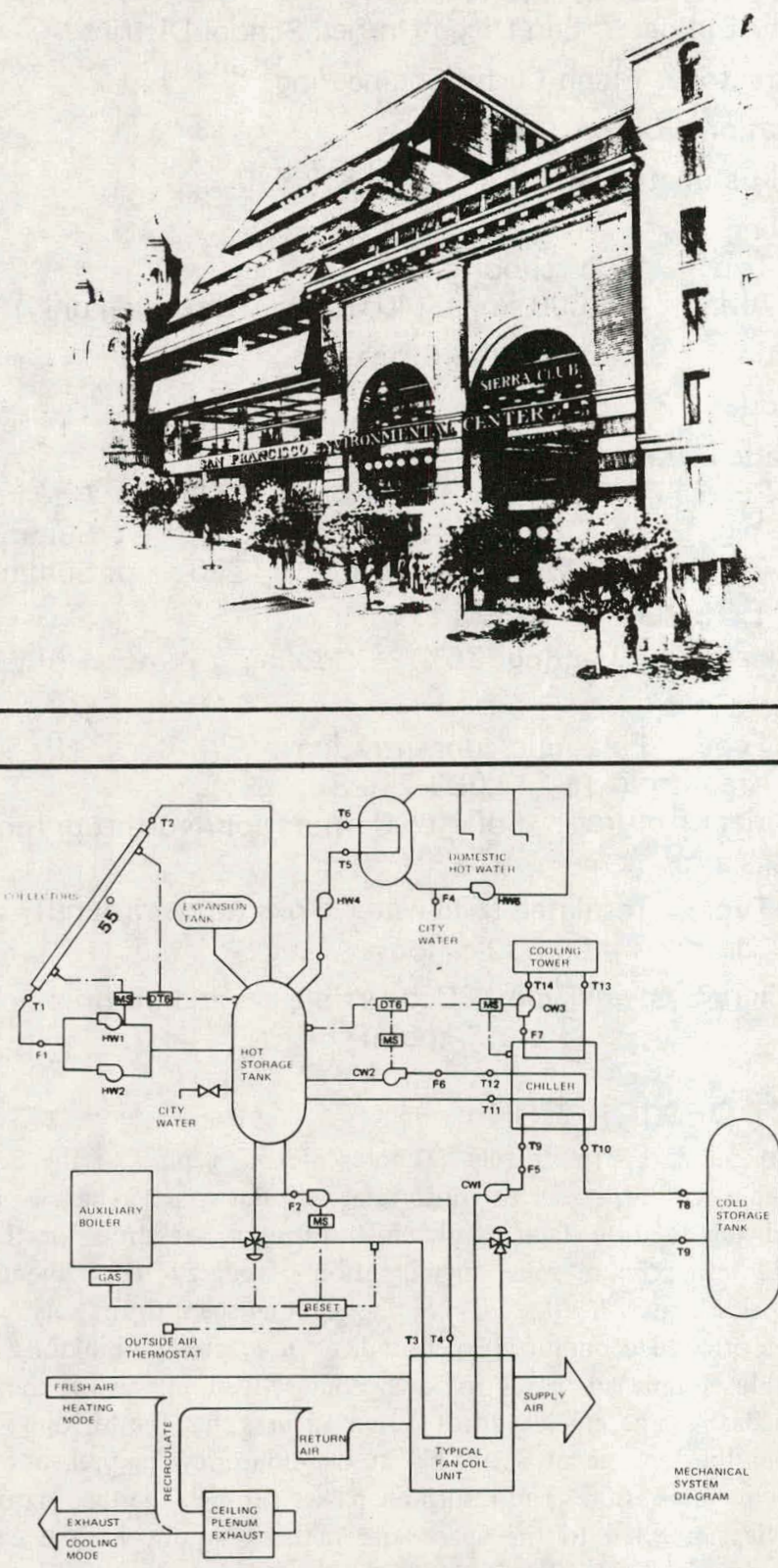


\section{PMOJECT INFORMATION}

Owner/Builder: Oak Grove School District

Solar System Designer: McCaughey \& Smith Energy Associates

Operational Date: October 1978

Total Estimated DOE Funds: $\quad \$ 318,615$

Building

Type: Elementary school

Area: 34,650 sq. $\mathrm{ft}$.

Location: San Jose, California

Latitude: $37^{\circ} \mathrm{N}$

Climatic Data

Degree Days

Avg. Temp. $\left({ }^{\circ} \mathrm{F}\right)$

Avg. Insol. (Ly/d)

$\begin{array}{llll}\text { Heating } & 2416 & \text { Cooling } & 443 \\ \text { Winter } & 54 & \text { Summer } & 65 \\ \text { Winter } & 313 & \text { Summer } & 570\end{array}$

\section{SOLAR ENERGY SYSTEM}

Application Heating $85 \%$

Cooling 55\%

Hot Water $0 \%$

Collector

Type: Unevacuated glass tubular

Area (sq. ft.): 5,184

Manufacturer: KTA Corporation

\section{Storage}

Type: Insulated steel water tank (above ground)

Capacity: 2,000 gallons

Auxiliary System Type: Gas fired absorption chiller and boiler

\section{PROJECT DESCRIPTION}

The solar collectors for this building will be distributed within the space between the existing rooftop equipment. Five thousand sq. ft. of collectors can be accommodated with proper manifolding and without interfering with the existing equipment. Two of the five existing chillers will be replaced. These chillers will operate on hot water pumped directly from the collectors or alternately from storage. Chillers 1 and 2 will usually be capable of handling the in-phase load during periods of moderate to high insolation. Chillers 3,4 , and 5 will be used on demand in sequence when chillers 1 and 2 cannot meet the load due to lack of insolation or extremely high demand for cooling. Space heating will be provided from storage when the system is in the heating mode. During periods when the solar collectors are over-supplying heat, the storage tank will first accept heat to a temperature of $210^{\circ} \mathrm{F}$. Any additional heat will be rejected by means of air cooled radiators. During vacation periods, the collectors will be drained into the storage tank.
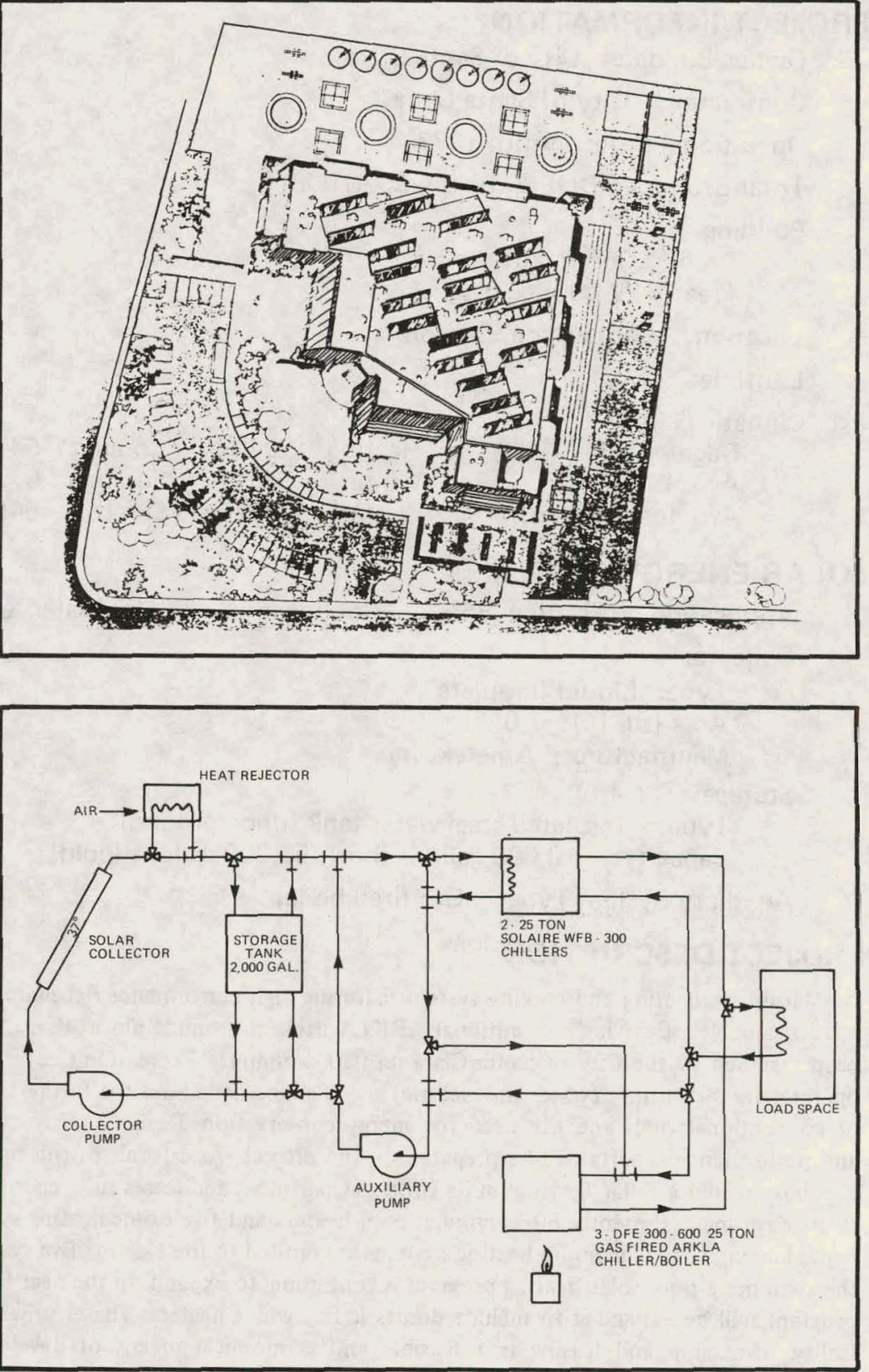


\section{PROJECT INFORMATION}

Owner/Builder: City of Santa Clara

Contractor: City of Santa Clara

Operational Date: April 1977

Total Estimated DOE Funds: $\quad \$ 670,000$

Building

Type: Community center

Area: 27,000 sq. $\mathrm{ft}$.

Location: Santa Clara, California

Latitude: $37.3^{\circ} \mathrm{N}$

Climatic Data

Degree Days

Avg. Temp. $\left({ }^{\circ} \mathrm{F}\right)$

Heating

Avg. Insol. (Ly/d)
2943

54.6

Winter 308

Cooling 647

Summer 67.6

Summer 545

\section{SOLAR ENERGY SYSTEM}

Application Heating $85 \%$

\section{Cooling $65 \%$}

Hot Water $\sqrt{ }$

Collector

Type: Liquid flat-plate

Area (sq. ft.): 7,085

Manufacturer: Ametek, Inc.

Storage

Type: Insulated steel water tank (underground)

Capacity: 10,000 gallons (hot); 50,000 gallons (cold)

Auxiliary System Type: Gas fired boiler

\section{PROJECT DESCRIPTION}

A solar-driven heating and cooling system featuring high performance flat-plate solar collectors capable of driving conventional ARKLA lithium bromide absorption chillers has been installed by the City of Santa Clara on its Community Recreation Center. The city operates its own utility (water and electric) and is concerned about the future availability of conventional fuels and the need for energy conservation. Design, construction, legal and performance reports will be prepared on the project. As a result of this project, the city has created a Solar Division in its Utility Department and leases solar energy systems to its customers. Presently 80 swimming pool heaters and five home heating systems are being leased. The solar home heating systems are limited to the existing five systems, but the swimming pool solar heating program is continuing to expand. In the near future, the program will be expanded to include domestic hot water heaters. The city believes that utility ownership and leasing is a feasible and economical means of developing and utilizing solar energy.
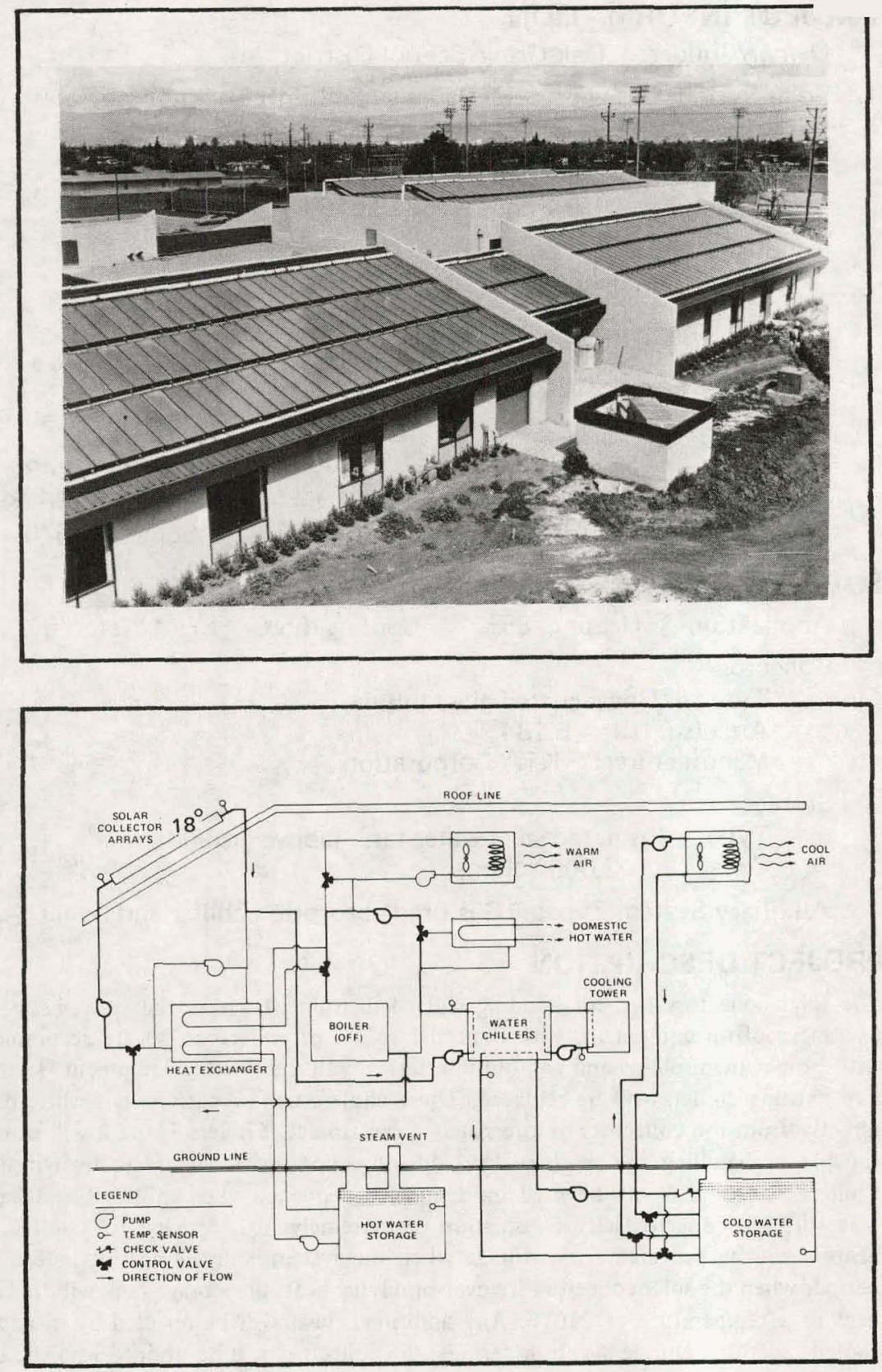


\section{OJECT INFORMATION}

Owner/Builder: Renault \& Handley

Contractor: Renault \& Handley

Operational Date: June 1978

Total Estimated DOE Funds: $\quad \$ 150,834$

Building

Type: Industrial buildings

Area: 105,000 sq. $\mathrm{ft}$.

Location: Santa Clara, California

Latitude: $37 \frac{1}{2} \mathrm{~N}$

Climatic Data

$\begin{array}{lllll}\text { Degree Days } & \text { Heating } & 2950 & \text { Cooling } & 420 \\ \text { Avg. Temp. }\left({ }^{\circ} \mathrm{F} \text { ) }\right. & \text { Winter } & 50 & \text { Summer } & 67 \\ \text { Avg. Insol. (Ly/d) } & \text { Winter } & 225 & \text { Summer } & 600\end{array}$

\section{SOLAR ENERGY SYSTEM}

\section{Application Heating 85\%}

Cooling $0 \%$

Hot Water $90 \%$

\section{Collector}

Type: Liquid flat-plate (active); concrete wall (passive)

Area (sq. ft.): $\quad 5,006$ (active); 2,800 (passive)

Manufacturer: Revere Copper \& Brass, Inc.

\section{Storage}

Type: Insulated steel water tank (above ground)

Capacity: 13,000 gallons

Auxiliary System Type: Natural gas boiler

\section{PROJECT DESCRIPTION}

Energy conservation was the starting point of the planning and architecture for this $\mathrm{R} \& \mathrm{D} /$ light manufacturing facility. This large demonstration project features a passive south wall collector in addition to an active system which will provide approximately $85 \%$ of the annual heating requirements from solar. The design was made compatible for a cooling absorption system which may be added later. A unique solar panel support provides a roof canopy at $45^{\circ}$. There will be $5006 \mathrm{sq}$. ft. of flat-plate high performance collectors and 2800 sq. ft. of passive collectors mounted on the south wall. An overhang at the south wall protects the passive collectors in the summer. The roof is highly insulated (R19) and the glass is thermopane. Landscaping complements the energy design with deciduous trees shading portions of the building from heat during the summer and allowing sun heat during the winter. Current standard construction methods were utilized for the design to keep costs competitive and insure predictability of maintenance expenses.
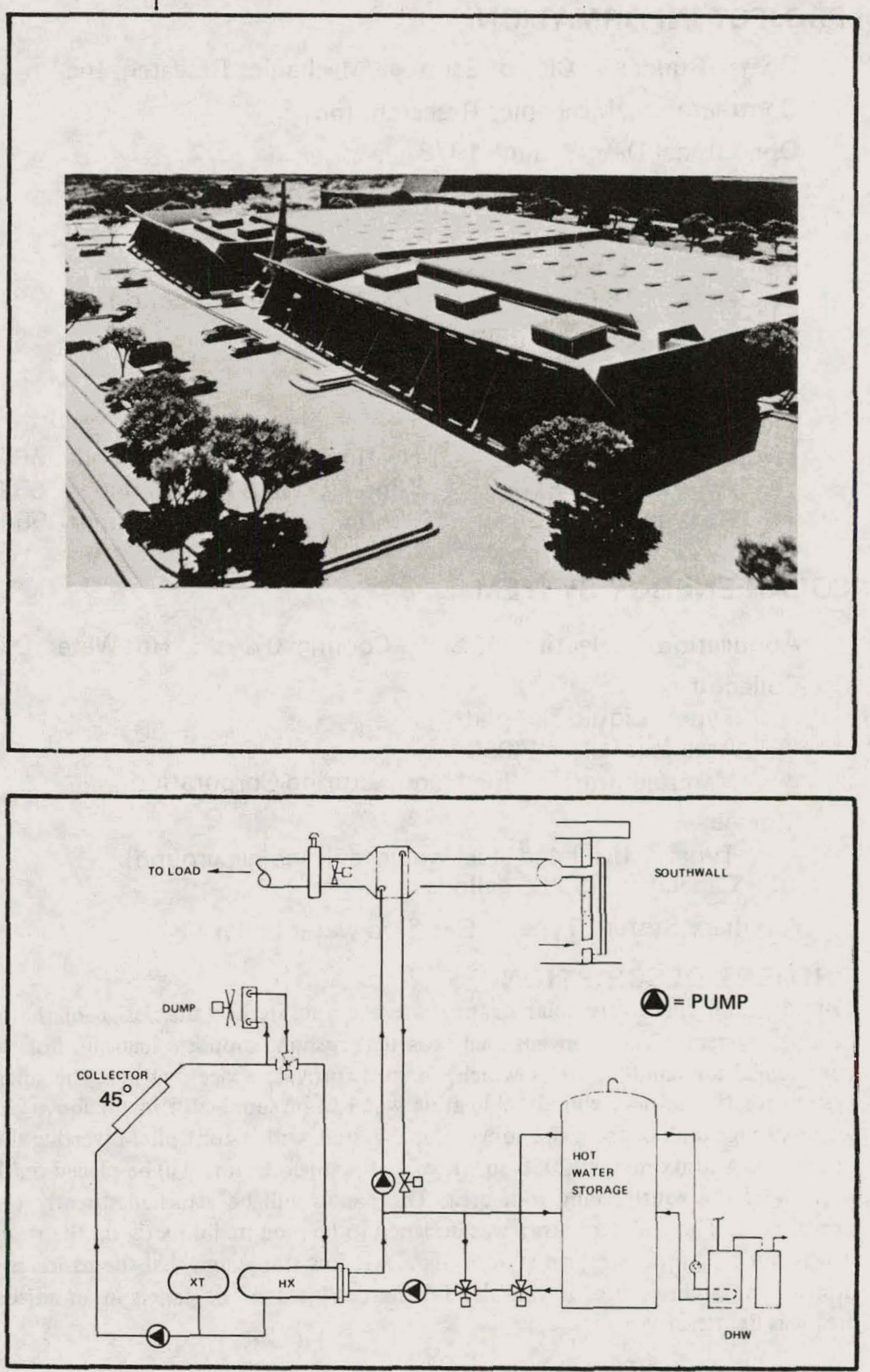


\section{PROJECT INFORMATION}

Owner/Builder: City of Saratoga/Mechanics Research, Inc.

Contractor: Mechanics Research, Inc.

Operational Date: June 1978

Total Estimated DOE Funds: $\$ \mathbf{8 8 , 3 8 9}$

Building

Type: Library

Area: 18,000 sq. ft. (total); 16,600 sq. ft. (cond.)

Location: Saratoga, California

Latitude: $37.3^{\circ} \mathrm{N}$

Climatic Data

$\begin{array}{lllll}\text { Degree Days } & \text { Heating } & 2794 & \text { Cooling } & 565 \\ \text { Avg. Temp. }\left({ }^{\circ} \mathrm{F} \text { ) }\right. & \text { Winter } & 50.8 & \text { Summer } & 65.6 \\ \text { Avg. Insol. (Ly/d) } & \text { Winter } & 231 & \text { Summer } & 554\end{array}$

\section{SOLAR ENERGY SYSTEM}

Application Heating 45\%

Cooling $0 \%$

Hot Water $0 \%$

Collector

Type: Liquid flat-plate

Area (sq. ft.): 2,050

Manufacturer: Ying Manufacturing Corporation Storage

Type: Insulated steel water tank (above ground)

Capacity: 3,700 gallons

Auxiliary System Type: Gas fired water boiler

\section{PROJECT DESCRIPTION}

Consideration for future solar heating was incorporated in the design of the building's heating system. The conventional heating system supplies heating hot water to commercial air handling units which, in turn, provide space heating. The solar heating system for this project will allow heating water to be supplied from an above ground hot water storage tank or from the conventional system with a controller diverting the flow as necessary. Approximately 2050 sq. ft. of flat-plate collectors will be placed on the major portion of the south-facing roof area. The panels will be attached directly to the $22^{\circ}$ sloped roof. The collector array was designed to be mounted directly on the roof because it was felt that most western style roofs are at low slopes and that the panels should not destroy the architecture. It was also felt that a "garden" of panels in an adjacent open area was unattractive.
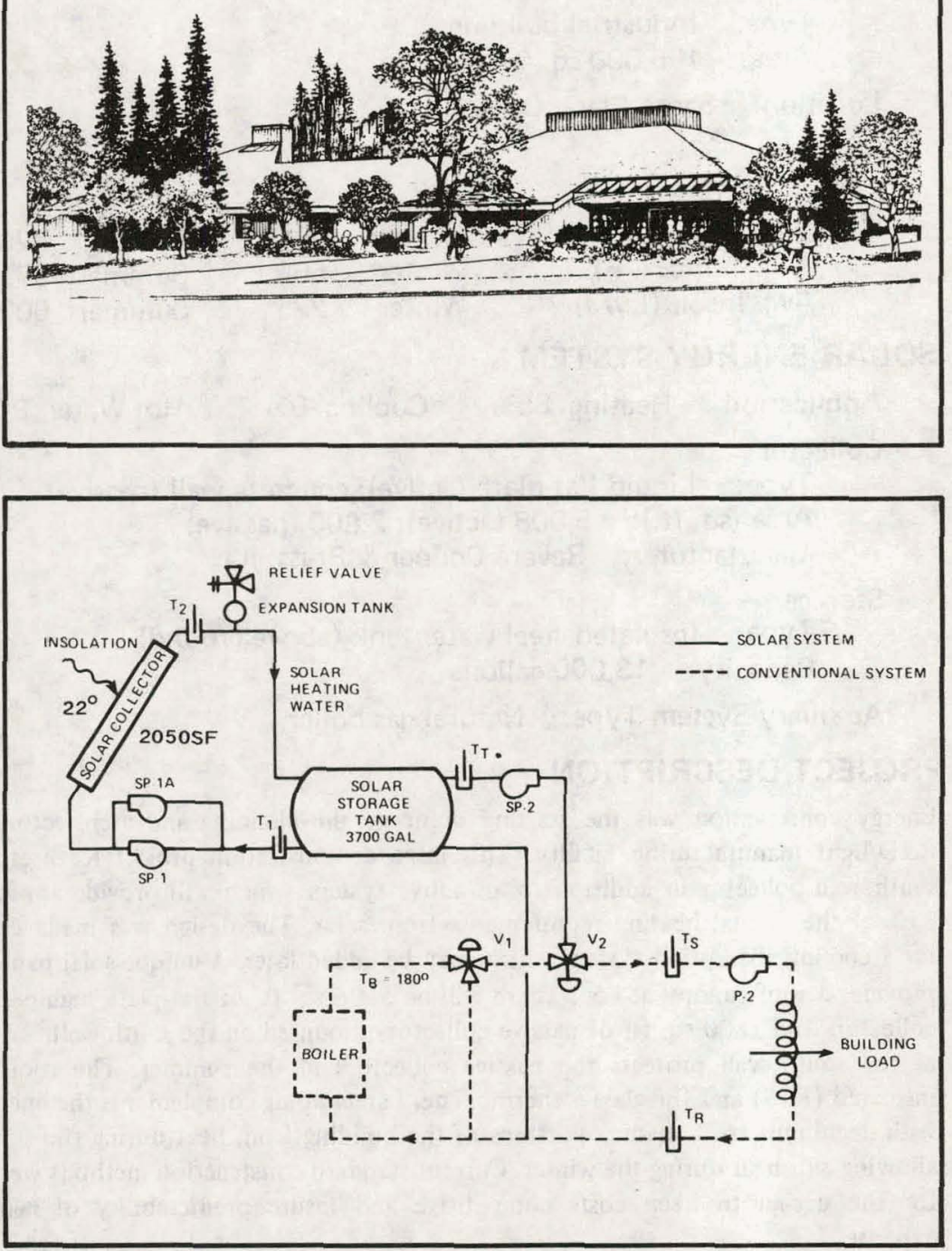


\section{PROJECT INFORMATION}

Owner/Builder: Lake Valley Fire District

Contractor: John Brooks Boyd Associates/William E. Harlow

Operational Date: April 1978

Total Estimated DOE Funds: $\$ 8,783$

Building

Type: Fire station

Area: 2,400 sq. ft.

Location: South Lake Tahoe, California

Latitude: $38.9^{\circ} \mathrm{N}$

Climatic Data

$\begin{array}{lllll}\text { Degree Days } & \text { Heating } & 8100 & \text { Cooling } & 492 \\ \text { Avg. Temp. }\left({ }^{\circ} \mathrm{F} \text { ) }\right. & \text { Winter } & 20 & \text { Summer } & 60 \\ \text { Avg. Insol. (Ly/d) } & \text { Winter } & 372 & \text { Summer } & 693\end{array}$

\section{SOLAR ENERGY SYSTEM}

Application Heating $50 \%$

Hot Water $50 \%$

Collector

Type: Liquid flat-plate

Area (sq. ft.): 352

Manufacturer: Western Energy, Inc.

Storage

Type: Insulated fiberglas water tank (above ground)

Capacity: 1,200 gallons

Auxiliary System Type: Gas boiler/wood burning heater

\section{PROJECT DESCRIPTION}

Solar energy provides heat and hot water for the interior of the newly constructed Lake Valley Firehouse No. 2, also known as the Montgomery Estates Fire Station. This includes the firemen's living quarters and the engine room. In winter, solar-heated water is used to melt snow on the driveway of the station. Performance monitoring of the solar system is carried out by the fire station personnel. This project should result in a reduction of operational costs. If this project is successful, a retrofit system for Lake Valley's main station will be considered. There are no other public facilities currently utilizing solar energy in this region; this project will serve as a model to county, city, and special districts considering potential solar projects.
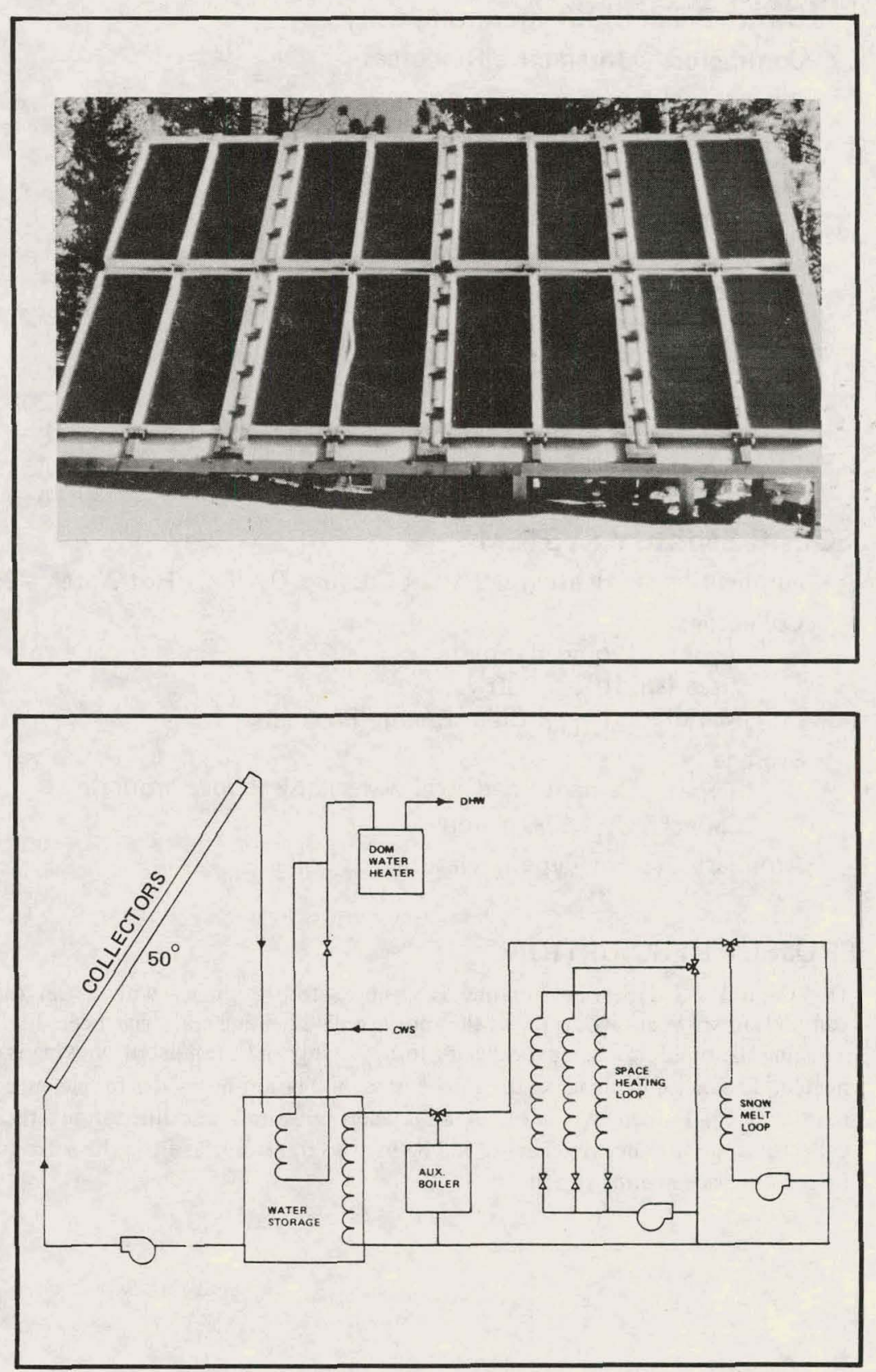


\section{ECT INFORMATION}

Owner/Builder: Stanford University

Contractor: Interactive Resources

Operational Date: August 1978

Total Estimated DOE Funds: $\quad \$ 57,250$

Building

Type: Food service

Area: 25,562 sq. ft. (total) ; 2,726 sq. ft. (cond.)

Location: Stanford, California

Latitude: $37^{\circ} \mathrm{N}$

Climatic Data

$\begin{array}{lllll}\text { Degree Days } & \text { Heating } & 2869 & \text { Cooling } & 200 \\ \text { Avg. Temp. }\left({ }^{\circ} \mathrm{F}\right) & \text { Winter } & 49 & \text { Summer } & 65 \\ \text { Avg. Insol. (Ly/d) } & \text { Winter } & 185 & \text { Summer } & 631\end{array}$

\section{SOLAR ENERGY SYSTEM}

Application Heating 79\%

Collector

Type: Liquid flat-plate

Area (sq. ft.): 830

Manufacturer: Solar Energy Products

Storage

Type: Cement lined steel water tank (above ground)

Capacity: 1,550 gallons

Auxiliary System Type: Natural gas boiler

\section{PROJECT DESCRIPTION}

The Central Food Service Building is a single-story complex with a flat roof. Since completion six years ago, three of the four installed heating coils have been disconnected, reducing the building's heating capacity to $87 \%$. Only the administration wing is currently heated. The major demand on the solar system will be for hot water for cleaning the meat packing area. Potable water under city water pressure runs throughout the $1000-\mathrm{ft}$. collector system; a heat exchanger will be used to transfer heat from the solar loop to the forced air space heating system.
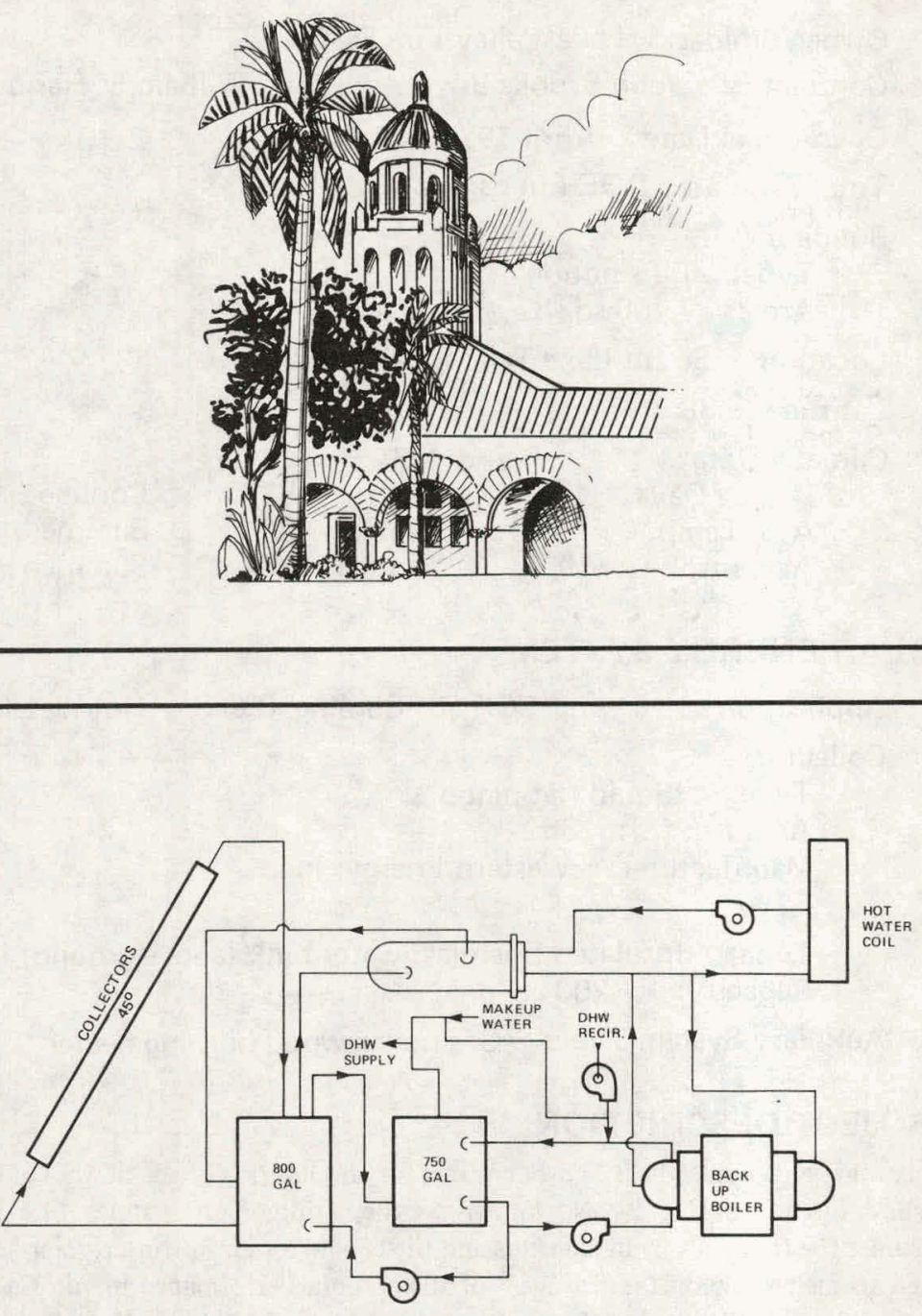


\section{PROJECT INFORMATION}

Owner/Builder: Fredricks Development Corporation

\section{Contractor: Southern California Gas Company}

\section{Operational Date: April 1976}

Total Estimated DOE Funds: $\quad \$ 391,900$ (includes EI Toro project)

Building

Type: Apartments (40 units)

Area: 57,600 sq. ft.

Location: Upland, California

Latitude: $34.1^{\circ} \mathrm{N}$

Climatic Data

$\begin{array}{lllll}\text { Degree Days } & \text { Heating } & 1282 & \text { Cooling } & 1215 \\ \text { Avg. Temp. ( }{ }^{\circ} \mathrm{F} \text { ) } & \text { Winter } & 59.6 & \text { Summer } & 76.3 \\ \text { Avg. Insol. (Ly/d) } & \text { Winter } & 390 & \text { Summer } & 561\end{array}$

\section{SOLAR ENERGY SYSTEM}

Application Heating $0 \%$ Cooling $0 \%$

Hot Water $70 \%$

Collector

Type: Liquid flat-plate

Area (sq. ft.): 800

Manufacturer: Lennox Industries, Inc./Honeywell, Inc. Storage

Type: Glass lined steel water tank

Capacity: 1,200 gallons

Auxiliary System Type: Gas boiler

\section{PROJECT DESCRIPTION}

In this project, a solar assisted gas water heater was installed during the construction of an apartment building in Upland, California. Data on system cost, installation, and performance will be used for technical and financial studies of the project, with particular emphasis being placed on determining optimum implementation procedures. The solar collectors used in this project consist of a steel absorber plate with integral copper waterways and a selective absorber coating (black chrome) with low iron single glazing. The building has copper piping to carry heat transfer fluid to and from the solar collectors. The emphasis in this project is on cost effectiveness, and system components were chosen with that in mind. Cost data from this project and others like it will be valuable, because it will help potential investors to determine the favorable and unfavorable aspects of investment in solar energy systems for multiple unit buildings. This project was partially funded by the National Science Foundation. Over 50\% was funded by Southern California Gas Company. DOE maintains technical cognizance.
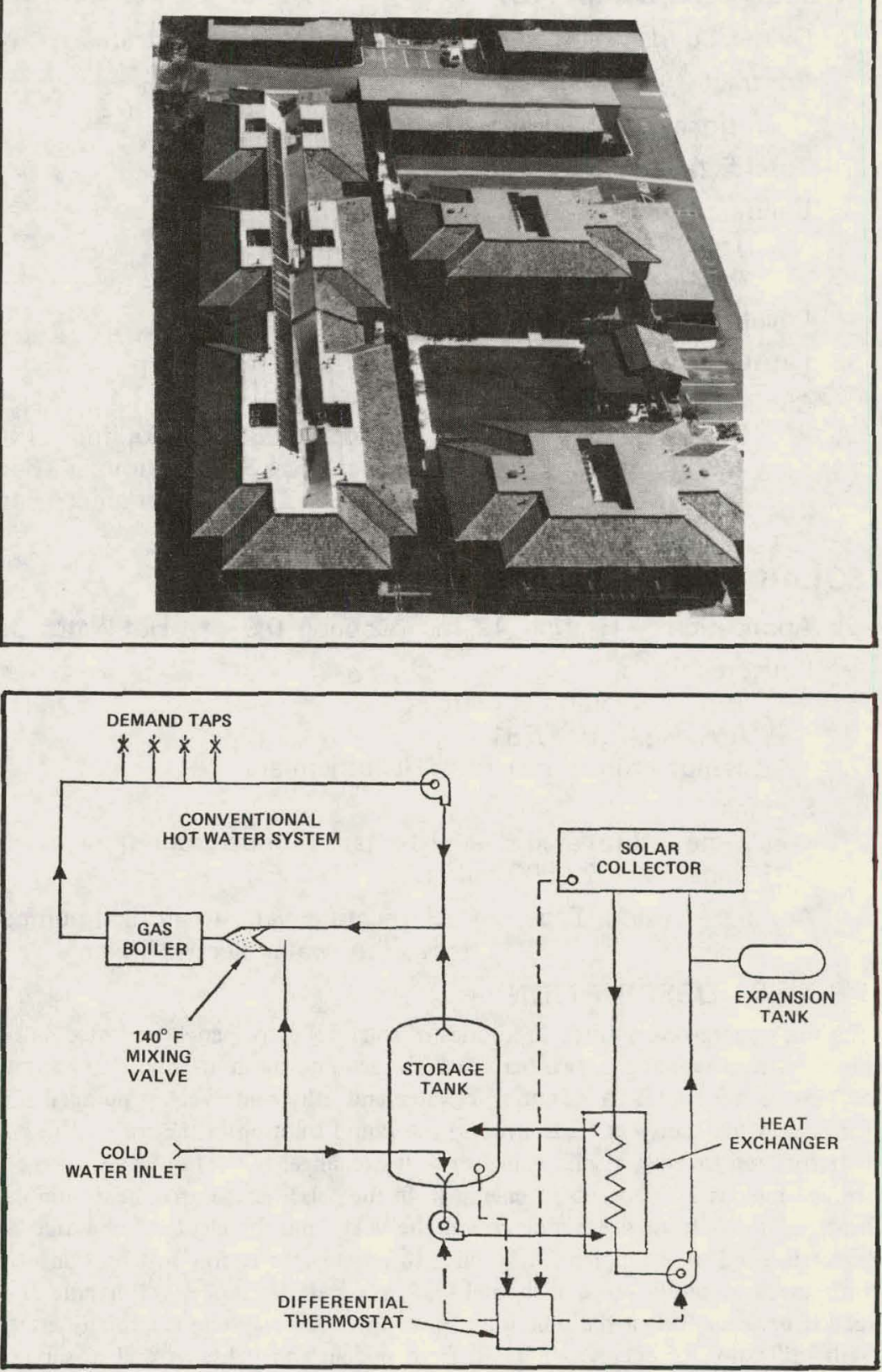


\section{PROJECT INFORMATION}

Owner/Builder: Adams-Arapahoe Joint School District

Contractor: Bridgers \& Paxton Engineers

Operational Date: February 1978

Total Estimated DOE Funds: $\$ 33,697$

Building

Type: Elementary school

Area: 49,347 sq. ft.

Location: Aurora, Colorado

Latitude: $39^{\circ} 45^{\prime} \mathrm{N}$

Climatic Data

$\begin{array}{lllll}\text { Degree Days } & \text { Heating } & 6283 & \text { Cooling } & 1500 \\ \text { Avg. Temp. }\left({ }^{\circ} \mathrm{F}\right) & \text { Winter } & 34.3 & \text { Summer } & 64.5 \\ \text { Avg. Insol. (Ly/d) } & \text { Winter } & 310 & \text { Summer } & 540\end{array}$

\section{SOLAR ENERGY SYSTEM}

Application Heating $42.4 \%$

Cooling $0 \%$

Hot Water $35.2 \%$

Collector

Type: Liquid flat-plate

Area (sq. ft.): 1,781

Manufacturer: American Heliothermal

\section{Storage}

Type: Insulated steel water tanks (underground)

Capacity: 27,800 gallons

Auxiliary System Type: Reciprocating water-to-air heat pumps with storage/hot water electric boiler

\section{PROJECT DESCRIPTION}

The sun's energy is captured in a series of solar collector panels mounted on the roof of this one-story building in two banks which face due south at an angle of approximately $53^{\circ}$ above horizontal. A mixture of water and ethylene glycol is pumped through the panels and the energy is transferred to the liquid solution in the form of heat. The heat is transferred through a solar collector heat exchanger to the hot water storage tank. The storage tank is able to accept energy from the solar heat source; heat pumps returning heat recovered from the building; and the heat from the electric hot water boiler. The boiler is sized as a supplemental boiler to provide the energy lost by transmission, but with the heat pump in parallel total loads are met. The boiler will handle $100 \%$ of the load if necessary when the building is shut down. This system is a totally integrated one with utilization of energy generated from people and lights as well as solar. The solar energy reduces the requirement of energy output by heat pumps and boiler.
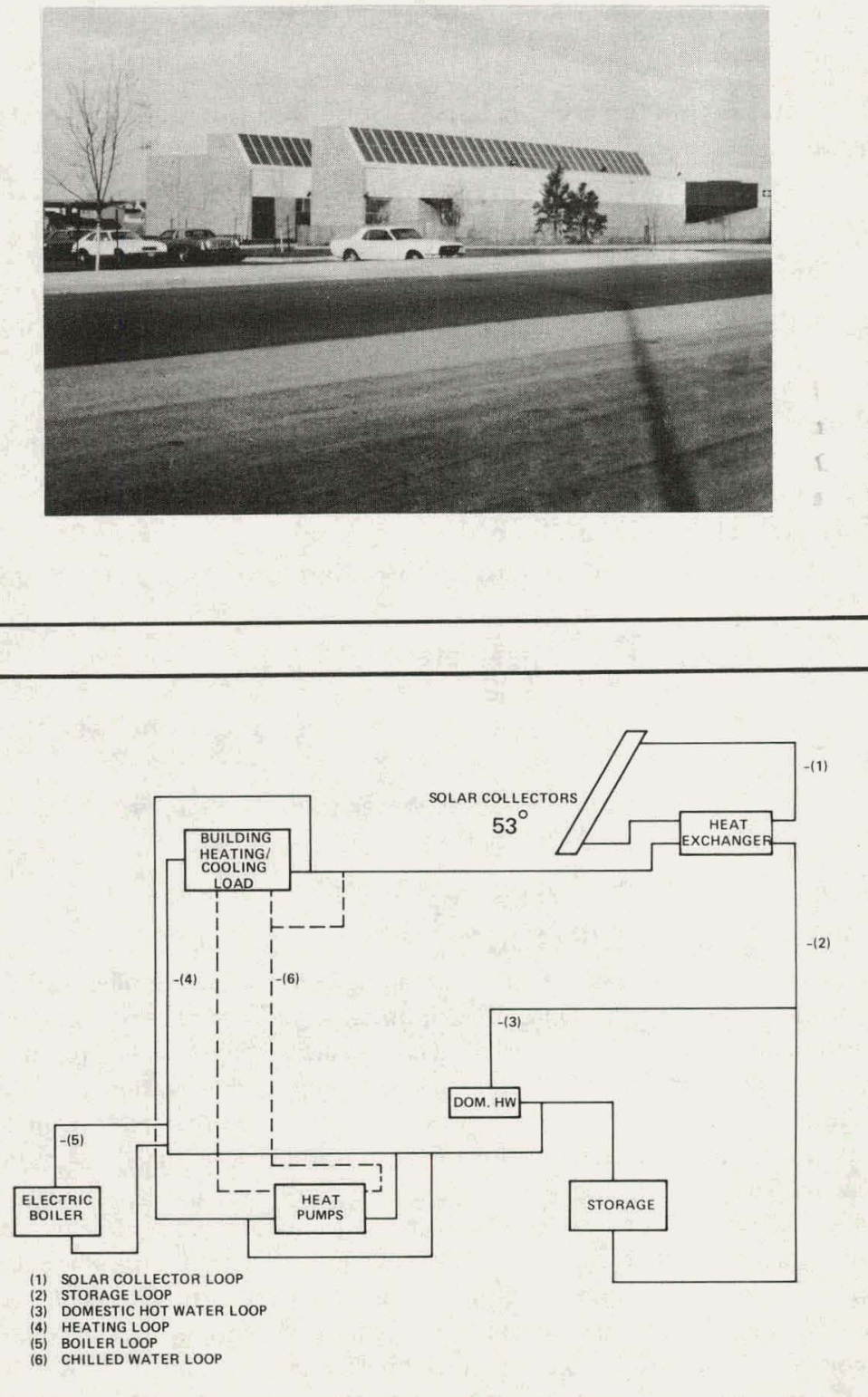


\section{PRUJECT INFORMATION}

Owner/Builder: Paul Shippee

Contractor: Colorado Sunworks

Operational Date: August 1978

Total Estimated DOE Funds: $\quad \$ 75,000$

Building

Type: High rise motel

Area: Not applicable to hot water systems

Location: Boulder, Colorado

Latitude: $40^{\circ} \mathrm{N}$

Climatic Data

$\begin{array}{lllll}\text { Degree Days } & \text { Heating } & 7420 & \text { Cooling } & 383 \\ \text { Avg. Temp. }\left({ }^{\circ} \mathrm{F}\right) & \text { Winter } & 38.5 & \text { Summer } & 66.9 \\ \text { Avg. Insol. (Ly/d) } & \text { Winter } & 292 & \text { Summer } & 528\end{array}$

\section{SOLAR ENERGY SYSTEM}

Application Heating $0 \%$ Cooling $0 \%$

Hot Water $76 \%$

Collector

Type: Liquid flat-plate

Area (sq. ft.): 4,488

Manufacturer: Colorado Sunworks

Storage

Type: Insulated wood tank lined with vinyl/steel tanks (in mechanical room)

Capacity: 7,000 gallons

Auxiliary System Type: Natural gas boiler

\section{PROJECT DESCRIPTION}

The solar collection and storage system is divided into two separate and distinct systems servicing two separate boiler rooms. Twelve banks ( 48 collectors) are to be placed on the two-story roof of the south wing at $45^{\circ}$ to the horizontal facing south. Fifty-six banks (224 collectors) are to be placed on the one-story roof of the service area and on the two-story roof of the west wing. The solar collectors will automatically drain down each time the solar pump turns off, thus providing freeze protection and eliminating the need for antifreeze and collector loop heat exchanger. The solar tank is interfaced with the service hot water tank by routing the city main water through a series of pressurized stainless steel tanks immersed in the open solar collection water storage. This scheme allows city pressure to drive the heat exchanger flow in the demand loop thereby eliminating the need for pumps and controls.
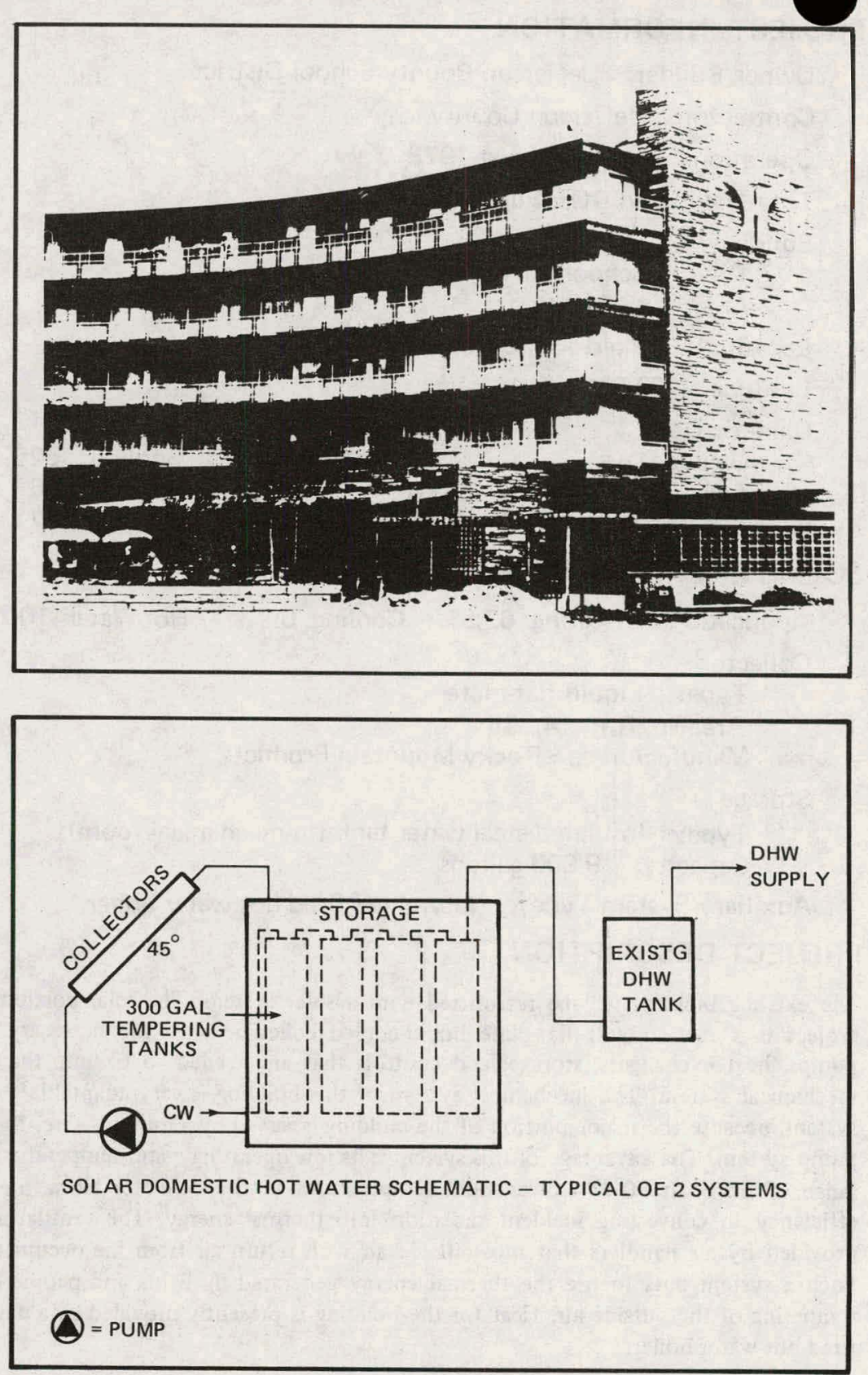


\section{rnUJECT INFORMATION}

Owner/Builder: Jefferson County School Disţrict

Contractor: Jefferson County

Operational Date: August 1978

Total Estimated DOE Funds: $\$ \mathbf{\$ 1 7 6 , 2 4 0}$

Building

Type: School for the retarded

Area: $42,000 \mathrm{sq} . \mathrm{ft}$.

Location: Lakewood, Colorado

Latitude: $39.8^{\circ} \mathrm{N}$

Climatic Data

Degree Days

Avg. Temp. $\left({ }^{\circ} \mathrm{F}\right)$

Avg. Insol. (Ly/d)

$\begin{array}{llll}\text { Heating } & 6283 & \text { Cooling } & 625 \\ \text { Winter } & 37 & \text { Summer } & 66 \\ \text { Winter } & 218 & \text { Summer } & 471\end{array}$

\section{SOLAR ENERGY SYSTEM}

Application Heating 62.5\%

Cooling $0 \%$

Hot Water $100 \%$

Collector

Type: Liquid flat-plate

Area(sq. ft.): 4,595

\section{Storage}

Type: Insulated steel water tank (in mechanical room)

Capacity: 9,000 gallons

Auxiliary System Type: Natural gas fired hot water boiler

\section{PROJECT DESCRIPTION}

The existing building will be retrofitted with a solar system. The solar portion of this project is a custom-built flat-plate liquid-cooled collector with the necessary piping, pumps, heat exchangers, storage, and controls that are needed to tie into the existing mechanical system. The mechanical system of this building is very adaptable to a solar system, because the major portion of the building is served by a unitary water-to-air heat pump system. The advantage of this system is its low operating water temperature, in the range of $60^{\circ} \mathrm{F}$ to $90^{\circ} \mathrm{F}$. Lower fluid temperatures in the collector allow for greater efficiency in converting incident radiation into thermal energy. The ventilation air is provided by air handlers that mix outside air with return air from the occupied space. Such a system puts to use the thermal energy generated by lights and people into the tempering of the outside air. Heat for the building is presently provided by a natural gas fired hot water boiler.
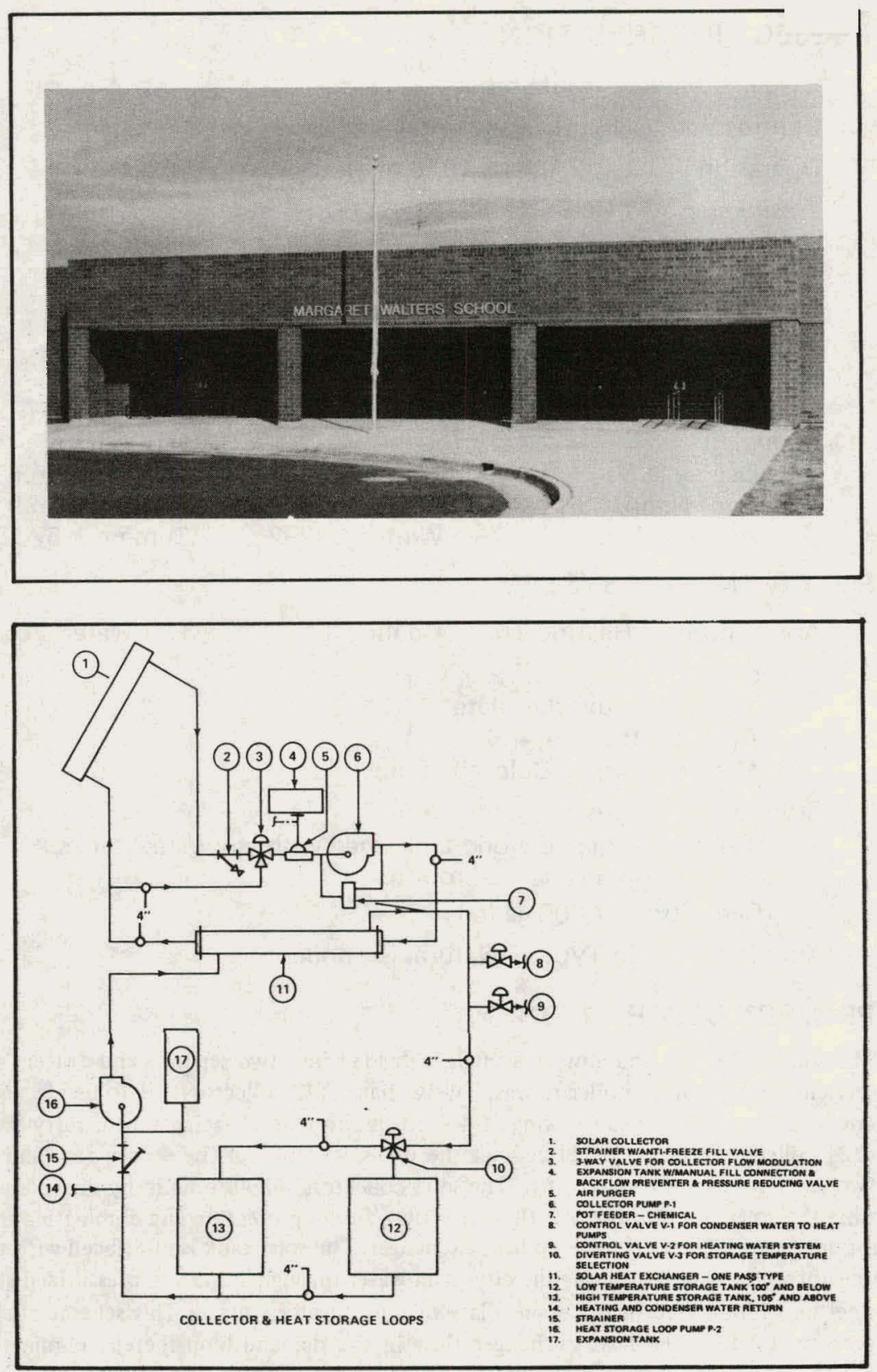
PhuJECT INFORMATION

Owner/Builder: City of Littleton

Contractor: Bridgers \& Paxton Engineers

Operational Date: December 1977

Total Estimated DOE Funds: $\quad \$ 184,455$

Building

Type: City Hall

Area: 56,000 sq. ft.

Location: Littleton, Colorado

Latitude: $39^{\circ} 5^{\prime} \mathrm{N}$

Climatic Data

Degree Days

Avg. Temp. $\left({ }^{\circ} \mathrm{F}\right)$

Heating 6283

Cooling

625

Avg. Insol. (Ly/d)

\section{SOLAR ENERGY SYSTEM}

Application Heating $89.2 \%$ Cooling $0 \%$ Hot Water $80 \%$

Collector

Type: Liquid flat-plate

Area (sq. ft.): 8,360

Manufacturer: Sunworks, Inc.

Storage

Type: Insulated steel water tanks (underground)

Capacity: 27,800 gallons

Auxiliary System Type: Electric hot water boiler and heater

\section{PROJECT DESCRIPTION}

The proposed solar energy system consists of flat-plate solar collectors, storage tanks, heat exchangers, pumps, piping and appurtenances required for the solar-assisted internal heat recovery pump system. The two-story brick center is a new building and will be open 24 hours a day. The project has been designed with an internal heat recovery heat pump as the basic system for the heating, ventilating, and air conditioning systems, with the solar collector system to provide an additional heat source. The flat-plate collectors are installed on the roof of the building facing due south and have an elevation of $60^{\circ}$ to horizontal. Collected solar energy will be stored outside in two underground insulated storage tanks. Solar heat is transferred from the ethylene glycol-water solar loop circuit to the water in the tanks by heat exchangers. Water in the tanks is used for domestic hot water heating, direct building heating, and as a heat source for the heat pumps to heat the building (when tank temperatures are not adequate for direct heating).
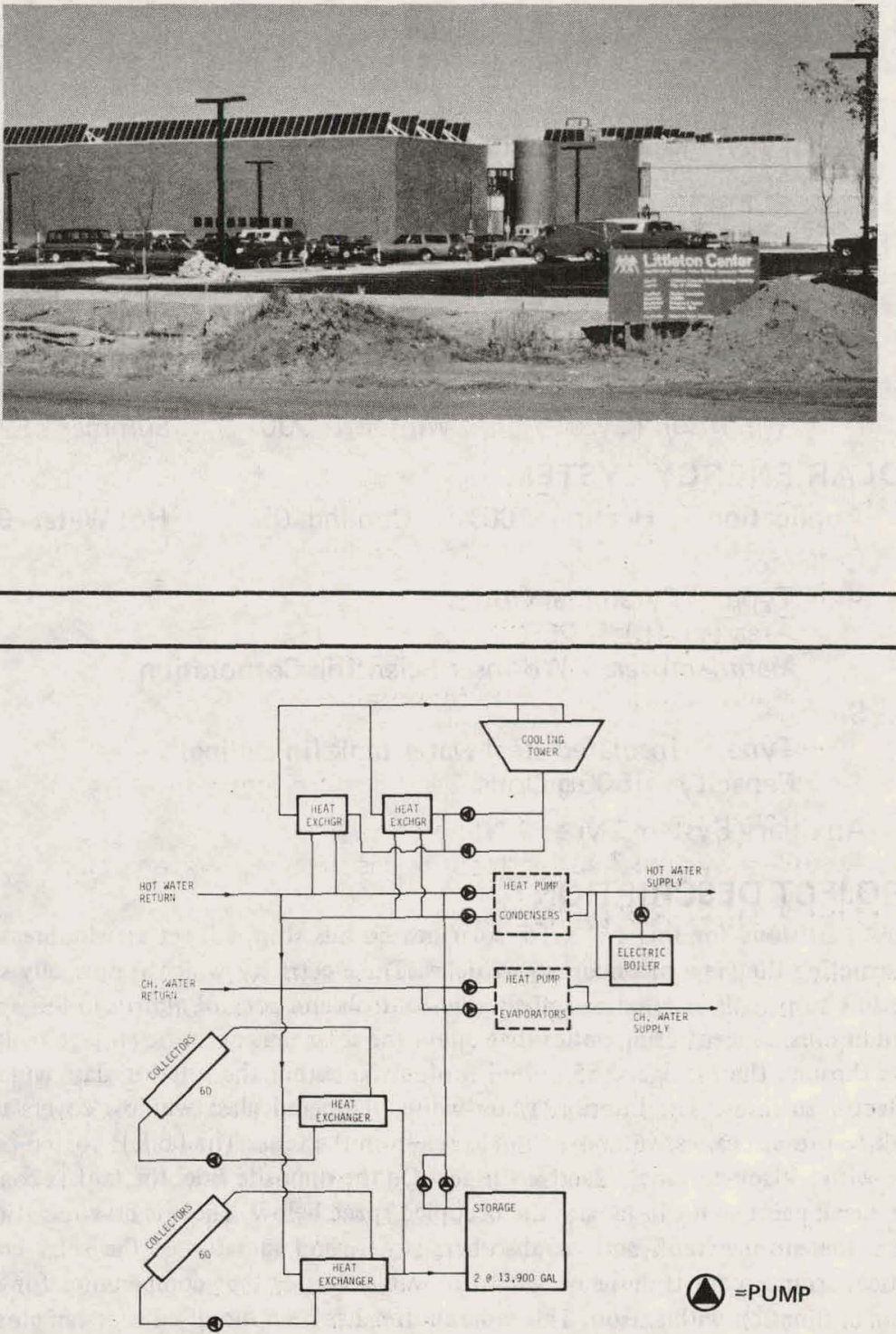

=PUMP 


\section{PROJECT INFORMATION}

Owner/Builder: Town of Vail

Contractor: InterTechnology, Inc.

Operational Date: August 1978

Total Estimated DOE Funds:

Building

Type: Bus stop shelter

Area: 250 sq. ft.

Location: Vail, Colorado

Latitude: $39.6^{\circ} \mathrm{N}$

Climatic Data

$\begin{array}{lllll}\text { Degree Days } & \text { Heating } & 8426 & \text { Cooling } & 400 \\ \text { Avg. Temp. ( }{ }^{\circ} \mathrm{F} \text { ) } & \text { Winter } & 10 & \text { Summer } & 60 \\ \text { Avg. Insol. (Ly/d) } & \text { Winter } & 290 & \text { Summer } & 525\end{array}$

SOLAR ENERGY SYSTEM

Application Heating 100\% Cooling 0\% Hot Water $0 \%$

Collector

Type: Pyramidal Optics

Area (sq. ft.): 250

Manufacturer: Wormser Scientific Corporation

Storage

Type: Insulated steel water tank (in ceiling)

Capacity: 500 gallons

Auxiliary System Type: None

\section{PROJECT DESCRIPTION}

Glass partitions for this $16^{\prime} \times 16^{\prime}$ solar heated bus stop will act as windbreaks without obstructing the view of oncoming vehicles. The electricity which is normally supplied to the bus stop will be used to activate the controls and control motors in this system. The system uses concentrating optics that direct the solar rays onto the storage tank. The rays pass through the Plexiglas, $55^{\circ}$ tilted roof, strike either the interior glass window or the reflector surfaces. The interior, water-white, tempered glass window covers the storage tank to prevent excessive convection losses from the tank. The tank is coated on the solar side with a black-chrome, selective surface. On the opposite side, the tank is coated with a flat black paint so it can radiate the occupied space below. There is no circulation of fluid since the storage tank acts as absorber, storer, and radiator of the solar energy. The optical arrangement is designed with a movable shutter that compensates for changes in solar declination with season. This same shutter has been modified so it can close over the tank, thereby preventing large night heat losses through the roof.
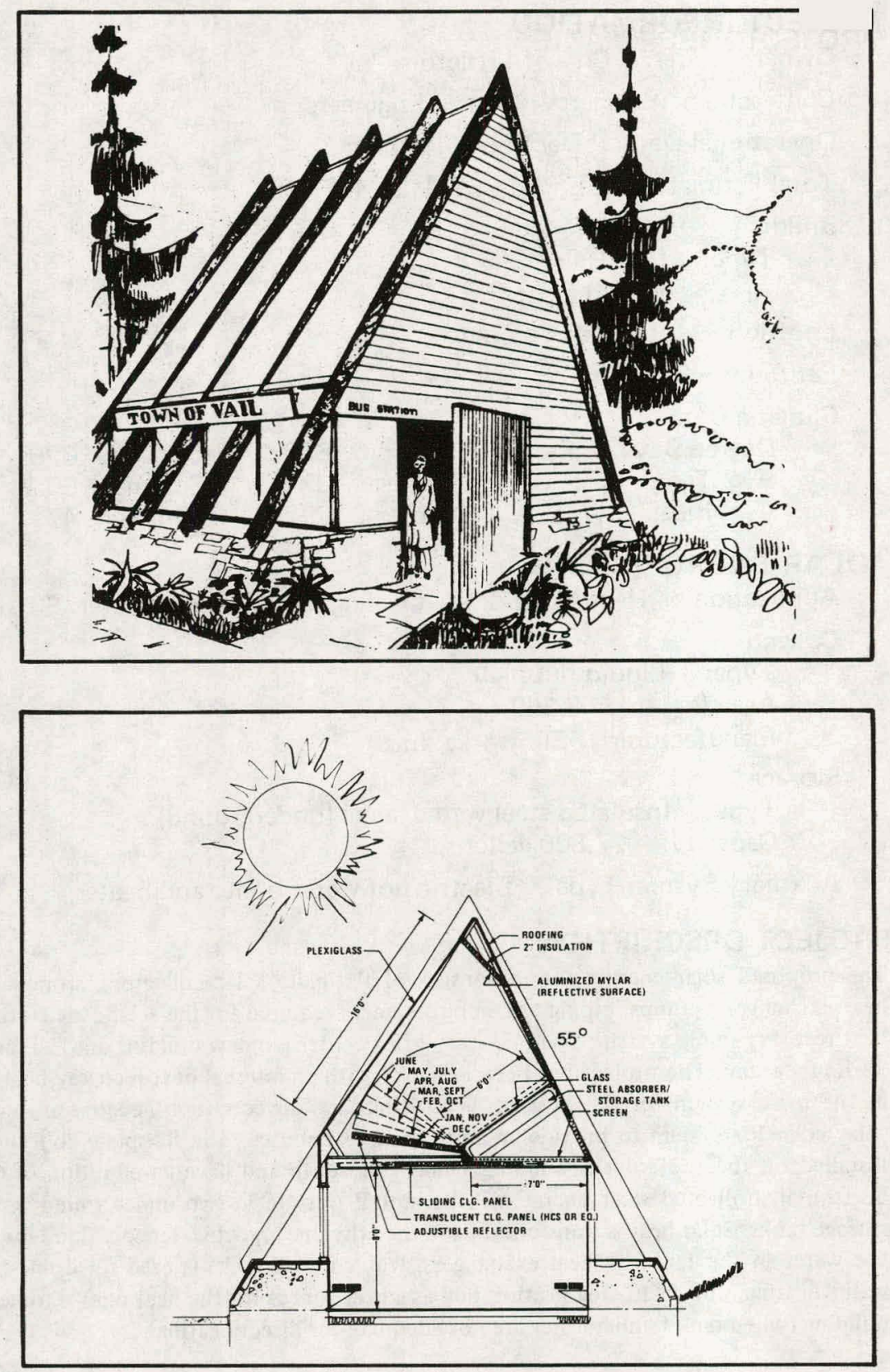


\section{PROJECT INFORMATION}

Owner/Builder: John R. McColl, Jr./ William H. Wade

Contractor: McColl-Wade, Inc.

Operational Date: February 1978

Total Estimated DOE Funds: $\quad \$ 62,788$

Building

Type: Commercial/industrial

Area: 7,135 sq. ft. (total); 6,367 sq. ft. (cond.)

Location: Branford, Connecticut

\section{Latitude: $41^{\circ} \mathrm{N}$}

Climatic Data

$\begin{array}{lllll}\text { Degree Days } & \text { Heating } & 5804 & \text { Cooling } & 800 \\ \text { Avg. Temp. }\left({ }^{\circ} \mathrm{F}\right) & \text { Winter } & 31.9 & \text { Summer } & 70.8 \\ \text { Avg. Insol. (Ly/d) } & \text { Winter } & 225 & \text { Summer } & 425\end{array}$

\section{SOLAR ENERGY SYSTEM}

Application Heating 65\% Cooling $0 \%$ Hot Water $85 \%$

Collector

Type: Air flat-plate

Area (sq. ft.): 1,950

Manufacturer: Solaron Corporation

Storage

Type: Rock bed (above ground, inside building)

Capacity: $975 \mathrm{cu} . \mathrm{ft}$. (pebble bed)

Auxiliary System Type: Gas fired warm air

\section{PROJECT DESCRIPTION}

A solar assisted heating system (gas fired auxiliary) utilizing warm air for space heating and domestic hot water heating via a finned coil and pebble bed storage is used in this thoroughly insulated wood-frame building. Because the office portion of the building is rental space and public space, there are five zones, each with a separate system incorporating five separate storage bins. All domestic hot water heating will be provided by the shop zone system; each individual system will provide its own space heating. The zone concept will minimize storage volumes and duct sizes. The design utilizes 100 panels, located on the steep $\left(51^{\circ}\right)$ south-facing roof.
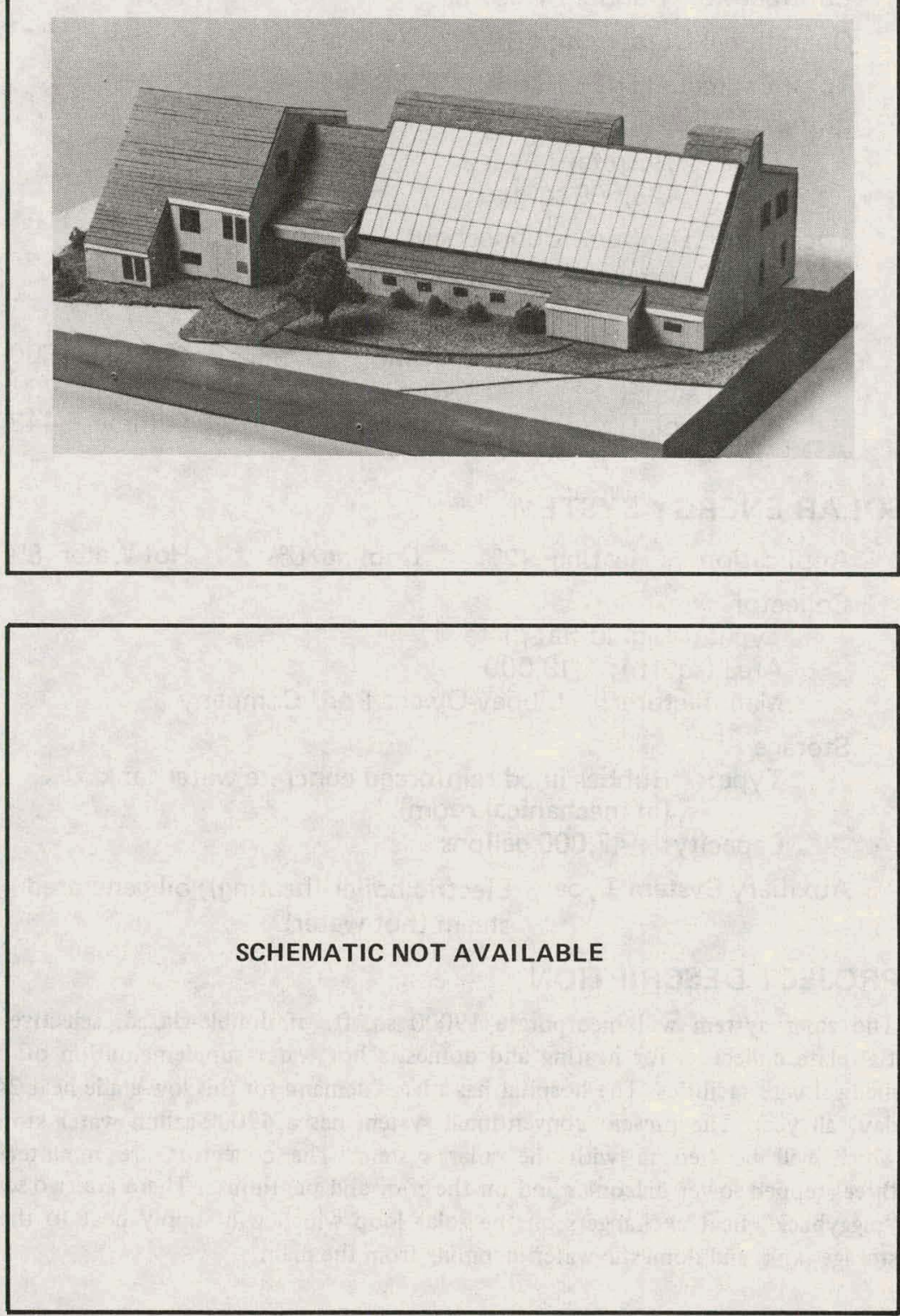


\section{PROJECT INFORMATION}

Owner/Builder: Danbury Hospital

Contractor: Danbury Hospital

Operational Date: June 1978

Total Estimated DOE Funds: $\quad \$ 436,641$

Building

Type: Hospital

Area: 423,500 sq. ft.

Location: Danbury, Connecticut

Latitude: $41.3^{\circ} \mathrm{N}$

Climatic Data

Degree Days

Avg. Temp. $\left({ }^{\circ} \mathrm{F}\right)$

Heating 5754

Cooling 800

Avg. Insol. (Ly/d)

Winter 146

Summer 73

Summer 443

\section{SOLAR ENERGY SYSTEM}

Application Heating 92\%

Collector

Type: Liquid flat-plate

Area (sq. ft.): 19,000

Manufacturer: Libbey-Owens-Ford Company

Storage

Type: Rubber lined reinforced concrete water tank

(in mechanical room)

Capacity: 47,000 gallons

Auxiliary System Type: Electric boiler (heating); oil generated steam (hot water)

\section{PROJECT DESCRIPTION}

The solar system will incorporate 19000 sq. ft. of double-glazed, selective surfaced flat-plate collectors for heating and domestic hot water supplementation of the acute medical care facilities. The hospital has a large demand for this low-grade heat 24 hours a day, all year. The present conventional system has a 47000-gallon water storage tank which will be tied in with the solar system. The collectors are mounted on the three-stepped lower balconies and on the roof and penthouse. There are two sets of two "piggyback" heat exchangers on the solar loop which will supply heat to the boilers, storage tank, and domestic water incoming from the main.
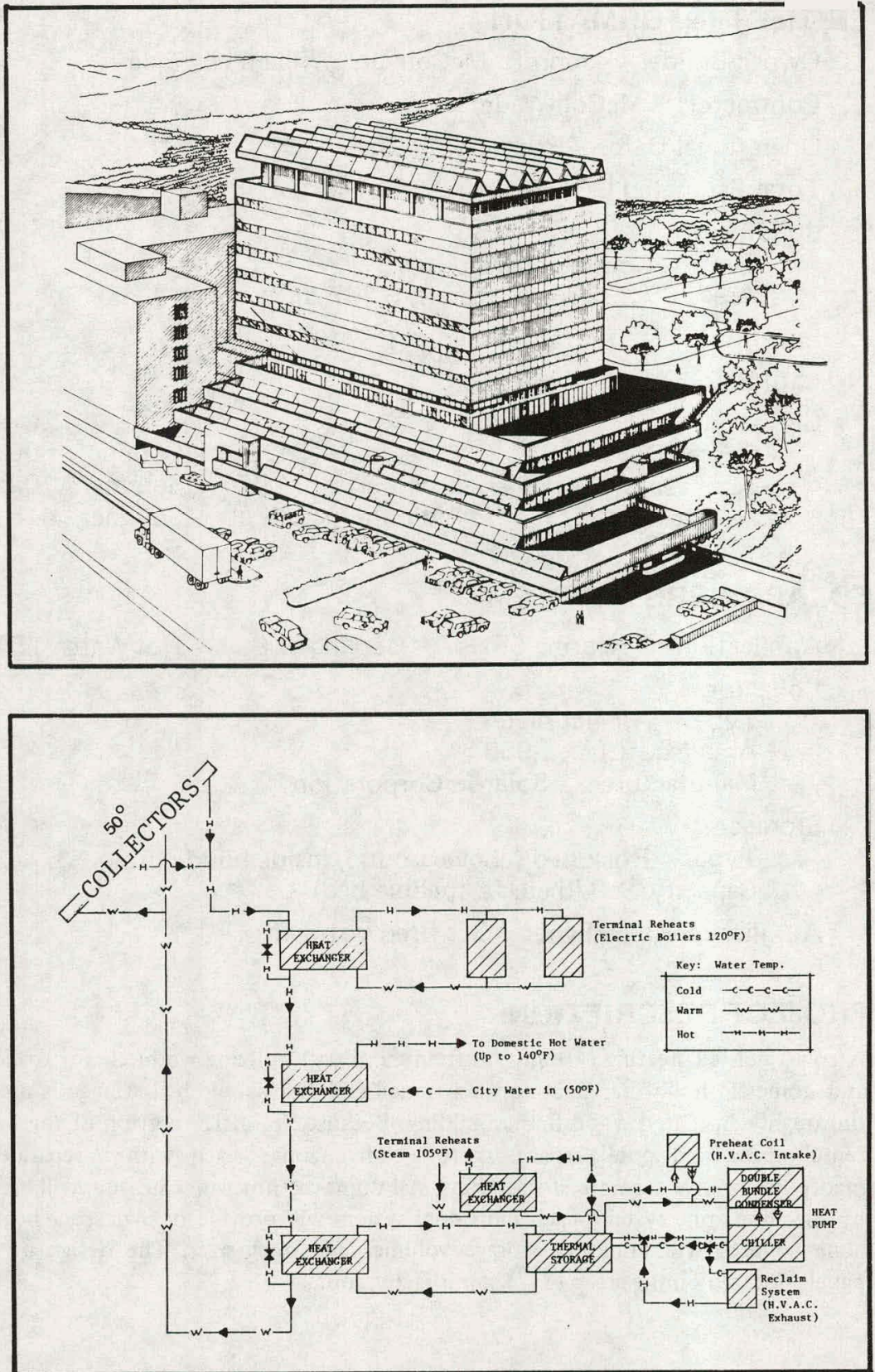


\section{PROJECT INFORMATION}

Owner/Builder: American Motor Inns, Inc.

Contractor: To be determined

Operational Date: October 1978

Total Estimated DOE Funds: $\$ 32,475$

\section{Building}

Type: High rise motor inn

Area: Not applicable to hot water systems

Location: East Hartford, Connecticut

Latitude: $41^{\circ} \mathrm{N}$

Climatic Data

$\begin{array}{lllll}\text { Degree Days } & \text { Heating } & 5707 & \text { Cooling } & 819 \\ \text { Avg. Temp. }\left({ }^{\circ} \mathrm{F}\right) & \text { Winter } & 28 & \text { Summer } & 71 \\ \text { Avg. Insol. (Ly/d) } & \text { Winter } & 250 & \text { Summer } & 450\end{array}$

\section{SOLAR ENERGY SYSTEM}

Application Heating $0 \%$

Hot Water $58 \%$

Collector

Type: Liquid flat-plate

Area (sq. ft.): 1,491

Manufacturer: Sunworks, Inc.

Storage

Type: Insulated steel water tanks (in mechanical room)

Capacity: 2,000 gallons

Auxiliary System Type: Boiler fired by natural gas

\section{PROJECT DESCRIPTION}

This proposed system consists of two distinct systems. One system, consisting of 16 collectors and a new 500-gallon storage tank, will provide hot water to the kitchen, dining area and managerial offices located in the commercial building. The existing 250-gallon hot water heater will provide any auxiliary energy. The other system, consisting of 55 collectors and the existing 1000-gallon storage tank will provide hot water to the 13 guest unit building and laundry. An additional 500-gallon storage tank will be connected to the discharge of the existing boiler. This boiler will provide any auxiliary energy required.
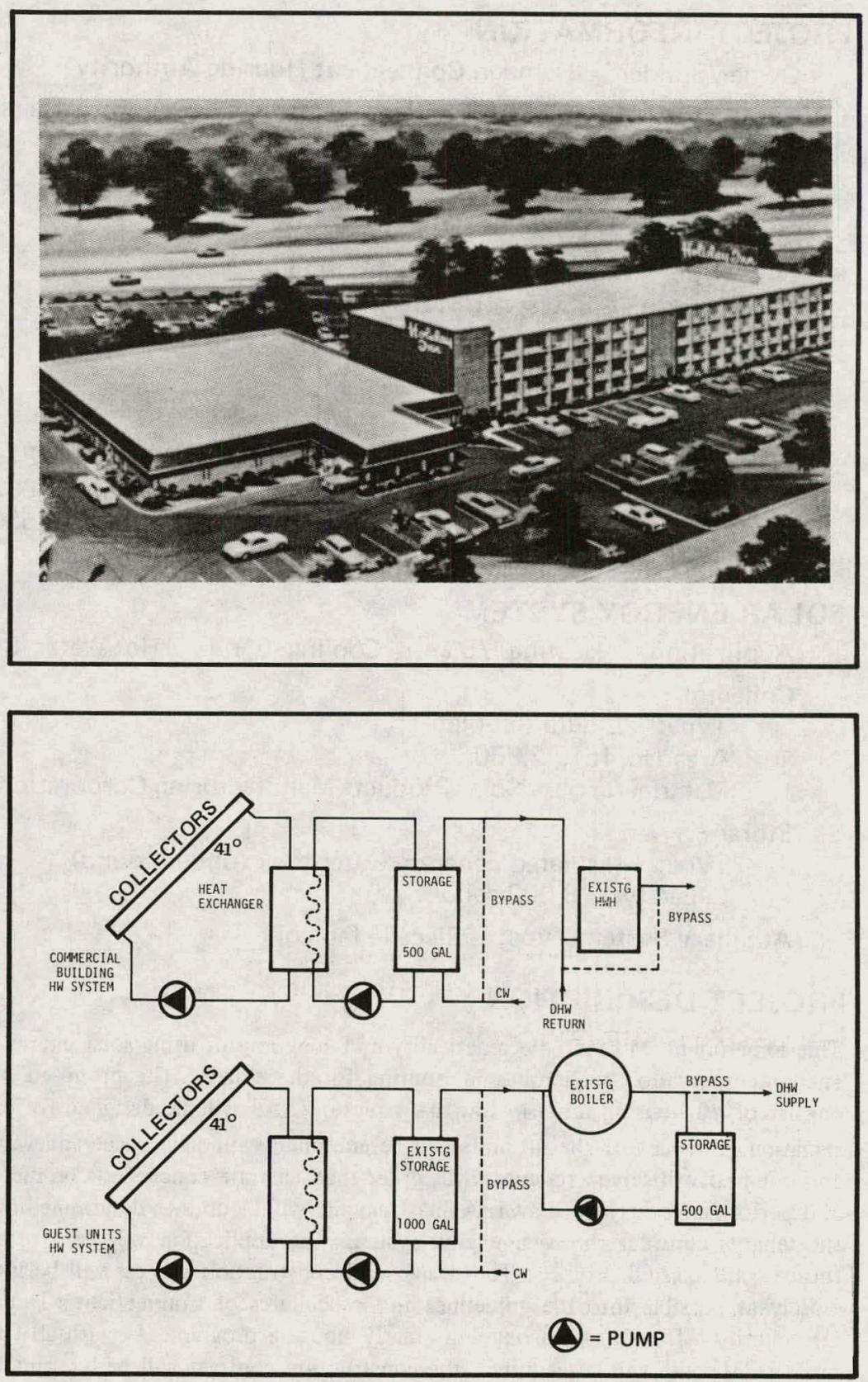


\section{PROJECT INFORMATION}

Owner/Builder: Hamden Connecticut Housing Authority

Contractor: State of Connecticut, Dept. of Community Affairs

Operational Date: March 1978

Total Estimated DOE Funds: $\quad \$ 389,200$

Building

Type: Multifamily elderly housing

Area: 16,800 sq. ft. (total); 8,400 sq. ft. (cond.)

Location: Hamden, Connecticut

Latitude: $41.4^{\circ} \mathrm{N}$

Climatic Data

$\begin{array}{lllll}\text { Degree Days } & \text { Heating } & 5555 & \text { Cooling } & 825 \\ \text { Avg. Temp. }\left({ }^{\circ} \mathrm{F}\right) & \text { Winter } & 33.0 & \text { Summer } & 68.0 \\ \text { Avg. Insol. (Ly/d) } & \text { Winter } & 150 & \text { Summer } & 550\end{array}$

\section{SOLAR ENERGY SYSTEM}

Application Heating $75 \%$

Cooling $0 \% \quad$ Hot Water $85 \%$

Collector

Type: Liquid flat-plate

Area (sq. ft.): 2,600

Manufacturer: Solar Products Manufacturing Corporation

Storage

Type: Insulated concrete water tank (underground)

Capacity: 8,000 gallons

Auxiliary System Type: Electric fan coil

\section{PROJECT DESCRIPTION}

This experiment will test the practicality and economy of using solar energy and other energy conservation techniques in housing for the elderly. The proposed project will consist of 40 housing units in low-rise structures. All will be designed for energy conservation. One-half of the 40 units will be equipped with solar space and water heating and one-half will serve as a control in order that accurate conclusions on life cycle costs and performance may be drawn. A questionnaire will be used to determine how effective the tenants consider the solar energy system. The application will be a prototype for future state-assisted projects. The design and construction process will be integrated as closely as possible into the guidelines and procedures of Connecticut's Department of Community Affairs' (DCA) ongoing elderly housing program. As with all DCA elderly projects, the site will be acquired, the construction contract will be let, and the project will be owned and managed by a local housing authority.
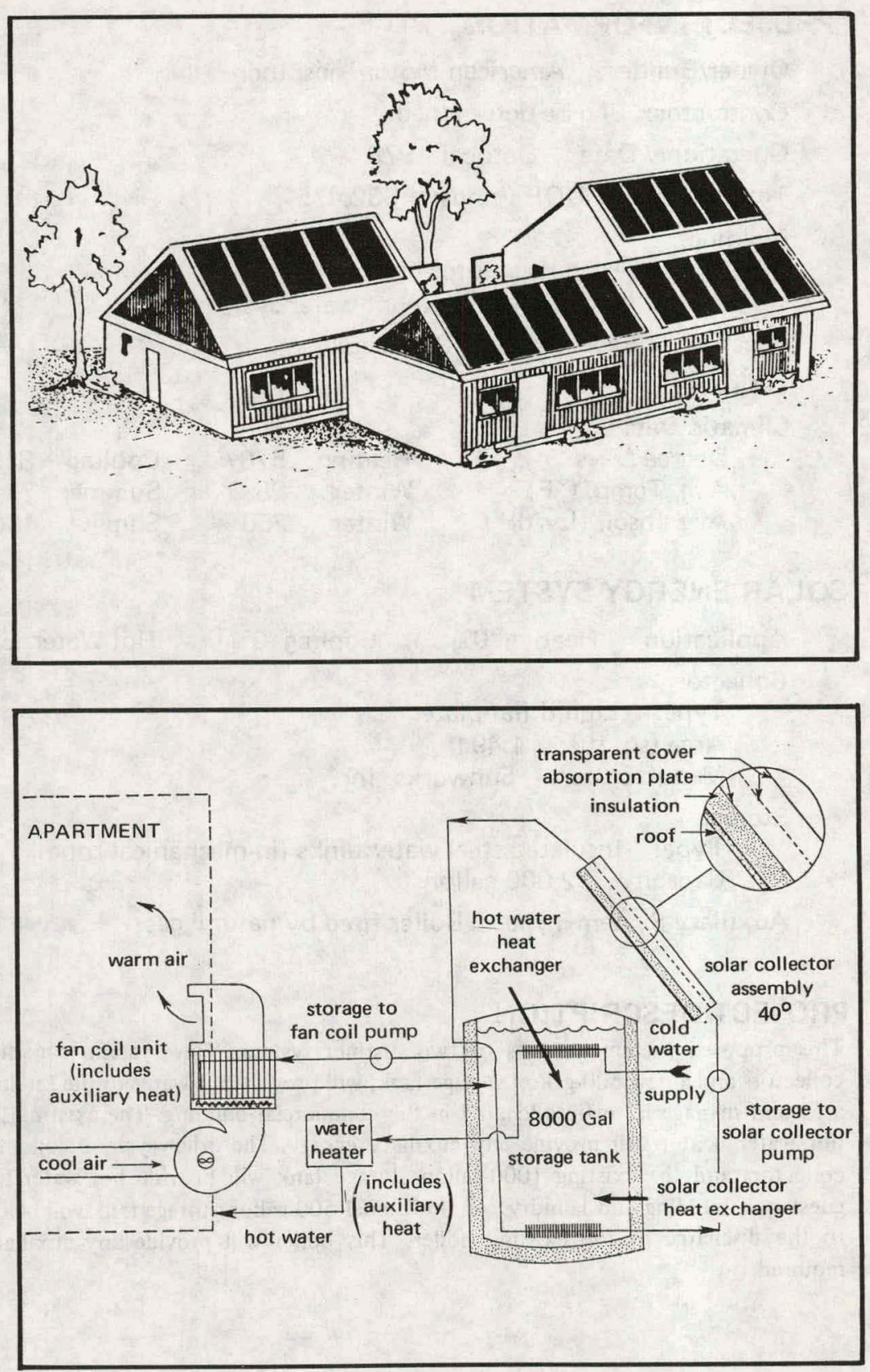


\section{PROJECT INFORMATION}

Owner/Builder: Albie Booth Memorial Boys Club

Contractor: Albie Booth Memorial Boys Club

Operational Date: September 1978

Total Estimated DOE Funds: $\$ 325,354$

Building

Type: Boys club and community center

Area: 35,000 sq. ft.

Location: New Haven, Connecticut

Latitude: $41.25^{\circ} \mathrm{N}$

Climatic Data

Degree Days

Avg. Temp. $\left({ }^{\circ} \mathrm{F}\right)$

Avg. Insol. (Ly/d)

$\begin{array}{ll}\text { Heating } & 5896 \\ \text { Winter } & 43.5 \\ \text { Winter } & 300\end{array}$

Cooling 584

Summer 71.9

Summer 475

\section{SOLAR ENERGY SYSTEM}

Application Heating $40.3 \%$ Cooling $0 \%$ Hot Water $56.6 \%$

Collector

Type: Liquid flat-plate

Area (sq. ft.): 6,300

Manufacturer: Solar Heating Systems Corporation

Storage

Type: Insulated steel water tanks (above ground)

Capacity: $\quad 16,000$ gallons

Auxiliary System Type: Oil/gas fired boiler

\section{PROJECT DESCRIPTION}

This solar system will be used in conjunction with the oil/gas fired conventional system and will supply approximately $40 \%$ of the annual heating load and $56 \%$ of the domestic hot water load. Thus, the conventional heating system is not an "auxiliary" or "back-up" but shares a co-role or complementary relationship with the solar system as designed. The conventional system is capable of supplying the entire building heating and hot water load by itself if necessary. There will be $240,3^{\prime} \times 8.75^{\prime}$ collectors facing true south at an elevation angle of $50^{\circ}$ retrofitted to the flat roof. The thermal energy collected will be transferred to two tanks containing 7500 gallons of water each, mounted vertically in an enclosure adjacent to the building. Transfer will be accomplished via a closed circulating loop containing a heat transfer fluid. An additional feature, the conversion of an existing roof-mounted air conditioning unit to a heat pump, will be added. The heat pump wil heat a specific portion of the building and will use solar assist whenever possible and practical.
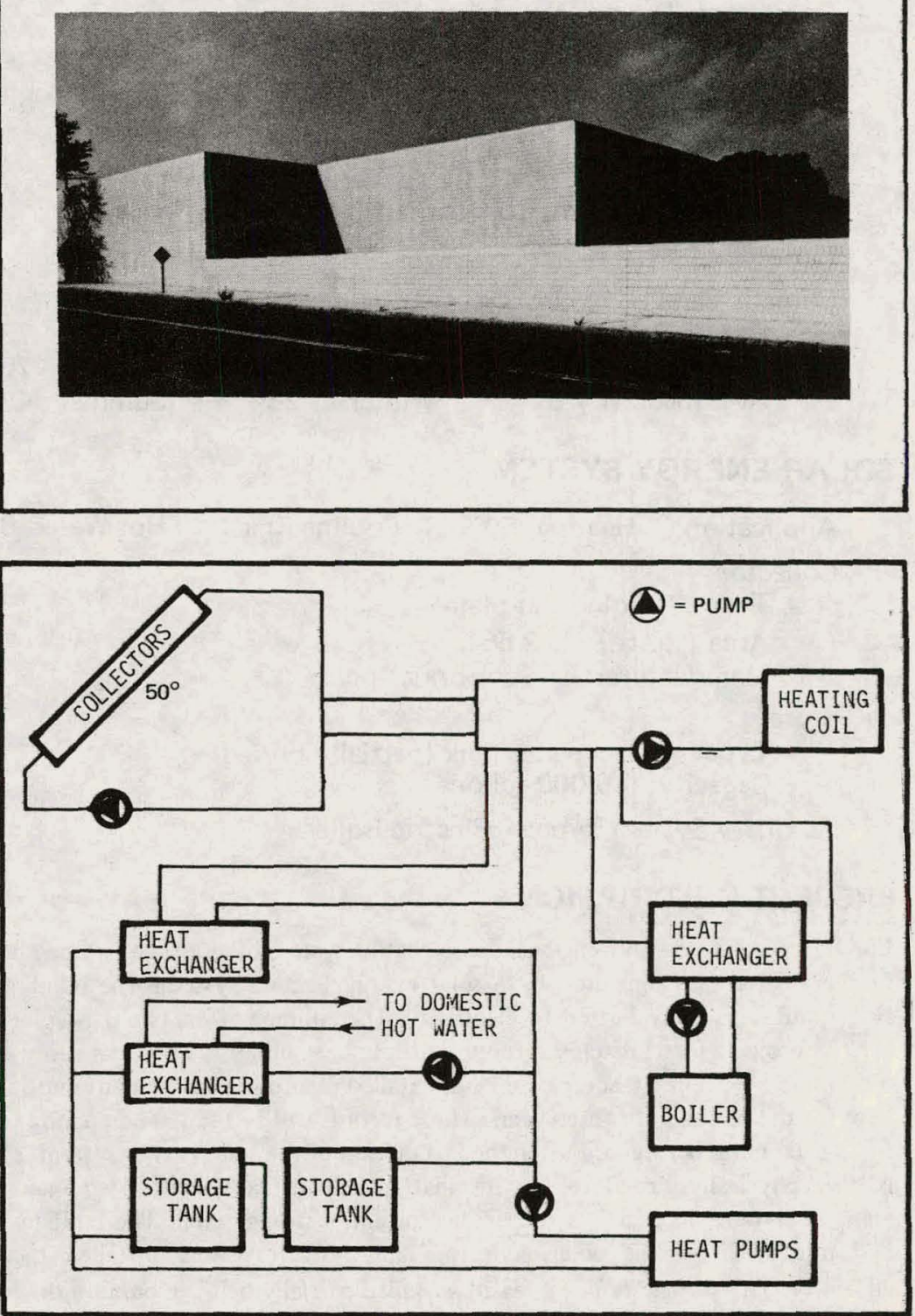


\section{PROJECT INFORMATION}

Owner/Builder: Lutz-Sotire Partnership

Contractor: Wormser Scientific Corporation

\section{Operational Date: November 1977}

Total Estimated DOE Funds: $\$ 357,100$

\section{Building}

Type: Office

Area: $\quad 25,000$ sq. ft. (cond.)

Location: Stamford, Connecticut

Latitude: $41.1^{\circ} \mathrm{N}$

Climatic Data

$\begin{array}{lllll}\text { Degree Days } & \text { Heating } & 5461 & \text { Cooling } 735 \\ \text { Avg. Temp. }\left({ }^{\circ} \mathrm{F}\right) & \text { Winter } & 42.8 & \text { Summer } & 70.2 \\ \text { Avg. Insol. (Ly/d) } & \text { Winter } & \mathbf{2 8 4} & \text { Summer } & \mathbf{4 8 9}\end{array}$

\section{SOLAR ENERGY SYSTEM}
Application Heating $50 \%$
Cooling $0 \%$
Hot Water $0 \%$
Collector
Type: Liquid flat-plate
Area (sq. ft.): 2,561
Manufacturer: Sunworks, Inc.
Storage
Type: Steel water tank (partially buried)
Capacity: 6,000 gallons
Auxiliary System Type: Electric Boiler

\section{PROJECT DESCRIPTION}

For this project, the conventional space heating system of an office building in Stamford, Connecticut is supplemented by a solar energy heating system. The building has three floors and is partially heated by electricity. The building offers two particular advantages for the project. First, its closed loop, multiple heat pump system was easily adapted for use with a solar energy source. Second, detailed records of energy consumption had been kept for the building for three years. These records will be used in comparing energy costs for the building before and after the installation of the solar energy system. The building is also physically suited to the installation of such a system. Two major pieces of equipment were necessary, a solar collector and a storage tank. The building roof is flat and unobstructed; the solar collectors and reflectors were installed there without difficulty. The storage tank was easily installed partially below ground in the rear parking lot of the building.
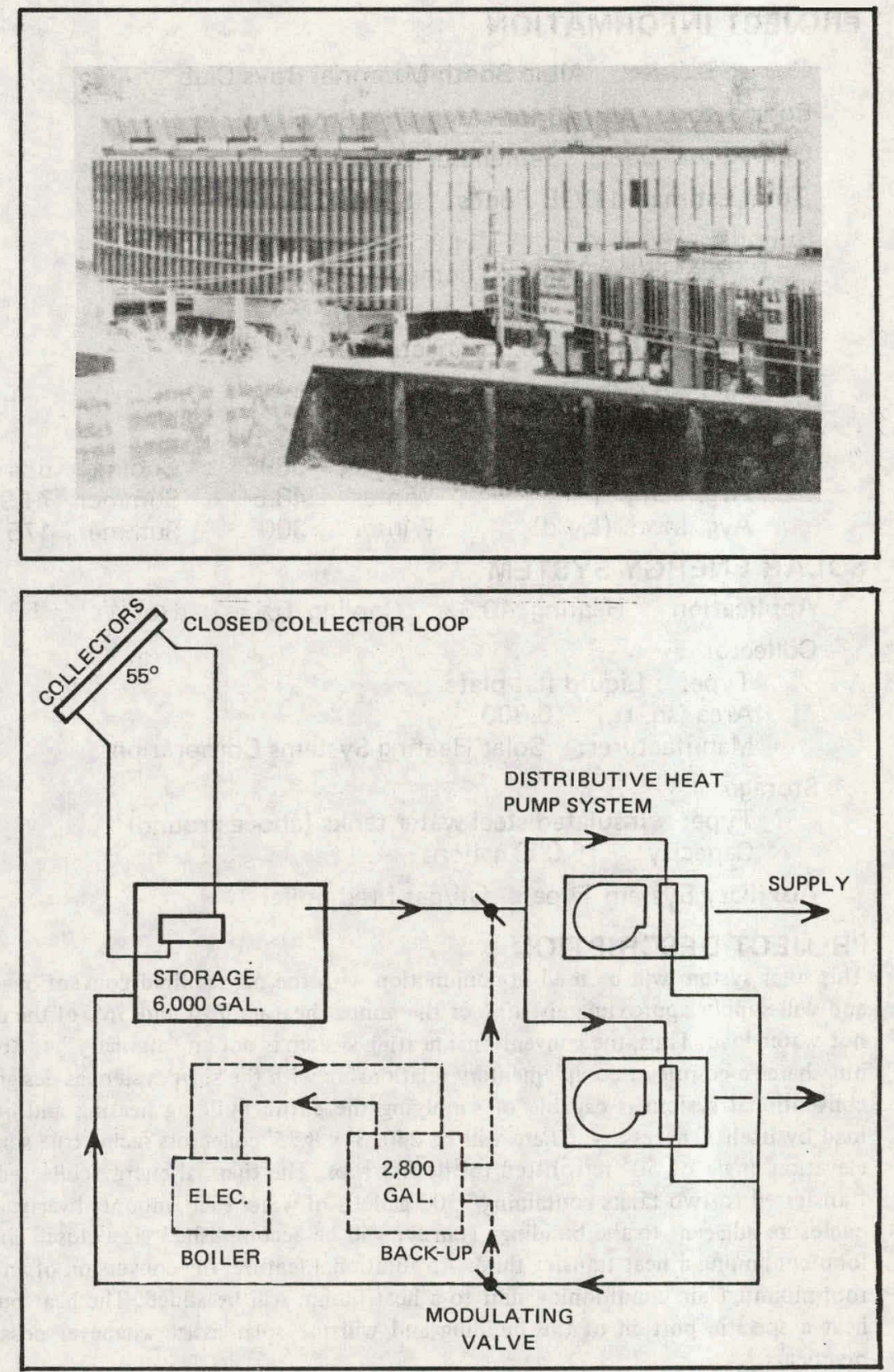


\section{PROJECT INFORMATION}

Owner/Builder: Marriott Corporation

Contractor: Marriott Corporation

Operational Date: January 1978

Total Estimated DOE Funds: $\$ 308,000$

Building

Type: Restaurant

Area: $\quad 45,000$ sq. ft.

Location: Washington, D.C.

Latitude: $38.9^{\circ} \mathrm{N}$

Climatic Data

Degree Days
Avg. Temp. ( $\left.{ }^{\circ} \mathrm{F}\right)$
Avg. Insol. (Ly/d)

\section{Heating 4100}

Winter 36.9

Cooling 1500
Summer 507
Summer 74.2

\section{SOLAR ENERGY SYSTEM}

Application Heating 0\%

Collector

Type: Liquid flat-plate

Area (sq. ft.): 6,300

Manufacturer: Sunworks, Inc.

Storage

Type: Glass lined steel water tanks (underground)

Capacity: 10,000 gallons

Auxiliary System Type: Gas fired water heater

\section{PROJECT DESCRIPTION}

Three hundred 3' $\times 7^{\prime}$ panels were placed on the roof of the restaurant as a retrofit. The system is designed to supplement the gas fired water heaters which furnish 10000 gallons of hot water per day for consumption. The collector array was designed around the existing roof configuration which did not allow for the optimum tilt angle. The structural support system for the array is totally enclosed in compliance with the Fine Arts Commission mandate. The system is designed so that a nontoxic antifreeze solution is pumped through the panels and the heat that is absorbed is released in two single-wall heat exchangers. Domestic water is circulated through the heat exchangers, down to two 5000-gallon storage tanks in the below-grade parking level, and then through a gas fired water heater to pick up additional heat as required for the hot water service.
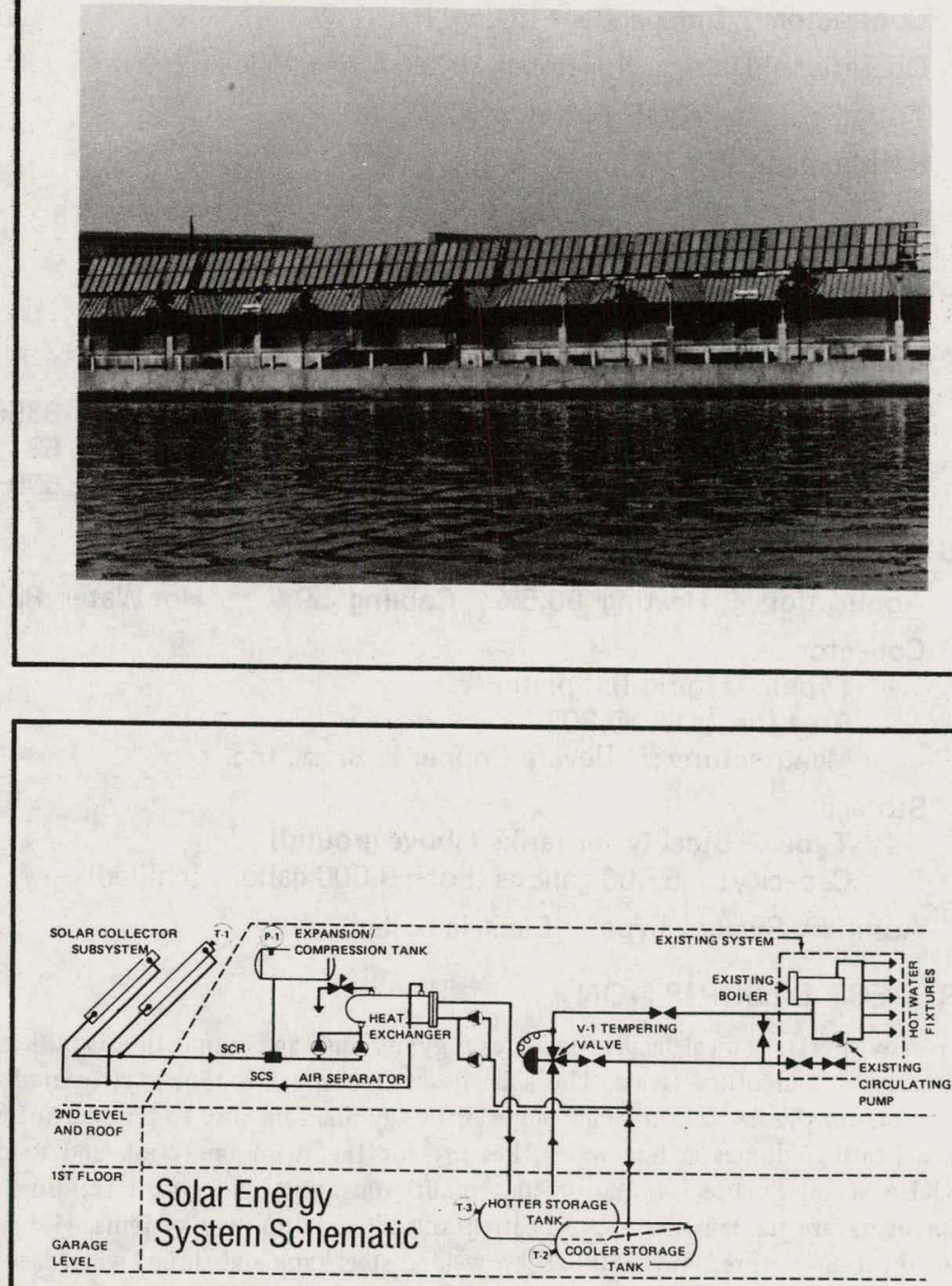


\section{PROJECT INFORMATION}

Owner/Builder: Brandon Swimming Association

Contractor: Independent Living, Inc.

Operational Date: November 1977

Total Estimated DOE Funds: $\quad \$ 208,080$

\section{Building}

Type: Sports/medical center

Area: 18,440 sq. $\mathrm{ft}$.

Location: Brandon, Florida

Latitude: $27^{\circ} 58^{\prime} \mathrm{N}$

\section{Climatic Data}

Degree Days

Avg. Temp. $\left({ }^{\circ} \mathrm{F}\right)$

Avg. Insol. (Ly/d)

$\begin{array}{llll}\text { Heating } & 718 & \text { Cooling } & 3366 \\ \text { Winter } & 62 & \text { Summer } & 82 \\ \text { Winter } & 400 & \text { Summer } & 500\end{array}$

\section{SOLAR ENERGY SYSTEM}

\section{Application Heating $90.5 \%$ \\ Cooling $59 \%$ \\ Hot Water $89 \%$}

Collector

Type: Liquid flat-plate

Area (sq. ft.): 5,301

Manufacturer: Revere Copper \& Brass, Inc.

Storage

Type: Steel water tanks (above ground)

Capacity: 5,500 gallons (hot); 9,000 gallons (chilled)

Auxiliary System Type: Electric boiler

\section{PROJECT DESCRIPTION}

This new sports/medical facility includes a gymnasium and supporting facilities, medical laboratories, and office space. The solar design incorporates tube-in-strip modular solar collectors on the $28^{\circ}$ south-facing slope of the gymnasium roof to provide hot water for space heating, domestic hot water, heating for the swimming pool, and to drive the ARKLA-Servel Solaire-300 25-ton air conditioning unit. No glycol solutions or heat exchangers are used in the space heating and air conditioning systems. Hot water for space heating is stored in a 5500-gallon welded steel tank and chilled water is stored in a 9000-gallon tank for cooling. If there is no demand for either space heating or hot water, the pool can be heated. In the low range of insolation, the collectors are used for pool heating only. An auxiliary boiler will be used to operate the system whenever available solar heat is inadequate. Auxiliary air conditioning is provided by the existing electrically operated chiller.
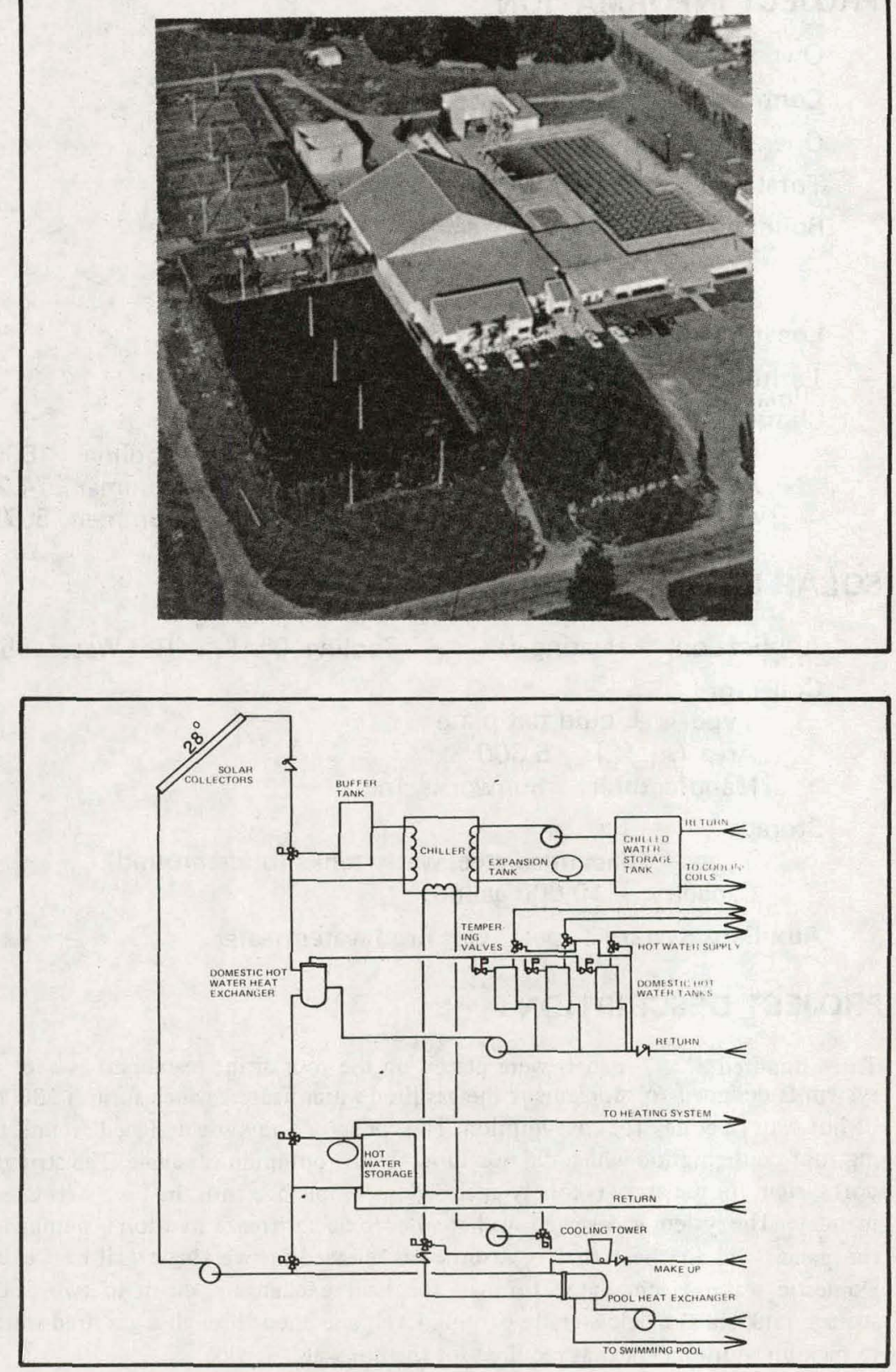


\section{JECT INFORMATION}

Owner/Builder: Florida Solar Energy Center

Contractor: To be determined

Operational Date: September 1978

Total Estimated DOE Funds: $\quad \$ 191,870$

Building

Type: Office

Area: 5,200 sq. ft. (cooling); 16,000 sq. ft. (heating)

Location: Cape Canaveral, Florida

Latitude: $28.4^{\circ} \mathrm{N}$

Climatic Data

Degree Days

Avg. Temp. $\left({ }^{\circ} \mathrm{F}\right)$

Heating

683

Cooling 2200

Avg. Insol. (Ly/d)

Winter 61

Summer 82

Winter 315 Summer 490

\section{SOLAR ENERGY SYSTEM}

Application Heating 49\% Cooling $70 \%$ Hot Water $0 \%$

Collector

Type: Evacuated glass tubular

Area (sq. ft.): 1,781

Manufacturer: General Electric Company

Storage

Type: Steel water tanks (above ground)

Capacity: 3,000 gallons (hot); 6,000 gallons (chilled)

Auxiliary System Type: Oil fired boiler, vapor compression A/C

\section{PROJECT DESCRIPTION}

The proposed building is a single-story cement block construction on a concrete slab, with a flat roof of built-up tar and gravel composition. The roof has 6 ' overhangs on the east, west, and south sides. The proposed retrofit solar air conditioning and heating system would be operated by heat from tubular type collectors with evacuated spaces around the heat collecting surfaces. For air conditioning, stored heat drives a lithium bromide water absorption chiller. Hot water storage will be placed between the collectors and the absorption chiller and the heating coil, and there will be chilled water storage between the chiller and the cooling coil. This system will be able to provide heat to all three of the office buildings in the complex, but cooling to only one building. The retrofit system will be completely backed up by the existing HVAC system.
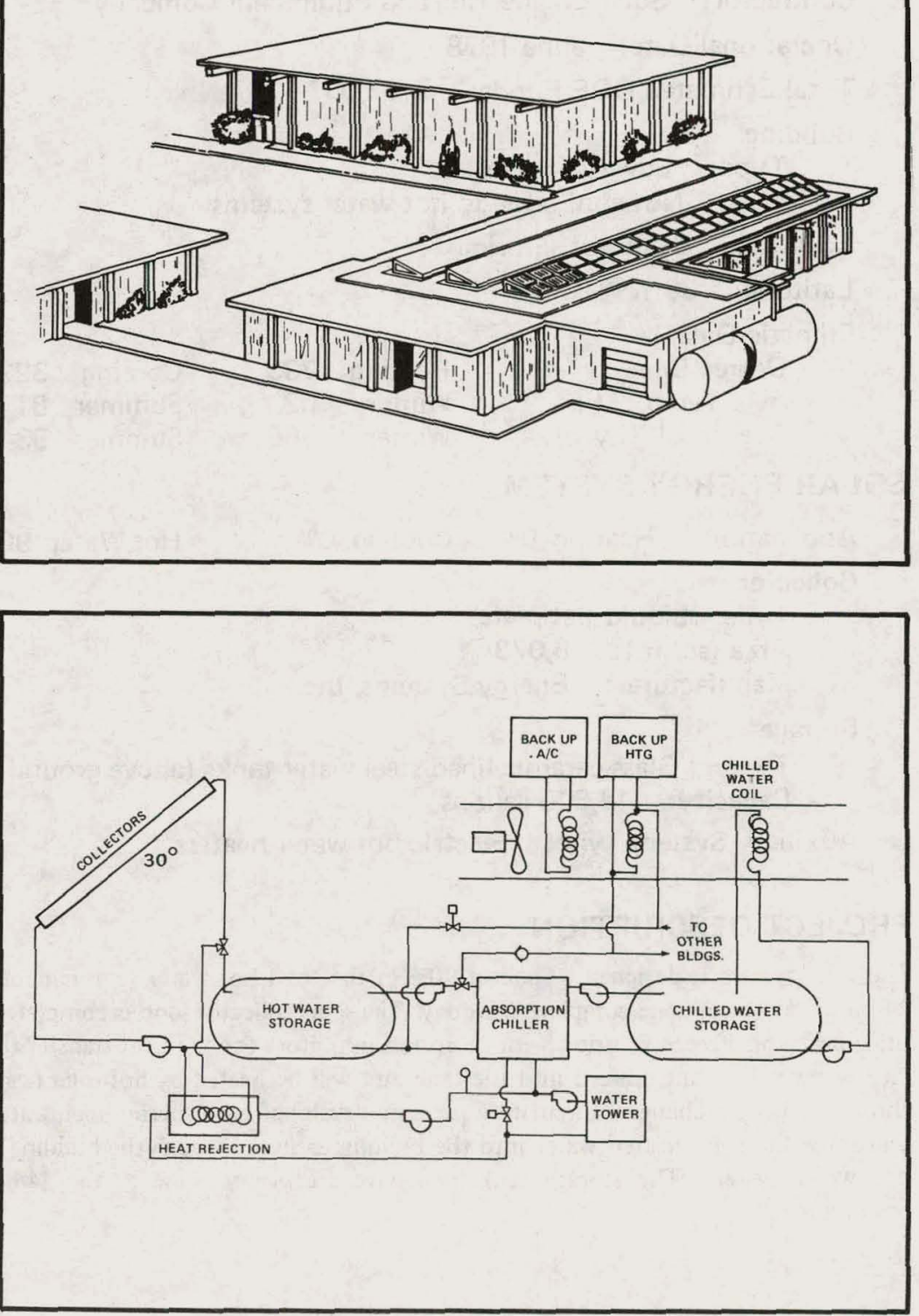


\section{PROJECT INFORMATION}

Owner/Builder: Days Inn of America, Inc.

Contractor: Solar Engineering and Equipment Company

Operational Date: June 1978

Total Estimated DOE Funds: $\$ \mathbf{\$ 1 6 7 , 0 3 7}$

Building

Type: Low rise motel

Area: Not applicable to hot water systems

Location: Clermont, Florida

Latitude: $30^{\circ} \mathrm{N}$

Climatic Data

$\begin{array}{lllll}\text { Degree Days } & \text { Heating } & 733 & \text { Cooling } & 3226 \\ \text { Avg. Temp. }\left({ }^{\circ} \mathrm{F}\right) & \text { Winter } & 62 & \text { Summer } & 81 \\ \text { Avg. Insol. (Ly/d) } & \text { Winter } & 366 & \text { Summer } & 534\end{array}$

\section{SOLAR ENERGY SYSTEM}

Application Heating $0 \%$ Cooling $0 \%$ Hot Water $90 \%$

\section{Collector}

Type: Liquid flat-plate

Area (sq. ft.): $\quad 8,073$

Manufacturer: Energy Systems, Inc.

Storage

Type: Glass-ceramic lined steel water tanks (above ground)

Capacity: 14,500 gallons

Auxiliary System Type: Electric hot water heaters

\section{PROJECT DESCRIPTION}

The solar system is designed to collect $90 \%$ of the total hot water requirements for one 24-hour day during one complete solar day. The solar collector loop is completely closed, utilizing an antifreeze solution with corrosion inhibitors for the heat transfer fluid. Cold city water will be introduced into the tank and will be heated by hot solar heated water through a heat exchanger. Circulation pressure developed by a thermo-mainwater syphon will force the solar heated water into the building system through the building's existing hot water system. The storage tanks will have a capacity equal to the 24-hour daily requirement.
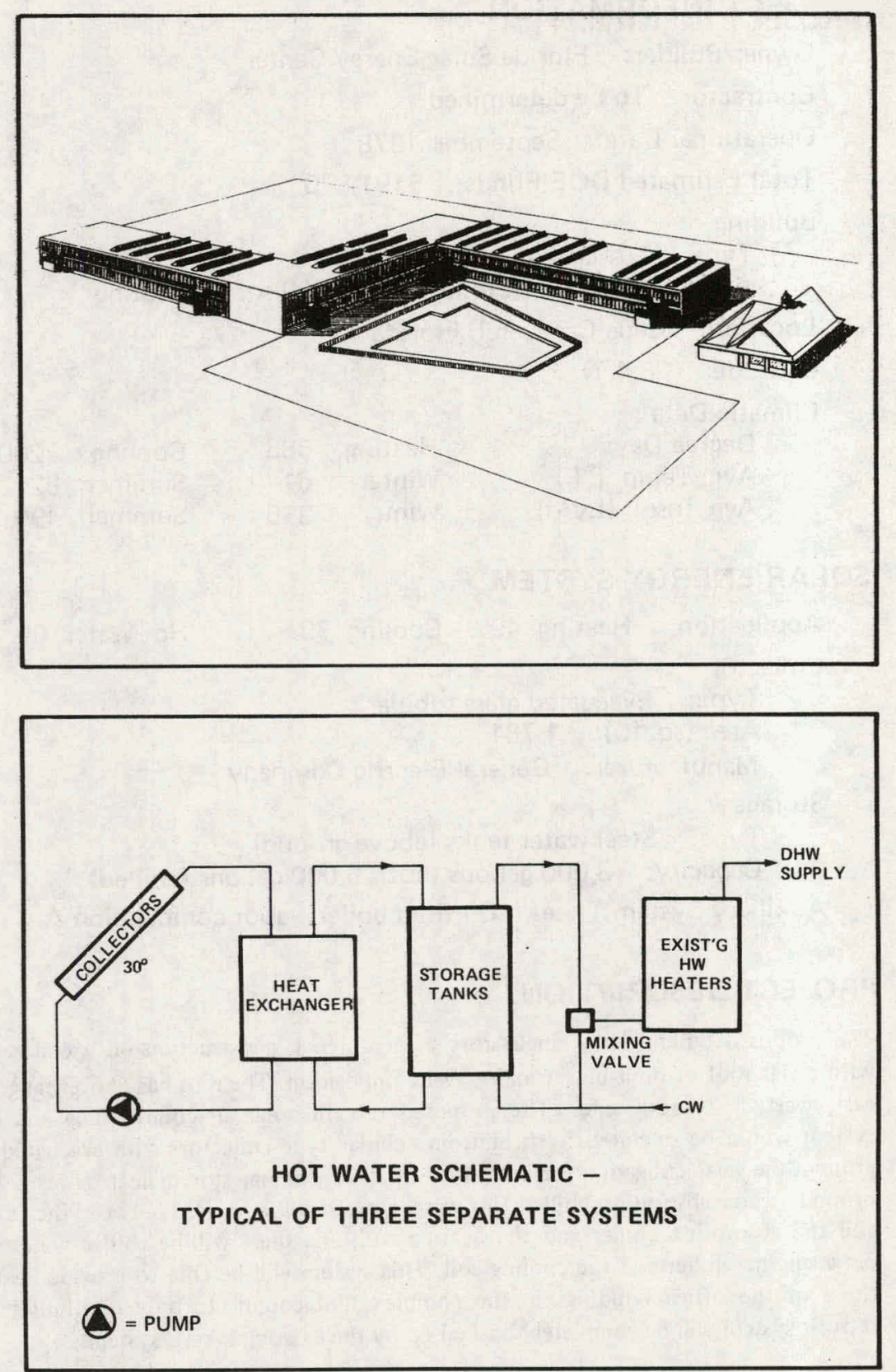


\section{PROJECT INFORMATION}

Owner/Builder: Dade County

Contractor: School Board of Dade County, Florida

Operational Date: October 1978

Total Estimated DOE Funds: $\quad \$ 869,770$

Building

Type: Elementary school

Area: $\quad 70,000$ sq. ft.

Location: Coral Gables, Florida

Latitude: $25.8^{\circ} \mathrm{N}$

Climatic Data

$\begin{array}{lllll}\text { Degree Days } & \text { Heating } & 206 & \text { Cooling } & 4038 \\ \text { Avg. Temp. }\left({ }^{\circ} \mathrm{F}\right) & \text { Winter } & 67.8 & \text { Summer } & 78.0 \\ \text { Avg. Insol. (Ly/d) } & \text { Winter } & 357 & \text { Summer } & 480\end{array}$

\section{SOLAR ENERGY SYSTEM}

Application Heating $0 \%$

Collector

Cooling $70 \% \quad$ Hot Water $90 \%$

Type: Liquid flat-plate

Area (sq. ft.): 20,000

Manufacturer: PPG Industries, Inc.

Storage

Type: Insulated steel water tanks (underground)

Capacity: 60,000 gallons

Auxiliary System Type: Centrifugal chiller and gas water heater

\section{PROJECT DESCRIPTION}

The project consists of the design, construction, and operational testing of elementary school " $\mathrm{K}$ " in Southwest Dade County at S.W. 128 Street and 109 Avenue. The two-story school will utilize solar energy to provide domestic hot water and cooling from roof-mounted flat-plate collectors and three steel storage tanks. The tanks will be buried in earth berms adjacent to the first floor perimeter walls. These berms will have a $20 \%$ gradient and will be sodded. Cooling will be derived from four, 25-ton Arkla chillers operated in unison or from a 125-ton centrifugal chiller. The cooling from the absorption units will be dependent upon solar energy, since the auxiliary energy will be supplied to the centrifugal unit as the back-up cooling system. Energy conservation measures will include earth berms, minimal fenestration, and a $7030 \mathrm{ft}^{3} / \mathrm{min}$ desiccant wheel.
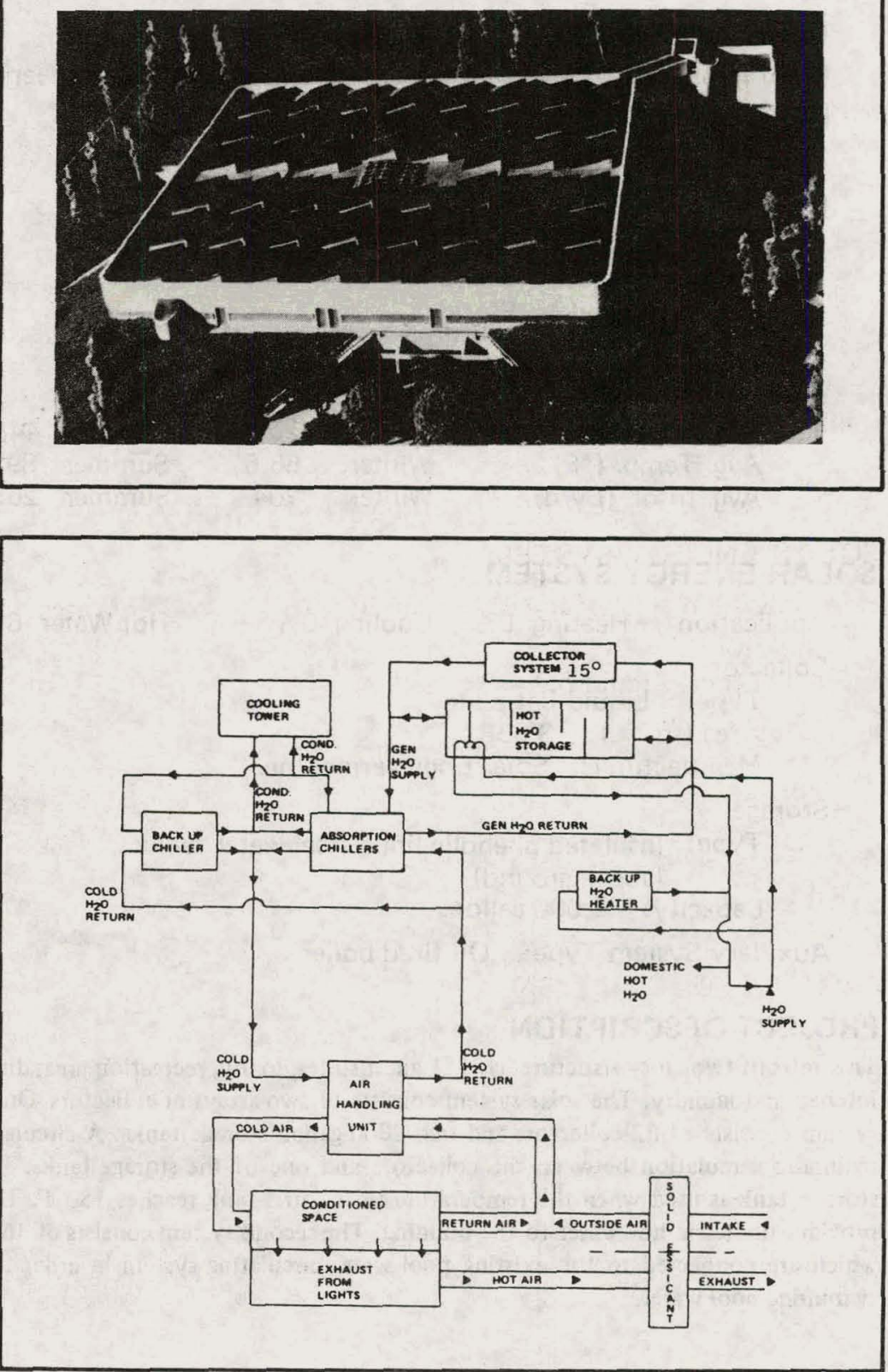


\section{PROJECT INFORMATION}

Owner/Builder: Diplomat Golf \& Racquet Club

Contractor: High Mechanical Contractors, Inc./Solar Engineering, Inc.

Operational Date: September 1978

Total Estimated DOE Funds: $\quad \$ 74,420$

Building

Type: Low rise motel

Area: Not applicable to hot water systems

Location: Hallandale, Florida

Photograph not available

Latitude: $25.7^{\circ} \mathrm{N}$

Climatic Data

$\begin{array}{lllll}\text { Degree Days } & \text { Heating } & 200 & \text { Cooling } & 4400 \\ \text { Avg. Temp. ( }{ }^{\circ} \mathrm{F} \text { ) } & \text { Winter } & 66.5 & \text { Summer } & 89 \\ \text { Avg. Insol. (Ly/d) } & \text { Winter } & 204 & \text { Summer } & 265\end{array}$

\section{SOLAR ENERGY SYSTEM}

Application Heating $0 \%$ Cooling $0 \%$ Hot Water $65 \%$

Collector
Type: Liquid flat-plate
Area (sq. ft.): 3,658
Manufacturer: Solar Engineering, Inc.

Storage

Type: Insulated phenolic-lined steel water tanks (above ground)

Capacity: 4,000 gallons

Auxiliary System Type: Oil fired boiler

\section{PROJECT DESCRIPTION}

This retrofit two-story structure has 151 guest suites, lobby, recreation area, dining room, kitchen and laundry. The solar system consists of two arrays of collectors. One collector system consists of 82 collectors and two 2000-gallon storage tanks. A circulating pump maintains circulation between the collectors and one of the storage tanks. The second storage tank is used when the temperature in the first tank reaches $150^{\circ} \mathrm{F}$. This system provides domestic hot water to the building. The second system consists of 36 collectors which are connected to the existing pool water circulating system in order to heat the swimming pool water.

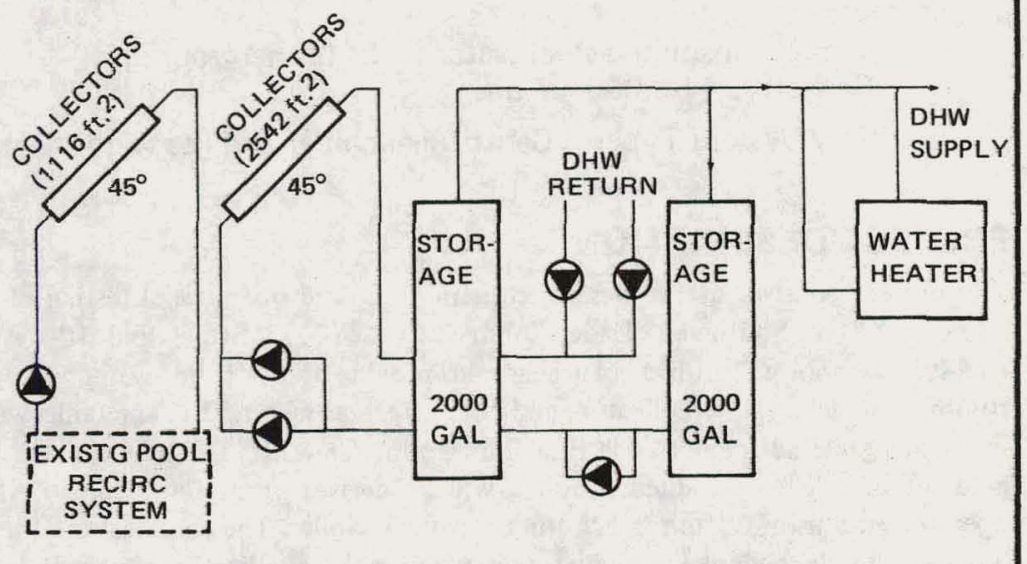

Q = PUMP 


\section{PROJECT INFORMATION}

Owner/Builder: Quality Inn

Contractor: Capital Solar Heating, Inc.

Operational Date: March 1978

Total Estimated DOE Funds: $\quad \$ 12,000$

Building

Type: Low and high rise motel

Area: Not applicable to hot water systems

Location: Key West, Florida

Latitude: $24.6^{\circ} \mathrm{N}$

Climatic Data

Degree Days

Avg. Temp. ( $\left.{ }^{\circ} \mathrm{F}\right)$

Avg. Insol. (Ly/d)

$\begin{array}{llll}\text { Heating } & 64 & \text { Cooling } & 4888 \\ \text { Winter } & 74 & \text { Summer } & 82.7 \\ \text { Winter } & 459 & \text { Summer } & 451\end{array}$

\section{SOLAR ENERGY SYSTEM}

Application Heating $0 \%$ Cooling $0 \%$ Hot Water $46.9 \%$

Collector

Type: Liquid flat-plate

Area (sq. ft.): 1,392

Manufacturer: Capital Solar Heating, Inc. Storage

Type: Insulated and lined steel water tank (above ground)

Capacity: 1,000 gallons

Auxiliary System Type: Oil fired burner

\section{PROJECT DESCRIPTION}

The collectors will be roof-mounted, at a tilt angle of $34^{\circ}$ above horizontal. The remaining equipment will be housed in the existing boiler room. The system will preheat the water supply to the existing hot water system, and is designed to supply all required hot water, without additional heat from the oil fired boiler, when the motel is $50 \%$ occupied. Domestic hot water will circulate directly through the solar collectors. The flat-plate collectors will be single-glazed and will have an aluminum absorber plate with copper tubing imbedded in the plate. The absorber coating will be flat black paint.
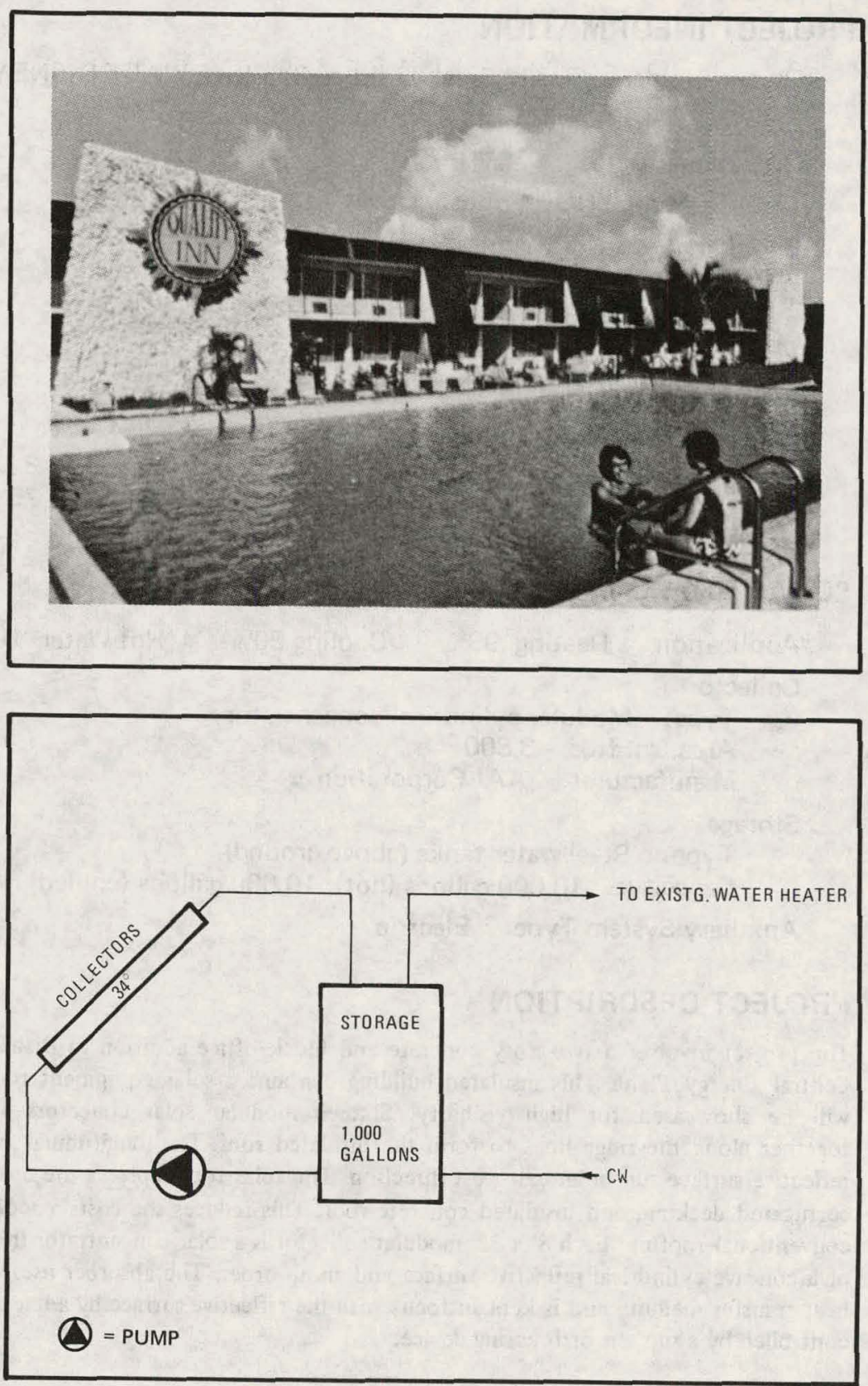


\section{PROJECT INFORMATION}

Owner/Builder: Reedy Creek Utilities Co., Inc. (WALT DISNEY WORLD) Contractor: Buena Vista Construction Company

Operational Date: February 1978

Total Estimated DOE Funds: $\$ 344,747$

Building

Type: Office

Area: 6,400 sq. ft. (cond.)

Location: Lake Buena Vista, Florida

Latitude: $28.4^{\circ} \mathrm{N}$

Climatic Data

$\begin{array}{lllll}\text { Degree Days } & \text { Heating } & 733 & \text { Cooling } 3226 \\ \text { Avg. Temp. ( }{ }^{\circ} \mathrm{F} \text { ) } & \text { Winter } & 61.1 & \text { Summer } & 75.3 \\ \text { Avg. Insol. (Ly/d) } & \text { Winter } & 315 & \text { Summer } 475\end{array}$

\section{SOLAR ENERGY SYSTEM}

\section{Application Heating $99 \%$ Cooling $80 \%$ Hot Water $100 \%$}

Collector

Type: Modular cylindrical concentrator

Area (sq. ft.): 3,800

Manufacturer: AAl Corporation

\section{Storage}

Type: Steel water tanks (above ground)

Capacity: $\quad 10,000$ gallons (hot); 10,000 gallons (chilled)

Auxiliary System Type: Electric

\section{PROJECT DESCRIPTION}

The project involves a two-story concrete and block office addition to Disney World's Central Energy Plant. This insulated building contains a solar equipment room which will be showcased for high visibility. Sixteen modular solar collectors are joined together along the ridge lines to form the insulated roof. The longitudinal axes of the reflective surface run in an east-west direction. The solar roof replaces the usual trusses, corrugated decking, and insulated concrete roof. This reduces the costs associated with conventional roofing. Each $8^{\prime} \times 32$ ' modular collector is a solar concentrator that consists of a concave cylindrical reflective surface and an absorber. The absorber uses water as a heat transfer medium and is kept in focus with the reflective surface by a linear actuator controlled by a sun sensor/focusing device.
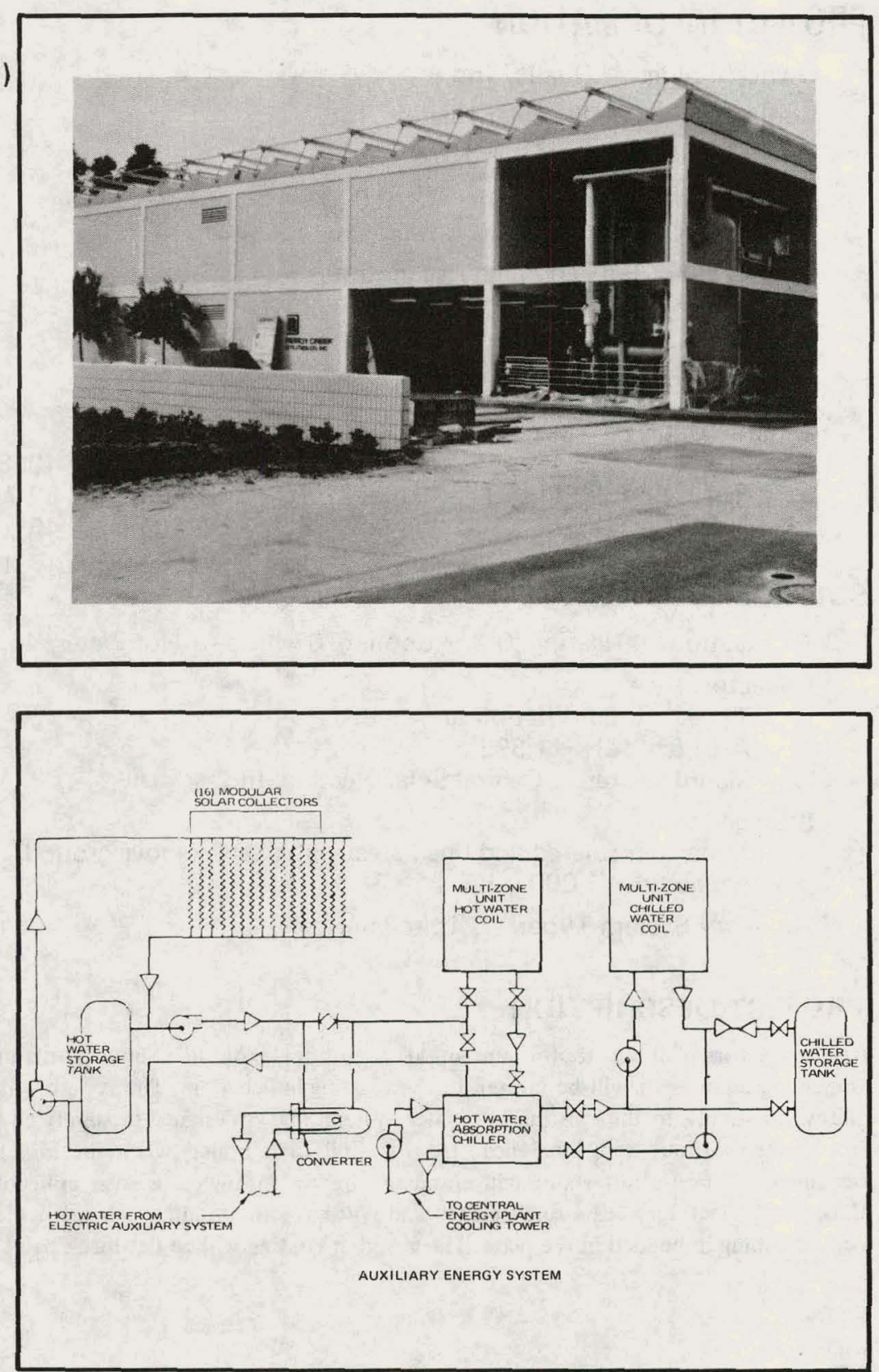


\section{PROJECT INFORMATION}

Owner/Builder: Florida Department of Commerce

Contractor: Florida Department of General Services/

Tompkins-Beckwith, Inc.

Operational Date: October 1977

Total Estimated DOE Funds: $\$ 280,000$

Building

Type: Welcome station

Area: 3,300 sq. ft. (cond.)

Location: Nassau County, Florida

Latitude: $30.7^{\circ} \mathrm{N}$

Climatic Data

$\begin{array}{lllll}\text { Degree Days } & \text { Heating } & 1327 & \text { Cooling } & 2596 \\ \text { Avg. Temp. }\left({ }^{\circ} \mathrm{F}\right) & \text { Winter } & 57.7 & \text { Summer } & 76.0 \\ \text { Avg. Insol. (Ly/d) } & \text { Winter } & 308 & \text { Summer } & 496\end{array}$

\section{SOLAR ENERGY SYSTEM}

Application Heating $99 \%$ Cooling $88 \%$ Hot Water $0 \%$

Collector

Type: Fresnel lens, concentrating and tracking

Area (sq. ft.): 2,840

Manufacturer: Northrup, Inc.

Storage

Type: Steel water tanks (above ground)

Capacity: 6,000 gallons (hot); 6,000 gallons (chilled)

Auxiliary System Type: Oil fired furnace

\section{PROJECT DESCRIPTION}

This Florida Welcome Station, located on Interstate 95 two miles south of the FloridaGeorgia line, is expected to accommodate a large number of visitors. To conserve energy, the one-story building utilizes a poured, light-weight, aggregate roof-deck, a suspended insulating tile ceiling, and windows that are protected from direct sunlight. Key system components include a 25-ton ARKLA WF-300 absorption chiller, a field of concentrating collectors, a hot water storage tank and a cooling tower that will provide condensing water. An oil fired hot water heater, a vapor compression air exchange air conditioner, and an oil fired furnace will be the auxiliary systems. The building's energy system (solar and conventional) will be controlled by a single set of valves and sensors. Automatic switching between the two systems will be possible, manual operation being necessary only for selecting the heating or cooling mode.
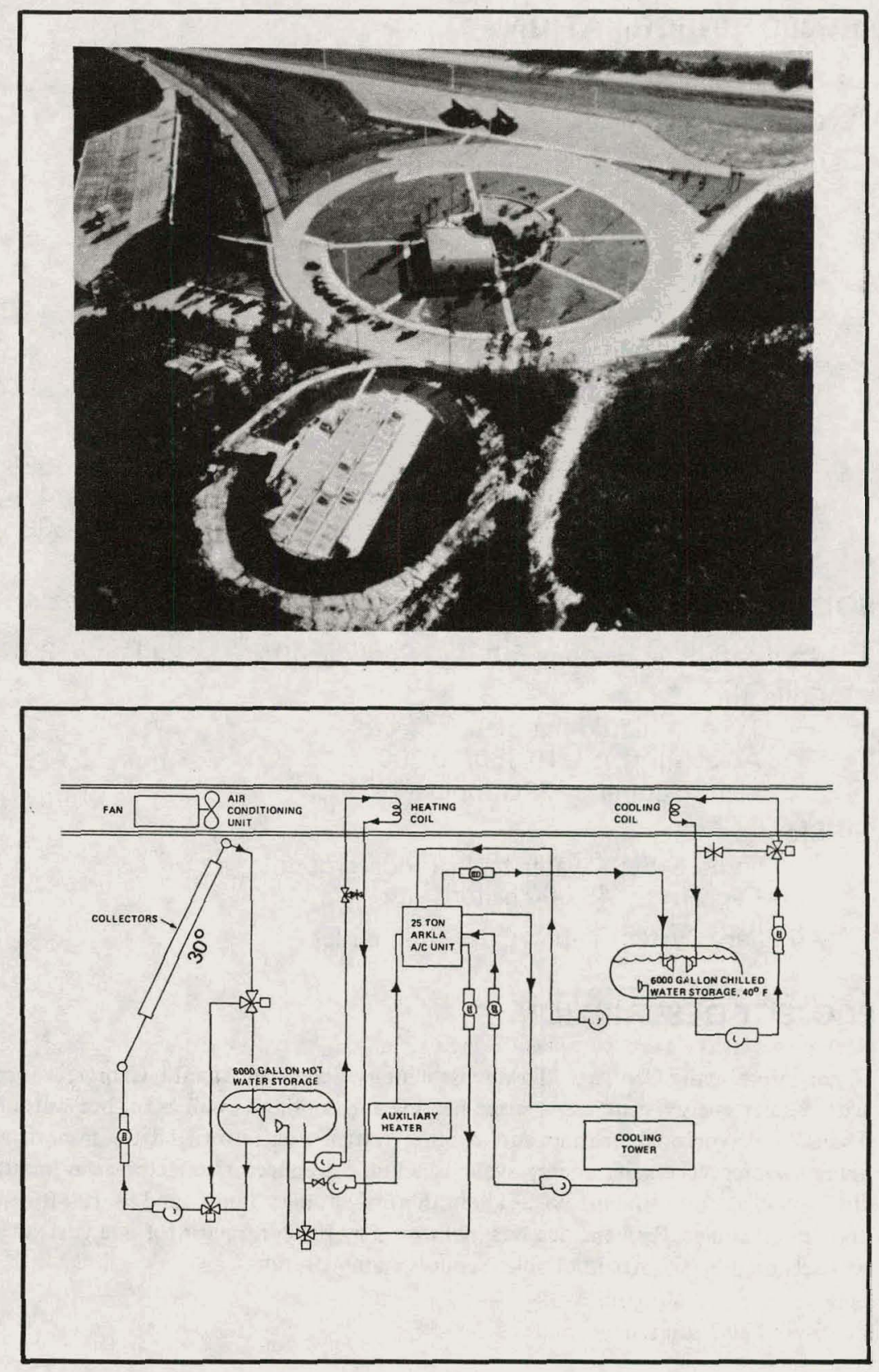


\section{PROJECT INFORMATION}

Owner/Builder: City of Atlanta

Contractor: Westinghouse Electric Company

Operational Date: September 1975

Total Estimated DOE Funds: $\$ 912,000$

Building

Type: Elementary school

Area: 32,000 sq. ft.

Location: Atlanta, Georgia

Latitude: $33.8^{\circ} \mathrm{N}$

Climatic Data

$\begin{array}{lllll}\text { Degree Days } & \text { Heating } & 3095 & \text { Cooling } & 1589 \\ \text { Avg. Temp. }\left({ }^{\circ} \mathrm{F}\right) & \text { Winter } & 51.0 & \text { Summer } & 74.5 \\ \text { Avg. Insol (Ly/d) } & \text { Winter } & 312 & \text { Summer } & 508\end{array}$

\section{SOLAR ENERGY SYSTEM}

Application Heating 50\%

Cooling $60 \%$

Hot Water $80 \%$

Collector

Type: Liquid flat-plate/reflector

Area:(sq. ft.): 10,360/10,800

Manufacturer: PPG Industries, Inc.

Storage

Type: Steel water tanks (underground)

Capacity: 45,000 gallons

Auxiliary System Type: Gas fired boiler

\section{PROJECT DESCRIPTION}

In this project, the George A. Towns Elementary School in Atlanta, Georgia was provided with a solar energy system for space heating and cooling as well as for hot water heating. The school's original heating and cooling system was retrofitted for use with a solar energy source. The solar energy system included a collector/reflector array mounted on the school's roof, three 15000-gallon thermal storage tanks, and a 100-ton ARKLA absorption chiller. Performance was monitored by the contractor for one year; the system was accepted by the Atlanta Public Schools administration.
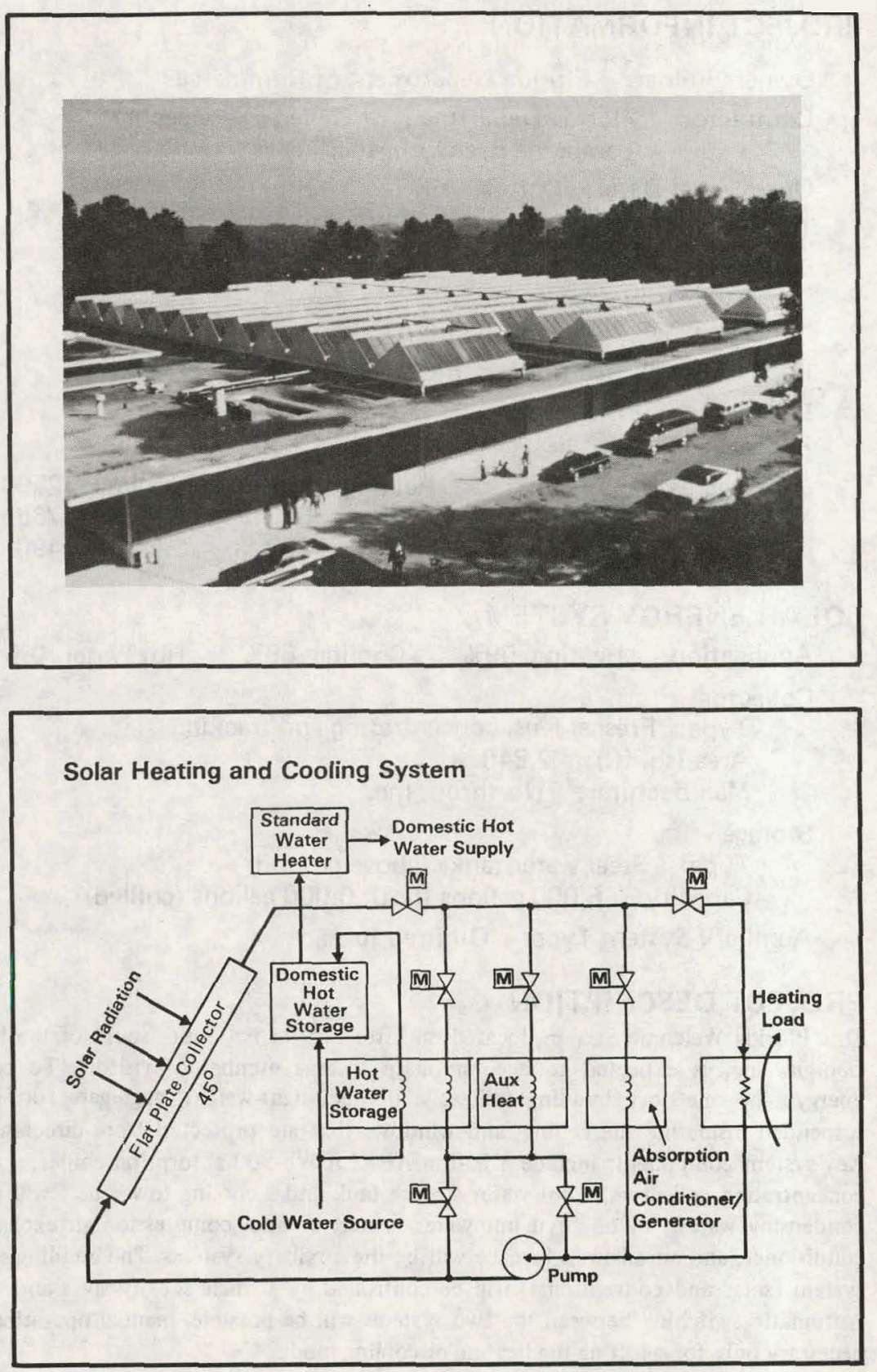


\section{JECT INFORMATION}

Owner/Builder: La Quinta Motor Inns, Inc.

Contractor: Travis-Braun \& Associates, Inc.

Operational Date: Late 1978

Total Estimated DOE Funds: $\$ 39,329$

Building

Type: Low rise motel

Area: Not applicable to hot water systems

Location: College Park, Georgia

Latitude: $33^{\circ} 4^{\prime} \mathrm{N}$

Climatic Data

$\begin{array}{lllll}\text { Degree Days } & \text { Heating } & 2960 & \text { Cooling } & \text { N/A } \\ \text { Avg. Temp. ( }{ }^{\circ} \mathrm{F} \text { ) } & \text { Winter } & 51.7 & \text { Summer } & 80 \\ \text { Avg. Insol. (Ly/d) } & \text { Winter } & 230 & \text { Summer } & 480\end{array}$

\section{SOLAR ENERGY SYSTEM}

Application Heating 0\% Cooling 0\%

Collector

Type: Liquid flat-plate

Area (sq. ft.): $2 ; 000$

Manufacturer: Revere Copper \& Brass, Inc.

\section{Storage}

Type: Steel water tank (above ground)

Capacity: 1,600 gallons

Auxiliary System Type: Electric boiler

\section{PROJECT DESCRIPTION}

A drain-down system is proposed under this grant. This system is one in which, each time the water circulation pump stops, the collector fluid water drains out and down into the protection of an enclosed space. In this proposal, this enclosed space is the mechanical room of the motel. This system is a hybrid version of a drain-down system employing a heat exchanger. By using this heat exchanger, the buildup of minerals in the solar collector is eliminated. On the solar loop of the system, a contained amount of water is employed. Even as this water level drops and makeup water is introduced into the system, new minerals, acids, etc., are also introduced; however, this introduction is extremely minor in comparison to the minerals which would be constantly introduced by a direct link between the storage vessel and the solar collectors.
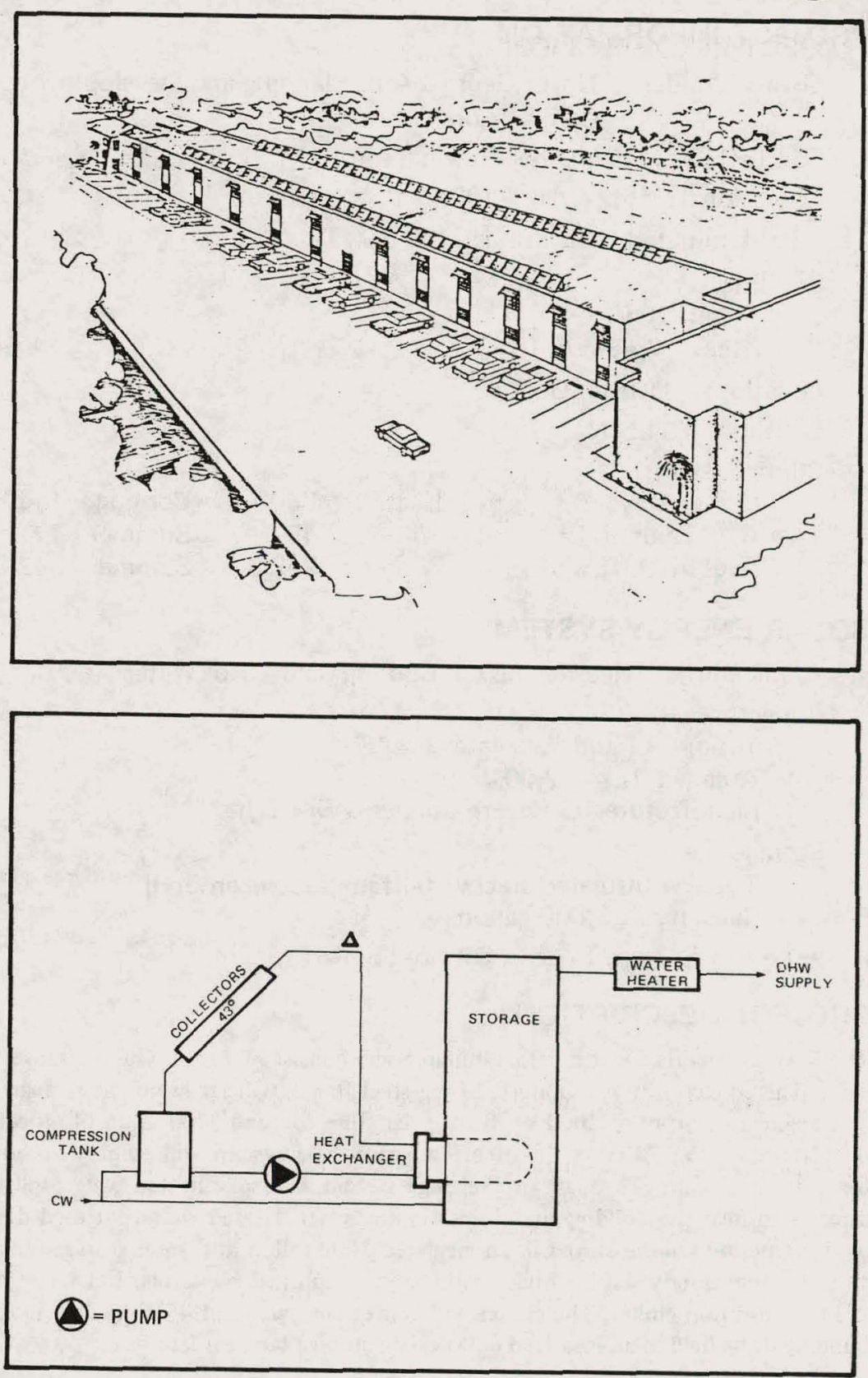


\section{PROJECT INFORMATION}

Owner/Builder: North Georgia Area Planning and Development Commission

Contractor: Independent Living, Inc.

Operational Date: April 1978

Total Estimated DOE Funds: $\$ 113,777$

Building

Type: Office

Area: 7,455 sq. ft.

Location: Dalton, Georgia

Latitude: $34.5^{\circ} \mathrm{N}$

Climatic Data

Degree Days

Avg. Temp. $\left({ }^{\circ} \mathrm{F}\right)$

Avg. Insol. (Ly/d)

Heating 33

Winter 43

Cooling 1460

Winter 2423

\section{SOLAR ENERGY SYSTEM}

Application Heating 80\%

Collector

Type: Liquid flat-plate

Area (sq. ft.): 2,001

Manufacturer: Revere Copper \& Brass, Inc.

Storage

Type: Insulated steel water tank (above ground)

Capacity: 9,000 gallons

Auxiliary System Type: Oil fired boiler

\section{PROJECT DESCRIPTION}

The solar collectors for this office building will consist of 115 modules arranged in five rows. The collector array, supported by a steel frame, will face south at an angle of $45^{\circ}$. The augmented array of 2000 sq. ft. of solar collectors and 2400 sq. ft. of reflectors will heat and cool the $7455 \mathrm{sq}$. ft. of office space. The system will employ an automatic drain-down system. Through an exchange system, the solar-heated water will be used directly to heat the building and domestic hot water. Heated water not used during the daylight period will be stored in an insulated 3000-gallon hot water storage tank for use at night and cloudy days. Cooling will be accomplished by a solar hot water powered Arkla absorption chiller. The chiller will deliver cool water at $45^{\circ} \mathrm{F}$ to directly cool the building or be held in an insulated 6000 -gallon storage tank for later use.
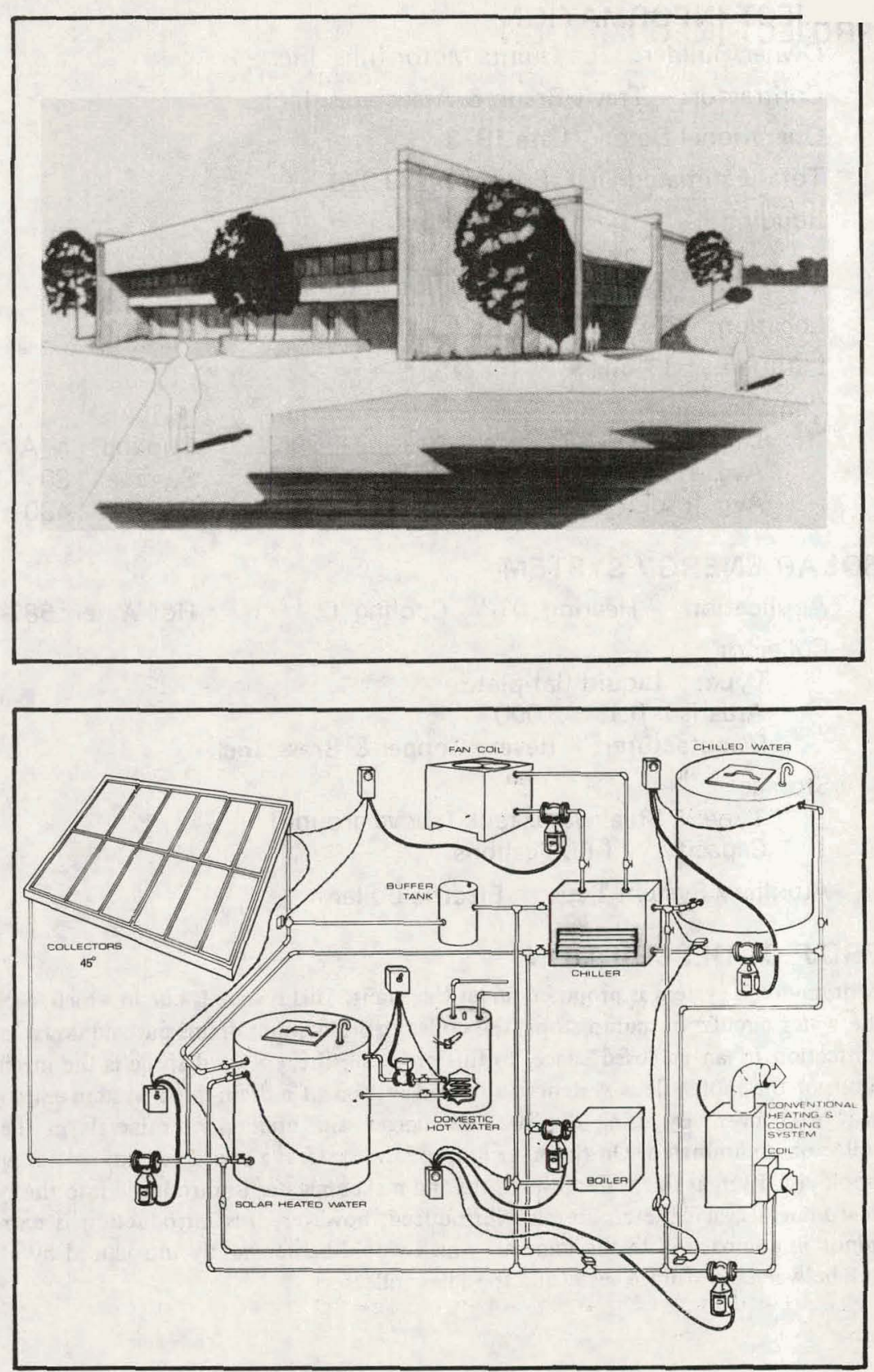


\section{PROJECT INFORMATION}

Owner/Builder: Shenandoah Development Corporation

Contractor: Georgia Institute of Technology

Operational Date: April 1977

Total Estimated DOE Funds: $\quad \mathbf{\$ 7 7 8 , 2 5 3}$

Building

Type: Recreational center

Area: $\quad 59,000$ sq. ft. (total); 58,000 sq. ft. (cond.)

Location: Shenandoah, Georgia

Climatic Data

$\begin{array}{lllll}\text { Degree Days } & \text { Heating } & 3095 & \text { Cooling } & 1589 \\ \text { Avg. Temp. }\left({ }^{\circ} \mathrm{F}\right) & \text { Winter } & 51.0 & \text { Summer } & 74.6 \\ \text { Avg. Insol. (Ly/d) } & \text { Winter } & 312 & \text { Summer } & 508\end{array}$

\section{SOLAR ENERGY SYSTEM}

Application Heating $90 \%$ Cooling $60 \%$ Hot Water $90 \%$

Collector

Type: Liquid flat-plate/reflector

Area (sq. ft.): $11,213 / 23,000$

Manufacturer: Revere Copper \& Brass, Inc.

Storage

Type: Steel water tank (underground)

Capacity: 15,000 gallons (hot); 60,000 gallons (chilled)

Auxiliary System Type: Gas and electric

\section{PROJECT DESCRIPTION}

The Georgia Institute of Technology has designed, installed, evaluated, and computermodeled this multipurpose community center for the new town of Shenandoah, approximately 25 miles south of Atlanta. The building is partially underground incorporating numerous energy conserving features. Twenty-three thousand square feet of polished aluminum reflectors augment the rooftop solar collectors for additional heat input during the summer months. The individual $21^{\prime} \times 8^{\prime}$ solar collector modules are factory-assembled for low-cost rooftop installation. Air conditioning is provided by a 100-ton lithium bromide absorption chiller. In the autumn and spring, heat from the solar collectors, which is not needed for space heating, cooling, or hot water is used to heat an outdoor olympicsized swimming pool.
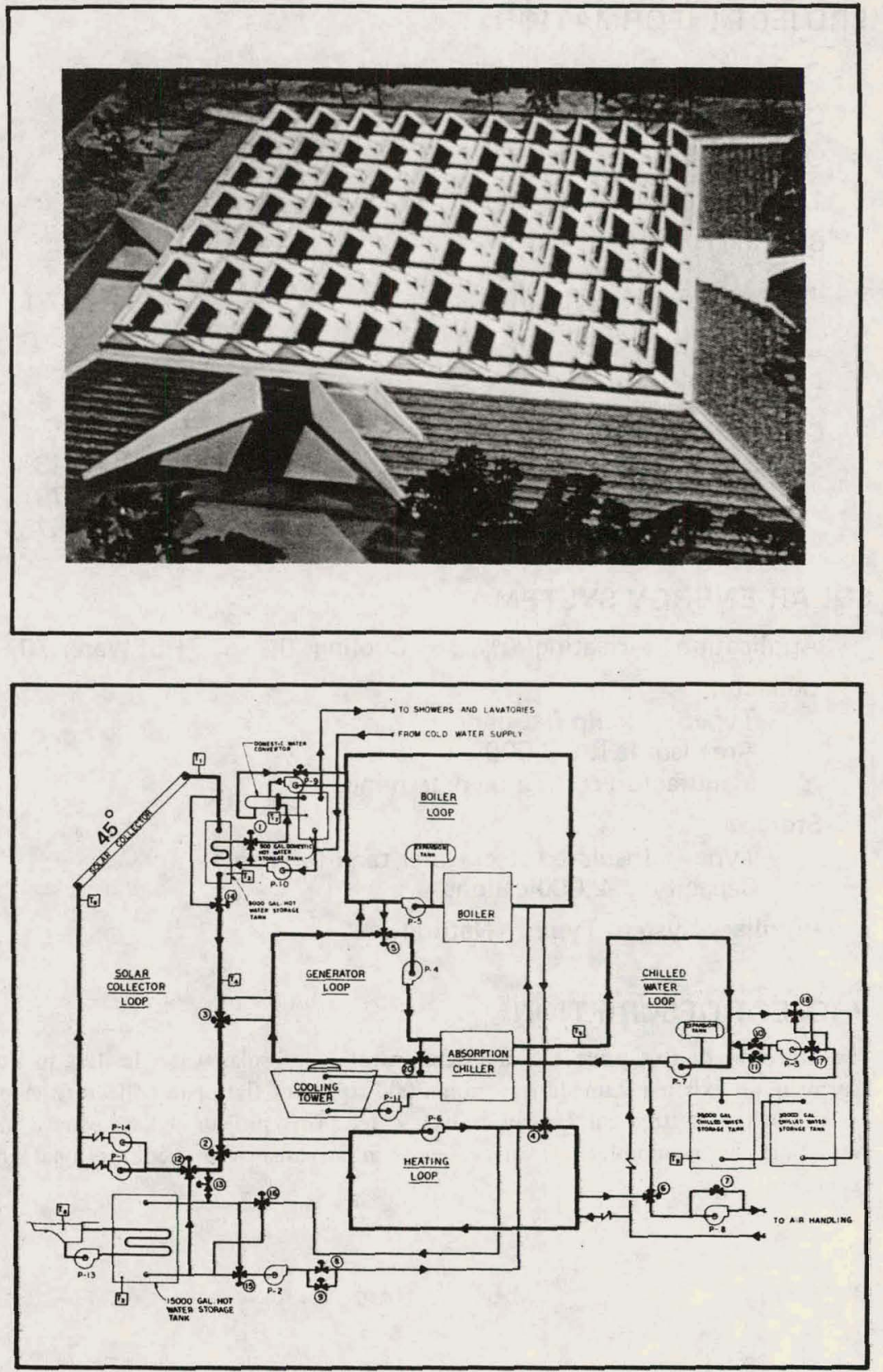


\section{PROJECT INFORMATION}

Owner/Builder: Airport Ramada Inn

Contractor: Bortles, Gates \& Associates

Operational Date: June 1978

Total Estimated DOE Funds: $\quad \$ 126,000$

Building

Type: Hote

Area: To be determined

Location: Honolulu, Hawaii

Latitude: $21^{\circ} 21^{\prime} \mathrm{N}$

Climatic Data

Degree Days

Avg. Temp. $\left({ }^{\circ} \mathrm{F}\right)$

Avg. Insol. (Ly/d)

$\begin{array}{llll}\text { Heating } & \text { N/A } & \text { Cooling } & 4395 \\ \text { Winter } & 73 & \text { Summer } & 79 \\ \text { Winter } & 450 & \text { Summer } & 575\end{array}$

\section{SOLAR ENERGY SYSTEM}

Application Heating 0\%

Hot Water $70 \%$

Collector

Type: Liquid flat-plate

Area (sq. ft.): 3,000

Manufacturer: To be determined

Storage

Type: Insulated steel water tank (on roof)

Capacity: 2,000 gallons

Auxiliary System Type: Natural gas

\section{PROJECT DESCRIPTION}

The objective of this project is the demonstration of solar water heating in Honolulu, Hawaii in an existing Ramada Inn using 3000 sq. ft. of flat-plate collectors. A principal use of energy in tropical Hawaii is hot water. This project will provide a means of evaluating the economics of solar energy in an area where conventional energy is expensive.
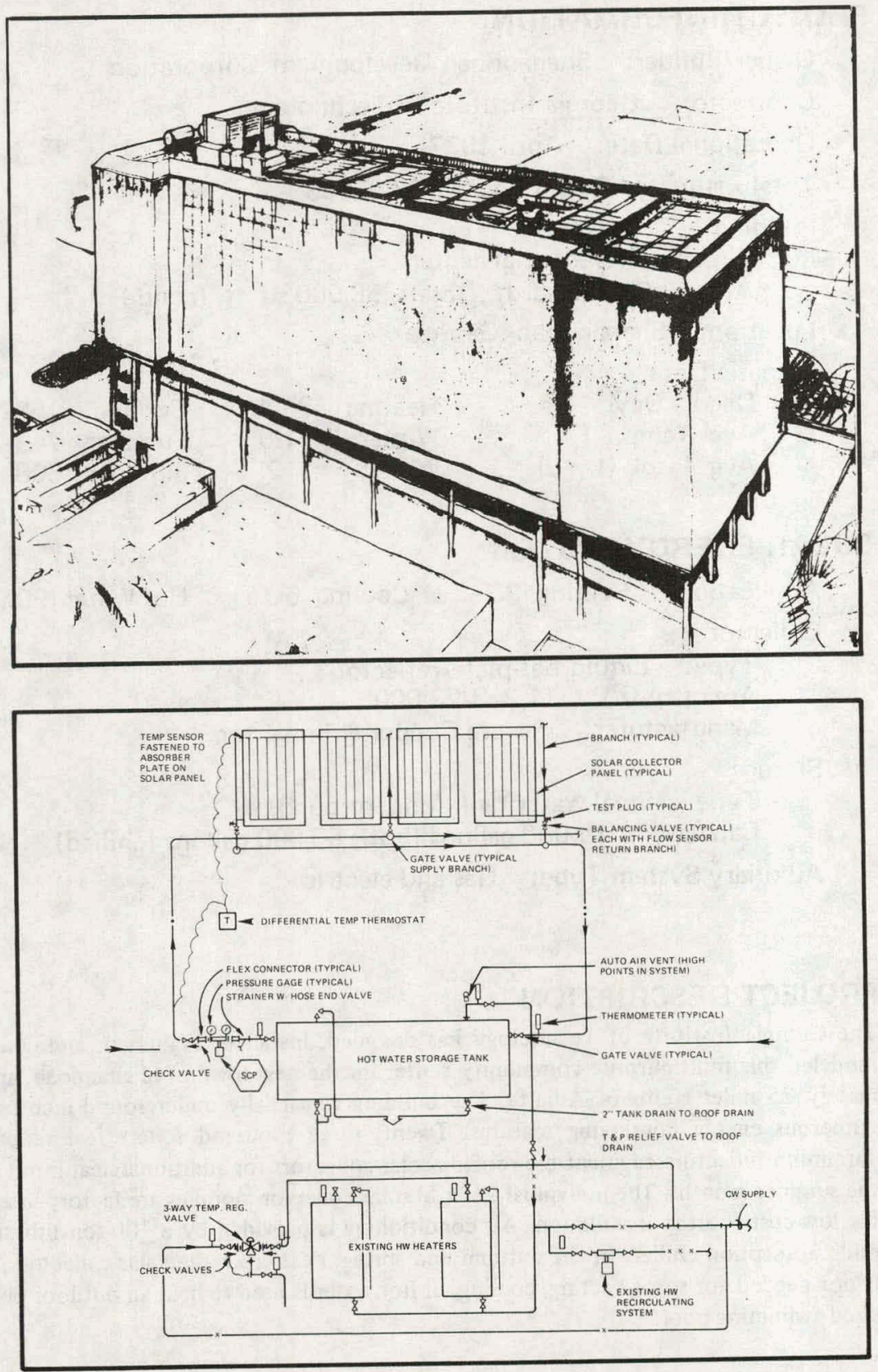


\section{PROJECT INFORMATION}

Owner/Builder: Iolanı School

Contractor: Northrup, Inc.

Operational Date: July 1978

Total Estimated DOE Funds: $\quad \$ 201,828$

Building

Type: School

Area: 12,000 sq. $\mathrm{ft}$.

Location: Honolulu, Hawaii

Latitude: $21^{\circ} \mathrm{N}$

Climatic Data

$\begin{array}{lllll}\text { Degree Days } & \text { Heating } & \text { N/A } & \text { Cooling } & 4221 \\ \text { Avg. Temp. }\left({ }^{\circ} \mathrm{F}\right) & \text { Winter } & 73 & \text { Summer } & 80 \\ \text { Avg. Insol. (Ly/d) } & \text { Winter } & 434 & \text { Summer } & 614\end{array}$

\section{SOLAR ENERGY SYSTEM}

Application Heating $0 \%$

\section{Collector}

Type: Tracking concentrating

Area (sq. ft.): 3,000

Manufacturer: Northrup, Inc.

Storage

Type: Insulated steel water tank (above ground)

Capacity: 5,000 gallons

Auxiliary System Type: Gas boiler

\section{PROJECT DESCRIPTION}

Three hundred and eight Northrup tracking, concentrating collectors will be installed on the flat roof of the main part of the school and the terraced roof of the auditorium. The primary function of the solar system is to augment existing water chillers, which will be retained as back-up. The absorption chiller and pumps will be installed in a new equipment room with a cooling tower on the roof. An expansion tank will be located nearby, above the ground. Air conditioning will serve the library, 12 classrooms, and a small auditorium. Water heating will serve showers in the gymnasium and athletic facilities.
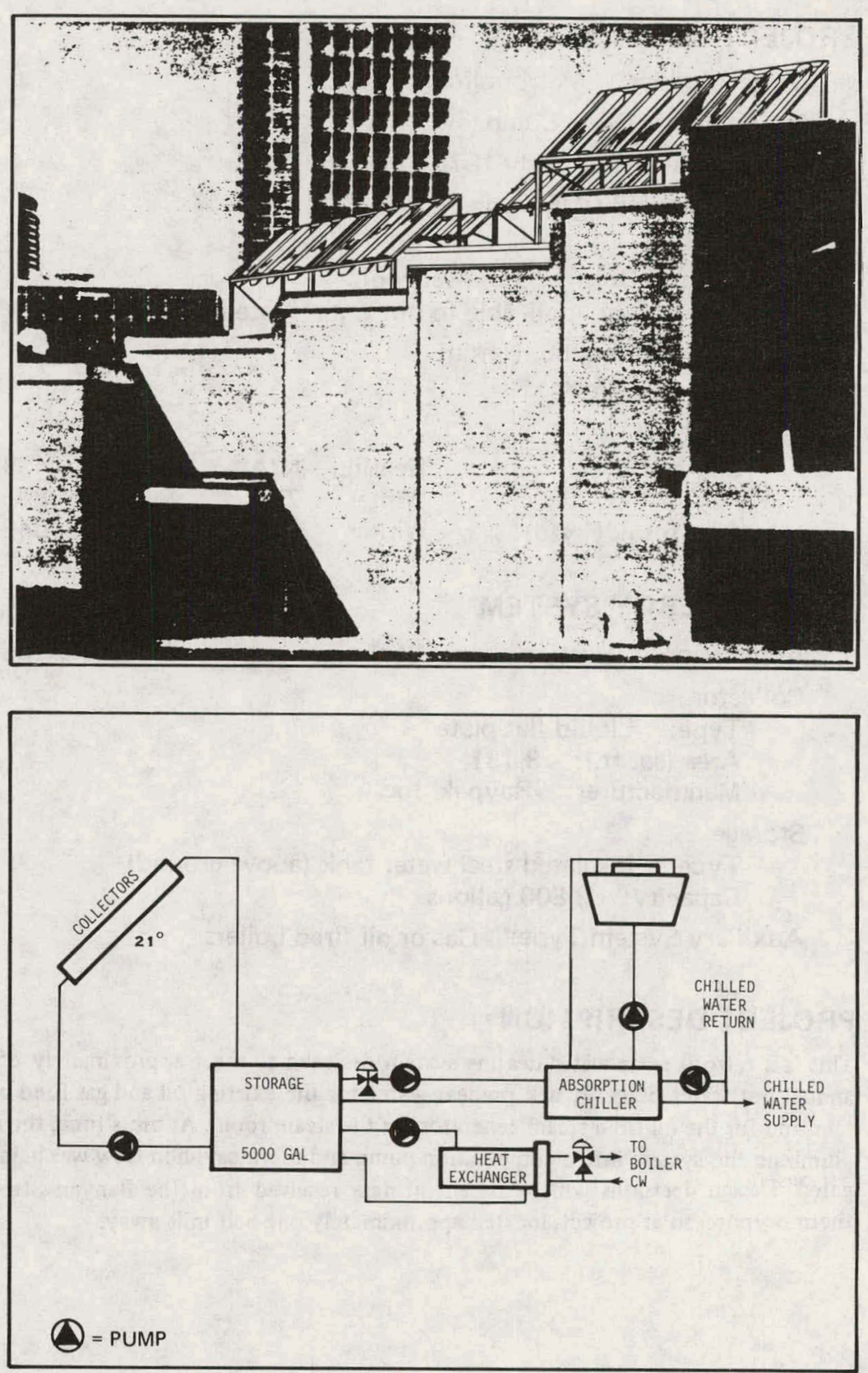


\section{PROJECT INFORMATION}

Owner/Builder: Metropolitan YMCA

Contractor: Cody Company

Operational Date: July 1978

Total Estimated DOE Funds: $\$ \mathbf{\$ 6 6 , 6 2 2}$

Building

Type: Dorm and shower room

Area: Not applicable to hot water systems

Location: Honolulu, Hawaii

Latitude: $21^{\circ} 30^{\prime} \mathrm{N}$

Climatic Data

$\begin{array}{lllll}\text { Degree Days } & \text { Heating } & \text { N/A } & \text { Cooling } & 4395 \\ \text { Avg. Temp. }\left({ }^{\circ} \mathrm{F}\right) & \text { Winter } & 75 & \text { Summer } & 80 \\ \text { Avg. Insol. (Ly/d) } & \text { Winter } & 542 & \text { Summer } & 542\end{array}$

\section{SOLAR ENERGY SYSTEM}

Application Heating $0 \%$ Cooling $0 \%$ Hot Water $85 \%$

Collector

Type: Liquid flat-plate

Area (sq. ft.): 3,131

Manufacturer: Raypak, Inc.

Storage

Type: Insulated steel water tank (above ground)

Capacity: 3,800 gallons

Auxiliary System Type: Gas or oil fired boilers

\section{PROJECT DESCRIPTION}

This is a retrofit solar water heating system designed to meet approximately $85 \%$ of the annual hot water usage. It will preheat water for the existing oil and gas fired boiler system, and for the oil fired steam generator for the steam room. At press time, the option of plumbing the system into a combination pump and thermosyphon flow was being investigated. Design decisions will be based on data received from the Banyan Street Manor thermosyphon solar project, located approximately one-half mile away.
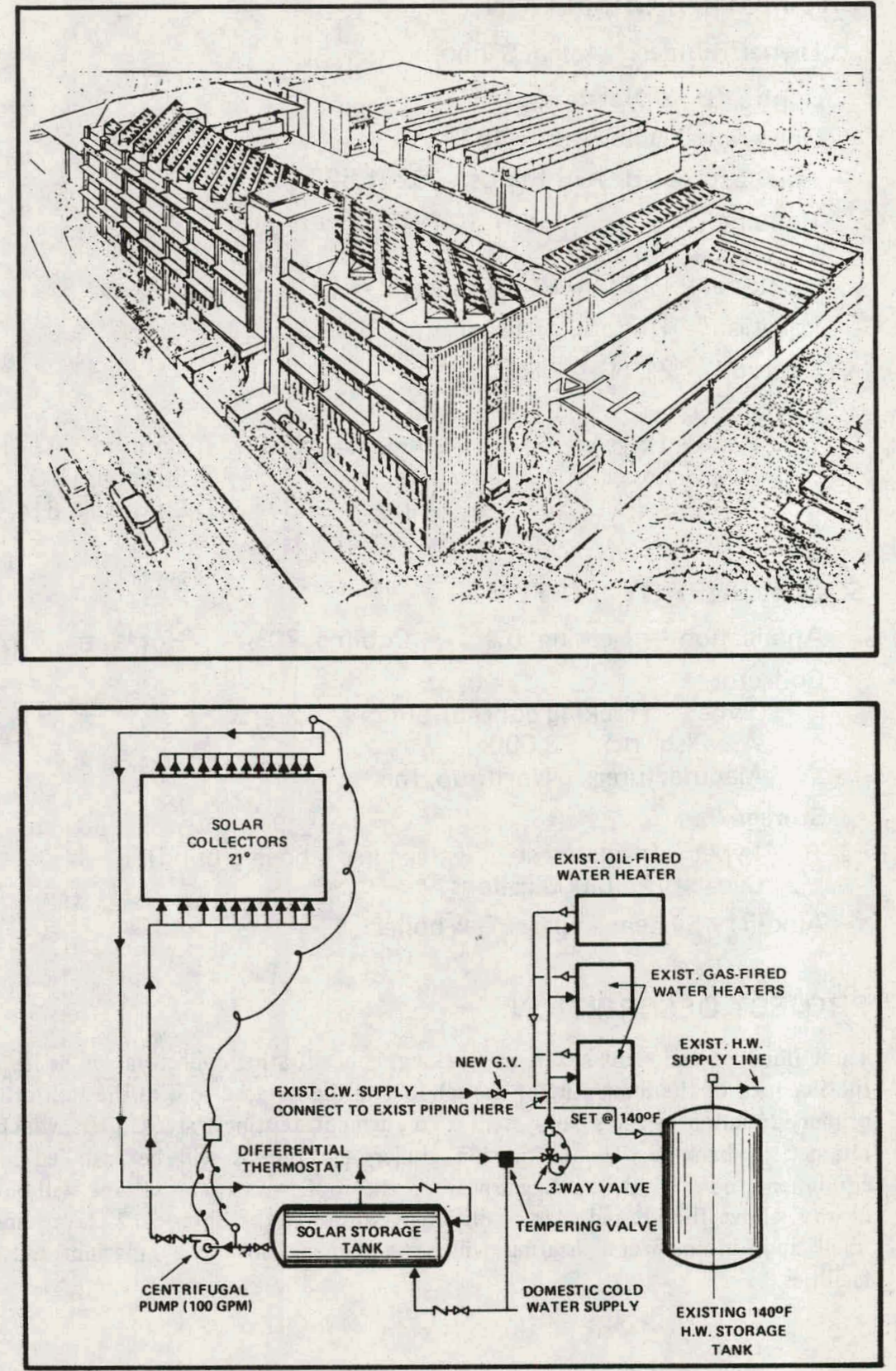


\section{PROJECT INFORMATION}

Owner/Builder: Hawaiian Pacific Resorts

Contractor: Hirano Brothers, Ltd.

Operational Date: May 1978

Total Estimated DOE Funds: $\$ 125,000$

Building

Type: High rise hotel

Area: Not applicable to hot water systems

Location: Kona, Hawaii

Latitude: $21^{\circ} \mathrm{N}$

Climatic Data

Degree Days

Avg. Temp. $\left({ }^{\circ} \mathrm{F}\right)$

Avg. Insol. (Ly/d)

$\begin{array}{llll}\text { Heating } & \text { N/A } & \text { Cooling } & 3930 \\ \text { Winter } & 80 & \text { Summer } & 80 \\ \text { Winter } & 467 & \text { Summer } & 510\end{array}$

\section{SOLAR ENERGY SYSTEM}

Application Heating $0 \%$ Cooling $0 \%$ Hot Water $34 \%$

Collector

Type: Liquid flat-plate

Area (sq. ft.): 5,000

Manufacturer: Raypak, Inc.

Storage

Type: Insulated steel water tank (on roof)

Capacity: 7,500 gallons

Auxiliary System Type: Liquid propane gas

\section{PROJECT DESCRIPTION}

Five thousand square feet of collectors will collect the solar energy and transfer it into the 7500 -gallon storage tank. This preheated water will be delivered to the existing gas fired water heater. This heater will turn on if the temperature of the water from the solar storage tank is below the required water temperature. No freeze protection is required for this system, due to high ambient temperatures throughout the year.
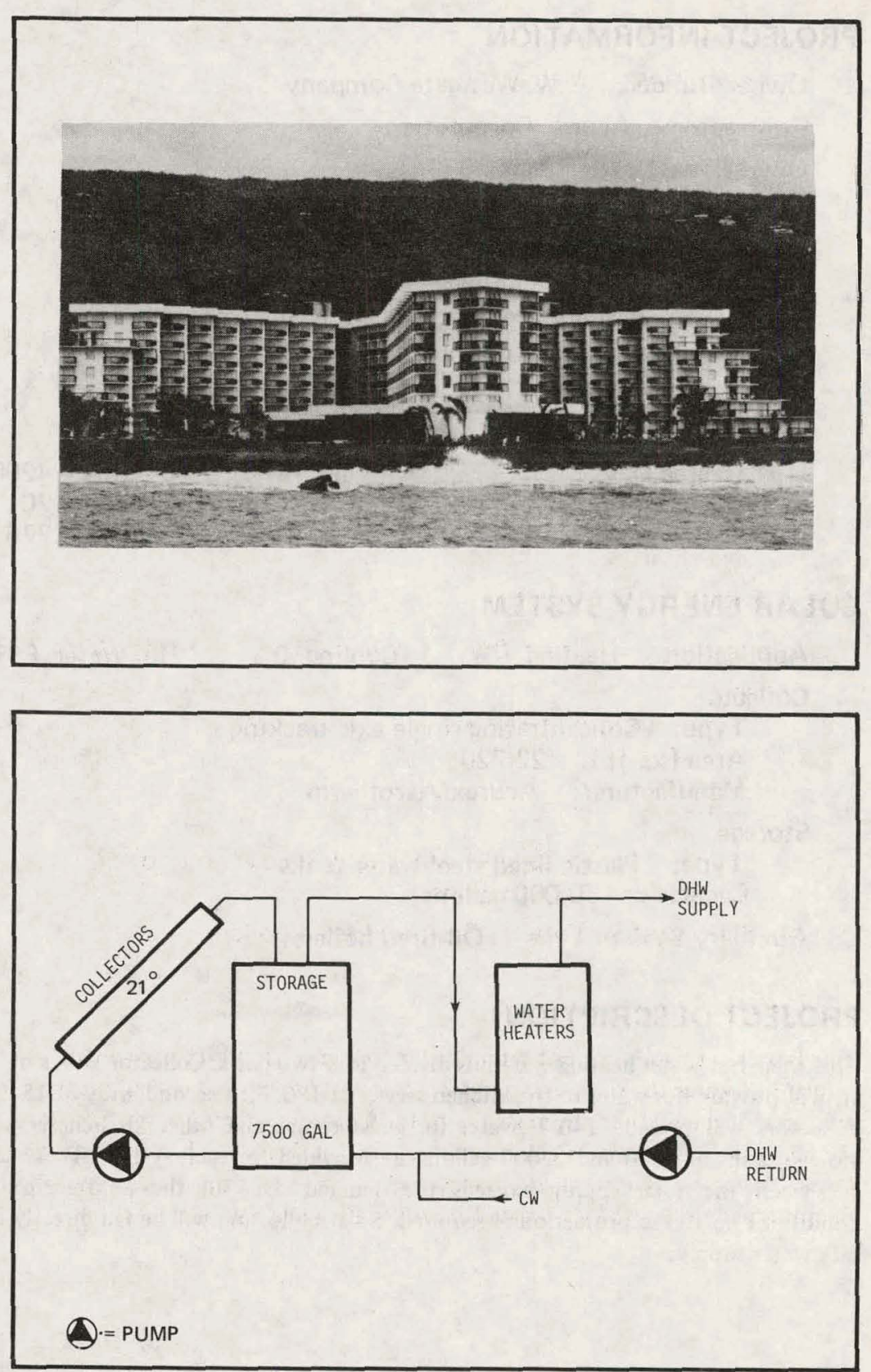


\section{PROJECT INFORMATION}

Owner/Builder: E.W. Westgate Company

Contractor: Acurex Corporation

Operational Date: June 1979

Total Estimated DOE Funds: $\quad \$ 647,480$

Building

Type: High rise hotel

Area: Not applicable to hot water systems

Location: Waikoloa, Hawaii

Latitude: $20^{\circ} \mathrm{N}$

Climatic Data

Degree Days

Avg. Temp. $\left({ }^{\circ} \mathrm{F}\right)$

Heating N/A

Avg. Insol. (Ly/d)

Winter 70

Cooling 4200

Summer 70

Summer 776

\section{SOLAR ENERGY SYSTEM}

\section{Application Heating $0 \%$}

Hot Water $86 \%$

\section{Collector}

Type: Concentrating-single axis tracking

Area (sq. ft.): $\quad 22,720$

Manufacturer: Acurex/Aerotherm

\section{Storage}

Type: Plastic lined steel water tanks

Capacity: 30,000 gallons

Auxiliary System Type: Oil fired boilers

\section{PROJECT DESCRIPTION}

This solar hot water heating system is divided into two parts. Collector arrays of 7224 sq. ft. will provide hot water to the kitchen service at $180^{\circ} \mathrm{F}$. A second array of $15496 \mathrm{sq}$. ft. collectors will provide $140^{\circ} \mathrm{F}$ water for guest rooms and other kitchen services. Two storage tanks of 8000 and 22000 gallons are provided for each system. These tanks will fill when the solar supply exceeds the demand. Due to the nonfreezing weather conditions no freeze protection is required. Solar collectors will be fed directly from the city water supply.
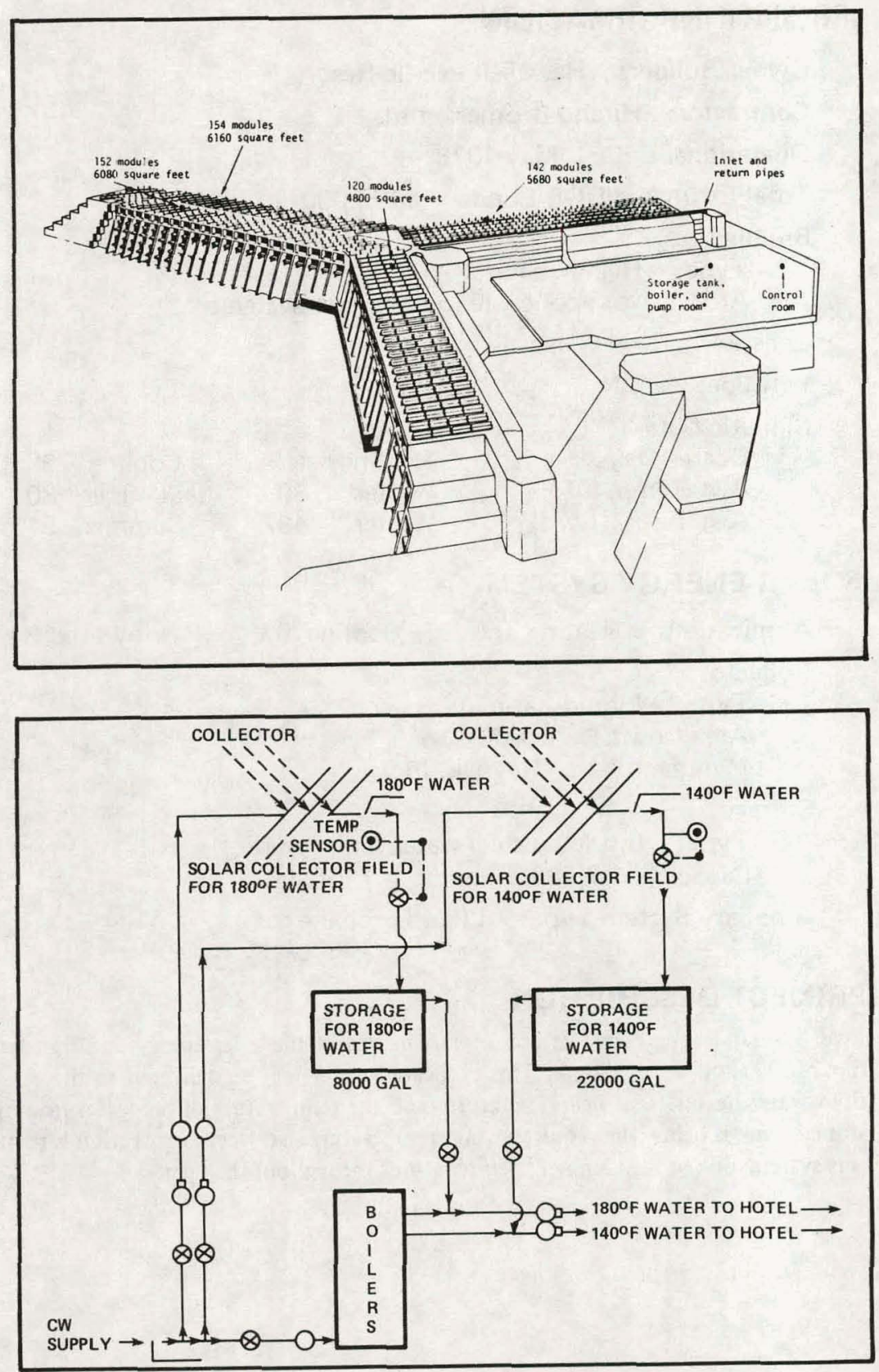


\section{PROJECT INFORMATION}

Owner/Builder: Museum of Science and Industry

Contractor: Scavo \& Associates

Operational Date: August 1978

Total Estimated DOE Funds: $\$ 364,165$

Building

Type: Museum

Area: $\quad 608,000$ sq. ft. (total); 71,333 sq. ft. (heating); 65,133 sq. ft. (cooling)

Location: Chicago, Illinois

Latitude: $41^{\circ} 50^{\prime} \mathrm{N}$

Climatic Data

$\begin{array}{lllll}\text { Degree Days } & \text { Heating } & 6155 & \text { Cooling } & 830 \\ \text { Avg. Temp. }\left({ }^{\circ} \mathrm{F}\right) & \text { Winter } & 38 & \text { Summer } & 69 \\ \text { Avg. Insol. (Ly/d) } & \text { Winter } & 172 & \text { Summer } & 414\end{array}$

\section{SOLAR ENERGY SYSTEM}

Application Heating 45\%

Collector

Type: Evacuated tubular

Area (sq. ft.): 7,072

Manufacturer: General Electric Company

Storage

Type: Insulated steel water tank (above ground)

Capacity: 3,000 gallons

Auxiliary System Type: Gas fired boiler

\section{PROJECT DESCRIPTION}

The Museum of Science and Industry is a three-story, three-building complex which opened in 1933. It will be retrofitted with roof-mounted collectors in rows on a structural frame. The energy storage tank, pumps, heating and cooling coils, absorption water cooler, and controls are located in the ground floor equipment room. A $40 \%$ glycol solution is used as collector fluid for freeze protection. This same solution is circulated in the absorption unit, heating coils and storage tank. A flexible control system (integrated with the existing heating and air conditioning components) will utilize automatic and manual control methods to provide a variety of heating and cooling modes.
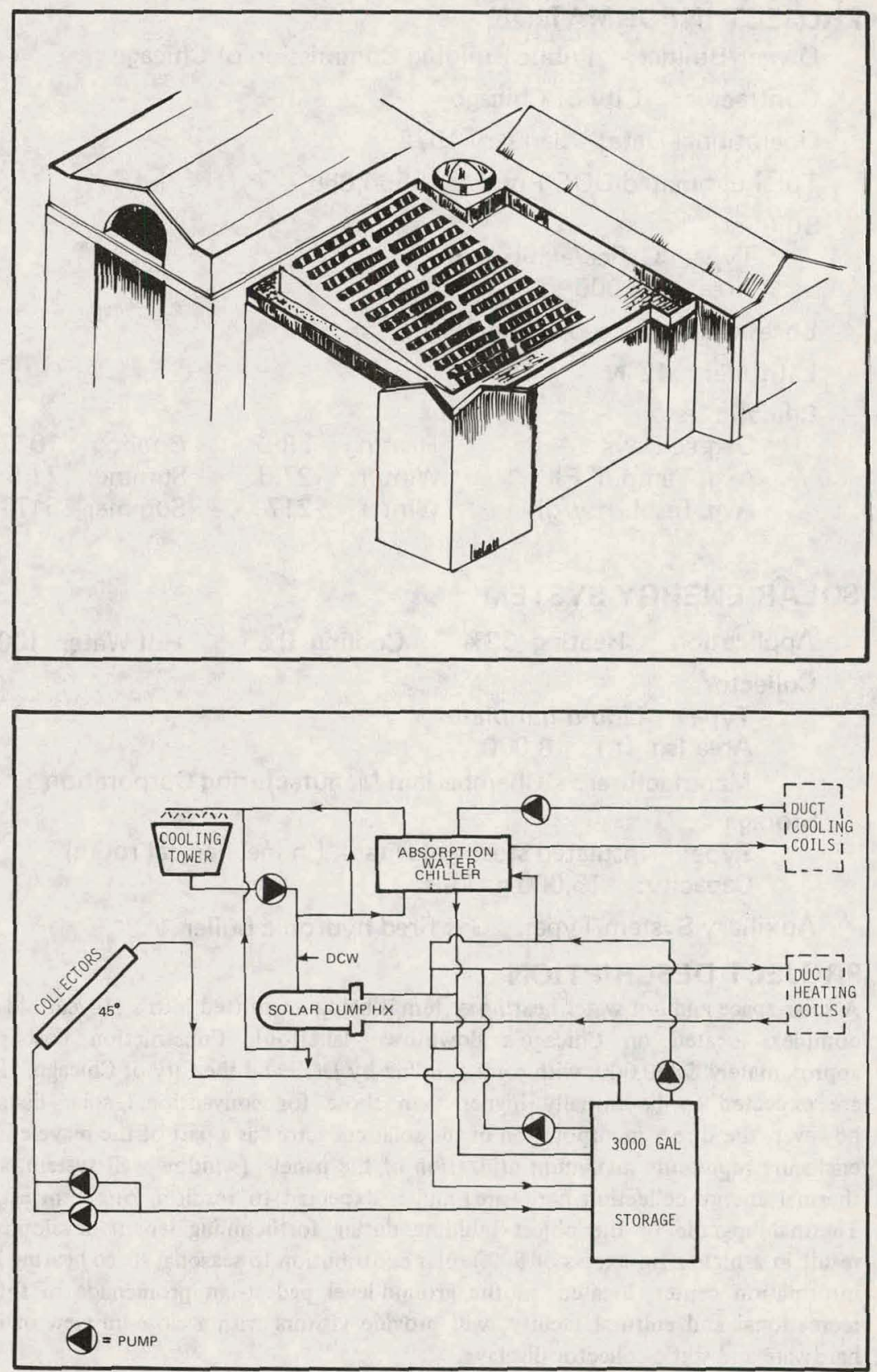


\section{PROJECT INFORMATION}

Owner/Builder: Public Building Commission of Chicago

Contractor: City of Chicago

Operational Date: January 1978

Total Estimated DOE Funds: $\quad \$ 564,656$

Building

Type: Office/exhibition

Area: 36,000 sq. ft.

Location: Chicago, Illinois

Latitude: $42^{\circ} \mathrm{N}$

Climatic Data

$\begin{array}{lllll}\text { Degree Days } & \text { Heating } & 5882 & \text { Cooling } & 1017 \\ \text { Avg. Temp. }\left({ }^{\circ} \mathrm{F}\right) & \text { Winter } & 27.0 & \text { Summer } & 71.5 \\ \text { Avg. Insol. }(\mathrm{Ly} / \mathrm{d}) & \text { Winter } & 217 & \text { Summer } & 517\end{array}$

Avg. Insol. (Ly/d) Winter $217 \quad$ Summer 517

\section{SOLAR ENERGY SYSTEM}

Application Heating $33 \%$

Collector

Type: Liquid flat-plate

Area (sq. ft.): 8,000

Manufacturer: Chamberlain Manufacturing Corporation

Storage

Type: Insulated steel water tank (in mechanical room)

Capacity: 15,000 gallons

Auxiliary System Type: Gas fired hydronic boiler

\section{PROJECT DESCRIPTION}

A solar space and hot water heating system is being retrofitted into a 60 -year old building complex located on Chicago's downtown lakefront. Construction costs will be approximately $\$ 800,000$, with joint funding by DOE and the City of Chicago. Unit costs are expected to be initially higher than those for conventional solar installations; however, the direct incorporation of the solar collectors as a part of the recycled building enclosure represents maximum utilization of the panels, (window-wall system, as well as thermal energy collection hardware) and is expected to result in long-term economies. Thermal upgrade of the object building during forthcoming tenant development will result in a higher (in excess of 50\%) solar contribution to seasonal space heating load. An information center, located on the ground level pedestrian promenade of this public recreational and cultural facility, will provide visitors with a close-up view of interface hardware and static collector displays.
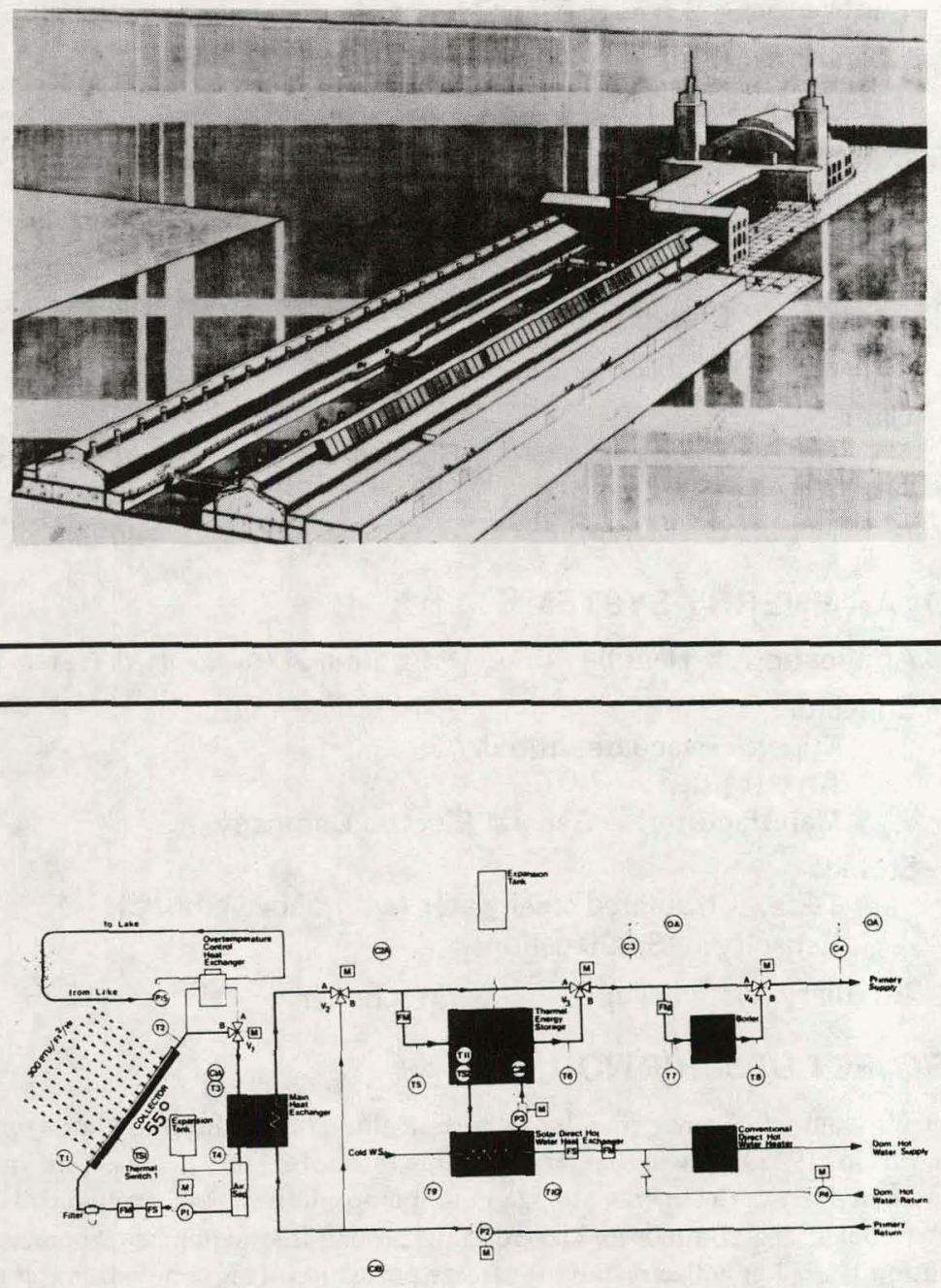


\section{PROJECT INFORMATION}

Owner/Builder: Rodeway Inns of America \& R. V. Development Contractor: Charter Builders, Inc. Company

Operational Date: July 1978

Total Estimated DOE Funds: $\quad \$ 99,777$

Building

Type: High rise hotel

Area: Not applicable to hot water systems

Location: Chicago, Illinois

Latitude: $42^{\circ} \mathrm{N}$

Climatic Data

Degree Days

Avg. Temp. $\left({ }^{\circ} \mathrm{F}\right)$

$\begin{array}{llll}\text { Heating } & 6000 & \text { Cooling } & 1000 \\ \text { Winter } & 33 & \text { Summer } & 77 \\ \text { Winter } & 267 & \text { Summer } & 438\end{array}$

Avg. Insol. (Ly/d)

\section{SOLAR ENERGY SYSTEM}

\section{Application Heating 0\%}

Collector

\section{Type: Liquid flat-plate}

Area (sq. ft.): 4,000

Manufacturer: Lennox Industries, Inc.

\section{Storage}

Type: Insulated steel water tank

Capacity: 4,000 gallons

Auxiliary System Type: Gas boiler

\section{PROJECT DESCRIPTION}

The collectors for this system will be located on the roof of the motel. The energy collected by the collectors will be transferred to a double bundle heat exchanger via a collector loop circulating pump. Through the heat exchanger, the absorbed energy will be transferred to the storage tank via the storage loop circulating pump. Utilization of the double bundle heat exchanger eliminates the danger of ethylene glycol leakage from the solar loop to the storage tank. Energy from the storage tank is utilized for the motel potable water and laundry.
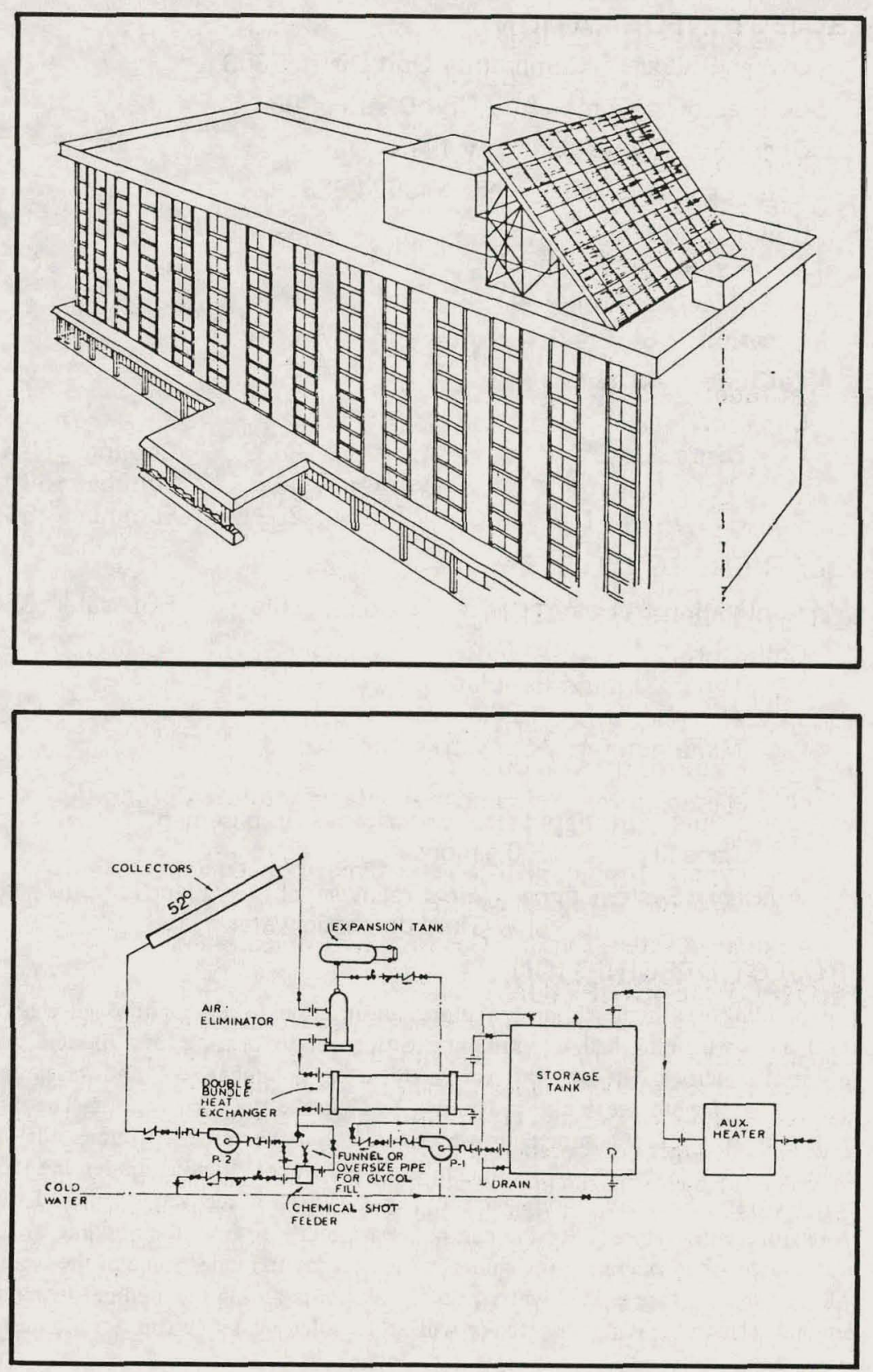


\section{PROJECT INFORMATION}

Owner/Builder: Community Unit District 303

Contractor: Community Unit District 303

Operational Date: January 1979

Total Estimated DOE Funds: $\$ 524,683$

Building

Type: High school

Area: 221,000 sq. ft.

Location: St. Charles, Illinois

Latitude: $42^{\circ} \mathrm{N}$

Climatic Data

Degree Days

Avg. Temp. $\left({ }^{\circ} \mathrm{F}\right)$

Avg. Insol. (Ly/d)

$\begin{array}{ll}\text { Heating } & 6639 \\ \text { Winter } & 44.5 \\ \text { Winter } & 209\end{array}$

Cooling N/A

Summer 66

Summer 486

\section{SOLAR ENERGY SYSTEM}

Application Heating 67\%

Cooling $0 \%$

Hot Water $65 \%$

Collector

Type: Liquid flat-plate

Area (sq. ft.): 15,000

Manufacturer: Sunworks, Inc.

Storage

Type: Insulated steel water tanks (in basement)

Capacity: $\quad 30,000$ gallons

Auxiliary System Type: Heat recovery chiller; electric boiler; gas fired domestic water heater

\section{PROJECT DESCRIPTION}

The building is a high school containing, in addition to air conditioned classrooms, a 1000 -seat performing hall, a gymnasium with spectator seating for 2700 and vocational education facilities. The building was occupied in September 1977 and was designed and built with solar storage tanks and piping to facilitate the solar retrofit. The building is cooled by two rotary compression water chillers serving variable volume, dual duct and single zone fan systems. One of the chillers has a double bundle condensing section for heat recovery. Separate storage capacity is provided for recovered heat and solar heat. Heat from either storage section can be used directly to heat the building or serve as a heat source when operating the chiller in the heat pump mode. Some of the storage tanks will be used to store chilled water in off peak hours during the summer to reduce peak demand while the remaining tanks will store solar heated water for domestic water preheating.
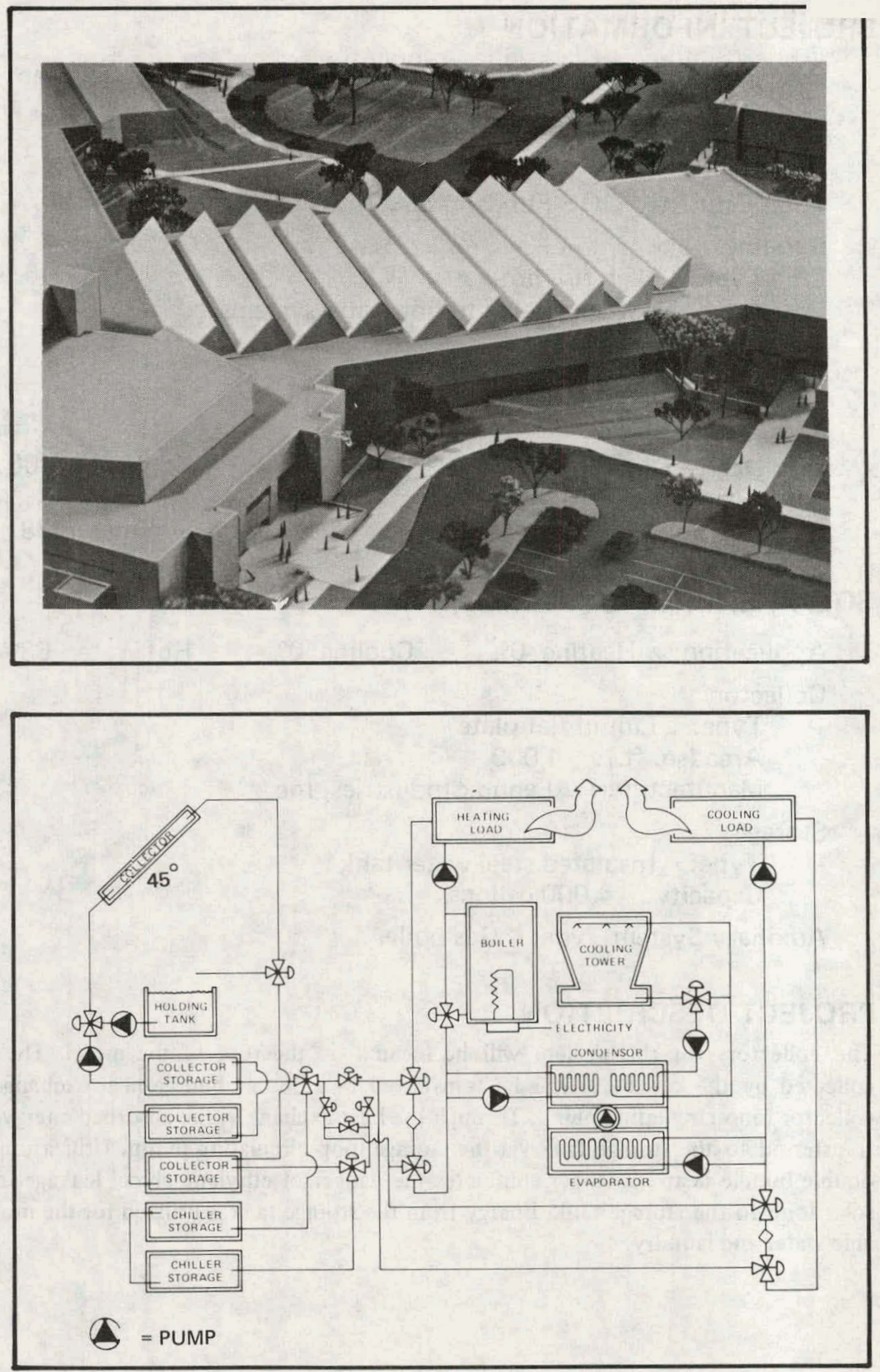


\section{PINUJECT INFORMATION}

Owner/Builder: Clarksville Community School Corporation

Contractor: To be determined

Operational Date: May 1978

Total Estimated DOE Funds: $\quad \$ 129,505$

Building

Type: Middle schoo

Area: 145,200 sq. ft.

Location: Clarksville, Indiana

Latitude: $38^{\circ} \mathrm{N}$

Climatic Data

$\begin{array}{lllll}\text { Degree Days } & \text { Heating } & 4660 & \text { Cooling } & \text { N/A } \\ \text { Avg. Temp. }\left({ }^{\circ} \mathrm{F}\right) & \text { Winter } & 44 & \text { Summer } & \text { N/A } \\ \text { Avg. Insol. (Ly/d) } & \text { Winter } & 278 & \text { Summer } & \text { N/A }\end{array}$

\section{SOLAR ENERGY SYSTEM}

Application Heating 100\% Cooling 0\%

Collector

Type: Liquid flat-plate

Area (sq. ft.): 6,520

Manufacturer: Solar Development, Inc.

Storage

Type: Insulated steel water tank (underground)

Capacity: 10,000 gallons

Auxiliary System Type: Electric resistance heat

\section{PROJECT DESCRIPTION}

The Clarksville Middle School will retrofit the heating of two gymnasiums from electric resistance heat to solar heat. At the present time the two gyms have a chilled water system for cooling. This system will be converted to a hot water solar heating system. The building is 11 years old and has few windows. It is well insulated and will be easy to retrofit. The existing air handlers will be used and controls can be adjusted for the new solar system. Storage for the solar systern will be provided by means of a buried stee storage tank. The flat-plate solar collectors will be installed on the roof of each gymnasium.
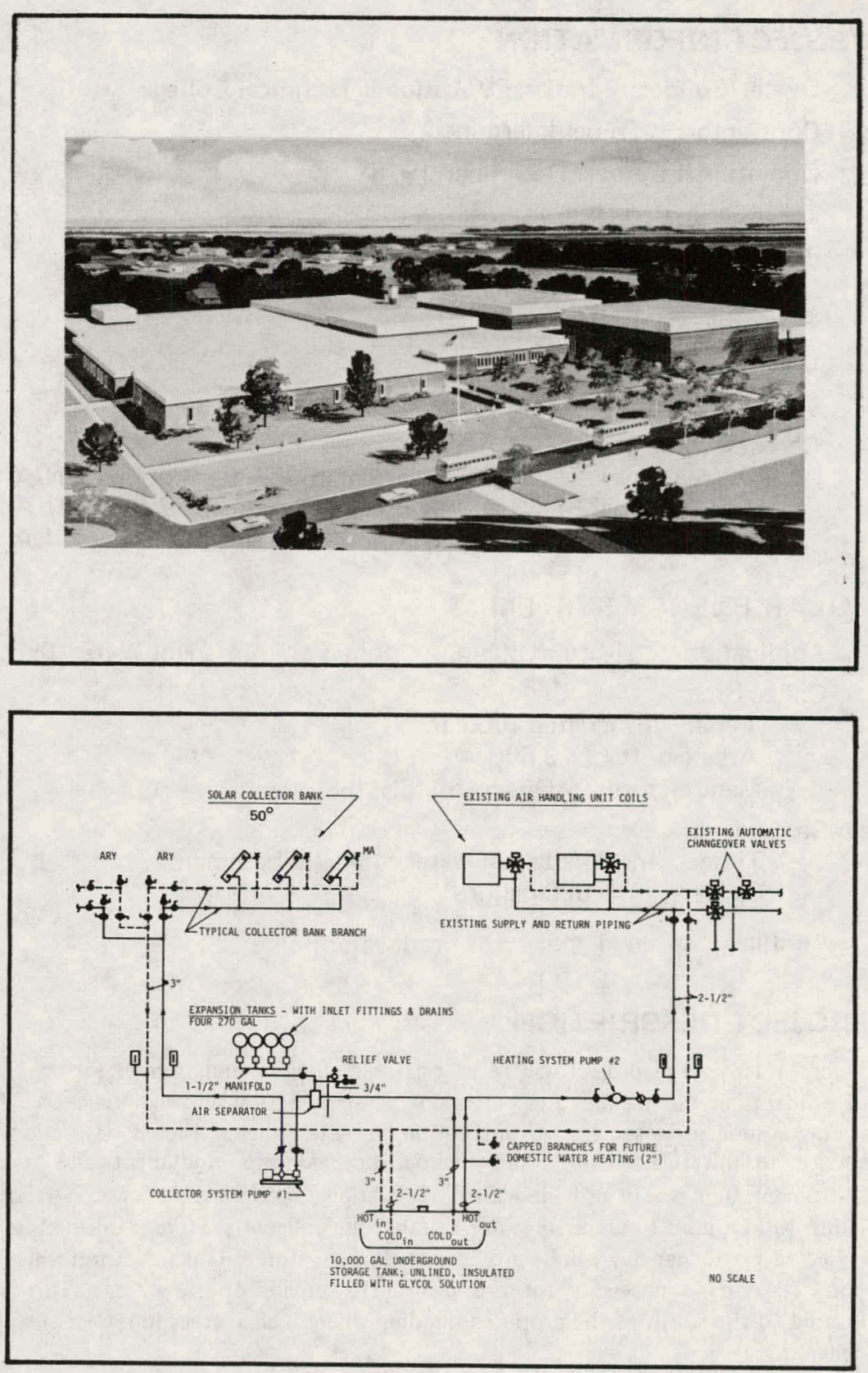


\section{PROJECT INFORMATION}

Owner/Builder: Indiana Vocational Technical College

Contractor: To be determined

Operational Date: December 1978

Total Estimated DOE Funds: $\$ 109,883$

Building

Type: Vocational school

Area: 24,104 sq. ft.

Location: Gary, Indiana

Latitude: $41^{\circ} \mathrm{N}$

Climatic Data

$\begin{array}{lllll}\text { Degree Days } & \text { Heating } & 6350 & \text { Cooling } & \text { N/A } \\ \text { Avg. Temp. }\left({ }^{\circ} \mathrm{F}\right) & \text { Winter } & 25 & \text { Summer } & \text { N/A } \\ \text { Avg. Insol. }(\text { Ly } / \text { d) } & \text { Winter } & 150 & \text { Summer } & \text { N/A }\end{array}$

\section{SOLAR ENERGY SYSTEM}

Application Heating $80 \%$ Cooling $0 \%$ Hot Water $0 \%$

Collector

Type: Evacuated tubular

Area (sq. ft.): 3,800

Manufacturer: Owens-Illinois, Inc.

Storage

Type: Insulated steel water tanks (in basement)

Capacity: 5,000 gallons

Auxiliary System Type: Oil fired water boiler

\section{PROJECT DESCRIPTION}

Incorporated in this project will be an Environmental Training Center for the education of students in the waste water treatment plant operation and maintenance. The solar energy system proposed for this institution will allow the additional instruction in solar energy technical assistance and maintenance. On-site equipment and monitoring instrumentation would provide a field application for all class students. A variable flow pump will be used to circulate water through the collectors. Storage for the total energy collected on a clear day will be provided in the four storage tanks. A storm water holding pond (lagoon) is necessary for this project to provide on-site storage. This lagoon is located to the south of the proposed building where it also serves to reflect energy to the collectors.
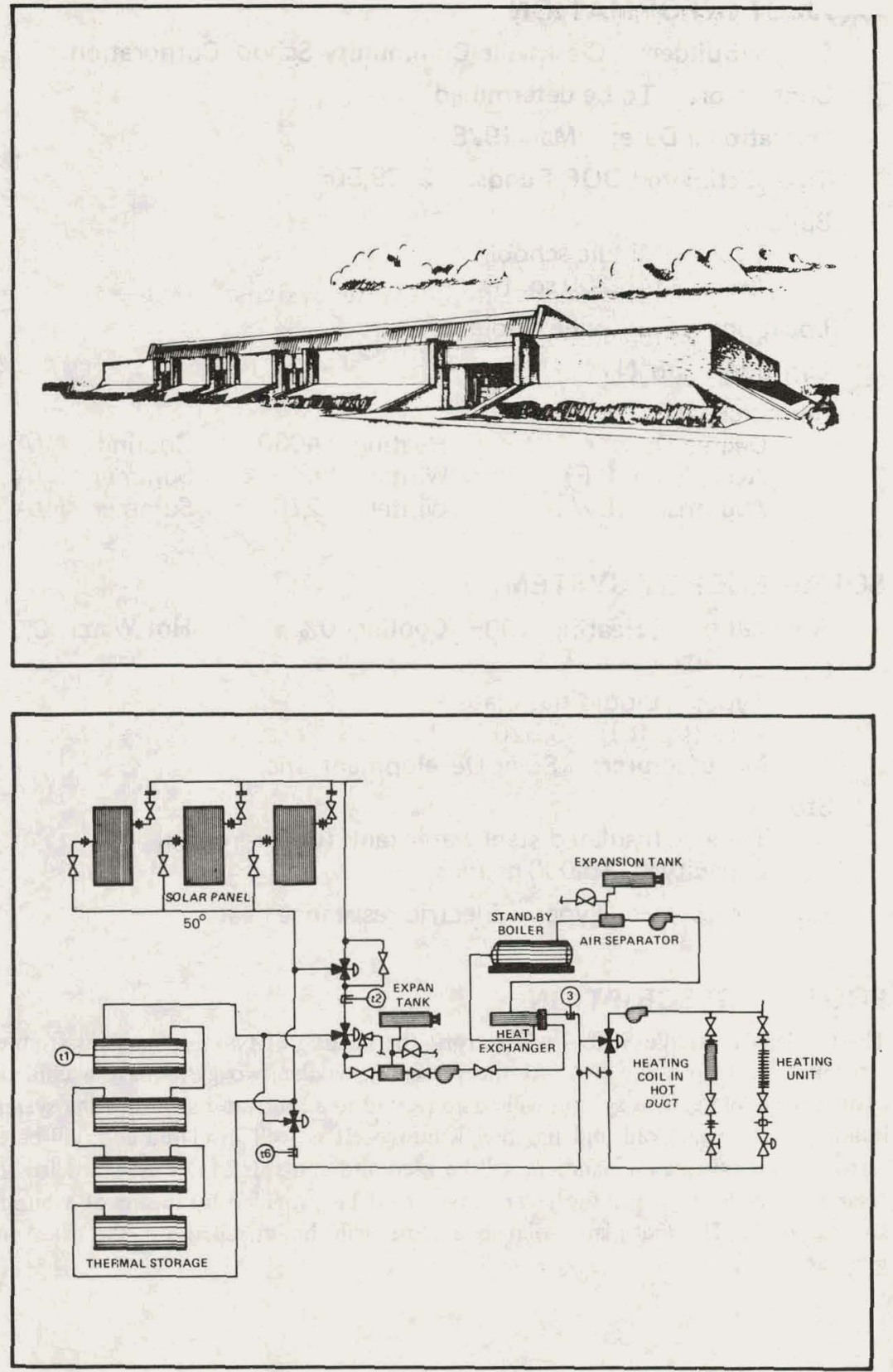


\section{PROJECT INFORMATION}

Owner/Builder: La Quinta Motor Inns, Inc.

Contractor: Travis-Braun \& Associates, Inc.

Operational Date: September 1978

Total Estimated DOE Funds:

$\$ 43,353$

Building

Type: Low rise motel

Area: Not applicable to hot water systems

Location: Indianapolis, Indiana

Latitude: $39^{\circ} 4^{\prime} \mathrm{N}$

Climatic Data

Degree Days

Avg. Temp. $\left({ }^{\circ} \mathrm{F}\right)$

Avg. Insol. (Ly/d)

$\begin{array}{ll}\text { Heating } & 5699 \\ \text { Winter } & 39.6 \\ \text { Winter } & 176\end{array}$

Cooling N/A

Summer N/A

Summer 390

\section{SOLAR ENERGY SYSTEM}

Collector

Cooling $0 \%$

Hot Water $66 \%$

\section{Type: Liquid flat-plate}

Area (sq. ft.): 2,000

Manufacturer: Lennox Industries, Inc.

\section{Storage}

Type: Insulated steel water tank (above ground)

Capacity: 1,600 gallons

Auxiliary System Type: Electric boiler

\section{PROJECT DESCRIPTION}

A freeze protected system is proposed under this grant. The collector circulating fluid is a water buffered ethylene glycol solution. This mixture prevents the occurrence of freezing in the collector. Even though many codes do not require a double separation insulating the potable water system, provisions for such a separation are included. The mixture of antifreeze and water can be further buffered to include corrosion inhibiters, thus prolonging the collector life. The antifreeze solution protects a collector from damage which could occur from low temperatures. Mineral buildup problems are eliminated by the contained, relatively nonchanging solution.
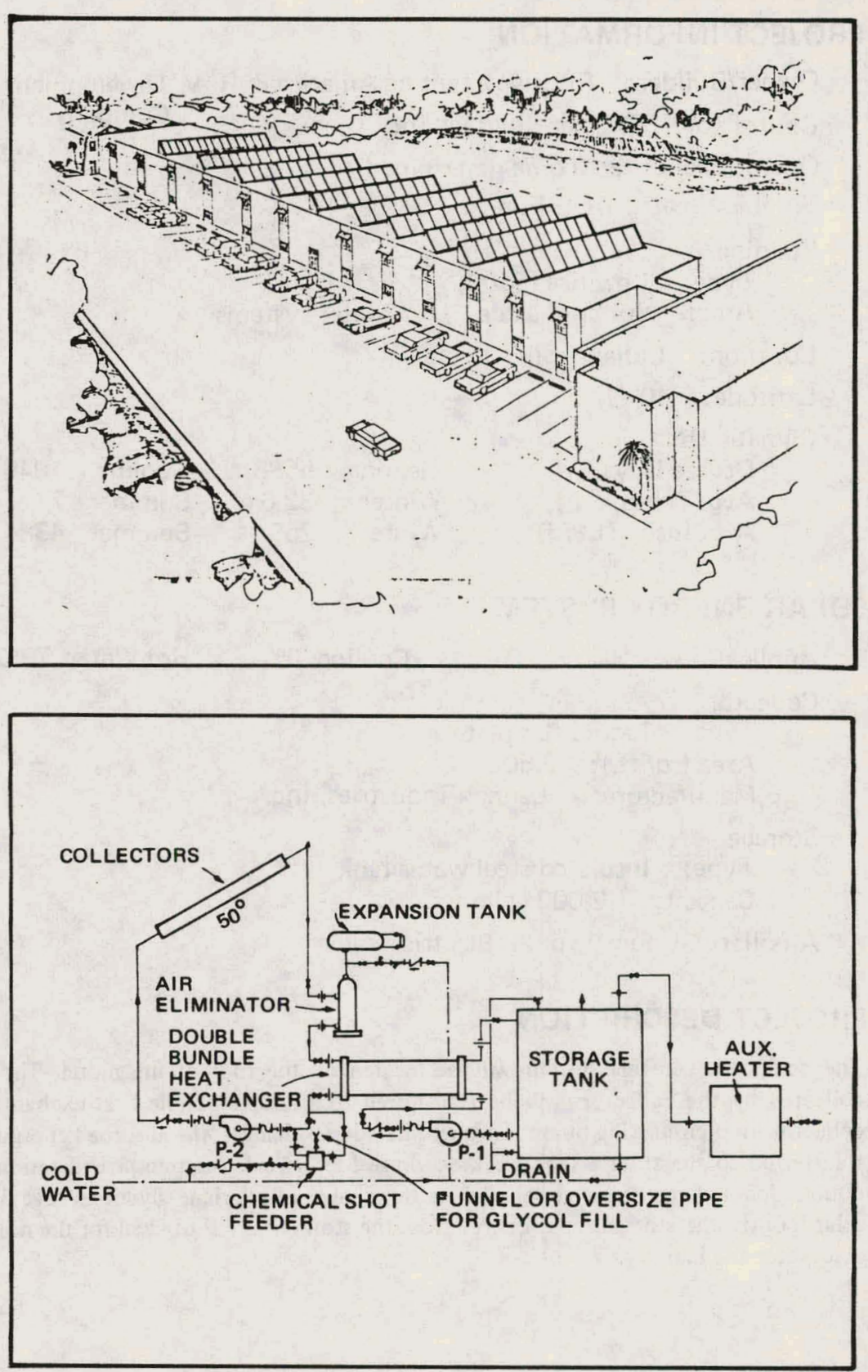


\section{PROJECT INFORMATION}

Owner/Builder: Rodeway Inns of America \& R. V. Development

Contractor: Charter Builders, Inc.

Company

Operational Date: To be determined

Total Estimated DOE Funds:

$\$ 49,934$

\section{Building}

Type: Low rise motel

Area: Not applicable to hot water systems

Location: Indianapolis, Indiana

Latitude: $40^{\circ} \mathrm{N}$

\section{Climatic Data}

$\begin{array}{lllll}\text { Degree Days } & \text { Heating } & 5588 & \text { Coaling } & 1046 \\ \text { Avg. Temp. ( }{ }^{\circ} \mathrm{F} \text { ) } & \text { Winter } & 32.6 & \text { Summer } & 77 \\ \text { Avg. Insol. (Ly/d) } & \text { Winter } & 255 & \text { Summer } & 438\end{array}$

Avg. Insol. (Ly/d) Winter $255 \quad$ Summer 438

\section{SOLAR ENERGY SYSTEM}

Application Heating 0\% Cooling 0\% Hot Water 73\%

Collector

Type: Liquid flat-plate

Area (sq. ft.): 2,500

Manufacturer: Lennox Industries, Inc.

Storage

Type: Insulated steel water tank

Capacity: 2,000 gallons

Auxiliary System Type: Electric/boiler

\section{PROJECT DESCRIPTION}

The collectors for this system will be located on the roof of the motel. The energy collected by the collectors will be transferred to a double bundle heat exchanger via a collector loop circulating pump. Through the heat exchanger, the absorbed energy will be transferred to the storage tank via the storage loop circulating pump. Utilization of the double bundle heat exchanger eliminates the danger of ethylene glycol leakage from the solar loop to the storage tank. Energy from the storage tank is utilized for the motel potable water and laundry.
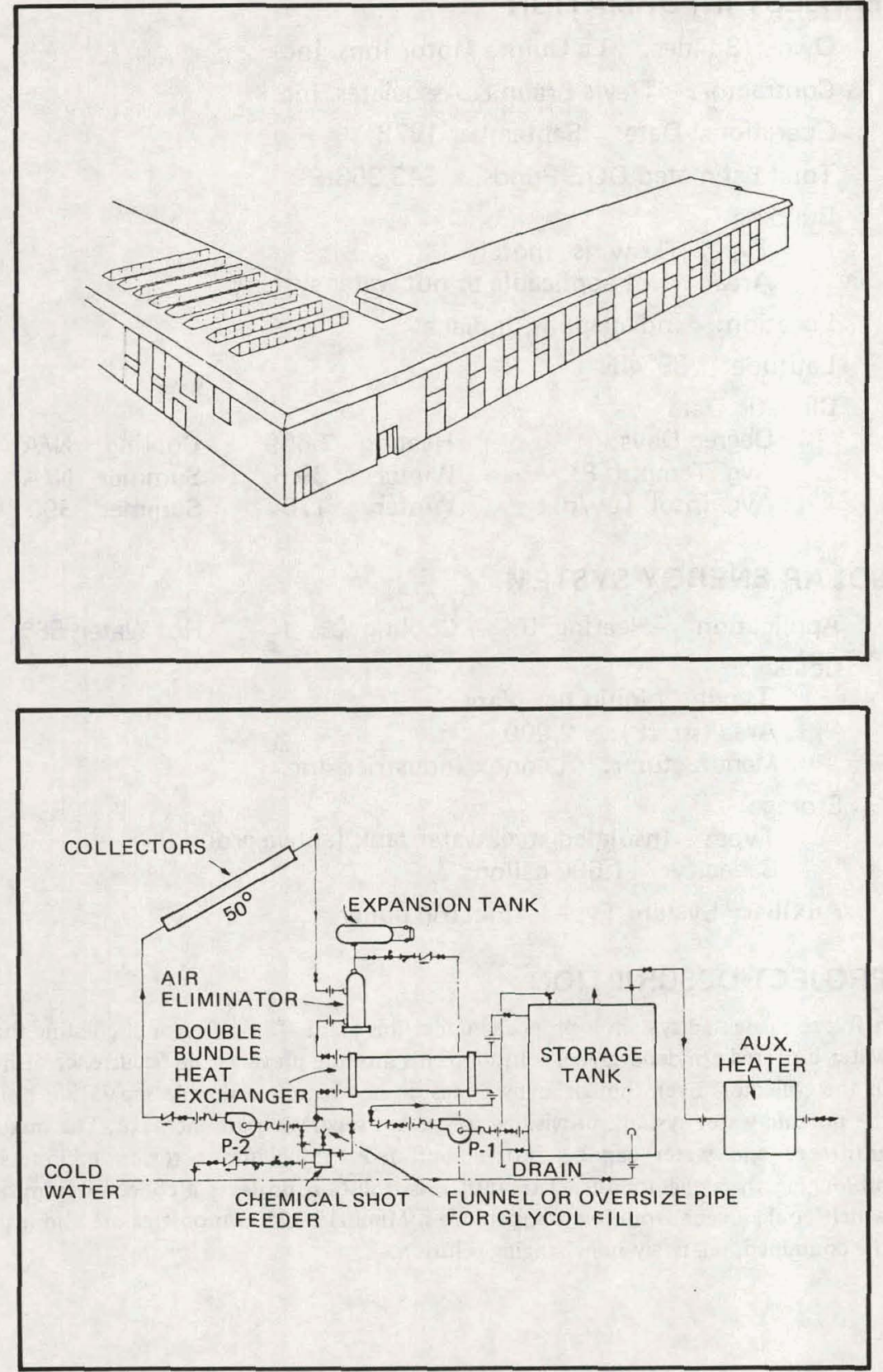


\section{PROJECT INFORMATION}

Owner/Builder: La Quinta Motor Inns, Inc.

Contractor: Travis-Braun \& Associates, Inc.

Operational Date: September 1978

Total Estimated DOE Funds: $\quad \$ 53,570$

Building

Type: Low rise motel

Area: Not applicable to hot water systems

Location: Merrillville, Indiana

Latitude: $42^{\circ} \mathrm{N}$

Climatic Data

$\begin{array}{lllll}\text { Degree Days } & \text { Heating } & 5700 & \text { Cooling } & 800 \\ \text { Avg. Temp. }\left({ }^{\circ} \mathrm{F}\right) & \text { Winter } & 42 & \text { Summer } & 76 \\ \text { Avg. Insol. (Ly/d) } & \text { Winter } & 165 & \text { Summer } & 430\end{array}$

\section{SOLAR ENERGY SYSTEM}

Application Heating $0 \%$ Cooling $0 \%$ Hot Water $60 \%$

Collector

Type: Evacuated tubular

Area (sq. ft.): 2,000

Manufacturer: General Electric Company

Storage

Type: Insulated steel water tank (above ground)

Capacity: 1,600 gallons

Auxiliary System Type: Electric boiler

\section{PROJECT DESCRIPTION}

A freeze protected system is proposed under this grant. The collector circulating fluid is a water buffered ethylene glycol solution. This mixture prevents the occurrence of freezing in the collector. Even though many codes do not require a double separation insulating the potable water system, provisions for such a separation are included. The mixture of antifreeze and water can be further buffered to include corrosion inhibiters, thus prolonging the collector life. The antifreeze solution protects a collector from damage which could occur from low temperatures. Mineral buildup problems are eliminated by the contained, relatively nonchanging solution.
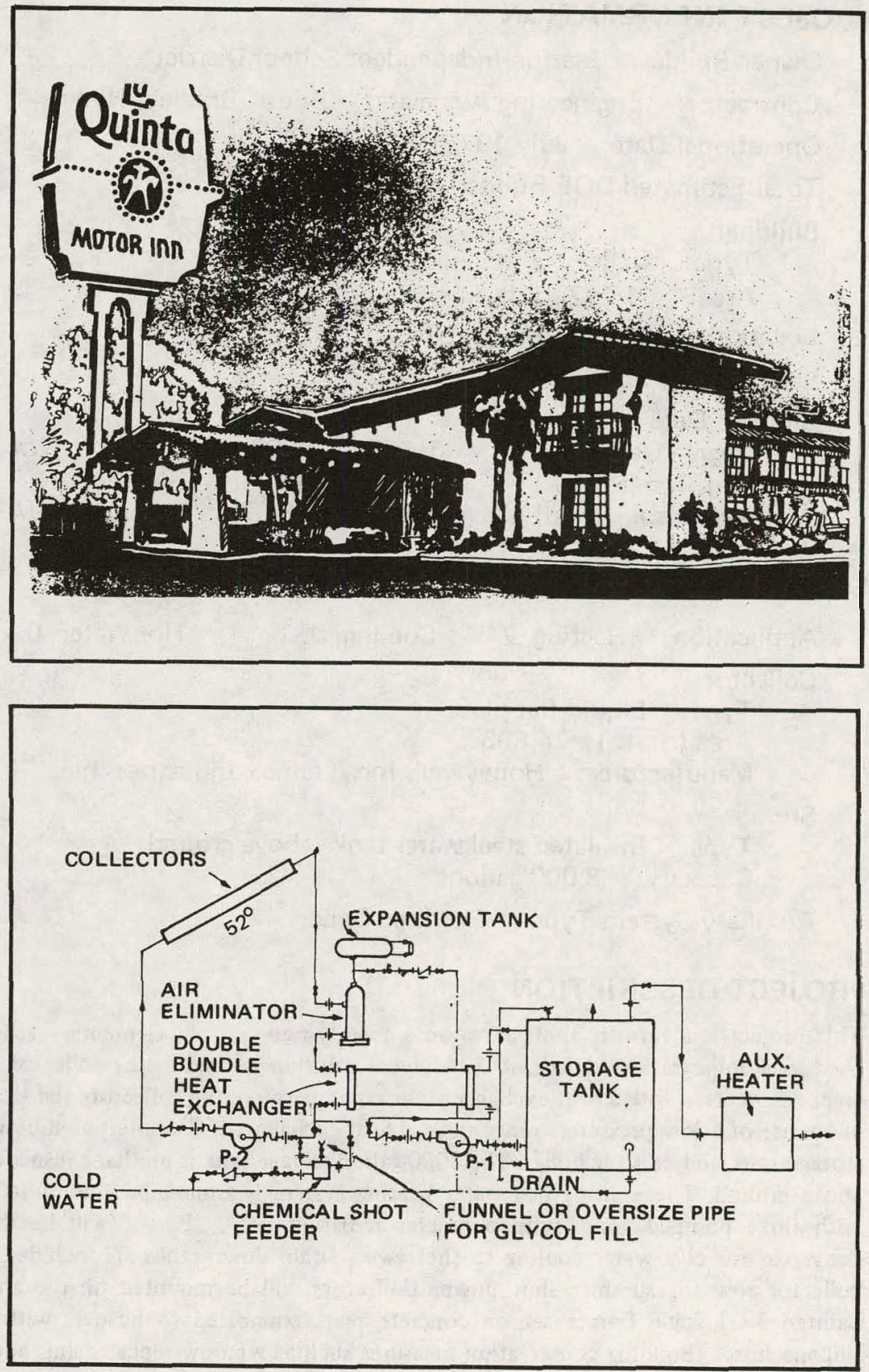


\section{PROJECT INFORMATION}

Owner/Builder: Marion Independent School District

Contractor: Engineering Associates - Bouse, Bradley, Hynes

Operational Date: July 1978

Total Estimated DOE Funds: $\quad \$ 223,400$

Building

Type: Office

Area: 11,762 sq. $\mathrm{ft}$.

Location: Marion, lowa

Latitude: $41.5^{\circ} \mathrm{N}$

Climatic Data

Degree Days

Avg. Temp. $\left({ }^{\circ} \mathrm{F}\right)$

Avg. Insol. (Ly/d)

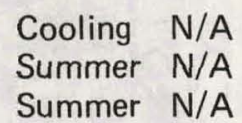

Winter 289.7

\section{SOLAR ENERGY SYSTEM}

Application Heating 74\% Cooling 0\%

Hot Water $0 \%$

Collector

Type: Liquid flat-plate

Area (sq. ft.): 4,896

Manufacturer: Honeywell, Inc./Lennox Industries, Inc.

\section{Storage}

Type: Insulated steel water tank (above ground)

Capacity: 8,000 gallons

Auxiliary System Type: Gas fired boiler

\section{PROJECT DESCRIPTION}

This project is a retrofit application on a twenty-two-year-old elementary school now used as administration offices. A $50 \%$ glycol solution is used as the collector fluid for freeze protection with a heat exchanger interposed between the collectors and storage. To allow use of a low pressure storage tank, a heat exchanger is also interposed between the storage tank and existing boiler. The 8000 -gallon storage tank is urethane insulated and is above ground. The existing hot water heating system is a one-pipe "mono-flo" system with three pumped zones with perimeter radiation only. "Purge" will be through a convertor for city water cooling to the sewer. Drain down tanks are included on each collector row for summer shut down. Collectors will be mounted on the ground on painted steel angle frames set on concrete piers connected to headers with flexible silicone hoses. Building conservation measures such as window replacement, added roof insulation, boiler water reset, and night set-back are being studied.
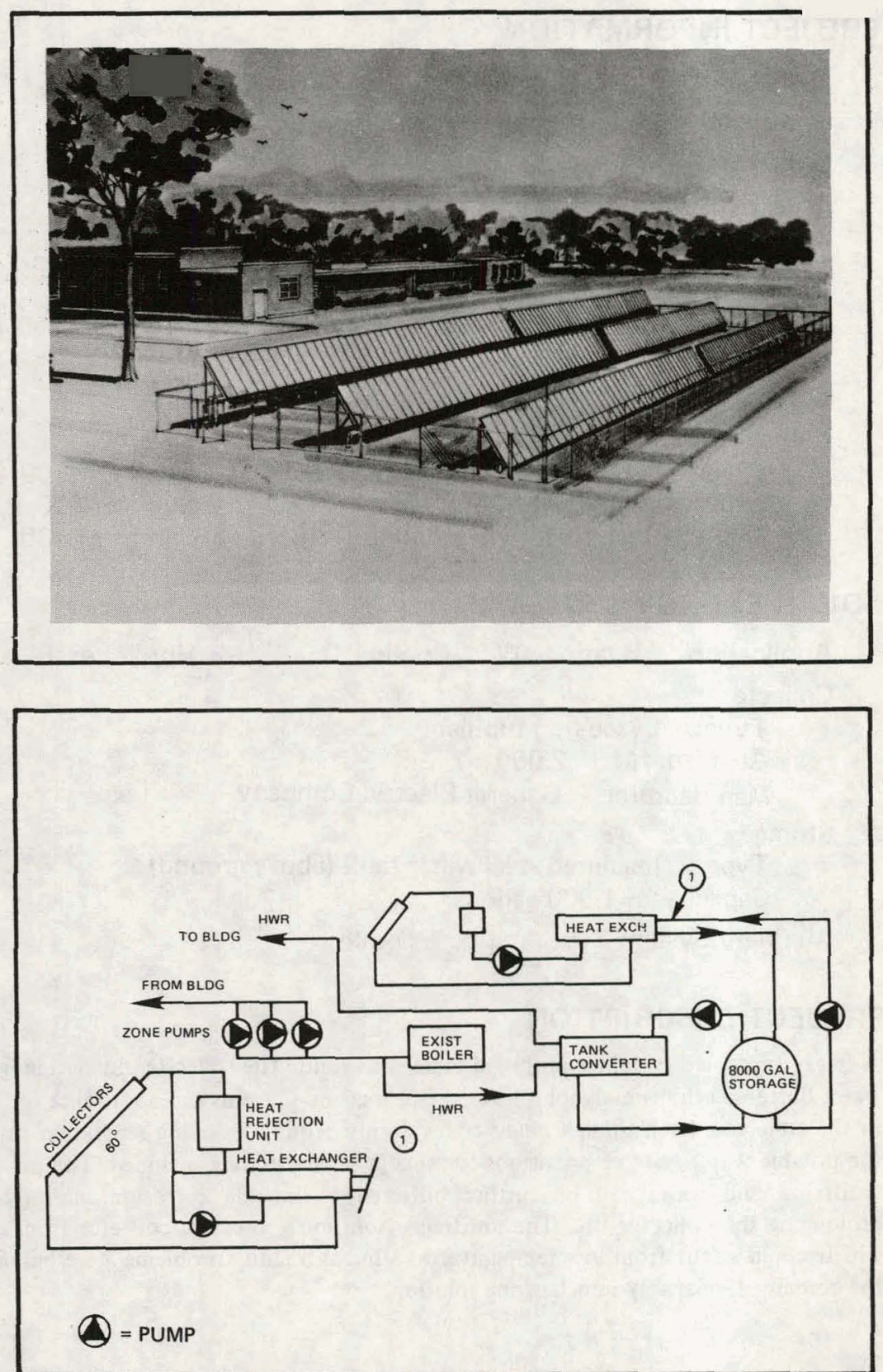


\section{PKUJECT INFORMATION}

Owner/Builder: Scattergood School

Contractor: Modern Metals, Inc.

Operational Date: June 1977

Total Estimated DOE Funds: $\quad \$ 82,898$

Building

Type: School gymnasium

Area: 7,966 sq. ft.

Location: West Branch, lowa

Latitude: $41.8^{\circ} \mathrm{N}$

Climatic Data

$\begin{array}{lllll}\text { Degree Days } & \text { Heating } & 7255 & \text { Cooling } & 800 \\ \text { Avg. Temp. }\left({ }^{\circ} \mathrm{F}\right) & \text { Winter } & 41.0 & \text { Summer } & 71.7 \\ \text { Avg. Insol. }(\text { Ly/d) } & \text { Winter } & 298 & \text { Summer } & 545\end{array}$

\section{SOLAR ENERGY SYSTEM}

Application Heating $75 \%$

Cooling $0 \%$

Hot Water $75 \%$

Collector

Type: Air flat-plate

Area (sq. ft.): 2,496

Manufacturer: Solaron Corporation

\section{Storage}

Type: Rock bed (above ground)

Capacity: $1,250 \mathrm{cu} . \mathrm{ft}$.

Auxiliary System Type: Gas fired unit heaters, gas furnace

\section{PROJECT DESCRIPTION}

The selected solar energy system for this school gymnasium is based on a prototype model which has been in continuous successful operation since 1957. The collector array, located against the south wall, is a combination of factory preassembled modules 36 " $\mathrm{x} 78$ ". Each module has double tempered glass covers and a sheet steel absorber, with an air duct below the permanent black absorber surface. At the site, these modular collector panels were plugged into each other with a minimum of installation time. The metal building was pre-engineered with 6900 sq. $\mathrm{ft}$. in the main portion and a $1066 \mathrm{sq}$. $\mathrm{ft}$. utility storage and locker room addition. The structural heating/cooling load is approximately 56000 Btu per degree day.
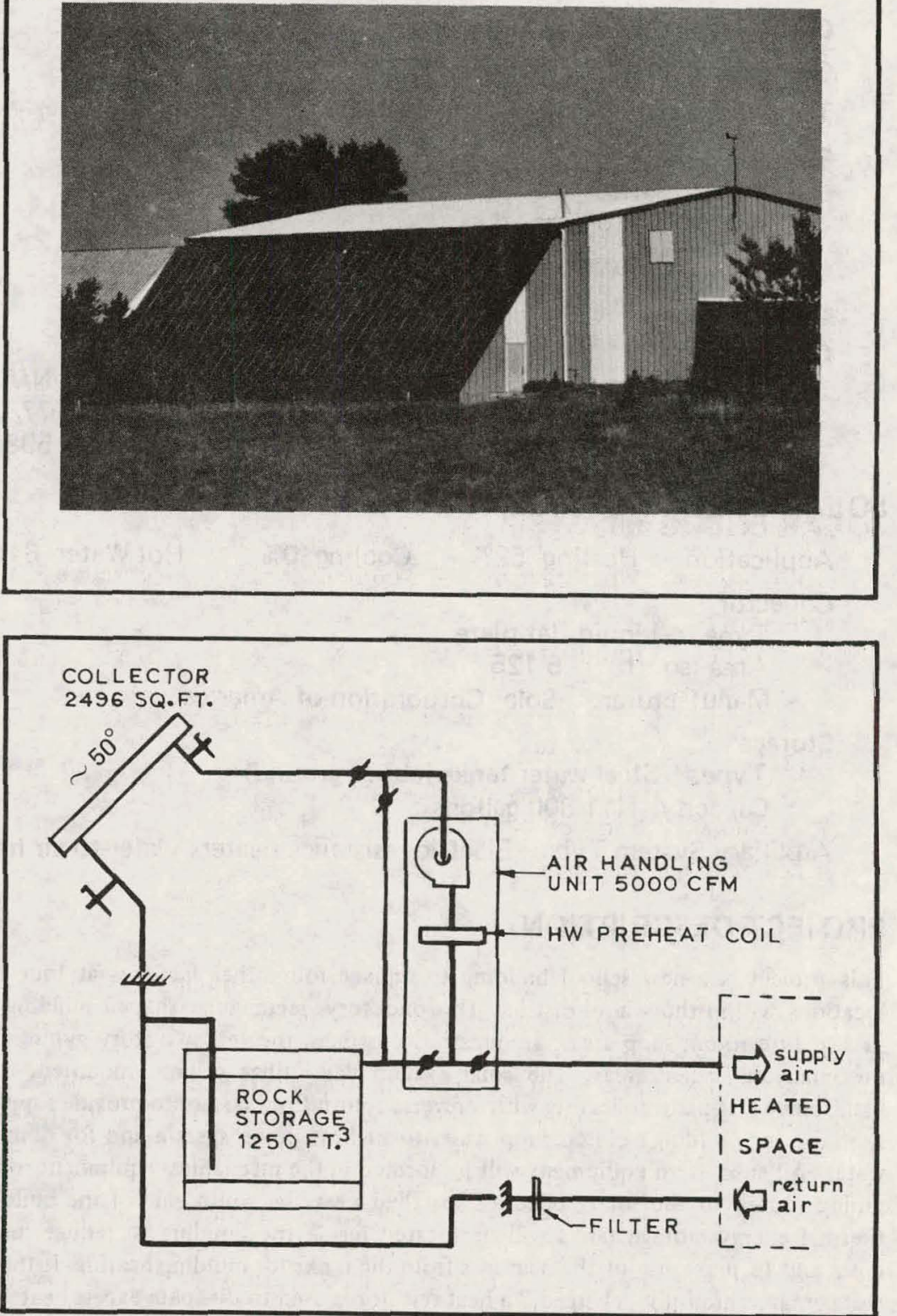


\section{PROJECT INFORMATION}

Owner/Builder: Unified School District No. 306

Contractor: Wilson \& Company Engineers \& Architects

Operational Date: December 1977

Total Estimated DOE Funds: $\$ \mathbf{1 8 1 , 4 1 1}$

Building

Type: Kindergarten through 12th grade school

Area: $138,000 \mathrm{sq} . \mathrm{ft}$.

Location: Gypsum, Kansas

Latitude: $39^{\circ} \mathrm{N}$

Climatic Data

$\begin{array}{lllll}\text { Degree Days } & \text { Heating } & 5211 & \text { Cooling } & \text { N/A } \\ \text { Avg. Temp. }\left({ }^{\circ} \mathrm{F}\right) & \text { Winter } & 46 & \text { Summer } & 77 \\ \text { Avg. Insol. (Ly/d) } & \text { Winter } & 350 & \text { Summer } & 598\end{array}$

SOLAR ENERGY SYSTEM

Application Heating $52 \%$

Cooling $0 \%$

Hot Water $84 \%$

Collector

Type: Liquid flat-plate

Area (sq. ft.): 5,125

Manufacturer: Solar Corporation of America

Storage

Type: Steel water tanks (above ground)

Capacity: 11,800 gallons

Auxiliary System Type: Electric resistance heaters/water-to-air heat pumps

\section{PROJECT DESCRIPTION}

This project is a new school building to replace four other facilities at four different locations within the school district. This one-story, rectangular shaped building consists of a lecture room, shop areas, administrative offices, theater, two-story gymnasium, and miscellaneous other areas. The solar system will utilize ground mounted, internally manifolded flat-plate collectors with a reverse return flow system to provide supplemental heat for the building's closed loop water-to-air heat pump system and for domestic hot water. All subsystem equipment will be located in the mechanical equipment room, with piping routed to the solar collectors installed near the south side of the building. The thermal energy storage tanks will be located inside the building to reduce installation costs and to make use of the heat loss from the tanks for building heating. If the thermal storage tanks are fully "charged," a heat rejector is used to dissipate excess heat.
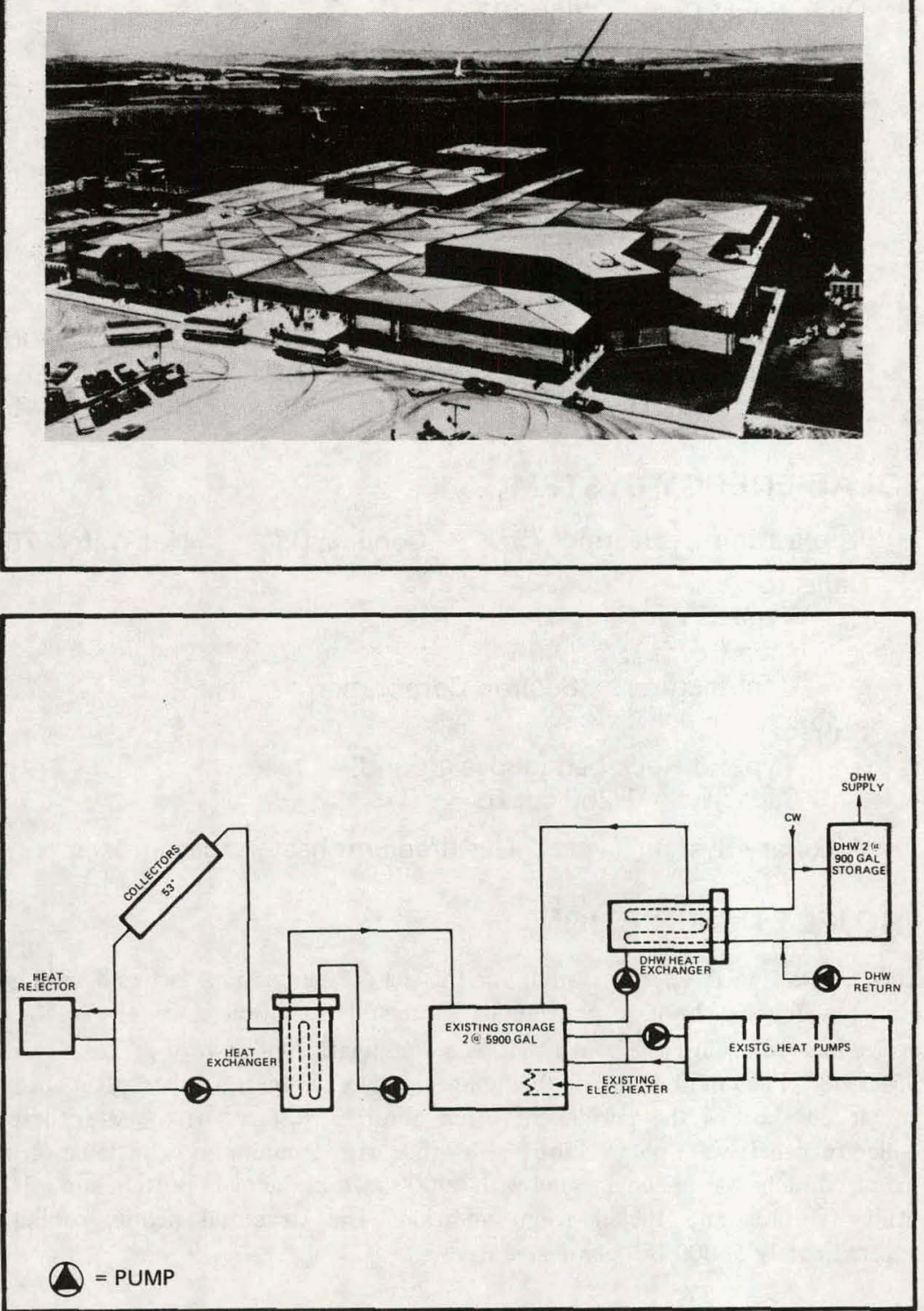


\section{PMUECT information}

Owner/Builder: Du Cat Investments, Inc.

Contractor: Du Cat Investments, Inc.

Operational Date: June 1978

Total Estimated DOE Funds: $\quad \$ 282,123$

Building

Type: Warehouse/office

Area: 48,800 sq. ft. (total); 39,000 sq. ft. (cond.)

Location: Kansas City, Kansas

Latitude: $39^{\circ} \mathrm{N}$

Climatic Data

$\begin{array}{lllll}\text { Degree Days } & \text { Heating } & 4711 & \text { Cooling } & \text { N/A } \\ \text { Avg. Temp. }\left({ }^{\circ} \mathrm{F}\right) & \text { Winter } & 31.4 & \text { Summer } & 75.2 \\ \text { Avg. Insol. (Ly/d) } & \text { Winter } & 198 & \text { Summer } & 563\end{array}$

\section{SOLAR ENERGY SYSTEM}

Application Heating $40.4 \%$ Cooling $0 \%$ Hot Watar $0 \%$

Collector

Type: Air flat-plate

Area (sq. ft.): 7,800 sq. ft.

Manufacturer: Solaron Corporation

Storage

Type: Passive (Warehouse contents store heat)

Capacity: Utilizes building enclosure and warehouse contents

Auxiliary System Type: Electric unit heaters

\section{PROJECT DESCRIPTION}

This office and leasable warehouse is a $100^{\prime} \times 488^{\prime}$ steel framed building with precast double tees for an exterior wall. Heat loss is reduced by insulating the building to a greater extent than the typical warehouse and by utilizing insulated dock doors. The solar system heats air which is directly utilized in the space with no diversion to a storage rock bed. The factory assembled solar air heating collectors containing a flat absorber/heat exchanger and internal manifolding, are located on the roof, on $24^{\prime}$ centers, and oriented $3^{\circ}$ east of true south at a tilt of $53^{\circ}$. The air handling module consists of a set of automatic dampers, blower, and motor. The air handler is custom-engineered for on-site integration into the conventional HVAC system. The automatic system controller, activated by a conventional thermostat, is designed to continually monitor and regulate the operating modes of the system. It includes the sensors and controls necessary to automatically maintain the desired comfort level.
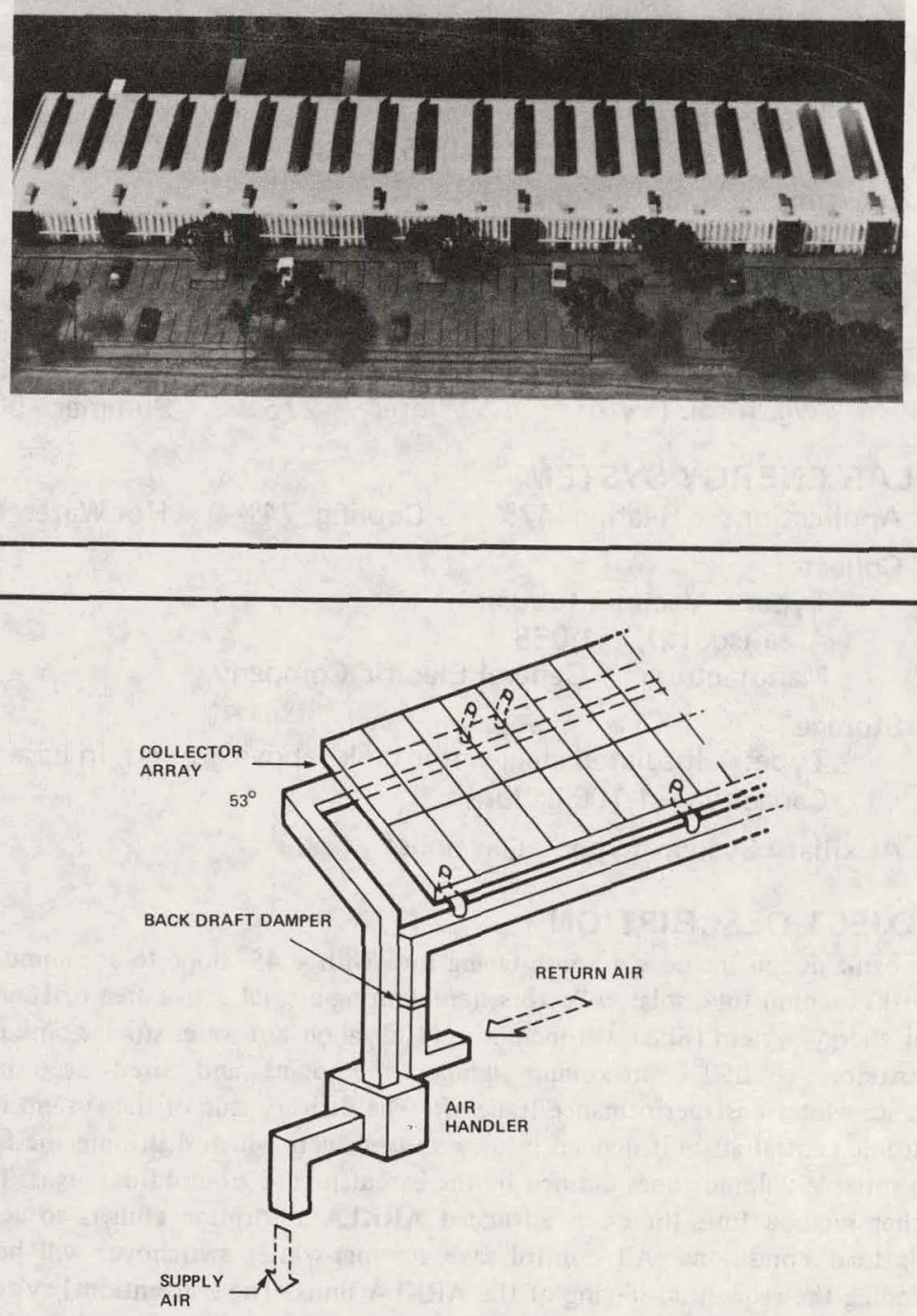


\section{PROJECT INFORMATION}

Owner/Builder: Kaw Valley State Bank and Trust Company

Contractor: Slemmons \& Assocs. Architects/Burgess Engineering Inc.

Operational Date: May 1978

Total Estimated DOE Funds: $\quad \$ \mathbf{\$ 7 , 1 6 0}$

Building

Type: Bank

Area: 6,588 sq. ft. (total); 5,600 sq. ft. (cond.)

Location: Topeka, Kansas

Latitude: $39^{\circ} \mathrm{N}$

Climatic Data

$\begin{array}{lllll}\text { Degree Days } & \text { Heating } & 5243 & \text { Cooling } & 1309 \\ \text { Avg. Temp. }\left({ }^{\circ} \mathrm{F}\right) & \text { Winter } & 43.3 & \text { Summer } & 73.4 \\ \text { Avg. Insol. (Ly/d) } & \text { Winter } & 275 & \text { Summer } & 509\end{array}$

SOLAR ENERGY SYSTEM

Application Heating $47 \%$ Cooling $74 \%$ Hot Water $95 \%$

Collector

Type: Vacuum tubular

Area (sq. ft.): 1,068

Manufacturer: General Electric Company

Storage

Type: Insulated steel water tank (above ground, in basement)

Capacity: 1,100 gallons

Auxiliary System Type: Gas boiler

\section{PROJECT DESCRIPTION}

The bank design includes a south-facing roof with a $45^{\circ}$ slope to accommodate $72 \mathrm{GE}$ TC-100 vacuum tube solar collectors, representing a total active area of $1068 \mathrm{sq} . \mathrm{ft}$. The solar energy system (SES) will include a 1100-gallon hot water storage tank designed for operation at $250^{\circ} \mathrm{F}$ maximum temperature point and sized according to the summer-winter cost/performance trade-off. The delivery side of the system is basically a hydronic central air unit divided into two main ducts which distribute the forced air to two variable volume zones defined by the basement and ground floor areas. The SES will further include four three-ton advanced ARKLA absorption chillers to accommodate peak load conditions. All control save summer-winter switchover will be automatic including the sequential staging of the ARKLA units. The conventional system will be a single gas boiler. Heating and cooling thermal energy requirements will be fully satisfied by the gas boiler when no solar energy is available.
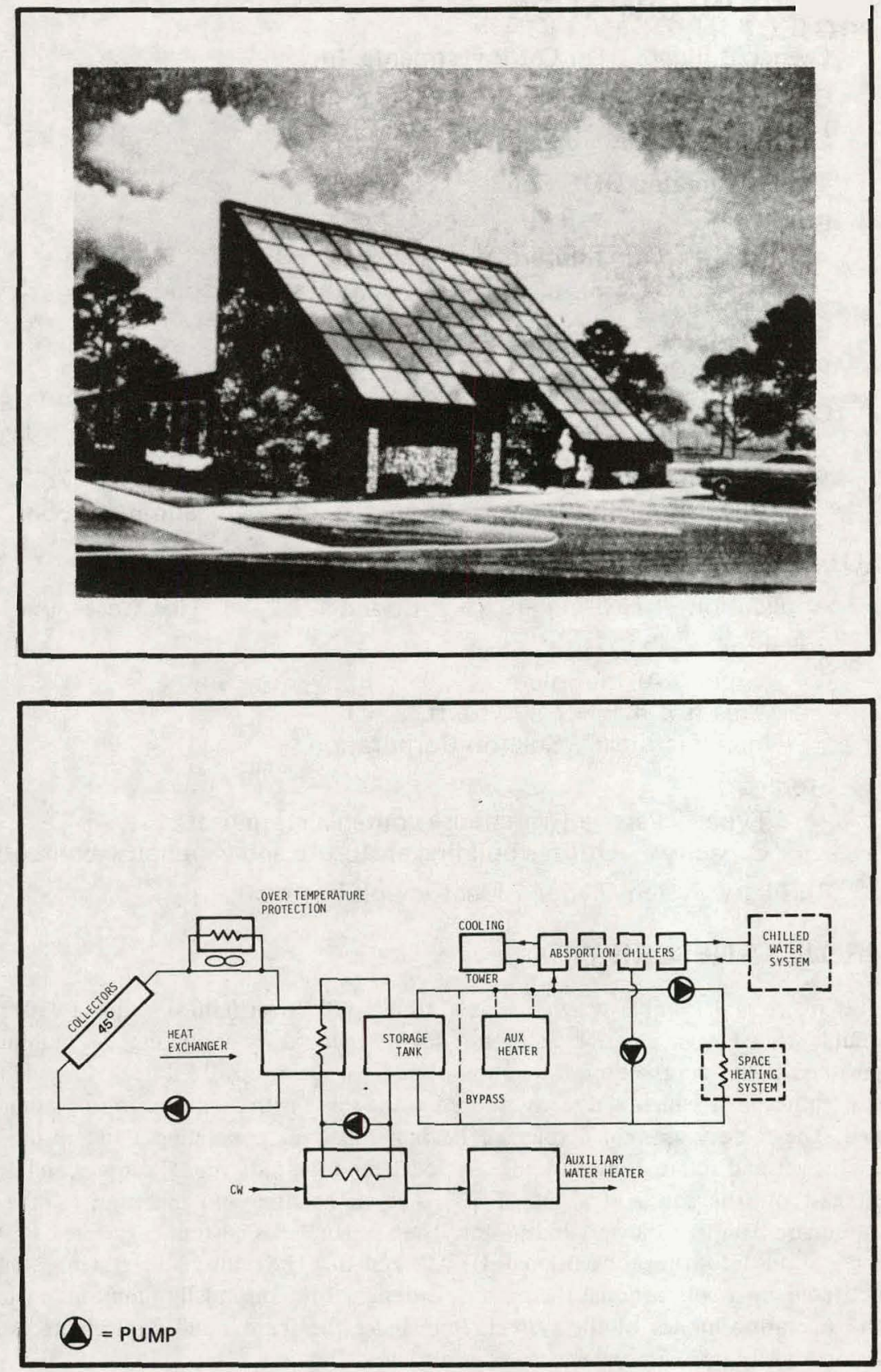


\section{PROJECT INFORMATION}

Owner/Builder: Charles F. Henning, M.D.

Contractor: Solar Services, Inc.

Operational Date: June 1978

Total Estimated DOE Funds: $\quad \$ \mathbf{7 5 , 1 6 6}$

Building

Type: Medical offices

Area: 4,764 sq. ft.

Location: Wichita, Kansas

Latitude: $37.5^{\circ} \mathrm{N}$

Climatic Data

$\begin{array}{lllll}\text { Degree Days } & \text { Heating } & 4620 & \text { Cooling } & \text { N/A } \\ \text { Avg. Temp. }\left({ }^{\circ} \mathrm{F}\right) & \text { Winter } & 35 & \text { Summer } & 80 \\ \text { Avg. Insol. (Ly/d) } & \text { Winter } & 200 & \text { Summer } & 575\end{array}$

Avg. Insol. (Ly/d)

Winter 200

\section{SOLAR ENERGY SYSTEM}

\section{Application Heating 85\%}

Collector

Type: Air flat-plate

Area (sq. ft.): 1,059

Manufacturer: Solar Services, Inc.

Storage

Type: Eutectic salt in trays (above ground, inside building)

Capacity: $624 \mathrm{cu} . \mathrm{ft}$. $(8,632$ trays $)$

Auxiliary System Type: Electric resistance forced air furnaces

\section{PROJECT DESCRIPTION}

A major criteria imposed by the building owner was that the project not appear substantially different from any conventional office building. As a result, the sola collector panels were placed vertically on the south wall in such a way that they appear to be a conventional window wall system. Each collector panel, partially assembled by the manufacturer, is made up of two separate black painted galvanized sheet metal absorber plates, spaced about 2" apart, with double glazing about 2" in from the front absorbe plate. The back absorber plate is nailed, on the job site, to the plywood sheathing of the south building wall and thereby includes the insulated wall construction as the back of the collector. Air is passed between the absorber plates to transport the solar energy collected to storage for later use. The heat storage system utilizes a heat-of-fusion eutectic salt material which is factory sealed in black trays of high density polyethylene plastic. The eutectic salt, or "Glauber's Salt" as it is commonly called, is a mixture of sodium sulfate decahydrate and borax.
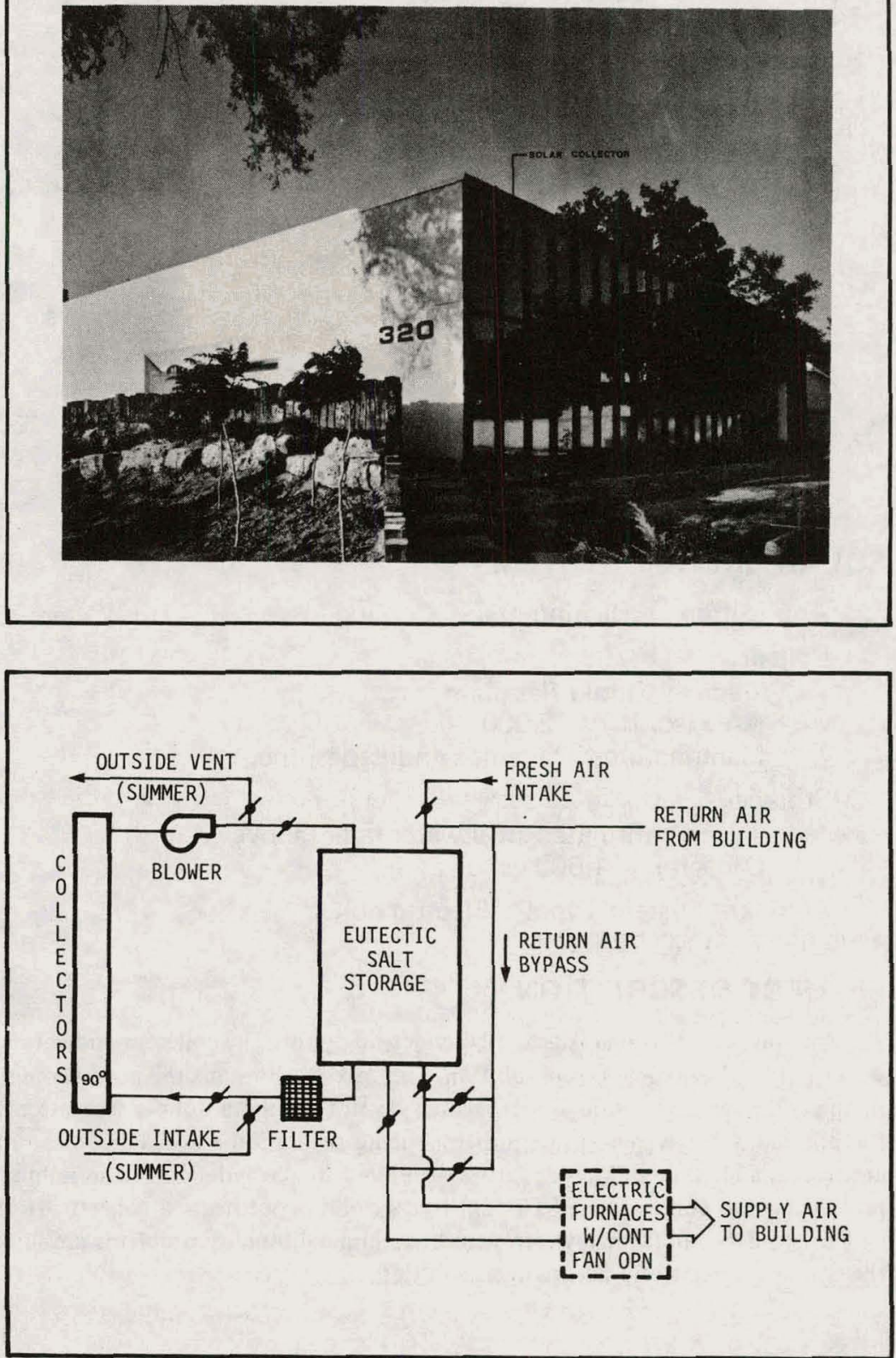


\section{PROJECT INFORMATION}

Owner/Builder: La Quinta Motor Inns, Inc.

Contractor: Travis-Braun \& Associates, Inc.

Operational Date: May 1978

Total Estimated DOE Funds: $\quad \$ 44,954$

\section{Building}

Type: Low rise motel

Area: Not applicable to hot water systems

Location: Wichita, Kansas

Latitude: $38^{\circ} \mathrm{N}$

Climatic Data

$\begin{array}{lllll}\text { Degree Days } & \text { Heating } & 4700 & \text { Cooling } & 1500 \\ \text { Avg. Temp. }\left({ }^{\circ} \mathrm{F}\right) & \text { Winter } & 38 & \text { Summer } & 74 \\ \text { Avg. Insol. (Ly/d) } & \text { Winter } & 285 & \text { Summer } & 540\end{array}$

\section{SOLAR ENERGY SYSTEM}

Application Heating $0 \%$

Collector

Type: Liquid flat-plate

Area (sq. ft.): 2,000

Manufacturer: Lennox Industries, Inc. Storage

Type: Insulated steel water tank (above ground)

Capacity: 1,600 gallons

Auxiliary System Type: Electric boiler

\section{PROJECT DESCRIPTION}

A freeze protected system is proposed under this grant. The collector circulating fluid is a water buffered ethylene glycol solution. This mixture prevents the occurrence of freezing in the collector. Even though many codes do not require a double separation insulating the potable water system, provisions for such a separation are included. The mixture of antifreeze and water can be further buffered to include corrosion inhibiters, thus prolonging the collector life. The antifreeze solution protects a collector from damage which could occur from low temperatures. Mineral buildup problems are eliminated by the contained, relatively nonchanging solution.
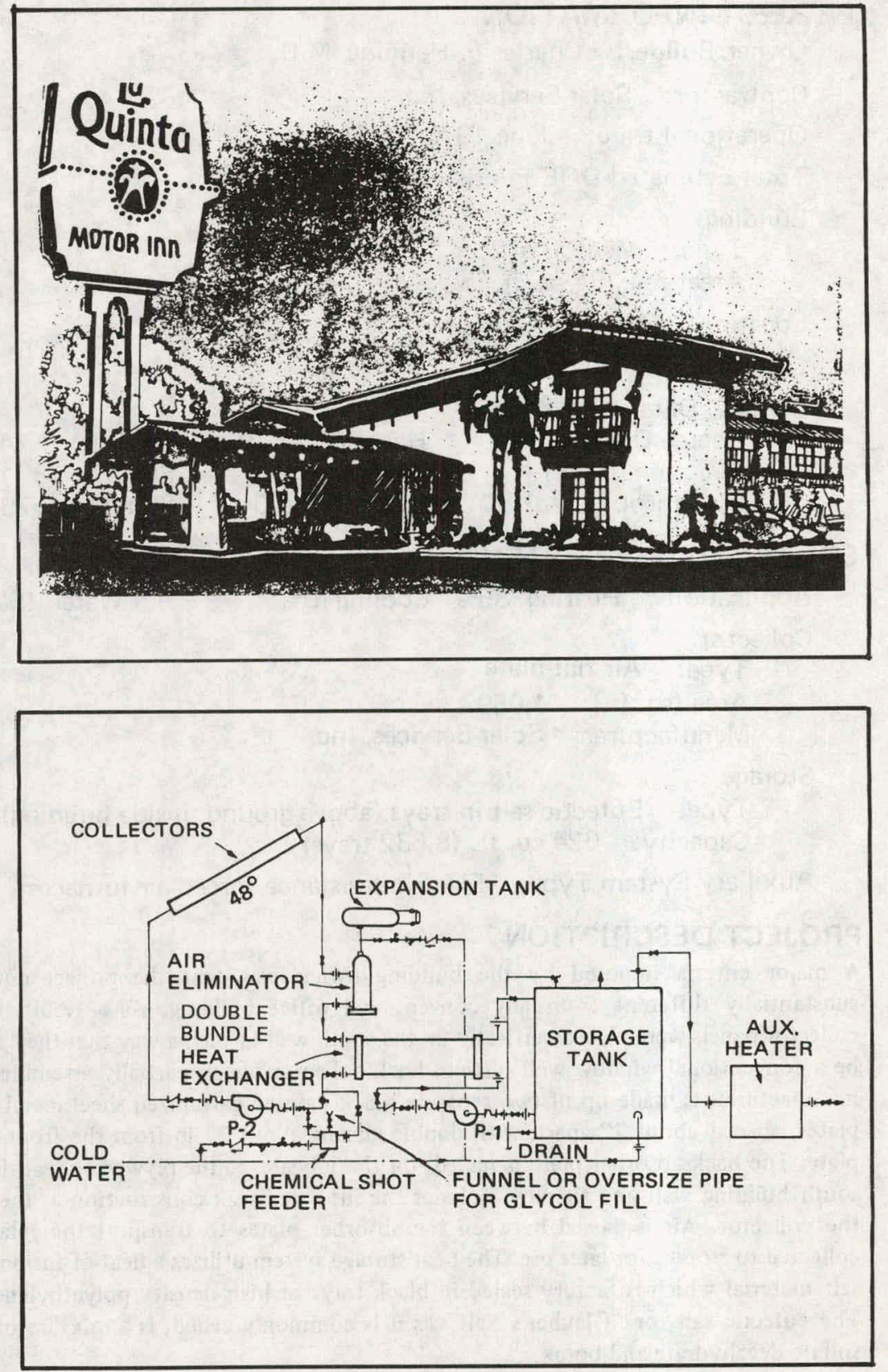


\section{PROJECT INFORMATION}

Owner/Builder: Rademaker Corporation

Contractor: Rademaker Corporation

Operational Date: July 1977

Total Estimated DOE Funds: $\quad \$ 20,729$

Building

Type: Office/warehouse

Area: 10,000 sq. ft. (total); 1,080 sq. ft. (cond.)

Location: Louisville, Kentucky

Latitude: $38.2^{\circ} \mathrm{N}$

Climatic Data

$\begin{array}{lllll}\text { Degree Days } & \text { Heating } & 4645 & \text { Cooling } & 1268 \\ \text { Avg. Temp. }\left({ }^{\circ} \mathrm{F}\right) & \text { Winter } & 46.2 & \text { Summer } & 73.2 \\ \text { Avg. Insol. (Ly/d) } & \text { Winter } & 287 & \text { Summer } & 504\end{array}$

\section{SOLAR ENERGY SYSTEM}

Application Heating $50 \%$

Collector

Type: Air flat-plate/liquid flat-plate

Area (sq. ft.): $\quad 195 / 240$

Manufacturer: Solaron Corporation/Solar Development, Inc.

\section{Storage}

Type: Rock bed/steel tank(above ground)

Capacity: $110 \mathrm{cu}$. ft./560 gallons

Auxiliary System Type: Natural gas

\section{PROJECT DESCRIPTION}

Solar energy provides heat for office space within a prefabricated steel building. Waste energy produced in excess of that demanded by office areas can be passed into the warehouse or second floor drafting room. Two systems are employed, a liquid heating system employing ethylene glycol through south facing collectors inclined at $53^{\circ}$, and an air collector system employing ten panels of $191 / 2 \mathrm{sq}$. ft. The liquid system employs a heat exchanger built into the hot water storage tank, the exchanger allowing ethylene glycol to pump through the collectors when solar radiation is available. This introduces heat into the stored water. The air collector system employs eight motor-operated dampers and a booster fan to introduce the air to the collectors and/or the rock storage bin. The air is then moved to the respective air handling system for distribution to the space.
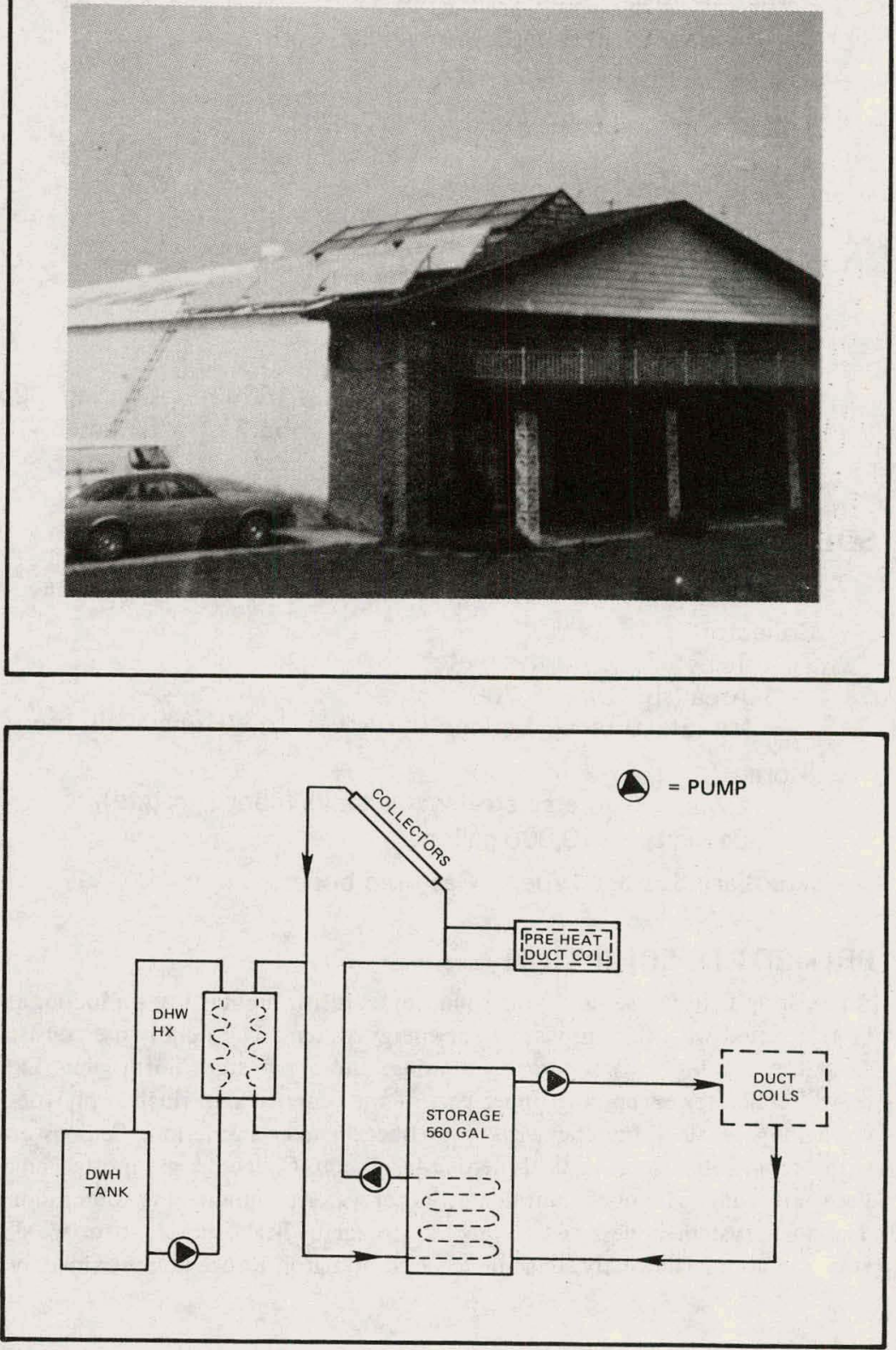


\section{PROJECT INFORMATION}

Owner/Builder: Louisiana State University \& A\&M College

Contractor: Bernhard Mechanical Contractors, Inc.

Operational Date: May 1978

Total Estimated DOE Funds: $\quad \$ 276,741$

Building

Type: Field house

Area: 101,200 sq. ft. (cond.)

Location: Baton Rouge, Louisiana

Latitude: $30.7^{\circ} \mathrm{N}$

Climatic Data

$\begin{array}{lllll}\text { Degree Days } & \text { Heating } & 1560 & \text { Cooling } & 2585 \\ \left.\text { Avg. Temp. ( }{ }^{\circ} \mathrm{F}\right) & \text { Winter } & 55.2 & \text { Summer } & 76.2 \\ \text { Avg. Insol. (Ly/d) } & \text { Winter } & 287 & \text { Summer } 490\end{array}$

\section{SOLAR ENERGY SYSTEM}

Application Heating $\sqrt{ }$

Cooling $0 \%$ Hot Water $\sqrt{ }$

Collector

Type: Liquid flat-plate

Area (sq. ft.): $\quad 5,700$

Manufacturer: Lennox Industries, Inc./Honeywell, Inc.

\section{Storage}

Type: Insulated steel water tanks (above ground)

Capacity: 10,000 gallons

Auxiliary System Type: Gas fired boilers

\section{PROJECT DESCRIPTION}

An existing field house used year round by students and faculty for indoor athletics will be retrofitted with the proposed solar energy system. The field house consists of a onestory center wing, a two-story south wing, and a two-story north wing. Exterior walls are 8 " concrete, except the upper part of the center wing, which is plywood sheathing on light gage steel framing with glass fiber blanket insulation. Ceilings are insulated with brown cellulose acoustical-thermal insulation. Collectors are located on the roof of the south wing. The maximum domestic hot water requirement is 1600 gallons per hour. The solar system is designed to provide storage of heat equivalent to two days of peak solar radiation. The yearly sunshine received by Baton Rouge is approximately $57 \%$. 


\section{PROJECT INFORMATION}

Owner/Builder: Ferguson Corporation

Contractor: Anthony F. Musolino/John E. Lawrence and Associates/Solar Energy Scientific Technical Services

Operational Date: May 1978

Total Estimated DOE Funds: $\quad \$ 90,357$

Building

Type: Motel

Area: 100 rooms and laundry

Location: Annapolis, Maryland

Latitude: $39.0^{\circ} \mathrm{N}$

Climatic Data
Degree Days
Avg. Temp. $\left({ }^{\circ} \mathrm{F}\right)$
Heating
Winter 45.9
Cooling 1108
Avg. Insol. (Ly/d)
Winter 288
Summer 73.1
Summer 488

\section{SOLAR ENERGY SYSTEM}

Application Heating 0\%

Collector

Type: Liquid flat-plate

Area (sq. ft.): 1,792

Manufacturer: Southwest Ener-Tech, Inc.

Storage

Type: Insulated steel water tanks (above ground)

Capacity: 3,000 gallons

Auxiliary System Type: Electric

\section{PROJECT DESCRIPTION}

In this project, the present water heating facilities of the Thr-Rift Inn in Annapolis, Md. will be supplemented by a solar energy system. The motel currently uses electricity to heat its water, but a more economical system has become increasingly desirable. The motel offers two special challenges for a solar energy system. First, the demand in the rooms for hot water during nondaylight hours is quite high. Second, the motel has a laundry, which also has a very high hot water requirement. The proposed solar energy system uses solar collectors, a heat exchanger, and a storage tank. It will provide water heated to $120^{\circ} \mathrm{F}$ for the occupant use. The solar system will be supplemented by an electrical water heater for the laundry. The electric heater will raise the temperature of the water from $120^{\circ} \mathrm{F}$ to $180^{\circ} \mathrm{F}$, the temperature required by Maryland State health codes.
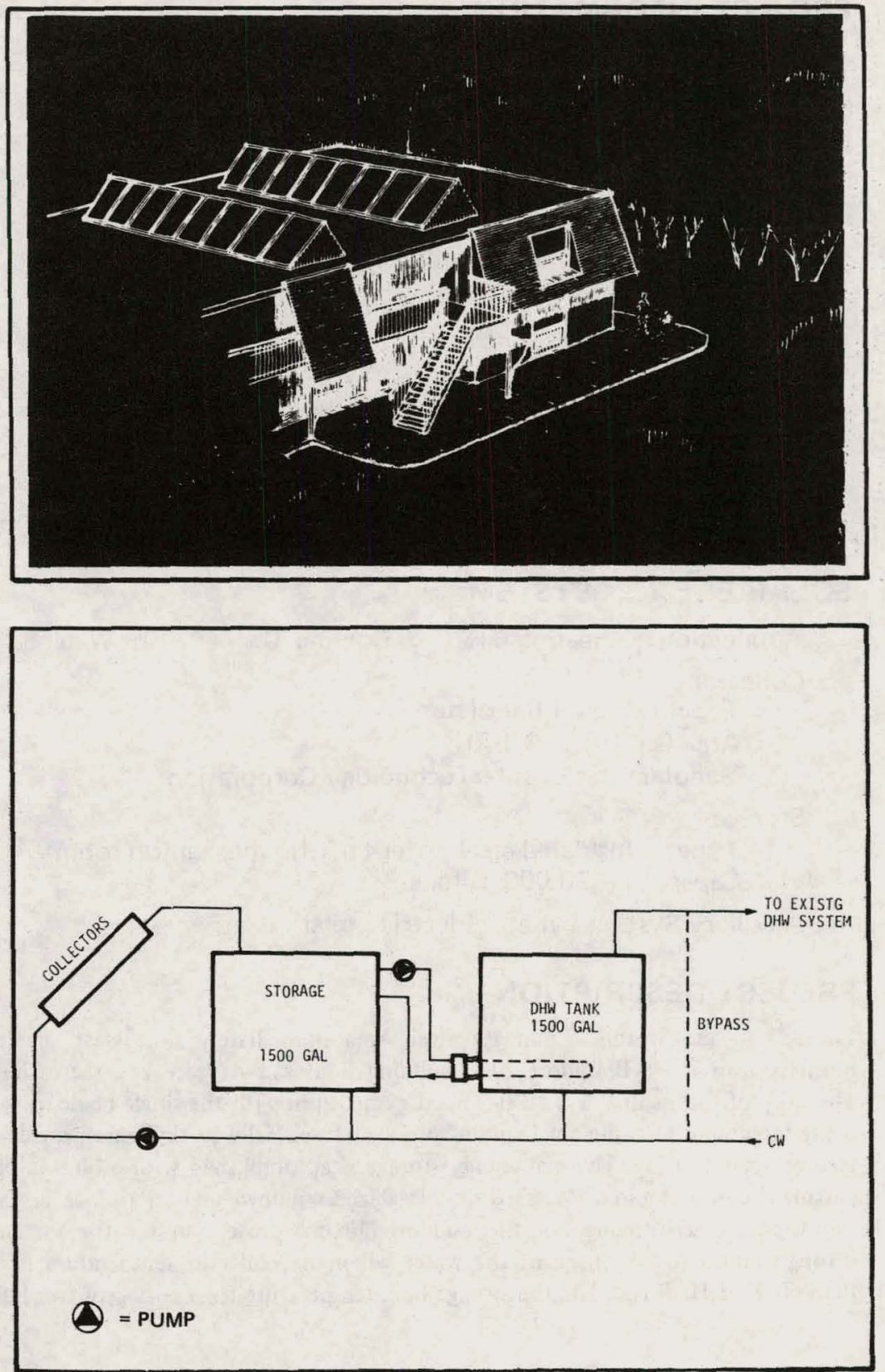


\section{PROJECT INFORMATION}

Owner/Builder: City of Baltimore

Contractor: Ingleside Contractors of Maryland

Operational Date: January 1979

Total Estimated DOE Funds: $\$ \mathbf{1 5 0 , 3 4 5}$

Building

Type: Community center

Area: 17,000 sq. $\mathrm{ft}$.

Location: Baltimore, Maryland

Latitude: $39.2^{\circ} \mathrm{N}$

Climatic Data

$\begin{array}{lllll}\text { Degree Days } & \text { Heating } & 4729 & \text { Cooling } 1108 \\ \text { Avg. Temp. }\left({ }^{\circ} \mathrm{F}\right) & \text { Winter } & 45.9 & \text { Summer } 73.1 \\ \text { Avg. Insol. }(\text { Ly } / \text { d) } & \text { Winter } & 288 & \text { Summer } & 488\end{array}$

\section{SOLAR ENERGY SYSTEM}

Application Heating 64\% Cooling $0 \%$ Hot Water $\sqrt{ }$

Collector

Type: Liquid flat-plate

Area (sq. ft.): 3,100

Manufacturer: InterTechnology Corporation

\section{Storage}

Type: Insulated steel water tank (in mechanical room)

Capacity: 20,000 gallons

Auxiliary System Type: Electric boiler

\section{PROJECT DESCRIPTION}

Located in the Upton Urban Renewal Area immediately northwest of the central business district of Baltimore, this building houses a daycare and recreation facility. The core of the facility is a steel-framed gymnasium with the single plane solar collector being integrated into the single-pitch roof structure. Hallway skylights provide light and passive solar heating. Thermal energy storage is accomplished with a built-in-place compartment concrete tank. Recessed double glazed windows and an air-lock entry improve the thermal performance of the building. Freeze protection for the system will be through automatic drainage of the water when the collector temperature is either less than $60^{\circ} \mathrm{F}$ or $10^{\circ} \mathrm{F}$ less than the storage tank temperature for a period of two hours.
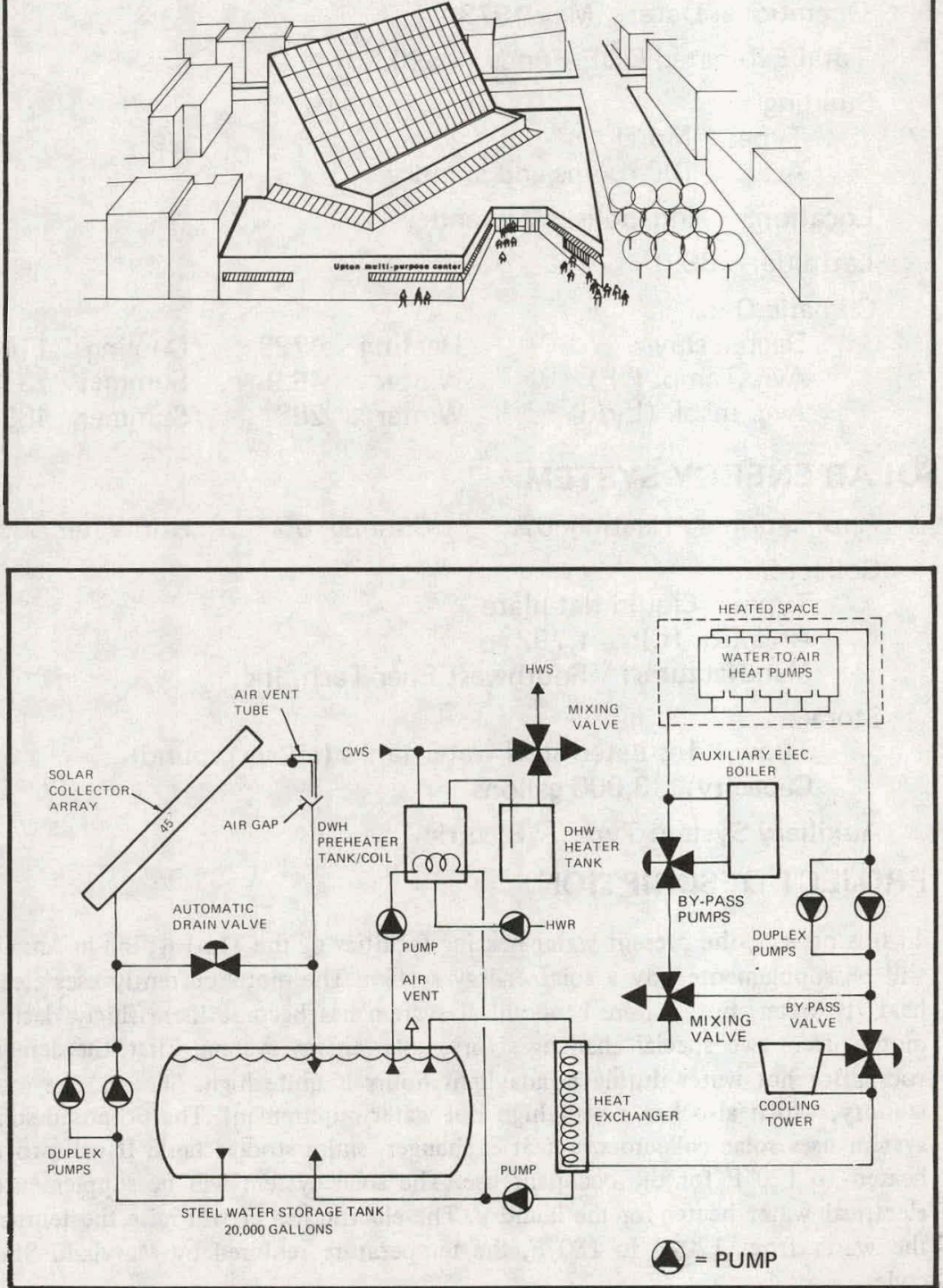


\section{PROUECT INFORMATION}

Owner/Builder: City of Baltimore

Contractor: To be determined

Operational Date: June 1978

Total Estimated DOE Funds: $\$ 231,709$

Building

Type: Fire station

Area: 8,500 sq. ft. (heated); 2,410 sq. ft. (cooled)

Location: Baltimore, Maryland

Latitude: $39^{\circ} \mathrm{N}$

Climatic Data

$\begin{array}{lllll}\text { Degree Days } & \text { Heating } & 4101 & \text { Cooling } & 1491 \\ \text { Avg. Temp. ( }{ }^{\circ} \mathrm{F} \text { ) } & \text { Winter } & 46.2 & \text { Summer } & 71.2 \\ \text { Avg. Insol. (Ly/d) } & \text { Winter } & 304 & \text { Summer } & 390\end{array}$

\section{SOLAR ENERGY SYSTEM}

Application Heating $77.6 \%$ Cooling $58.9 \%$ Hot Water $100 \%$

Collector

Type: Liquid flat-plate

Area (sq. ft.): 2,000

Manufacturer: To be determined

Storage

Type: Insulated steel water tank (in mechanical room)

Capacity: 6,000 gallons

Auxiliary System Type: Heating - oil fired boiler; cooling - reciprocating

\section{PROJECT DESCRIPTION}

chiller; hot water - electric heater

This new fire station has been designed specifically to integrate normal building functions with the visual drama of the solar-energy collector array. The bank of 320 solar collectors faces due south and is mounted at a $45^{\circ}$ angle from horizontal. The $60^{\prime}$ high structure for the collectors will be highly visible in a neighborhood of low-lying commercial structures. The main storage tank will provide sufficient thermal capacity to store the maximum amount of excess solar energy generated. Potable hot water is isolated with a double wall heat exchanger from the solar energy transport loop to prevent possible contamination even though water is used as the heat transfer medium. Major materials for this firehouse will include insulated industrial corregated metal exterior panels over concrete block walls; exposed steel structure and spiral mechanical HVAC ducts; high intensity, low voltage lighting; a pre-engineered skylight of acrylic plastic; and, exposed steel trusses supporting the bank of collectors.
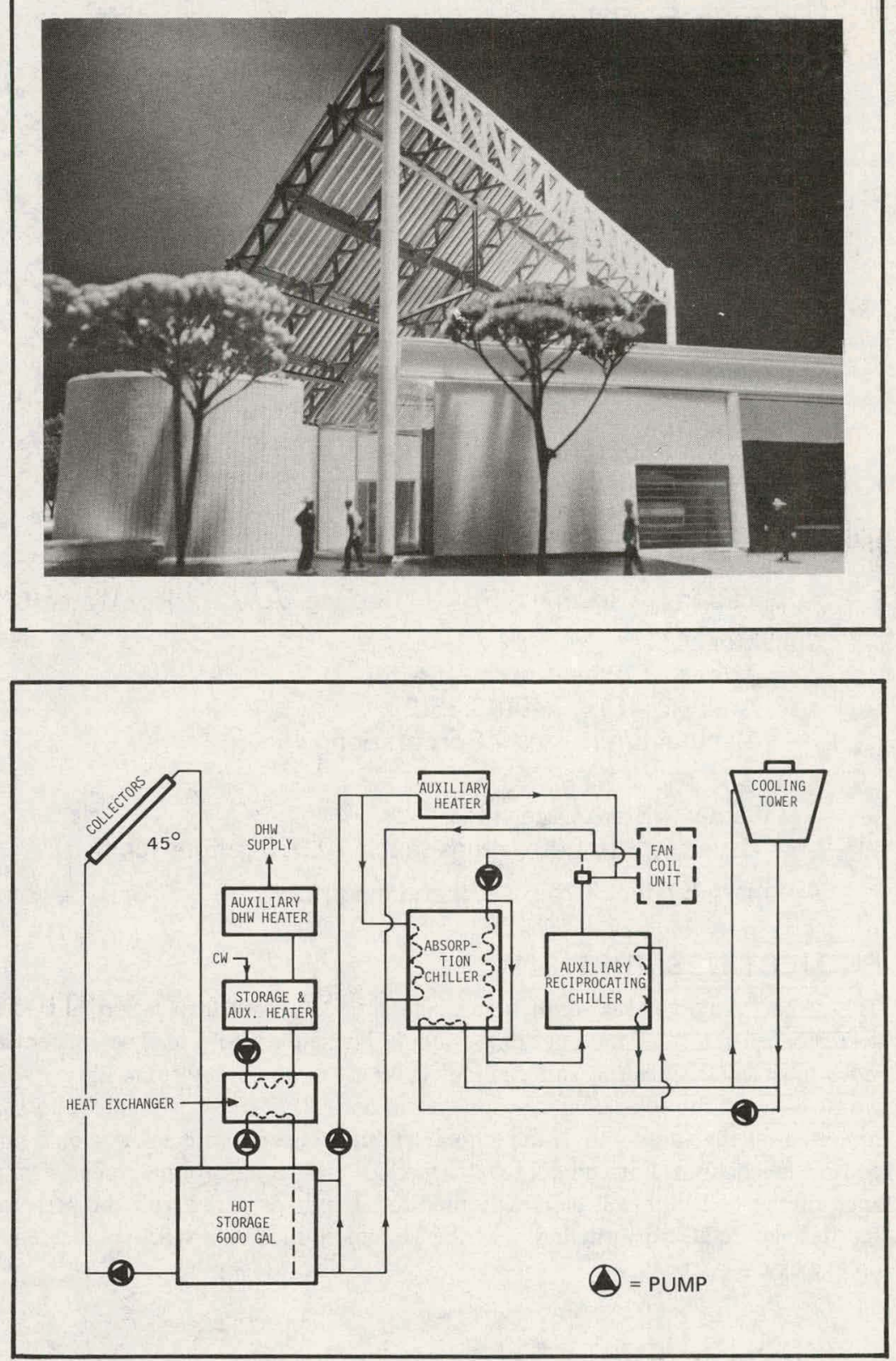


\section{...OJECT INFORMATION}

Owner/Builder: Baltimore County

Contractor: AAI Corporation

Operational Date: February 1978

Total Estimated DOE Funds: $\$ 616,166$

Building

Type: Elementary school

Area: $\quad 45,000$ sq. ft. (total); 10,000 (cond.)

Location: Cockeysville, Maryland

Latitude: $39.9^{\circ} \mathrm{N}$

Climatic Data

$\begin{array}{lllll}\text { Degree Days } & \text { Heating } & 4729 & \text { Cooling } & 1108 \\ \text { Avg. Temp. }\left({ }^{\circ} \mathrm{F}\right) & \text { Winter } & 45.9 & \text { Summer } & 73.1 \\ \text { Avg. Insol. (Ly/d) } & \text { Winter } & 288 & \text { Summer } & 488\end{array}$

\section{SOLAR ENERGY SYSTEM}

Application Heating $75 \%$ Cooling $75 \%$ Hot Water $0 \%$

Collector

Type: Concentrator/reflector

Area (sq. ft.): $\quad 400 / 3,350$

Manufacturer: AAI Corporation

\section{Storage}

Type: Steel water tank

Capacity: 10,000 gallons (hot); 10,000 gallons (chilled)

Auxiliary System Type: Oil and electric

\section{PROJECT DESCRIPTION}

The project encompasses the design, manufacture, retrofit installation, and testing of a solar concentrator for the one-story Padonia Elementary School. The concentrator provides most of the heating and cooling required for the cafetorium, library and administrative suite. The solar concentrator system consists of fixed parabolic reflector mirrors mounted on the south end of the school, a liquid collector with an electronic sun-sensing control mechanism, hot and cold water storage, and an absorption chiller. The performance of the collector will be closely monitored and compared with the performance of the flat-plate collector installation at the Timonium Elementary School located only two miles away. 
PRUJECT INFORMATION

Owner/Builder: Maryland National Capital Park and Planning Commission

Contractor: Greenhorne \& O'Mara, Inc.

Operational Date: July 1978

Total Estimated DOE Funds: $\quad \$ 49,016$

Building

Type: Office

Area: 3,000 sq. ft.

Location: Gaithersburg, Maryland

Latitude: $39.0^{\circ} \mathrm{N}$

Climatic Data

$\begin{array}{lllll}\text { Degree Days } & \text { Heating } & 4211 & \text { Cooling } & 1415 \\ \text { Avg. Temp. }\left({ }^{\circ} \mathrm{F}\right) & \text { Winter } & 42.2 & \text { Summer } & 69.9 \\ \text { Avg. Insol. (Ly/d) } & \text { Winter } & 262 & \text { Summer } & 483\end{array}$

Avg. Insol. (Ly/d) Winter $262 \quad$ Summer 483

\section{SOLAR ENERGY SYSTEM}

\section{Application Heating: $50 \%$ \\ Hot Water $0 \%$}

\section{Collector}

Type: Liquid tubular

Area (sq. ft.): 1,500

Manufacturer: KTA Corporation

Storage

Type: Steel water tank (above ground)

Capacity: 3,000 gallons

Auxiliary System Type: Electric boiler

\section{PROJECT DESCRIPTION}

For this project, a solar energy system will provide heat to a one-story office building. The solar system will use collectors on the building's roof, a heat exchanger, pump, and storage tank. It should provide $50 \%$ of the building's space heating requirement during peak demand periods and $100 \%$ of the requirement when the demand is lowest. The building has 9" of insulation in the roof and 6" in the walls. Wall insulation is further improved by 6 ' earth berms. All windows are double insulated; windows on the northern side of the building have been minimized. The use of glass in walls and skylights should significantly reduce electric lighting demands. The abundance of existing trees and shrubs around the building will significantly reduce heating demands during the winter and cooling demands in the summer.
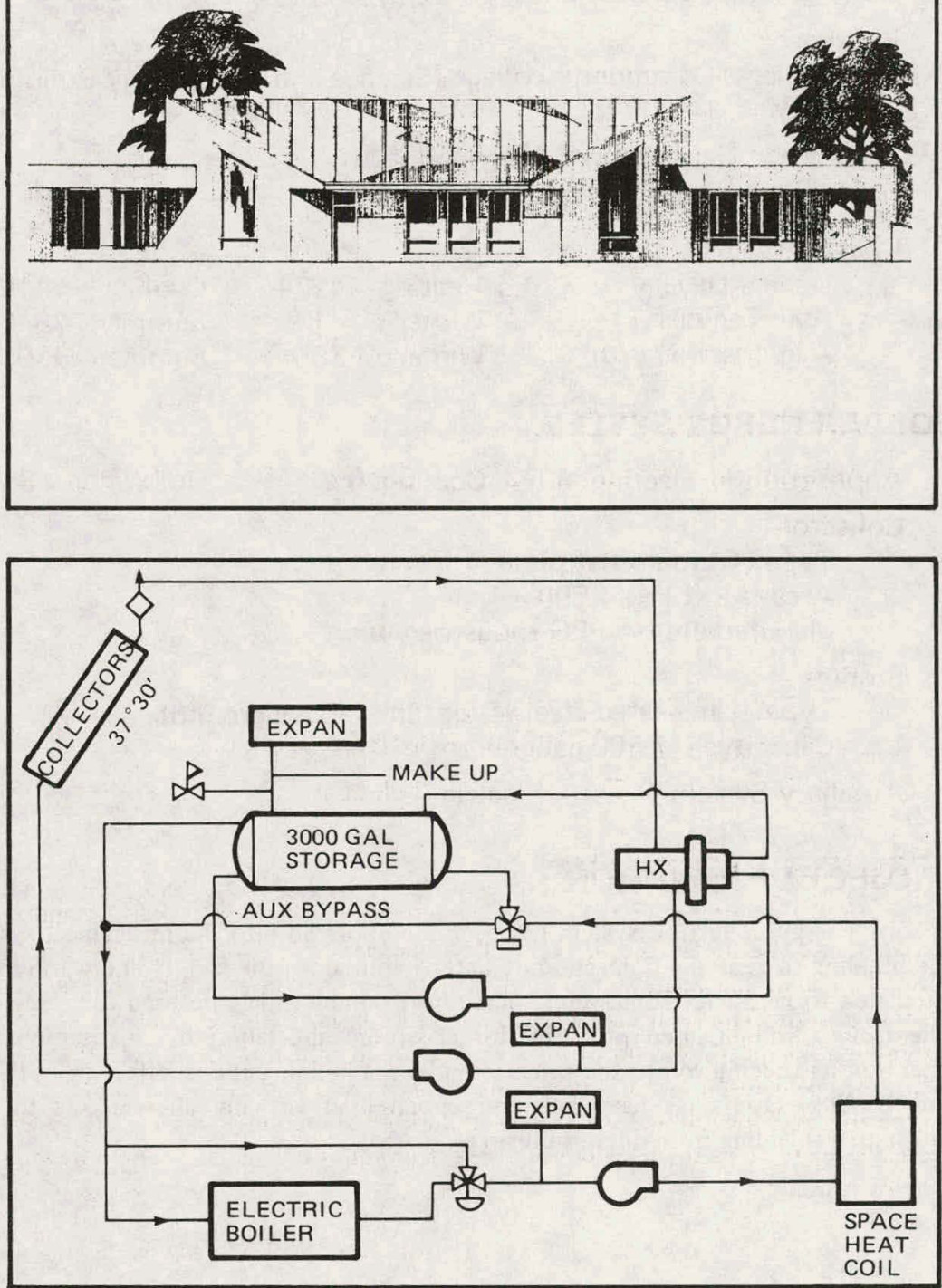


\section{-...JECT INFORMATION}

Owner/Builder: Montgomery Community Cóllege

Contractor: Silver, Schwartz and Associates

Operational Date: May 1978

Total Estimated DOE Funds: $\quad \$ 22,379$

Building

Type: Community college (Science and Technology Building)

Area: $\quad 14,000$ sq. ft.

Location: Germantown, Maryland

Latitude: $40^{\circ} \mathrm{N}$

Climatic Data

$\begin{array}{lllll}\text { Degree Days } & \text { Heating } & 4224 & \text { Cooling } & 1415 \\ \text { Avg. Temp. }\left({ }^{\circ} \mathrm{F}\right) & \text { Winter } & 41.8 & \text { Summer } & 78.6 \\ \text { Avg. Insol. }(\text { Ly/d) } & \text { Winter } & 385 & \text { Summer } & 430\end{array}$

\section{SOLAR ENERGY SYSTEM}

Collector

Type: Liquid flat-plate

Area (sq. ft.): 4,500

Manufacturer: PPG Industries, Inc.

Storage

Type: Insulated steel water tank (above ground)

Capacity: 7,500 gallons

Auxiliary System Type: Electric

\section{PROJECT DESCRIPTION}

A solar energy collection system has been incorporated into the mechanical systems of the building to heat the domestic hot water required for the facility and warm the water circulated to perimeter zone water source heat pumps which are used for space heating. The facility will be used primarily for classroom and laboratory instruction. Careful attention has been given to the orientation of the building and its effect on both heating and cooling. Overhangs have been incorporated at virtually all windows to provide substantial shielding from direct sunlight.
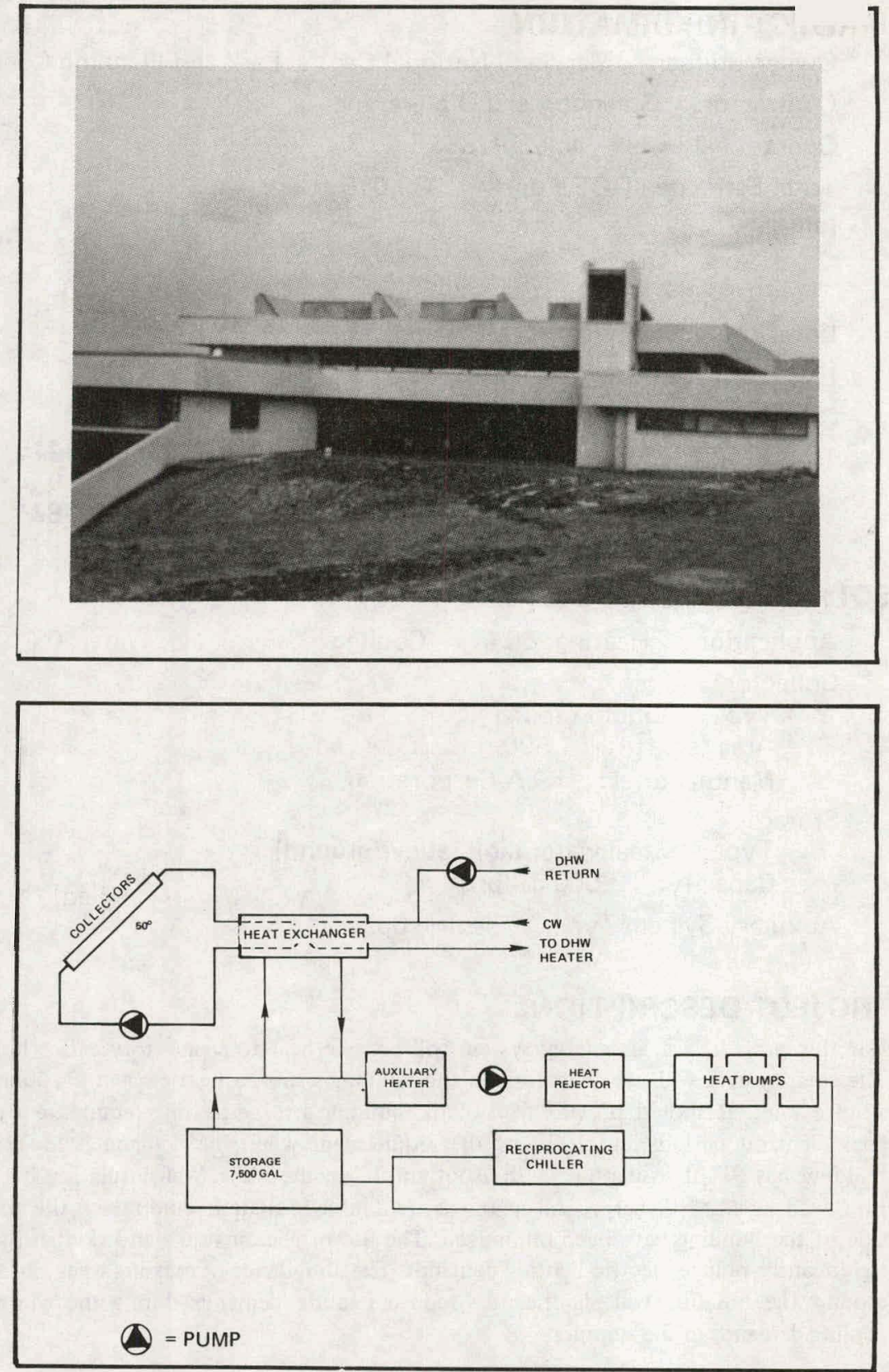


\section{PROUJECT INFORMATION}

Owner/Builder: Baltimore County

\section{Contractor: AAl Corporation}

Operatonal Date: March 1974 (heating); May 1975 (cooling) Total Estimated DOE Funds: $\quad \$ 1,151,020$

Building

Type: Elementary school

Area: $\quad 60,000$ sq. ft. (total); 8,580 (cond.)

Location: Timonium, Maryland

Latitude: $39.5^{\circ} \mathrm{N}$

Climatic Data

$\begin{array}{lllll}\text { Degree Days } & \text { Heating } & 4729 & \text { Cooling } & 1108 \\ \text { Avg. Temp. }\left({ }^{\circ} \mathrm{F}\right) & \text { Winter } & 45.9 & \text { Summer } & 73.1 \\ \text { Avg. Insol. (Ly/d) } & \text { Winter } & 288 & \text { Summer } & 488\end{array}$

\section{SOLAR ENERGY SYSTEM}

Application Heating 60\%

Hot Water $0 \%$

Collector

Type: Liquid flat-plate/reflector

Area (sq. ft.): $\quad 5,040 / 5,300$

Manufacturer: AAl Corporation

\section{Storage}

Type: Insulated steel water tank (above ground)

Capacity: $\quad 15,000$ gallons (hot); 40,000 gallons (chilled)

Auxiliary System Type: Oil boiler

\section{PROJECT DESCRIPTION}

This project provided for the design, fabrication, and installation of a retrofit solar heating and cooling system for one wing of the Timonium Elementary School. The solar system consists of liquid honeycomb construction flat-plate collectors with fixed mirrors, hot and cold storage tank, and a 150-ton York absorption chiller. Two principal modifications were made. A cooling tower was added and a condensate drain line was run to convectors in the classrooms. This was the first school in the U.S. to have solar heating and cooling. The project also called for studies of the feasibility of installing systems similar to this in other buildings. This project was partially funded by the National Science Foundation and is one of the four early proof-of-concept experiments started in 1974
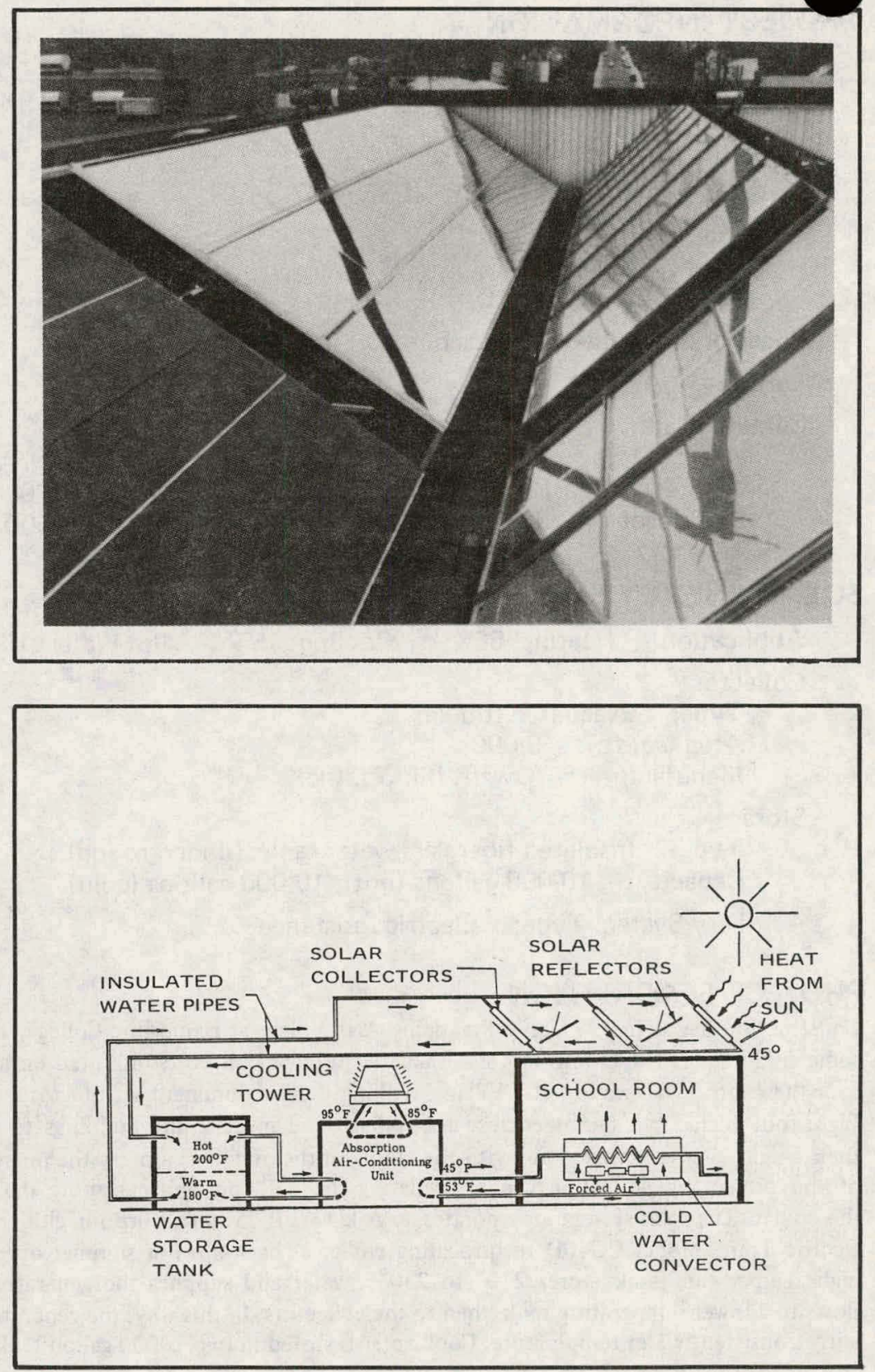


\section{r חUJECT INFORMATION}

Owner/Builder: Hampshire College

Contractor: Hampshire College

Operational Date: Mid 1978

Total Estimated DOE Funds: $\$ 355,027$

Building

Type: College

Area: 50,000 sq. $\mathrm{ft}$

Location: Amherst, Massachusetts

Latitude: $42.3^{\circ} \mathrm{N}$

Climatic Data

$\begin{array}{lllll}\text { Degree Days } & \text { Heating } & 7578 & \text { Cooling } & \text { N/A } \\ \text { Avg. Temp. }\left({ }^{\circ} \mathrm{F}\right) & \text { Winter } & 30 & \text { Summer } & 70 \\ \text { Avg. Insol. (Ly/d) } & \text { Winter } & 280 & \text { Summer } & 500\end{array}$

\section{SOLAR ENERGY SYSTEM}

Application Heating 65\% Cooling 95\% Hot Water $100 \%$

Collector

Type: Evacuated tubular

Area (sq. ft.): 5,000

Manufacturer: Owens-Illinois, Inc.

Storage

Type: Insulated fiberglass water tanks (underground)

Capacity: 10,000 gallons (hot); 10,000 gallons (cold)

Auxiliary System Type: Electric resistance

\section{PROJECT DESCRIPTION}

Construction began in 1975 on a Practicing Arts Village at Hampshire College. There are some 5000 sq. ft. of Owens-Illinois evacuated tubular collectors mounted on a canopy over the central walkway of the Village, making them a dominant architectural element. Eight-foot high earth berms enclose the Village and insulate the buildings to one-half their height. These berms along with the siding of the buildings modify the microclimate of the project by deflecting winds, insulating the building, and capturing the sun for the courts. The solar system incorporates an Arkla WFB 25-ton absorption chiller with an electric Trane Model CG40D reciprocating chiller as back-up. For summer operation, a high temperature tank stores $210^{\circ}$ to $230^{\circ} \mathrm{F}$ water and supplies the generator. Water flows to a lower temperature tank, then to the collectors. In this way, the generator sees a fairly consistent water temperature. Cool water is stored in two 10000-gallon tanks which protrude from a berm.
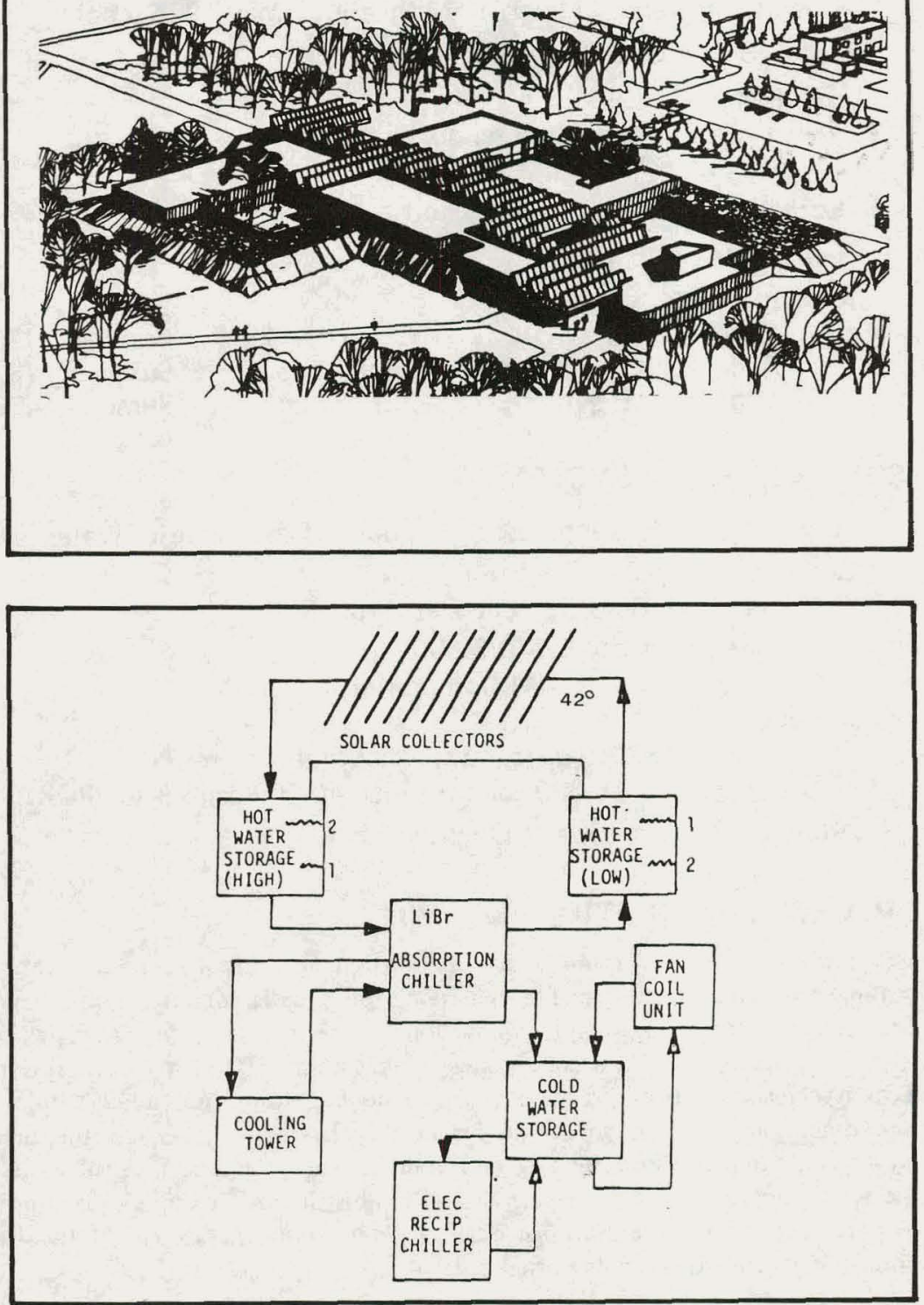


\section{PROJECT INFORMATION}

Owner/Builder: City of Boston (Dorchester)

Contractor: General Electric Company

Operational Date: March 1974

Total Estimated DOE Funds: $\$ \mathbf{\$ 6 0 0 , 2 3 6}$

Building

Type: School

Area: 61,000 sq. ft. (total); 21,000 (cond.)

Location: Boston (Dorchester), Massachusetts

Latitude: $42.4^{\circ} \mathrm{N}$

\section{Climatic Data}

Degree Days

Avg. Temp. $\left({ }^{\circ} \mathrm{F}\right)$

Heating 5621

Avg. Insol. (Ly/d)
Cooling 661

Summer 70.9

Summer 479

\section{SOLAR ENERGY SYSTEM}

Application Heating 65\%

Cooling $0 \%$

Hot Water $0 \%$

Collector

Type: Liquid flat-plate

Area (sq. ft.): $\quad 4,600$

Manufacturer: General Electric Company

Storage

Type: Insulated water tank (above ground)

Capacity: 2,000 gallons

Auxiliary System Type: Electric

\section{PROJECT DESCRIPTION}

In 41 days this 144 collector, rooftop solar heating system was designed, fabricated, and installed on the Grover Cleveland School in Boston. This was followed by an operation and evaluation period during which the system provided about $50 \%$ of the heating needs for the 21000 sq. ft. area of the school. In the fall of 1974, the system provided all the heat until early December, when it was discovered that the conventional electric resistant heating had been inadvertently left off following summer servicing. Early in 1976, the system was refurbished, the control system simplified, and the ethylene glycol heat transfer fluid replaced with silicone oil. Since then, the system has performed well in a fully automatic mode without maintenance. The city of Boston accepted ownership of the installation in 1977. This project was partially funded by the National Science Foundation and is one of the four early proof-of-concept experiments started in 1974.
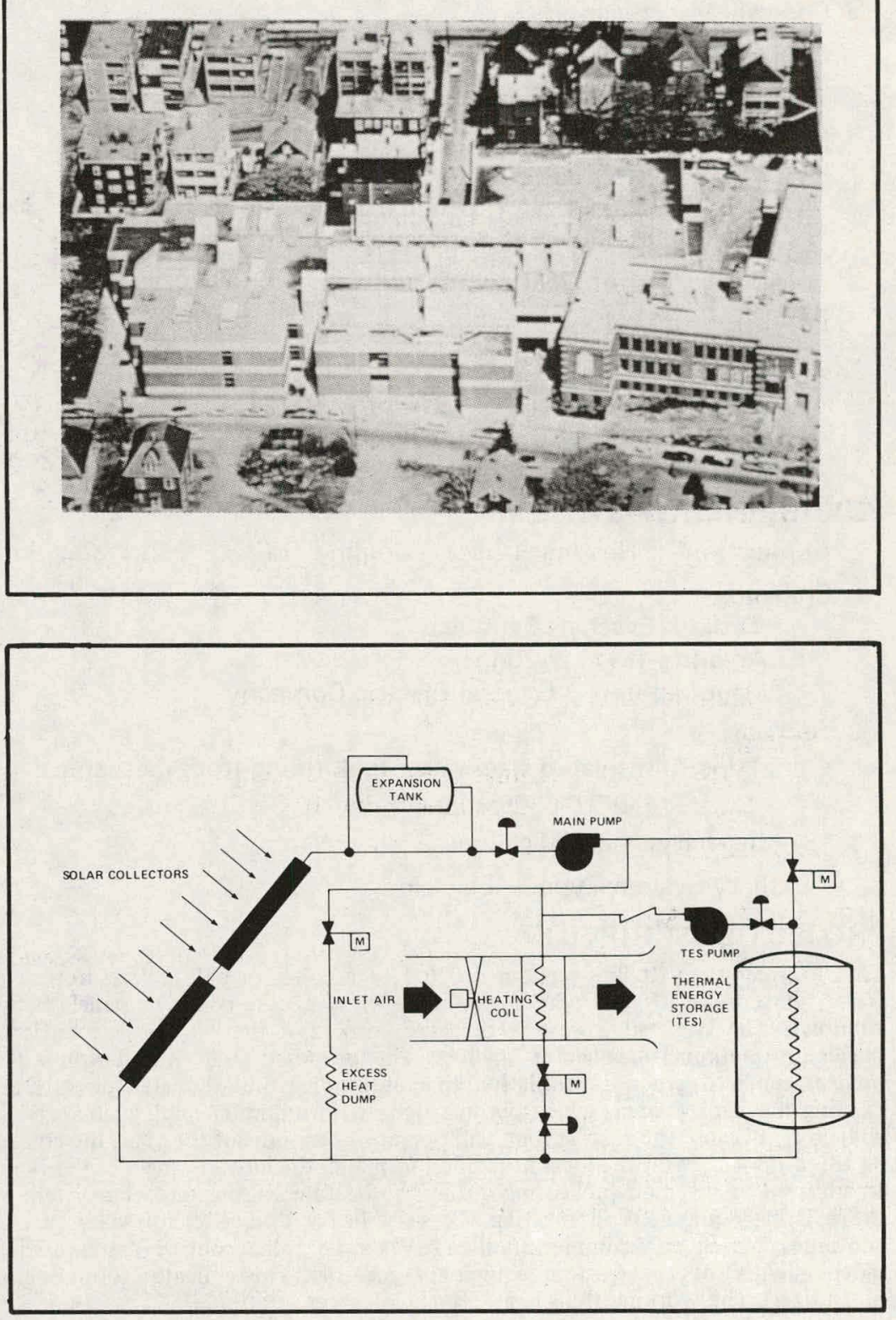


\section{PROJECT INFORMATION}

Owner/Builder: Children's Hospital Medical Center

Contractor: Balco, Inc.

Operational Date: April 1978

Total Estimated DOE Funds: $\quad \$ 148,150$

Building

Type: Hospital

Area: $\quad 180,000$ sq. ft. (total) ; 24,000 sq. ft. (heating); 96,000 sq. ft. (domestic hot water)

Location: Boston, Massachusetts

Latitude: $42^{\circ} \mathrm{N}$

Climatic Data

$\begin{array}{lllll}\text { Degree Days } & \text { Heating } & 5634 & \text { Cooling } & \text { N/A } \\ \text { Avg. Temp. }\left({ }^{\circ} \mathrm{F}\right) & \text { Winter } & 42 & \text { Summer } & 70 \\ \text { Avg. Insol. (Ly/d) } & \text { Winter } & 265 & \text { Summer } & 492\end{array}$

SOLAR ENERGY SYSTEM

Application Heating $12.5 \%$ Cooling $0 \%$ Hot Water $11.9 \%$

Collector

Type: Evacuated tubular

Area (sq. ft.): 2,294

Manufacturer: General Electric Company

Storage

Type: Insulated steel water tank (hung from mechanical room ceiling)

Capacity: 2,000 gallons

Auxiliary System Type: Electric

\section{PROJECT DESCRIPTION}

This fourteen-story building is constructed of a concrete pan and reinforced concrete frame. Exterior walls are poured concrete with precast concrete panels between the windows. The two tall towers at opposite corners of the roof pose a difficult design problem to eliminate collector shading. The proposed solar installation will provide preheat capability to one ventilation/air conditioning unit. Located directly above the existing mechanical area, which permits tie-in with minimum piping runs, are 155 solar collectors. Because the solar system will operate 12 months of the year, the collectors will be tilted up $42^{\circ}$ from the local horizontal to match the latitude angle of the Boston area. In addition to space air preheating during the heating season, the solar system will assist the existing equipment in meeting the very heavy domestic hot water demand that continues during the summer months. A simple solar control system will operate independently of the existing equipment controls. The collector loop is closed and pressurized. The working fluid is a $35 \%$ glycol-water solution.
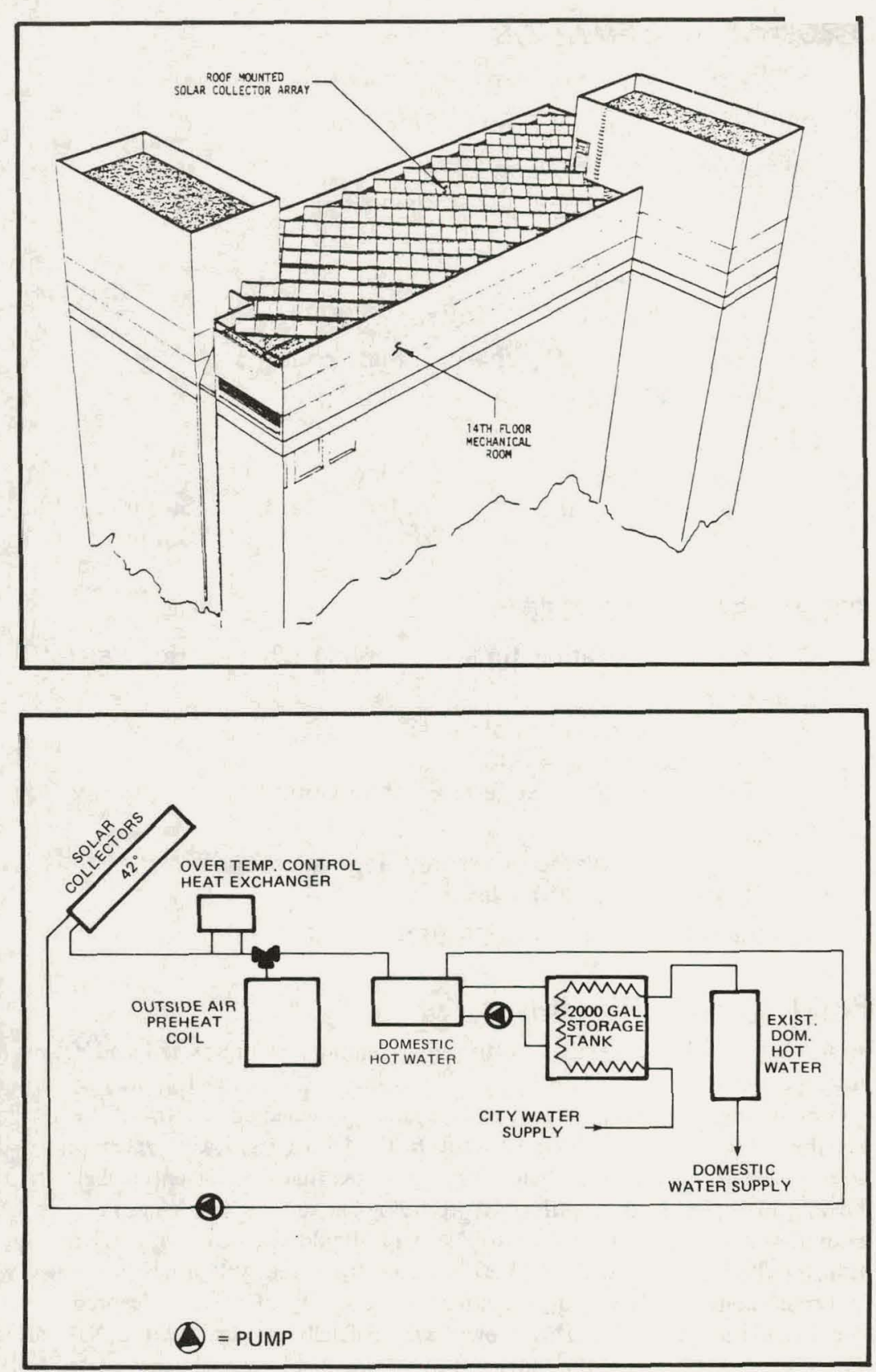


\section{PROJECT INFORMATION}

Owner/Builder: Metropolitan District Commission

Contractor: Massachusetts Design

Operational Date: July 1978

Total Estimated DOE Funds: $\quad \$ 91,489$

Building

Type: Community, conference, teaching and referral center

Area: 5,776 sq. ft.

Location: Boston, Massachusetts

Latitude: $42^{\circ} \mathrm{N}$

Climatic Data

$\begin{array}{lllll}\text { Degree Days } & \text { Heating } & 5621 & \text { Cooling } & \text { N/A } \\ \text { Avg. Temp. }\left({ }^{\circ} \mathrm{F}\right) & \text { Winter } & 30.9 & \text { Summer } & 70.8 \\ \text { Avg. Insol. (Ly/d) } & \text { Winter } & 115 & \text { Summer } & 486\end{array}$

\section{SOLAR ENERGY SYSTEM}

Application Heating $61 \%$ Cooling $0 \%$ Hot Water $51 \%$

Collector

Type: Liquid flat-plate

Area (sq. ft.): 1,200

Manufacturer: Daystar Corporation

Storage

Type: Insulated steel glycerol/water tank (underground)

Capacity: 4,560 gallons

Auxiliary System Type: Oil fired hot air

\section{PROJECT DESCRIPTION}

This project proposes to retrofit the Herter Center, a two-story steel-frame landmark, with a combined space and hot water heating system. The building will be modified to incorporate the solar collectors on the facade. This is a flat-plate, high-efficiency, liquid antifreeze collection system. Domestic hot water is preheated by circulating stored water through a coil immersed in the lower region of an electrical hot water heater. Collection pumping is controlled by a pair of temperature sensors, one on a collector absorber panel and the other in the heat store, both feeding signals to a differential temperature controller which controls the circulator pump.
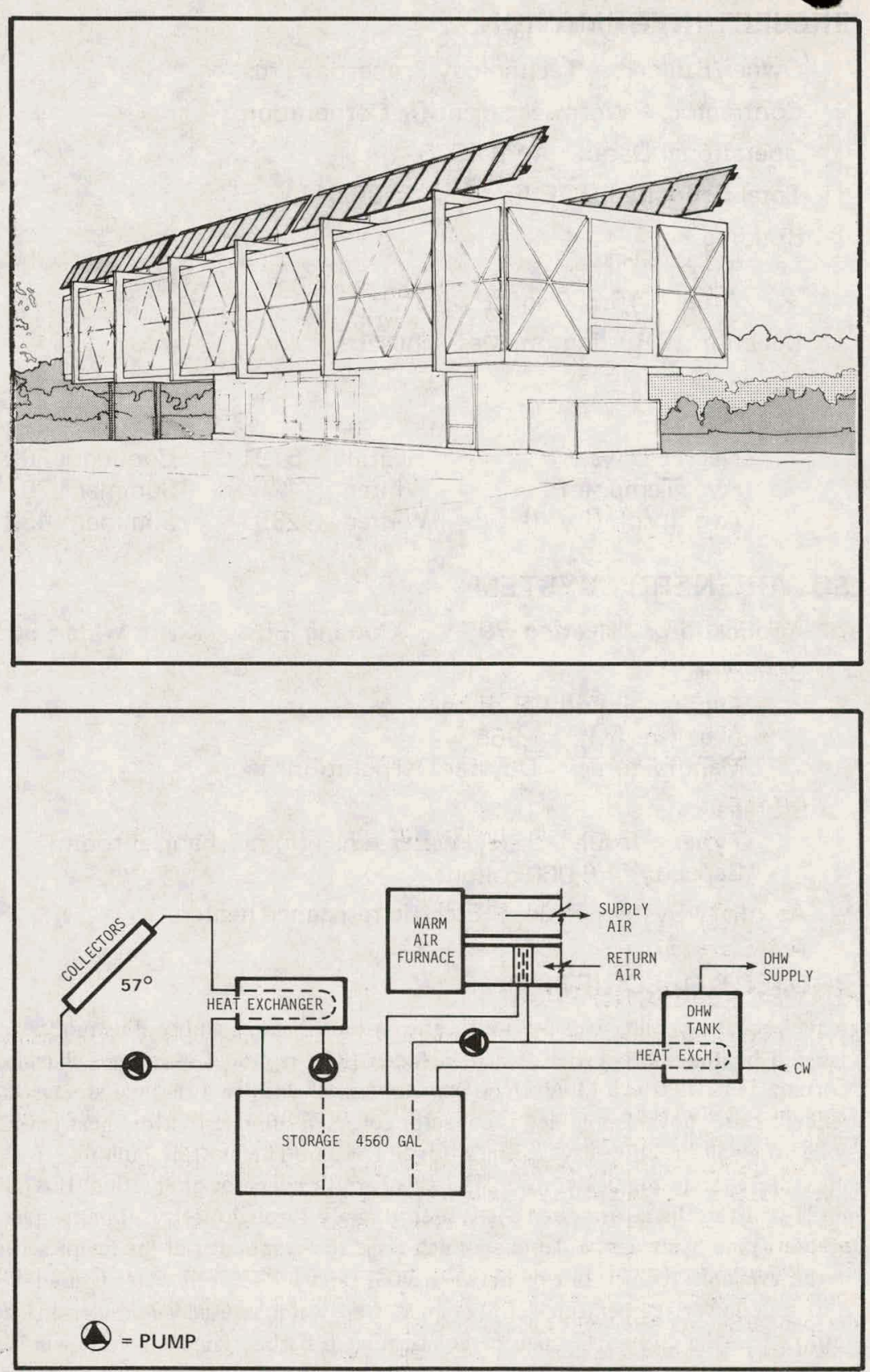


\section{PROJECT INFORMATION}

Owner/Builder: Technology Properties Trust

Contractor: Wormser Scientific Corporation

Operational Date: April 1978

Total Estimated DOE Funds: $\$ \$ 180,411$

Building

Type: Office

Area: 18,300 sq. $\mathrm{ft}$.

Location: Burlington, Massachusetts

Latitude: $42.5^{\circ} \mathrm{N}$

Climatic Data

$\begin{array}{lllll}\text { Degree Days } & \text { Heating } & 5791 & \text { Cooling } & 800 \\ \text { Avg. Temp. }\left({ }^{\circ} \mathrm{F}\right) & \text { Winter } & 42 & \text { Summer } & 70 \\ \text { Avg. Insol. (Ly/d) } & \text { Winter } & 265 & \text { Summer } & 452\end{array}$

\section{SOLAR ENERGY SYSTEM}

\section{Application Heating $79 \%$ Cooling $80 \%$ Hot Water $90 \%$}

\section{Collector}

Type: Liquid flat-plate

Area (sq. ft.): 1,965

Manufacturer: Daystar Corporation

Storage

Type: Insulated steel water tanks (in mechanical room)

Capacity: 6,000 gallons

Auxiliary System Type: Electric resistance heaters

\section{PROJECT DESCRIPTION}

A reciprocating chiller will use well water in both heating and cooling modes and will be assisted by the solar system which includes $1872 \mathrm{sq}$. ft. of reflector enhanced Daystar Corporation collectors tilted at $60^{\circ}$ to horizontal with two thermal storage tanks. The reflectors are movable and act as collector covers in summer to avoid heat rejection. Two collectors will be utilized year-round for hot water. The existing building's location and structural system predicated the $21^{\circ}$ east of south collector orientation. If $87^{\circ} \mathrm{F}$ water is available from the solar system, it is used directly through deep coil units manufactured by the Trane Company. Solar energy will assist the evaporator of the reciprocating chiller if the available temperature is between $70^{\circ} \mathrm{F}$ and $87^{\circ} \mathrm{F}$. Well water is used as the heat source at lower temperatures. In summer, well water is used as condensing water and returned to the ground through percolating catch basins. The well water will have a near constant temperature of $55^{\circ} \mathrm{F}$ and can supply a large part of the cooling load directly.
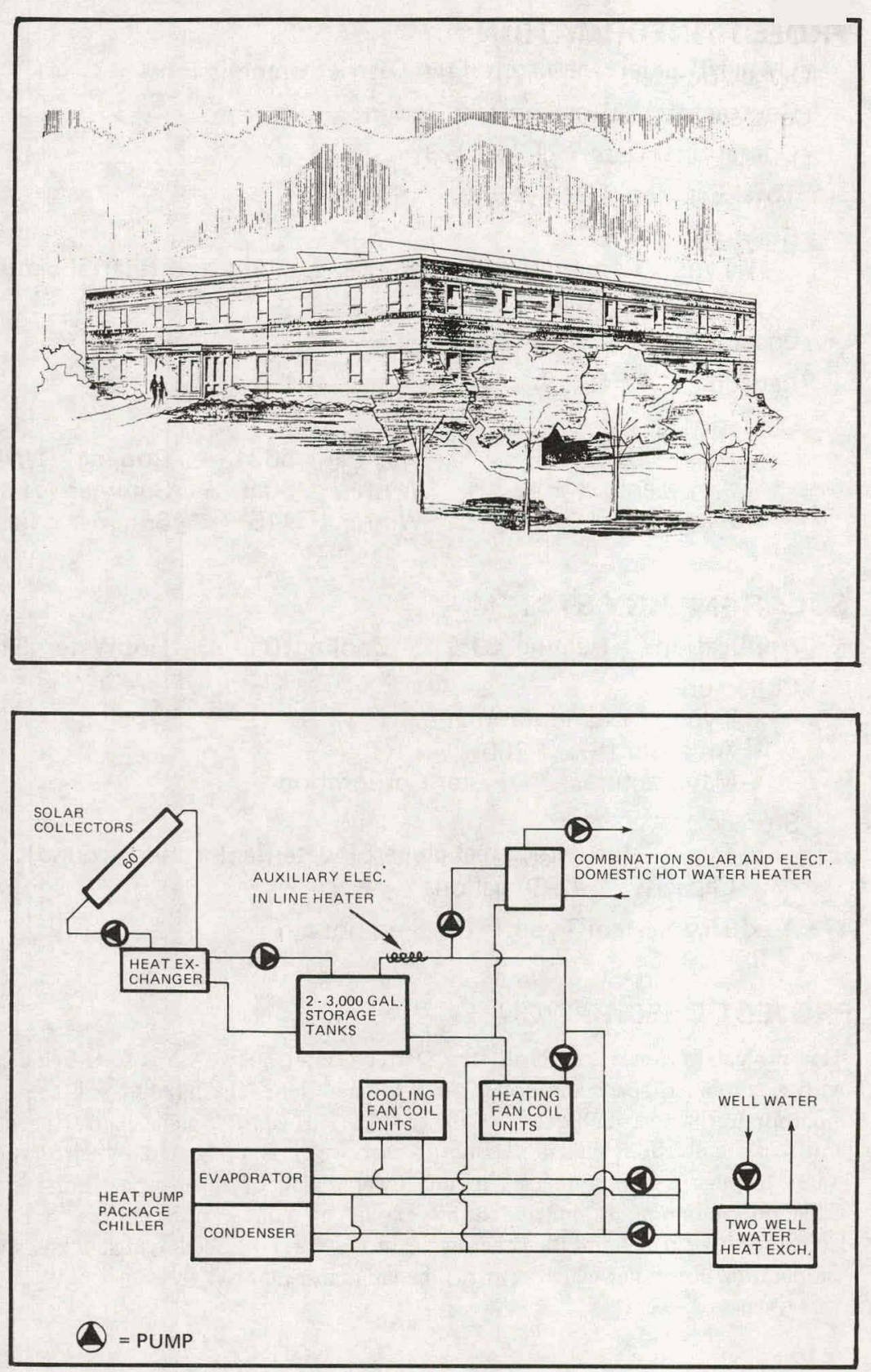


\section{PROJECT INFORMATION}

Owner/Builder: Town of Concord

Contractor: Worcester Air Conditioning Company, Inc.

Operational Date: March 1978

Total Estimated DOE Funds: $\quad \$ 145,000$

Building

Type: Office/warehouse

Area: 9,300 sq. ft.

Location: Concord, Massachusetts

Lat itude: $42.3^{\circ} \mathrm{N}$

Climatic Data

$\begin{array}{lllll}\text { Degree Days } & \text { Heating } & 7517 & \text { Cooling } & 500 \\ \text { Avg. Temp. }\left({ }^{\circ} \mathrm{F}\right) & \text { Winter } & 32 & \text { Summer } & 65 \\ \text { Avg. Insol. (Ly/d) } & \text { Winter } & 250 & \text { Summer } & 475\end{array}$

\section{SOLAR ENERGY SYSTEM}

Application Heating $75 \%$ Cooling $0 \%$ Hot Water $0 \%$

Collector

Type: Air flat-plate

Area (sq. ft.): 1,932

Manufacturer: Sunworks, Inc.

Storage

Type: Rock bed (above ground)

Capacity: $1,210 \mathrm{cu} . \mathrm{ft}$.

Auxiliary System Type: Radiant electric heat

\section{PROJECT DESCRIPTION}

An air space heating system is being retrofitted at the town's municipal light plant building. It will heat $8400 \mathrm{sq}$. ft. of office and warehouse space (volume: 118,695 cu. ft.). The air system was selected to determine the efficiency of air as a medium in a large volume space heating application. The design requirements are to maintain a temperature of $68^{\circ} \mathrm{F}$ in the office area and $50^{\circ} \mathrm{F}$ in the warehouse area. The design philosophy included adding insulation to the existing roof and walls to maximize the efficiency/performance of the solar system. Public visibility will be provided. The system will be instrumented to monitor performance and efficiency and will be transmitting data by the end of January.
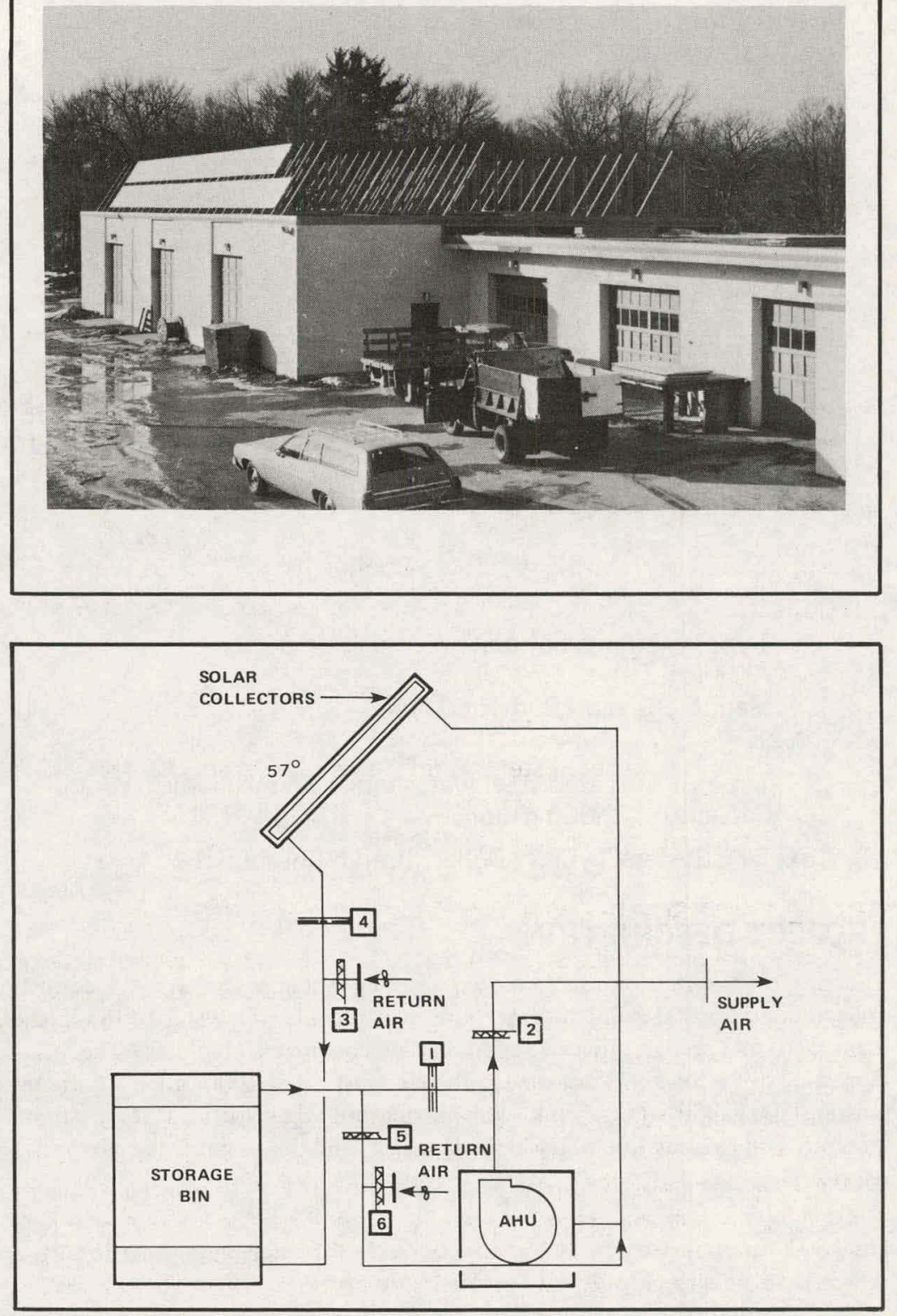


\section{PRUJECT INFORMATION}

Owner/Builder: American Motor Inns, Inc.

Contractor: To be determined

Operational Date: October 1978

Total Estimated DOE Funds: $\quad \$ 32,863$

Building

Type: Low rise motor inn

Area: Not applicable to hot water systems

Location: Lennox, Massachusetts

Latitude: $42^{\circ} \mathrm{N}$

Climatic Data

$\begin{array}{lllll}\text { Degree Days } & \text { Heating } & \text { N/A } & \text { Cooling } & \text { N/A } \\ \text { Avg. Temp. }\left({ }^{\circ} \mathrm{F}\right) & \text { Winter } & 26 & \text { Summer } & 68 \\ \text { Avg. Insol. }(\text { Ly } / \text { d) } & \text { Winter } & 475 & \text { Summer } & 607\end{array}$

\section{SOLAR ENERGY SYSTEM}

Application Heating $0 \%$

Hot Water $59 \%$

Collector

Type: Liquid flat-plate

Area (sq. ft.): 1,533

Manufacturer: Sunworks, Inc.

\section{Storage}

Type: Insulated steel water tanks (in mechanical room)

Capacity: 2,000 gallons

Auxiliary System Type: Boiler, fired by natural gas

\section{PROJECT DESCRIPTION}

The proposed system consists of two distinct systems. One system, consisting of 22 collectors and a 500-gallon storage tank, will provide hot water to the kitchen, dining areas and managerial offices located in the commercial building. The other system, consisting of 51 collectors arranged in three arrays, a new 1000-gallon storage tank and an existing 500-gallon storage tank, will provide hot water to the 120 guest units and the laundry. The existing hot water heaters in each building will provide any back-up energy necessary.
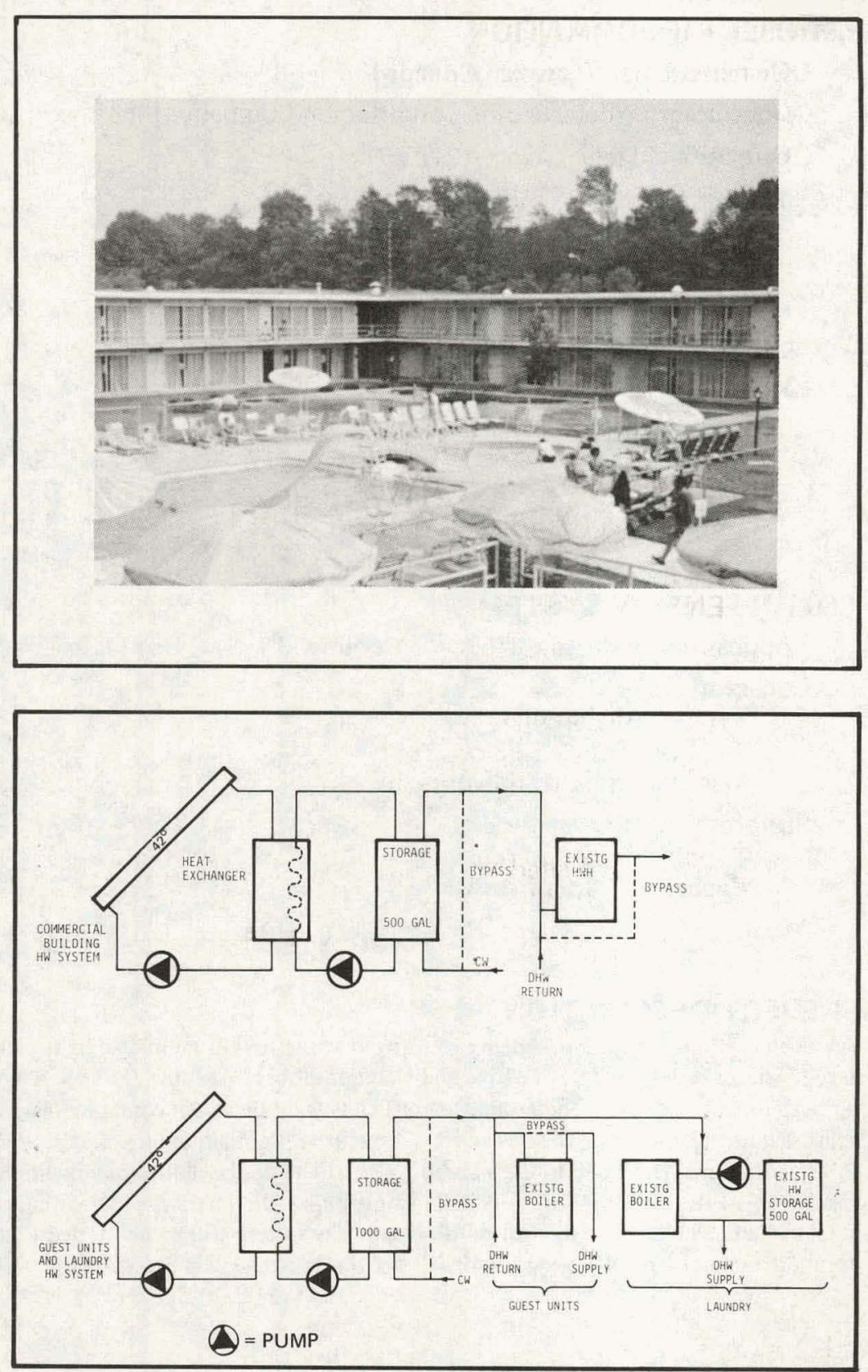


\section{PROJECT INFORMATION}

Owner/Builder: Jordan College

Contractor: Fair, Brother, Gunther and Company

Operational Date: December 1977

Total Estimated DOE Funds: $\$ 98,660$

Building

Type: Residence hall

Area: 6,700 sq. ft. (total); 6,200 sq. ft. (cond.)

Location: Cedar Springs, Michigan

Latitude: $42^{\circ} 7^{\prime} \mathrm{N}$

Climatic Data

Degree Days

Avg. Temp. $\left({ }^{\circ} \mathrm{F}\right)$

Avg. Insol. (Ly/d)

$\begin{array}{llll}\text { Heating } & 6801 & \text { Cooling } & \text { N/A } \\ \text { Winter } & 46.5 & \text { Summer } & 70.4 \\ \text { Winter } & 2354 & \text { Summer } & 1553\end{array}$

\section{SOLAR ENERGY SYSTEM}

Application Heating 52\%

Collector

Type: Liquid flat-plate

Area (sq. ft.): 2,520

Manufacturer: PPG Industries, Inc.

Storage

Type: Insulated steel water tanks (above ground)

Capacity: 5,300 gallons

Auxiliary System Type: Gas boiler and gas water heater

\section{PROJECT DESCRIPTION}

This building, located on a mostly tree-free rolling farm land, is a one-story, slab on grade, frame construction with a flat roof. The building provides dormitory space with 13 student rooms, a guest room, house parents apartment, lounge, bathrooms, laundry and other support facilities. Because the hot water heating system is designed for $180^{\circ} \mathrm{F}$ water, the solar system must provide $180^{\circ} \mathrm{F}$ water in the quickest and most efficient manner. This is accomplished by utilization of a day tank which floats in the system. Heat from the collectors is transported to the day tank and is concentrated to the desired temperature. From the day tank, heat is extracted and utilized for space heating and domestic water heating. If a surplus of heat is available in the day tank, it is transferred to a larger underground storage tank. During periods of no solar insolation, heat energy is transferred from the underground storage tank to the day tank for use as required.
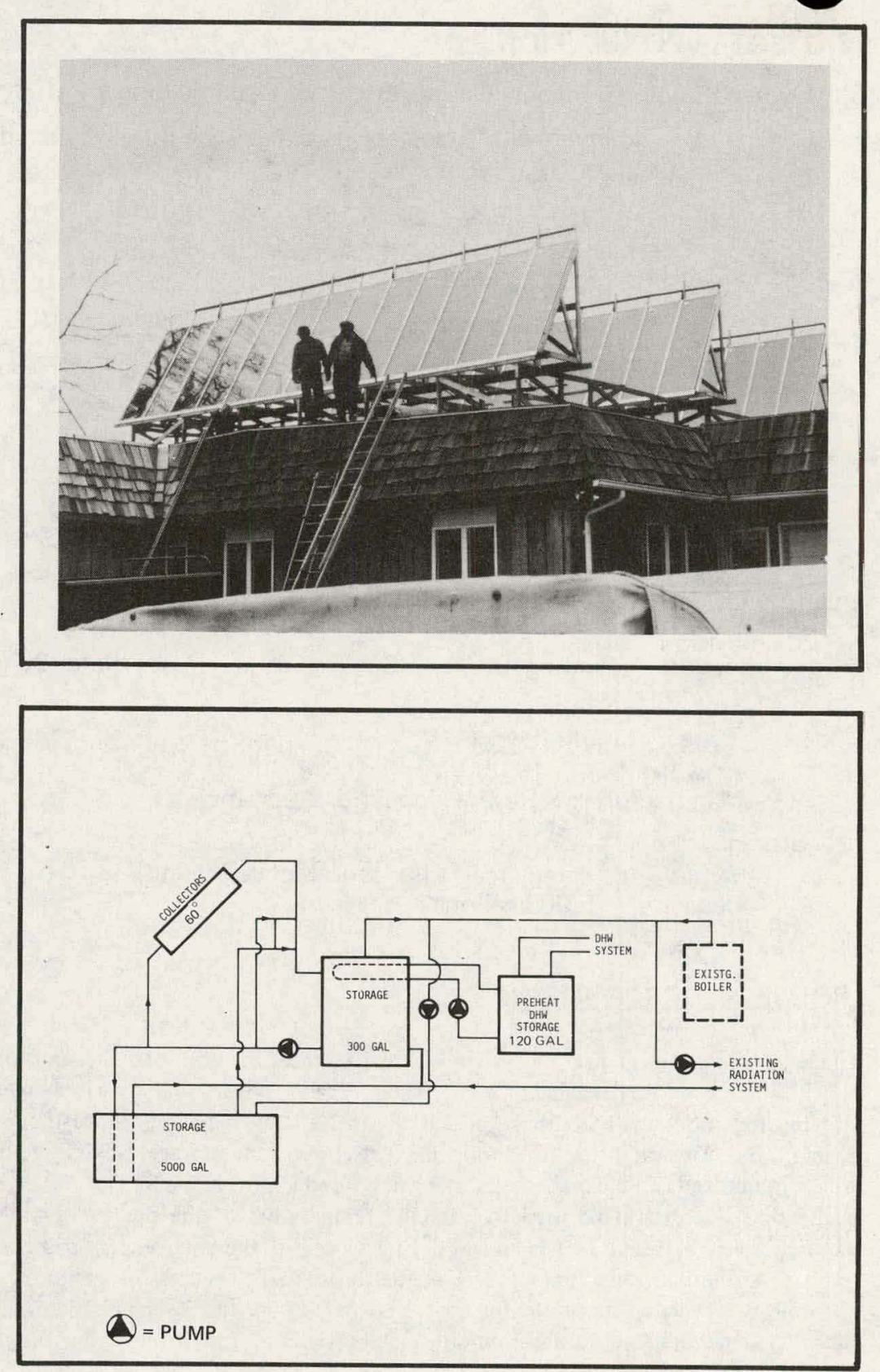


\section{PROJECT INFORMATION}

Owner/Builder: Ingham County Board of Commissioners

Contractor: Manyam and Associates and Michigan State University

Operational Date: May 1978

Total Estimated DOE Funds: $\$ 336,700$

Building

Type: Health center/hospital

Area: To be determined

Location: Okemos, Michigan

Latitude: $42.7^{\circ} \mathrm{N}$

Climatic Data

$\begin{array}{lllll}\text { Degree Days } & \text { Heating } & 6904 & \text { Cooling } & 535 \\ \text { Avg. Temp. ( }{ }^{\circ} \mathrm{F} \text { ) } & \text { Winter } & 40.2 & \text { Summer } & 69.2 \\ \text { Avg. Insol. (Ly/d) } & \text { Winter } & 267 & \text { Summer } & 526\end{array}$

\section{SOLAR ENERGY SYSTEM}

Application Heating $0 \%$

Hot Water $25 \%$

\section{Collector}

Type: Liquid flat-plate

Area (sq. ft.): 10,000

Manufacturer: Revere Copper \& Brass, Inc.

\section{Storage}

Type: Insulated steel water tank (above ground)

Capacity: 5,000 gallons

Auxiliary System Type: Oil

\section{PROJECT DESCRIPTION}

The solar energy water heating system will help to meet the hot water demands of a 204 bed hospital and geriatric facility. The water heating system will be supplemented by systems for solid waste combustion and thermal energy recycling. Since much of the demand for hot water occurs during daylight hours, the storage facility requirement will be minimized and the preheated water will be used almost immediately. A conventional oil heating system will be used to raise the temperature of the preheated water to its required level, between $140^{\circ} \mathrm{F}$ and $180^{\circ} \mathrm{F}$. The use of the solar energy system should result in an annual reduction of $25 \%$ in fuel oil cost. The successful operation of such a system is especially important for relatively energy poor states such as Michigan, which currently depend almost entirely on out-of-state sources for their fuel and energy supply.
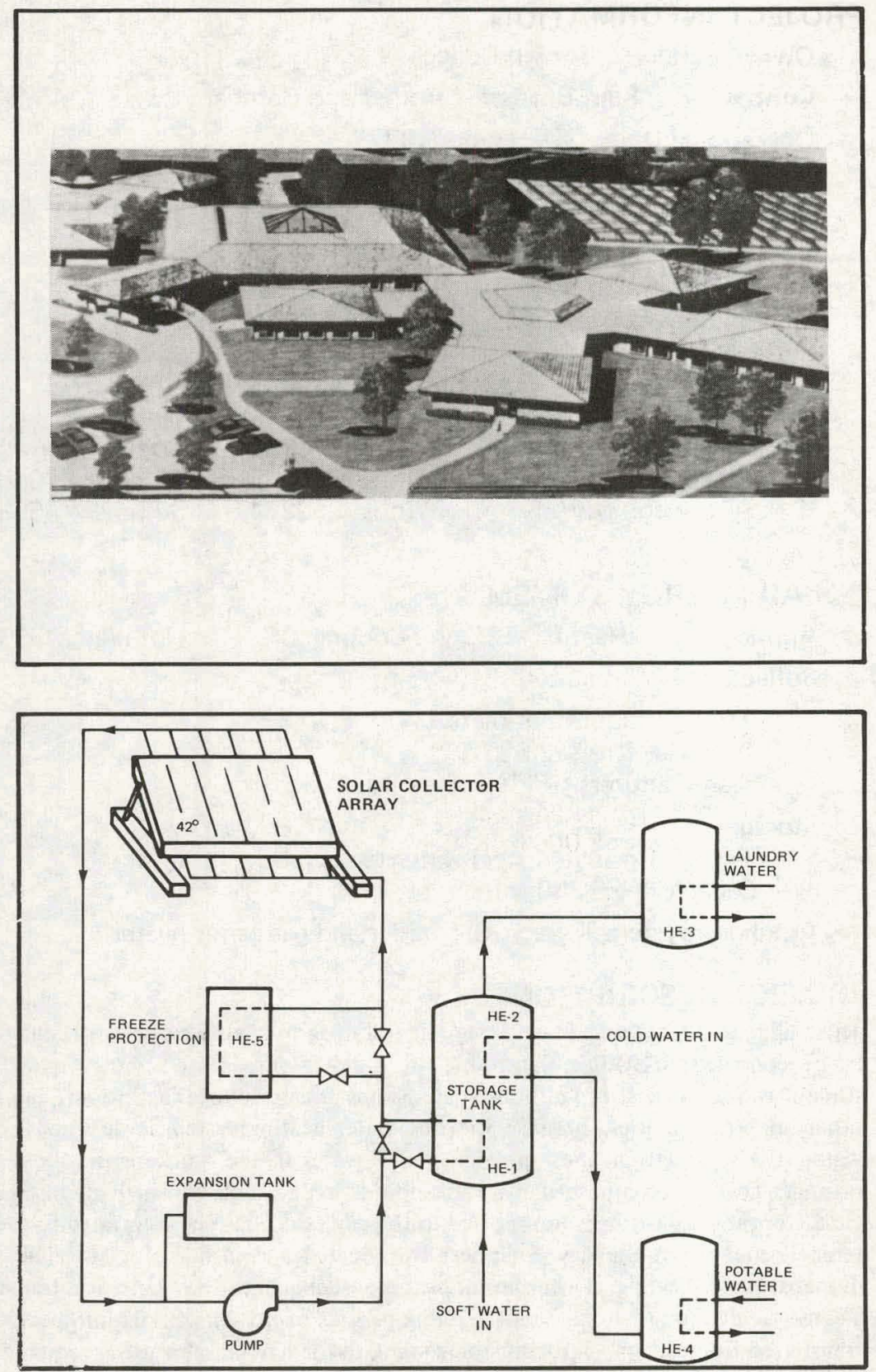


\section{PROJECT INFORMATION}

Owner/Builder: Petoskey Motel/Leonard Sieraoski, Sr.

Contractor: Sunrise Energy Products, Inc.

Operational Date: October 1978

Total Estimated DOE Funds: $\quad \$ 69,931$

Building

Type: Low rise motel

Area: Not applicable to hot water systems

Location: Petoskey, Michigan

Latitude: $45.37^{\circ} \mathrm{N}$

Climatic Data

$\begin{array}{lllll}\text { Degree Days } & \text { Heating } & 8162 & \text { Cooling } & \text { N/A } \\ \text { Avg. Temp. }\left({ }^{\circ} \mathrm{F}\right) & \text { Winter } & 21.7 & \text { Summer } & 63.3 \\ \text { Avg. Insol. (Ly/d) } & \text { Winter } & 210 & \text { Summer } & 485\end{array}$

\section{SOLAR ENERGY SYSTEM}

Application Heating $0 \%$

Collector

Type: Liquid flat-plate

Area (sq. ft.): 3,048

Manufacturer: Southwest Ener-Tech, Inc.

Storage:

Type: Insulated steel water tank (underground)

Capacity: 3,000 gallons

Auxiliary System Type: Natural gas

\section{PROJECT DESCRIPTION}

This is a unique solar energy system designed especially as a model for northern latitude sites. An essential design criteria was to develop a system to provide greater than $75 \%$ of the post-addition motel domestic hot water needs. The system includes a hot laundry waste water heat exchanger for reclaiming up to $20 \%$ of the energy contained in the motel laundry waste water discharge. Thus normally lost energy will serve to pre-heat the incoming cold water from $40^{\circ} \mathrm{F}$ to $80^{\circ} \mathrm{F}$. The 3048 sq. ft. solar collector array will be intergrated with a collector support structure to form the roof and enclosure for the existing motel swimming pool. The insulation necessary for the solar collector will also provide the insulation required for the cathedral ceiling over the pool area. A 3000-gallon stainless steel storage tank will be used for hot water storage and a 300-gallon stainless steel tank will provide thermal expansion and drain-down volume for freeze protection. A by-pass loop will allow the 40000-gallon pool volume to be circulated through a spare heat exchanger in the 300-gallon tank to provide over temperature protection.
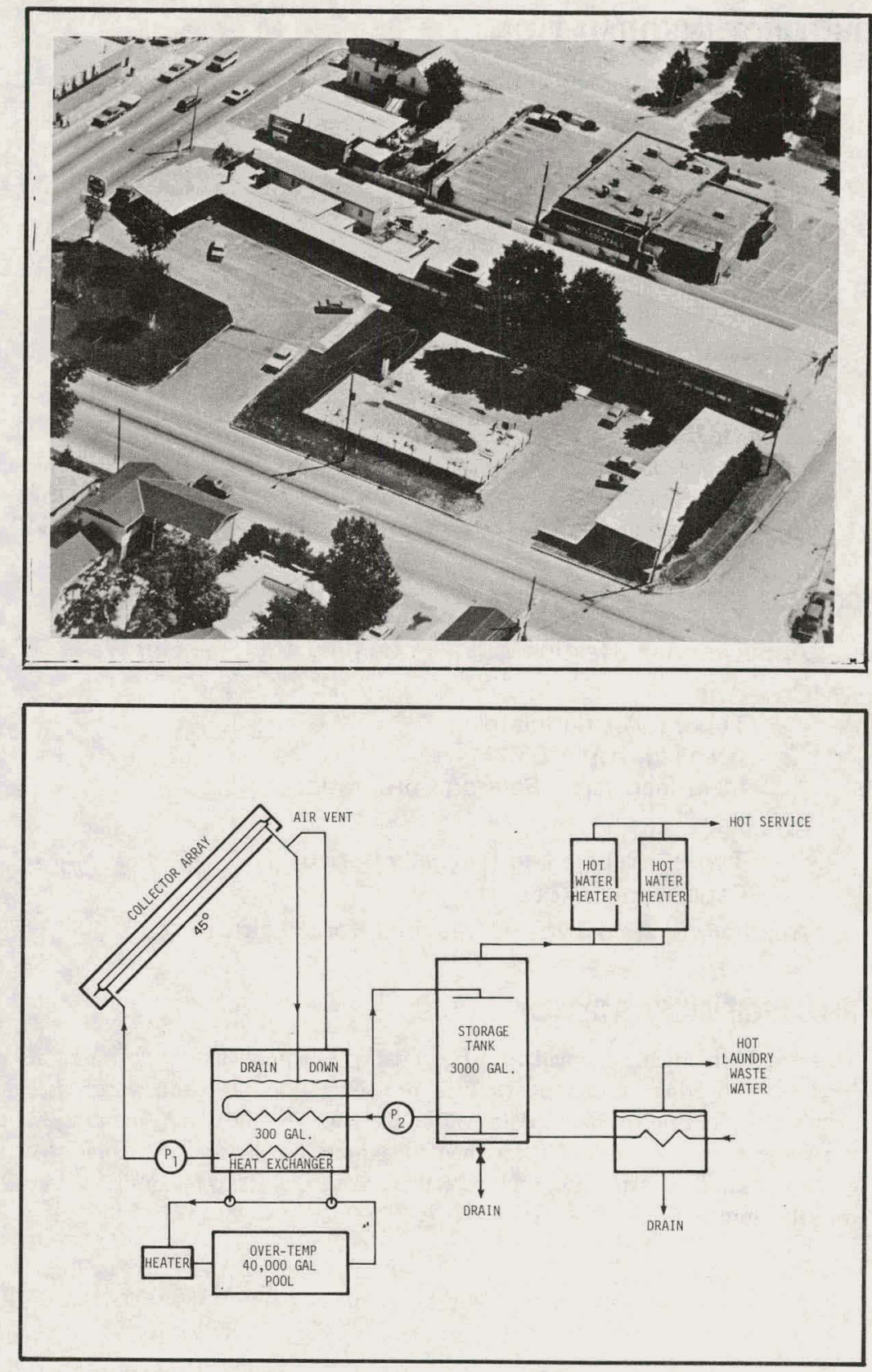


\section{PROJECT INFORMATION}

Owner/Builder: John O. Esslinger, M.D./Valentine Esslinger, M.D.

Contractor: G.M. Design, Inc.

Operational Date: January 1978

Total Estimated DOE Funds: $\quad \$ 25,280$

Building

Type: Medical offices

Area: 2,468 sq. $\mathrm{ft}$.

Location: Traverse City, Michigan

Latitude: $46.5^{\circ} \mathrm{N}$

Climatic Data

$\begin{array}{lllll}\text { Degree Days } & \text { Heating } & 9048 & \text { Cooling } & \text { N/A } \\ \text { Avg. Temp. }\left({ }^{\circ} \mathrm{F}\right) & \text { Winter } & 17 & \text { Summer } & 61 \\ \text { Avg. Insol. (Ly/d) } & \text { Winter } & 152.87 & \text { Summer } & 540.33\end{array}$

\section{SOLAR ENERGY SYSTEM}

Application Heating 22\% Cooling $0 \%$ Hot Water $67 \%$

Collector

Type: Air flat-plate

Area (sq. ft.): 663

Manufacturer: Solaron Corporation

Storage

Type: Pebble bed (partially buried)

Capacity: $342 \mathrm{cu} . \mathrm{ft}$.

Auxiliary System Type: Gas fired, forced air furnace

\section{PROJECT DESCRIPTION}

This northern Michigan medical office facility is equipped to solar assist its gas fired forced air heating system as well as providing domestic hot water preheat. Cost, installation, and performance data will be used for technical and financial evaluation of the project. The structure is designed to express the nature of a solar structure, and employ insulative, structural, and reflective characteristics to maximize energy efficiency for solar application.
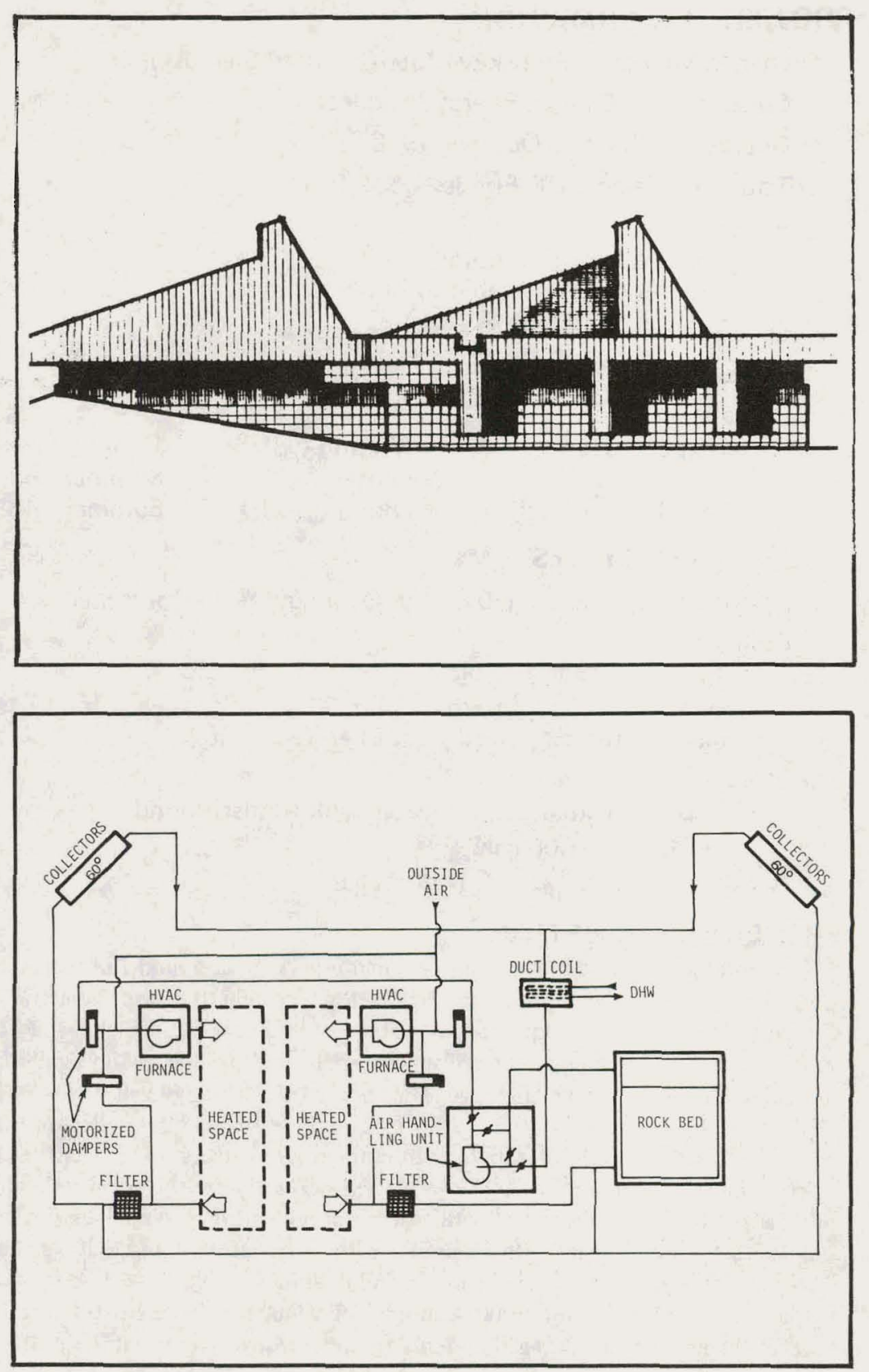


\section{PROJECT INFORMATION}

Owner/Builder: Troy School District

Contractor: TMP Associates

Operational Date: September 1978

Total Estimated DOE Funds: $\mathbf{\$ 2 0 6 , 7 7 0}$

Building

Type: Elementary school

Area: 50,000 sq. ft. (total); 56,000 sq. ft. (cond.)

Location: Troy, Michigan

Latitude: $42^{\circ} \mathrm{N}$

Climatic Data

Degree Days

Avg. Temp. $\left({ }^{\circ} \mathrm{F}\right)$

Avg. Insol. (Ly/d)

$\begin{array}{llll}\text { Heating } & 6232 & \text { Cooling } & 731 \\ \text { Winter } & 35 & \text { Summer } & 72 \\ \text { Winter } & 187 & \text { Summer } & 518\end{array}$

\section{SOLAR ENERGY SYSTEM}

Application Heating 40\%

Cooling $0 \%$

Hot Water $33 \%$

Collector

Type: Liquid flat-plate

Area (sq. ft.): $\quad 5,000$

Manufacturer: Libbey-Owens-Ford Company

\section{Storage}

Type: Concrete water tank (underground)

Capacity: 40,000 gallons

Auxiliary System Type: Electric boiler

\section{PROJECT DESCRIPTION}

Three identical highly energy efficient schools will be built, one with solar and the other two with the option for future solar systems. Heating is provided by water-to-air heat pumps. Heat is added to the condenser loop from the storage tank, solar collectors, heat recovered from lights and people in interior zones, or by the back-up electric boiler. Each heat pump is provided with outdoor air and return air dampers and is capable of utilizing $100 \%$ outdoor air for cooling when conditions permit. Domestic hot water is preheated by a thermosyphon coil in the water storage tank. Solar collection and storage is provided by flat-plate, single-glazed collectors at $45^{\circ}$ tilt, a glycol solar loop to a shell and tube water-to-water converter, storage tank and necessary pumps and piping. For additional energy conservation, the building's HVAC system will be connected to the school system's city-wide central environmental control system to control outdoor air damper positions and day/night programming.
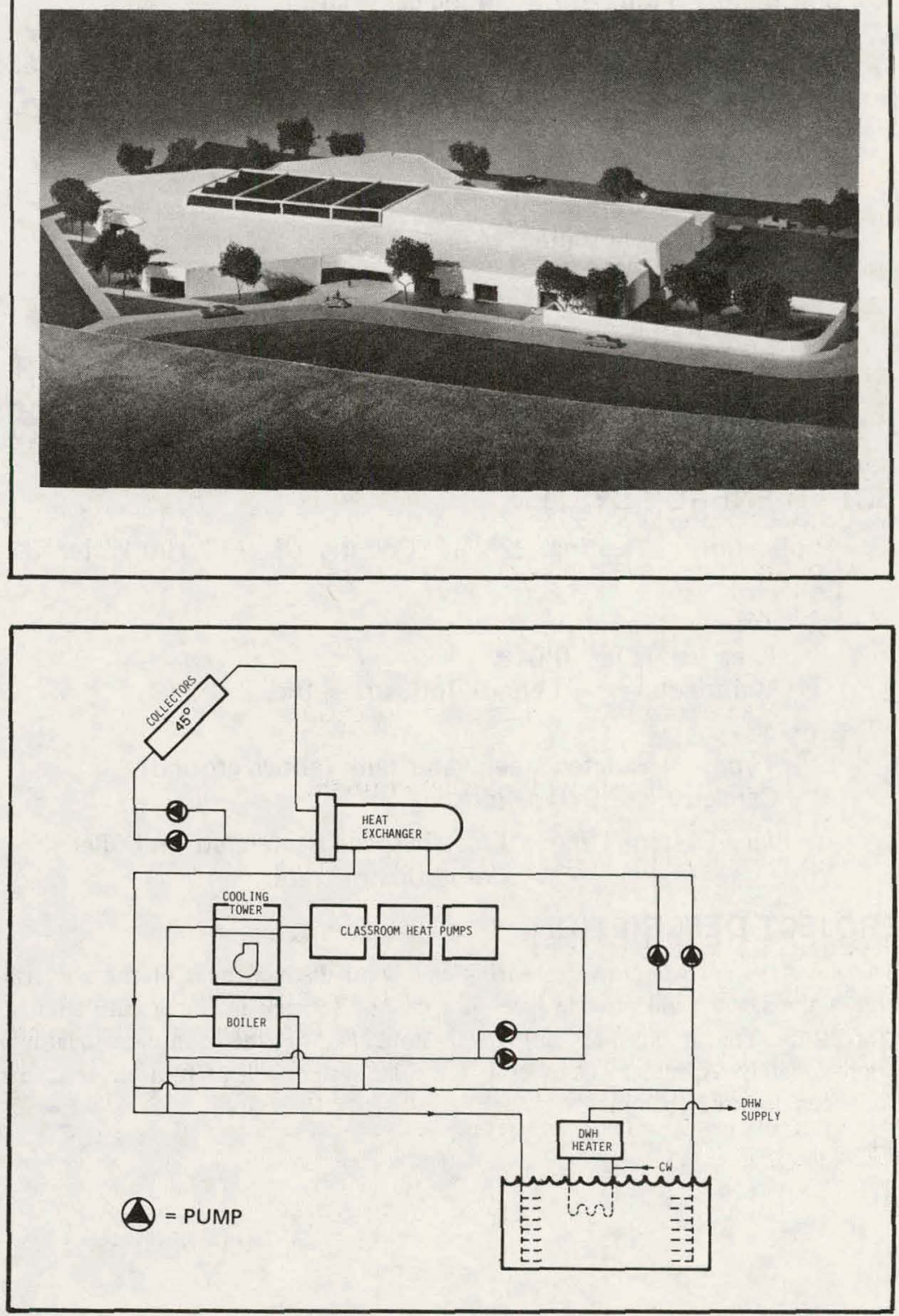


\section{PROJECT INFORMATION}

Owner/Builder: Minnesota Zoological Board

Contractor: Minnesota Zoological Board

Operational Date: August 1978

Total Estimated DOE Funds: $\$ 313,458$

Building

Type: Zoo ride station

Area: 14,160 sq. ft.

Location: Apple Valley, Minnesota

Latitude: $44.08^{\circ} \mathrm{N}$

Climatic Data

Degree Days

Avg. Temp. $\left({ }^{\circ} \mathrm{F}\right)$

Avg. Insol. (Ly/d)

$\begin{array}{llll}\text { Heating } & 8382 & \text { Cooling } & \text { N/A } \\ \text { Winter } & 28.3 & \text { Summer } & 70.3 \\ \text { Winter } & 213.2 & \text { Summer } & 526\end{array}$

\section{SOLAR ENERGY SYSTEM}

Application Heating 22.2\%

Cooling $0 \%$

Hot Water $32.7 \%$

Collector

Type: Liquid flat-plate

Area (sq. ft.): $\quad 9,018$

Manufacturer: Lennox Industries, Inc. Storage

Type: Insulated steel water tank (above ground)

Capacity: 9,240 gallons

Auxiliary System Type: Electric space heaters/steam boiler for domestic hot water

\section{PROJECT DESCRIPTION}

The solar system will provide heating energy to distinct areas of the zoo. During the winter the system will provide space heating and temper incoming ventilation air for the Zoo Ride Transit Station and Rest Stop. During the nonspace heating months, approximately April 1 to October 1, the solar system will preheat incoming main water for the main building complex.
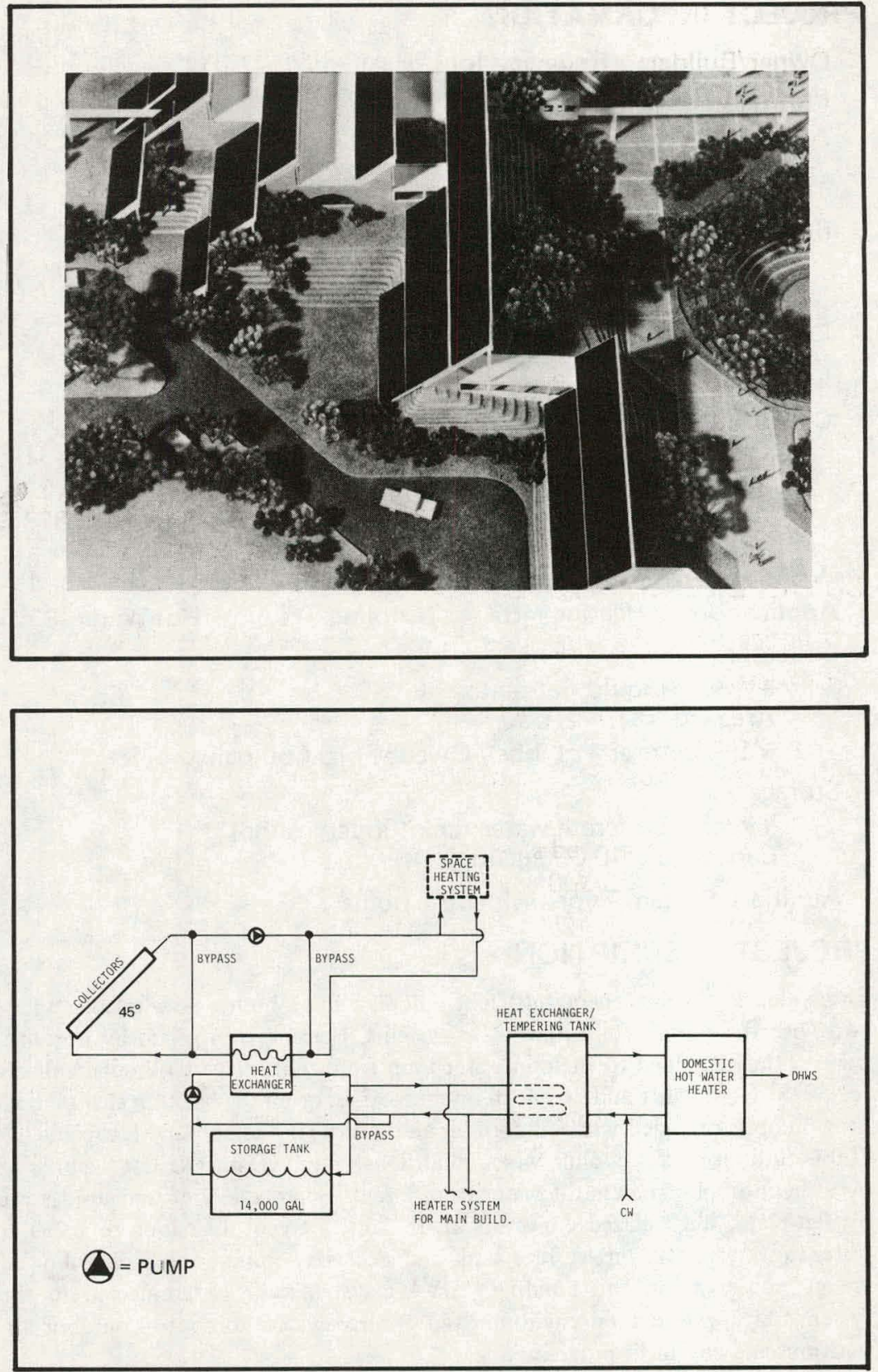


\section{PROJECT INFORMATION}

Owner/Builder: Rodeway Inns of America \& R. V. Development Company Contractor: Charter Builders, Inc.

Operational Date: July 1978

Total Estimated DOE Funds: $\quad \$ 94,492$

Building

Type: High rise hotel

Area: Not applicable to hot water systems

Location: Bloomington, Minnesota

Latitude: $45^{\circ} \mathrm{N}$

Climatic Data

$\begin{array}{lllll}\text { Degree Days } & \text { Heating } & 8382 & \text { Cooling } 800 \\ \text { Avg. Temp. }\left({ }^{\circ} \mathrm{F}\right) & \text { Winter } & 16 & \text { Summer } & 71 \\ \text { Avg. Insol. (Ly/d) } & \text { Winter } & 212 & \text { Summer } & 357\end{array}$

\section{SOLAR ENERGY SYSTEM}

Application Heating $0 \%$

Collector

Type: Liquid flat-plate

Area (sq. ft.): 4,000

Manufacturer: Lennox Industries, Inc.

Storage

Type: Insulated steel water tank

Capacity: 5,000 gallons

Auxiliary System Type: Electric boiler

\section{PROJECT DESCRIPTION}

The collectors for this system will be located on the roof of the motel. The energy collected by the collectors will be transferred to a double bundle heat exchanger via a collector loop circulating pump. Through the heat exchanger, the absorbed energy will be transferred to the storage tank via the storage loop circulating pump. Utilization of the double bundle heat exchanger eliminates the danger of ethylene glycol leakage from the solar loop to the storage tank. Energy from the storage tank is utilized for the motel potable water and laundry.
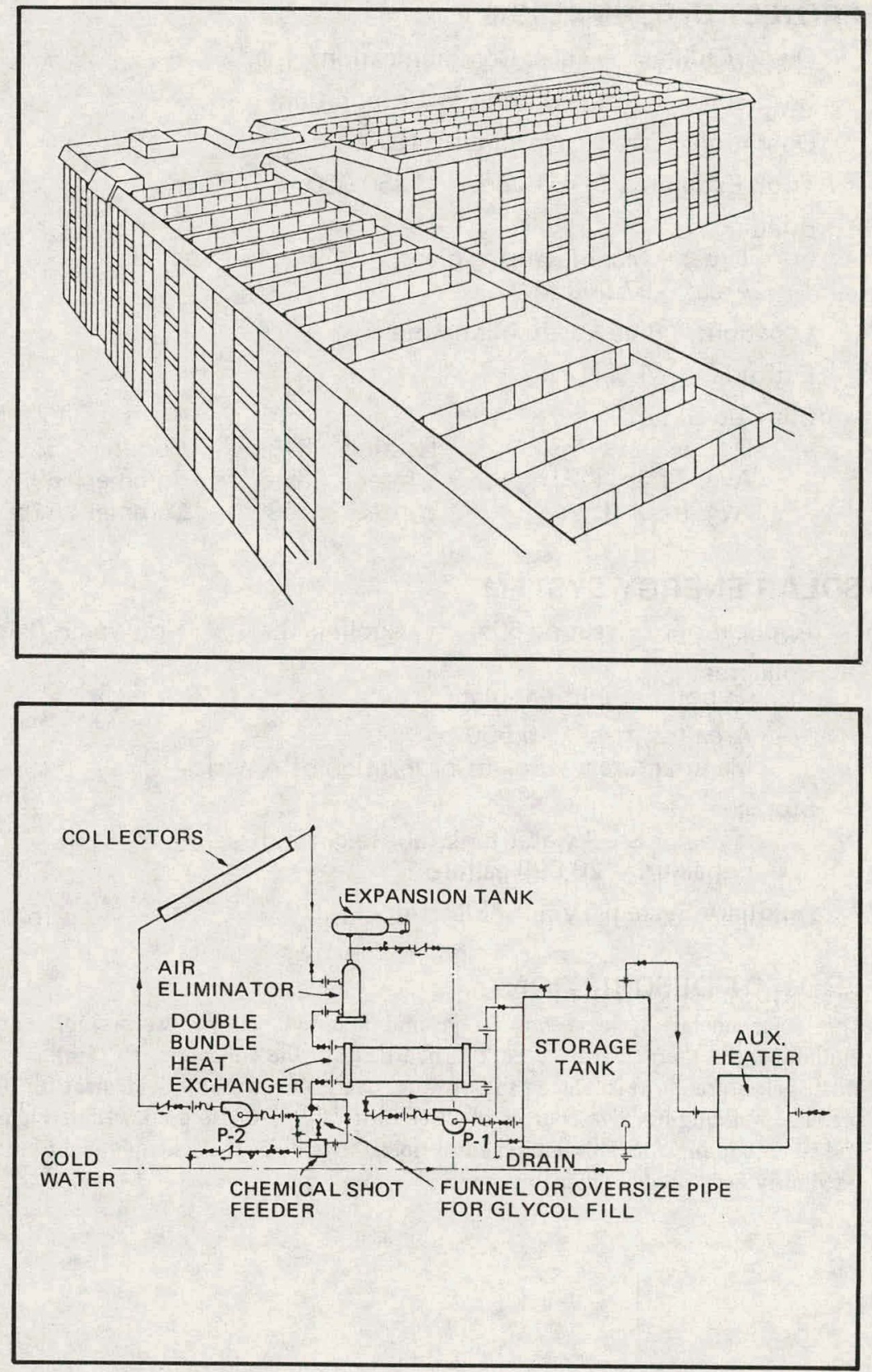


\section{PROJECT INFORMATION}

Owner/Builder: Telex Communications, Inc.

Contractor: InterTechnology Corporation

Operational Date: November 1977

Total Estimated DOE Funds: $\quad \$ 350,000$

Building

Type: Manufacturing plant

Area: 97,000 sq. ft.

Location: Blue Earth, Minnesota

Latitude: $44.9^{\circ} \mathrm{N}$

Climatic Data

$\begin{array}{lllll}\text { Degree Days } & \text { Heating } & 8154 & \text { Cooling } & 585 \\ \text { Avg. Temp. }\left({ }^{\circ} \mathrm{F}\right) & \text { Winter } & 35.6 & \text { Summer } & 69.7 \\ \text { Avg. Insol (Ly/d) } & \text { Winter } & 269 & \text { Summer } & 516\end{array}$

\section{SOLAR ENERGY SYSTEM}

Application Heating $60 \%$

Collector

Type: Liquid flat-plate

Area (sq. ft.): $\quad 10,550$

Manufacturer: Solar Corporation of America

Storage

Type: Steel water tank (above ground)

Capacity: 20,000 gallons

Auxiliary System Type: Electric

\section{PROJECT DESCRIPTION}

This solar energy system employs ground mounted solar collectors adjacent to the building and a thermal storage tank buried beneath the collectors. The tank is below the frost line. Stored heat is relayed to hot water heating coils that provide heat for the building. The building has two sources of "free heat" that are also used, a soldering machine, and an air compressor. This equipment is operated daily in the assembly plant but had not previously been used as an energy source.
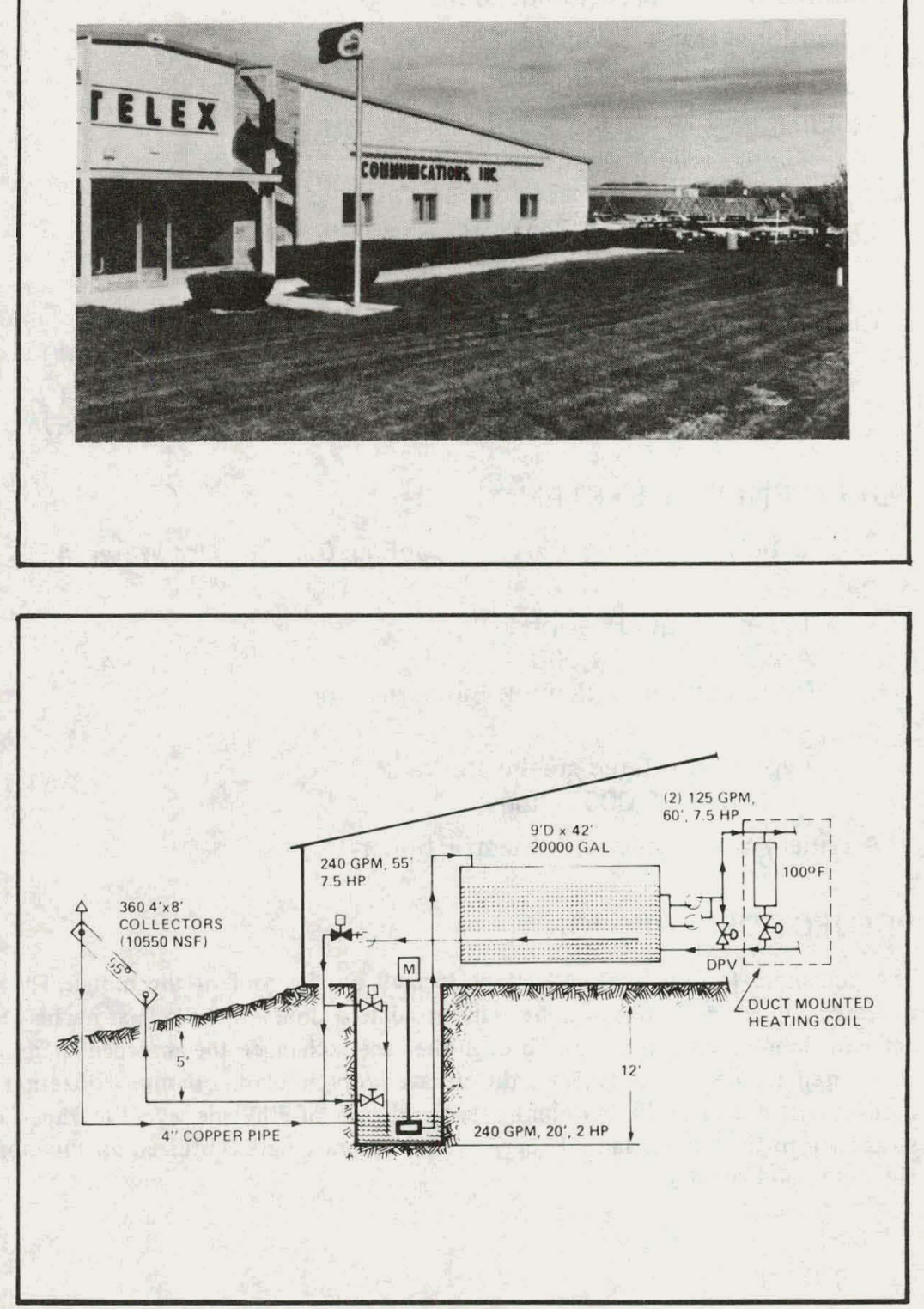


\section{PROJECT INFORMATION}

Owner/Builder: Osseo School District

Contractor: Honeywell, Inc.

Operational Date: April 1974

Total Estimated DOE Funds: $\quad \$ 509,633$

Building

Type: Junior high school

Area: $\quad 165,583$ sq. ft. (total); one room (cond.)

Location: Brooklyn Center, Minnesota

Latitude: $45.1^{\circ} \mathrm{N}$

Climatic Data

$\begin{array}{lllll}\text { Degree Days } & \text { Heating } & 8159 & \text { Cooling } & 585 \\ \text { Avg. Temp. }\left({ }^{\circ} \mathrm{F}\right) & \text { Winter } & 35.6 & \text { Summer } & 69.7 \\ \text { Avg. Insol. (Ly/d) } & \text { Winter } & 269 & \text { Summer } & 516\end{array}$

\section{SOLAR ENERGY SYSTEM}

Application Heating $54 \%$

Hot Water $21 \%$

Collector

Type: Liquid flat-plate

Area (sq. ft.): $\quad 5,000$

Manufacturer: Honeywell, Inc.

Storage

Type: Insulated steel water tank (above ground)

Capacity: 3,000 gallons

Auxiliary System Type: Gas fired boiler

\section{PROJECT DESCRIPTION}

This project provides for the design, installation, and testing of a solar energy system for the North View Junior High School. The system meets a part of the space and hot water heating requirements of the school's indoor swimming pool. During the first year of system operation, the performance of the system was evaluated, and a heat exchanger was installed in the swimming pool's recirculation system. The Tedlar film on one-sixth of the collectors was replaced with a second antireflective cover glass, and collector performance has been reevaluated. Besides reducing energy consumption, this system should provide useful data on solar collection and system performance. The data can be used in designing similar systems for other schools and in future research and development work. This project was partially funded by the National Science Foundation and is one of the early proof-of-concept experiments started in 1974.
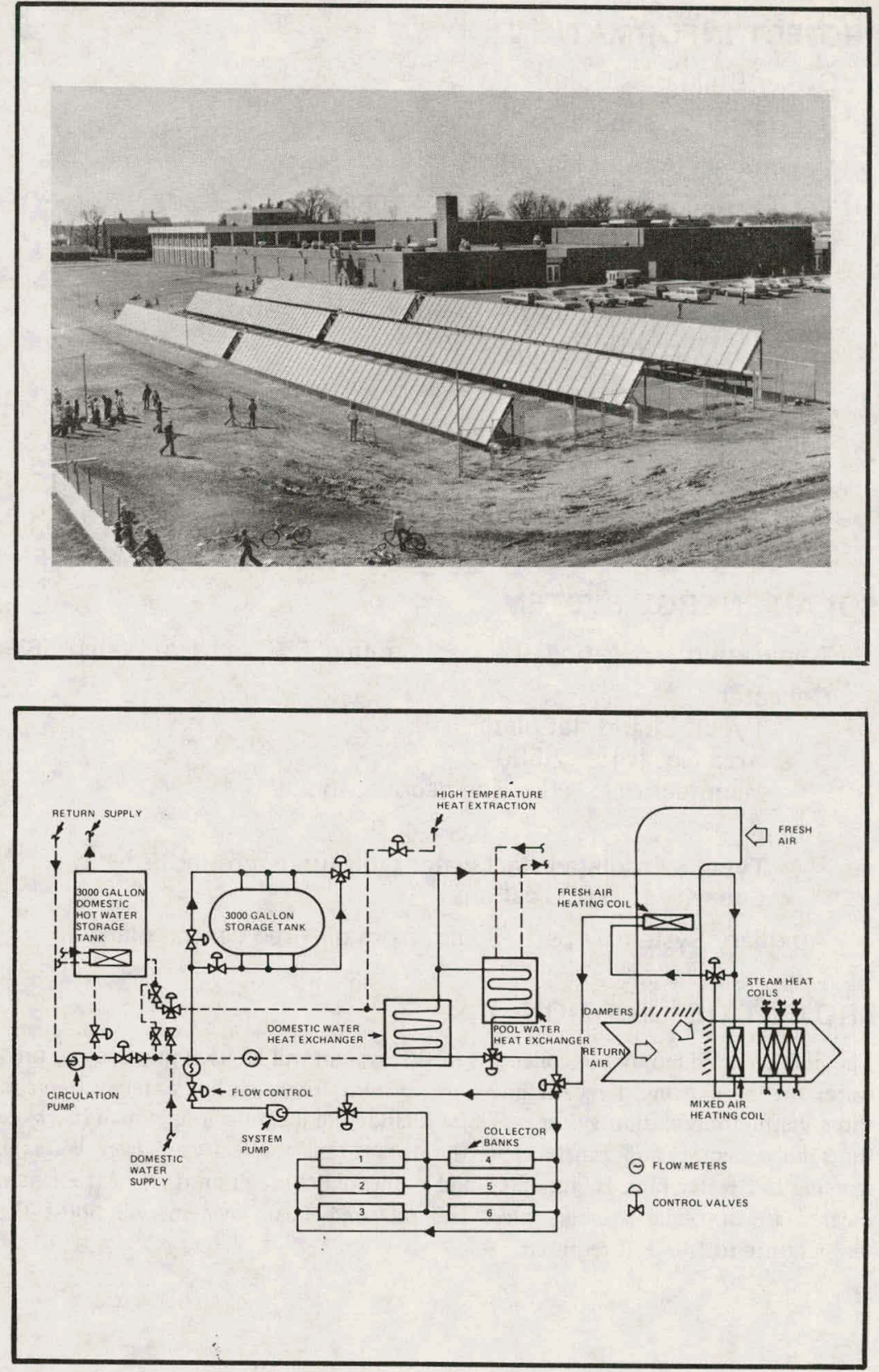


\section{PROJECT INFORMATION}

Owner/Builder: Duluth YWCA

Contractor: Bob Bean

Operational Date: May 1978

Total Estimated DOE Funds: $\quad \$ 47,565$

\section{Building}

Type: High rise hotel

Area: Not applicable to hot water systems

Location: Duluth, Minnesota

Latitude: $46^{\circ} 5^{\prime} \mathrm{N}$

Climatic Data

$\begin{array}{lllll}\text { Degree Days } & \text { Heating } & 10000 & \text { Cooling } & 225 \\ \text { Avg. Temp. }\left({ }^{\circ} \mathrm{F}\right) & \text { Winter } & 26 & \text { Summer } & 68 \\ \text { Avg. Insol. (Ly/d) } & \text { Winter } & 212 & \text { Summer } & 493\end{array}$

\section{SOLAR ENERGY SYSTEM}

Application Heating $0 \%$

\section{Collector}

\section{Cooling $0 \% \quad$ Hot Water $56 \%$}

Type: Liquid flat-plate

Area (sq. ft.): 2,500

Manufacturer: IIse Engineering, Inc.

Storage

Type: Insulated steel water tank (underground)

Capacity: 5,000 gallons

Auxiliary System Type: Steam from oil fired central plant

\section{PROJECT DESCRIPTION}

The energy provided by the collectors of this system will be used primarily to preheat the water for the existing domestic hot water system. The solar hot water system consists of three distinct circulation systems. These include a collection loop which takes heat from the solar collectors and transfers it to the storage tank via heat exchanger. Water from the existing hot water tank is circulated and preheated through another heat exchanger coil located in the solar storage tank. The oil fired steam system will boost the water temperature to $140^{\circ} \mathrm{F}$ if required.

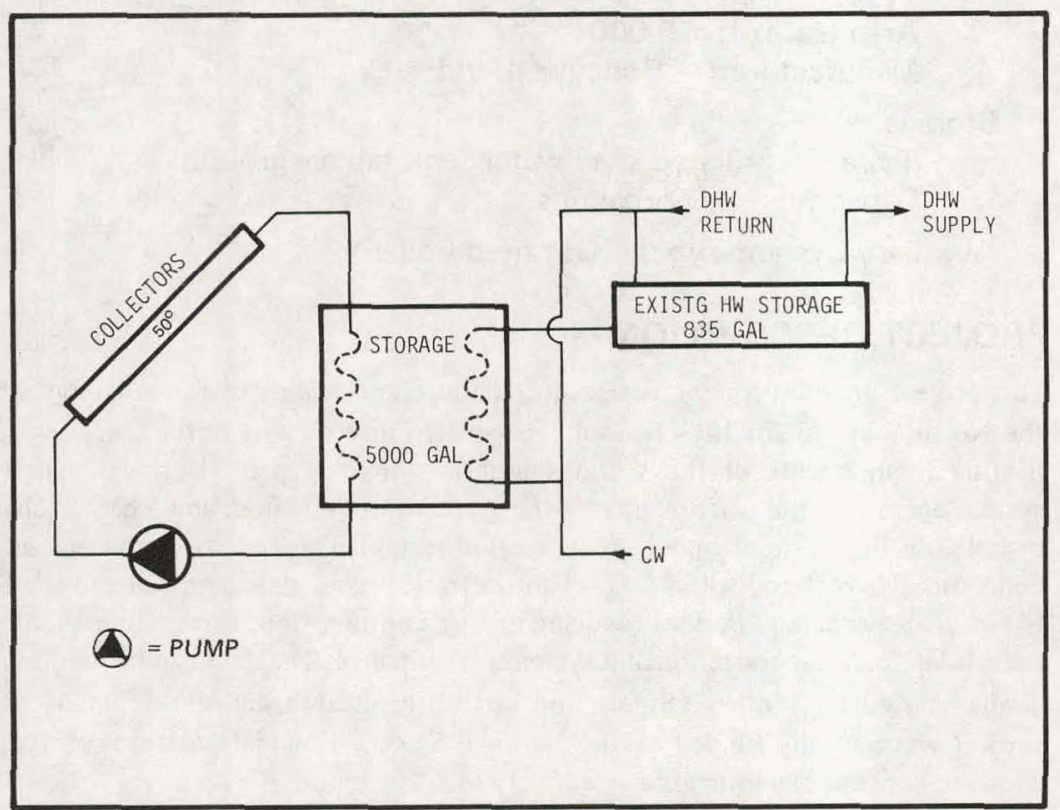

$\theta$ = PUMP

\section{Photograph not available}




\section{PROJECT INFORMATION}

Owner/Builder: Radisson Hotel Corporation

Contractor: Foster, Jacobs \& Johnson

Operational Date: June 1978

Total Estimated DOE Funds: $\$ 43,033$

Building

Type: High rise hotel

Area: Not applicable to hot water systems

Location: Duluth, Minnesota

Latitude: $47^{\circ} \mathrm{N}$

Climatic Data

Degree Days

Avg. Temp. $\left({ }^{\circ} \mathrm{F}\right)$

Winter

10000

Cooling

225

Avg. Insol. (Ly/d)

Winter 212

ummer 68

Summer 493

\section{SOLAR ENERGY SYSTEM}

Collector

Cooling $0 \%$

Hot Water $53 \%$

Type: Liquid flat-plate

Area (sq. ft.): 2,016

Manufacturer: Lennox Industries, Inc.

\section{Storage}

Type: Insulated steel water tank (above ground)

Capacity: 2,000 gallons

Auxiliary System Type: Electric boiler

\section{PROJECT DESCRIPTION}

The proposed solar system consists of $2016 \mathrm{sq}$. ft. of hydronic flat-plate solar collectors mounted above the swimming pool area on the Radisson Duluth Hotel, Duluth, Minnesota. The solar collector array will preheat incoming service water, held in a storage tank, and supplied from that tank as make-up water to the conventional electric water heater. This preheater concept will enable the solar system to operate at lower average temperatures, thereby increasing its operating efficiency. The conventional water heating system consists of a $480 \mathrm{~kW}$ electric boiler and a storage tank which provides approximately 3500 gallons of $125^{\circ} \mathrm{F}$ water per day. The proposed solar preheater system will provide approximately $53 \%$ of that load.
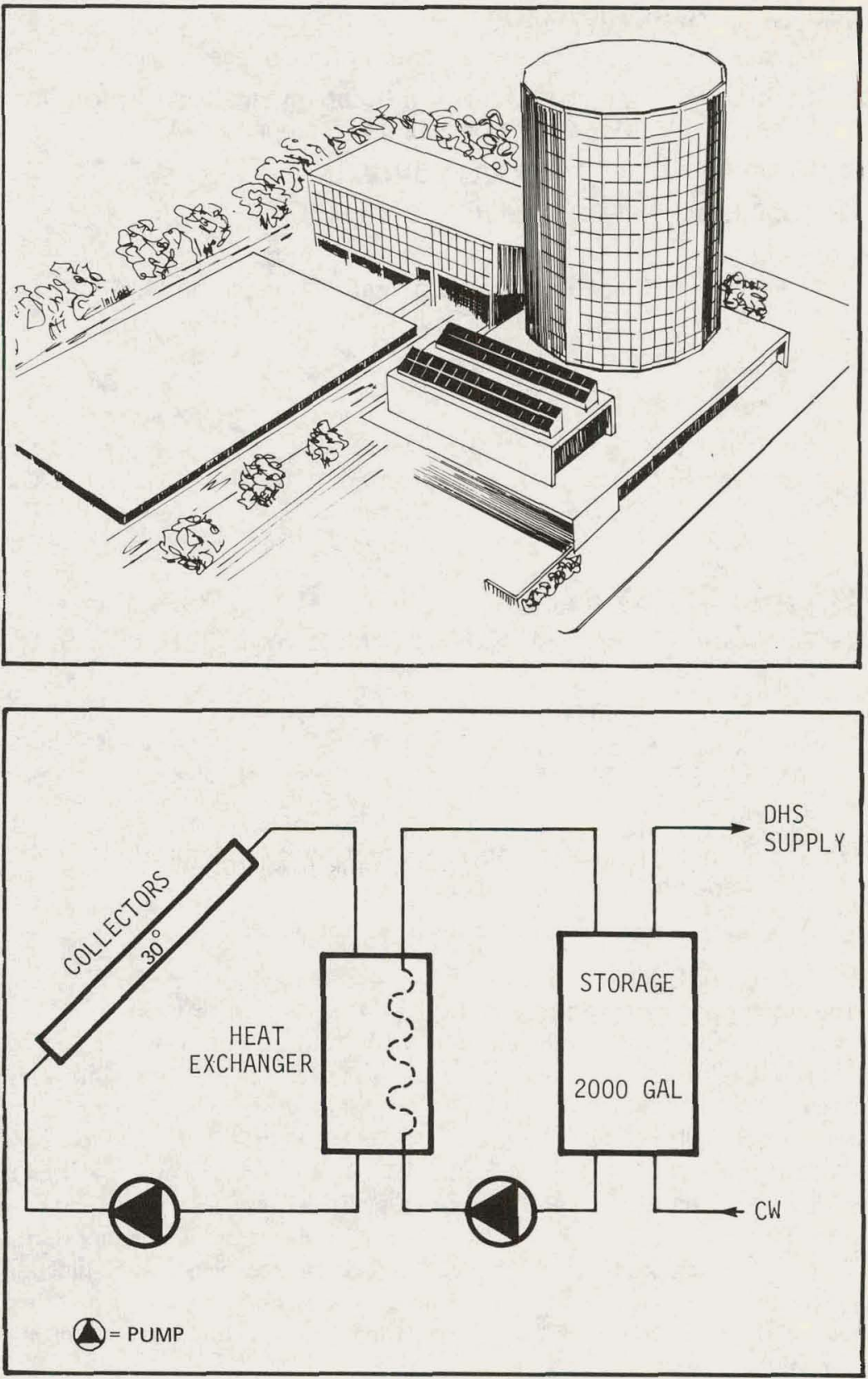


\section{PROJECT INFORMATION}

Owner/Builder: Minnesota Community College

Contractor: Mesaba Mechanical Company; Málton Electric Company; Max Gray Construction Company

Operational Date: November 1978

Total Estimated DOE Funds: $\$ 145,500$

Building

Type: Planetarium/environmental science center

Area: 4,850 sq. $\mathrm{ft}$.

Location: Hibbing, Minnesota

Latitude: $47.4^{\circ}$

Climatic Data

$\begin{array}{lllll}\text { Degree Days } & \text { Heating } & 10,000 & \text { Cooling } & 200 \\ \text { Avg. Temp. }\left({ }^{\circ} \mathrm{F}\right) & \text { Winter } & 12.4 & \text { Summer } & 76.1 \\ \text { Avg. Insol. (Ly/d) } & \text { Winter } & 184 & \text { Summer } & 666\end{array}$

\section{SOLAR ENERGY SYSTEM}

Application Heating 100\% Cooling 0\% Hot Water $0 \%$

Collector

Type: Concentrating

Area (sq. ft.): 3,600

Manufacturer: Sheldahl, Inc.

Storage

Type: Insulated concrete water tank (underground)

Capacity: 225,000 gallons

Auxiliary System Type: Fuel fired hot water

\section{PROJECT DESCRIPTION}

The main floor of the facility consists of the planetarium hyposphere, museum and display area, room for foucalt pendulum, lobby, offices, bathrooms, etc. The below-grade floor will be used as a mechanical equipment area and will house the 225000-gallon insulated concrete water storage tank. The below-grade walls are poured concrete; the above-grade walls will be of concrete block and all floors will be of poured concrete. The roof structure is steel with metal roofing. All interior surfaces above grade will be sprayed with urethane insulation with fireproof vapor barrier over 6" on walls and 8 " on ceiling. All below-grade areas will be insulated with 2" perimeter insulation on exterior surfaces. There is no fenestration in the building because the planetarium function requires maximum light control. The exterior design consists of a north sloping "shed" roof to receive the solar collectors. Roof orientation is due south to receive maximum solar insolation.
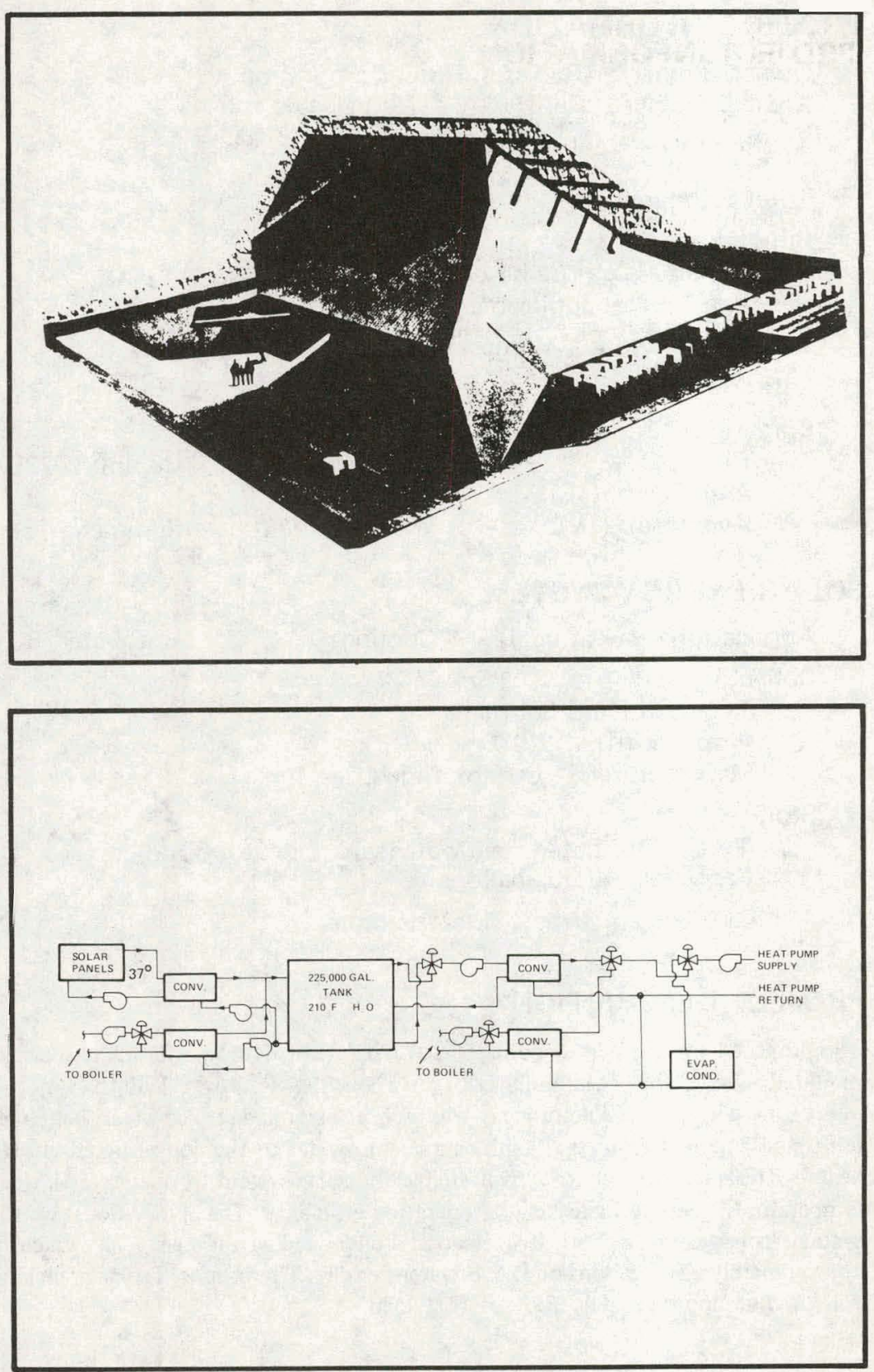


\section{PROJECT INFORMATION}

Owner/Builder: University of Minnesota

Contractor: Depts. of Mechanical Engineering, Civil \& Mineral Engineering, University of Minnesota

Operational Date: Spring 1978

Total Estimated DOE Funds: $\quad \$ 92,000$ (design)

Building
Type: Bookstore/office
Area: 83,000 sq. $\mathrm{ft}$.

Location: Minneapolis, Minnesota

Latitude: $44.9^{\circ} \mathrm{N}$

Climatic Data

$\begin{array}{lllll}\text { Degree Days } & \text { Heating } & 8159 & \text { Cooling } & 585 \\ \text { Avg. Temp. }\left({ }^{\circ} \mathrm{F} \text { ) }\right. & \text { Winter } & 35.6 & \text { Summer } & 69.7 \\ \text { Avg. Insol. (Ly/d) } & \text { Winter } & 269 & \text { Summer } & 516\end{array}$

\section{SOLAR ENERGY SYSTEM}

Application Heating/Cooling 50\%

Collector

Type: Concentrating

Area (sq. ft.): 6,600

Manufacturer: SheldahI SLATS

Storage

Type: Insulated steel water tank (underground)

Capacity: 8,000 gallons

Auxiliary System Type: Central steam system

\section{PROJECT DESCRIPTION}

A solar assisted heating and cooling system has been designed and will be installed in a large building constructed on the Minneapolis campus of the University of Minnesota. The building, Williamson Hall, houses a bookstore and records and admissions offices, and was built $95 \%$ below ground. The underground construction should provide energy savings of about $60 \%$, the exact figure depending on the thermal characteristics of the surrounding rock and soil. The building fits effectively into its surroundings and disrupts as little as possible the space occupied. A flat-plate collector system was compared to a concentrator system. On the basis of useful energy collected per unit area and on the cost effectiveness in $\$ / \mathrm{kwh} / \mathrm{yr}$, the concentrator system was selected for this project.
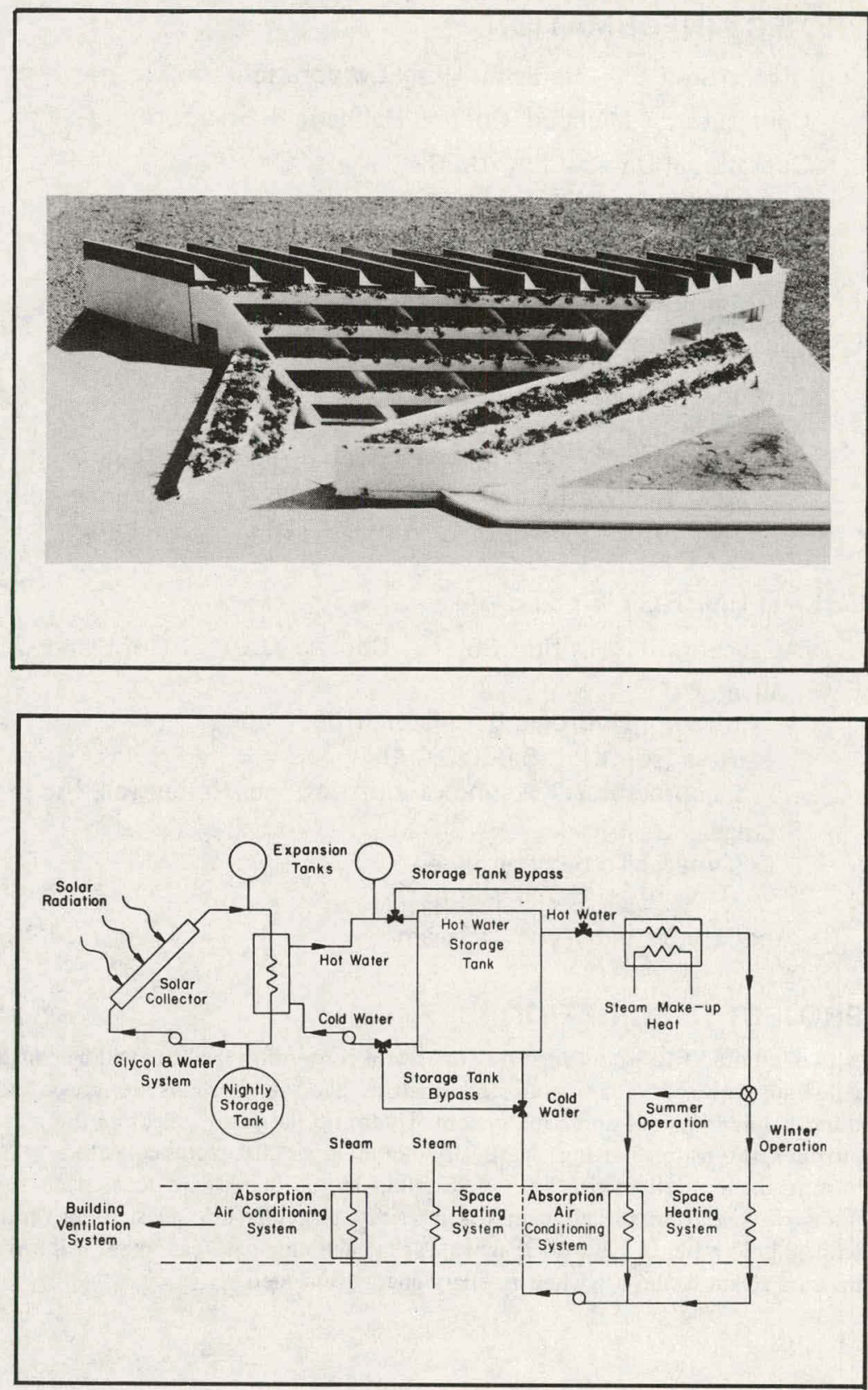


\section{PROJECT INFORMATION}

Owner/Builder: Radisson Hotel Corporation

Contractor: Michaud, Cooley, Hallberg, \& Erickson

Operational Date: July 1980

Total Estimated DOE Funds: $\quad \$ 360,000$

Building

Type: Hotel

Area: 193,770 sq. ft.

Location: St. Paul, Minnesota

Latitude: $44.9^{\circ} \mathrm{N}$

Climatic Data

$\begin{array}{lllll}\text { Degree Days } & \text { Heating } & 8159 & \text { Cooling } & 585 \\ \text { Avg. Temp. }\left({ }^{\circ} \mathrm{F} \text { ) }\right. & \text { Winter } & 35.6 & \text { Summer } & 69.7 \\ \text { Avg. Insol. (Ly/d) } & \text { Winter } & 269 & \text { Summer } & 516\end{array}$

\section{SOLAR ENERGY SYSTEM}

Application Heating 35\% Cooling 0\% Hot Water 25\%

Collector

Type: Hydronic flat-plate/air flat-plate

Area (sq. ft.): $\quad 5,000 / 3,000$

Manufacturer: Lennox Industries, Inc./Honeywell, Inc.

Storage

Type: To be determined

Capacity: 8,000 gallons

Auxiliary System Type: Steam

\section{PROJECT DESCRIPTION}

A two-hundred fifty room high-rise hotel with convention facilities will be constructed in a downtown location. The collector panels of two solar systems are integrated into the exterior building wall and roof system. Hydronic flat-plate collectors tilted at $51^{\circ}$ will provide hot water heating. Vertically-mounted air flat-plate collectors will provide heating of ventilation air. Two 4000-gallon storage tanks are located on the ground floor. Hot air from the air panels is interjected directly into guest room ventilation or used to heat water in the storage tanks. A central municipal steam plant will provide highpressure steam to the site when auxiliary energy is needed.
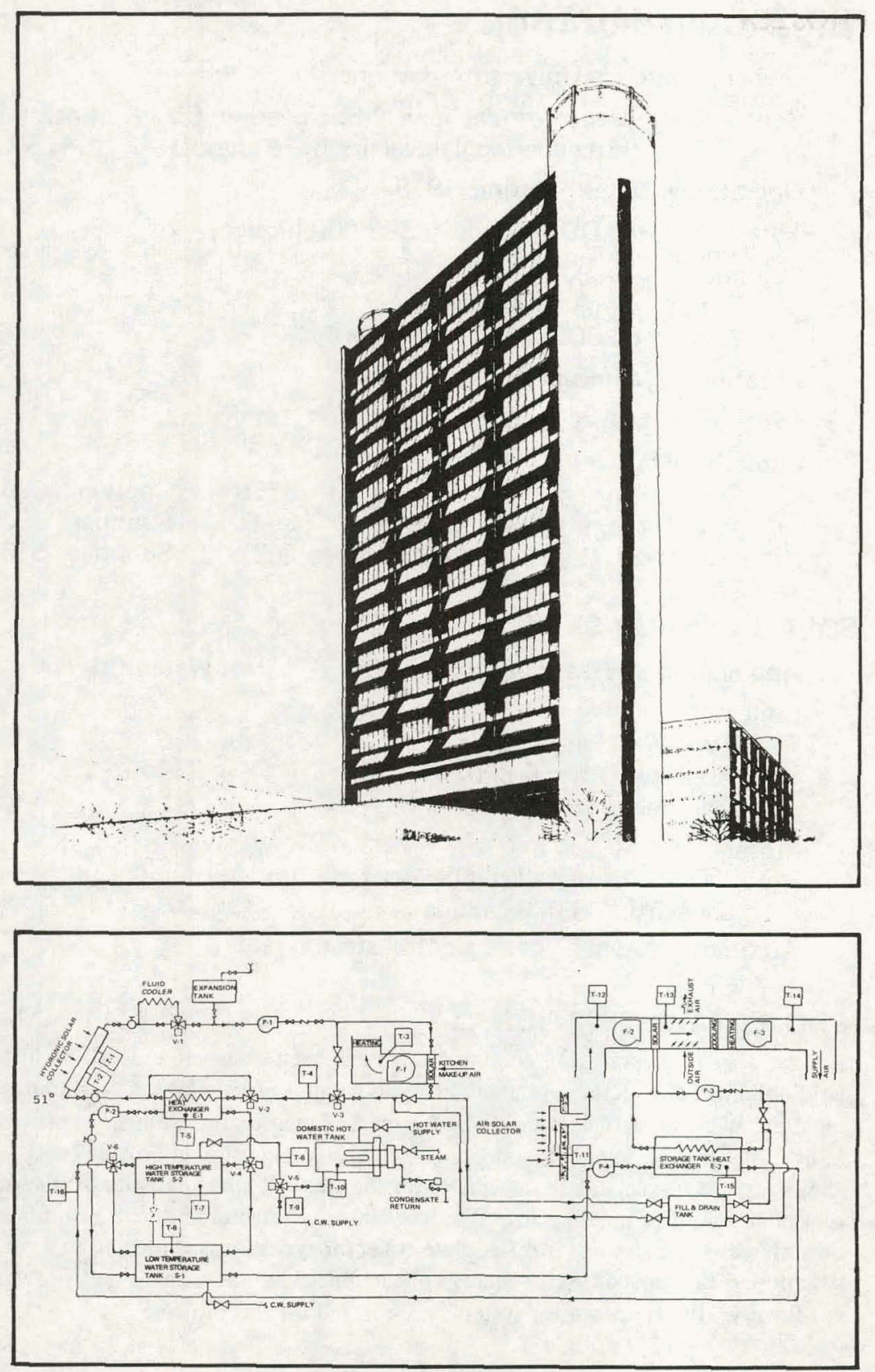


\section{PROJECT INFORMATION}

Owner/Builder: Stephens College

Contractor: Sövik, Mathre, Sathrum, Quanbeck Architects

Operational Date: October 1978

Total Estimated DOE Funds: $\$ 83,358$

Building

Type: Visitors center

Area: 13,900 sq. ft.

Location: Columbia, Missouri

Latitude: $38.97^{\circ} \mathrm{N}$

Climatic Data

Degree Days
Avg. Temp. ( $\left.{ }^{\circ} \mathrm{F}\right)$
Avg. Insol. (Ly/d)

$\begin{array}{llll}\text { Heating } & 5046 & \text { Cooling } & 1100 \\ \text { Winter } & 43 & \text { Summer } & 72.1 \\ \text { Winter } & 245 & \text { Summer } & 515\end{array}$

\section{SOLAR ENERGY SYSTEM}

Application Heating $47 \%$ Cooling $0 \%$ Hot Water $0 \%$

Collector

Type: Liquid flat-plate

Area (sq.ft.): 3,168

Manufacturer: Honeywell, Inc./Lennox Industries, Inc.

\section{Storage}

Type: Steel water tank (above ground)

Capacity: 5,000 gallons

Auxiliary System Type: Gas fired boiler

\section{PROJECT DESCRIPTION}

The visitors center will house the admissions office, the faculty lounge, and rooms for guests of the college. The collectors are integrated into the roof in a series/parallel arrangement with one in-line pump circulating a 50/50 glycol-water solution through the heat-exchanger coil in the storage tank. The heating system will be mainly fan-coil units and air handlers with hot/chilled water coils. Water for this system will be circulated through a closed loop by one or more pumps receiving energy from the immersed heat exchanger coil in storage. If the system water temperature drops below design conditions, a gas fired boiler will supply the supplemental heat through a shell-and-tube heat exchanger to the system loop.
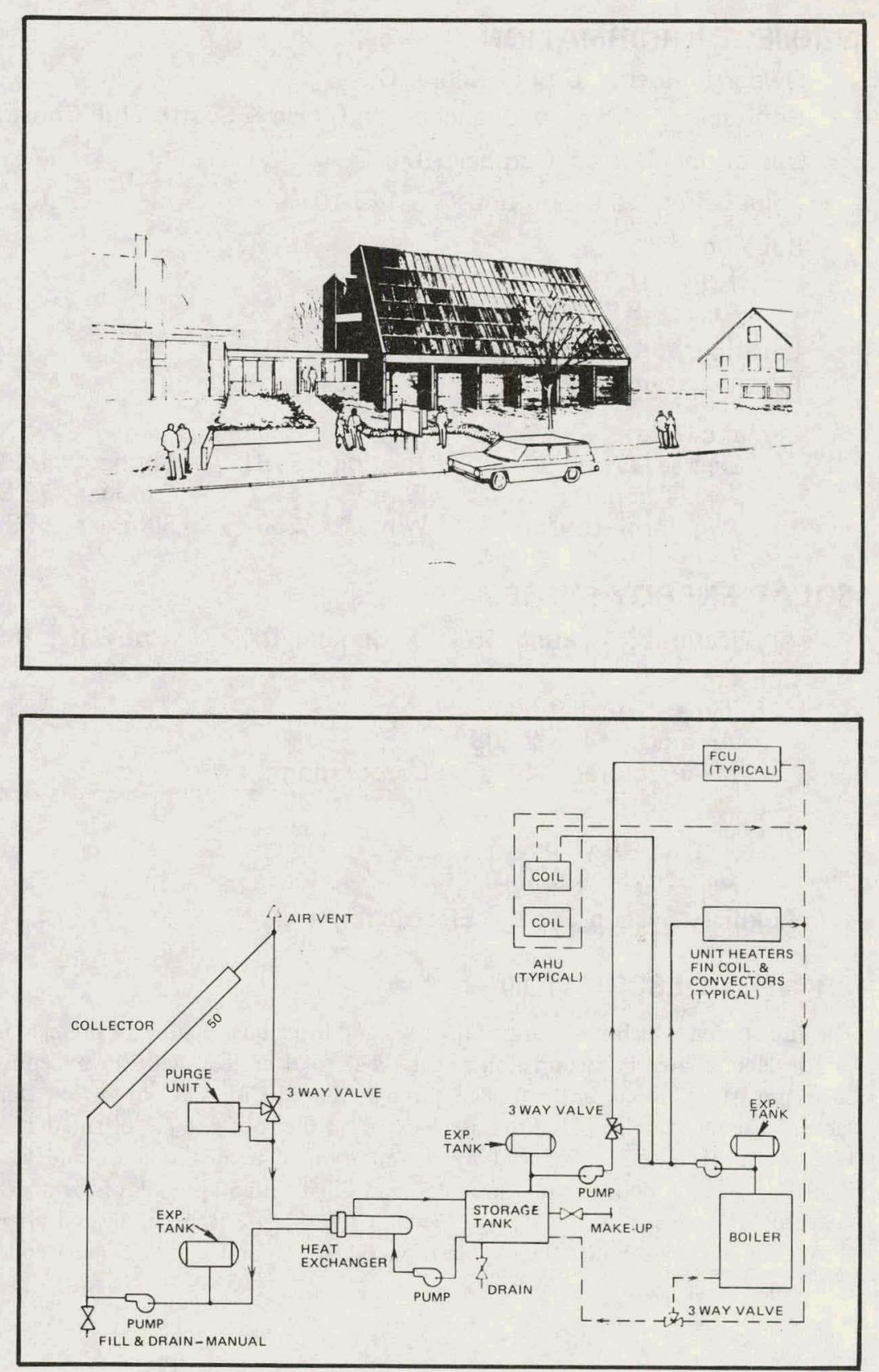


\section{PROJECT INFORMATION}

Owner/Builder: City of Kansas City

Contractor: Midgley, Shaughnessy, Fickle \& Scott/Cahill Const.

Operational Date: October 1978

Total Estimated DOE Funds: $\$ 143,101$

Building

Type: Fire station

Area: 8,200 sq. ft.

Location: Kansas City, Missouri

Latitude: $39.3^{\circ} \mathrm{N}$

Climatic Data

Degree Days
Avg. Temp. ( $\left.{ }^{\circ} \mathrm{F}\right)$
Avg. Insol. (Ly/d)

Heating 5161

Winter 41.7

Cooling 1421

Winter 266

Summer 72.8

Summer 528

\section{SOLAR ENERGY SYSTEM}

Application Heating 45\%

Hot Water $75 \%$

Collector

Type: Air flat-plate

Area (sq. ft.): 2,808

Manufacturer: Solaron Corporation

Storage

Type: Rock bed

Capacity: $1,400 \mathrm{cu} . \mathrm{ft}$.

Auxiliary System Type: Electric furnaces

\section{PROJECT DESCRIPTION}

The fire station which has 3 apparatus bays and living quarters for 14 firemen, is located in a residential area in eastern Kansas City. The total project, with the exception of the solar provisions, is currently funded through Kansas City Fire Protection Bonds. The factory-assembled solar collectors are located on the roof and are oriented $15^{\circ}$ west of true south. Heat loss is reduced by the addition of extra insulation and by utilizing insulating glass. A concrete box insulated and filled with 50 pounds of rock per sq. $\mathrm{ft}$. of collector area serves as the storage medium for solar heat. Solar heated air is routed through the storage unit, thereby heating the rocks, and returns to the collector for reheating.
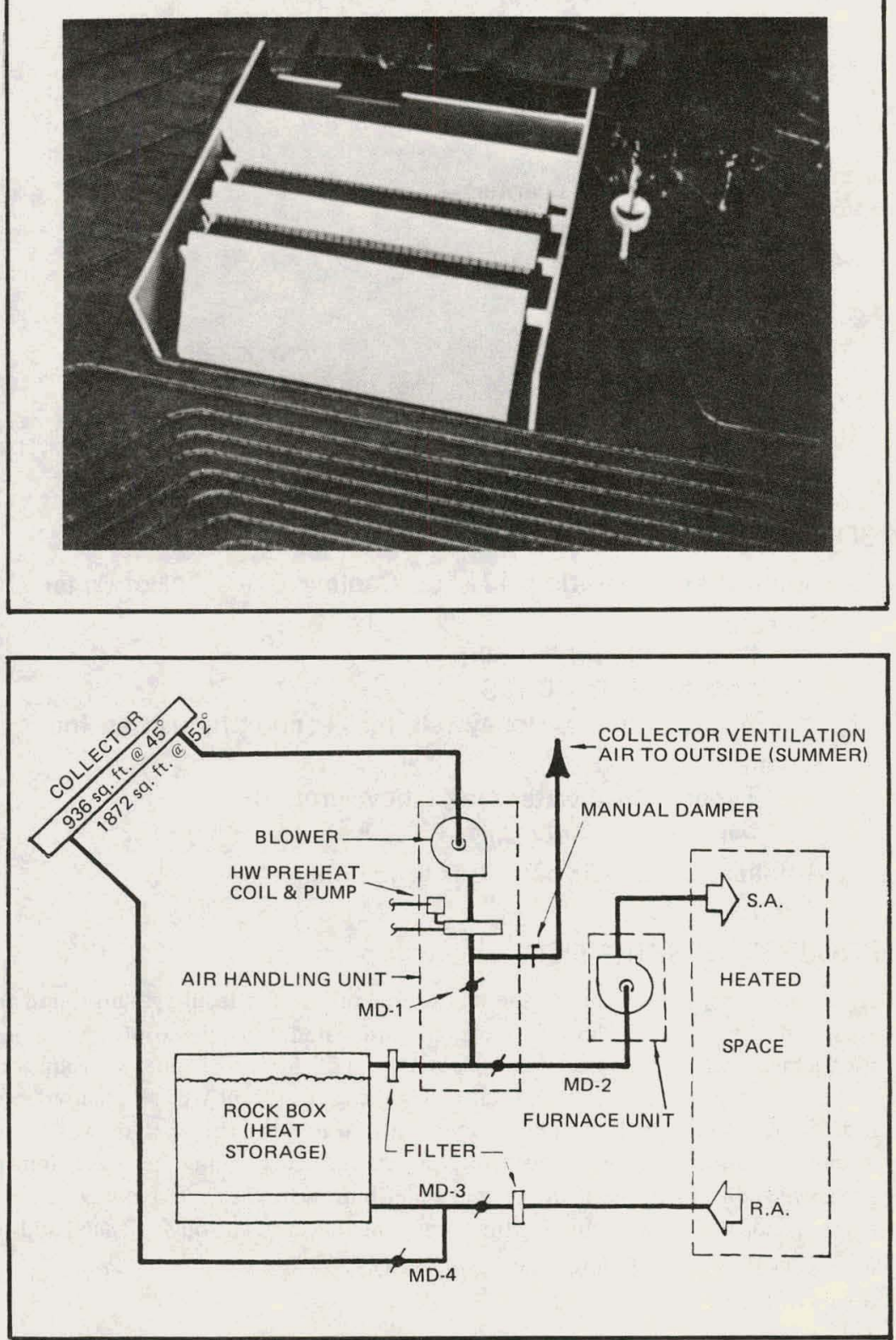


\section{PROJECT INFORMATION}

Owner/Builder: William Tao \& Associates, Inc.

Contractor: William Tao \& Associates, Inc .

Operational Date: August 1977

Total Estimated DOE Funds: $\$ 9,512$

Building

Type: Office

Area: 1,007 sq. ft.

Location: St. Louis, Missouri

Latitude: $38.8^{\circ} \mathrm{N}$

Climatic Data

$\begin{array}{lllll}\text { Degree Days } & \text { Heating } & 4900 & \text { Cooling } & 1475 \\ \text { Avg. Temp. }\left({ }^{\circ} \mathrm{F}\right) & \text { Winter } & 43.1 & \text { Summer } & 70.9 \\ \text { Avg. Insol. (Ly/d) } & \text { Winter } & 275 & \text { Summer } & 475\end{array}$

\section{SOLAR ENERGY SYSTEM}

Application Heating 45\% Cooling 0\%

Collector

Type: Concentrating glass tubular

Area (sq. ft.): 244

Manufacturer: KTA Corporation

\section{Storage}

Type: Steel water tank (underground)

Capacity: 1,000 gallons

Auxiliary System Type: Electric resistance heating/gas fired hot water

\section{PROJECT DESCRIPTION}

This is a 1-story addition with the east wall attached to the existing office building. The major part of the new building consists of a single office space for drafting, meetings, and conferences. The addition will be solar heated with conventional back-up units providing auxiliary heating and cooling. The solar system consists of a roof-mounted variable tilt collector array linked to an underground hot water storage tank by a shell and tube heat exchanger. In-line centrifugal pumps circulate fluids through the collector circuit and storage/heating circuit. Preheat of incoming city water is provided by a coil inserted in the storage tank. The conventional back-up unit is a roof-mounted air handler with electric resistance heating and DX cooling. The solar hot water coil is placed at the return air side of the unit.
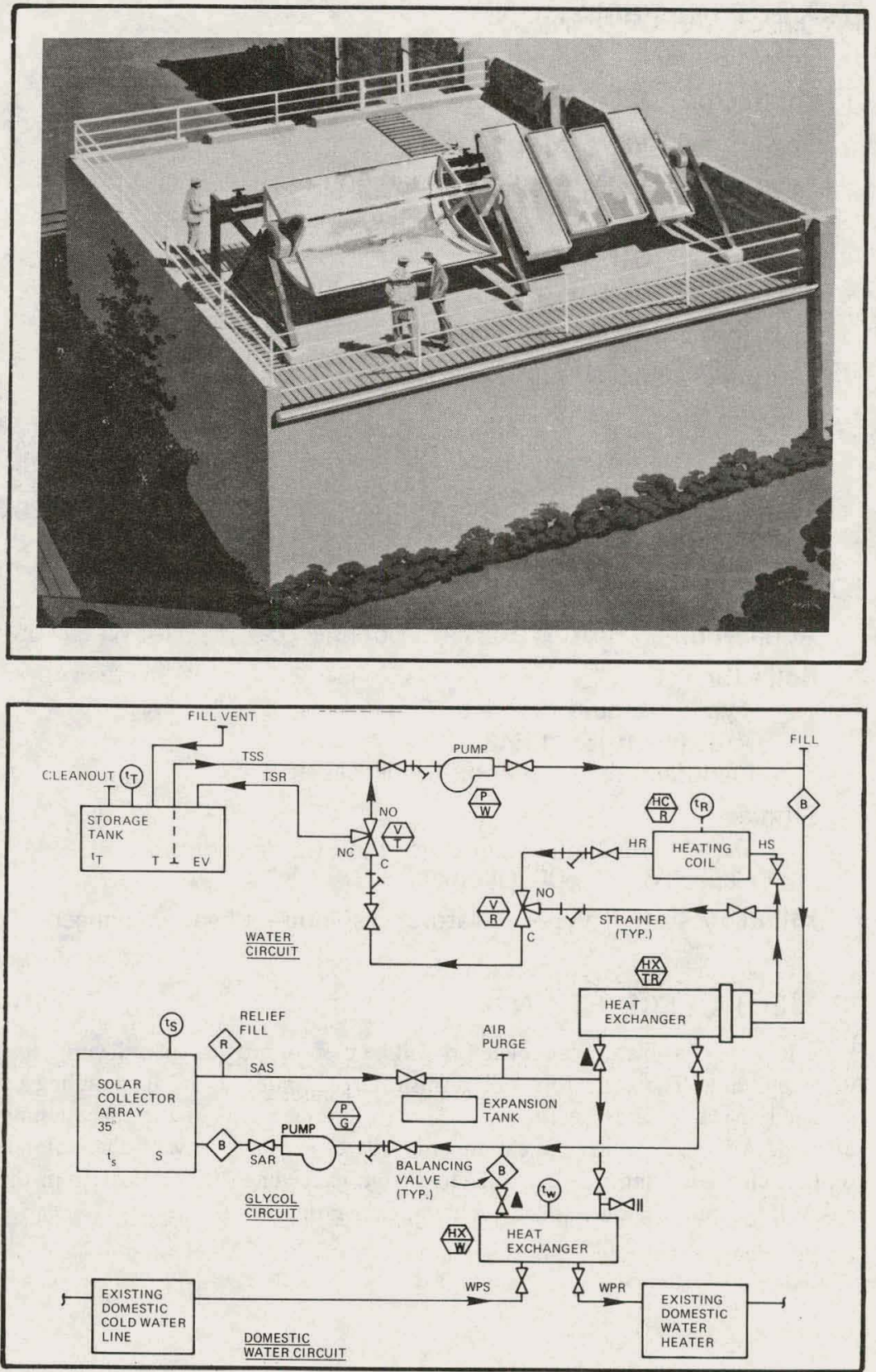


\section{PROJECT INFORMATION}

Owner/Builder: Billings Shipping Corporation

Contractor: CTA Architects

Operational Date: March 1978

Total Estimated DOE Funds: $\$ \mathbf{6 0 , 9 0 0}$

Building

Type: Office

Area: 46,976 sq. ft. (total); 4,900 sq. ft. (cond.)

Location: Billings, Montana

Latitude: $45^{\circ} 5^{\prime} \mathrm{N}$

Climatic Data

$\begin{array}{lllll}\text { Degree Days } & \text { Heating } & 7049 & \text { Cooling } & \text { N/A } \\ \text { Avg. Temp. }\left({ }^{\circ} \mathrm{F}\right) & \text { Winter } & 34.5 & \text { Summer } & 71.3 \\ \text { Avg. Insol. (Ly/d) } & \text { Winter } & 227 & \text { Summer } & 588.3\end{array}$

\section{SOLAR ENERGY SYSTEM}

Application Heating 52\%

Collector

Type: Liquid flat-plate

Area (sq .ft.): 1,848

Manufacturer: Lennox Industries, Inc.

\section{Storage}

Type: Insulated steel water tank (underground)

Capacity: 2,500 gallons

Auxiliary System Type: Natural gas, indirect heat exchanger

\section{PROJECT DESCRIPTION}

Water-to-water flat-plate solar collectors will be used to provide space heating for this new office building. The collectors will furnish heated water to an air handling unit if the occupied space requires heating or to a water storage tank if the space temperature is satisfied. An outdoor heat rejection unit will be used to prevent the water-antifreeze solution circulated through the collectors from exceeding $200^{\circ} \mathrm{F}$. Heat from the storage tank will be used when the collectors are not operating.
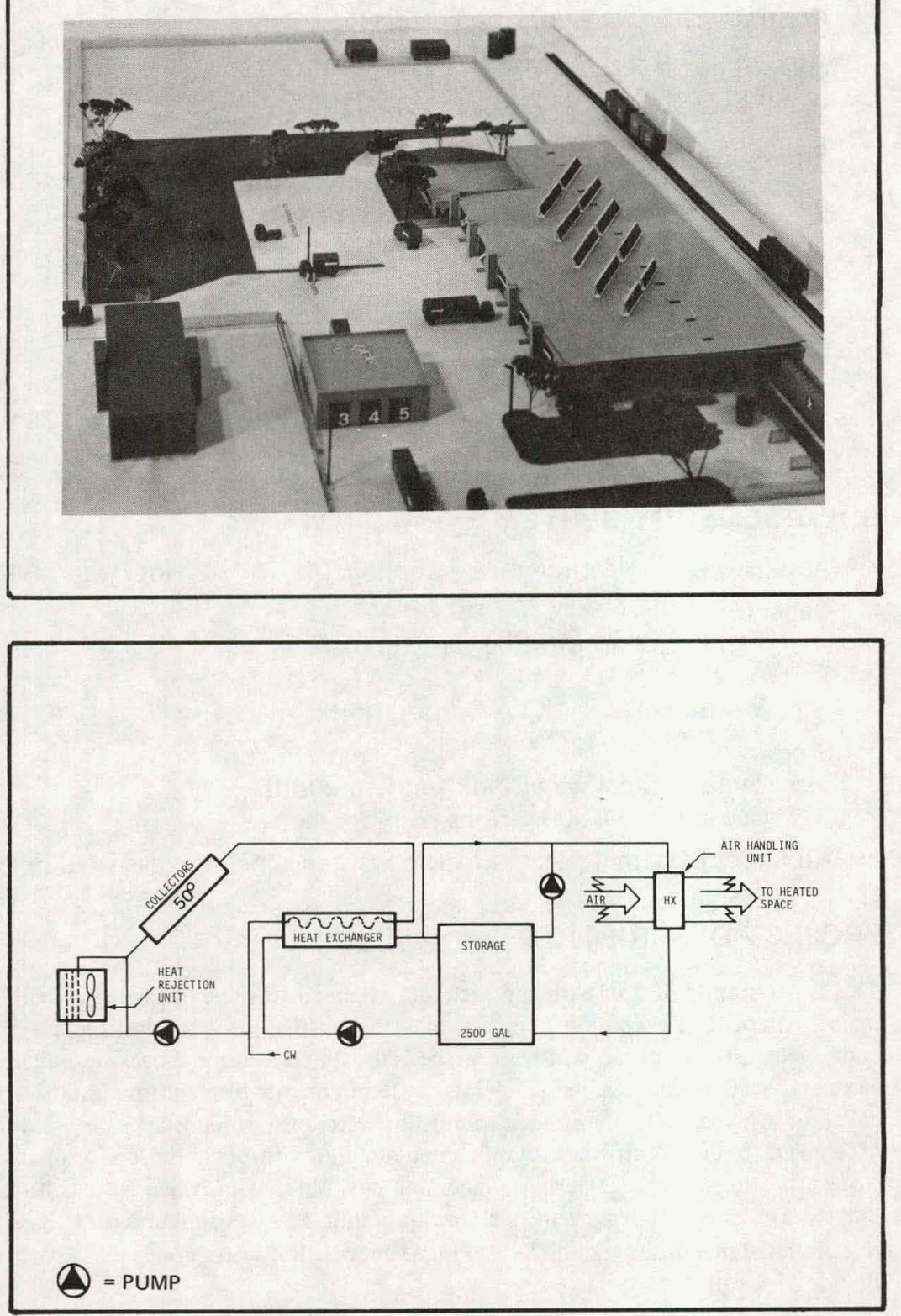


\section{PROJECT INFORMATION}

Owner/Builder: Lincoln Housing Authority

\section{Contractor: Clark Enerson Partners}

Operational Date: March 1978

Total Estimated DOE Funds: $\quad \$ 13,787$

Building

Type: Office

Area: $\quad 14,653$ sq. ft. (total) ; 13,533 sq. ft. (cond.)

Location: Lincoln, Nebraska

Latitude: $41^{\circ} \mathrm{N}$

Climatic Data

$\begin{array}{lllll}\text { Degree Days } & \text { Heating } & 5864 & \text { Cooling } & 1148 \\ \text { Avg. Temp. }\left({ }^{\circ} \mathrm{F} \text { ) }\right. & \text { Winter } & 37.9 & \text { Summer } & 71.1 \\ \text { Avg. Insol. (Ly/d) } & \text { Winter } & 269.6 & \text { Summer } & 510.1\end{array}$

\section{SOLAR ENERGY SYSTEM}

Application Heating $50 \%$

Collector

Type: Liquid flat-plate

Area (sq.ft.): 1,297

Manufacturer: unamberlain Manufacturing Corporation

Storage

Type: Insulated steel water tank (in mechanical room)

Capacity: 5,330 gallons

Auxiliary System Type: Natural gas boiler

\section{PROJECT DESCRIPTION}

The solar system for this two story masonry office building will consist of a solar space heating system and a solar domestic water heating system. The two systems will be completely independent. The solar space heating system will consist of an array of flat-plate solar collectors on the roof of the building, connected by a piping system to a hot water storage tank located in the lower level mechanical equipment room. The collectors are arranged in six east-west rows, facing due south, tilted $56^{\circ}$ above the horizontal. The heated water in the tank will be circulated to the building hot water equipment by separate pumps. The building will be heated by finned tube radiators at the perimeter of the building and cabinet unit heaters at building entrances. A heating coil in the variable volume air distribution system is used to warm the building after night setback. The solar domestic water heating system will consist of two roof-mounted, flat-plate solar collectors connected by a piping system to the hot water storage tank. The collectors will be mounted on the same racks as the solar space heating system collectors.
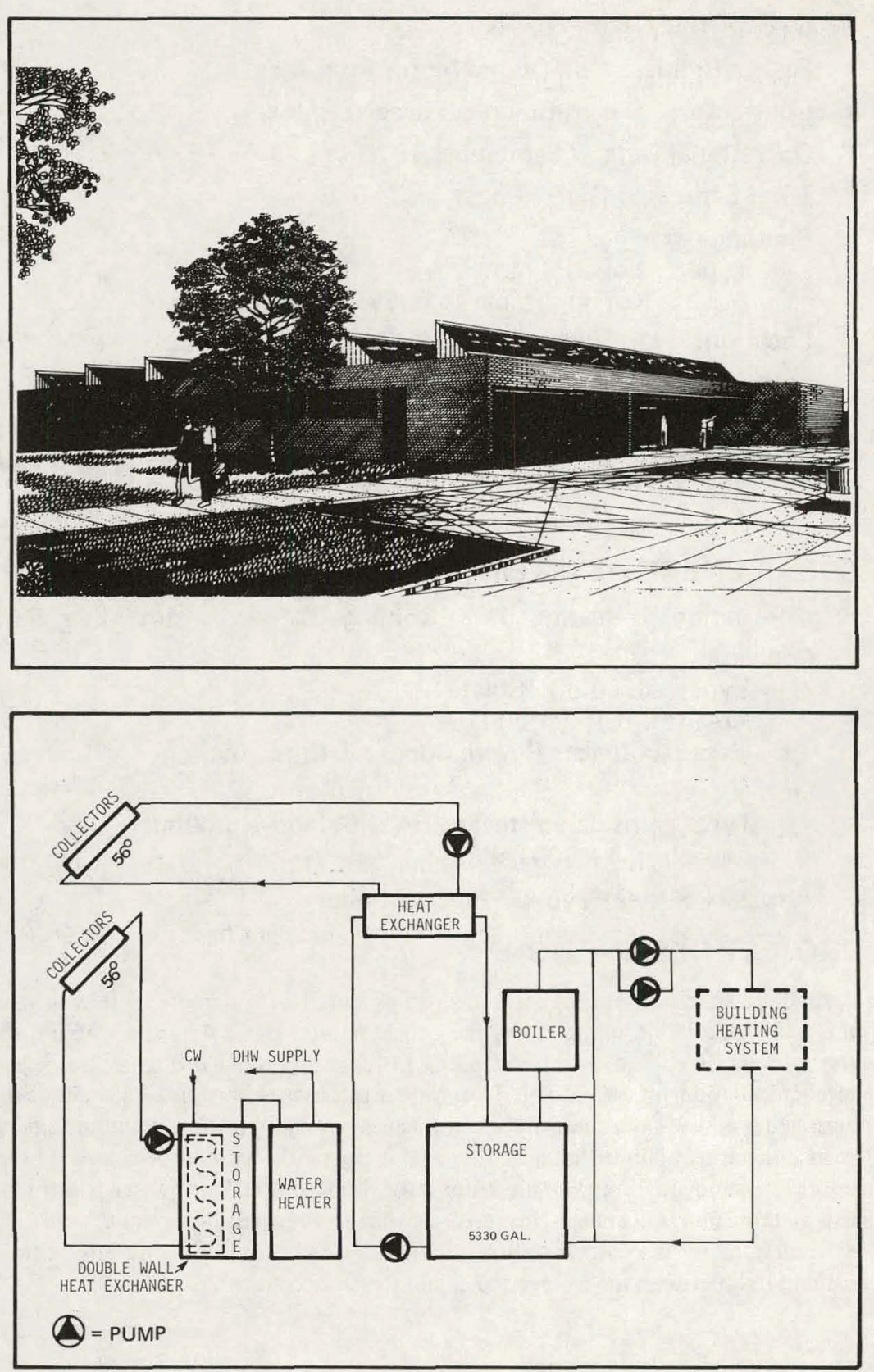


\section{PROJECT INFORMATION}

Owner/Builder: La Quinta Motor Inns, Inc.

Contractor: Travis-Braun \& Associates, Inc.

Operational Date: September 1978

Total Estimated DOE Funds: $\$ 34,660$

Building

Type: Low rise motel

Area: Not applicable to hot water systems

Location: Las Vegas, Nevada

Latitude: $36^{\circ} 1^{\prime} \mathrm{N}$

Climatic Data

$\begin{array}{lllll}\text { Degree Days } & \text { Heating } & 2709 & \text { Cooling } & 2900 \\ \text { Avg. Temp. }\left({ }^{\circ} \mathrm{F}\right) & \text { Winter } & 53.5 & \text { Summer } & 86.0 \\ \text { Avg. Insol. (Ly/d) } & \text { Winter } & 312 & \text { Summer } & 570\end{array}$

\section{SOLAR ENERGY SYSTEM}

Application Heating $0 \%$

Collector

Type: Liquid flat-plate

Area (sq. ft.): 1,200

Manufacturer: Revere Copper \& Brass, Inc.

Storage

Type: Insulated steel water tank (above ground)

Capacity: 1,600 gallons

Auxiliary System Type: Electric boiler

\section{PROJECT DESCRIPTION}

A drain-down system is proposed under this grant. This system is one in which, each time the water circulation pump stops, the collector fluid water drains out of and down into the protection of an enclosed space. In this proposal, this enclosed space is the mechanical room of the motel. This system is a hybrid version of a drain-down system employing a heat exchanger. By using this heat exchanger, the buildup of minerals in the solar collector is eliminated. On the solar loop of the system, a contained amount of water is employed. Even as this water level drops and makeup water is introduced into the system, new minerals, acids, etc., are also introduced; however, this introduction is extremely minor in comparison to the minerals which would be constantly introduced by a direct link between the storage vessel and the solar collectors.
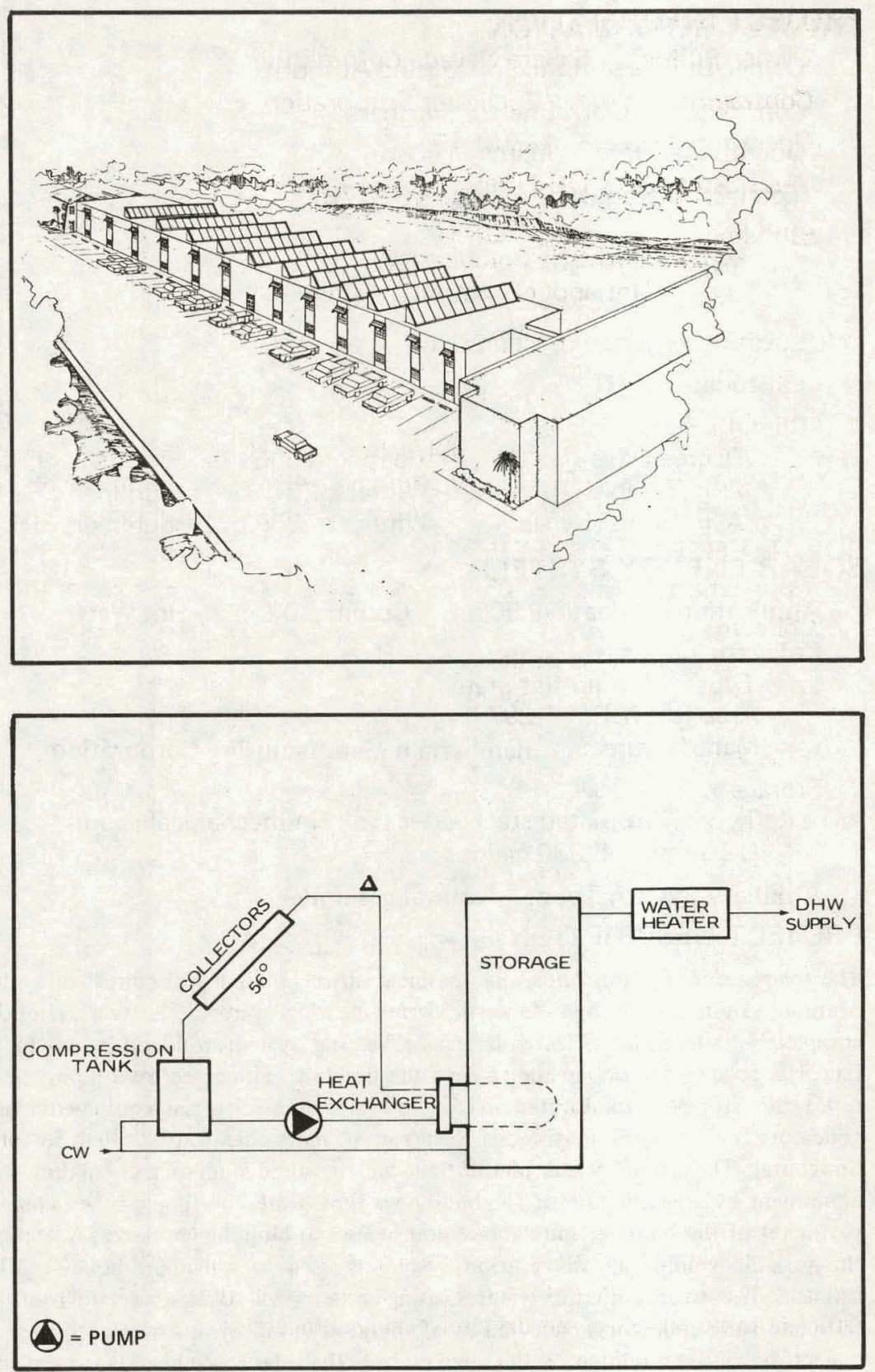


\section{PROJECT INFORMATION}

Owner/Builder: Sahara Nevada Corporation

Contractor: Young/Rochester Corporation

\section{Operational Date: August 1978}

Total Estimated DOE Funds: $\quad \$ 104,880$

Building

Type: High rise hotel/casino

Area: Not applicable to hot water systems

Location: Las Vegas, Nevada

Latitude: $36^{\circ} 05^{\prime} \mathrm{N}$

Climatic Data

$\begin{array}{lllll}\text { Degree Days } & \text { Heating } & 2601 & \text { Cooling } & 2946 \\ \text { Avg. Temp. }\left({ }^{\circ} \mathrm{F}\right) & \text { Winter } & 48 & \text { Summer } & 86 \\ \text { Avg. Insol. (Ly/d) } & \text { Winter } & 360 & \text { Summer } & 683\end{array}$

\section{SOLAR ENERGY SYSTEM}

Application Heating $0 \%$

Collector

Cooling $0 \%$

Hot Water $58.4 \%$

Type: Air flat-plate

Area (sq. ft.): 15,200

Manufacturer: Young Energy Systems, Inc.

\section{Storage}

Type: Insulated steel water tank (in mechanical room)

Capacity: 60,000 gallons

Auxiliary System Type: Steam boilers

\section{PROJECT DESCRIPTION}

The solar system will function as a preheater for cold water entering the existing domestic hot water system. The solar system will consist of $15200 \mathrm{sq}$. ft. of collectors with an equal area of reflectors to enhance performance at solar altitudes in excess of $35^{\circ}$. The collectors utilized were designed for large applications; nominal collector length is 100 feet, and represents a considerable improvement in cost effectiveness. The collectors are single-glazed with an acrylic material. The collector absorber is also made from an acrylic material. Air type collectors were chosen to eliminate any requirement for protective chemicals in the solar system. An air-to-water heat transfer coil will transfer heat from the solar air loops to the domestic hot water storage system. During the portion of the year of peak ambient temperatures and insolation, the system is sized to produce preheated hot water at sufficient temperatures to allow $100 \%$ solar contribution to the heating of domestic hot water for nearly 24 hours. At all times, the storage capacity is sufficient to store $125 \%$ of one day's solar energy production.
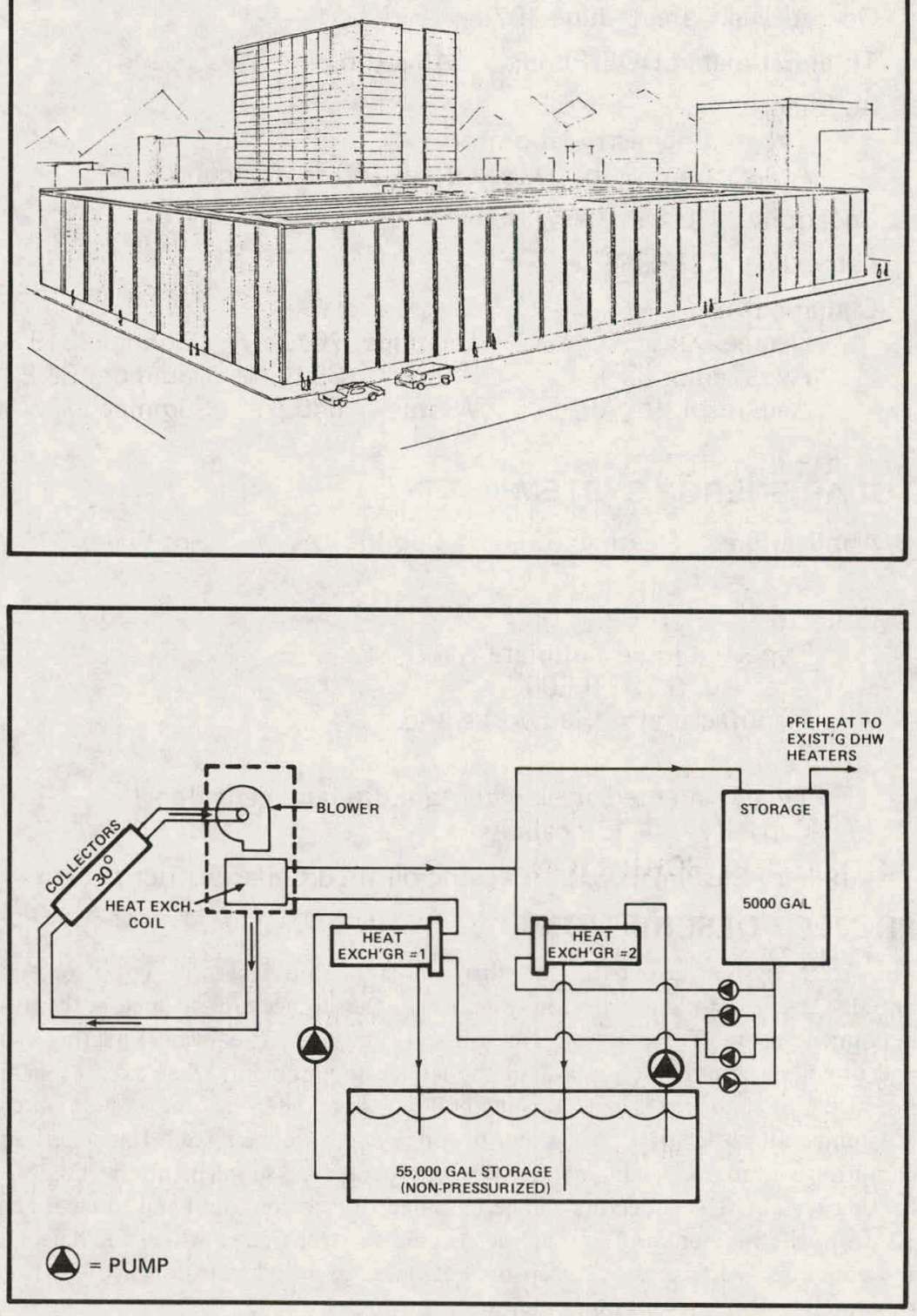


\title{
PROJECT INFORMATION
}

Owner/Builder: University of New Hampshire

Contractor: University of New Hampshire

Operational Date: June 1978

Total Estimated DOE Funds: $\quad \$ 192,156$

Building

Type: Chemistry laboratory

Area: 54,380 sq. ft. (total); 48,750 sq. ft. (cond.)

Location: Durham, New Hampshire

Latitude: $43^{\circ} 08^{\prime} \mathrm{N}$

Climatic Data

$\begin{array}{lllll}\text { Degree Days } & \text { Heating } & 7612 & \text { Cooling } & 315 \\ \text { Avg. Temp. }\left({ }^{\circ} \mathrm{F}\right) & \text { Winter } & 32.6 & \text { Summer } & 61.8 \\ \text { Avg. Insol. (Ly/d) } & \text { Winter } & 640.81 & \text { Summer } & 775.46\end{array}$

\section{SOLAR ENERGY SYSTEM}

Application Heating 63\% Cooling 0\% Hot Water $37 \%$

\section{Collector}

\author{
Type: Liquid flat-plate \\ Area (sq.ft.): 3,500 \\ Manufacturer: Sunworks, Inc.
}

Storage

Type: Vented steel water tank (in basement floor)

Capacity: 4,179 gallons

Auxiliary System Type: Existing oil fired boiler district system

\section{PROJECT DESCRIPTION}

The solar system proposed for this two-story building will be a roof-mounted, double-glazed, flat-plate collector system with the storage tank located in the mechanical equipment room. The solar system will serve the space (hot water) heating system and will provide approximately $100 \%$ of the annual requirement. When excess solar energy is produced beyond the needs of the building hot water heating system, the campus low-temperature "district" hot water heating system will be served. Under certain surplus conditions, available solar energy will be provided to supplement the domestic water heating system. The collectors will be mounted to face due south and tilted at an angle of $53^{\circ}$ from the horizontal. They will be secured to steel frames which will diagonally span the building. The frames will keep the bottom edge of the collectors about 10' above the classroom roof to prevent unwanted snow drifting.

\section{Photograph not available}

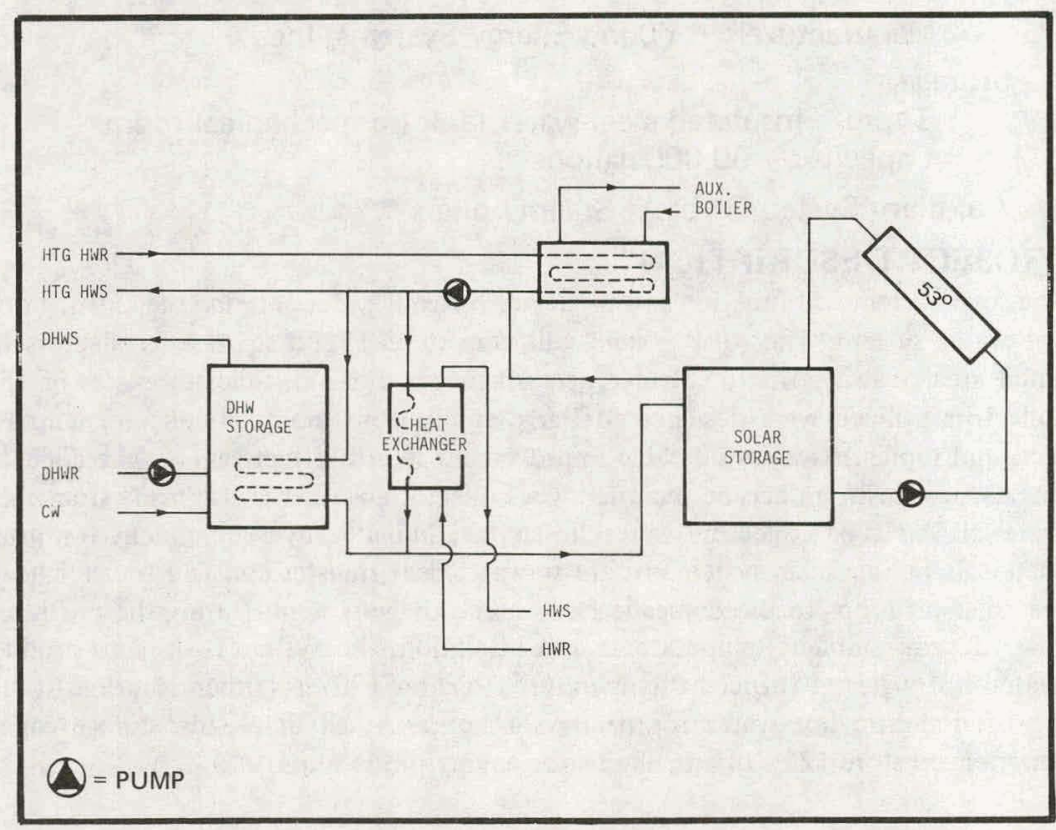




\section{PROJECT INFORMATION}

Owner/Builder: Contemporary Systems, Inc.

Contractor: Contemporary Systems, Inc.

Operational Date: July 1978

Total Estimated DOE Funds: $\quad \mathbf{\$ 7 5 , 9 3 8}$

Building

Type: Office/manufacturing

Area: 4,560 sq. ft.

Location: Jaffrey, New Hampshire

Latitude: $42^{\circ} \mathrm{N}$

Climatic Data

Degree Days

Avg. Temp. $\left({ }^{\circ} \mathrm{F}\right)$

Heating 7400

Cooling N/A

Avg. Insol. (Ly/d)

Winter 31

Summer 72

Summer 450

\section{SOLAR ENERGY SYSTEM}

\section{Application Heating $57 \%$}

Winter 200

Collector

Cooling 0\%

Hot Water $65 \%$

Type: Air flat-plate

Area (sq .ft.): 1,500 (active); 300 (passive)

Manufacturer: Contemporary Systems, Inc.

\section{Storage}

Type: Rock bed (underground)

Capacity: $2,900 \mathrm{cu} . \mathrm{ft}$.

Auxiliary System Type: Oil fired warm air system

\section{PROJECT DESCRIPTION}

The Contemporary Systems solar demonstration project consists of a highly solar sufficient commercial structure, utilizing both active and passive solar heating techniques. The building will serve as the engineering, administrative, and production facility for Contemporary Systems. The building will be used for the development and production of solar components. The active array will consist of 1500 sq. ft. of active low temperature air collectors. This will inter-connect through an air transport system to the distribution and storage subsystems. The passive system will consist of four elements. The entrance foyer will be a greenhouse type passive collection area. Excess heat will be removed via the active air handling system. Clerestory lighting over the engineering area and window surface in the office space will provide controlled passive heat and light. This will be coupled to the air transport system to control excess heat gain. Solar skylights in the production shop will admit controlled solar radiation for space heating and general lighting.
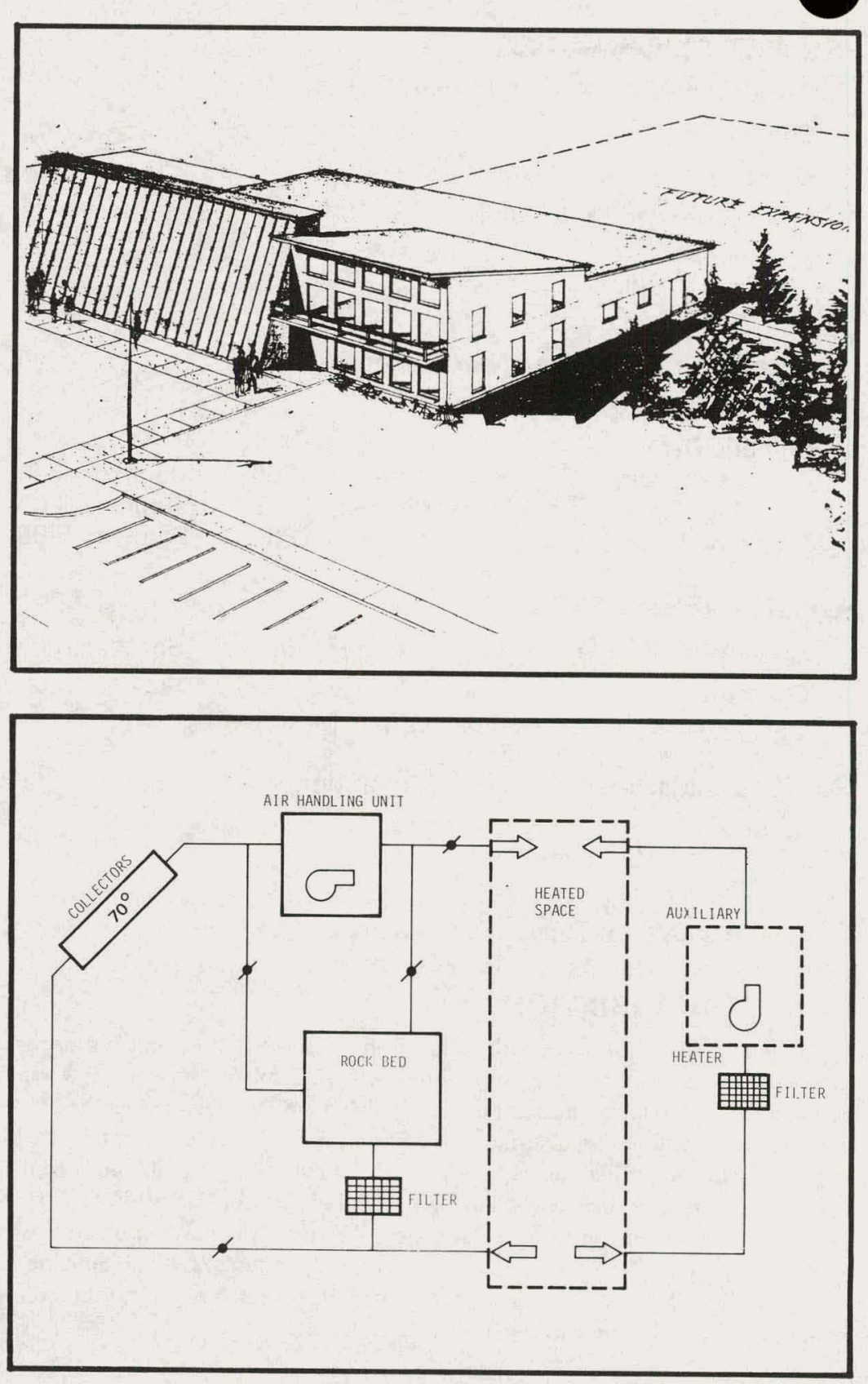


\section{PROJECT INFORMATION}

Owner/Builder: Kalwall Corporation

\section{Contractor: Kalwall Corporation}

Operational Date: September 1976

Total Estimated DOE Funds: $\$ \$ 28,600$

Building

Type: Warehouse

Area: 8,640 sq. ft.

Location: Manchester, New Hampshire

Latitude: $43.0^{\circ} \mathrm{N}$

Climatic Data

$\begin{array}{lllll}\text { Degree Days } & \text { Heating } & 7360 & \text { Cooling } & 349 \\ \text { Avg. Temp. ( }{ }^{\circ} \mathrm{F} \text { ) } & \text { Winter } & 38.5 & \text { Summer } & 68.5 \\ \text { Avg. Insol. (Ly/d) } & \text { Winter } & 266 & \text { Summer } & 488\end{array}$

\section{SOLAR ENERGY SYSTEM}

\section{Application Heating 50\% \\ Cooling $0 \%$ \\ Hot Water 0\%}

\section{Collector}

Type: Vertical wall panels (passive system)

Area (sq. ft.): $\quad 1,750$

Manufacturer: Kalwall Corporation

Storage

Type: Concrete floor

Capacity: N/A

Auxiliary System Type: Oil fired boiler

\section{PROJECT DESCRIPTION}

Approximately $90 \%$ of the south-facing wall of a wood post and beam construction commercial warehouse has been retrofitted with an insulated solar window panel system which permits maximum insolation, yet is highly insulated to reduce heat losses. The concrete floors and exposed surfaces of adjacent fixtures inside the warehouse have been painted black. The inside area acts as part of the collector, trapping both heat radiation and convection. This area could have an overall absorption factor of $98 \%$ or $99 \%$ even though the same paint used in a flat-plate collector might have an inherent absorption coefficient of only $95 \%$. The warehouse currently houses a retail building materials center. A 5000-sq. ft. area has been partitioned off for retail sales, and this area will continue to be heated by the existing hot water boiler.

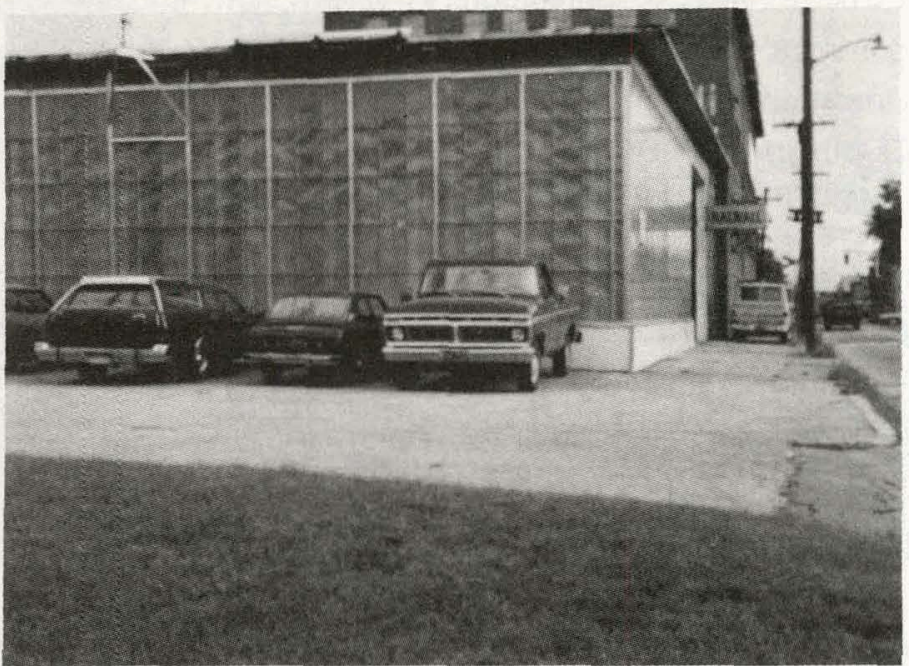

SUNWALL AS PASSIVE SYSTEM COLLECTOR COVER

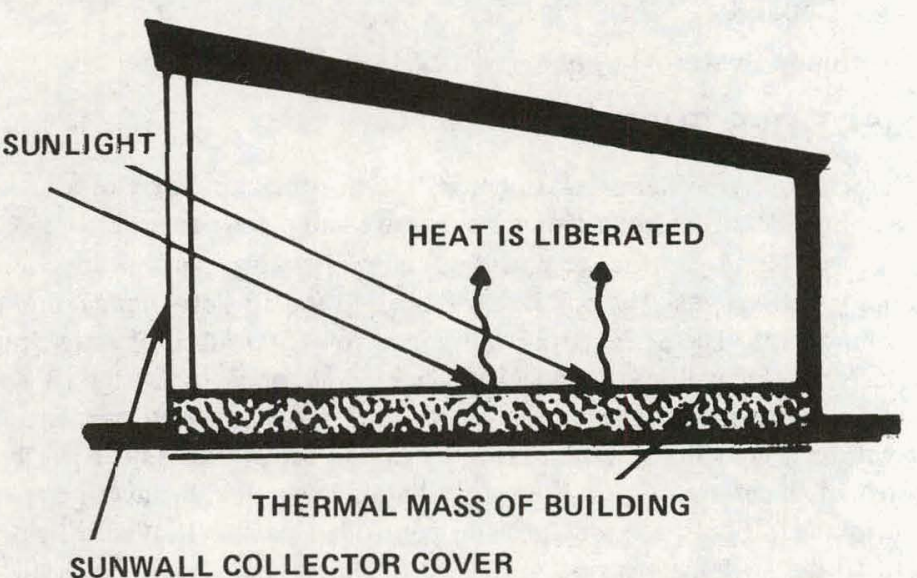




\section{PROJECT DESCRIPTION}

Owner/Builder: Somerset County Park Commission

Contractor: Somerset County Park Commission

Operational Date: October 1976

Total Estimated DOE Funds: $\quad \$ 725,236$

Building

Type: Auditorium/classrooms/office

Area: 18,000 sq. ft. (total); 18,000 sq. ft. (heat); 9,500 sq. ft. (cool)

Location: Basking Ridge, New Jersey

Latitude: $40.8^{\circ} \mathrm{N}$

Climatic Data

$\begin{array}{lllll}\text { Degree Days } & \text { Heating } & 4897 & \text { Cooling } & 1021 \\ \text { Avg. Temp. }\left({ }^{\circ} \mathrm{F}\right) & \text { Winter } & 51.6 & \text { Summer } & 72.5 \\ \text { Avg. Insol. (Ly/d) } & \text { Winter } & 300 & \text { Summer } & 466\end{array}$

\section{SOLAR ENERGY SYSTEM}

Application Heating $50-60 \%$ Cooling $70-75 \%$ Hot Water $100 \%$

Collector

Type: Liquid flat-plate

Area (sq. ft.): 3,105

Manufacturer: General Electric Company

Storage

Type: Steel water tank (underground)

Capacity: 6,000 gallons

Auxiliary System Type: Oil fired boiler, electric

\section{PROJECT INFORMATION}

This project incorporates "an aesthetically and environmentally pleasing" solar system into an Environmental Education Center which opened January 3, 1977. Single glazed collectors are contained within the roof, covered by plastic panels. The collector array provides energy to heat the building directly and cool it through an absorption air conditioner. Hot water is stored in underground tanks to provide storage and retrieval capability for excess energy. A pond acts as a cooling sink for the 25 -ton absorption air conditioner instead of a standard cooling tower. The system is fully instrumented to evaluate performance. An instrumentation console provides for data display and recording and a display panel graphically illustrates system operation. This equipment is part of an overall energy conservation display available to visitors to the Environmental Center as part of its educational program.
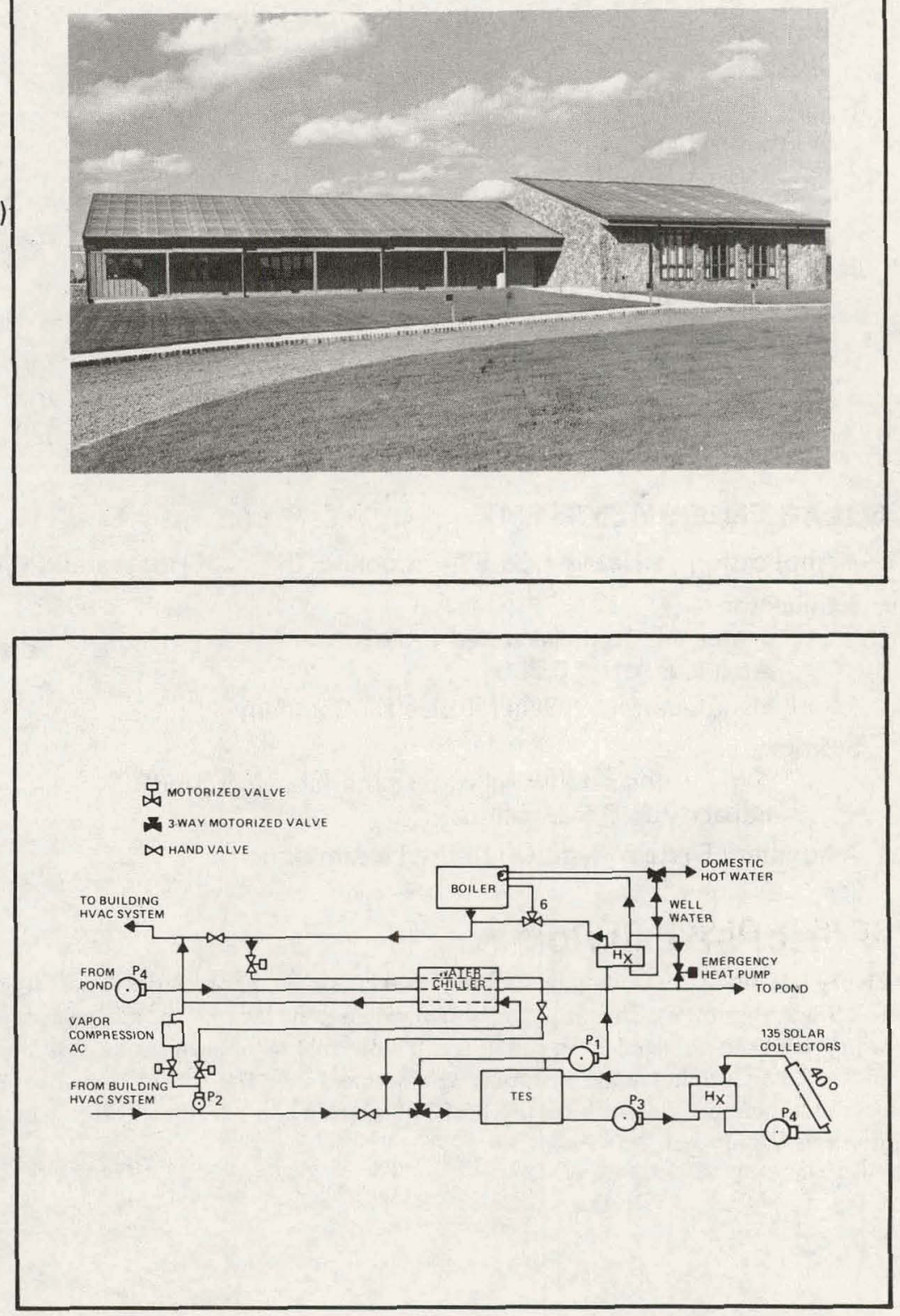


\section{PROJECT INFORMATION}

Owner/Builder: Garden State Racing Association

Contractor: Colm Engineering/The Franklin Institute

Operational Date: October 1978

Total Estimated DOE Funds: $\$ 315,491$

Building

Type: Hotel

Area: 70,000 sq. ft.

Location: Cherry Hill, New Jersey

Latitude: $40^{\circ} \mathrm{N}$

Climatic Data

$\begin{array}{lllll}\text { Degree Days } & \text { Heating } & 4600 & \text { Cooling } 700 \\ \text { Avg. Temp. }\left({ }^{\circ} \mathrm{F}\right) & \text { Winter } & 42 & \text { Summer } & 70 \\ \text { Avg. Insol. (Ly/d) } & \text { Winter } & 357 & \text { Summer } & 522\end{array}$

\section{SOLAR ENERGY SYSTEM}

Application Heating 31.5\% Cooling 0\% Hot Water $29.8 \%$

Collector

Type: Liquid evacuated tubes

Area (sq. ft.): $\quad 5,700$

Manufacturer: General Electric Company

Storage

Type: Insulated steel water tank (above ground)

Capacity: 7,500 gallons

Auxiliary System Type: Oil fired steam boilers

\section{PROJECT DESCRIPTION}

Cherry Hill Inn offers accommodations for 600 guests and has facilities to host 4000 people in 15 meeting rooms. The proposed system would assist the existing space heating system which is a main air handler fan coil unit and individual room heater coils. It is intended to preheat domestic hot water in spring, summer, and fall. The collectors will be mounted on an aluminum framework on the roof in five rows at a $40^{\circ}$ tilt. Storage temperatures are expected to reach $200^{\circ} \mathrm{F}$.
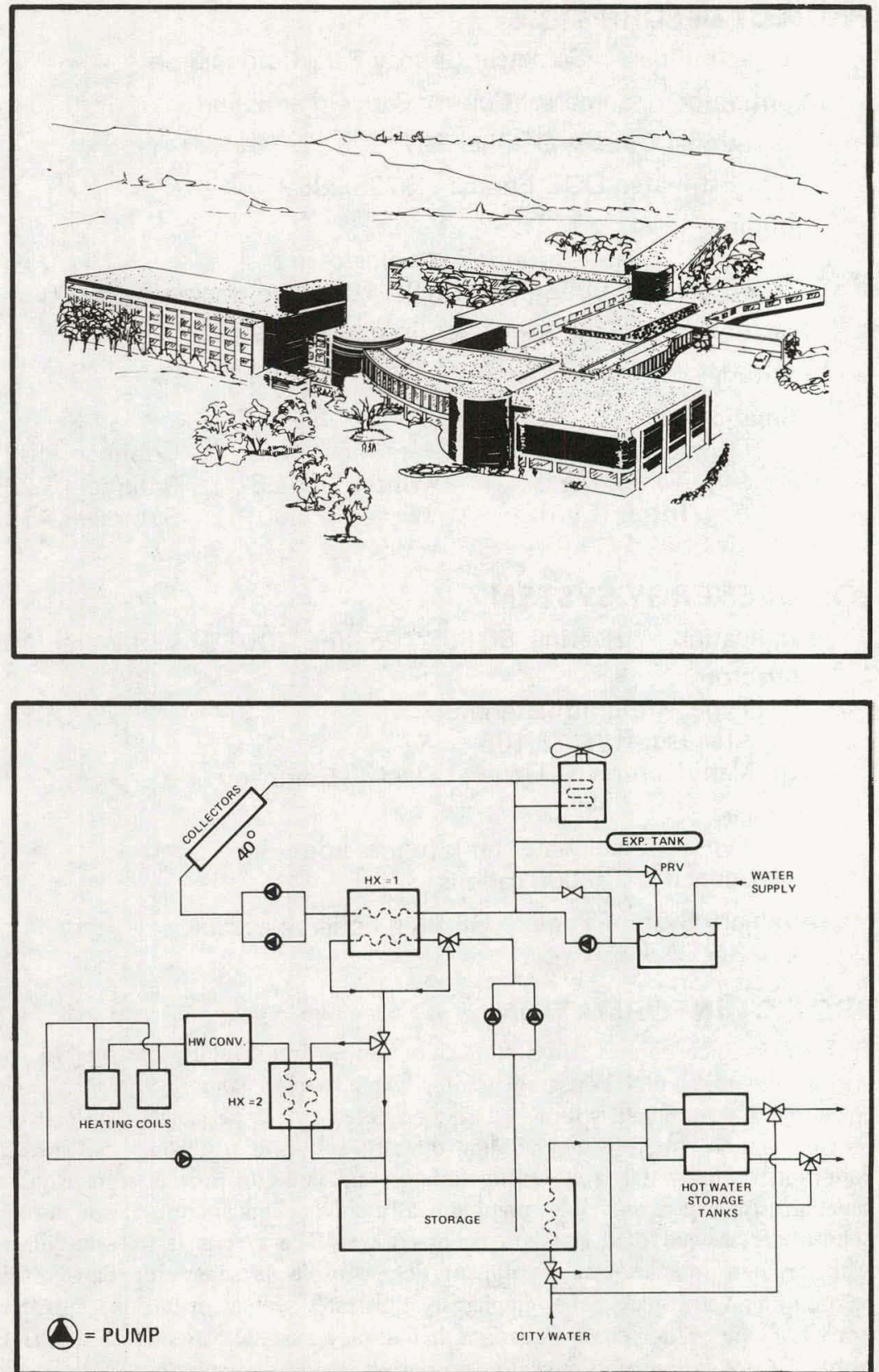


\section{PROJECT INFORMATION}

Owner/Builder: Sea Loft

Contractor: Stephen Giddio Construction Company/Smith Hinchman and Grylls Associates, Inc./Harvey Myers, AIA

Operational Date: January 1979

Total Estimated DOE Funds: $\quad \$ 184,757$

Building

Type: Restaurant

Area: $\quad 24,700$ sq. ft. (total); 13,600 sq. ft. (heating);

11,100 sq. ft. (cooling)

Location: Long Branch, New Jersey

Latitude: $42.3^{\circ} \mathrm{N}$

Climatic Data

$\begin{array}{lllll}\text { Degree Days } & \text { Heating } & 4859 & \text { Cooling } & 1024 \\ \left.\text { Avg. Temp. ( }{ }^{\circ} \mathrm{F}\right) & \text { Winter } & 42 & \text { Summer } & 68 \\ \text { Avg. Insol. (Ly/d) } & \text { Winter } & 187 & \text { Summer } & 408\end{array}$

\section{SOLAR ENERGY SYSTEM}

Application Heating 43\%

Cooling $28 \%$

Hot Water $50 \%$

Collector

Type: Glass evacuated tube

Area (sq. ft.): 2,808

Manufacturer: Owens-IIlinois, Inc.

Storage

Type: Insulated steel water tank (above ground)

Capacity: 4,000 gallons

Auxiliary System Type: Oil fired boiler

\section{PROJECT DESCRIPTION}

The Sea Loft Restaurant is to operate as a contemporary seafood restaurant, with lounge and catering on the oceanfront in Long Branch, New Jersey. The restaurant and lounge will sit on top of an $18^{\prime}$ elevation giving diners an unobstructed ocean front view at its southern orientation. The collectors ( 85 panels at $40^{\circ}$ tilt, 19 panels at $0^{\circ}$ tilt) are to be used as a primary source for space heating, cooling, and domestic hot water heating. Solar-heated water will be used whenever available during the cooling season to provide an energy source to operate a 25 -ton absorption chiller. The chilled water produced will pre-cool the main chilled water loop. During the heating season, a finned tube radiation terminal subsystem will use solar heated water as available via a water-to-water heat exchanger. A solar assist will help provide $100^{\circ} \mathrm{F}$ domestic hot water which will be boosted locally as required for kitchen equipment. Reclamation of available heat generated within the building will be optimized for instantaneous and/or later use.
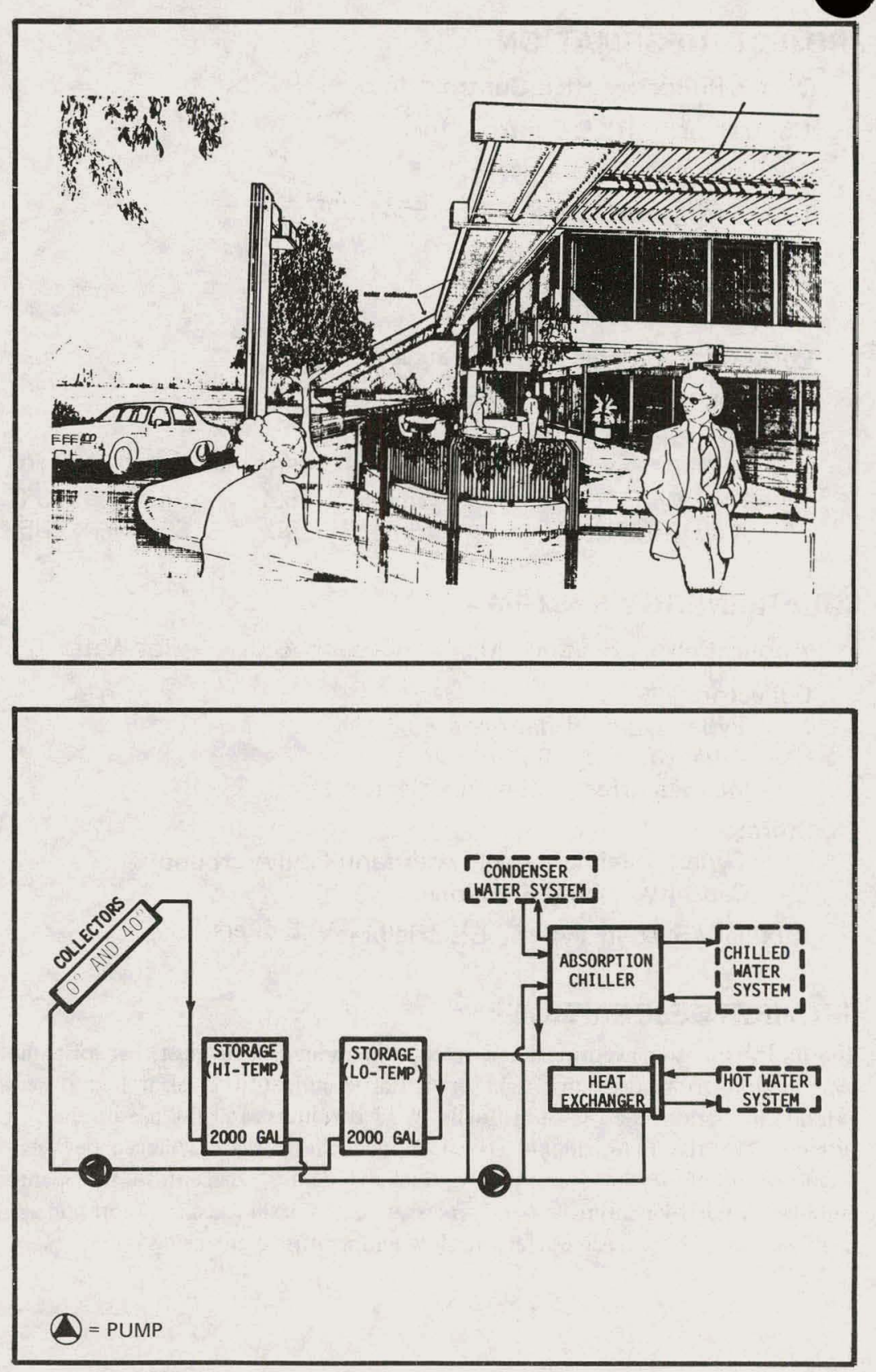


\section{PROJECT INFORMATION}

Owner/Builder: RKL Controls, Inc.

Contractor: RKL Controls, Inc.

Operational Date: June 1978

Total Estimated DOE Funds: $\$ 541,605$

Building

Type: Manufacturing

Area: $\quad 40,000$ sq. ft.

Location: Lumberton, New Jersey

Latitude: $40.0^{\circ} \mathrm{N}$

Climatic Data

$\begin{array}{lllll}\text { Degree Days } & \text { Heating } & 4865 & \text { Cooling } & 1104 \\ \text { Avg. Temp. }\left({ }^{\circ} \mathrm{F}\right) & \text { Winter } & 45.4 & \text { Summer } & 73.0 \\ \text { Avg. Insol. (Ly/d) } & \text { Winter } & 290 & \text { Summer } & 486\end{array}$

\section{SOLAR ENERGY SYSTEM}

Application Heating 90\%

Cooling $80 \%$

Hot Water $0 \%$

Collector

Type: Liquid flat-plate

Area (sq. ft.): 6,000

Manufacturer: Sunworks, Inc.

Storage

Type: Stainless steel water tank (above ground)

Capacity: 50,000 gallons

Auxiliary System Type: Electric boiler

\section{PROJECT DESCRIPTION}

The building is a conventional one-story, cinderblock, steel post, bar joist, metal deck construction to be used for light industrial manufacturing. Heat loss is reduced by external insulation, the use of air locks on all entrances, and the use of energy recovery systems. The flat-plate, double glazed, liquid collectors are arranged between earthen berms on three separate seasonably trackable arrays adjacent to the manufacturing building. A nearby man-made pond serves as a catch basin for rain runoff and as a cooling facility to supply the basin chiller with low temperature condensing water.
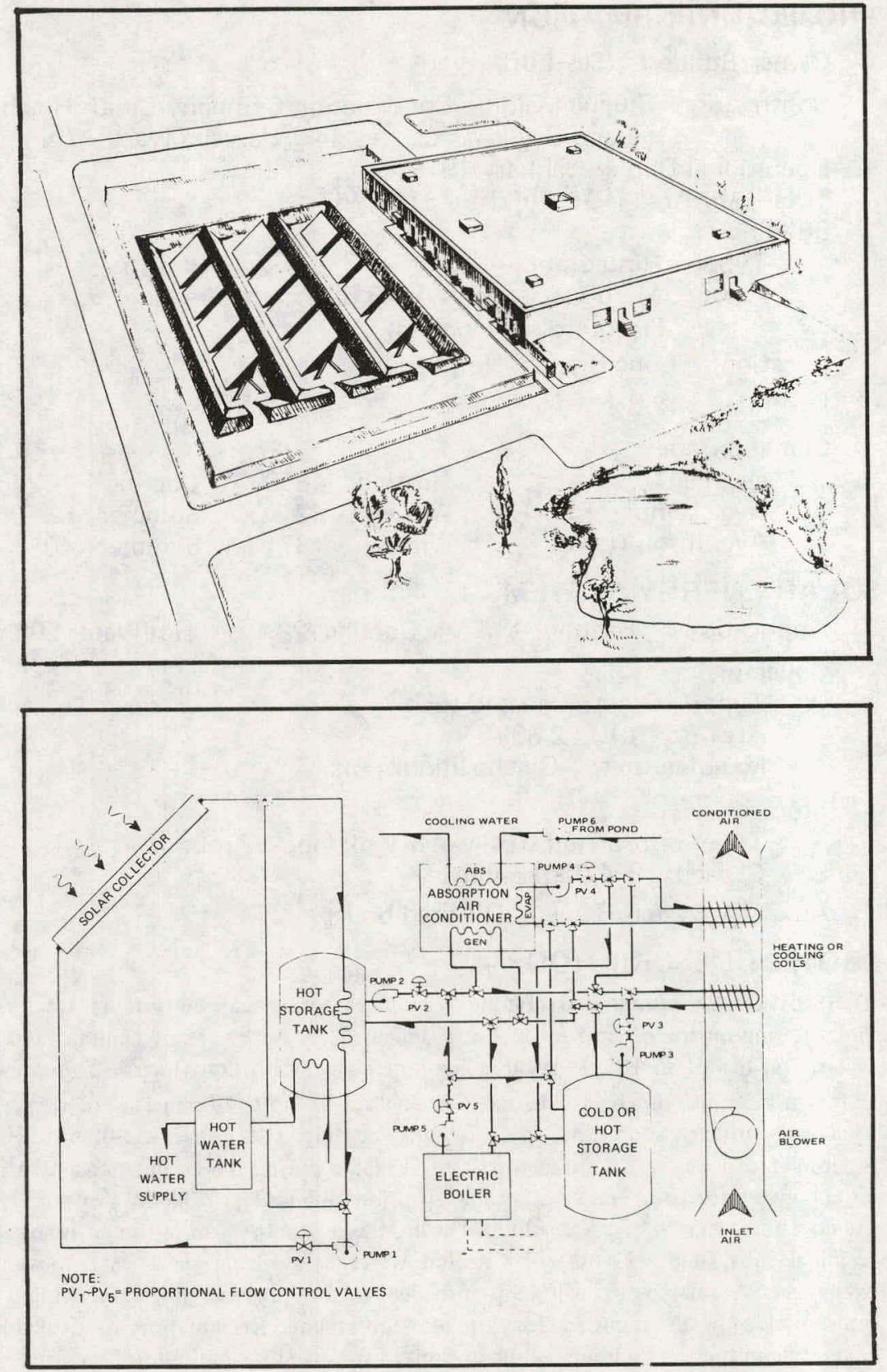


\section{PROJECT INFORMATION}

Owner/Builder: Joseph Broda

Contractor: Solar Engineering Group

Operational Date: June 1978

Total Estimated DOE Funds: $\quad \$ 44,750$

Building

Type: Low rise motel

Area: Not applicable to hot water systems

Location: Neptune, New Jersey

Latitude: $40^{\circ} \mathrm{N}$

Climatic Data

$\begin{array}{lllll}\text { Degree Days } & \text { Heating } & 4418 & \text { Cooling } & 1053 \\ \text { Avg. Temp. ( }{ }^{\circ} \mathrm{F} \text { ) } & \text { Winter } & 40.8 & \text { Summer } & 67.2 \\ \text { Avg. Insol. (Ly/d) } & \text { Winter } & 295 & \text { Summer } & 404\end{array}$

\section{SOLAR ENERGY SYSTEM}

Application Heating $0 \%$

Collector

Type: Liquid flat-plate

Area (sq. ft.): 2,205

Manufacturer: Sunworks, Inc.

Storage

Type: Insulated steel water tank

Capacity: 4,000 gallons

Auxiliary System Type: Electric

\section{PROJECT DESCRIPTION}

The proposed system consists of 105 Sunworks flat-plate collectors mounted on the roof. Hot water is stored in a 4000 -gallon tank surrounded by crushed rock in an insulated container above ground in order to provide thermal mass. The system is designed to provide $46 \%$ of the annual Btu requirements of this 78 -unit motel.
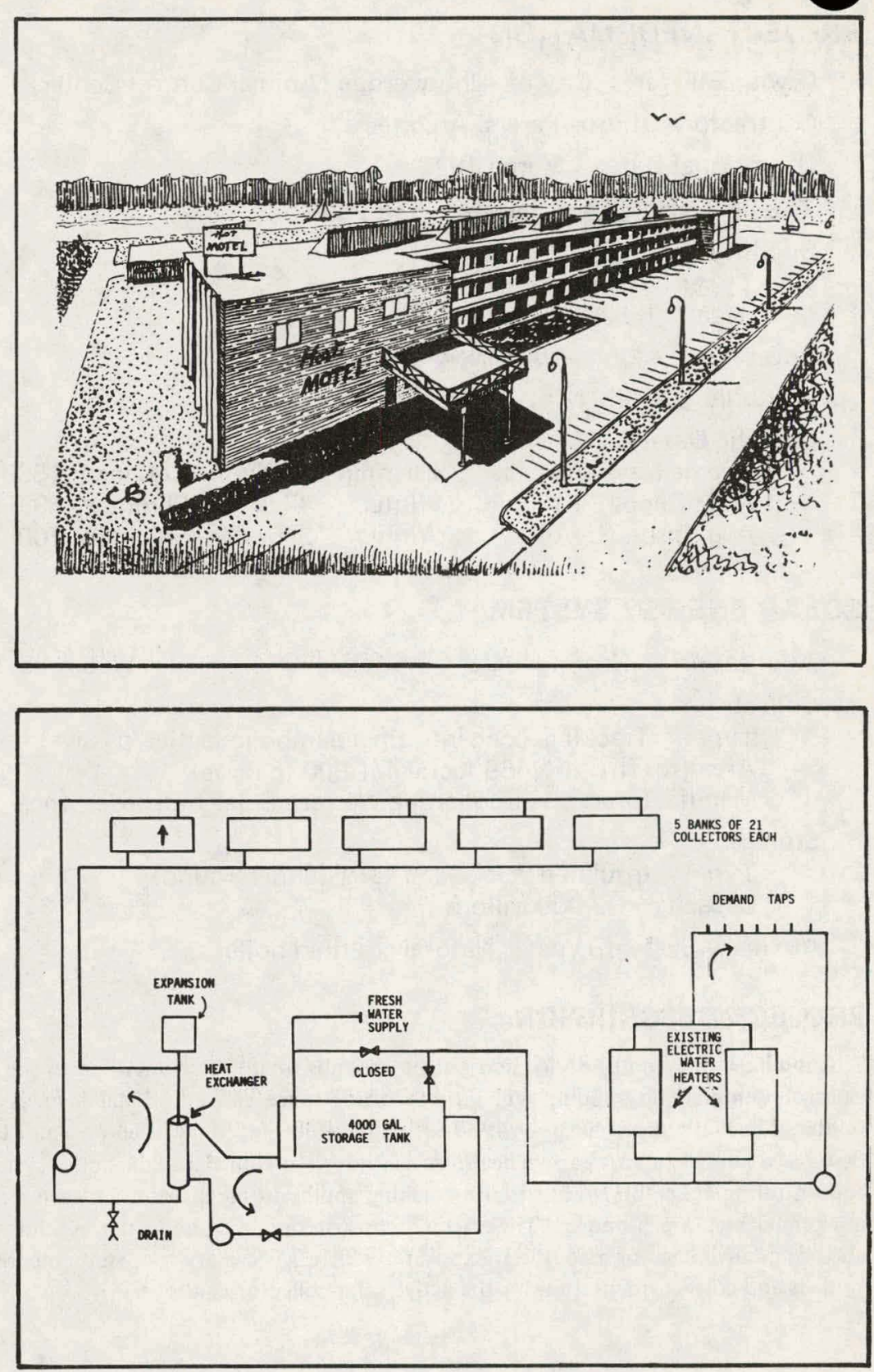


\section{PROJECT INFORMATION}

Owner/Builder: City of Albuquerque (Animal Control Center)

Contractor: Burns/Peters, Architects

Operational Date: March 1978

Total Estimated DOE Funds: $\$ 39,250$

Building

Type: Office/kennel

Area: $6,520 \mathrm{sq} . \mathrm{ft}$.

Location: Albuquerque, New Mexico

Latitude: $35.05^{\circ} \mathrm{N}$

Climatic Data

Degree Days

Avg. Temp. $\left({ }^{\circ} \mathrm{F}\right)$

Avg. Insol. (Ly/d)

$\begin{array}{llll}\text { Heating } & 4350 & \text { Cooling } & 1300 \\ \text { Winter } & 47.5 & \text { Summer } & 89.5 \\ \text { Winter } & 275 & \text { Summer } & 700\end{array}$

\section{SOLAR ENERGY SYSTEM}

Collector

Type: Tracking, concentrating, parabolic (active/passive)

Area (sq. ft.): 1,469 (active) /1,500 (passive)

Manufacturer: Albuquerque Western Solar Industries, Inc. Storage

Type: Insulated steel water tank (underground)

Capacity: 2,000 gallons

Auxiliary System Type: Natural gas fired boiler

\section{PROJECT DESCRIPTION}

This is a new building to be located on the grounds of the City of Albuquerque Animal Control Center. The building will provide office space and additional kennels for the Center. There are approximately $4980 \mathrm{sq}$. ft. of office and nonkennel area and $1540 \mathrm{sq}$. ft. of new kennel area. A passive heating system for the kennels and an active system (5:1 concentrating collectors with azimuth tracking and hydronic distribution system) for the nonkennel area are proposed. The selected construction site allows the building to take maximum advantage of a southern exposure, which is necessary for "sun-tempering" the kennels and correct orientation for the active solar collector banks.
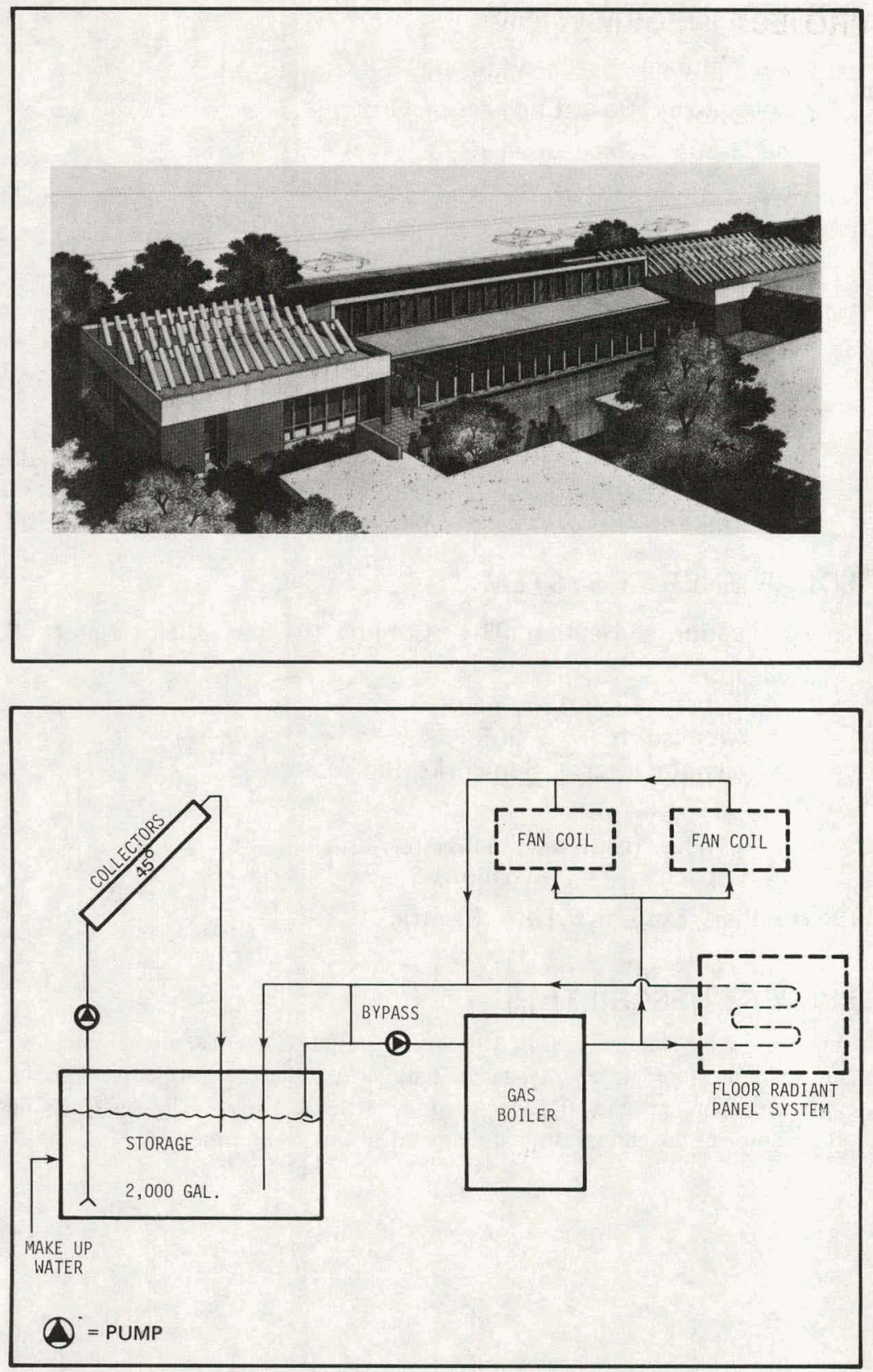


\section{PROJECT INFORMATION}

Owner/Builder: Coachlight Inn, Las Cruces, Ltd.

Contractor: Terry's Interstate, Inc.

Operational Date: April 1978

Total Estimated DOE Funds: $\quad \$ 23,204$

Building

Type: Low rise motel

Area: Not applicable to hot water systems

Location: Las Cruces, New Mexico

Latitude: $32^{\circ} \mathrm{N}$

Climatic Data

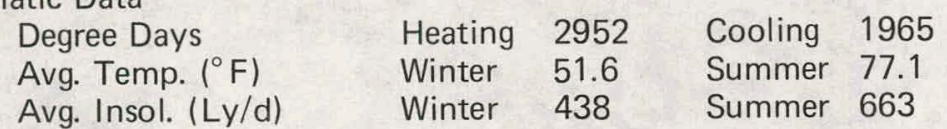

\section{SOLAR ENERGY SYSTEM}

Application Heating 0\% Cooling 0\%

Hot Water $75 \%$

Collector

Type: Liquid flat-plate

Area (sq. ft.): 1,054

Manufacturer: Solar Systems, Inc.

Storage

Type: Insulated steel water tank (above ground)

Capacity: 1,050 gallons

Auxiliary System Type: Gas fired hot water heater

\section{PROJECT DESCRIPTION}

This system is a single domestic hot water system. Three systems are used on each of the three units composing the 108 unit motel. A drain back system is used for freeze protection. Solenoid valves isolate the city water from the collectors. The system is designed to produce 3000 gallons per day at the peak on an average solar day. The collectors are supported on treated wood frames.
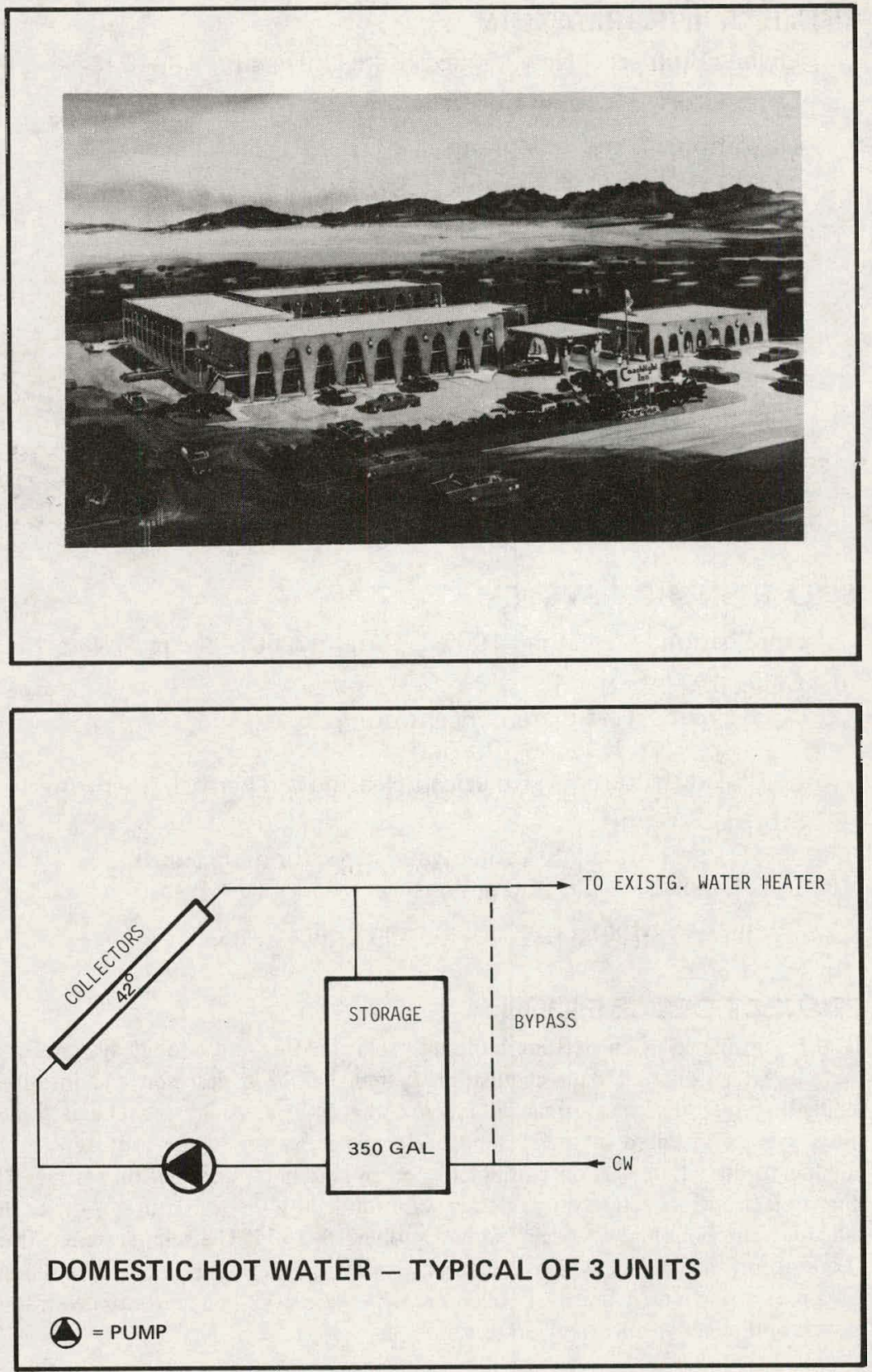


\section{PROJECT INFORMATION}

Owner/Builder: New Mexico State University

Contractor: Wooten Construction Company

Operational Date: September 1975

Total Estimated DOE Funds: $\$ 155,000$

Building

Type: Office

Area: 25,535 sq. $\mathrm{ft}$.

Location: Las Cruces, New Mexico

Latitude: $32.3^{\circ} \mathrm{N}$

Climatic Data

$\begin{array}{lllll}\text { Degree Days } & \text { Heating } & 2952 & \text { Cooling } & 1965 \\ \text { Avg. Temp. }\left({ }^{\circ} \mathrm{F}\right) & \text { Winter } & 51.6 & \text { Summer } & 77.1 \\ \text { Avg. Insol. (Ly/d) } & \text { Winter } & 438 & \text { Summer } & 663\end{array}$

\section{SOLAR ENERGY SYSTEM}

Application Heating $100 \%$ Cooling $50 \%$ Hot Water $100 \%$

Collector

Type: Flat-plate/concentrating

Area (sq. ft.): $\quad 6,190 / 540$

Manufacturer: American Heating \& Thermal/Northrup, Inc.

Storage

Type: Insulated steel water tank (underground)

Capacity: 28,000 gallons

Auxiliary System Type: Gas fired boiler

\section{PROJECT DESCRIPTION}

The performance of an existing building's solar heating and cooling system is being evaluated. An automated data acquisition system has been designed and installed, and is collecting historical performance data on the facility. Analysis includes evaluation of flow sensors installed in the system, performance testing of the prototype multiplexer/ analog to digital conversion equipment and pyranometer comparison testing. The building project and its solar system design were funded by the legislature of the State of New Mexico. The building was occupied on October 15, 1975. The solar system utilizes a large York absorption chiller which is derated to provide the required 55-ton building load. It also uses a portion of the roof collectors which are 10:1 concentrators with Fresnel lens covers and selective absorber surfaces.
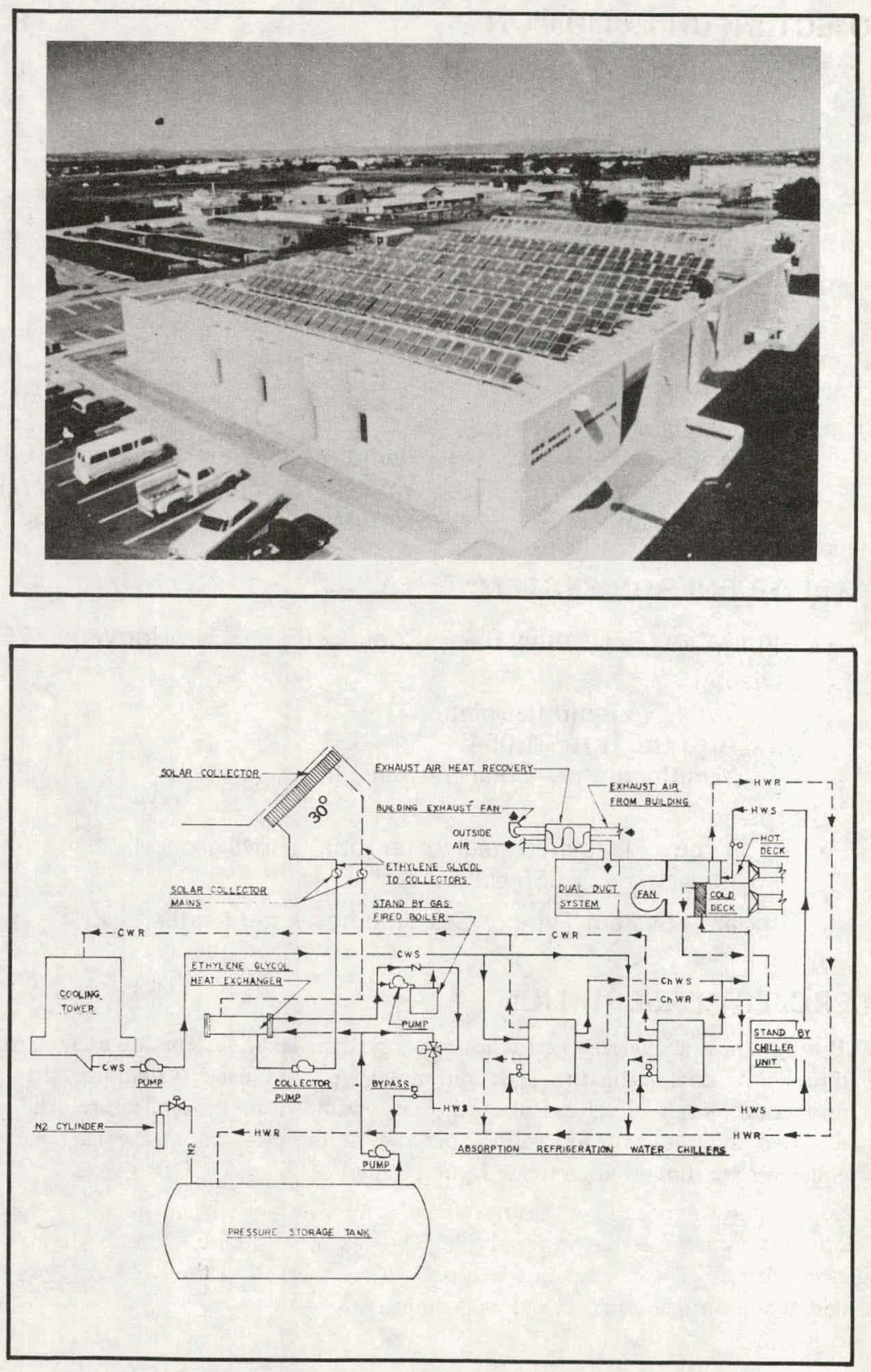


\section{PROJECT INFORMATION}

Owner/Builder: Nambe Indian Pueblo

Contractor: Los Alamos Scientific Laboratory

Operational Date: November 1977

Total Estimated DOE Funds: $\$ 113,000$

Building

Type: Community center

Area: 3,000 sq. ft.

Location: Nambe, New Mexico

Latitude: $35.9^{\circ} \mathrm{N}$

Climatic Data

$\begin{array}{lllll}\text { Degree Days } & \text { Heating } & 5760 & \text { Cooling } & 1098 \\ \left.\text { Avg. Temp. ( }{ }^{\circ} \mathrm{F}\right) & \text { Winter } & 43.7 & \text { Summer } & 70.3 \\ \text { Avg. Insol. (Ly/d) } & \text { Winter } & 394 & \text { Summer } & 645\end{array}$

\section{SOLAR ENERGY SYSTEM}

\section{Application Heating 55\% Cooling $0 \%$ Hot Water $0 \%$}

Collector

Type: Air cooled flat-plate

Area (sq. ft.): 440

Manufacturer: Los Alamos Scientific Laboratory

\section{Storage}

Type: Rock bed

Capacity: Unknown

Auxiliary System Type: Gas furnace

\section{PROJECT DESCRIPTION}

The community center building accommodates two meeting rooms and tribal offices. The architecture is in the Southwest Pueblo style and the construction is of traditional adobe. As adobe is characteristically a high mass material, the structure per se will provide considerable thermal storage. The design incorporates appropriate passive elements and a solar-assisted hot water heater. The collectors are of LASL design combining collector, insulation, and a water-tight roof into one structure. The building and solar systems are sufficiently instrumented to observe the hourly thermal response. The design analysis, building performance, and modeling results will be published in the technical press and presented at appropriate seminars and workshops.
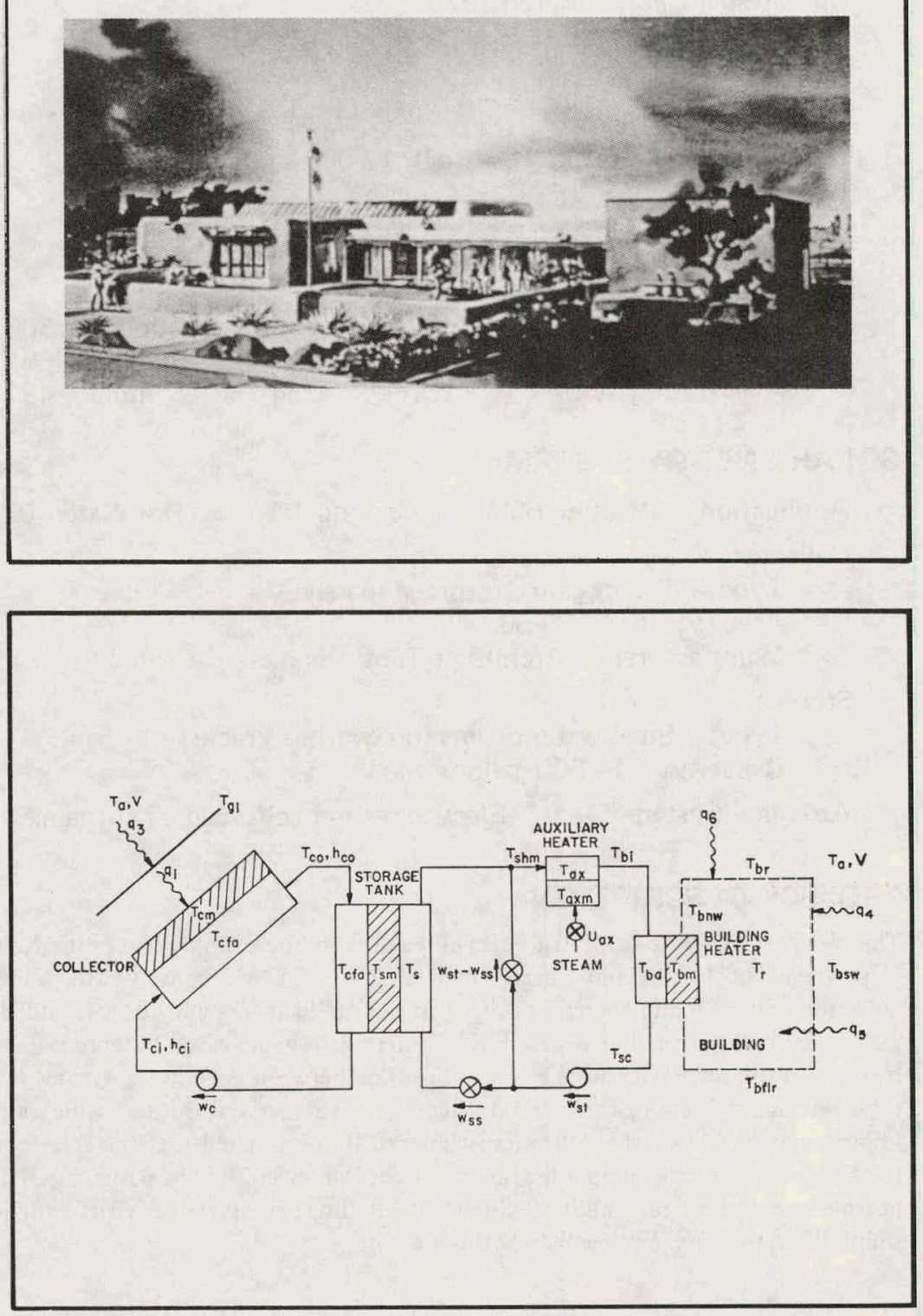


\section{PROJECT INFORMATION}

Owner/Builder: State of New Mexico Property Control Division Contractor: Architects Taos, Architect

Operational Date: March 1978

Total Estimated DOE Funds: $\$ 45,000$

\section{Building}

Type: Office

Area: 12,500 sq. ft. (total); 12,000 sq. ft. (cond.)

Location: Taos, New Mexico

Latitude: $36.5^{\circ} \mathrm{N}$

Climatic Data

Degree Days

Avg. Temp. $\left({ }^{\circ} \mathrm{F}\right)$

Avg. Insol. (Ly/d)

$\begin{array}{llll}\text { Heating } & 7000 & \text { Cooling } & 300 \\ \text { Winter } & 31 & \text { Summer } & 60 \\ \text { Winter } & 284 & \text { Summer } & 491\end{array}$

\section{SOLAR ENERGY SYSTEM}

Application Heating $50 \%$

Cooling $0 \%$

Hot Water $0 \%$

Collector

Type: Direct gain to storage (passive)

Area (sq. ft.): 2,450

Manufacturer: Architects Taos

\section{Storage}

Type: Steel water drums (on overhead racks)

Capacity: 14,500 gallons

Auxiliary System Type: Electric resistance forced air furnance

\section{PROJECT DESCRIPTION}

This nearly square, one-story structure will be used to house employees of the New Mexico Department of Health and Social Services. The solar system is passive, utilizing roof collectors which input energy and light to the office spaces and to water-filled thermal storage tanks suspended at ceiling level. System gain is increased by approximately $20 \%$ by the use of reflective surfaces on the roofing between collector apertures. Collection rates and night heat losses are controlled by servo-operated shutters which are located immediately inside of the collection windows. It is estimated that the solar system will contribute $50 \%$ of the annual heating requirec. Energy conserving design has reduced the heating energy requirements to less than 35000 Btu per sq. ft. per year, with solar gain supplying approximately one-half of this amount.
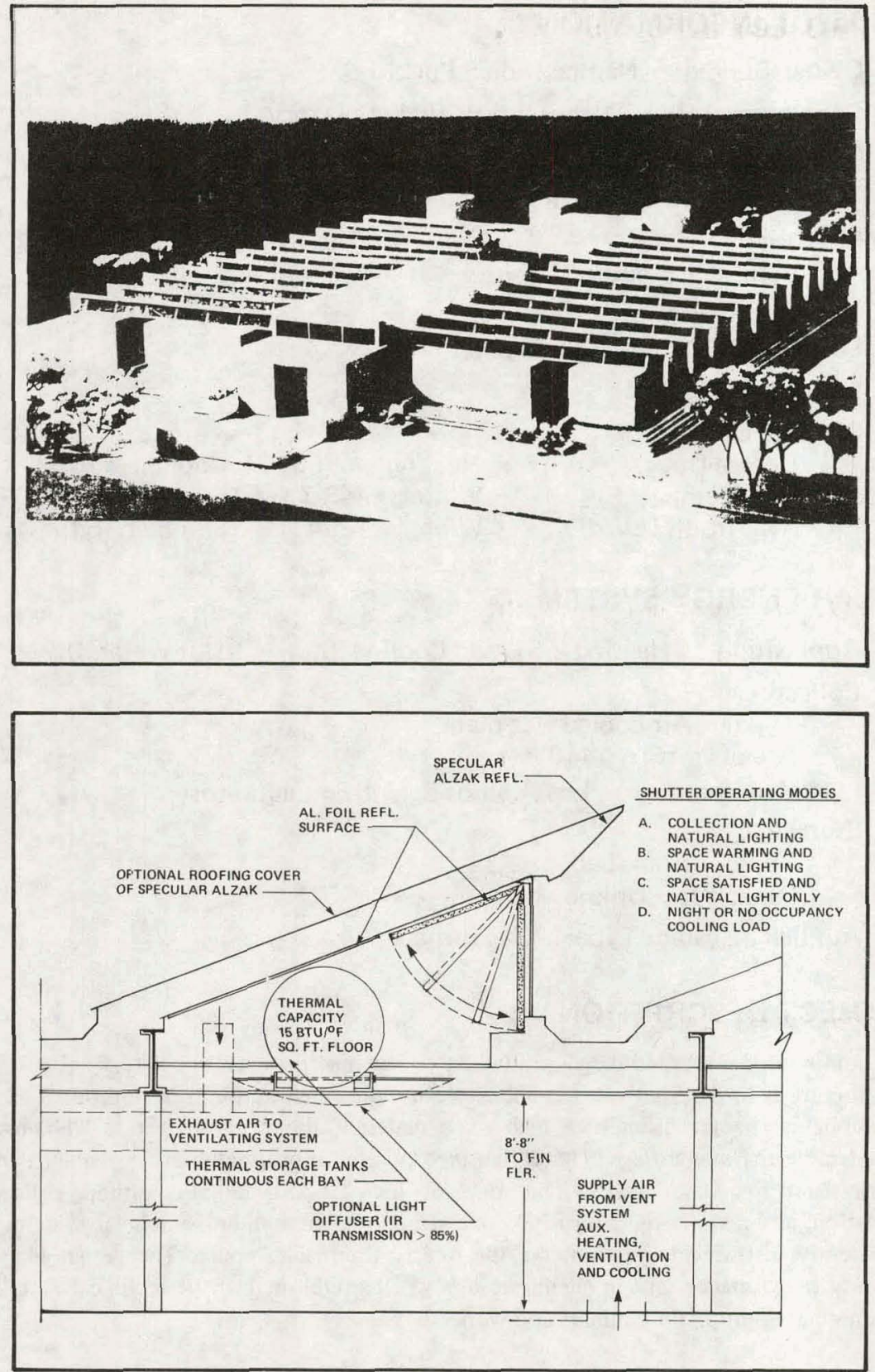


\title{
PROJECT INFORMATION
}

Owner/Builder: Ballston Spa Central School District

Contractor: Ballston Spa Central School District

Operational Date: September 1979

Total Estimated DOE Funds: $\quad \$ 470,000$

Building

Type: Middle and elementary school

Area: 144,000 sq. ft.

Location: Ballston Spa, New York

Latitude: $42.4^{\circ} \mathrm{N}$

Climatic Data

$\begin{array}{lllll}\text { Degree Days } & \text { Heating } & 6875 & \text { Cooling } & 574 \\ \left.\text { Avg. Temp. ( }{ }^{\circ} \mathrm{F}\right) & \text { Winter } & 37.5 & \text { Summer } & 67.8 \\ \text { Avg. Insol. (Ly/d) } & \text { Winter } & 388 & \text { Summer } & 385\end{array}$

\section{SOLAR ENERGY SYSTEM}

\author{
Application Heating $63.9 \%$ Cooling $0 \%$ Hot Water $87.8 \%$ \\ Collector \\ Type: Liquid flat-plate \\ Area (sq. ft.): 18,000 \\ Manufacturer: To be determined

\section{Storage} \\ Type: Insulated steel water tank (above ground) \\ Capacity: 30,000 gallons
}

Auxiliary System Type: Resistance heaters in the storage tank

\section{PROJECT DESCRIPTION}

The collectors are ground-mounted in this retrofit application. The building has a slab floor and concrete block walls with a brick veneer. Urethane insulating board under a metal panel is included on the interior walls. Energy conservation measures such as window reglazing and construction of vestibules are planned. The solar system will provide space heating from storage utilizing existing fan coil units. The control system is simplified by installing the auxiliary heater in the storage tank of this all-electric school. 


\section{PROJECT INFORMATION}

Owner/Builder: Dayton T. Brown, Inc.

Contractor: Dayton T. Brown, Inc.

Operational Date: April 1978

Total Estimated DOE Funds: $\$ \$ 129,725$

Building

Type: Office

Area: 6,600 sq. ft.

Location: Bohemia, New York

Latitude: $40^{\circ} \mathrm{N}$

Climatic Data

$\begin{array}{lllll}\text { Degree Days } & \text { Heating } & 5000 & \text { Cooling } & \text { N/A } \\ \text { Avg. Temp. }\left({ }^{\circ} \mathrm{F}\right) & \text { Winter } & 48 & \text { Summer } & \text { N/A } \\ \text { Avg. Insol. (Ly/d) } & \text { Winter } & 250 & \text { Summer } & \text { N/A }\end{array}$

\section{SOLAR ENERGY SYSTEM}

Application Heating $70 \%$

Collector

Type: Liquid flat-plate

Area (sq. ft.): 2,700 sq. ft.

Manufacturer: Sunworks, Inc.

Storage

Type: Glass lined steel water tank (underground)

Capacity: 5,000 gallons

Auxiliary System Type: Oil fired hot water boiler

\section{PROJECT DESCRIPTION}

The existing engineering offices are presently heated by hot water coils located in the air distribution system. The system will be converted to a primary source of solar energy by the installation of coils in the air distribution system which uses solar heated water. The solar design was done by Dayton T. Brown, Inc., and consists of three piping loops. A heat exchanger transfers the collected solar energy from a glycol working fluid to water, which is then stored. The stored energy is transferred to the space upon demand. A differential thermostat controls the operation of the collection/transfer loop. Proportional thermostats control the amount used from the primary and auxiliary energy sources.
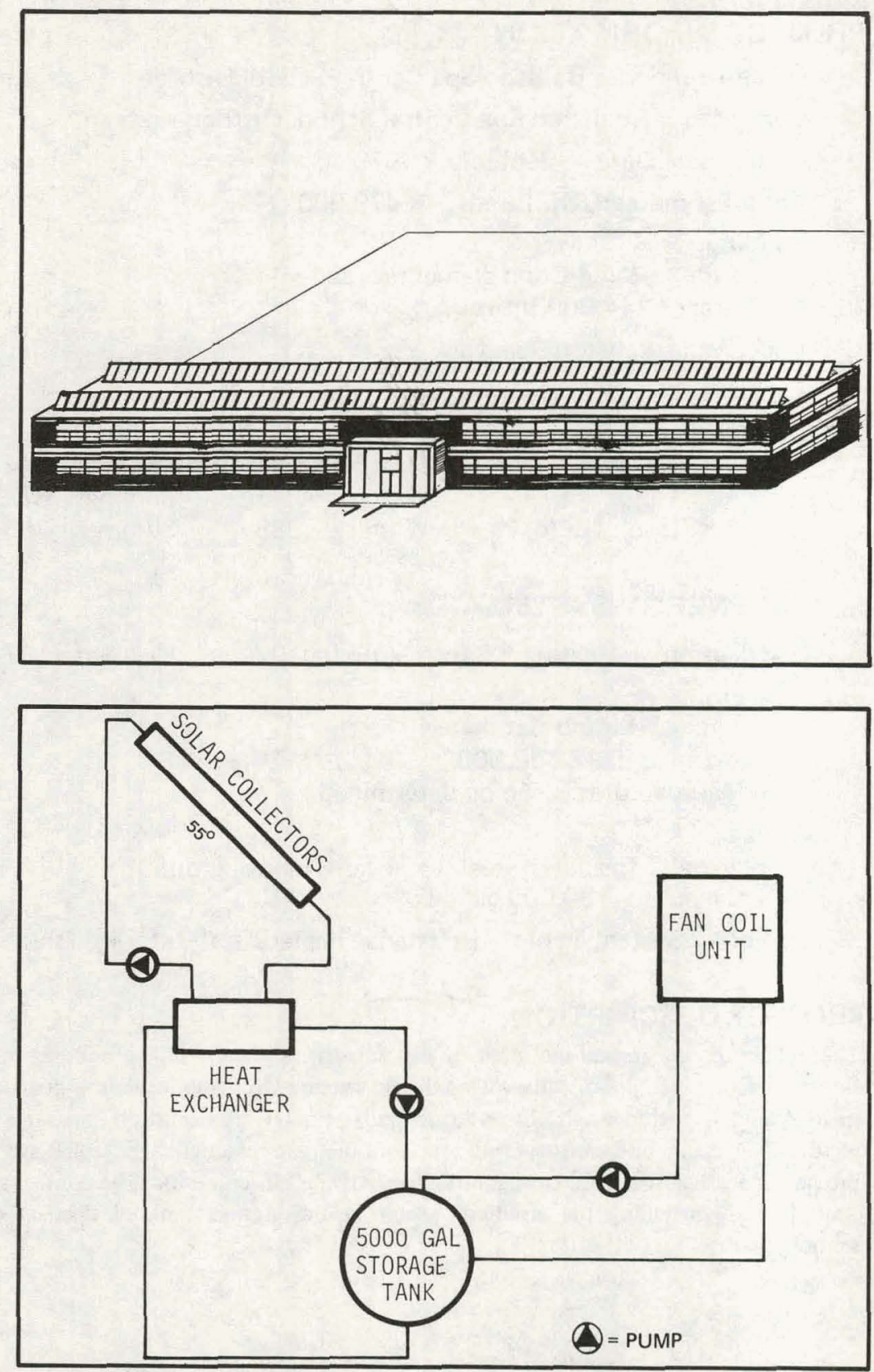


\section{PROJECT INFORMATION}

Owner/Builder: New York Botanical Garden

Contractor: John Lowry, Inc.

Operational Date: February 1978

Total Estimated DOE Funds:

$\$ 122,229$

Building

Type: Office/laboratory

Area: 27,400 sq. $\mathrm{ft}$.

Location: Millbrook, New York

Latitude: $41^{\circ} \mathrm{N}$

Climatic Data

$\begin{array}{lllll}\text { Degree Days } & \text { Heating } & 5800 & \text { Cooling } & 2800 \\ \text { Avg. Temp. }\left({ }^{\circ} \mathrm{F}\right) & \text { Winter } & 32 & \text { Summer } & 68 \\ \text { Avg. Insol. (Ly/d) } & \text { Winter } & 254 & \text { Summer } & 530\end{array}$

SOLAR ENERGY SYSTEM

Application Heating $85 \%$ Cooling $0 \%$ Hot Water $60 \%$

Collector

Type: Liquid flat-plate/concentrating glass tubular

Area (sq. ft.): $\quad 3,050 / 2,595$

Manufacturer: Chamberlain Manufacturing Corporation/ KTA Corporation

Storage

Type: Insulated concrete water tanks (partially buried)

Capacity: 15,000 gallons

Auxiliary System Type: Heat pump/well water/electric generator/ waste heat

\section{PROJECT DESCRIPTION}

This two-story structure is of massive construction to provide thermal inertia. It is partly buried underground to minimize exposed surfaces. Daylight enters the building through windows facing a covered courtyard and through "light tubes" through the sawtooth roof. The solar collector system consists of 3050 sq. ft. of collectors supplied by Chamberlain and 2595 sq. ft. of collectors provided by KTA. The seven 110' long rows of collectors are mounted on the roof of the building. Approximately $126 \mathrm{sq}$. ft. of collector area is dedicated to the domestic hot water system with the remainder for space heating. For frost protection of the collectors, a heat exchanger is installed between the collector and the storage tanks. The primary (collector) side contains an antifreeze solution of propylene glycol and water and the secondary (storage) side contains water. To use available solar energy most effectively, hot water coils in the heating units operate with a supply temperature of $100^{\circ} \mathrm{F}$ and the chiller has been designed to operate as both a heat pump and a chiller.
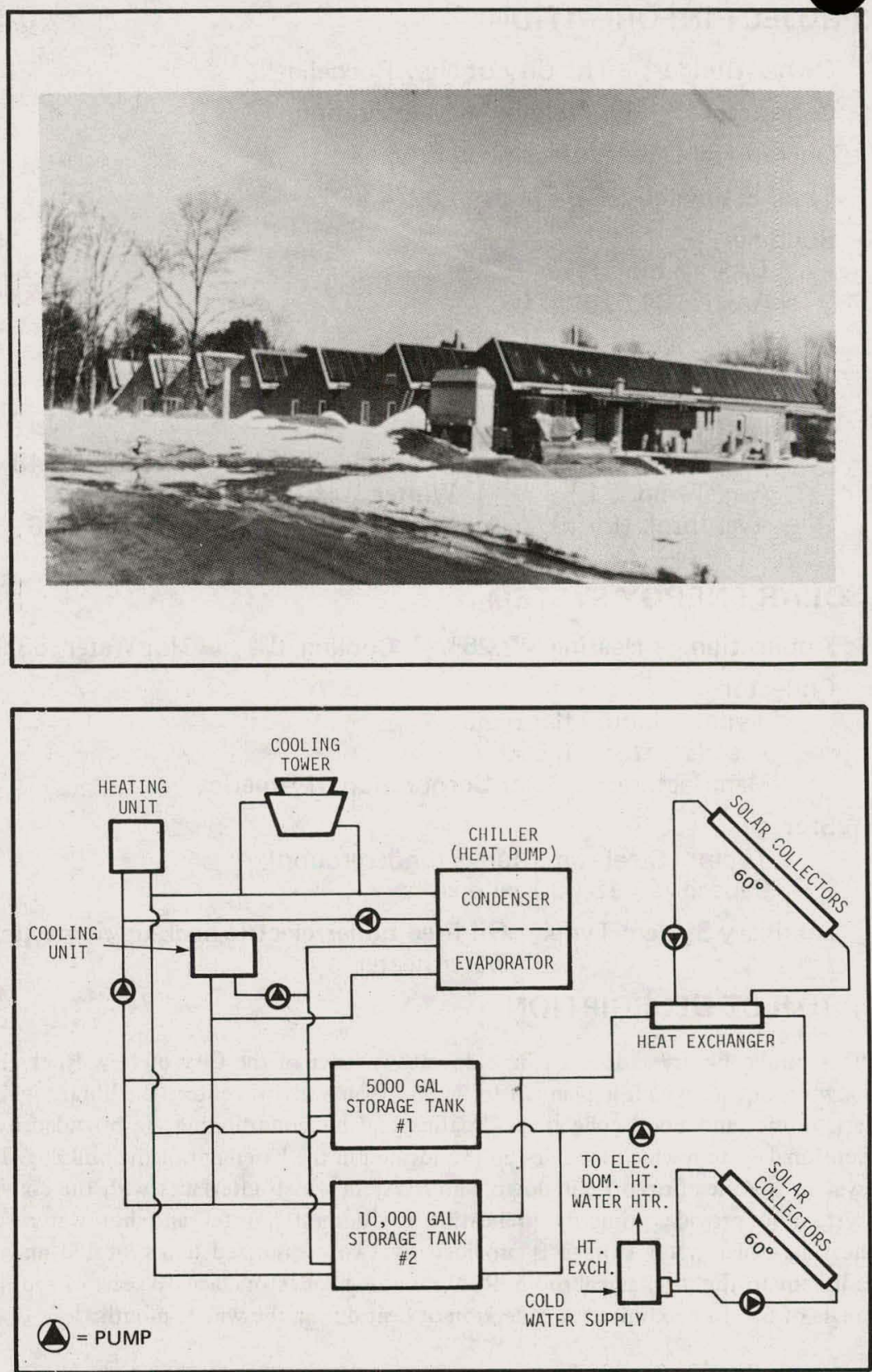


\section{r חUJECT INFORMATION}

Owner/Builder: The City of New Rochelle Contractor: InterTechnology Corporation

Operational Date: December 1978

Total Estimated DOE Funds: $\$ 274,855$

Building

Type: Library

Area: 64,020 sq. $\mathrm{ft}$.

Location: New Rochelle, New York

Latitude: $40^{\circ} 46 \mathrm{~N}$

Climatic Data

$\begin{array}{lllll}\text { Degree Days } & \text { Heating } & 4909 & \text { Cooling } & 1048 \\ \text { Avg. Temp. }\left({ }^{\circ} \mathrm{F}\right) & \text { Winter } & 40.5 & \text { Summer } & 69 \\ \text { Avg. Insol. (Ly/d) } & \text { Winter } & 248 & \text { Summer } & 456\end{array}$

\section{SOLAR ENERGY SYSTEM}

\section{Application Heating $42.26 \%$ Cooling $0 \%$ Hot Water $83.9 \%$}

Collector

Type: Liquid flat-plate

Area (sq. ft.): 6,500

Manufacturer: Solar Corporation of America

Storage

Type: Steel water tanks (underground)

Capacity: 15,000 gallons

Auxiliary System Type: Oil fired boiler/electric back-up domestic water heater

\section{PROJECT DESCRIPTION}

This public library is located in a downtown area of the City of New Rochelle called Lawton Square which is planned to be an urban activity center. The library will include art, music, and book collections. Heating and air conditioning are provided by a conventional system which includes boilers located in the basement of the building. The solar system is a pressurized drain-down water system which interfaces with the conventional system to provide primarily preheating for domestic water and hot water for space heating. Solar water storage is provided by two pressurized tanks located underground adjacent to the mechanical room. Roof-mounted collectors face $30^{\circ}$ east of south at a tilt angle of $55^{\circ}$ to maximize for collection of heat during the winter months.
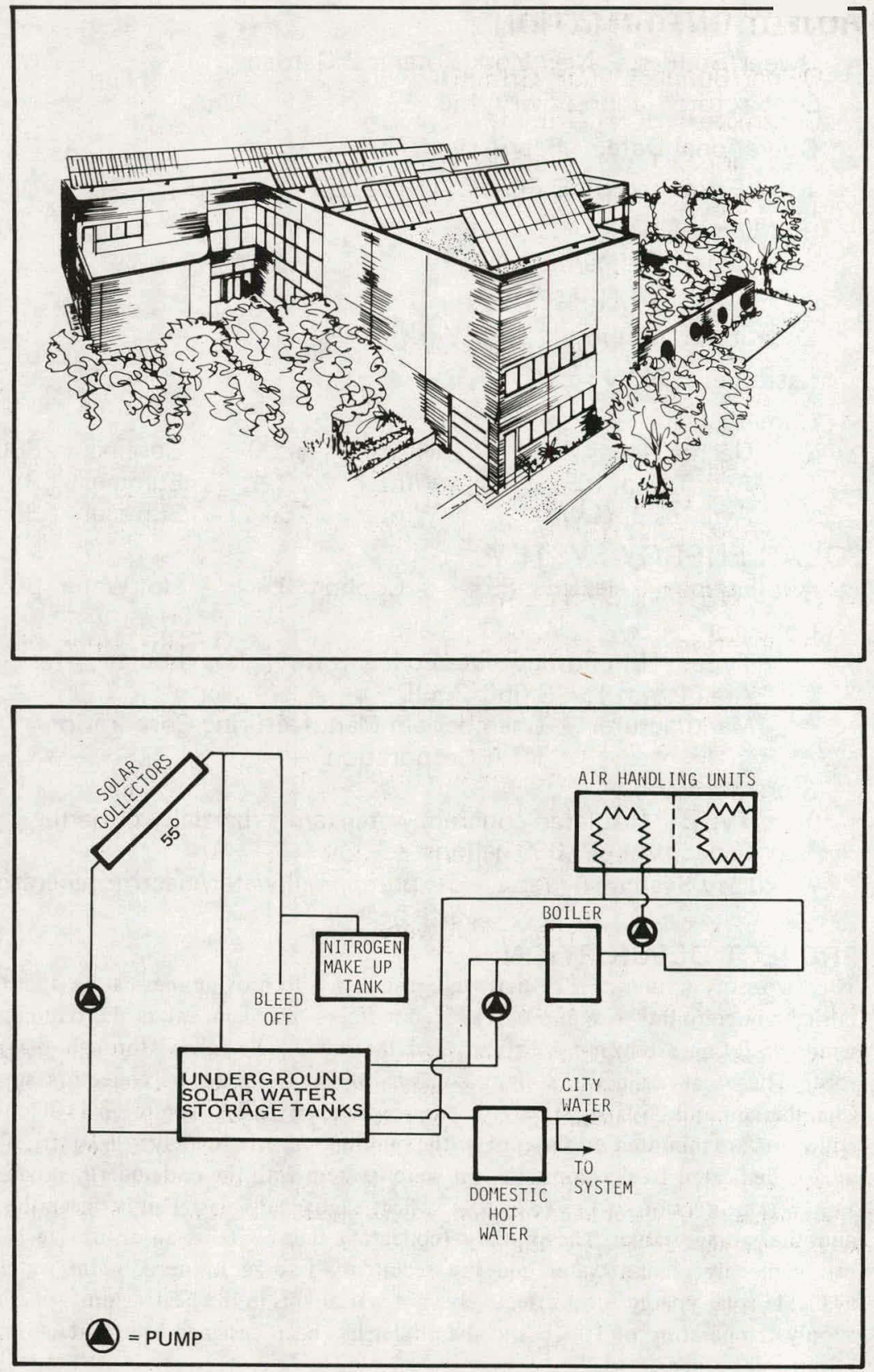


\section{PROJECT INFORMATION}

Owner/Builder: Carl Grimm

Contractor: Carl Grimm

Operational Date: October 1978

Total Estimated DOE Funds: $\quad \$ 141,632$

\section{Building}

Type: Retail

Area: 140,000 sq. ft.

Location: Troy, New York

Latitude: $45^{\circ} \mathrm{N}$

Climatic Data

$\begin{array}{lllll}\text { Degree Days } & \text { Heating } & 6875 & \text { Cooling } & \text { N/A } \\ \text { Avg. Temp. }\left({ }^{\circ} \mathrm{F}\right) & \text { Winter } & 34.6 & \text { Summer } & 69 \\ \text { Avg. Insol. (Ly/d) } & \text { Winter } & 167 & \text { Summer } & 428\end{array}$

\section{SOLAR ENERGY SYSTEM}

Application Heating 52.3\% Cooling 0\% Hot Water 0\%

Collector

Type: Liquid flat-plate

Area (sq. ft.): 10,050

Manufacturer: Lennox Industries, Inc.

\section{Storage}

Type: Glass lined water tank (above ground)

Capacity: 20,000 gallons

Auxiliary System Type: Hot water boiler

\section{PROJECT DESCRIPTION}

The solar collectors will be mounted on the roof of this two-story shopping mall located in downtown Troy. The proposed solar installation provides space heating through a solar assisted heat pump system. Potable water load will be determined when the mall is occupied and provisions have been made to couple this loop to the storage tank. If a restaurant occupies space in the mall, a full collector array can be used to meet its requirements. Covers for the collectors will be employed during warm months to avoid excessive temperatures in the array.
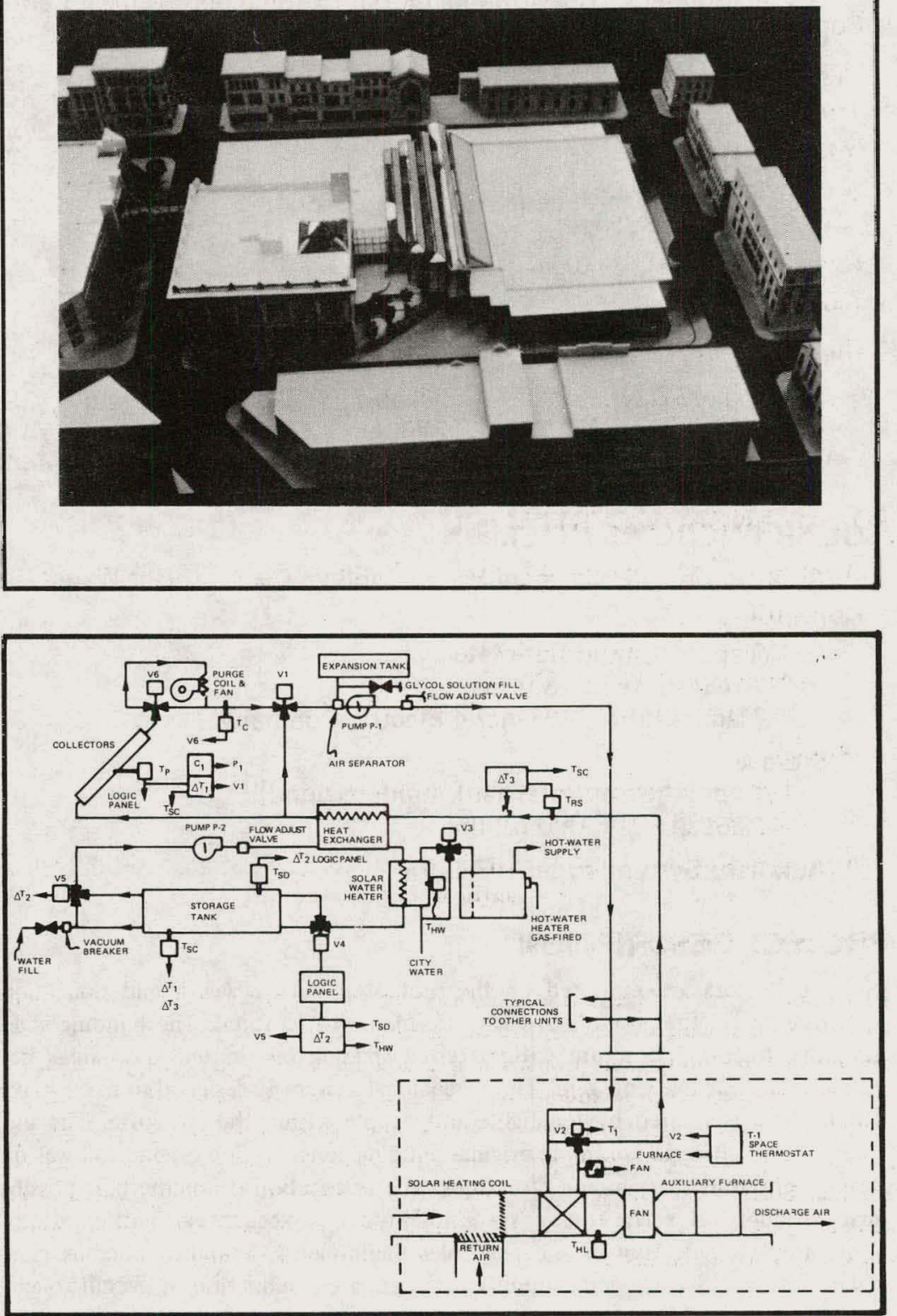


\section{PROJECT INFORMATION}

Owner/Builder: Charlotte Memorial Hospital and Medical Center Contractor: FWA Engineers, Inc.

Operational Date: July 1977

Total Estimated DOE Funds: $\quad \$ 204,515$

Building

Type: Health center/office/classroom

Area: 65,000 sq. ft.

Location: Charlotte, North Carolina

Latitude: $35.2^{\circ} \mathrm{N}$

\section{Climatic Data}

$\begin{array}{lllll}\text { Degree Days } & \text { Heating } & 3218 & \text { Cooling } & 1596 \\ \text { Avg. Temp. }\left({ }^{\circ} \mathrm{F}\right) & \text { Winter } & 50.4 & \text { Summer } & 74.6 \\ \text { Avg. Insol. (Ly/d) } & \text { Winter } & 318 & \text { Summer } & 444\end{array}$

\section{SOLAR ENERGY SYSTEM}

Application Heating $40 \%$

\section{Collector}

Type: Liquid flat-plate

Area (sq. ft.): 3,950

Manufacturer: General Electric Company

\section{Storage}

Type: Steel water tank (underground)

Capacity: 6,000 gallons

Auxiliary System Type: Electric

\section{PROJECT DESCRIPTION}

Solar collectors are mounted on the roof of the Area Health and Education Facility constructed on the grounds of Charlotte Memorial Hospital. The building is a compact, six-story high-rise structure with external shading on limited glass areas designed to reduce the heat loss and gain. The mechanical system is designed to make maximum use of the heat generated by the lights and people within the structure. The use of solar energy was not included in the original building concept. Site orientation was dictated by topography and surrounding structures. The orientation is not the best possible for the installation of a solar energy system. However, excellent insulation offered by the structure, the selection of superior solar components, and the judicious placement of solar collectors have together nullified the apparent reduction in overall solar efficiency caused by the building's orientation.
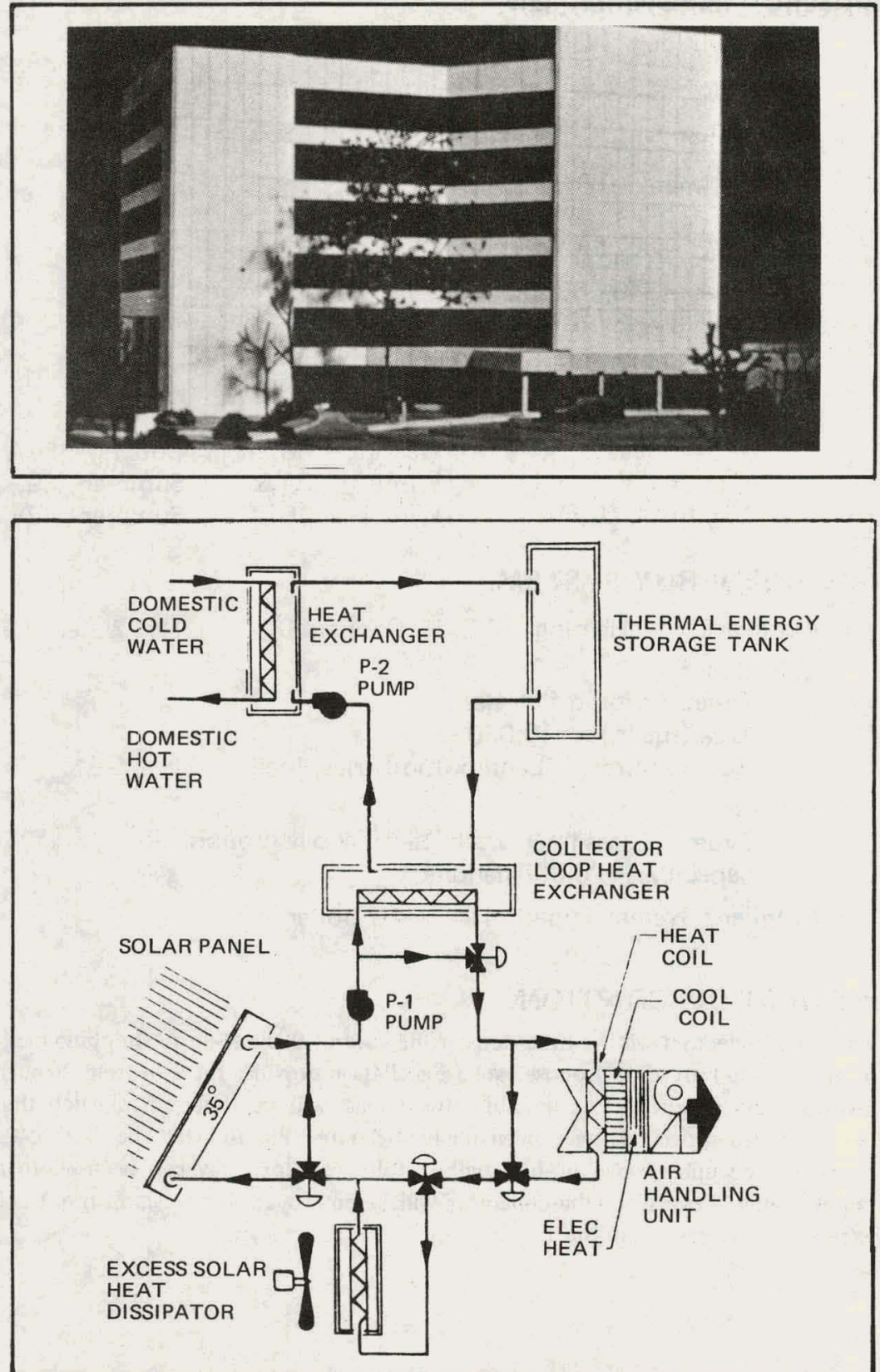


\section{PROJECT INFORMATION}

Owner/Builder: Office Parks of Charlotte, Inc.

Contractor: Solar Engineering and Equipment Company

Operational Date: March 1978

Total Estimated DOE Funds: $\quad \$ 120,929$

Building

Type: Low rise motel

Area: Not applicable to hot water systems

Location: Charlotte, North Carolina

Latitude: $35^{\circ} \mathrm{N}$

Climatic Data

Degree Days

Avg. Temp. $\left({ }^{\circ} \mathrm{F}\right)$

Avg. Insol. (Ly/d)

$\begin{array}{llll}\text { Heating } & 3345 & \text { Cooling } 1486 \\ \text { Winter } & 45 & \text { Summer } 76 \\ \text { Winter } & 245 & \text { Summer } 531\end{array}$

\section{SOLAR ENERGY SYSTEM}

Application Heating $0 \%$

Cooling $0 \%$

Hot Water $95 \%$

Collector

Type: Liquid flat-plate

Area (sq. ft.): 6,318

Manufacturer: Energy Systems, Inc.

Storage

Type: Glass lined steel water tank (underground)

Capacity: 8,000 gallons

Auxiliary System Type: To be determined

\section{PROJECT DESCRIPTION}

The system consists of a series of flat-plate collectors designed for total hot water energy supply. An antifreeze solution will transfer heat, through a closed loop, to an insulated storage tank having a one day hot water requirement capacity. A differential thermostat activates the system. Cold city water is introduced into a storage tank where it will be heated via a heat exchanger. Thermo-mainwater siphon circulation pressure forces the solar-heated water into the building system.
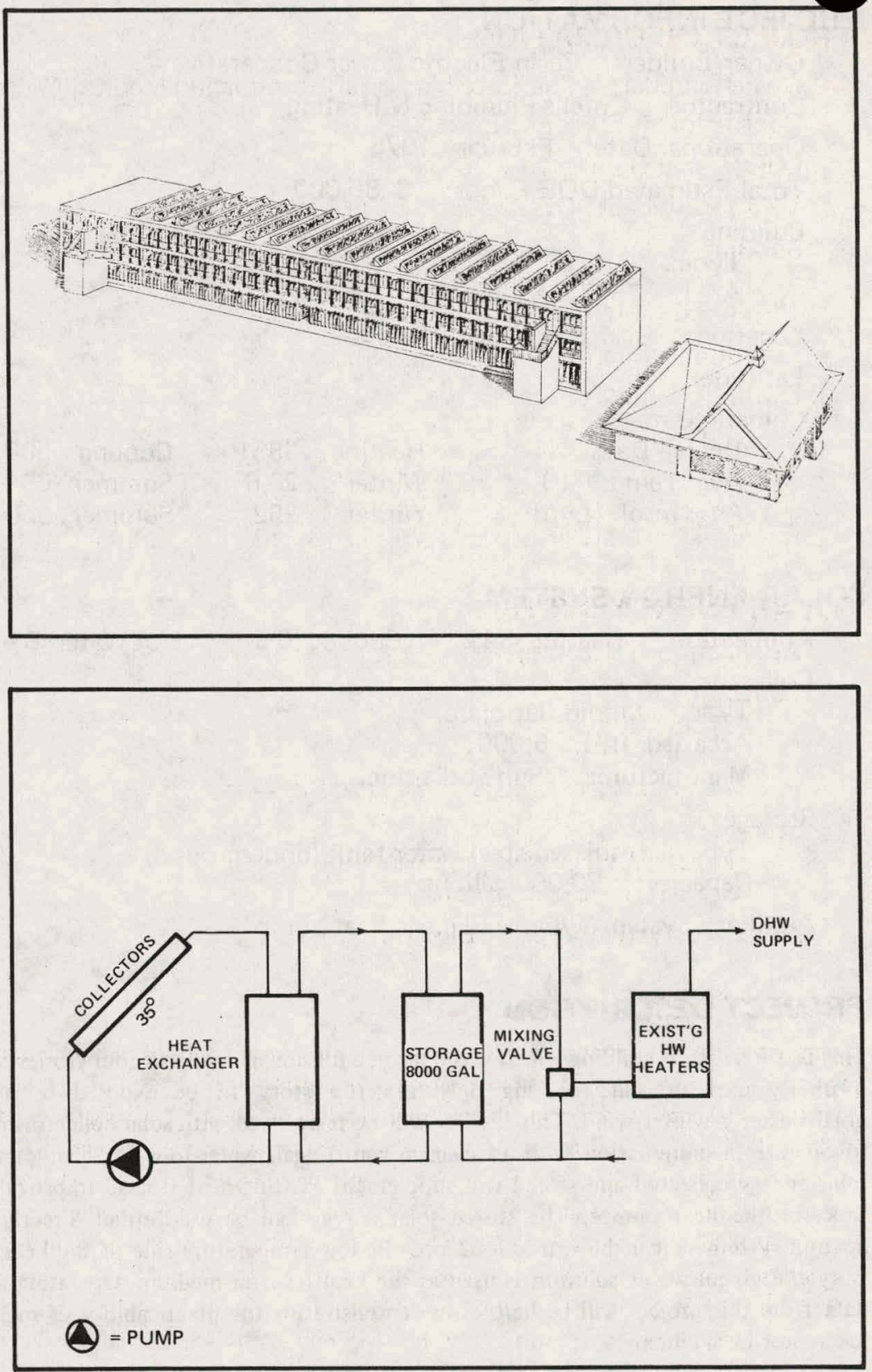


\section{RMUJECT INFORMATION}

Owner/Builder: Basin Electric Power Cooperative

Contractor: Cofells Plumbing \& Heating

Operational Date: February 1978

Total Estimated DOE Funds: $\$ 380,000$

Building

Type: Office

Area: 75,000 sq. $\mathrm{ft}$

Location: Bismarck, North Dakota

Latitude: $46^{\circ} 5^{\prime} \mathrm{N}$

Climatic Data

Degree Days

Avg. Temp. $\left({ }^{\circ} \mathrm{F}\right)$

Heating 8851

Avg. Insol. (Ly/d)

Cooling 500

Summer 65

Summer 550

\section{SOLAR ENERGY SYSTEM}

\section{Application Heating 34\% Cooling 0\% Hot Water 0\%}

\section{Collector}

Type: Liquid flat-plate

Area (sq. ft.): 5,000

Manufacturer: Sunworks, Inc.

Storage

Type: Insulated steel water tank (underground)

Capacity: 20,000 gallons

Auxiliary System Type: Electric heat pump

\section{PROJECT DESCRIPTION}

This is a four story building which was built in a hillside allowing all four stories to have a southerly exposure and causing only the top story to be exposed to prevailing northwesterly winter wind. This facility will be retrofitted with solar collectors designed to operate in conjunction with an electric centrifugal, water-to-water heat pump. The solar energy collected and stored will supplement existing heat storage to provide a heat sink for the heat pumps. The stored solar energy can be used either directly by the heating system or can be introduced into the low temperature side of the heat pumps. Ethylene glycol/water solution is used as the heat transfer medium. Operating and cost data from this project will be helpful in demonstrating the practicability of solar use in severe northern climates.
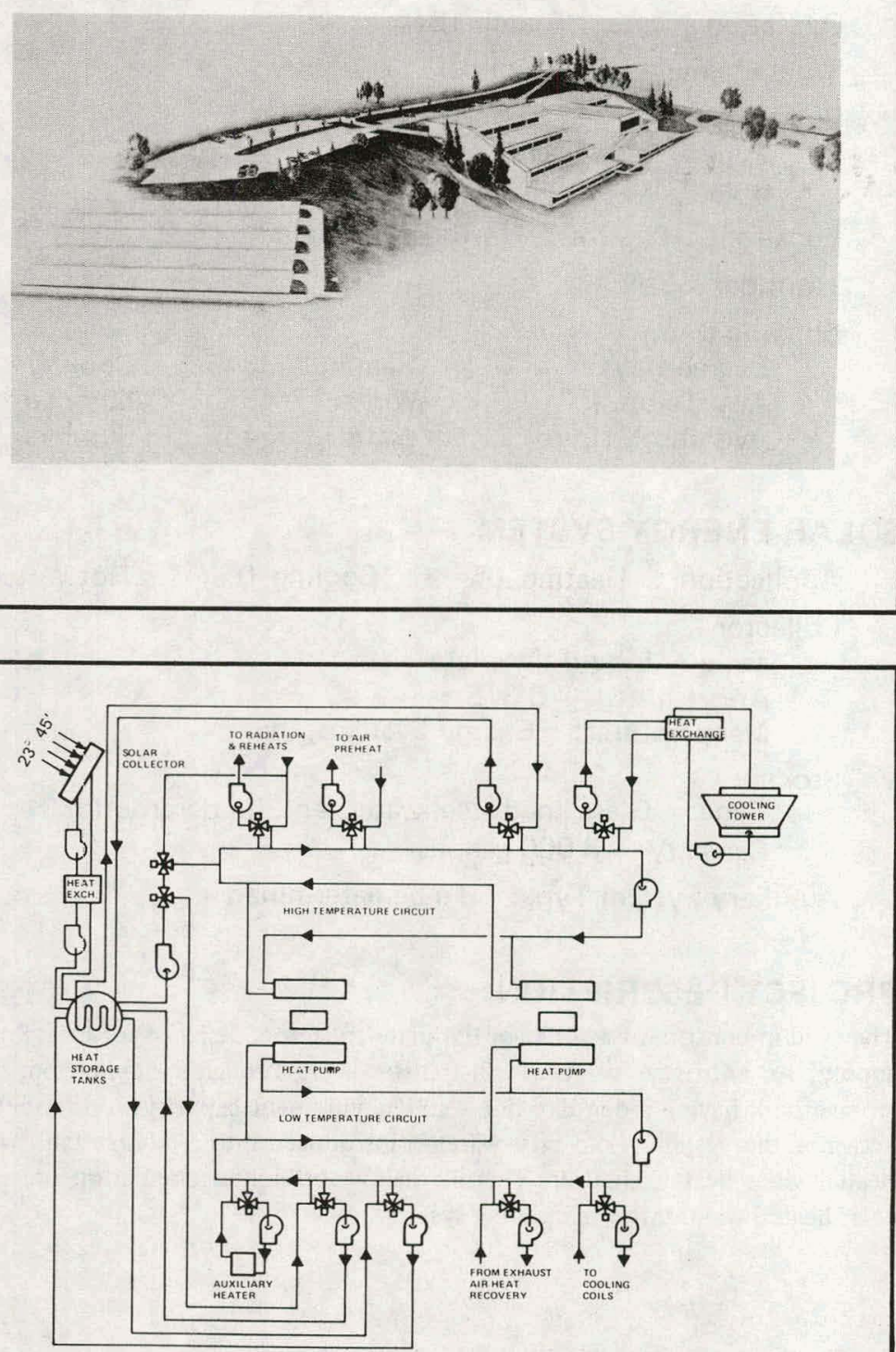


\section{PROJECT INFORMATION}

Owner/Builder: Mid-State Investment Corporation

Contractor: Mid-State Investment Corporation

Operational Date: June 1978

Total Estimated DOE Funds: $\$ 40,000$

Building

Type: High rise hote

Area: Not applicable to hot water systems

Location: Bismarck, North Dakota

Latitude: $46^{\circ} \mathrm{N}$

Climatic Data

$\begin{array}{lllll}\text { Degree Days } & \text { Heating } & 8851 & \text { Cooling } & 491 \\ \text { Avg. Temp. }\left({ }^{\circ} \mathrm{F}\right) & \text { Winter } & 10 & \text { Summer } & 85 \\ \text { Avg. Insol. (Ly/d) } & \text { Winter } & 147 & \text { Summer } & 574\end{array}$

\section{SOLAR ENERGY SYSTEM}

Application Heating $0 \%$

Collector

Type: Liquid flat-plate

Area (sq. ft.): 3,300

Manufacturer: Lennox Industries, Inc.

Storage

Type: Glass lined steel water tank (underground)

Capacity: 2,000 gallons

Auxiliary System Type: Gas fired boiler

\section{PROJECT DESCRIPTION}

Patterson Hotel was built in 1910 as an European Plan Railroad hotel. The ten-story concrete structure, the first of its kind in the upper midwest, encompasses an entire quarter city block. In June 1977 it was purchased by Mid-State Investment Corp., of Bismarck, with plans for $100 \%$ rehabilitation. It has been renamed "Patterson Place" related to a new concept; "a place to stay, eat, drink, visit, and shop." Architectually, the concept is to demonstrate the cost advantages of rehabilitating older buildings verses new construction. With a new solar domestic hot water heating system, two new $400-\mathrm{ft} / \mathrm{min}$ exterior glass elevators, a system-efficient monitored mechanical system, energy efficient designed kitchen and banquet areas, the complex is bringing much interest in the local community. Since the unveiling of the Patterson Project, it has been a catylist for the rehabilitation of downtown Bismarck to "old town Bismarck."
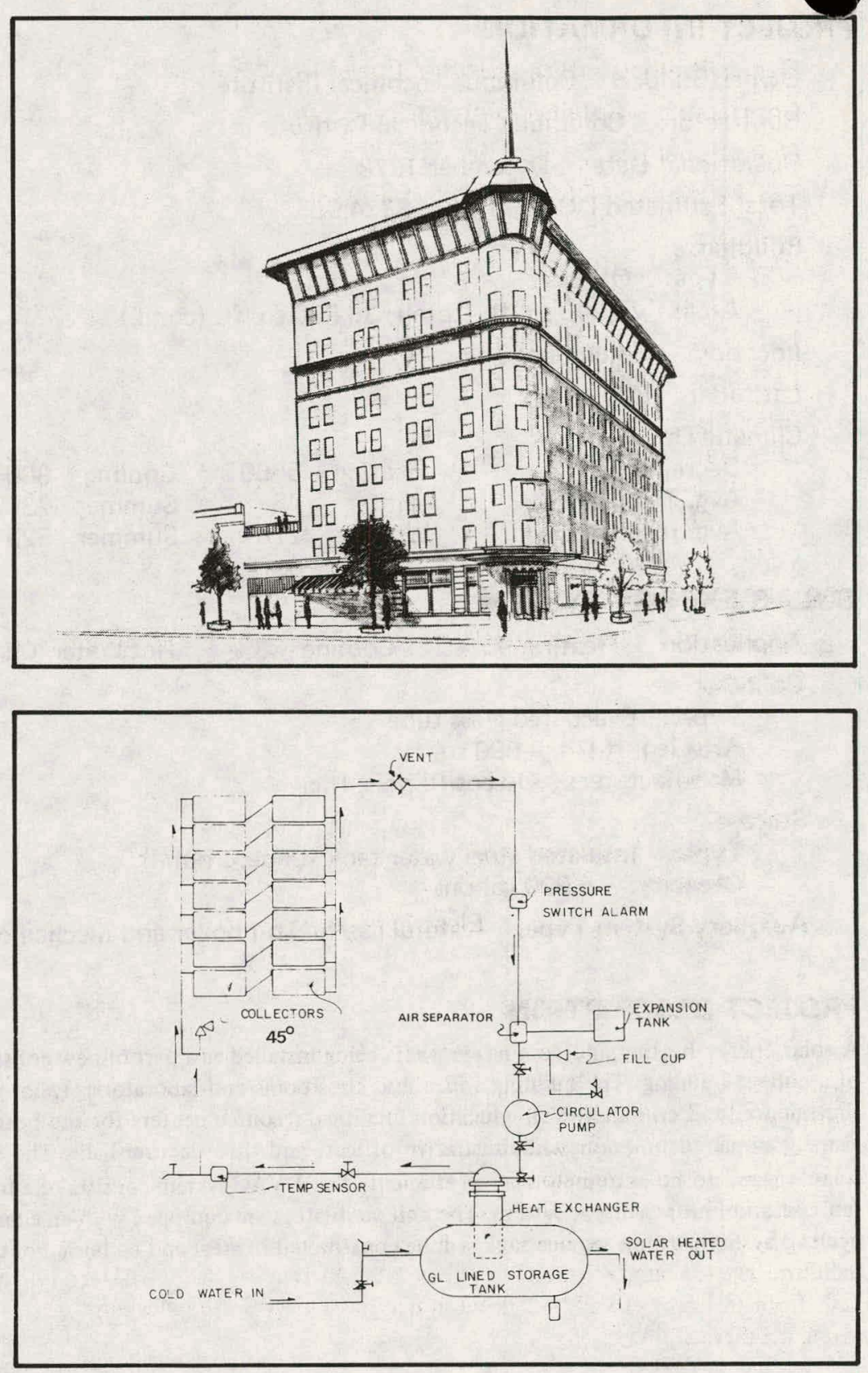


\section{PROJECT INFORMATION}

Owner/Builder: Columbus Technical Institute

Contractor: Columbus Technical Institute

Operational Date: December 1978

Total Estimated DOE Funds: $\quad \$ 334,985$

Building

Type: Offices

Area: 47,900 sq. ft. (total); 33,830 sq. ft. (cond.)

Location: Columbus, Ohio

Latitude: $40.0^{\circ} \mathrm{N}$

Climatic Data

$\begin{array}{lllll}\text { Degree Days } & \text { Heating } & 5660 & \text { Cooling } & 800 \\ \left.\text { Avg. Temp. ( }{ }^{\circ} \mathrm{F}\right) & \text { Winter } & 45 & \text { Summer } & 73 \\ \text { Avg. Insol. (Ly/d) } & \text { Winter } & 278 & \text { Summer } & 525\end{array}$

Avg. Insol. (Ly/d)

Winter 278

Summer 525

\section{SOLAR ENERGY SYSTEM}

\section{Application Heating $77 \%$ Cooling $38 \%$ Hot Water $0 \%$}

\section{Collecter}

Type: Evacuated glass tube

Area (sq. ft.): 4,096 sq. ft.

Menufacturer: Owens-Illinois, Inc.

\section{Storage}

Type: Insulated steel water tank (underground)

Capacity: 5,000 gallons

Auxiliary System Type: Natural gas/fuel oil boiler and mechanical chiller

\section{PROJECT DESCRIPTION}

A solar energy heating and cooling system is being installed as a part of new construction of a college building. The building will house classrooms and laboratories (photography, fire science, and criminalistics), education facilities, resource centers for the hearing and visually impaired programs, administrative offices, and three lecture halls. The building was designed to be extremely energy efficient. The HVAC system consists of a four-pipe fan coil and unit ventilator system. The unit ventilators are equipped with an economizer cycle. The 5000-gallon storage tank will be constructed of steel and be buried outside the building.
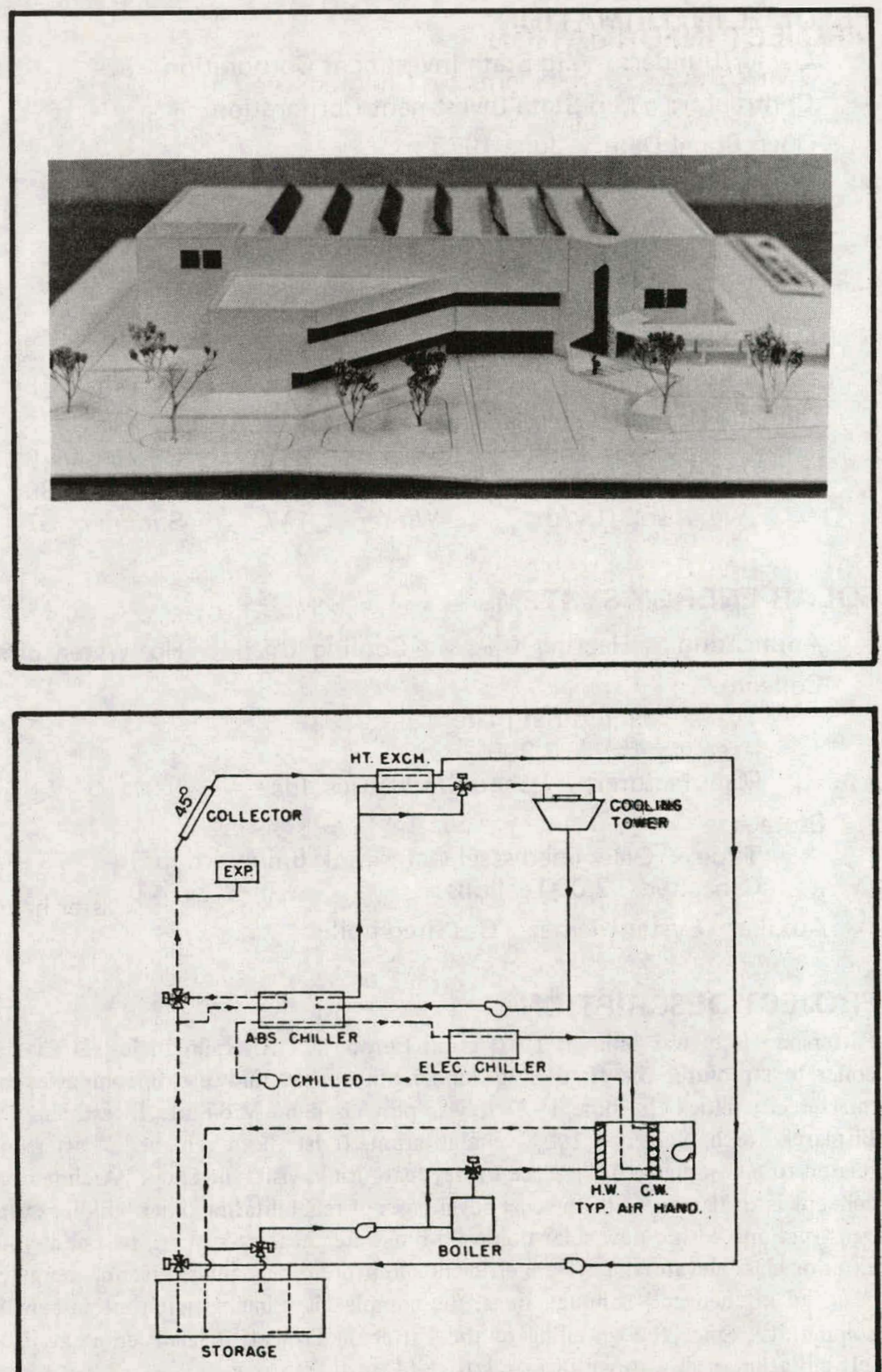


\section{PROJECT INFORMATION}

Owner/Builder: Highlights for Children, Inc.

Contractor: Columbia Gas System Service Corporation

Operational Date: July 1977

Total Estimated DOE Funds: $\quad \mathbf{\$ 2 6 5 , 5 0 8}$

Building

Type: Office

Area: 25,000 sq. $\mathrm{ft}$.

Location: Columbus, Ohio

Latitude: $40^{\circ} \mathrm{N}$

Climatic Data

$\begin{array}{lllll}\text { Degree Days } & \text { Heating } & 5700 & \text { Cooling } & 893 \\ \text { Avg. Temp. }\left({ }^{\circ} \mathrm{F}\right) & \text { Winter } & 43 & \text { Summer } & 67 \\ \text { Avg. Insol. (Ly/d) } & \text { Winter } & 220 & \text { Summer } & 460\end{array}$

\section{SOLAR ENERGY SYSTEM}

Application Heating 35\%

Cooling $26 \%$

Hot Water $78 \%$

Collector

Type: Parabolic concentrator

Area (sq. ft.): 3,000

Manufacturer: Honeywell, Inc.

Storage

Type: Insulated steel water tank (above ground)

Capacity: 5,000 gallons

Auxiliary System Type: Natural gas boiler/natural gas hot water heater

\section{PROJECT DESCRIPTION}

This building is a research project for the Columbia Gas System Service Corporation to design, install, operate, and evaluate a solar energy system for a typical three-story office building. The solar energy system being installed in the Highlights Building is designed to provide solar energy for space heating, space cooling, and domestic hot water applications. The collector array is the first installation of the Honeywell single-axis tracking concentrating collector which tracks north to south. The Honeywell collector is a north/south tracking collector with a $40: 1$ concentration ratio. The system in the Highlights Building includes 44 collector panels arranged in 11 rows with a total field area of approximately $3000 \mathrm{sq}$. ft. The primary loop heat transfer fluid is a Dowtherm SR1/Water Solution. The storage system consists of a 5000-gallon ASME pressure vessel located in an addition to the existing building. The fluid in the secondary loop and storage system is a Mogul 0-301/Water Solution, and the maximum temperature of the heated storage water is $220^{\circ} \mathrm{F}$.

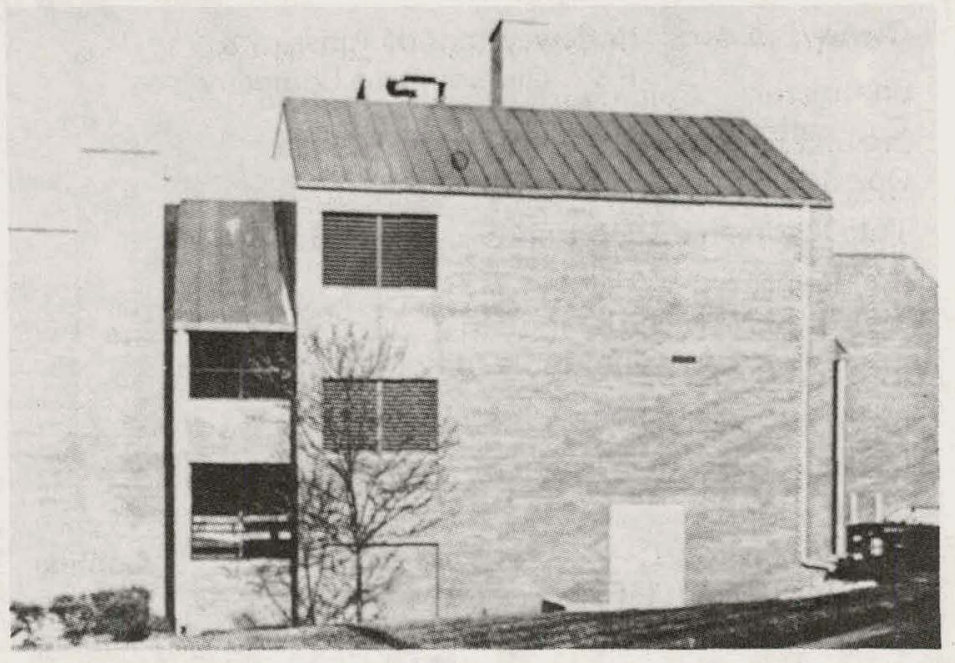

(East)

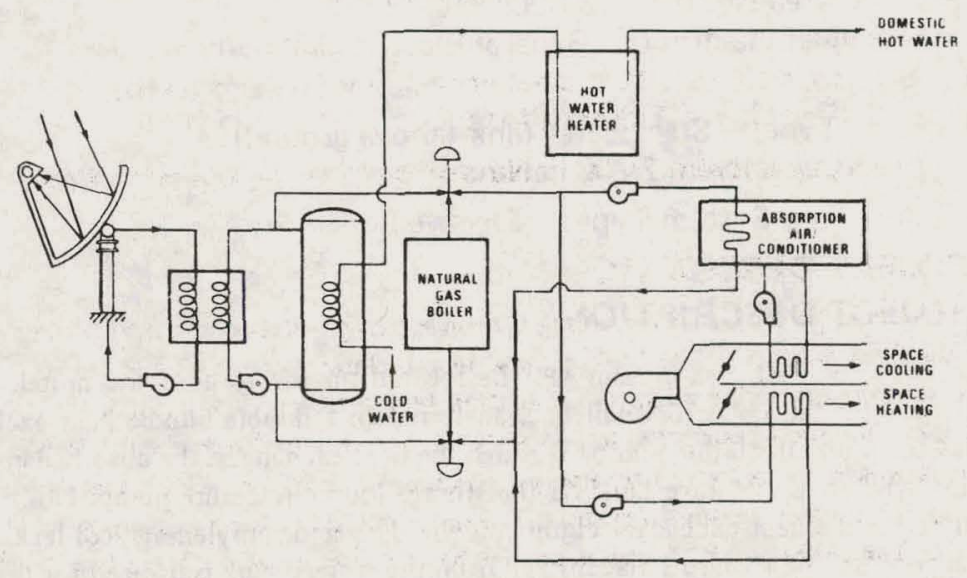




\section{...JJECT INFORMATION}

Owner/Builder: Rodeway Inns of America \&

R. V. Development Company

Contractor: Charter Builders, Inc.

Operational Date: July, 1978

Total Estimated DOE Funds: $\quad \$ 79,253$

Building

Type: High rise motel

Area: Not applicable to hot water systems

Location: Columbus, Ohio

Latitude: $40^{\circ} \mathrm{N}$

Climatic Data

Degree Days

Avg. Temp. $\left({ }^{\circ} \mathrm{F}\right)$

Avg. Insol. (Ly/d)

$\begin{array}{llll}\text { Heating } & 5427 & \text { Cooling } & 1147 \\ \text { Winter } & 33 & \text { Summer } & 76 \\ \text { Winter } & 225 & \text { Summer } & 429\end{array}$

\section{SOLAR ENERGY SYSTEM}

Application Heating $0 \%$

Cooling $0 \%$

Hot Water $52 \%$

Collector

Type: Evacuated tubes

Area (sq. ft.): 3,000

Manufacturer: General Electric Company

\section{Storage}

Type: Steel water tank (above ground)

Capacity: 2,700 gallons

Auxiliary System Type: Electric boiler

\section{PROJECT DESCRIPTION}

The collectors for this system will be located on the roof of the motel. The energy collected by the collectors will be transferred to a double bundle heat exchanger via a collector loop circulating pump. Through the heat exchanger, the absorbed energy will be transferred to the storage tank via the storage loop circulating pump. Utilization of the double bundle heat exchanger eliminates the danger of ethylene glycol leakage from the solar loop to the storage tank. Energy from the storage tank is utilized for the motel potable water and laundry.
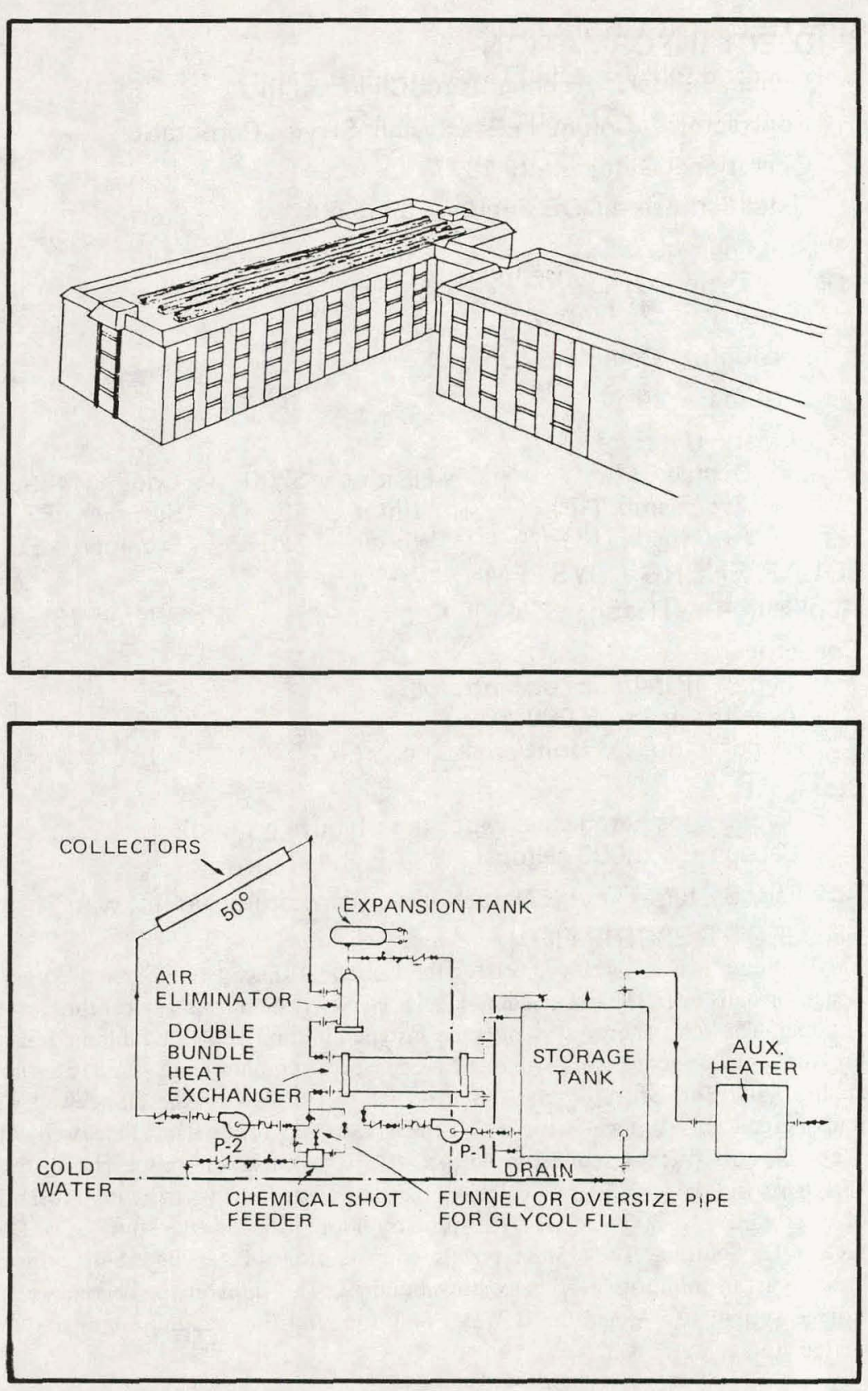


\section{PROJECT INFORMATION}

Owner/Builder: Ohio Department of Natural Resources

Contractor: PDT, Inc.

Operational Date: December 1979

Total Estimated DOE Funds: $\quad \$ 180,000$

Building

Type: Low rise lodge

Area: 135,000 sq. ft.

Location: Deer Creek Park, Ohio

Latitude: $40^{\circ} \mathrm{N}$

Climatic Data

Degree Days

Avg. Temp. $\left({ }^{\circ} \mathrm{F}\right)$

Avg. Insol. (Ly/d)

$\begin{array}{llll}\text { Heating } & 5221 & \text { Cooling } & 852 \\ \text { Winter } & 36 & \text { Summer } & 67.7 \\ \text { Winter } & 264 & \text { Summer } & 392\end{array}$

\section{SOLAR ENERGY SYSTEM}

Application Heating 20.8\%

Cooling $0 \%$

Hot Water $58.8 \%$

\section{Collector}

Type: Liquid flat-plate

Area (sq. ft.): $\quad 10,000$

Manufacturer: Revere Copper \& Brass, Inc.

Storage

Type: Insulated steel water tanks (underground)

Capacity: 20,000 gallons

Auxiliary System Type: Electric fired boiler

\section{PROJECT DESCRIPTION}

A 10000 sq. ft. collector system shall be integrated into the south-facing roof. The system shall be drain-down type, requiring no antifreeze. Water for the swimming pool and domestic hot water shall be preheated via heat exchangers located in the storage tank. When excess heat is available from the solar system, it will be utilized by the water source heat pumps for space heating. Existing electric boilers shall provide the auxiliary energy.
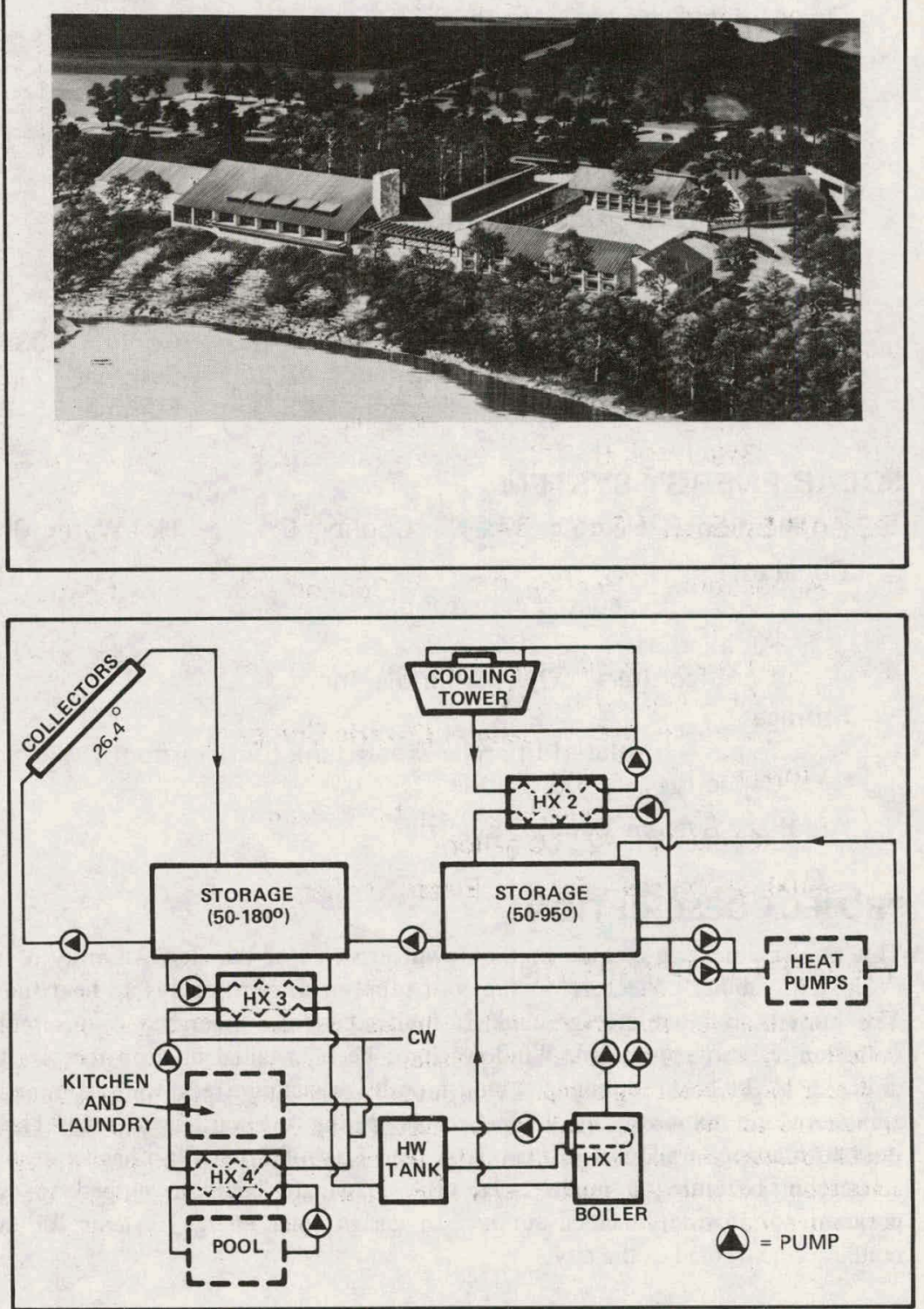


\section{RMUJECT INFORMATION}

Owner/Builder: Troy-Miami County Public Library

Contractor: Richard Levin Associates, Inc.

Operational Date: October 1977

Total Estimated DOE Funds: $\quad \$ 272,896$

Building

Type: Library

Area: 23,000 sq. ft.

Location: Troy, Ohio

Latitude: $40.0^{\circ} \mathrm{N}$

Climatic Data

Degree Days

Avg. Temp. $\left({ }^{\circ} \mathrm{F}\right)$

Avg. Insol. (Ly/d)

$\begin{array}{llll}\text { Heating } & 5641 & \text { Cooling } & 936 \\ \text { Winter } & 42.3 & \text { Summer } & 71.3 \\ \text { Winter } & 287 & \text { Summer } & 519\end{array}$

\section{SOLAR ENERGY SYSTEM}

Application Heating $67 \%$

Hot Water $0 \%$

Collector

Type: Evacuated glass tubular

Area (sq. ft.): 3,264

Manufacturer: Owens-IIlinois, Inc.

Storage

Type: Insulated fiberglas water tank (underground)

Capacity: 5,000 gallons

Auxiliary System Type: Electric

\section{PROJECT DESCRIPTION}

This public library is located in the downtown area of the city. An array of advanced, evacuated, tubular collectors on the roof supply sufficient energy to heat the building. The buried insulated storage tank is fabricated from fiberglass to insure long-term corrosion-resistant operation. Windows have been installed in deep recesses to reduce direct heat build-up during summer months. Existing trees were trimmed to give maximum sun exposure to the collectors during the various seasons. The ratio of glass to masonry walls is less than $20 \%$. The City of Troy, Ohio has expressed serious interest in becoming a model solar city. Plans are being developed to establish a program to provide financial support to design solar energy systems for every new building constructed in the city.
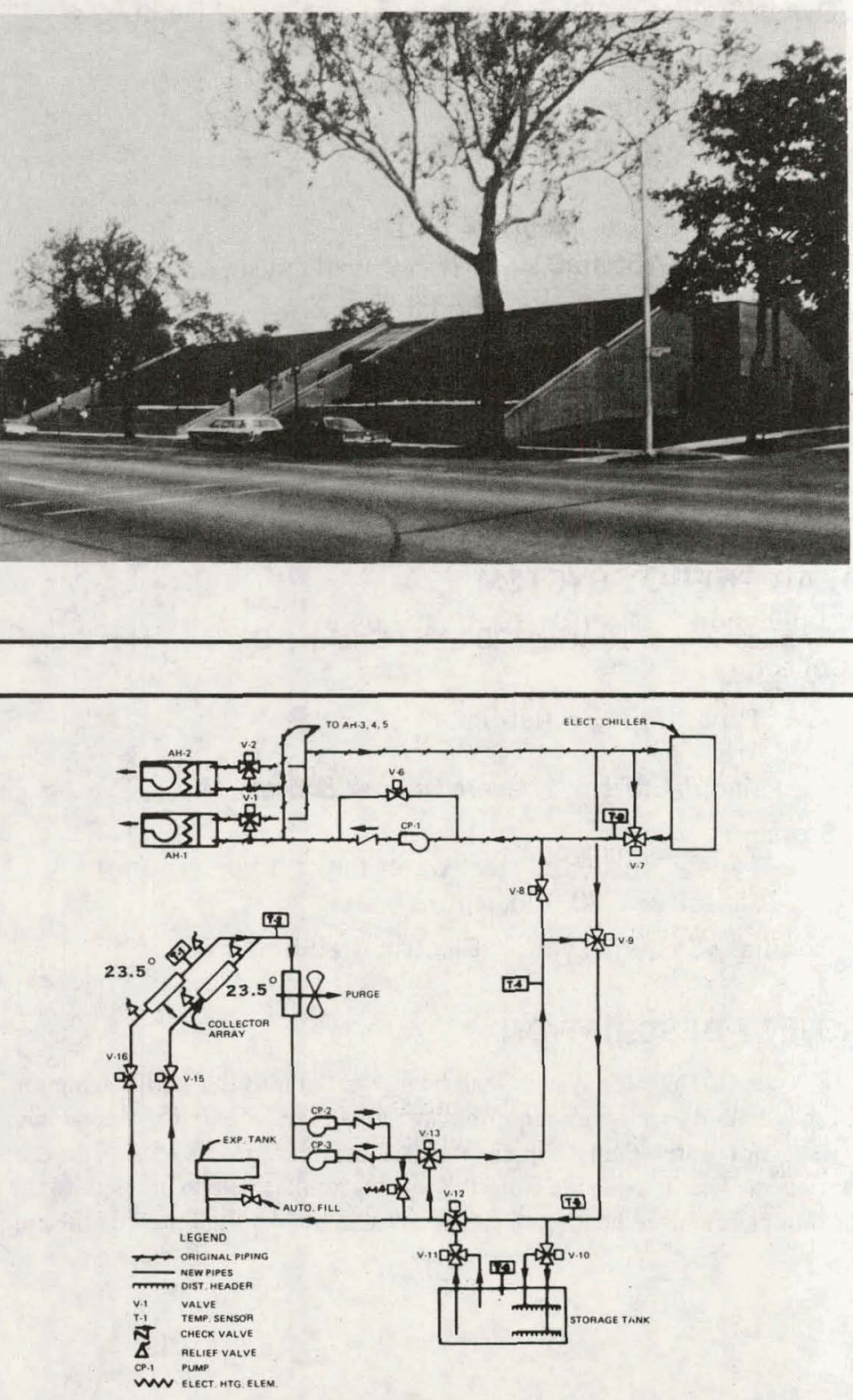


\section{PROJECT INFORMATION}

Owner/Builder: Oklahoma Department of Tourism and Recreation Contractor: John Buckley

Operational Date: October 1978

Total Estimated DOE Funds: $\$ \mathbf{4 7 , 4 0 0}$

Building

Type: Low rise hotel

Area: Not applicable to hot water systems

Location: Kingston, Oklahoma

Latitude: $35^{\circ} \mathrm{N}$

Climatic Data

$\begin{array}{lllll}\text { Degree Days } & \text { Heating } & 3800 & \text { Cooling } 1800 \\ \text { Avg. Temp. }\left({ }^{\circ} \mathrm{F}\right) & \text { Winter } & 45 & \text { Summer } & 73 \\ \text { Avg. Insol. (Ly/d) } & \text { Winter } & 415 & \text { Summer } & 488\end{array}$

\section{SOLAR ENERGY SYSTEM}

Application Heating 0\% Cooling 0\%

Collector

Type: Liquid flat-plate

Area (sq. ft.): 2,248

Manufacturer: Daystar Corporation

Storage

Type: Steel water tank (above ground)

Capacity: 4,160 gallons

Auxiliary System Type: Fuel oil

\section{PROJECT DESCRIPTION}

This system is intended to replace the existing hot water heating system. The present oi fired boilers are not very energy efficient, as they must be fired all year long. Excess solar heat will be used for space heating. Supply water will be preheated by a liquid-to-liquid heat exchanger during the summer and by an air-to-water heat exchanger in the boiler exhaust flue in the winter. A recirculation loop improves system efficiency.
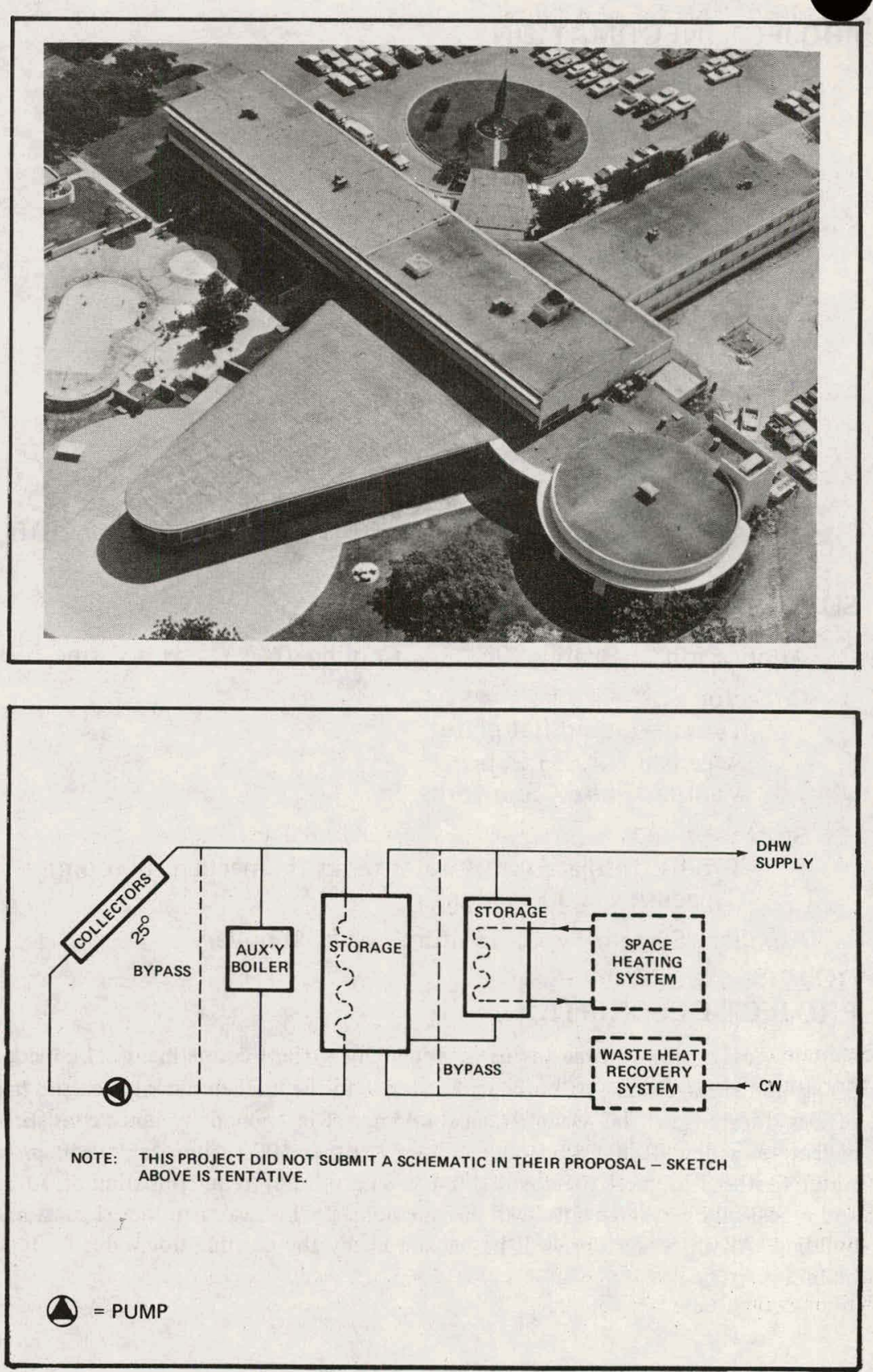


\section{PROJECT INFORMATION}

Owner/Builder: American Motor Inns, Inc.

Contractor: To be determined

Operational Date: October 1978

Total Estimated DOE Funds: $\quad \$ 38,039$

Building

Type: Low rise motor inn

Area: Not applicable to hot water systems

Location: Lancaster, Pennsylvania

Latitude: $40^{\circ} \mathrm{N}$

Climatic Data

$\begin{array}{lllll}\text { Degree Days } & \text { Heating } & 5347 & \text { Cooling } & 1026 \\ \text { Avg. Temp. }\left({ }^{\circ} \mathrm{F}\right) & \text { Winter } & 32 & \text { Summer } & 73 \\ \text { Avg. Insol. (Ly/d) } & \text { Winter } & 495 & \text { Summer } & 610\end{array}$

\section{SOLAR ENERGY SYSTEM}

Application Heating 0\%

Hot Water $58 \%$

Collector

Type: Liquid flat-plate

Area (sq. ft.); 1,995

Manufacturer: Sunworks, Inc.

Storage

Type: Insulated steel water tanks (in mechanical room)

Capacity: 3,000 gallons

Auxiliary System Type: Natural gas fired boiler

\section{PROJECT DESCRIPTION}

This project consists of three distinct systems. One system, consisting of 24 collectors and a 500-gallon storage tank, will provide hot water to the kitchen, dining area and managerial offices located in the commercial building. The second system, consisting of 55 collectors, a new 1000-gallon tank and an existing 1000-gallon tank, will provide hot water to the 126 guest units and laundry. The third system, consisting of 16 collectors and a 500-gallon storage tank, will provide domestic hot water to the 64 guest unit annex building. All three systems will be backed up by the existing hot water heaters in each building.
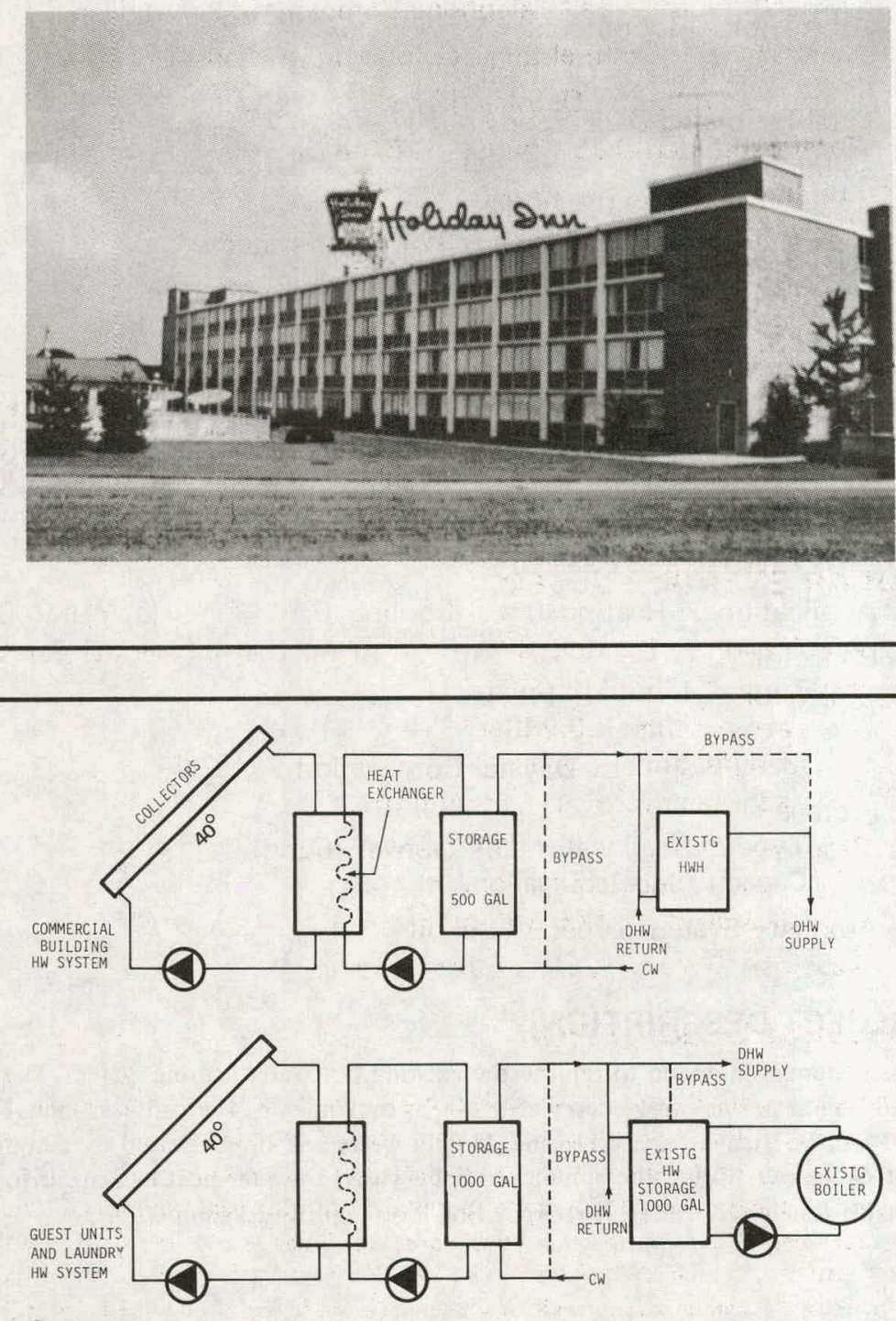

A = PUMP

* NOTE: DHW system schematic for guest rooms in annex building is similar to commercial building HW system schematic shown. 


\section{PROJECT INFORMATION}

Owner/Builder: Bell Telephone Company of Pennsylvania

Contractor: Hummel Engineering Corporation

Operational Date: October 1977

Total Estimated DOE Funds:

$\$ 201,429$

Building

Type: Office/storage

Area: $\quad 9,800$ sq. ft.

Location: West Goshen, Pennsylvania

Latitude: $40.0^{\circ} \mathrm{N}$

Climatic Data

$\begin{array}{lllll}\text { Degree Days } & \text { Heating } & 5144 & \text { Cooling } & 1050 \\ \text { Avg. Temp. }\left({ }^{\circ} \mathrm{F}\right) & \text { Winter } & 41.8 & \text { Summer } & 73.0 \\ \text { Avg. Insol. (Ly/d) } & \text { Winter } & 290 & \text { Summer } & 486\end{array}$

\section{SOLAR ENERGY SYSTEM}

Application Heating 62\%

Hot Water $0 \%$

Collector

Type: Liquid flat-plate

Area (sq. ft.): 1,900

Manufacturer: Heliotherm, Inc.

\section{Storage}

Type: Insulated steel water tank

Capacity: 6,000 gallons

Auxiliary System Type: Electric boiler

\section{PROJECT DESCRIPTION}

This is a T-shaped, one-story building, consisting of an office section and a large open storeroom section. The office section contains 20 separate enclosures, heated and cooled by 20 unitary heat pumps. The storeroom section is heated by a fan-coil unit connected to air ducts and diffusers. The heat source for both the heat pumps and the fan-coil unit is solar energy, backed up by an electric boiler. Solar energy is stored in a 6000-gallon, above-ground, insulated steel tank. The solar array consists of two rows of flat-plate solar collectors, 44 panels each. Provisions have been made for draining the water from the collectors into a 300-gallon holding tank and replacing it with nitrogen, to avoid freezing. The solar panels are mounted above the roof, facing south, at $55^{\circ}$ from the horizontal.
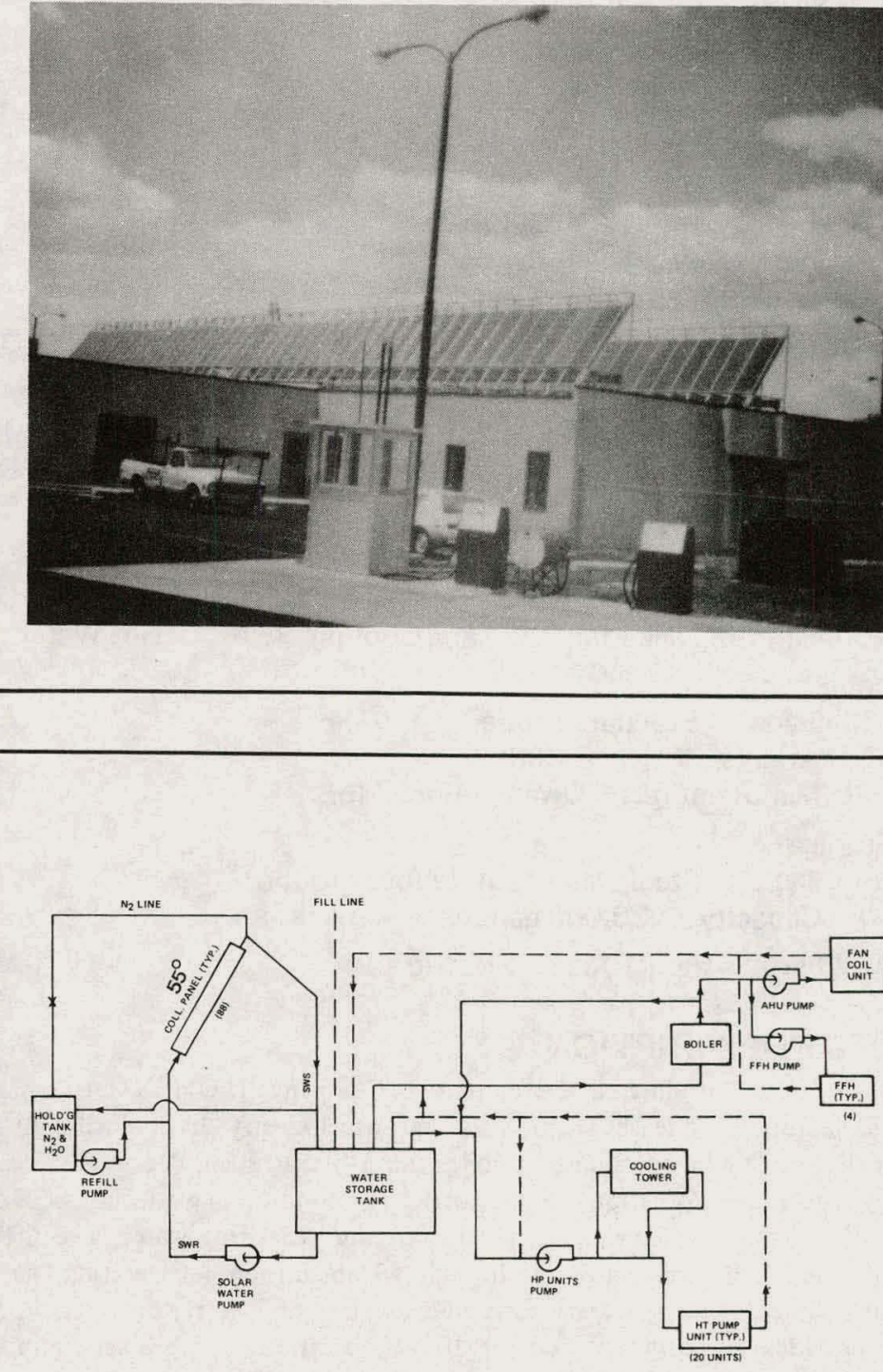


\section{PROJECT INFORMATION}

Owner/Builder: Commonwealth of Puerto Rico

Contractor: Department of Natural Resources

Operational Date: September 1978

Total Estimated DOE Funds: $\$ \$ 587,000$

Building

Type: Industrial factory

Area: 10,800 sq. ft.

Location: Canovanas, Puerto Rico

Latitude: $18.5^{\circ} \mathrm{N}$

Climatic Data

Degree Days

Avg. Temp. $\left({ }^{\circ} \mathrm{F}\right)$

Avg. Insol. (Ly/d)

$\begin{array}{ll}\text { Heating } & \text { N/A } \\ \text { Winter } & 76.7 \\ \text { Winter } & 494\end{array}$

Cooling 4982

Summer 80.6

Summer 570

\section{SOLAR ENERGY SYSTEM}

Application Heating $0 \%$

Hot Water $45 \%$

Type: Evacuated tube

Area (sq. ft.): $\quad 7,600$

Manufacturer: Owens-Illinois, Inc.

\section{Storage}

Type: Steel water tank (above ground)

Capacity: 20,000 gallons

Auxiliary System Type: Electric

\section{PROJECT DESCRIPTION}

The Puerto Rico Industrial Development Company (FOMENTO), which provides standard factories and leases them at low rates to industry, has contributed this factory and its site, in Guaynabo, about six miles south of San Juan. Puerto Rico has one of the highest year-round insolations in the world. Air conditioning will be needed every day, and data collection will be done throughout the year. Hot water is secured from the roof-top solar collectors and run through an absorption refrigerating machine which generates chilled water necessary for cooling. A 30-ton electric drive reciprocating water chiller provides for auxiliary cooling. If the operation of this solar-equipped building proves commercially practical and energy conservative, it would be used as a prototype for a number of buildings constructed by FOMENTO. It would also create the opportunity for a new solar industry to be started in Puerto Rico.
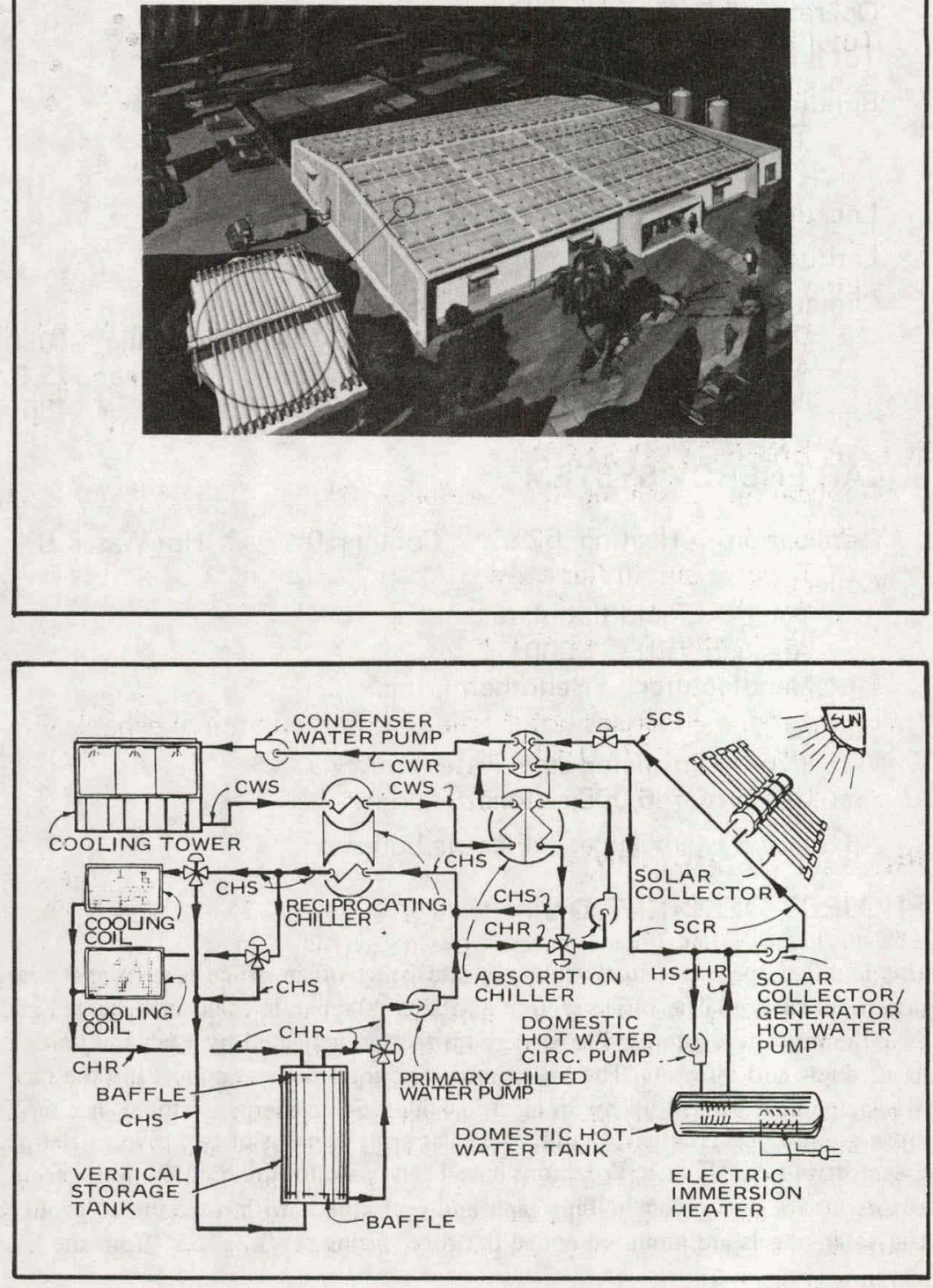


\section{PROJECT INFORMATION}

Owner/Builder: Days Inn of America, Inc.

Contractor: Georgia-Carolina Heating \& Air-Conditioning, Inc.

Operational Date: November 1977

Total Estimated DOE Funds: $\quad \$ 10,162$

Building

Type: Low rise motel

Area: Not applicable to hot water systems

Location: Anderson, South Carolina

Latitude: $32^{\circ} \mathrm{N}$

Climatic Data

Degree Days

Avg. Temp. ( $\left.{ }^{\circ} \mathrm{F}\right)$

Heating 3163

Avg. Insol. (Ly/d)

Winter 45

Cooling 1573

SOLAR ENERGY SYSTEM

Application Heating $0 \%$ Cooling $0 \%$ Hot Water $45 \%$

Collector

Type: Liquid flat-plate

Area (sq. ft.): 750

Manufacturer: Gulf Thermal

Storage

Type: Fiberglas water tank (above ground, in mechanical room)

Capacity: 1,000 gallons

Auxiliary System Type: Electric boiler

\section{PROJECT DESCRIPTION}

The solar system designed for this building will have 25 flat-plate collectors with single-glazing and flat black absorbers facing due south, mounted on the roof of the building at a tilt angle of $35^{\circ}$ The solar array will consist of five rows of collectors, with each row containing five collectors in parallel flow. This system operates at atmospheric pressure. Water is used as the heat transfer fluid. There are no heat exchangers between the storage tank and collector loop. The collectors are protected from freezing by a simple drain-down technique. The drain system operates as follows: when plate temperature reaches $35^{\circ} \mathrm{F}$ the controller activates a N.O. valve, this allows air to enter the system and the water drains back through the supply and return lines. The system is fail-safe, since the valve opens if power is lost. Usable heat is transferred to the existing electric hot water boilers via a 200 -foot copper coil immersed in the storage tank operating at line pressure.

\section{Photograph not available}

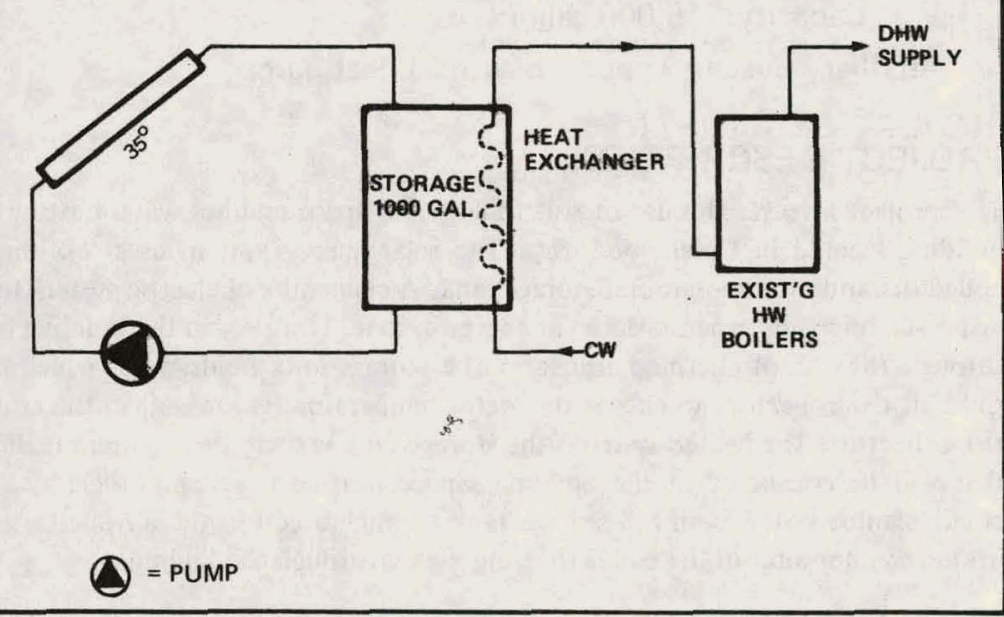




\section{PROJECT INFORMATION}

Owner/Builder: Blakedale Professional Center, Inc.

Contractor: W.E. Gilbert and Associates

Operational Date: August 1977

Total Estimated DOE Funds: $\quad \$ 52,616$

Building

Type: Office

Area: $4,400 \mathrm{sq} . \mathrm{ft}$.

Location: Greenwood, South Carolina

Latitude: $34.4^{\circ} \mathrm{N}$

Climatic Data

$\begin{array}{lllll}\text { Degree Days } & \text { Heating } & 2926 & \text { Cooling } & 1789 \\ \text { Avg. Temp. }\left({ }^{\circ} \mathrm{F}\right) & \text { Winter } & 51.9 & \text { Summer } & 75.7 \\ \text { Avg. Insol. (Ly/d) } & \text { Winter } & 320 & \text { Summer } & 521\end{array}$

\section{SOLAR ENERGY SYSTEM}

Application Heating 85\%

Cooling $0 \%$

Hot Water $100 \%$

Collector

Type: Liquid flat-plate

Area (sq. ft.): 954

Manufacturer: PPG Industries, Inc.

Storage

Type: Steel water tank (underground)

Capacity: 5,000 gallons

Auxiliary System Type: Electrical heat pump

\section{PROJECT DESCRIPTION}

This project involves the use of solar energy for space and hot water heating in an office building located in Greenwood, S.C. The solar energy system uses roof-mounted solar collectors and an underground storage tank. A conventional electric system for space and water heating supplements the solar energy system. Heat loss in the building is minimized through the use of thermopane glass. The storage tank holds water which is circulated through the collectors whenever the water temperature is lower than the temperature of the collectors. The heated water in the storage tank is then used to preheat the city water that will be consumed in the building. Space heating is accomplished by a pump that circulates hot water from the storage tank through a coil in the air duct system. The air heated by the water in the coil is then circulated through the building.
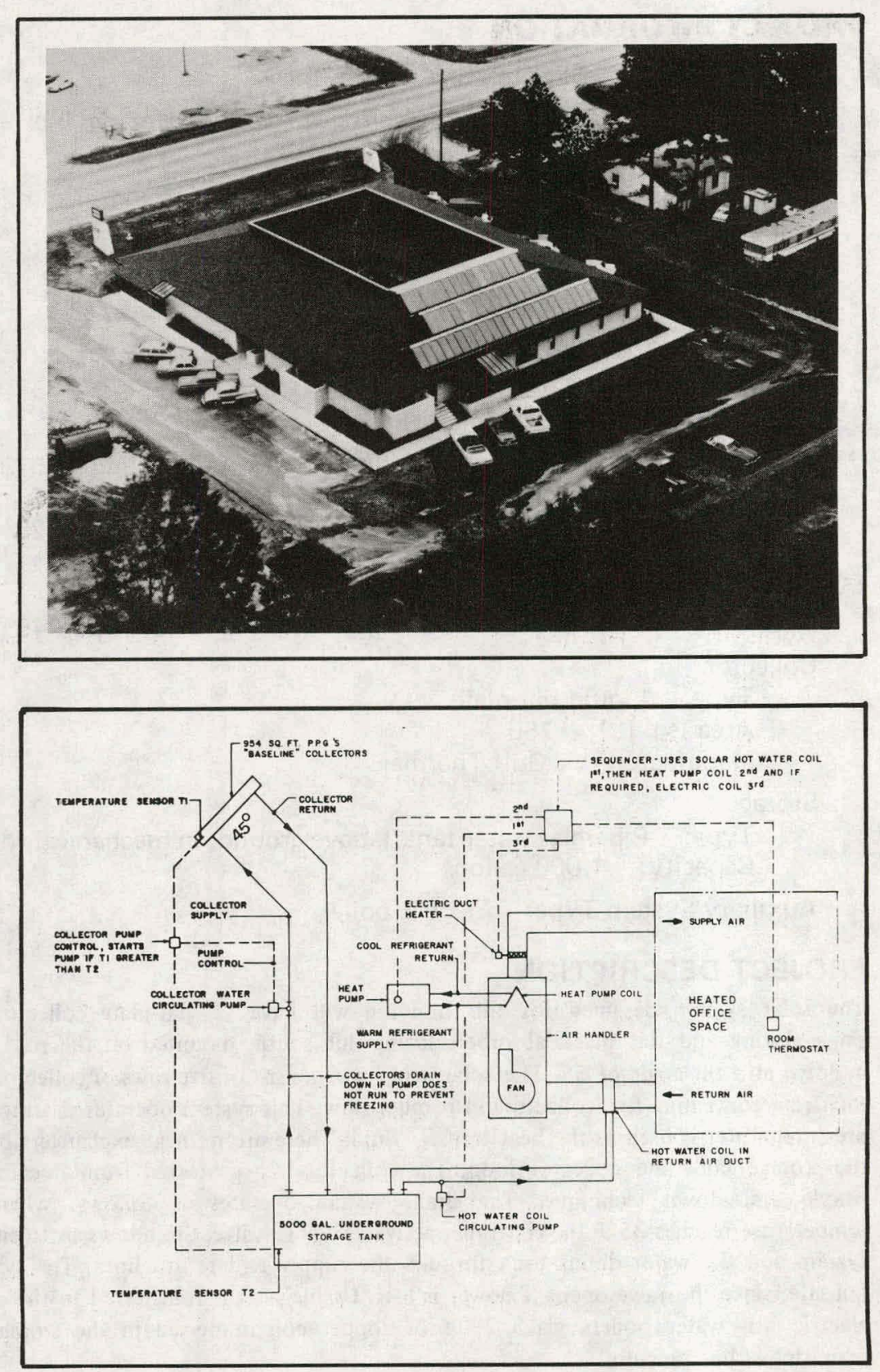


\section{PROJECT INFORMATION}

Owner/Builder: First Baptist Church

Contractor: Michaud, Cooley, Halberg, Erickson and Associates Operational Date: April 1978

Total Estimated DOE Funds: \$69,942

Building

Type: Church

Area: $\quad 12,486 \mathrm{sq} . \mathrm{ft}$. (total); $7,050 \mathrm{sq} . \mathrm{ft}$. (cond.)

Location: Aberdeen, South Dakota

Latitude: $44^{\circ} 3^{\prime} \mathrm{N}$

Climatic Data

$\begin{array}{lllll}\text { Degree Days } & \text { Heating } & 8223 & \text { Cooling } & 800 \\ \text { Avg. Temp. }\left({ }^{\circ} \mathrm{F} \text { ) }\right. & \text { Winter } & 28.8 & \text { Summer } & 72.1 \\ \text { Avg. Insol. (Ly/d) } & \text { Winter } & 264 & \text { Summer } & 351\end{array}$

Avg. Insol. (Ly/d) Winter $264 \quad$ Summer 351

\section{SOLAR ENERGY SYSTEM}

\section{Application Heating 21\%}

\section{Collector}

Type: Air flat-plate

Area (sq. ft.): 1,253

Manufacturer: Solaron Corporation

\section{Storage}

Type: Pebble bed (below mechanical room floor)

Capacity: $700 \mathrm{cu} . \mathrm{ft}$.

Auxiliary System Type: Forced air with electric boiler

\section{PROJECT DESCRIPTION}

The site for this church is absolutely flat. To diminish the wind effect, a 70' wide shelter-belt will be planted around the perimeter of the site. To further blunt the wind effect, the building design is much like an arrowhead pointed north. The main sanctuary is nearly circular to produce the maximum floor area with the least wall perimeter and minimum wind resistance by the roof form. The solar air collectors, mounted on the roof at a $50^{\circ}$ tilt, will provide space heating and domestic water preheating. Space heat can be provided either directly from the solar air collectors or from the storage bed. Supplementary heat is provided with an auxiliary electric boiler
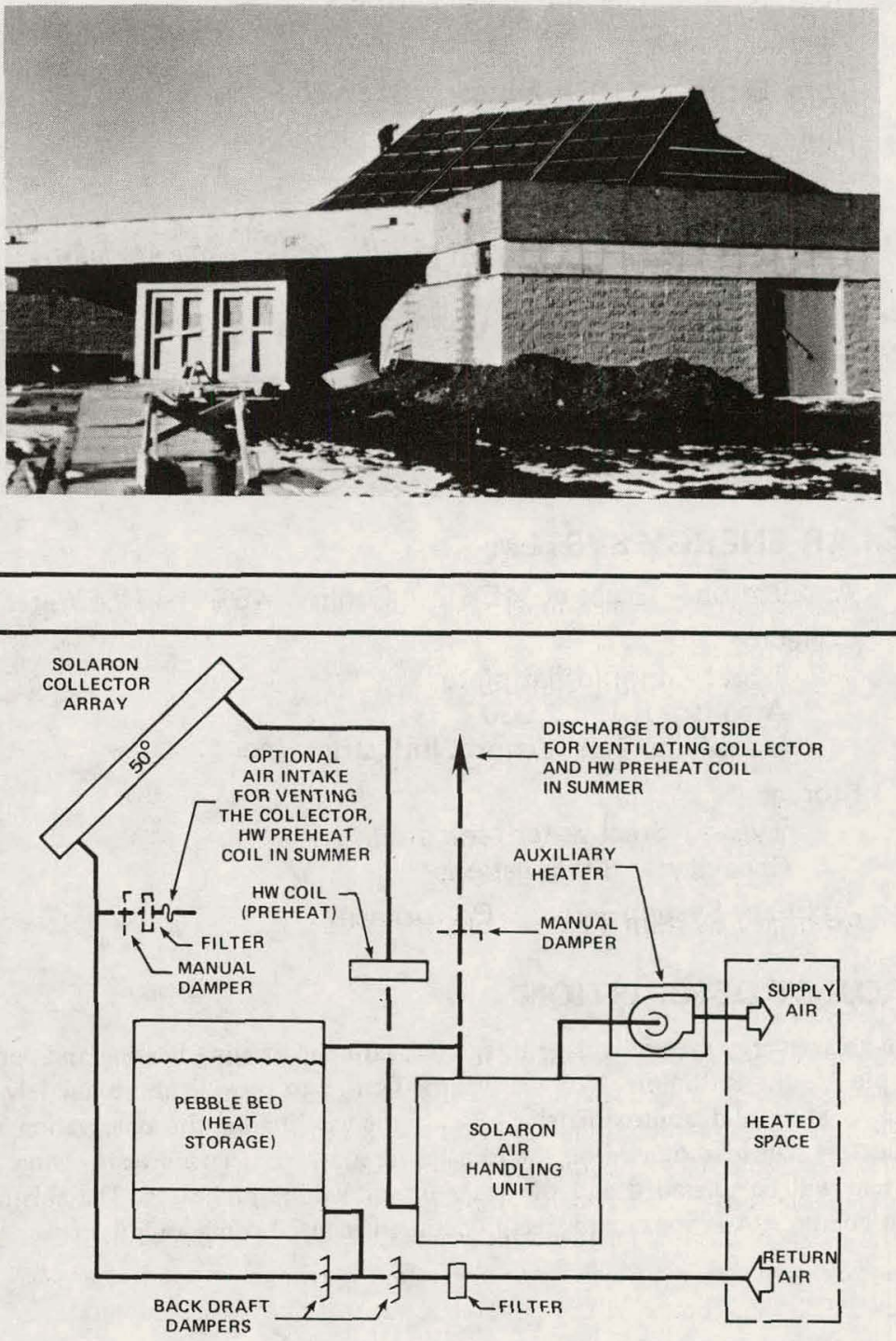


\section{PROJECT INFORMATION}

Owner/Builder: National Park Service, Dept. of Interior

Contractor: The Spitznagel Partners

Operational Date: November 1977

Total Estimated DOE Funds: $\$ 228,280$

Building

Type: Visitors center

Location: Keystone, South Dakota (Mt. Rushmore National Memorial) Latitude: $43.9^{\circ} \mathrm{N}$

Climatic Data

$\begin{array}{lllll}\text { Degree Days } & \text { Heating } & 7292 & \text { Cooling } & 1488 \\ \text { Avg. Temp. }\left({ }^{\circ} \mathrm{F}\right) & \text { Winter } & 27.8 & \text { Summer } & 69.5 \\ \text { Avg. Insol. (Ly/d) } & \text { Winter } & 332 & \text { Summer } & 577\end{array}$

\section{SOLAR ENERGY SYSTEM}

Application Heating 45\%

Collector

Type: Liquid flat-plate

Area (sq. ft.): 2,000

Manufacturer: Lennox Industries, Inc.

Storage

Type: Steel water tank

Capacity: 3,000 gallons

Auxiliary System Type: Oil furnace

\section{PROJECT DESCRIPTION}

The solar energy system will be integrated with the existing heating and cooling system of the Mount Rushmore National Visitor Center to provide approximately $45 \%$ of the total heating and approximately $45 \%$ of the cooling of the observation room. Solar collectors will be mounted on the roof facing southwest. To conserve energy, the control system will be upgraded and the make up air will be preheated. The existing refrigeration compressor is a standard, reciprocating, Freon-22 condensing unit.
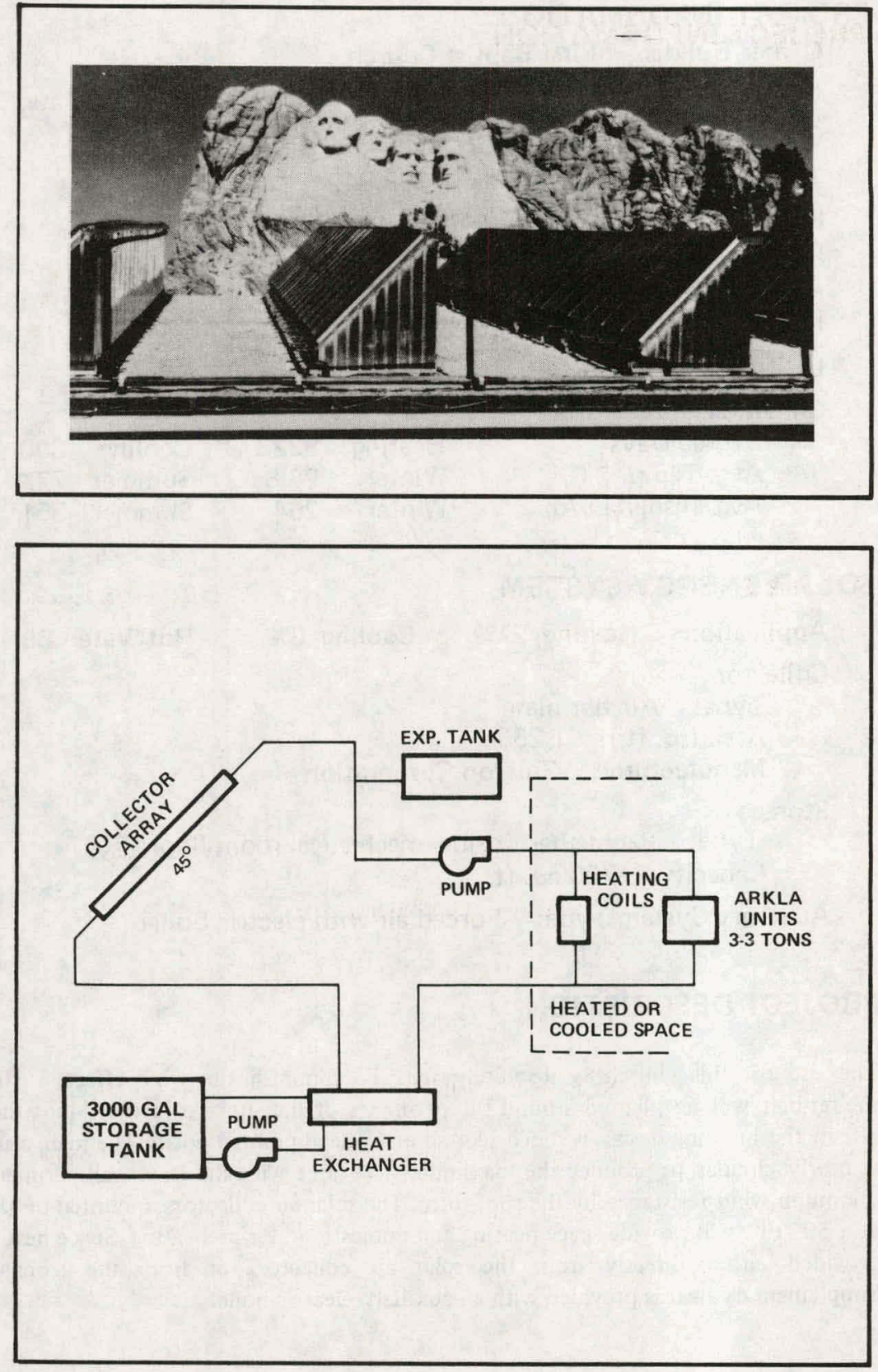


\section{PROJECT INFORMATION}

Owner/Builder: Spearfish School District No. 40-2

Contractor: Hengle, Berg and Associates, Architects-Engineers

Operational Date: September 1979

Total Estimated DOE Funds: $\$ \mathbf{\$ 1 9 9 , 5 0 2}$

Building

Type: High school

Area: 85,000 sq. ft. (total); 43,200 sq. ft. (cond.)

Location: Spearfish, South Dakota

Latitude: $49^{\circ} 48^{\prime} \mathrm{N}$

Climatic Data

Avg. Temp. $\left({ }^{\circ} \mathrm{F}\right)$

Heating 7345

Cooling N/A

Avg. Insol. (Ly/d)

Summer 68.6

Winter $208.7 \quad$ Summer 582.6

\section{SOLAR ENERGY SYSTEM}

Application Heating 55\% Cooling $0 \%$ Hot Water $90 \%$

Collector

Type: Air flat-plate

Area (sq. ft.): 7,308

Manufacturer: Solaron Corporation

Storage

Type: Rock bed (underground)/steel water tanks (in mechanical room)

Capacity: $4,620 \mathrm{cu}$. ft./1,000 gallons

Auxiliary System Type: Natural gas boiler

\section{PROJECT DESCRIPTION}

This is an air system using flat-plate collectors. The system will provide space heating and domestic hot water to the arts and drama wing and to classroom areas. Collectors are mounted on the roof and heat is stored in a rock storage compartment under the ground floor of the building. Heat is supplied to the building by roof-mounted heat pumps, or from the solar heating system. Domestic hot water is heated to $120^{\circ} \mathrm{F}$ by an air-to-water heat exchanger located upstream from the storage compartment, and is stored in two 500-gallon, insulated tanks located in front of the storage compartment.
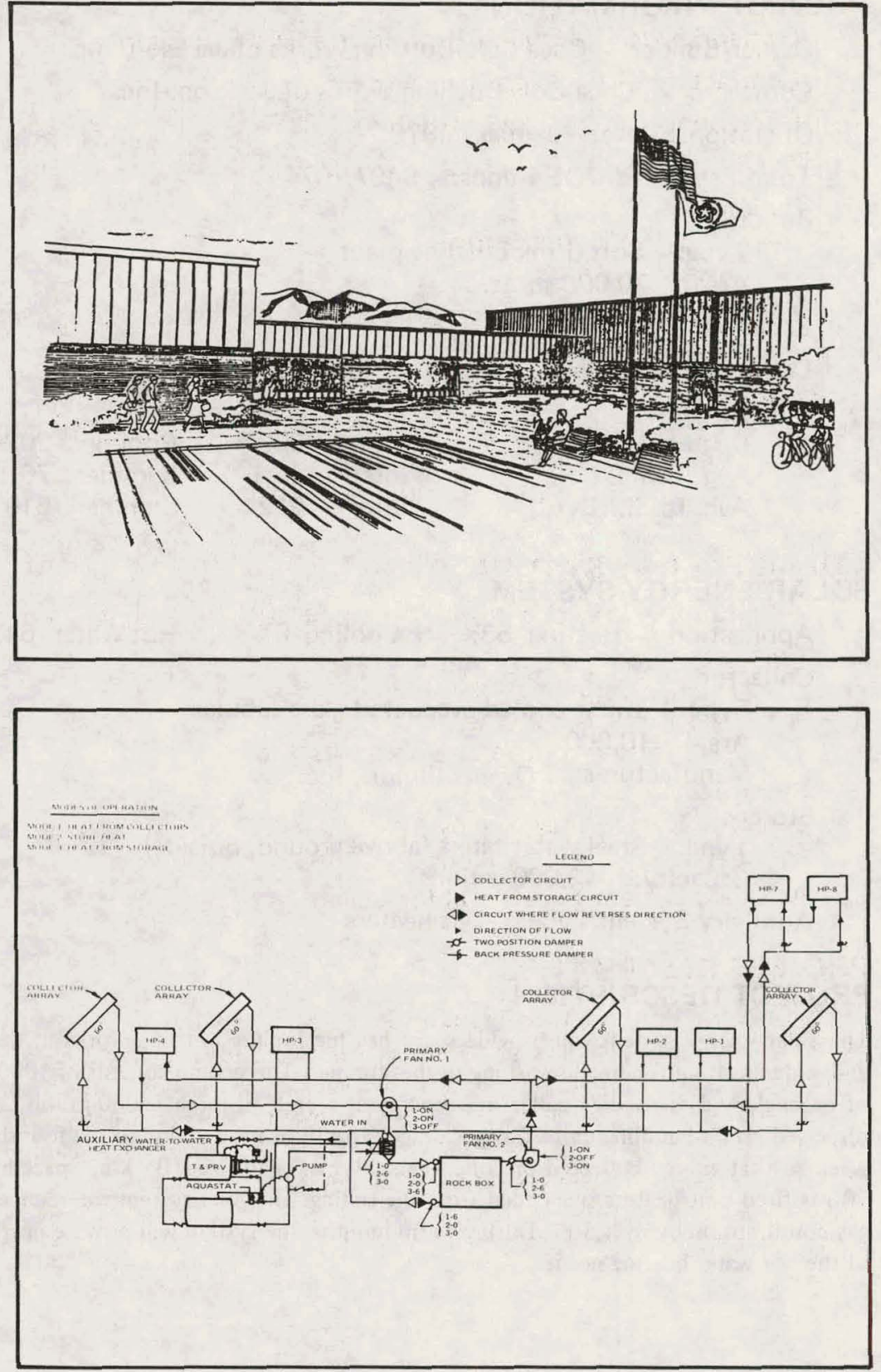


\section{PROJECT INFORMATION}

Owner/Builder: Coca-Cola Bottling Works of Jackson, Inc.

Contractor: Coca-Cola Bottling Works of Jackson, Inc.

Operational Date: January 1979

Total Estimated DOE Funds: $\quad \$ 487,107$

Building

Type: Soft drink bottling plant

Area: $70,000 \mathrm{sq} . \mathrm{ft}$.

Location: Jackson, Tennessee

Latitude: $35^{\circ} \mathrm{N}$

Climatic Data

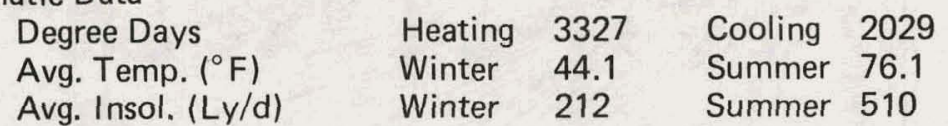

\section{SOLAR ENERGY SYSTEM}

\section{Application}

Heating $53 \%$

Cooling $0 \%$

Hot Water $54 \%$

Collector

Type: Water cooled evacuated glass tubular

Area: 10,000

Manufacturer: Owens-Illinois, Inc.

\section{Storage}

Type: Steel water tanks (above ground, outside)

Capacity: 42,000 gallons

Auxiliary System Type: Gas heaters

\section{PROJECT DESCRIPTION}

The solar energy system will provide space heating for the bottling works in the winter and water heating for bottle-washing in the summer. The system consists of $10000 \mathrm{sq} . \mathrm{ft}$. of evacuated glass tubular collectors. Energy is stored in three 14000-gallon tanks and dispersed via air-handling units. Large storage capacity is needed due to the four-day work week so that energy collected on long weekends can be utilized. Back-up space heating is 20 gas fired unit heaters suspended from the ceiling. The solar system will reduce natural gas consumption by over 50\%. During warm months, the system will provide nearly $100 \%$ of the hot water heating needs.
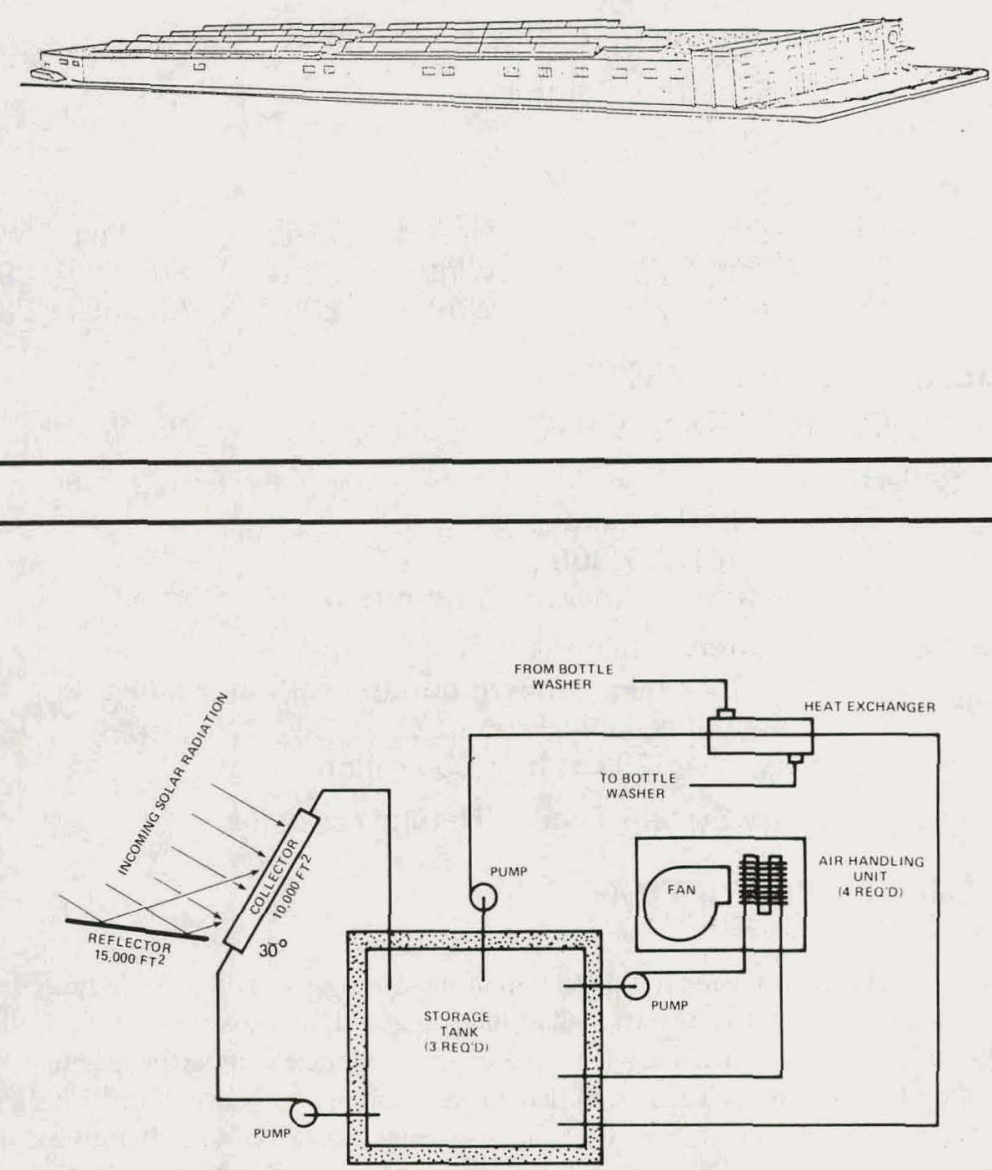


\section{PROJECT INFORMATION}

Owner/Builder: La Quinta Motor Inns, Inc.

Contractor: Travis-Braun \& Associates, Inc.

Operational Date: October 1978

Total Estimated DOE Funds: $\quad \$ 38,767$

Building

Type: Low rise motel

Area: Not applicable to hot water systems

Location: Nashville, Tennessee

Latitude: $36^{\circ} 1^{\prime} \mathrm{N}$

Climatic Data

$\begin{array}{lllll}\text { Degree Days } & \text { Heating } & 3573 & \text { Cooling } & 1600 \\ \text { Avg. Temp. }\left({ }^{\circ} \mathrm{F} \text { ) }\right. & \text { Winter } & 48.9 & \text { Summer } & 75 \\ \text { Avg. Insol. (Ly/d) } & \text { Winter } & 175 & \text { Summer } & 400\end{array}$

\section{SOLAR ENERGY SYSTEM}

Application Heating $0 \%$ Cooling $0 \%$

Collector

Type: Liquid flat-plate

Area (sq. ft.): 1,500

Manufacturer: Lennox Industries, Inc.

\section{Storage}

Type: Insulated steel water tank (above ground)

Capacity: 1,600 gallons

Auxiliary System Type: Electric boiler

\section{PROJECT DESCRIPTION}

A freeze protected system is proposed under this grant. The collector circulating fluid is a water buffered ethylene glycol solution. This mixture prevents the occurrence of freezing in the collector. Even though many codes do not require a double separation insulating the potable water system, provisions for such a separation are included. The mixture of antifreeze and water can be further buffered to include corrosion inhibiters, thus prolonging the collector life. The antifreeze solution protects a collector from damage which could occur from low temperatures. Mineral buildup problems are eliminated by the contained, relatively nonchanging solution.

Hot Water $57.6 \%$
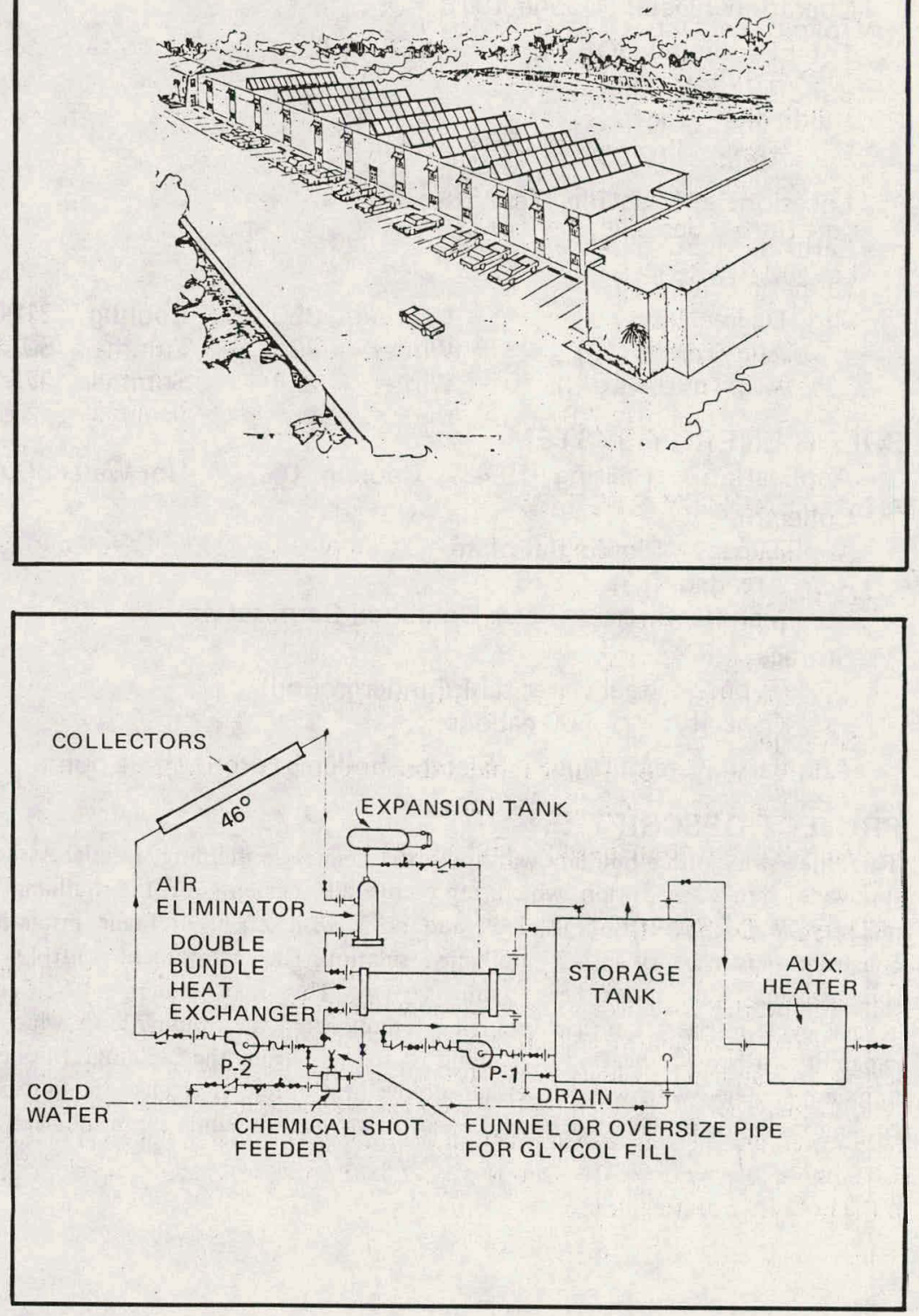


\section{PROJECT INFORMATION}

Owner/Builder: Tennessee Building Material Association

Contractor: I. C. Thomasson Engineers

Operational Date: June 1978

Total Estimated DOE Funds: $\quad \mathbf{\$ 6 8 , 1 9 3}$

Building

Type: Office

Area: $\quad 12,036$ sq. ft.

Location: Nashville, Tennessee

Latitude: $36^{\circ} 7^{\prime} \mathrm{N}$

Climatic Data

$\begin{array}{lllll}\text { Degree Days } & \text { Heating } & 3508 & \text { Cooling } & 2100 \\ \text { Avg. Temp. }\left({ }^{\circ} \mathrm{F}\right) & \text { Winter } & 48.3 & \text { Summer } & 80 \\ \text { Avg. Insol. (Ly/d) } & \text { Winter } & 244 & \text { Summer } & 475\end{array}$

SOLAR ENERGY SYSTEM

Application Heating $19.4 \%$ Cooling $0 \%$ Hot Water $90 \%$

Collector

Type: Liquid flat-plate

Area (sq. ft.): $\quad 576$

Manufacturer: Solar Unlimited Corporation

\section{Storage}

Type: Steel water tank (underground)

Capacity: 1,500 gallons

Auxiliary System Type: Electric boiler/hydronic heat pump

\section{PROJECT DESCRIPTION}

This three-story office building will house the Tennessee Building Material Association, a statewide trade association which represents all segments of the building material industry. Wall construction is block and brick with 2" of urethane insulation; roof construction is masonry with 2" urethane insulation. The environment control system is a solar-assisted, water-to-air heat pump system. This is a system of self-contained, reverse-cycle refrigeration machines, all interconnected via a piping loop, which have the capability to provide heating or cooling to rooms within the building. The heat pump units are supplied with water to either remove heat of rejection when the units are in the cooling mode, or provide the heat of absorption when the units are in the heating mode.
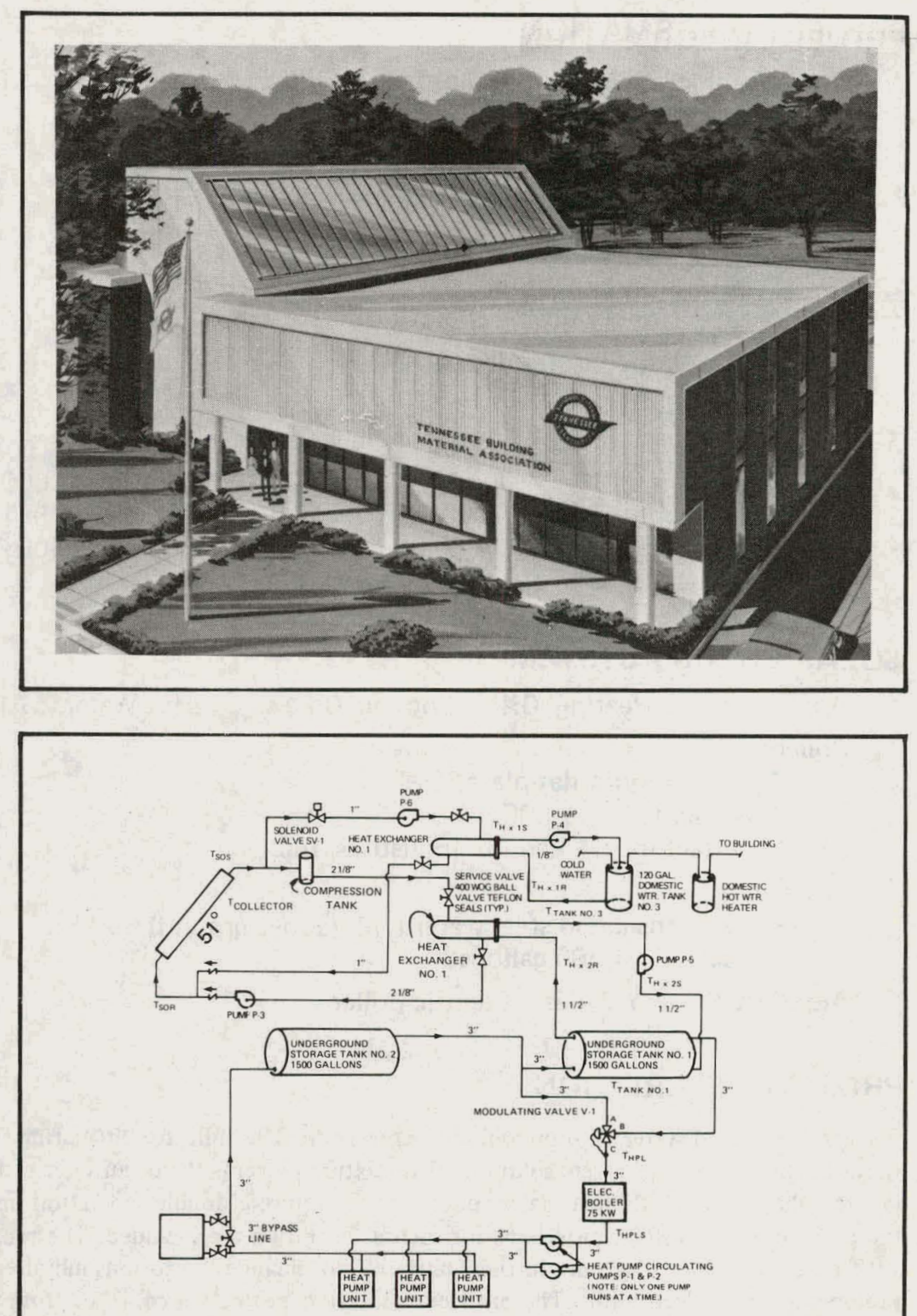


\section{PROJECT INFORMATION}

Owner/Builder: Lloyd A. Bell/American Ornamental Metal Company Contractor: American Ornamental Metal Company

Operational Date: September 1977

Total Estimated DOE Funds: $\quad \$ 70,329$

Building

Type: Factory/office

Area: 11,500 sq. ft.

Location: Austin, Texas

Latitude: $30.5^{\circ} \mathrm{N}$

\section{Climatic Data}

$\begin{array}{lllll}\text { Degree Days } & \text { Heating } & 1737 & \text { Cooling } & 1706 \\ \text { Avg. Temp. }\left({ }^{\circ} \mathrm{F}\right) & \text { Winter } & 54 & \text { Summer } & 80 \\ \text { Avg. Insol. (Ly/d) } & \text { Winter } & 660 & \text { Summer } & 783\end{array}$

\section{SOLAR ENERGY SYSTEM}

\section{Application Heating 100\% Cooling 90\% Hot Water $0 \%$}

Collector

Type: Thermoponds

Area (sq. ft.): 8,800

Manufacturer: To be determined

\section{Storage}

Type: Plastic thermoponds on a metal deck

Capacity: 70,000 gallons

Auxiliary System Type: Heat pump

\section{PROJECT DESCRIPTION}

This building will have tilt-up, load-bearing concrete walls with stuccoed polystyrene exterior insulation. The capacitance of the concrete will be varied to obtain different thermal time lags for unlike exposure to transient thermal flow. Sun screens on south-facing windows will decrease summer heat gain while allowing winter insolation. In this installation, 12 "-deep thermoponds will provide 70000 gallons of water storage over the roof deck supported by bar joists spaced approximately 4' on centers. Inexpensive plastic films are used as a black liner over the roofdeck for the transparent thermopond covers. During summer months, moveable insulation panels are closed during the day with comfort resulting from radiation of body heat to the $75^{\circ}$ ceiling. At night, the panels are opened and the interior heat is re-radiated to the night sky. During the summer humid period, indirect evaporative cooling will be obtained by flooding the thermoponds. Convection losses will contribute as well. An air cell is used over the bags to maximize heat collection in cooler months.
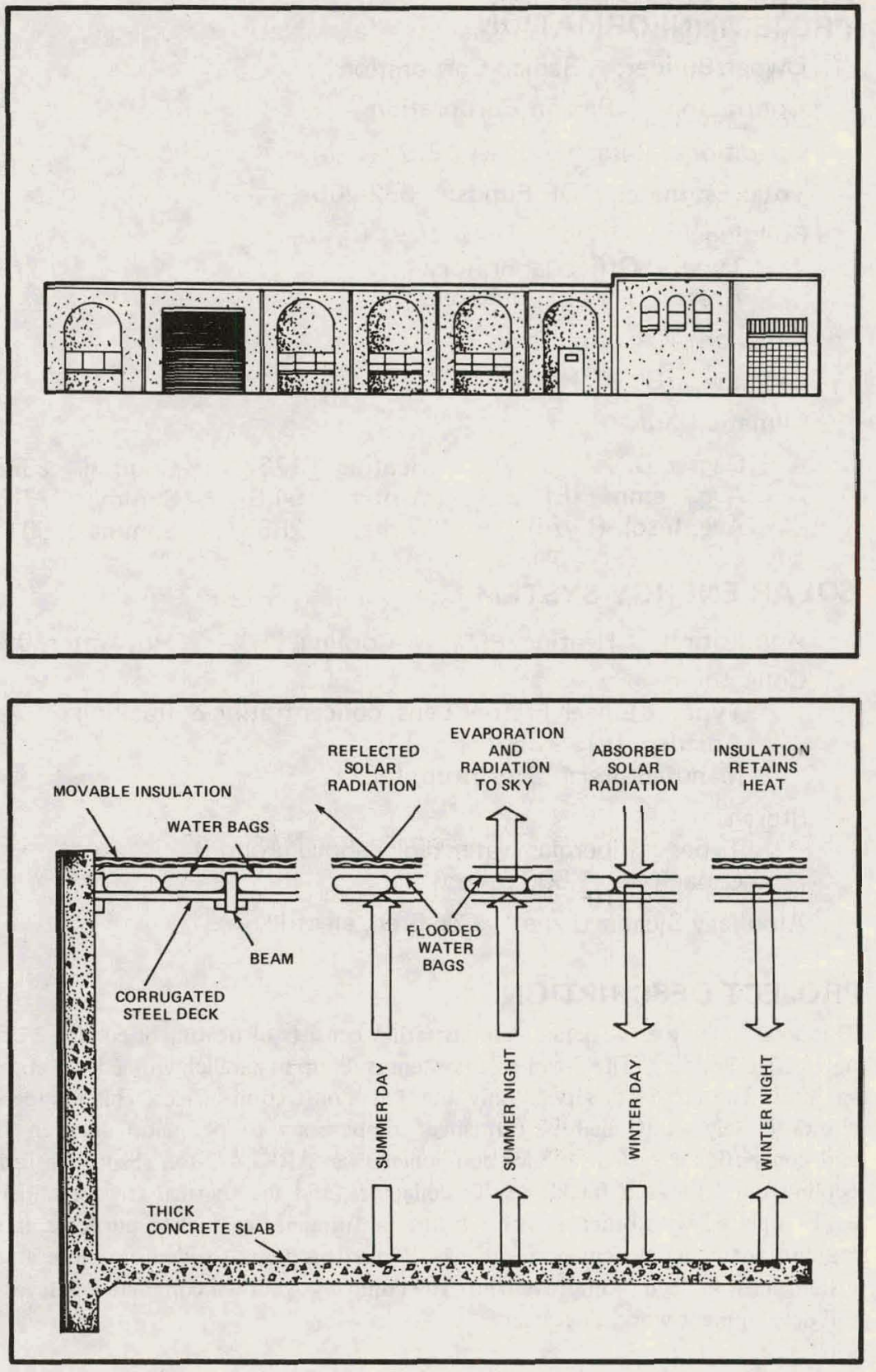


\section{PROJECT INFORMATION}

Owner/Builder: Radian Corporation

\section{Contractor: Radian Corporation}

Operational Date: August 1977

Total Estimated DOE Funds: $\quad \$ 32,205$

Building

Type: Office/laboratory

Area: 850 sq. ft. (cond.)

Location: Austin, Texas

Latitude: $30.3^{\circ} \mathrm{N}$

Climatic Data

Degree Days
Avg. Temp. (
Avg. Insol. (Ly/d)

$\begin{array}{ll}\text { Heating } & 1737 \\ \text { Winter } & 54.8 \\ \text { Winter } & \mathbf{2 8 6}\end{array}$

Cooling 2908

Summer 77.7

Summer 501

\section{SOLAR ENERGY SYSTEM}

Application Heating $85 \%$ Cooling $75 \%$ Hot Water $0 \%$

Collector

Type: Linear Fresnel Lens, concentrating \& tracking

Area. (sq. ft.): 350

Manufacturer: Northrup, Inc.

Storage

Type: Fiberqlas water tank (above ground)

Capacity: 1,500 gallons

Auxiliary System Type: Gas fired, electric

\section{PROJECT DESCRIPTION}

This solar heating and cooling demonstration consists of heating or cooling 3 offices in a new office building. The 3-ton solar system is set up in parallel with a 3-ton conventional gas unit. The air ducts service only the 3 demonstration offices. This unique situation allows closely controlled performance comparisons to be made between the solar and conventional systems. Major components (an ARKLA 3-ton absorptive heating and cooling unit, the sun tracking solar collectors, and the thermal storage tank) may be easily replaced with other units for future performance evaluation purposes. In monitoring and analyzing system performance, Radian proposes to identify those areas of the system most in need of improvement. The company will then complete whatever research and development work is necessary.
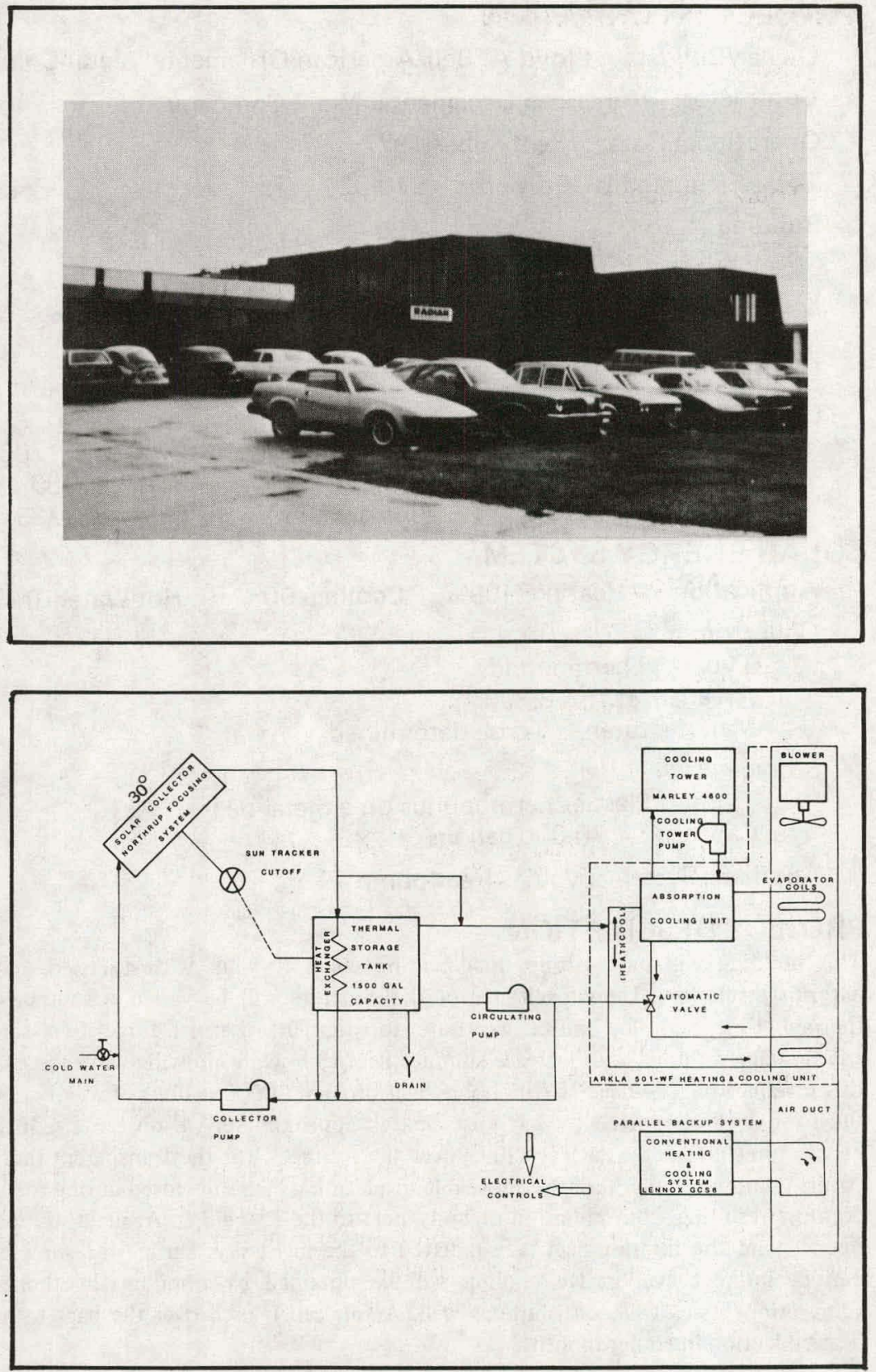


\section{PROJECT INFORMATION}

Owner/Builder: La Quinta Motor Inns, Inc.

Contractor: Travis-Braun \& Associates, Inc.

Operational Date: To be determined

Total Estimated DOE Funds: $\quad \$ 53,415$

Building

Type: Low rise motel

Area: Not applicable to hot water systems

Location: Beaumont, Texas

Latitude: $30^{\circ} 0^{\prime} \mathrm{N}$

Climatic Data

Degree Days

Avg. Temp. ( $\left.{ }^{\circ} \mathrm{F}\right)$

Avg. Insol. (Ly/d)

$\begin{array}{ll}\text { Heating } & 1274 \\ \text { Winter } & 62.2\end{array}$

Winter 270

Cooling N/A

Summer N/A

Summer 520

\section{SOLAR ENERGY SYSTEM}

Application Heating $0 \%$

Collector

Type: Evacuated tube

Area (sq. ft.): 2,000

Manufacturer: General Electric Company

\section{Storage}

Type: Steel water tank (above ground)

Capacity: 1,600 gallons

Auxiliary System Type: Electric boiler

\section{PROJECT DESCRIPTION}

A freeze protected system is proposed under this grant. The collector circulating fluid is a water buffered ethylene glycol solution. This mixture prevents the occurrence of freezing in the collector. Even though many codes do not require a double separation insulating the potable water system, provisions for such a separation are included. The mixture of antifreeze and water can be further buffered to include corrosion inhibiters, thus prolonging the collector life. The antifreeze solution protects a collector from damage which could occur from low temperatures. Mineral buildup problems are eliminated by the contained, relatively nonchanging solution.
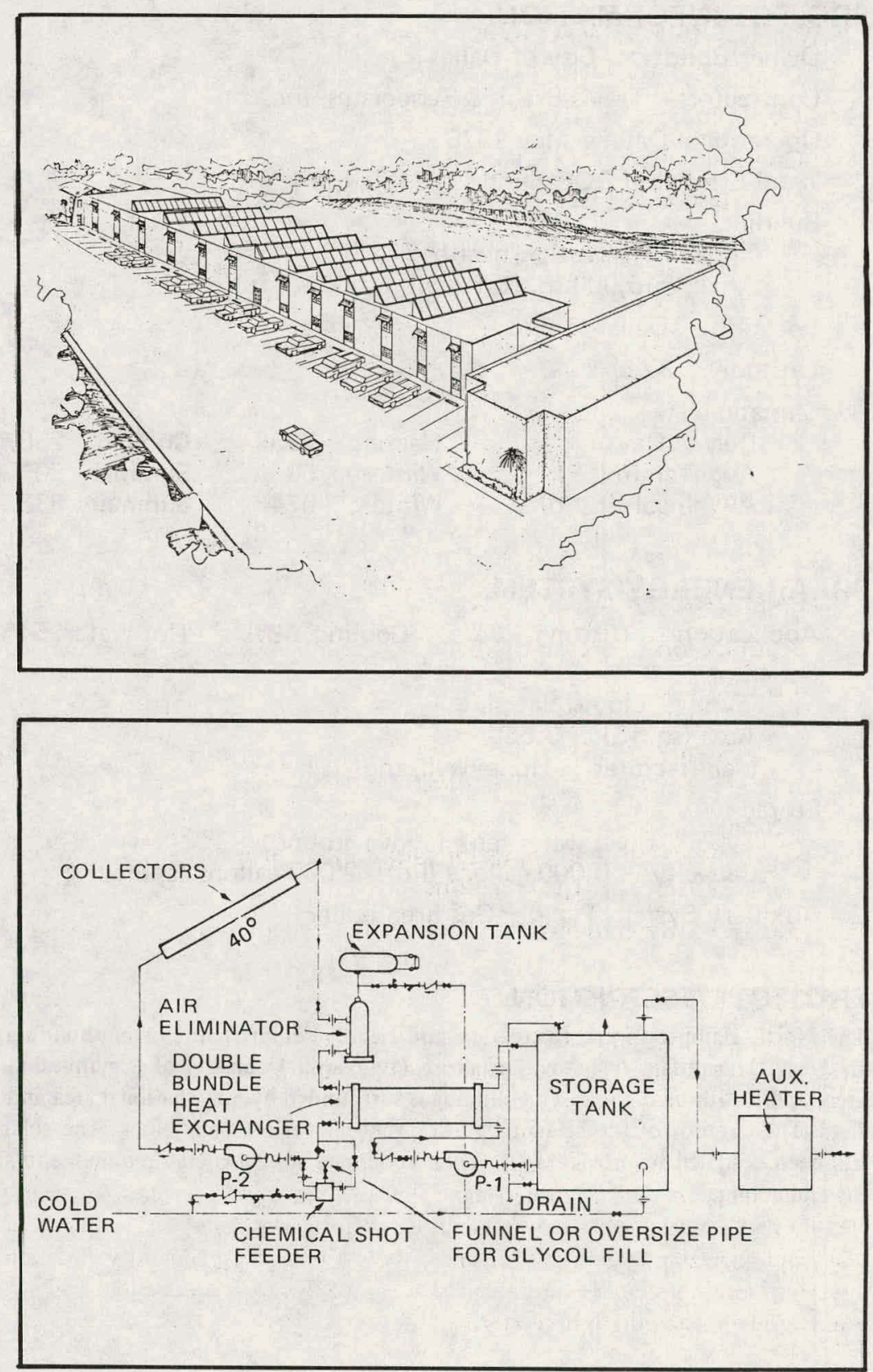


\section{PROJECT INFORMATION}

Owner/Builder: City of Dallas

Contractor: Travis-Braun \& Associates, Inc.

Operational Date: May 1978

Total Estimated DOE Funds: $\$ 430,430$

Building

Type: Recreation/health care

Area: $\quad 16,000$ sq. ft. (total); 8,000 sq. ft. (cond.)

Location: Dallas, Texas

Latitude: $32.5^{\circ} \mathrm{N}$

Climatic Data

Degree Days

Avg. Temp. $\left({ }^{\circ} \mathrm{F}\right)$

Avg. Insol. (Ly/d)

$\begin{array}{ll}\text { Heating } & 2382 \\ \text { Winter } & 50\end{array}$

Cooling 2587

Winter 674

\section{SOLAR ENERGY SYSTEM}

Application Heating $80 \%$

Collector

Cooling $48 \% \quad$ Hot Water $54 \%$

Type: Liquid flat-plate

Area (sq. ft.): 3,650

Manufacturer: Honeywell, Inc.

Storage

Type: Steel water tank (above ground)

Capacity: 6,000 gallons (hot), 2,000 gallons (chilled)

Auxiliary System Type: Gas fired boiler

\section{PROJECT DESCRIPTION}

The North Hampton Park Recreation and Health Center is an existing building located in West Dallas. The one-story structure (two levels) consists of a gymnasium, locker area, and health care clinic. The building is surrounded by a recreational area and athletic field. The exterior of the building is brick veneer over masonry block. The solar system has been designed to provide $54 \%$ of the combined annual energy requirements for heating and cooling.
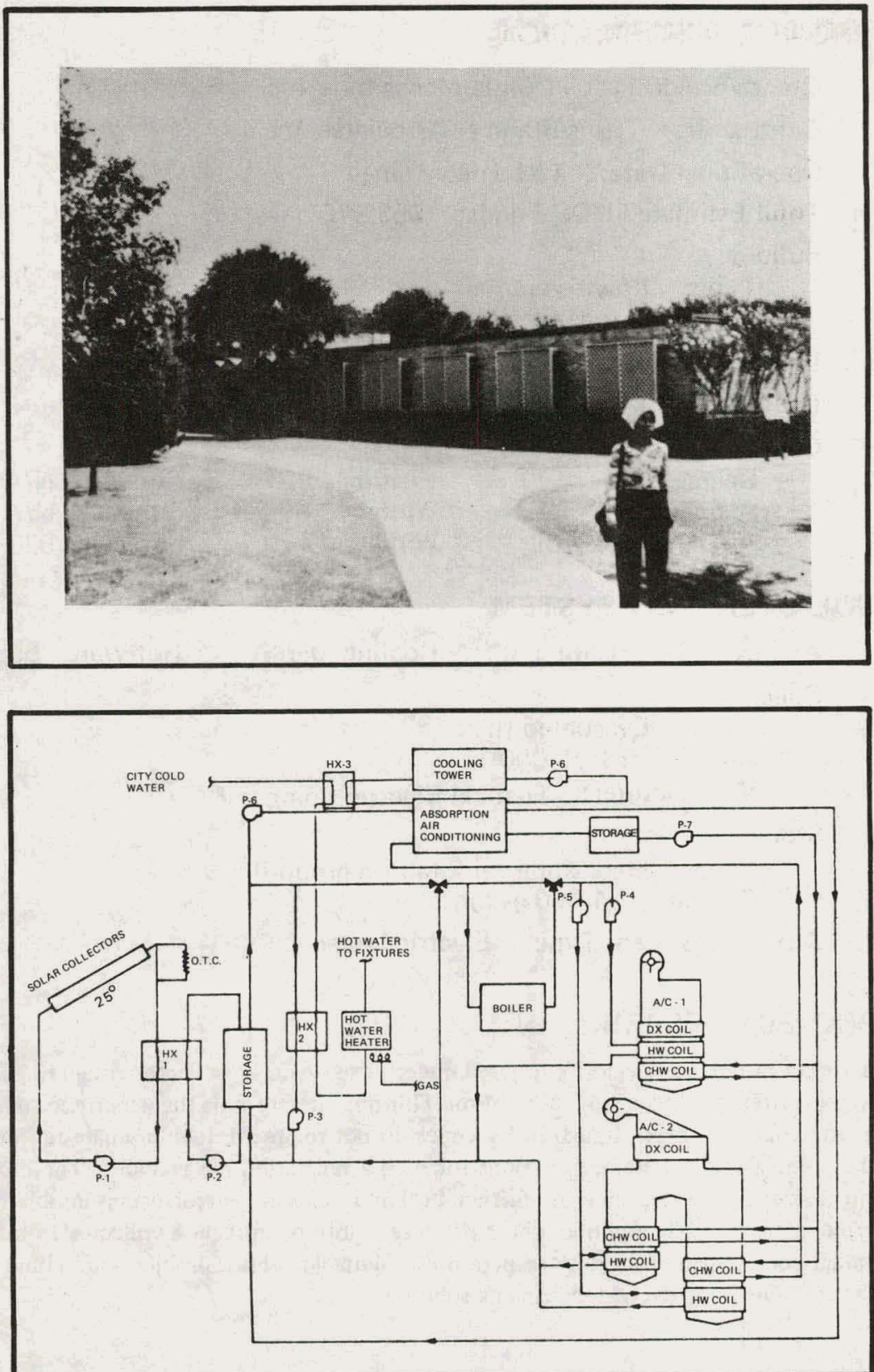


\section{PROJECT INFORMATION}

Owner/Builder: Lon W. Travis/Earl E. Braun, Jr. Partnership Contractor: Travis-Braun and Associates, Inc.

Operational Date: July 1978

Total Estimated DOE Funds: $\$ \mathbf{6 5 , 1 0 7}$

Building

Type: Office

Area: 10,000 sq. $\mathrm{ft}$.

Location: Dallas, Texas

Latitude: $32^{\circ} \mathrm{N}$

Climatic Data

Degree Days

Avg. Temp. $\left({ }^{\circ} \mathrm{F}\right)$

Avg. Insol. (Ly/d)

$\begin{array}{llll}\text { Heating } & 2382 & \text { Cooling } & 2587 \\ \text { Winter } & 47 & \text { Summer } & 83.4 \\ \text { Winter } & 250 & \text { Summer } & 600\end{array}$

\section{SOLAR ENERGY SYSTEM}

Application Heating $85 \%$

Collector

Cooling $0 \% \quad$ Hot Water $100 \%$

Type: Liquid flat-plate

Area (sq. ft.): 1,596

Manufacturer: Solargenics, Inc.

\section{Storage}

Type: Concrete water tank (above ground)

Capacity: 3,500 gallons

Auxiliary System Type: Electric heaters/electric resistance space heating

\section{PROJECT DESCRIPTION}

The collector system serves as a roof above the lobby with brightly painted storage tanks below, making the solar system an important architectural element. The system is designed for a future addition of solar absorption or Rankine cycle cooling because this is a large part of the yearly energy load and the modification could be accomplished with a minimal amount of revision to the solar space heating system. The system is part of a 6238 sq. ft. addition to the existing $3100 \mathrm{sq}$. $\mathrm{ft}$. one-story building. The collectors are mounted in a metal frame $40^{\prime}$ square on the south side at a $42^{\circ}$ tilt.
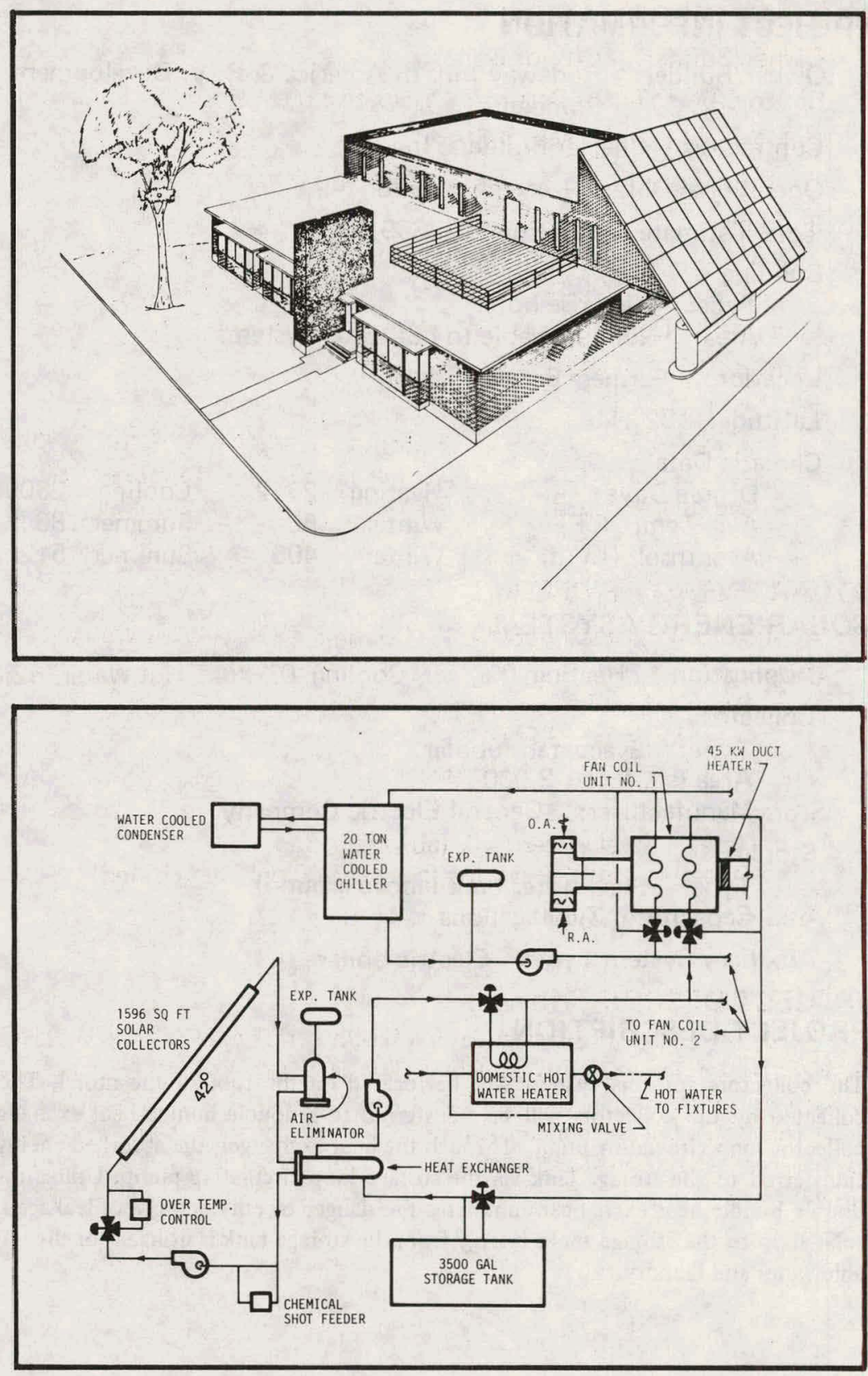


\section{PROJECT INFORMATION}

Owner/Builder: Rodeway Inns of America \& R. V. Development Company

Contractor: Charter Builders, Inc.

Operational Date: December 1978

Total Estimated DOE Funds: $\quad \$ 69,967$

Building

Type: High rise hotel

Area: Not applicable to hot water systems

Location: Farmers Branch, Texas

Latitude: $32^{\circ} \mathrm{N}$

Climatic Data

$\begin{array}{lllll}\text { Degree Days } & \text { Heating } & 2342 & \text { Cooling } & 2609 \\ \text { Avg. Temp. }\left({ }^{\circ} \mathrm{F}\right) & \text { Winter } & 50 & \text { Summer } & 86 \\ \text { Avg. Insol. (Ly/d) } & \text { Winter } & 406 & \text { Summer } & 512\end{array}$

\section{SOLAR ENERGY SYSTEM}

Application Heating $0 \%$ Cooling $0 \%$ Hot Water $52 \%$

\section{Collector}

Type: Evacuated tubular

Area (sq. ft.): 3,000

Manufacturer: General Electric Company

Storage

Type: Steel water tank (above ground)

Capacity: 3,800 gallons

Auxiliary System Type: Electric boiler

\section{PROJECT DESCRIPTION}

The collectors for this system will be located on the roof of the motel. The energy collected by the collectors will be transferred to a double bundle heat exchanger via a collector loop circulating pump. Through the heat exchanger, the absorbed energy will be transferred to the storage tank via the storage loop circulating pump. Utilization of the double bundle heat exchanger eliminates the danger of ethylene glycol leakage from the solar loop to the storage tank. Energy from the storage tank is utilized for the motel potable water and laundry.
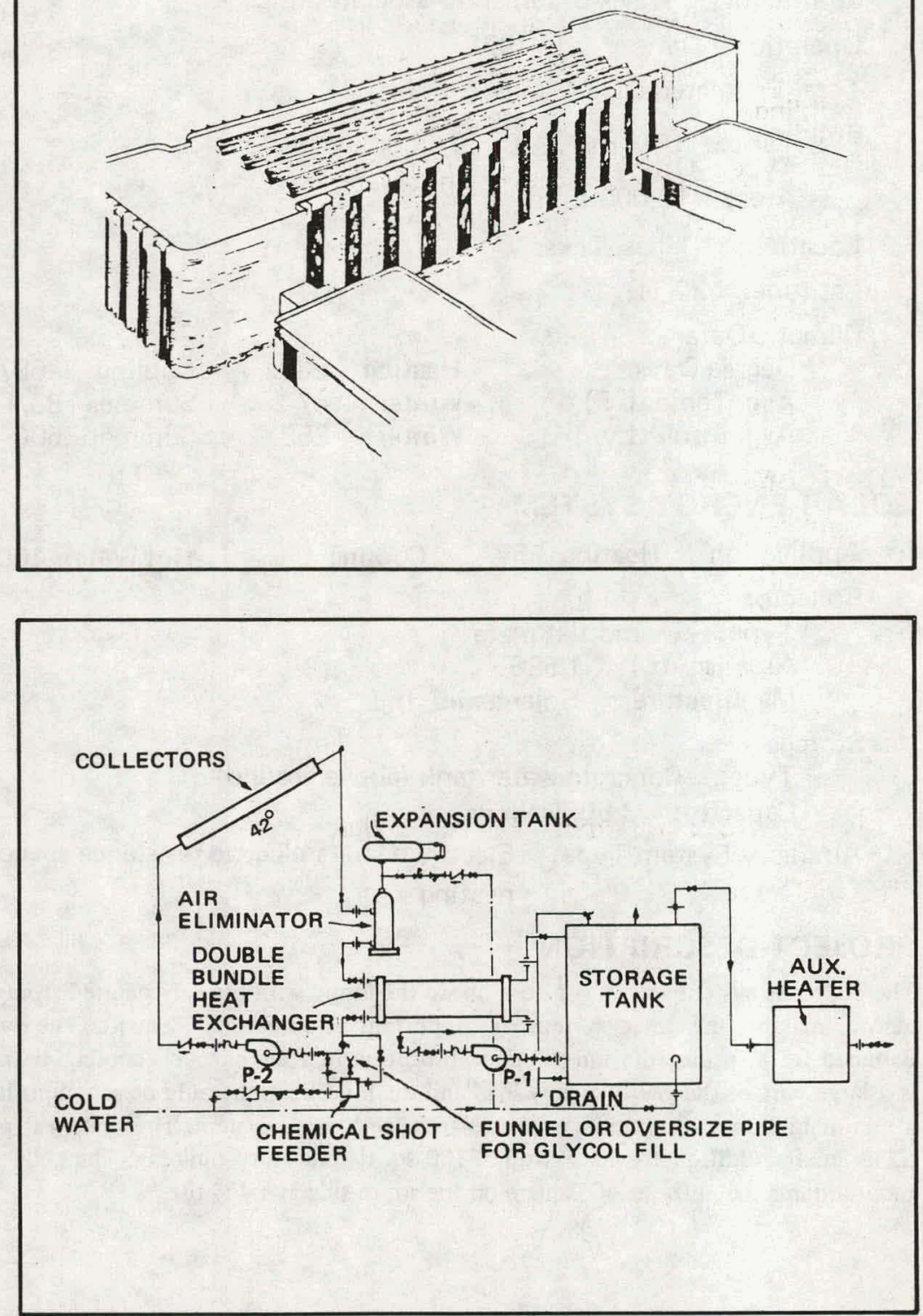


\section{PROJECT INFORMATION}

Owner/Builder: La Quinta Motor Inns, Inc.

Contractor: Travis-Braun \& Associates, Inc.

Operational Date: To be determined

Total Estimated DOE Funds: $\quad \$ 38,039$

\section{Building}

Type: Low rise motel

Area: Not applicable to hot water systems

Location: San Antonio, Texas

Latitude: $29^{\circ} 3^{\prime} \mathrm{N}$

Climatic Data

$\begin{array}{lllll}\text { Degree Days } & \text { Heating } & 1715 & \text { Cooling } & 2846 \\ \text { Avg. Temp. ( }{ }^{\circ} \mathrm{F} \text { ) } & \text { Winter } & 53 & \text { Summer } & 78 \\ \text { Avg. Insol. (Ly/d) } & \text { Winter } & 260 & \text { Summer } & 520\end{array}$

\section{SOLAR ENERGY SYSTEM}

Application Heating $0 \%$

Collector

Cooling $0 \%$

Hot Water $70 \%$

Type: Liquid flat-plate

Area (sq. ft.): 1,800

Manufacturer: Revere Copper \& Brass, Inc.

\section{Storage}

Type: Steel water tank (above ground)

Capacity: 1,600 gallons

Auxiliary System Type: Electric boiler

\section{PROJECT DESCRIPTION}

A drain-down system is proposed under this grant. This system is one in which, each time the water circulation pump stops, the collector fluid water drains out of and down into the protection of an enclosed space. In this proposal, this enclosed space is the mechanical room of the motel. This system is a hybrid version of a drain-down system employing a heat exchanger. By using this heat exchanger, the buildup of minerals in the solar collector is eliminated. On the solar loop of the system, a contained amount of water is employed. Even as this water level drops and makeup water is introduced into the system, new minerals, acids, etc., are also introduced; however, this introduction is extremely minor in comparison to the minerals which would be constantly introduced by a direct link between the storage vessel and the solar collectors.
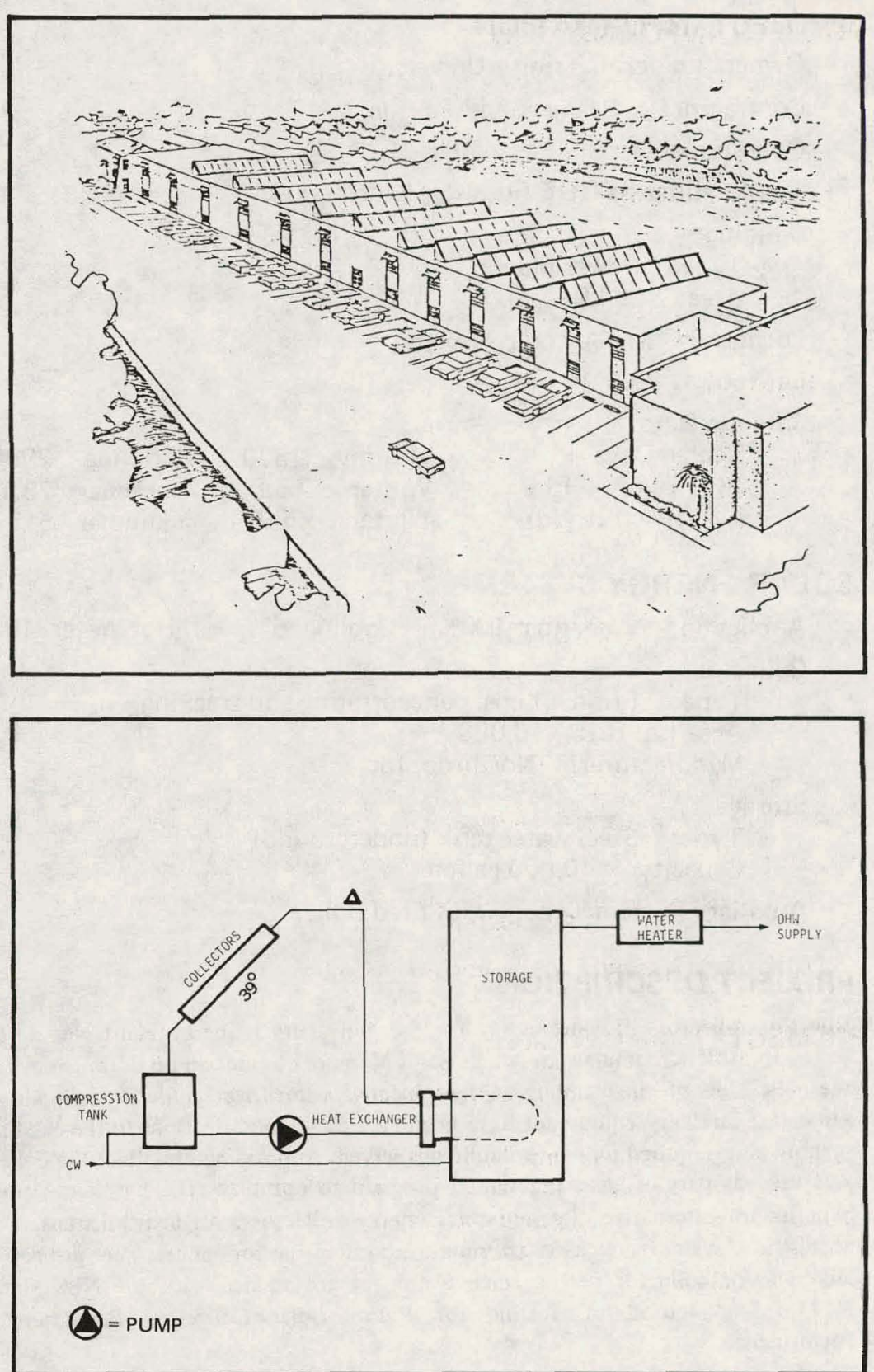


\section{PROJECT INFORMATION}

Owner/Builder: Trinity University

Contractor: Bridgers and Paxton

Operational Date: September 1977

Total Estimated DOE Funds: $\quad \$ 1,100,000$

Building

Type: Power plant

Area: 284,928 sq. ft.

Location: San Antonio, Texas

Latitude: $29.5^{\circ} \mathrm{N}$

Climatic Data

Degree Days

Avg. Temp. $\left({ }^{\circ} \mathrm{F}\right)$

Avg. Insol. (Ly/d)

$\begin{array}{ll}\text { Heating } & 1570 \\ \text { Winter } & 55.8 \\ \text { Winter } & 299\end{array}$

Cooling 2994

Summer 78.1

Summer 515

\section{SOLAR ENERGY SYSTEM}

Application Heating 100\%

Collector

Type: Fresnel Lens, concentrating and tracking

Area (sq. ft.): $\quad 16,080$

Manufacturer: Northrup, Inc.

\section{Storage}

Type: Steel water tank (underground)

Capacity: 40,000 gallons

Auxiliary System Type: Gas fired boiler

\section{PROJECT DESCRIPTION}

Rooftop collectors provide energy for the University's Energy Plant No. 2. The plant serves an athletic complex known as Sams Memorial Center and 6 dormitories located on the west side of the campus. A new electric centrifugal chiller, cooling-tower, and associated auxiliary equipment have been added. No modifications to the existing HVAC system were required within the buildings served. Approximately $3 \%$ of the collector area was used as part of an experimental program to optimize efficiency and compare cost benefits for alternative types of solar energy collectors. An instrumentation and data acquisition system are used to monitor system performance. The project provides facilities for collector performance testing in accordance with the NBS Manual NBS IR74-635, "Method of Testing for Rating Solar Collectors Based on Thermal Performance,"
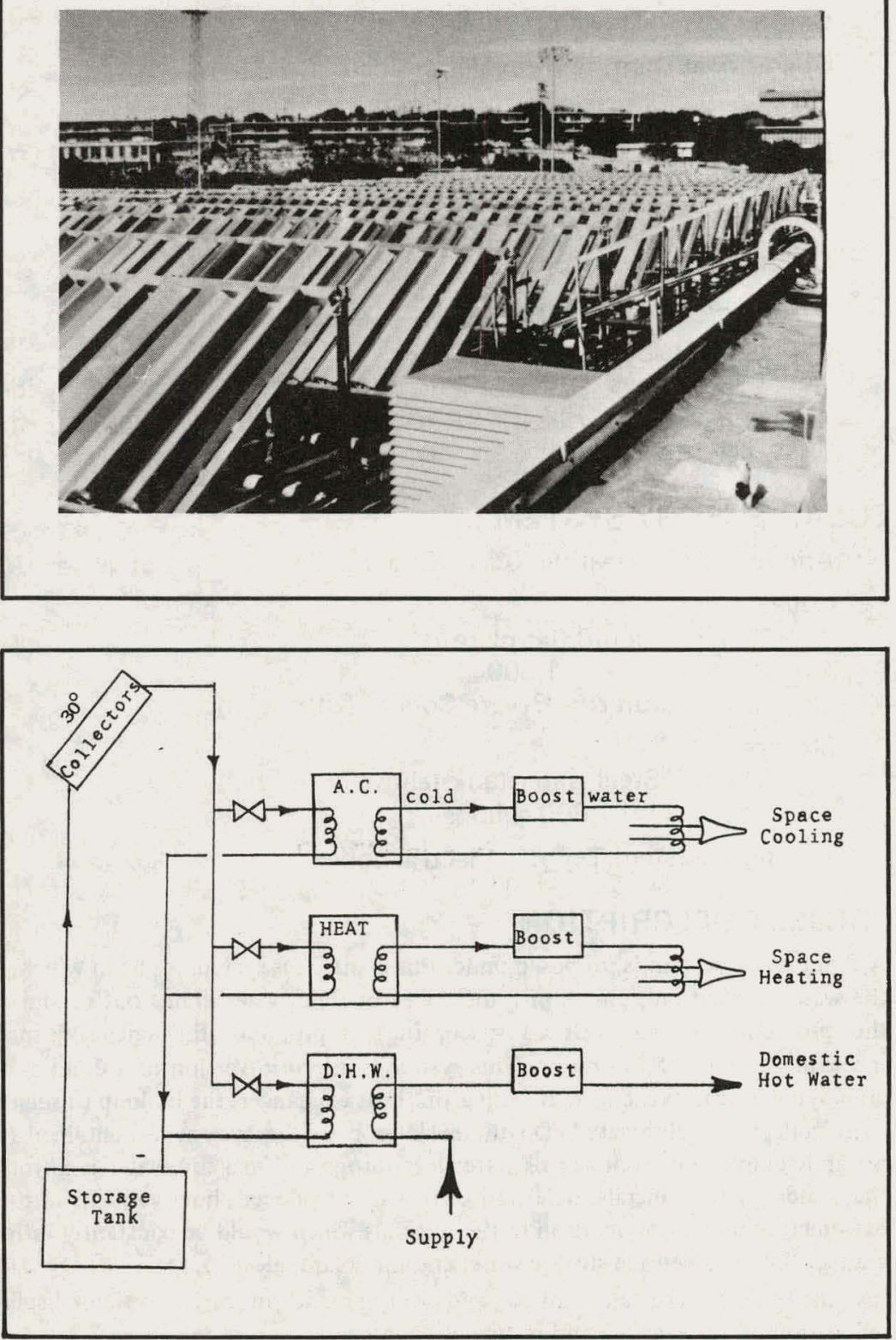


\section{PROJECT INFORMATION}

Owner/Builder: John W. Thompson

Contractor: Thompson Construction Company

Operational Date: To be determined

Total Estimated DOE Funds: $\quad \$ 21,670$

Building

Type: Low rise motel

Area: Not applicable to hot water systems

Location: Taylor, Texas

Latitude: $30^{\circ} \mathrm{N}$

Climatic Data

Degree Days

Avg. Temp. $\left({ }^{\circ} \mathrm{F}\right)$

Avg. Insol. (Ly/d)

Heating 2833
Winter 53

Cooling 2039

Summer 84

Winter $283 \quad$ Summer 353

\section{SOLAR ENERGY SYSTEM}

\section{Application Heating 0\% \\ Cooling $0 \%$ \\ Collector \\ Type: Liquid flat-plate \\ Area (sq. ft.): 1,232 \\ Manufacturer: Lennox Industries, Inc.}

Hot Water $73 \%$

Storage

Type: Steel water tank (above ground)

Capacity: 2,000 gallons

Auxiliary System Type: Electric

\section{PROJECT DESCRIPTION}

A central solar facility, on ground level for public accessibility, will assist the hot water systems of three surrounding buildings: a two-story building with 30 conventional rental units, a one-story building with 32 rental units for railroad employees, and a one-story commercial building with a restaurant and offices. Each building will have a separate circulating hot water system which will be tied to a central solar storage tank. When the tank can contribute heat to a loop, the tank is included in that loop; otherwise it is bypassed by a three-way valve. The solar collectors, mechanical shed, and tall storage tank will be constructed in the center of the motel complex and will be open for walking tours by the public. The mechanical shed will include an active system display for the education of motel guests and restaurant customers.
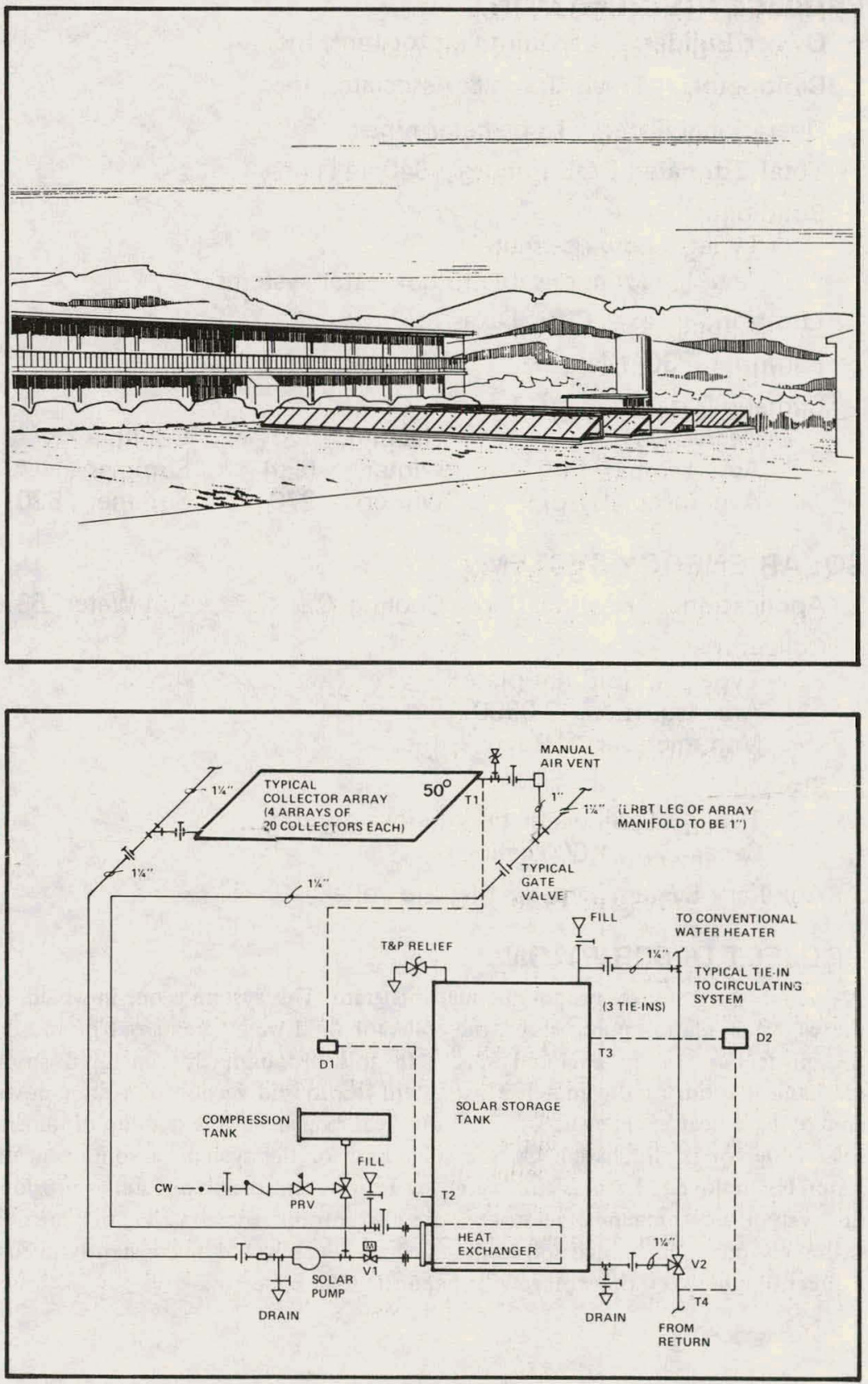


\section{PROJECT INFORMATION}

Owner/Builder: La Quinta Motor Inns, Inc.

Contractor: Travis-Braun \& Associates, Inc.

Operational Date: To be determined

Total Estimated DOE Funds: $\quad \$ 40,441$

Building

Type: Low rise motel

Area: Not applicable to hot water systems

Location: Texas City, Texas

Latitude: $30^{\circ} 1^{\prime} \mathrm{N}$

Climatic Data

Degree Days

Avg. Temp. $\left({ }^{\circ} \mathrm{F}\right)$

Avg. Insol. (Ly/d)

$\begin{array}{ll}\text { Heating } & 1274 \\ \text { Winter } & 62.4 \\ \text { Winter } & 270\end{array}$

Cooling N/A

Summer N/A

Summer 520

\section{SOLAR ENERGY SYSTEM}

Application Heating $0 \%$

Collector

Type: Liquid flat-plate

Area (sq. ft.): 2,0000

Manufacturer: Raypak, Inc.

Storage

Type: Steel water tank (above ground)

Capacity: 1,600 gallons

Auxiliary System Type: Electric boiler

\section{PROJECT DESCRIPTION}

A drain-down system is proposed under this grant. This system is one in which, each time the water circulation pump stops, the collector fluid water drains out of and down into the protection of an enclosed space. In this proposal, this enclosed space is the mechanical room of the motel. This system is a hybrid version of a drain-down system employing a heat exchanger. By using this heat exchanger, the buildup of minerals in the solar collector is eliminated. On the solar loop of the system, a contained amount of water is employed. Even as this water level drops and makeup water is introduced into the system, new minerals, acids, etc., are also introduced; however, this introduction is extremely minor in comparison to the minerals which would be constantly introduced by a direct link between the storage vessel and the solar collectors.
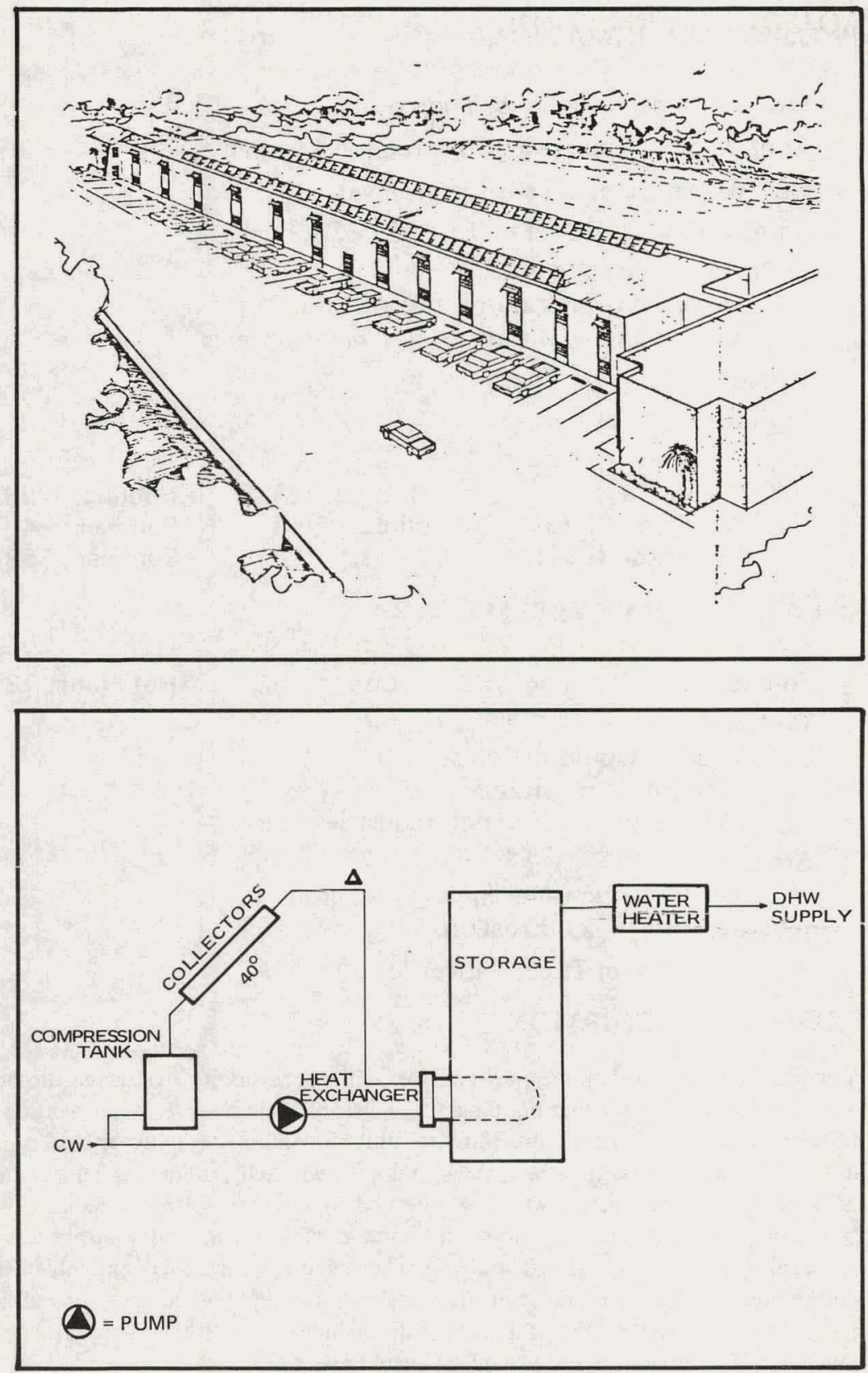


\section{PROJECT INFORMATION}

Owner/Builder: The Woodlands Commercial Development Company Contractor: Interactive Resources, Inc.

Operational Date: August 1978

Total Estimated DOE Funds: $\quad \$ 46,719$

Building

Type: Low rise hotel

Area: Not applicable to hot water systems

Location: The Woodlands, Texas

Latitude: $29^{\circ} \mathrm{N}$

Climatic Data

$\begin{array}{lllll}\text { Degree Days } & \text { Heating } & 1334 & \text { Cooling } & 2656 \\ \text { Avg. Temp. }\left({ }^{\circ} \mathrm{F}\right) & \text { Winter } & 54 & \text { Summer } & 82 \\ \text { Avg. Insol. (Ly/d) } & \text { Winter } & 370 & \text { Summer } & 607\end{array}$

\section{SOLAR ENERGY SYSTEM}

Application Heating 0\% Cooling 0\% Hot Water $56.3 \%$

Collector

Type: Liquid flat-plate

Area (sq. ft.): 4,080

Manufacturer: Solar Energy Products, Inc.

Storage

Type: Insulated steel water tank (above ground)

Capacity: 1,520 gallons

Auxiliary System Type: Electricity/natural gas

\section{PROJECT DESCRIPTION}

This project consists of two distinct systems. One system consists of 1200 sq. ft. of collectors on the roof and a 1520-gallon solar water storage tank. This system will operate in pre-heat mode, supplying $57 \%$ of the yearly load. An electric water heater will serve as a back-up. The other system, consisting of $2880 \mathrm{sq}$. ft. of collectors will supply $56 \%$ of the indoor swimming pool's year-round heating load. The existing gas fired heater will serve as the back-up.
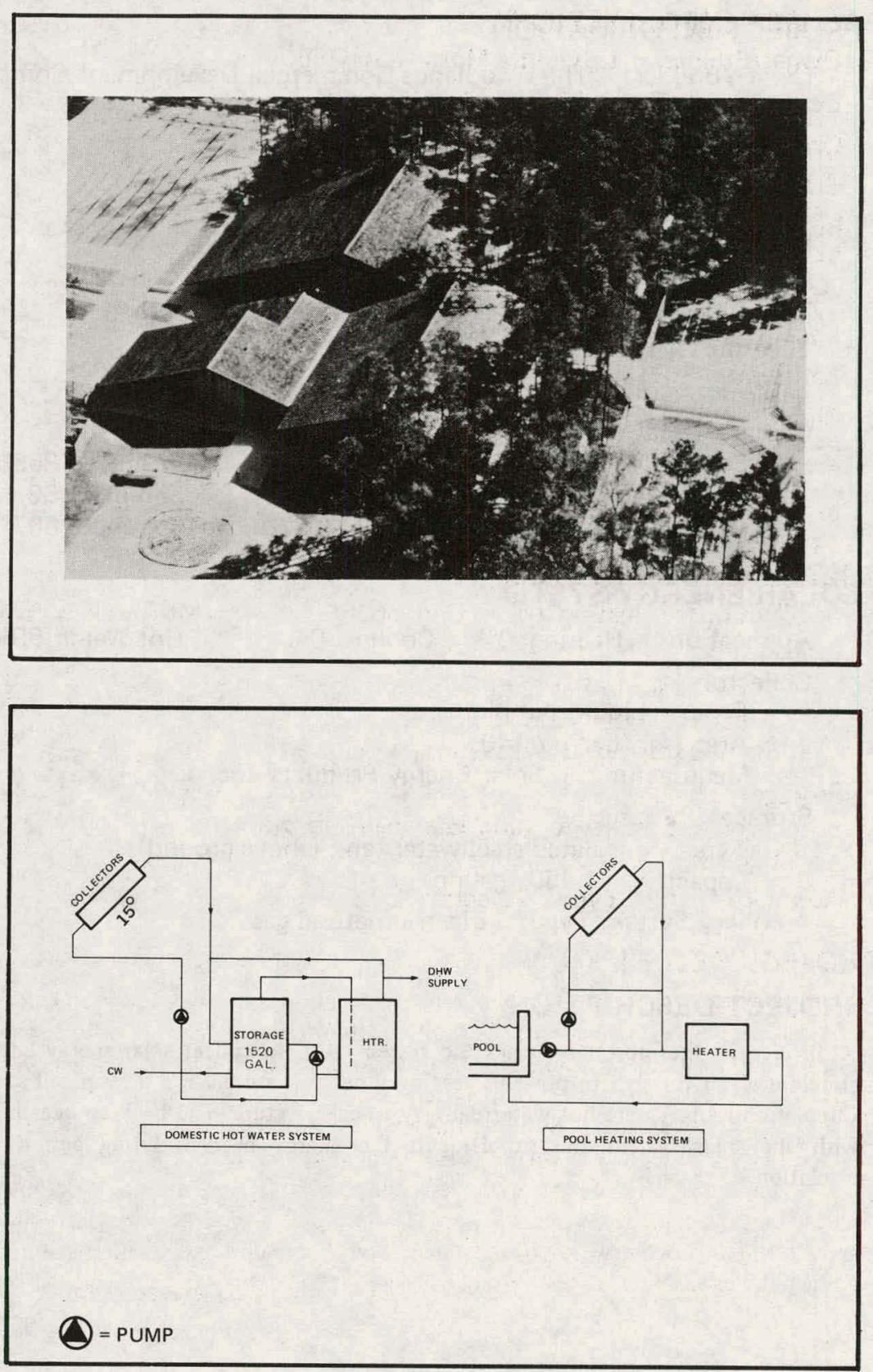


\section{PROJECT INFORMATION}

Owner/Builder: The Woodlands Commercial Development Company

Contractor: Interactive Resources, Inc.

Operational Date: August 1978

Total Estimated DOE Funds: $\quad \$ 130,301$

Building

Type: Low rise hotel

Area: Not applicable to hot water systems

Location: The Woodlands, Texas

Latitude: $29^{\circ} \mathrm{N}$

Climatic Data

$\begin{array}{lllll}\text { Degree Days } & \text { Heating } & 1334 & \text { Cooling } & 2656 \\ \text { Avg. Temp. }\left({ }^{\circ} \mathrm{F}\right) & \text { Winter } & 54 & \text { Summer } & 82 \\ \text { Avg. Insol. (Ly/d) } & \text { Winter } & 370 & \text { Summer } & 607\end{array}$

\section{SOLAR ENERGY SYSTEM}

Application Heating $0 \%$ Cooling $0 \%$ Hot Water 58\%

Collector

Type: Liquid flat-plate

Area (sq. ft.): 7,140

Manufacturer: Solar Energy Products, Inc.

Storage

Type: Insulated steel water tank (above ground)

Capacity: 7,450 gallons

Auxiliary System Type: Electric/natural gas

\section{PROJECT DESCRIPTION}

A differential thermostat activates the system both to collect solar energy and also to circulate water through to prevent freezing. Energy is stored in a pressurized steel tank. Circulation loops assure hot water delivery to each fixture. The back-up heat is in series with the solar system and supplements the energy needed during periods of low insolation.
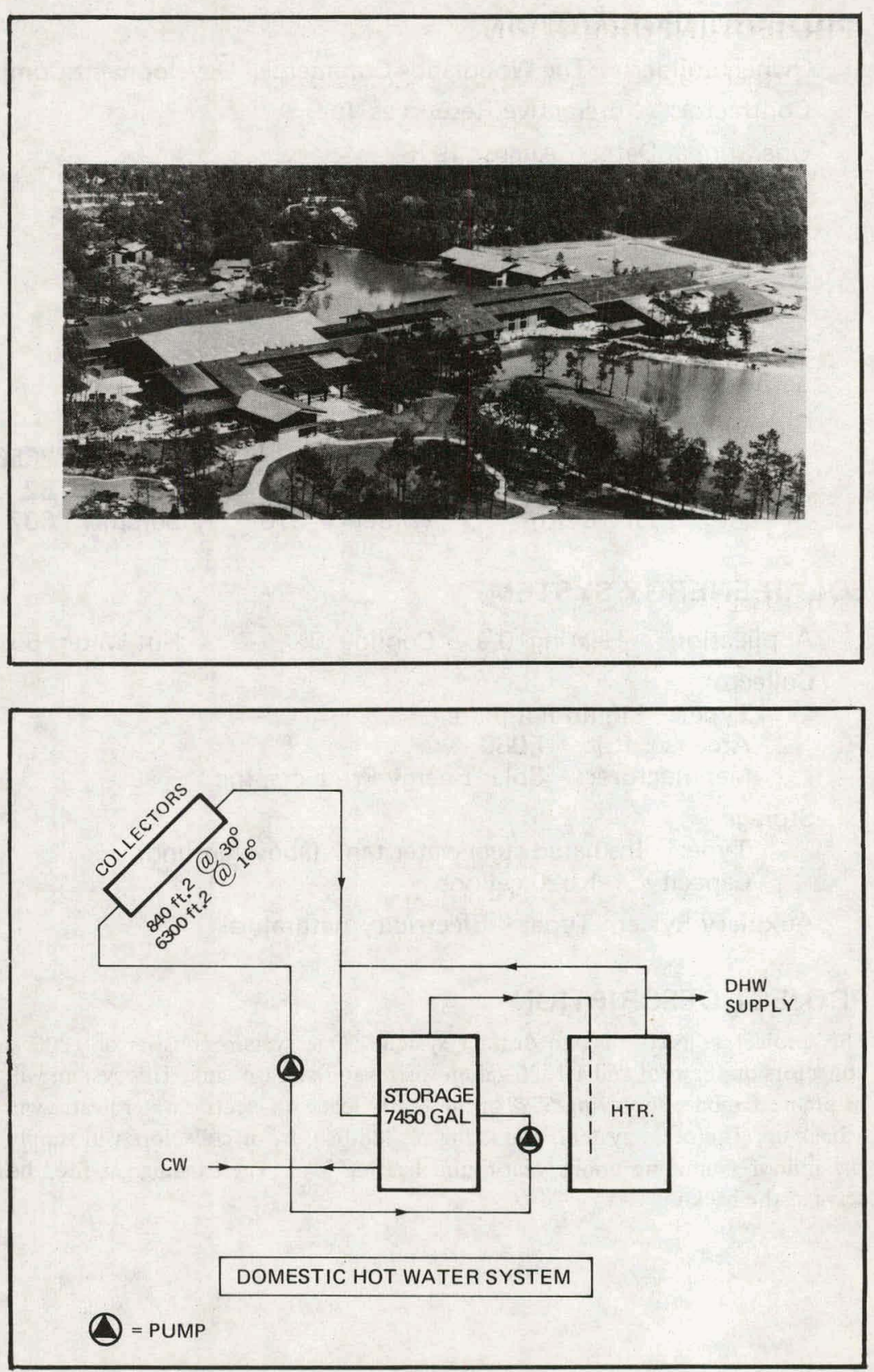


\section{PROJECT INFORMATION}

Owner/Builder: Young Ideas Consultants

Contractor: To be determined

Operational Date: March 1978

Total Estimated DOE Funds: $\quad \$ 101,943$

Building

Type: Light manufacturing

Area: $\quad 17,000$ sq. ft. (total); 9,751 sq. ft. (cond.)

Location: Ogden, Utah

Latitude: $40^{\circ} \mathrm{N}$

Climatic Data

Degree Days

Avg. Temp. $\left({ }^{\circ} \mathrm{F}\right)$

Avg. Insol. (Ly/d)

$\begin{array}{llll}\text { Heating } & 6052 & \text { Cooling } & \text { N/A } \\ \text { Winter } & 41 & \text { Summer } & 71 \\ \text { Winter } & 183 & \text { Summer } 643\end{array}$

\section{SOLAR ENERGY SYSTEM}

Application Heating 62\%

Collector

Type: Air flat-plate

Area (sq. ft.): 3,800

Manufacturer: Permaloy Corporation/Young Ideas Consultants Storage

Type: Rock bed (underground)

Capacity: $1,360 \mathrm{cu} . \mathrm{ft}$.

Auxiliary System Type: Natural gas heaters

\section{PROJECT DESCRIPTION}

The solar system will be retrofitted to the existing Permaloy building. Solar heated air can be used to directly heat the building or it can be blown through a rock storage bin. The storage bin is utilized to store solar heat for later use or it can be vented to outside air, releasing its heat. Cool night air can then be blown through the rock storage bin to provide daytime cooling. An automatic control system with associated sensors is utilized to select the proper damper positions for the various operating modes.

\section{Photograph not available}

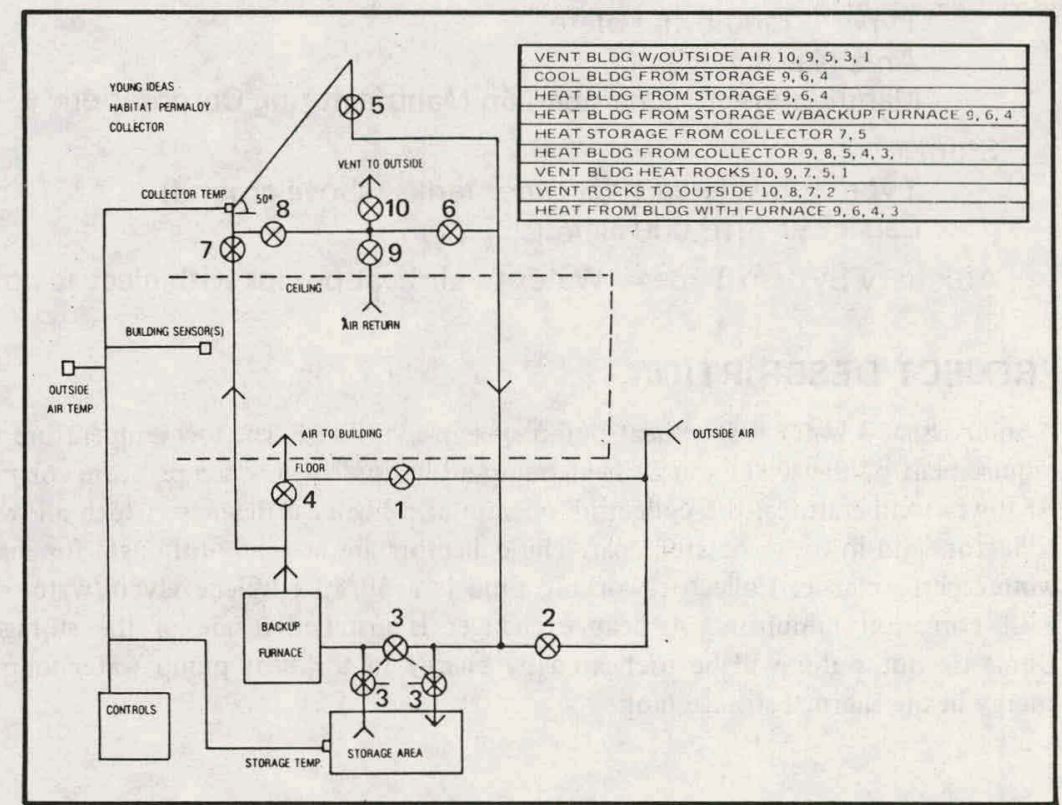




\section{PROJECT INFORMATION}

Owner/Builder: La Quinta Motor Inns, Inc.

Contractor: William Francis Construction

Operational Date: July 1978

Total Estimated DOE Funds: $\quad \$ 133,050$

Building

Type: Low rise motel

Area: $\quad 41,400$ sq. $\mathrm{ft}$

Location: Salt Lake City, Utah

Latitude: $40^{\circ} 50^{\prime}$

Climatic Data

$\begin{array}{lllll}\text { Degree Days } & \text { Heating } & 6052 & \text { Cooling } 927 \\ \text { Avg. Temp. }\left({ }^{\circ} \mathrm{F} \text { ) }\right. & \text { Winter } & 38.4 & \text { Summer } & 73 \\ \text { Avg. Insol. (Ly/d) } & \text { Winter } & 258 & \text { Summer } & 597\end{array}$

\section{SOLAR ENERGY SYSTEM}

\section{Application Heating 25\% \\ Cooling $0 \%$ \\ Hot Water $61 \%$}

Collector

Type: Liquid flat-plate

Area (sq. ft.): 3,000

Manufacturer: Chamberlain Manufacturing Corporation Storage

Type: Insulated steel water tanks (above ground)

Capacity: 10,000 gallons

Auxiliary System Type: Water-to-air heat pumps with electric boiler

\section{PROJECT DESCRIPTION}

A solar-assisted water source heat pump system is utilized. The low temperature thermal requirement of the water source heat pump allows use of low temperature solar energy. At lower temperatures, the collectors operate at a higher efficiency, which allows fewer collectors and lower associated cost. The collectors are at a $55^{\circ}$ tilt angle for maximum winter performance. Collector working fluid is a $50 / 50$ ethylene glycol/water solution with corrosion inhibitors. A heat exchanger is installed inside of the storage tank. Domestic hot water will be preheated by energy in the heat pump water loop and/or energy in the thermal storage tank.
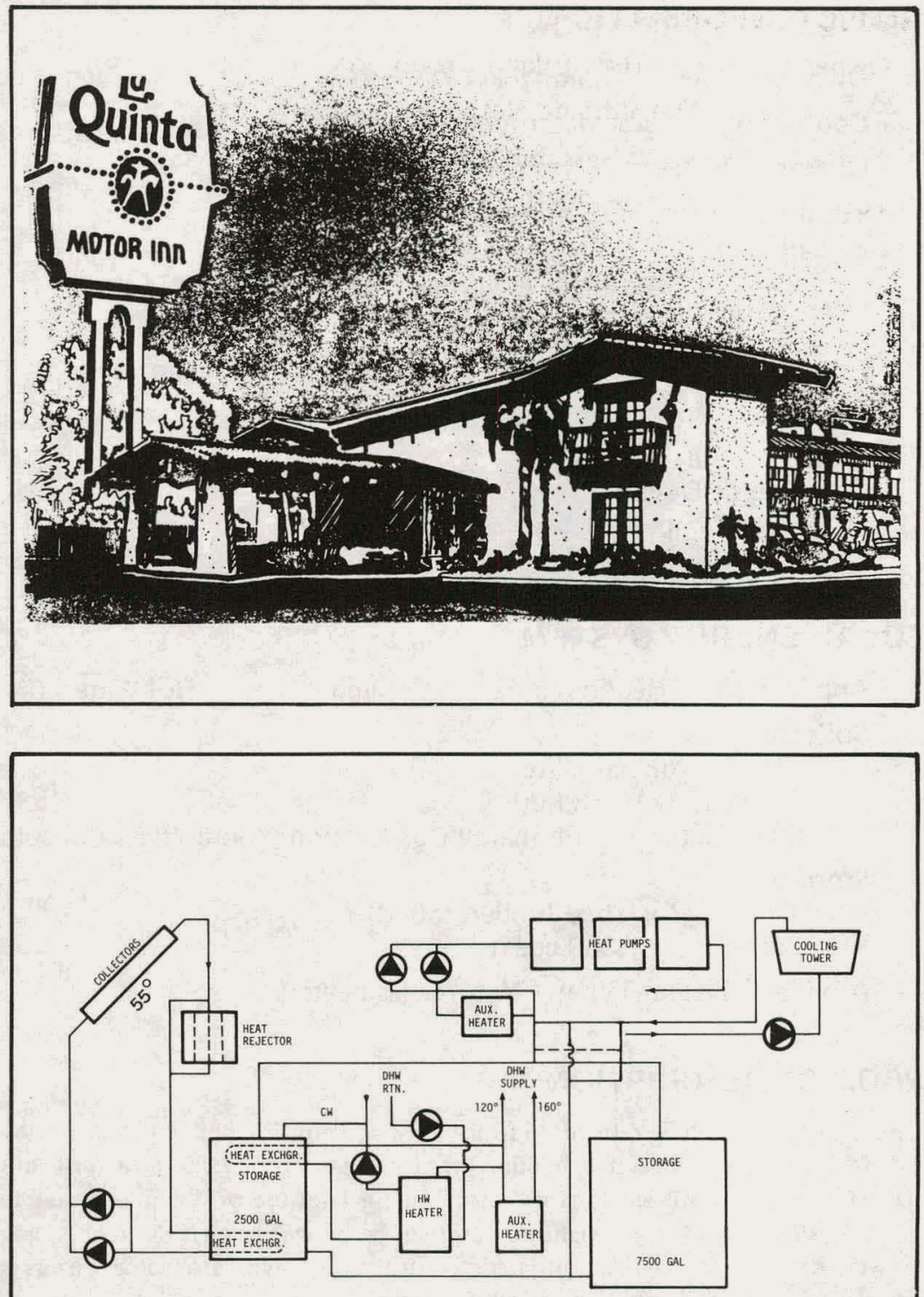

$\theta$ = PUMP 


\section{PROJECT INFORMATION}

Owner/Builder: The Rutland Group, Inc.

Contractor: The Rutland House Construction Corporation

Operational Date: September 1978

Total Estimated DOE Funds: $\$ 22,287$

Building

Type: Office/warehouse

Area: 5,020 sq. ft. (total); 1,900 sq. ft. (cond.)

Location: Rutland, Vermont

Latitude: $43.6^{\circ} \mathrm{N}$

Climatic Data

Degree Days

Avg. Temp. $\left({ }^{\circ} \mathrm{F}\right)$

Avg. Insol. (Ly/d)

\section{Cooling 496 \\ Summer 65.4 \\ Summer 188}

\section{SOLAR ENERGY SYSTEM}

Application Heating 75\% Cooling 0\% Hot Water $0 \%$

Collector

Type: Air flat-plate

Area (sq. ft.): 2,000

Manufacturer: The Rutland Group, Inc.

Storage

Type: Rock bed

Capacity: $1,000 \mathrm{cu}$. ft.

Auxiliary System Type: Fuel oil furnace

\section{PROJECT DESCRIPTION}

The Rutland Group, Inc. is a small, privately-owned real estate and development firm. They are planning to construct a pre-engineered Armco Steel Building for their new offices and warehouse. The solar energy system will utilize air-cooled vertical south wall and roof collectors with the Armco "steelox" sheathing as the absorber plate. Heated air from the roof is passed through a concrete masonry cavity wall on the interior then to an underslab perimeter distribution "moat" which is a concrete plenum supplying the rock bed through perforated tubes. The masonry wall and washed rock is thermal storage. The collectors are thoroughly integrated with the building forming a vital element for the facade.
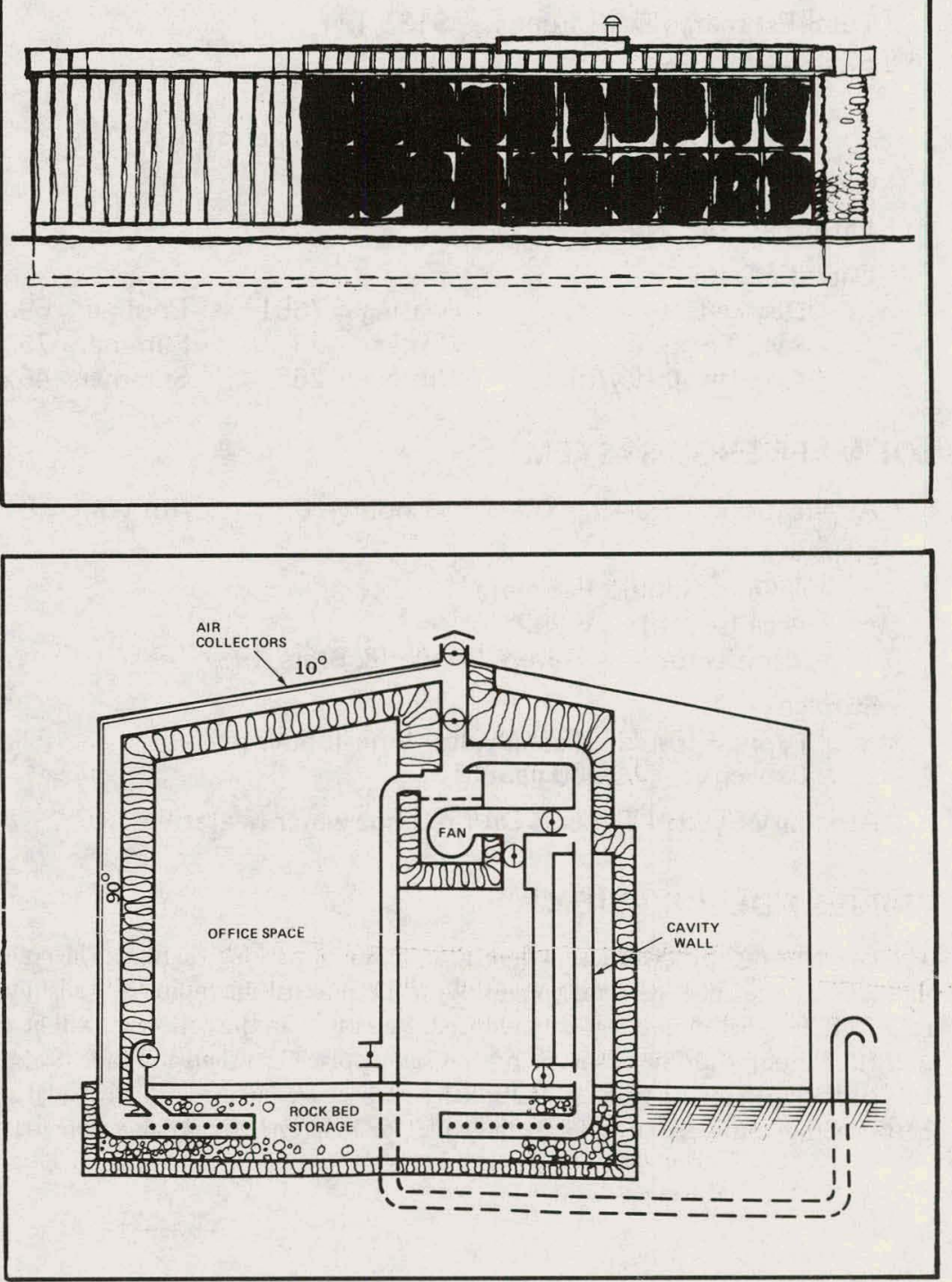


\section{PROJECT INFORMATION}

Owner/Builder: Woodstock Resort Corporation

Contractor: Wormser Scientific Corporation

Operational Date: Fall 1978

Total Estimated DOE Funds: $\quad \$ 138,194$

Building

Type: Low rise hotel

Area: Not applicable to hot water systems

Location: Woodstock, Vermont

Latitude: $43^{\circ} \mathrm{N}$

Climatic Data

$\begin{array}{lllll}\text { Degree Days } & \text { Heating } & 7601 & \text { Cooling } & 699 \\ \text { Avg. Temp. }\left({ }^{\circ} \mathrm{F}\right) & \text { Winter } & 23 & \text { Summer } & 75 \\ \text { Avg. Insol. (Ly/d) } & \text { Winter } & 265 & \text { Summer } & 462\end{array}$

\section{SOLAR ENERGY SYSTEM}

Application Heating $0 \%$ Cooling $0 \%$ Hot Water $84 \%$

Collector

Type: Liquid flat-plate

Area (sq. ft.): 5,292

Manufacturer: Revere Copper \& Brass, Inc.

Storage

Type: Insulated steel water tank (underground)

Capacity: 10,000 gallons

Auxiliary System Type: Oil fired hot water heater

\section{PROJECT DESCRIPTION}

The collector mounting structure forms two units of parking shelters. The collectors are piped in a series parallel arrangement. With the internal manifolding available with this collector, external piping is greatly reduced. Fluid flow in the collectors will be contained in a closed loop with the exchange of heat taking place in a shell and tube heat exchanger adjacent to the storage tank. A multiplicity of heat exchangers provides dual separation between the antifreeze solution in the collector loop and the potable domestic water.
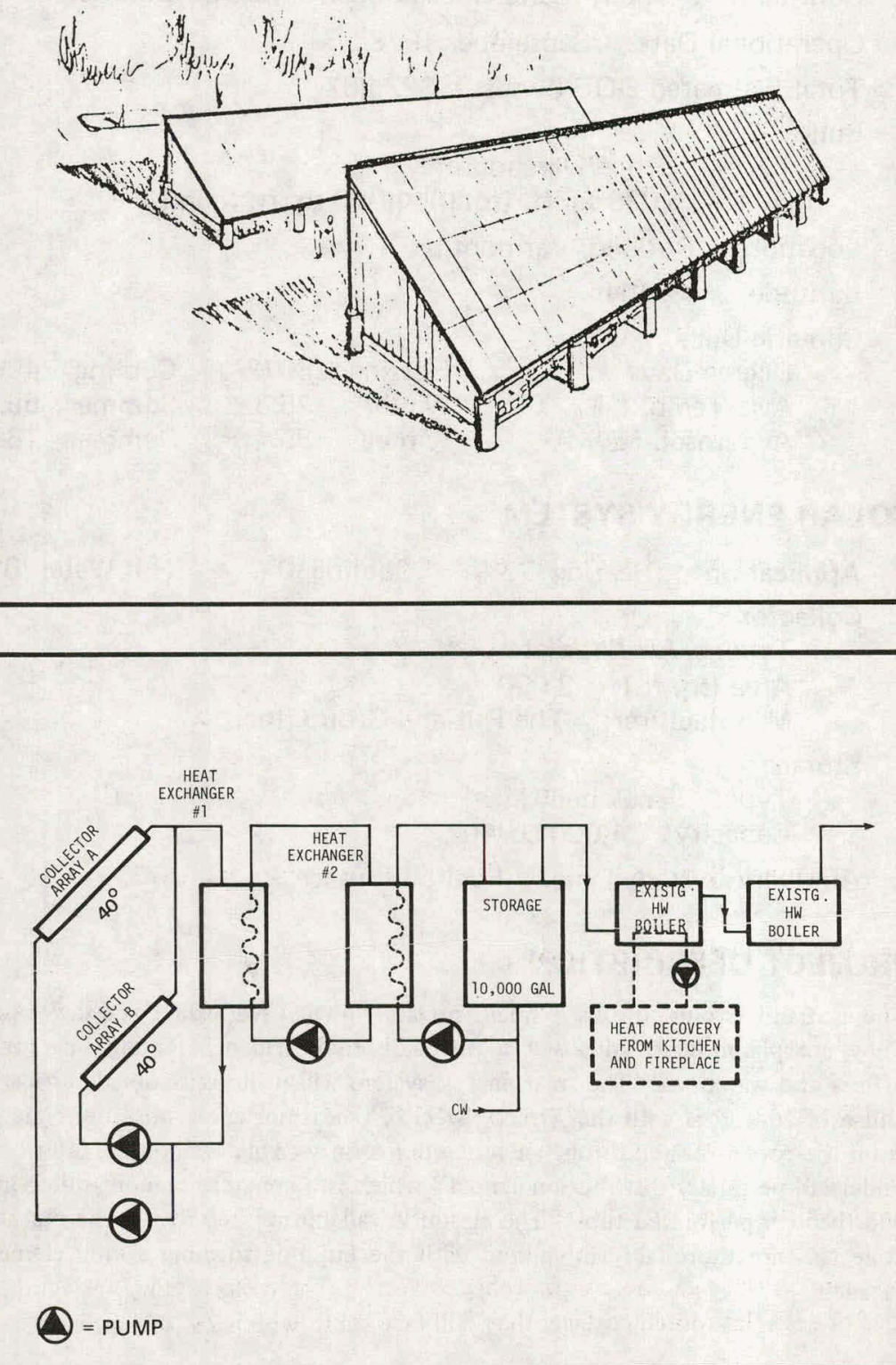


\section{PROJECT INFORMATION}

Owner/Builder: Rockresorts, Inc.

Contractor: Owen \& Mayes

Operational Date: August 1978

Total Estimated DOE Funds: $\quad \$ 72,996$

Building

Type: Duplex cottages/low rise hotel

Area: Not applicable to hot water systems

Location: St. John, Virgin Islands

Latitude: $18^{\circ} \mathrm{N}$

\section{Climatic Data}

Degree Days

Avg. Temp. $\left({ }^{\circ} \mathrm{F}\right)$

Avg. Insol. (Ly/d)

$\begin{array}{llll}\text { Heating } & \text { N/A } & \text { Cooling } & 4982 \\ \text { Winter } & 77 & \text { Summer } & 81 \\ \text { Winter } & 494 & \text { Summer } & 570\end{array}$

\section{SOLAR ENERGY SYSTEM}

Application Heating $0 \%$

\section{Collector}

Cooling $0 \%$ Hot Water $67 \%$

Type: Liquid flat-plate

Area (sq. ft.): 4,365

Manufacturer: Revere Copper \& Brass, Inc.

Storage

Type: Glass lined steel water tanks (above ground)

Capacity: 6,220 gallons

Auxiliary System Type: Electric immersion heater

\section{PROJECT DESCRIPTION}

The domestic hot water solar energy system proposed for Caneel Bay Plantation is a series of individual domestic hot water systems for 104 of the guest rooms in addition to the two kitchens and laundry facilities. The 104 guest rooms are located in 25 separate buildings. The kitchens and the laundry are located in separate buildings with each building having an individual solar hot water system. Since the temperature in the Virgin Islands rarely drops below $70^{\circ} \mathrm{F}$ and the all time low is $63^{\circ} \mathrm{F}$, there is no need for freeze protection on the solar system. This considerably simplifies the design of the domestic hot water system and improves the overall system efficiency since the potable water can be pumped through the copper tubed collector. The collectors will be mounted on the roof of each flat-roofed cottage; they will face south with a $28^{\circ}$ tilt angle.
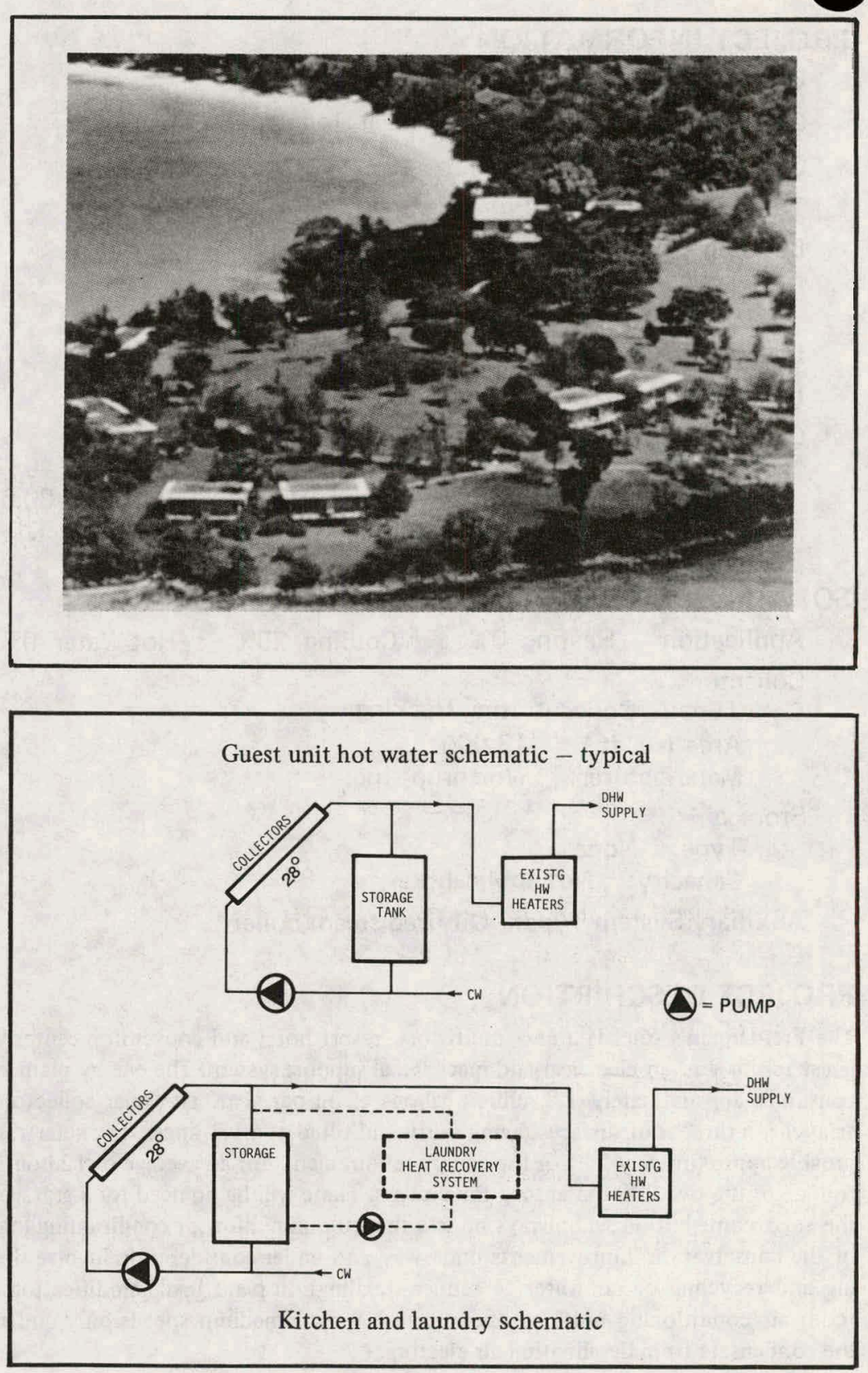


\section{PROJECT INFORMATION}

Owner/Builder: American Motor Inns, Inc.

Contractor: Oversea's Mechanical, Inc.

Operational Date: September 1977

Total Estimated DOE Funds: $\quad \$ 411,447$

Building

Type: Hotel

Area: 250,000 sq. $\mathrm{ft}$.

Location: St. Thomas, Virgin Islands

Latitude: $18.4^{\circ} \mathrm{N}$

Climatic Data

$\begin{array}{lllll}\text { Degree Days } & \text { Heating } & \text { N/A } & \text { Cooling } & 4982 \\ \text { Avg. Temp. }\left({ }^{\circ} \mathrm{F}\right) & \text { Winter } & 76.7 & \text { Summer } & 80.6 \\ \text { Avg. Insol. (Ly/d) } & \text { Winter } & 494 & \text { Summer } & 570\end{array}$

\section{SOLAR ENERGY SYSTEM}

Application Heating 0\%

Collector

Cooling $25 \% \quad$ Hot Water $0 \%$

Type: Concentrating tracking

Area (sq. ft.): $\quad 13,000$

Manufacturer: Northrup, Inc.

Storage

Type: None

Capacity: Not applicable

Auxiliary System Type: Oil fired steam boiler

\section{PROJECT DESCRIPTION}

The Frenchman's Reef is a new multistory resort hotel and convention center with 300 guest rooms and an electrical and mechanical support system. The energy plant currently consumes approximately 1.2 million gallons of oil per year. The solar collector is to be arrayed on three roof surfaces facing south and tilted at a $15^{\circ}$ angle. The solar system will provide approximately $54 \%$ of the energy requirements for an average of 12 hours per day for one of the two 200-ton absorption chillers. There will be no need for a storage system; the solar contribution will always be less than the minimum air conditioning load. Some of the conservation improvements underway and under consideration involve the capturing and recycling of rainwater to reduce desalination plant load, modification of guest room air conditioning units to operate on low and medium speeds only and recycling the condensate from desalination air ejectors.
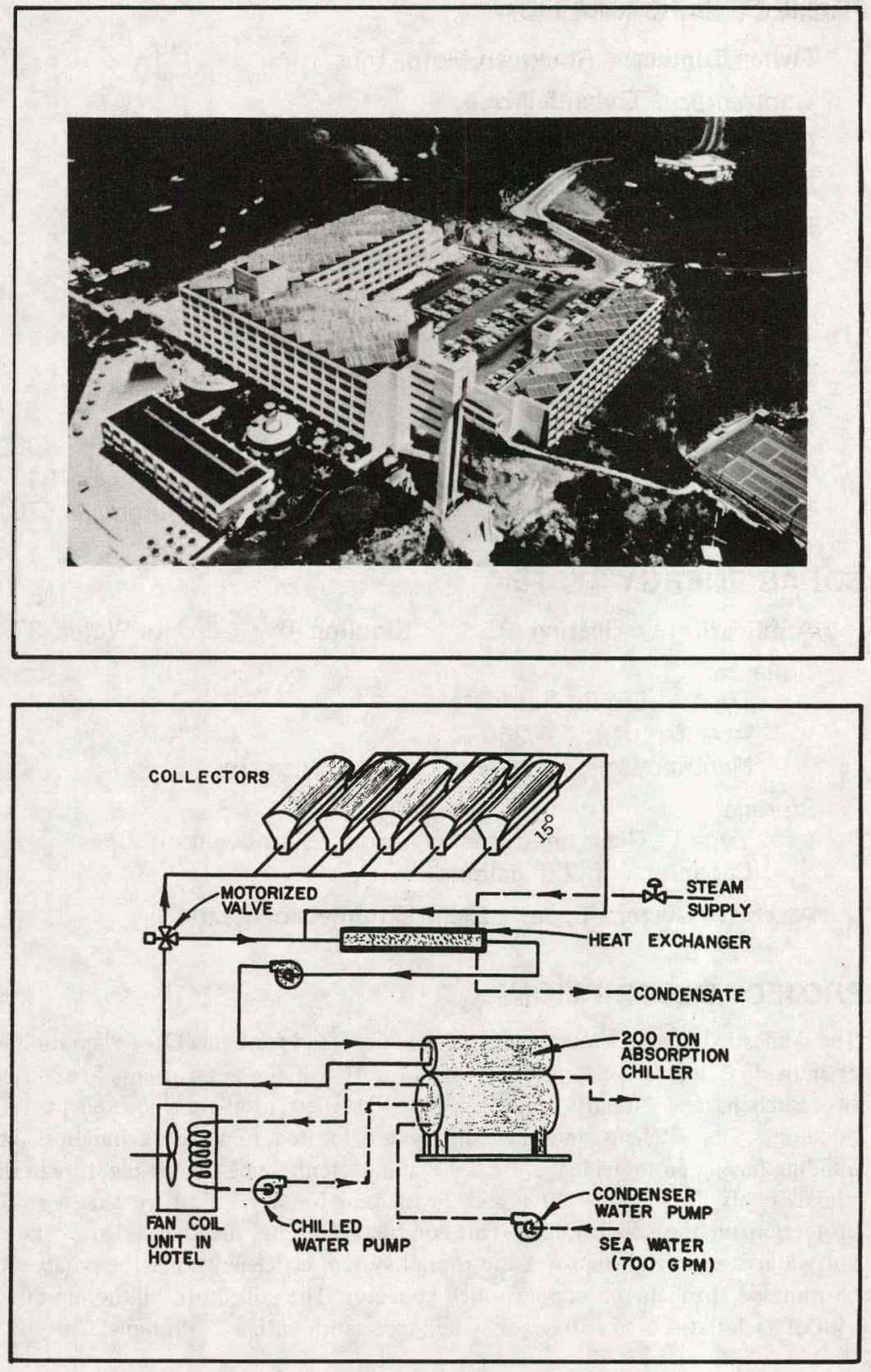


\section{PROJECT INFORMATION}

Owner/Builder: American Motor Inns, Inc.

Contractor: To be determined

Operational Date: October 1978

Total Estimated DOE Funds: $\quad \$ 32,800$

Building

Type: High rise motor inn

Area: Not applicable to hot water systems

Location: Alexandria, Virginia

Latitude: $38^{\circ} \mathrm{N}$

Climatic Data

Degree Days

Avg. Temp. ( $\left.{ }^{\circ} \mathrm{F}\right)$

Avg. Insol. (Ly/d)

$\begin{array}{llll}\text { Heating } & 3413 & \text { Cooling } & 1554 \\ \text { Winter } & 44 & \text { Summer } & 70 \\ \text { Winter } & 550 & \text { Summer } & 614\end{array}$

\section{SOLAR ENERGY SYSTEM}

Application Heating $0 \%$

Hot Water $62 \%$

Collector

Type: Liquid flat-plate

Area (sq. ft.): 1,533

Manufacturer: Sunworks, Inc.

Storage

Type: Insulated steel water tanks (underground)

Capacity: 2,000 gallons

Auxiliary System Type: Natural gas fired boiler

\section{PROJECT DESCRIPTION}

This proposed system consists of two distinct systems. One system, consisting of 22 collectors and a 500-gallon storage tank, provides hot water to the kitchen and dining area located in the commercial building. A new 70-gallon hot water heater will be installed as a back-up for this system. The other system, consisting of 51 collectors and two 750-gallon storage tanks, connected in series, will provide hot water to the ten-story, 204 guest unit building. The existing boiler will provide any necessary auxiliary energy.
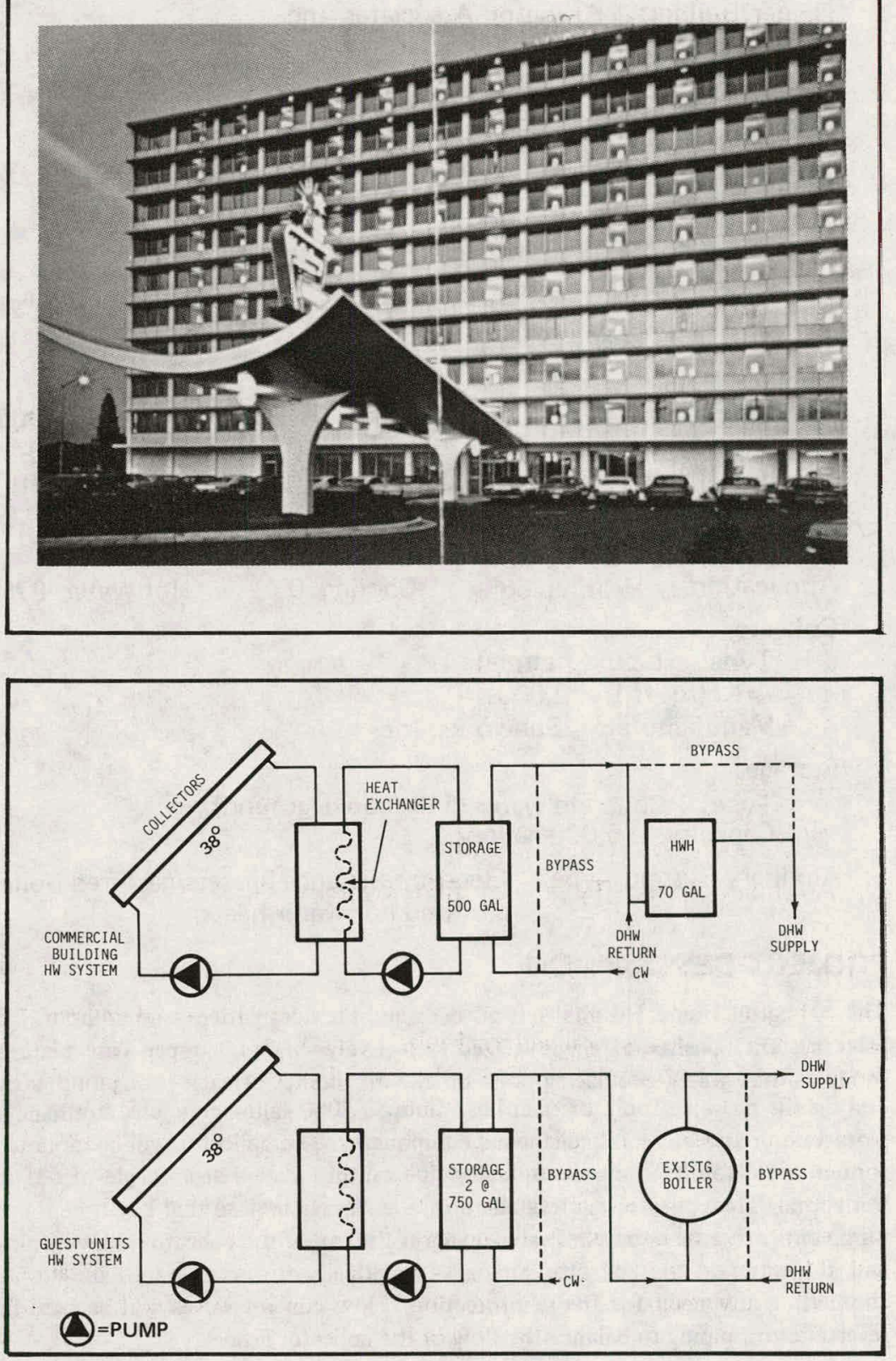


\section{PROJECT INFORMATION}

Owner/Builder: Arlington Associates, Inc.

Contractor: Owen and Mayes Consulting Engineers

Operational Date: October 1978

Total Estimated DOE Funds: $\$ \mathbf{6 4 , 6 3 7}$

\section{Building}

Type: Psychiatric hospital

Area: 32,000 sq. ft. (total); 7,200 sq. ft. (cond.)

Location: Charlottesville, Virginia

Latitude: $37.5^{\circ} \mathrm{N}$

Climatic Data

$\begin{array}{lllll}\text { Degree Days } & \text { Heating } & 4166 & \text { Cooling } & 1000 \\ \text { Avg. Temp. }\left({ }^{\circ} \mathrm{F}\right) & \text { Winter } & 40 & \text { Summer } & 68 \\ \text { Avg. Insol. (Ly/d) } & \text { Winter } & 200 & \text { Summer } & 450\end{array}$

Avg. Insol. (Ly/d) Winter $200 \quad$ Summer 450

\section{SOLAR ENERGY SYSTEM}

\section{Application Heating 66\% Cooling 0\% Hot Water $87 \%$}

Collector

Type: Liquid flat-plate

Area (sq. ft.): 2,000

Manufacturer: Sunworks, Inc.

Storage

Type: Concrete water tank (above ground)

Capacity: 5,000 gallons

Auxiliary System Type: Electric resistance heaters/gas fired boiler/ gas fired hot water heater

\section{PROJECT DESCRIPTION}

The Arlington House Hospital has 50 beds and provides patient care 24 hours a day. The solar system consists of single glazed, selectively coated, copper base plate collector modules; hot water circulating coils on the air intakes of each heat pump; a hot water coil on the hot air supply of each heat pump; 5000 gallon concrete, urethane-insulated storage tank and other miscellaneous components. The collector will be mounted on the roof in a sawtooth arrangement facing due south, inclined at an angle of $53^{\circ}$ from the horizontal. The collector is elevated above the storage tank so that any time the collector pump cuts off, a vacuum relief valve opens at the top of the collector allowing air to enter and the water in the collector piping automatically flows back into the storage tank, eliminating any need for freeze protection. Flow control valves will be used in lieu of reverse return piping to balance the flow of the collector arrays.

\section{Photograph not available}

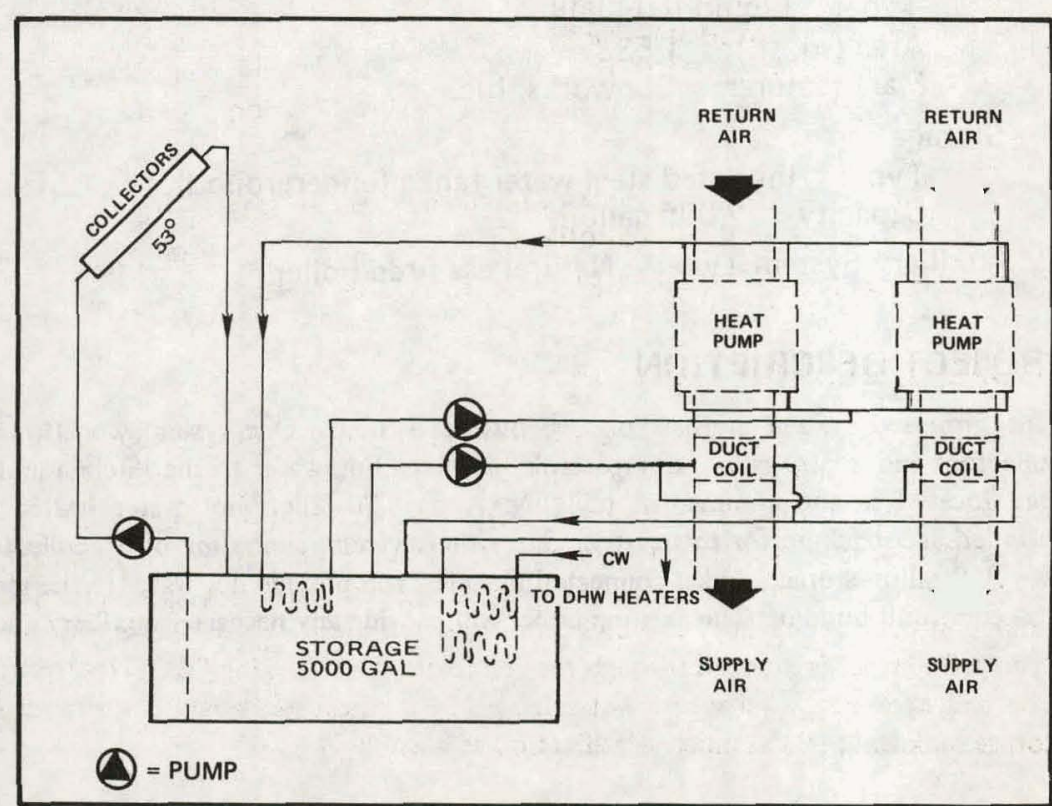




\section{PROJECT INFORMATION}

Owner/Builder: Allen Management, Inc.

Contractor: Solar Systems of Virginia, Inc.

Operational Date: March 1978

Total Estimated DOE Funds: $\quad \$ 11,928$

Building

Type: Low rise motel

Area: Not applicable to hot water systems

Location: Hampton, Virginia

Latitude: $37.5^{\circ} \mathrm{N}$

Climatic Data

$\begin{array}{lllll}\text { Degree Days } & \text { Heating } & 3865 & \text { Cooling } & 1353 \\ \text { Avg. Temp. }\left({ }^{\circ} \mathrm{F}\right) & \text { Winter } & 43 & \text { Summer } & 73 \\ \text { Avg. Insol. (Ly/d) } & \text { Winter } & 260 & \text { Summer } & 550\end{array}$

\section{SOLAR ENERGY SYSTEM}

\author{
Collector \\ Type: Liquid flat-plate \\ Area (sq. ft.): 1,024 \\ Manufacturer: Solar Systems of Virginia, Inc. \\ Storage \\ Type: Insulated steel water tanks (above ground) \\ Capacity: 1,500 gallons
}

Auxiliary System Type: Electric hot water heater

\section{PROJECT DESCRIPTION}

The solar collectors for this system are flat-plate, double glazed, with black painted absorbers. The outer glazing is premium grade .040 " Sunlite, the inner glazing is fourmils thick Tedlar, and the collectors incorporate a tube-fin design. Sunlite was chosen over glass because of the light weight and ease and safety of assembly. The collectors are tilted at $30^{\circ}$ to obtain maximum insolation during summer months when the motels are running at peak occupancy. The collectors face due south. A solution of $40 \%$ propylene glycol $/ 60 \%$ water is pumped through the collectors. This working fluid is transported to a tube and shell heat exchanger. Water heated in the heat exchanger is stored in vertical storage tank to obtain as much stratification as possible.

Hot Water $68 \%$
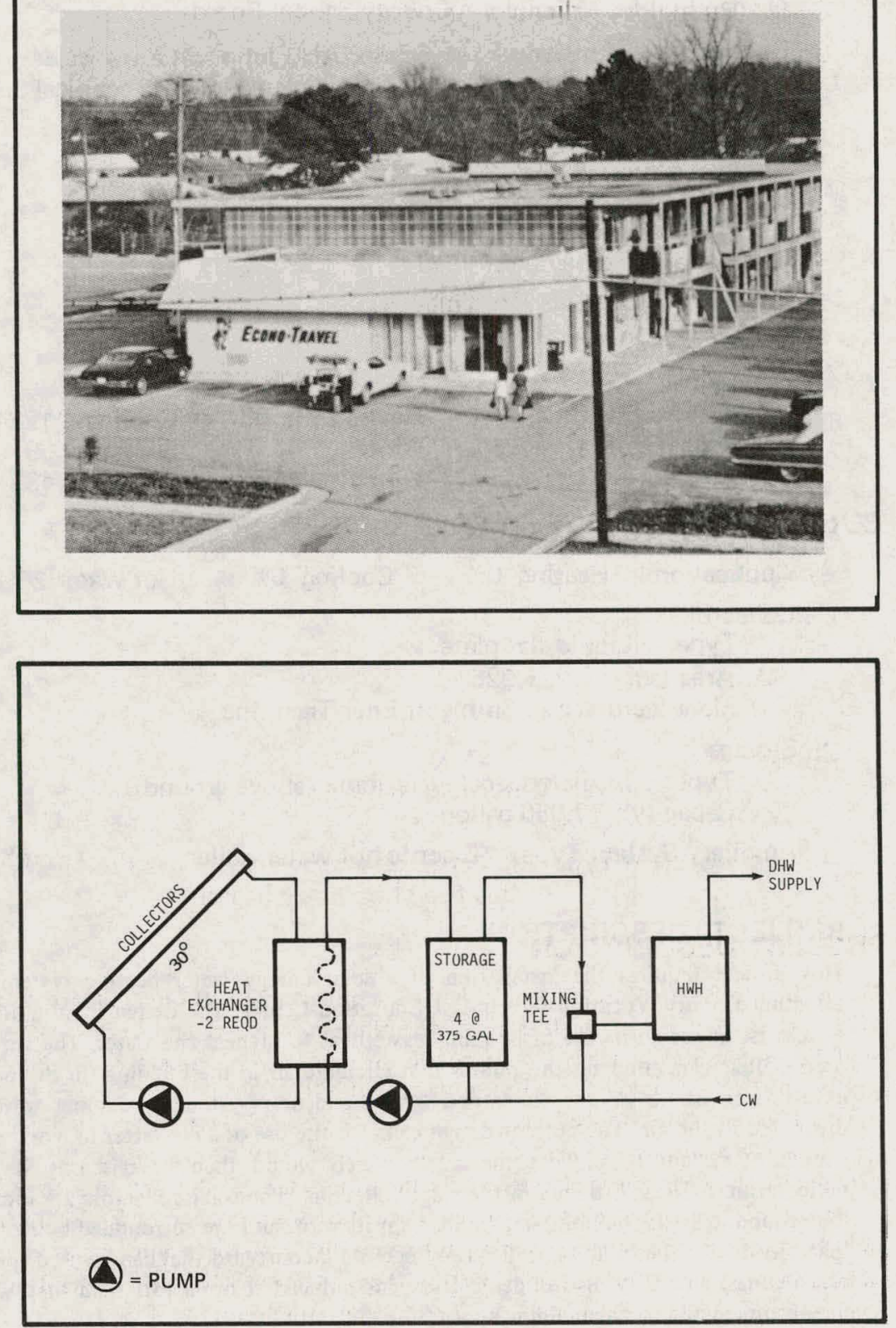


\section{PROJECT INFORMATION}

Owner/Builder: Loudoun County School Board

Contractor: Anthony F. Musolino, AIA/John F. Lawrence \& Associates/Solar Energy Scientific and Technical Services Operational Date: March 1978

Total Estimated DOE Funds: $\$ \$ 56,336$

Building

Type: Vocational school

Area: To be determined

Location: Leesburg, Virginia

Latitude: $39.1^{\circ} \mathrm{N}$

Climatic Data

$\begin{array}{lllll}\text { Degree Days } & \text { Heating } & 4503 & \text { Cooling } & 1284 \\ \text { Avg. Temp. }\left({ }^{\circ} \mathrm{F}\right) & \text { Winter } & 41.6 & \text { Summer } & 69.4 \\ \text { Avg. Insol. (Ly/d) } & \text { Winter } & 247 & \text { Summer } & 485\end{array}$

\section{SOLAR ENERGY SYSTEM}

Application Heating $0 \%$

Cooling $0 \%$

Hot Water $26 \%$

Collector

Type: Liquid flat-plate

Area (sq. ft.): 1,225

Manufacturer: Southwest Ener-Tech, Inc.

Storage

Type: Insulated steel water tank (above ground)

Capacity: 2,056 gallons

Auxiliary System Type: Electric hot water boiler

\section{PROJECT DESCRIPTION}

This project requires the installation of a solar energy water heating system in the Loudoun County Vocational-Technical Education Center. The design for the hot water system is unique in its use of building waste heat to preheat the water. The waste heat used is that generated by the pumps that circulate air in the building. In the past, this excess heat would have been carried by a condenser system to cooling towers and dissipated in the air. The current design calls for the use of a converter to work with the condenser system to preheat the water which would then be raised to its proper temperature by heat gathered in the solar collectors. The solar collectors are located on the ground near the building, rather than on its roof, and are surrounded by stone walls that blend with the building walls. They enclose a courtyard that can be used for classes or meetings, and they also undergo less wind-induced thermal loss than they would if they were located on the building's roof.

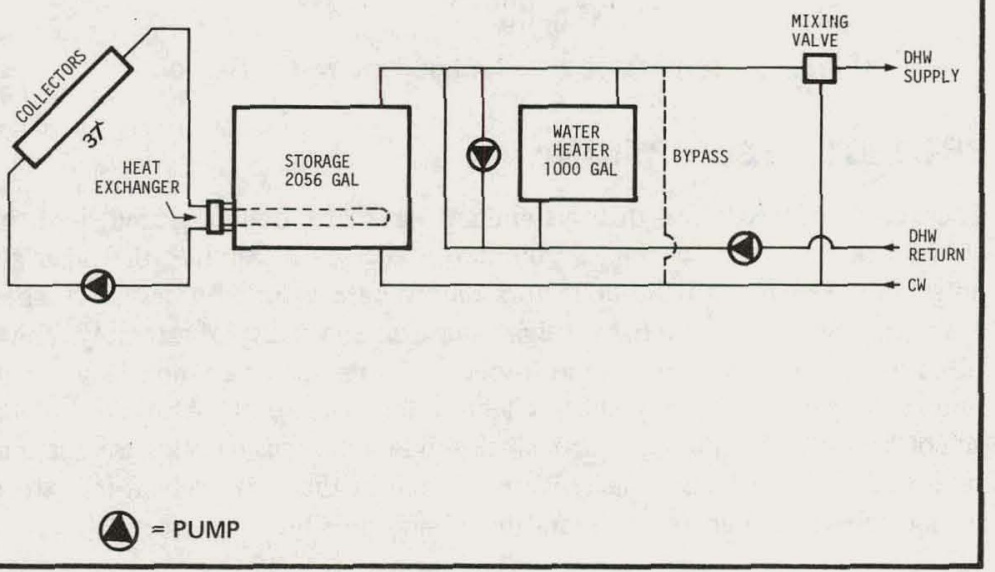




\section{PROJECT INFORMATION}

Owner/Builder: Terrell E. Moseley, Inc.

Contractor: Terrell E. Moseley, Inc.

Operational Date: November 1976

Total Estimated DOE Funds: $\quad \$ 15,630$

Building

Type: Office

Area: $\quad 1,780$ sq. ft.

Location: Lynchburg, Virginia

Latitude: $37.3^{\circ} \mathrm{N}$

Climatic Data

$\begin{array}{lllll}\text { Degree Days } & \text { Heating } & 4200 & \text { Cooling } & 1400 \\ \text { Avg. Temp. }\left({ }^{\circ} \mathrm{F}\right) & \text { Winter } & 44 & \text { Summer } & 71 \\ \text { Avg. Insol. (Ly/d) } & \text { Winter } & 900 & \text { Summer } & 2500\end{array}$

\section{SOLAR ENERGY SYSTEM}

Application Heating $70 \%$

Collector

Type: Liquid flat-plate

Area (sq. ft.): 400

Manufacturer: Terrell E. Moseley, Inc.

Storage

Type: Insulated steel water tank (above ground)

Capacity: 2,000 gallons

Auxiliary System Type: Gas fired hot water boiler

\section{PROJECT DESCRIPTION}

This project calls for the space and hot water heating for a one-story cement block office building. A packaged water-to-air heat pump forces heat to the offices through a conventional insulated duct system. Heat is supplied to the evaporator of the pump by a south-facing solar collector array on the building's roof. Heat collected by the array is transmitted to a steel storage tank and then relayed to the pump. The storage tank is also used to preheat water needed in the building. The preheated water will be brought to its required temperature by a gas fired hot water heater.
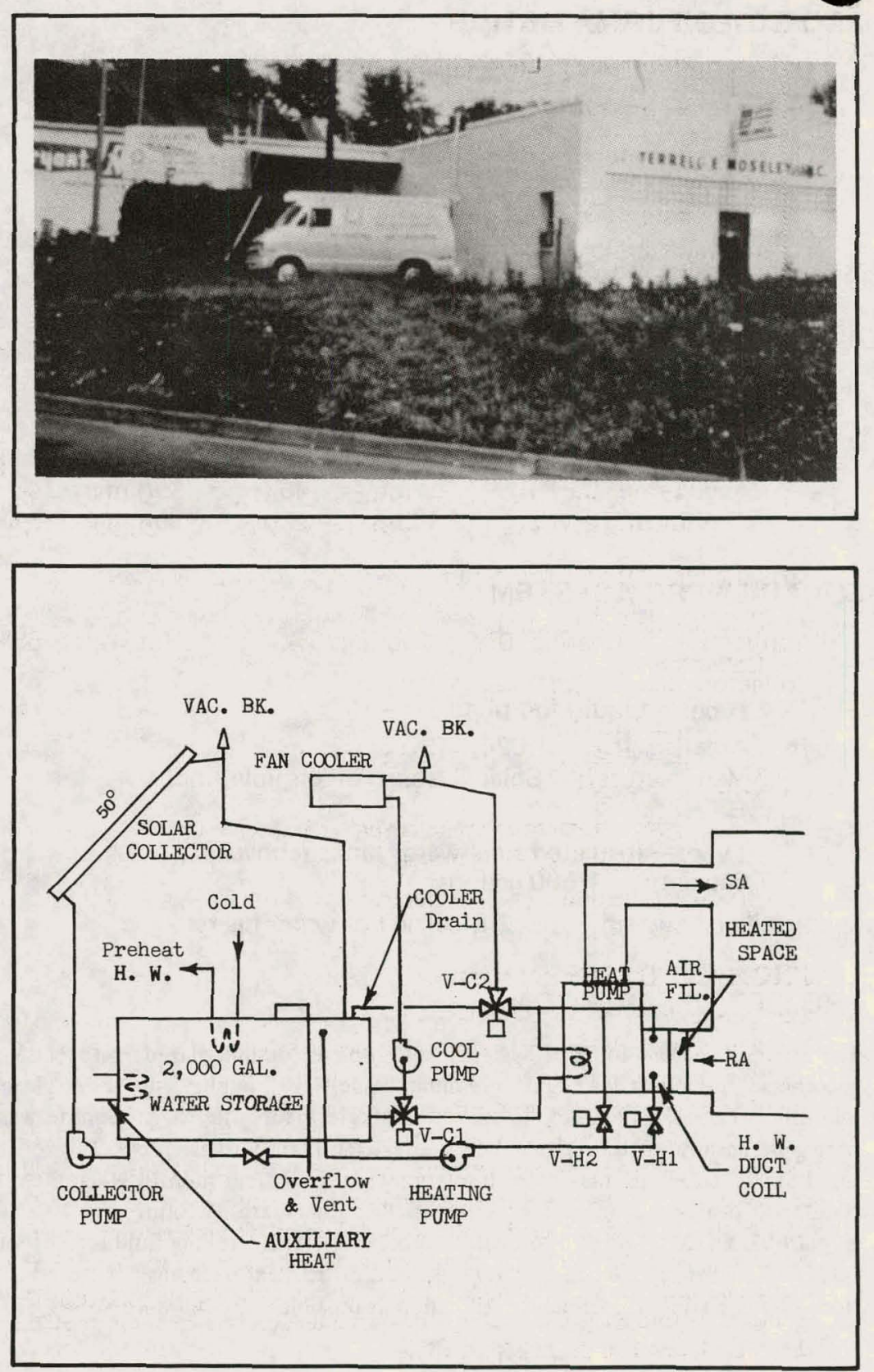


\section{PROJECT INFORMATION}

Owner/Builder: Allen Management, Inc.

Contractor: Solar Systems of Virginia, Inc.

Operational Date: March 1978

Total Estimated DOE Funds: $\quad \$ 11,928$

Building

Type: Low rise motel

Area: Not applicable to hot water systems

Location: Portsmouth, Virginia

Latitude: $37.5^{\circ} \mathrm{N}$

Climatic Data

Degree Days

Avg. Temp. $\left({ }^{\circ} \mathrm{F}\right)$

Avg. Insol. (Ly/d)

$\begin{array}{llll}\text { Heating } & 3421 & \text { Cooling } & 1441 \\ \text { Winter } & 46 & \text { Summer } & 74 \\ \text { Winter } & 260 & \text { Summer } & 550\end{array}$

\section{SOLAR ENERGY SYSTEM}

Application Heating $0 \%$ Cooling $0 \%$ Hot Water $68 \%$

\section{Collector}

Type: Liquid flat-plate

Area (sq. ft.): 1,024

Manufacturer: Solar Systems of Virginia, Inc.

Storage

Type: Insulated steel water tanks (above ground)

Capacity: 1,500 gallons

Auxiliary System Type: Electric hot water heater

\section{PROJECT DESCRIPTION}

The solar collectors for this system are flat-plate, double glazed, with black painted absorbers. The outer glazing is premium grade .040 " Sunlite, the inner glazing is 4 mils thick Tedlar, and the collectors incorporate a tube-fin design. Sunlite was chosen over glass because of the light weight and ease and safety of assembly. The collectors are tilted at $30^{\circ}$ to obtain maximum insolation during summer months when the motels are running at peak occupancy. The collectors face due south. A solution of $40 \%$ propylene glycol/ $60 \%$ water is pumped through the collectors. This working fluid is transported to a tube and shell heat exchanger. Water heated in the heat exchanger is stored in vertical storage tank to obtain as much stratification as possible.
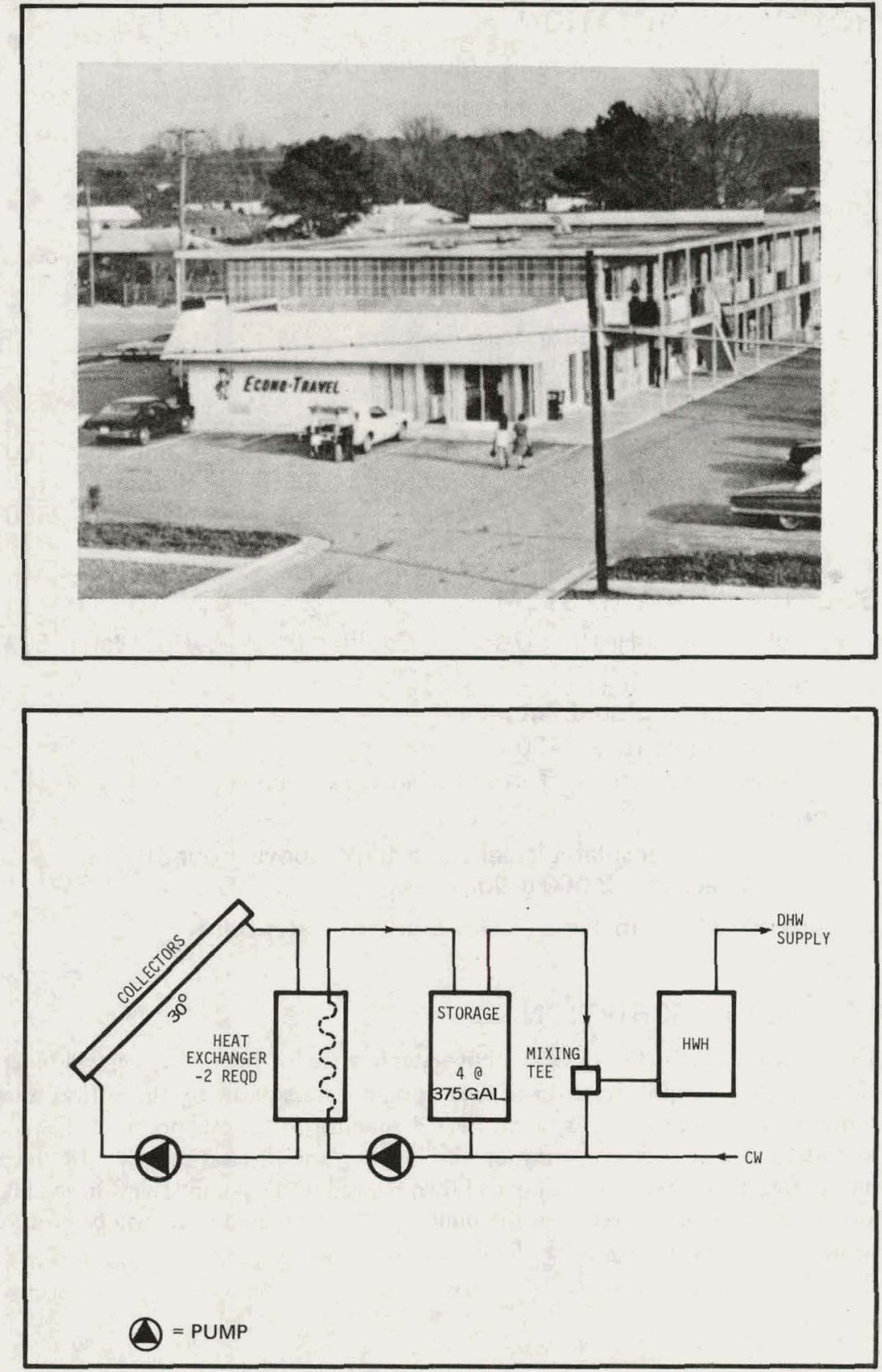


\section{PROJECT INFORMATION}

Owner/Builder: Allen Management, Inc.

Contractor: Solar Systems of Virginia, Inc.

Operational Date: March 1978

Total Estimated DOE Funds: $\$ 11,928$

Building

Type: Low rise motel

Area: Not applicable to hot water systems

Location: Sandston, Virginia

Latitude: $37^{\circ} 51^{\prime} \mathrm{N}$

Climatic Data

$\begin{array}{lllll}\text { Degree Days } & \text { Heating } & 3865 & \text { Cooling } & 1353 \\ \text { Avg. Temp. }\left({ }^{\circ} \mathrm{F}\right) & \text { Winter } & 43 & \text { Summer } & 73 \\ \text { Avg. Insol. (Ly/d) } & \text { Winter } & 260 & \text { Summer } & 550\end{array}$

\section{SOLAR ENERGY SYSTEM}

Application Heating $0 \%$ Cooling $0 \%$

Hot Water $68 \%$

Collector

Type: Liquid flat-plate

Area (sq. ft.): 1,024

Manufacturer: Solar Systems of Virginia, Inc.

Storage

Type: Insulated steel water tanks (above ground)

Capacity: 1,500 gallons

Auxiliary System Type: Electric hot water

\section{PROJECT DESCRIPTION}

The solar collectors for this system are flat-plate, double glazed, with black painted absorbers. The outer glazing is premium grade .040" Sunlite, the inner glazing is 4-mils thick Tedlar, and the collectors incorporate a tube-fin design. Sunlite was chosen over glass because of the light weight and ease and safety of assembly. The collectors are tilted at $30^{\circ}$ to obtain maximum insolation during summer months when the motels are running at peak occupancy. The collectors face due south. A solution of $40 \%$ propylene glycol $/ 60 \%$ water is pumped through the collectors. This working fluid is transported to a tube and shell heat exchanger. Water heated in the heat exchanger is stored in vertical storage tank to obtain as much stratification as possible.
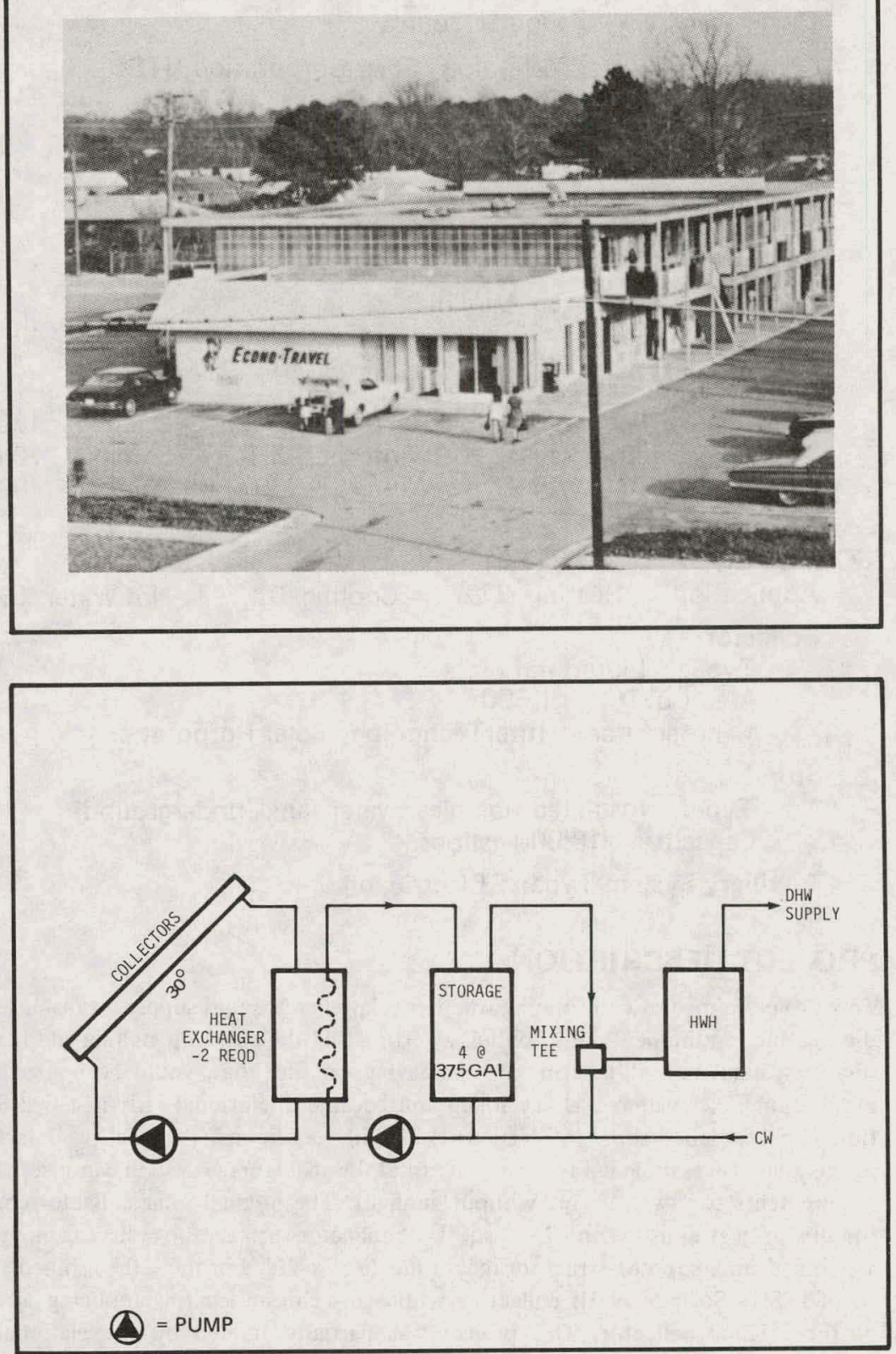


\section{PKUJECT INFORMATION}

Owner/Builder: Fauquier County

Contractor: InterTechnology Solar Corporation (ITSC)

Operational Date: February 1978

Total Estimated DOE Funds: $\quad \$ 560,884$

Building

Type: School (five detached temporary buildings)

Area: 4,100 sq. $\mathrm{ft}$.

Location: Warrenton, Virginia

Latitude: $38.9^{\circ} \mathrm{N}$

Climatic Data

$\begin{array}{lllll}\text { Degree Days } & \text { Heating } & 4217 & \text { Cooling } & 1330 \\ \text { Avg. Temp. }\left({ }^{\circ} \mathrm{F}\right) & \text { Winter } & 43.1 & \text { Summer } & 70.0 \\ \text { Avg. Insol. (Ly/d) } & \text { Winter } & 269 & \text { Summer } & 489\end{array}$

\section{SOLAR ENERGY SYSTEM}

Application Heating $77 \%$ Cooling $0 \%$ Hot Water $0 \%$

Collector

Type: Liquid flat-plate

Area (sq. ft.): 1,600

Manufacturer: InterTechnology Solar Corporation

Storage

Type: Insulated fiberglas water tank (underground)

Capacity: $\quad 10,000$ gallons

Auxiliary System Type: Electric, oil

\section{PROJECT DESCRIPTION}

This project aimed at determining whether solar energy could supply a substantial part of the heating requirements of a school, at estimating the cost of installing and maintaining such a system, and at determining the savings in fuel that would be realized from its installation. The system was developed and became operational early in 1974. Since that time it has supplied some ( $60 \%$ current) heating requirements of the five detached classrooms that it was designed to serve. The total thermal storage system can meet all heating requirements for twelve days without sunlight. The original solar collector constructed for this project consisted of $2540 \mathrm{sq}$. ft. of collector surface, the collector modules being assembled on a support structure measuring $126^{\prime} \times 26^{\prime}$. For the refurbishment, 1600 sq. ft. of ITSC's Solar Mark III collectors with black chrome coating are being used in place of the original collector. This project was partially funded by the National Science Foundation and is one of the early proof-of-concept experiments started in 1974.
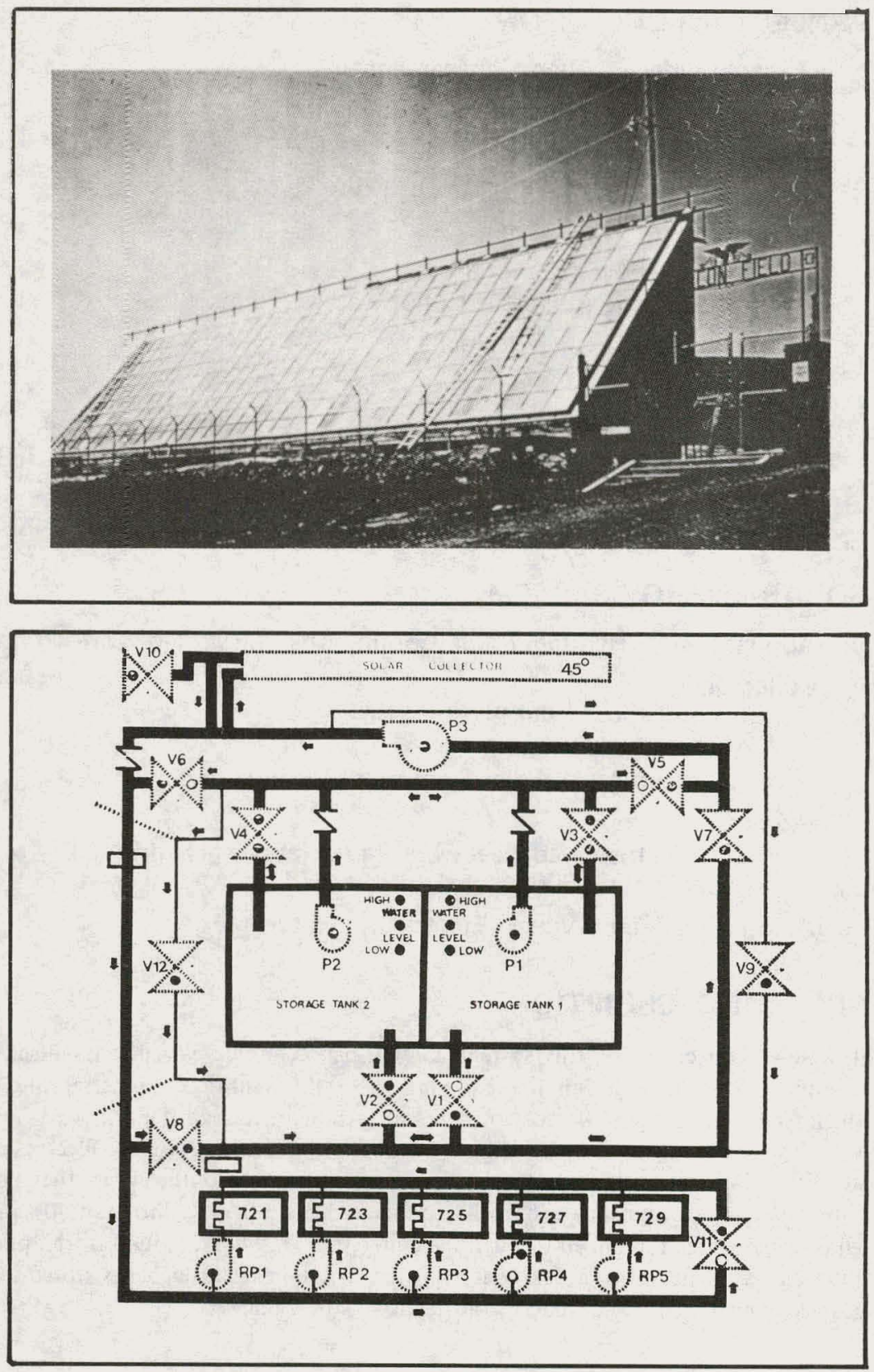


\section{PROJECT INFORMATION}

Owner/Builder: Allen Management, Inc.

Contractor: Solar Systems of Virginia, Inc.

Operational Date: March 1978

Total Estimated DOE Funds: $\quad \$ 16,150$

Building

Type: Low rise motel

Area: Not applicable to hot water systems

Location: Woodbridge, Virginia

Latitude: $39^{\circ} \mathrm{N}$

Climatic Data

$\begin{array}{lllll}\text { Degree Days } & \text { Heating } & 4224 & \text { Cooling } & 779 \\ \text { Avg. Temp. }\left({ }^{\circ} \mathrm{F}\right) & \text { Winter } & 41 & \text { Summer } & 73 \\ \text { Avg. Insol. (Ly/d) } & \text { Winter } & 225 & \text { Summer } & 485\end{array}$

\section{SOLAR ENERGY SYSTEM}

Application Heating $0 \%$ Cooling $0 \%$

Hot Water $71 \%$

Collector

Type: Liquid flat-plate

Area (sq. ft.): 1,536

Manufacturer: Solar Systems of Virginia, Inc.

\section{Storage}

Type: Insulated steel water tanks (above ground)

Capacity: 2,500 gallons

Auxiliary System Type: Electric hot water heater

\section{PROJECT DESCRIPTION}

The solar collectors for this system are flat-plate, double glazed, with black painted absorbers. The outer glazing is premium grade .040" Sunlite, the inner glazing is 4-mils thick Tedlar, and the collectors incorporate a tube-fin design. Sunlite was chosen over glass because of the light weight and ease and safety of assembly. The collectors are tilted at $30^{\circ}$ to obtain maximum insolation during summer months when the motels are running at peak occupancy. The collectors face due south. A solution of $40 \%$ propylene glycol $/ 60 \%$ water is pumped through the collectors. This working fluid is transported to a tube and shell heat exchanger. Water heated in the heat exchanger is stored in vertical storage tank to obtain as much stratification as possible.
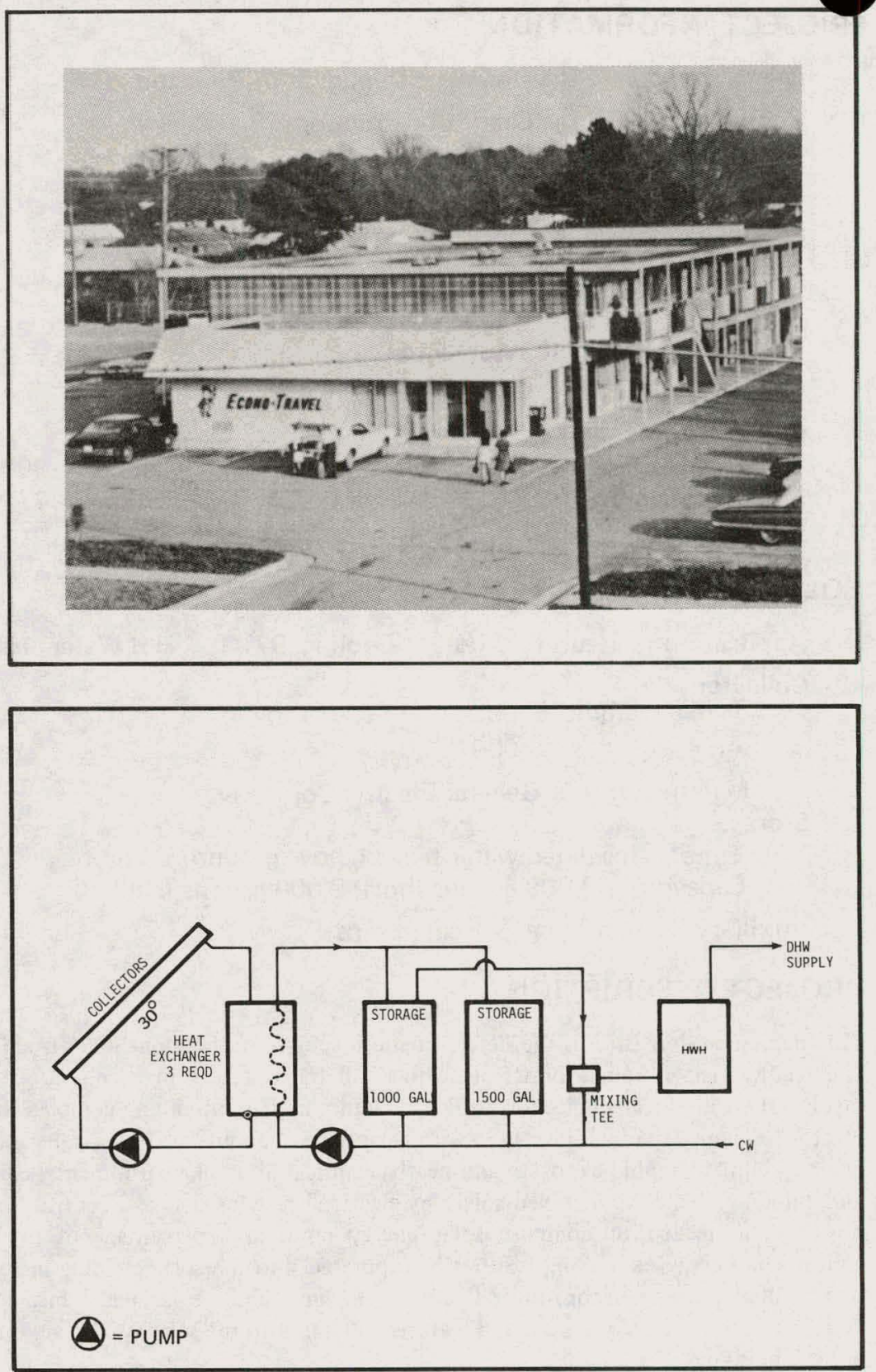


\section{RKOJECT INFORMATION}

Owner/Builder: Development Dynamics of Richland

Contractor: George Grant Construction

Operational Date: March 1978

Total Estimated DOE Funds: \$710,295

Building

Type: Office

Area: 14,400 sq. ft.

Location: Richland, Washington

Latitude: $46.3^{\circ} \mathrm{N}$

Climatic Data

$\begin{array}{lllll}\text { Degree Days } & \text { Heating } & 5267 & \text { Cooling } & 800 \\ \text { Avg. Temp. }\left({ }^{\circ} \mathrm{F}\right) & \text { Winter } & 29 & \text { Summer } & 77 \\ \text { Avg. Insol. (Ly/d) } & \text { Winter } & 125 & \text { Summer } & 675\end{array}$

\section{SOLAR ENERGY SYSTEM}

Application Heating $71 \%$ Cooling $97 \%$ Hot Water $100 \%$

Collector

Type: Liquid flat-plate

Area (sq. ft.): 6,000

Manufacturer: General Electric Company Storage

Type: Insulated water tanks (above ground)

Capacity: 9,000 gallons (hot); 2,000 gallons (chilled)

Auxiliary System Type: Heat pumps

\section{PROJECT DESCRIPTION}

This demonstration site, in the desert of south central Washington State, is adjacent to and readily visible from a principal north-south traffic artery in Richland. The design involves two identical single-story office buildings in a four-building complex known as Hanford Square. The buildings, each with a capacity of about 100 persons, have the same external climatographic exposure and nearly identical internal environmental conditions. One building, heated and cooled solely by electrical systems, acts as a control, furnishing power data needed to compute solar energy input as a percentage of total power consumed. Energy conserving features incorporated into the solar building include solar ponds, dual purpose absorption/reflection venetian blinds, solar panel insulation and double windows. Energy conserving features unrelated to the solar system are duplicated in both buildings.
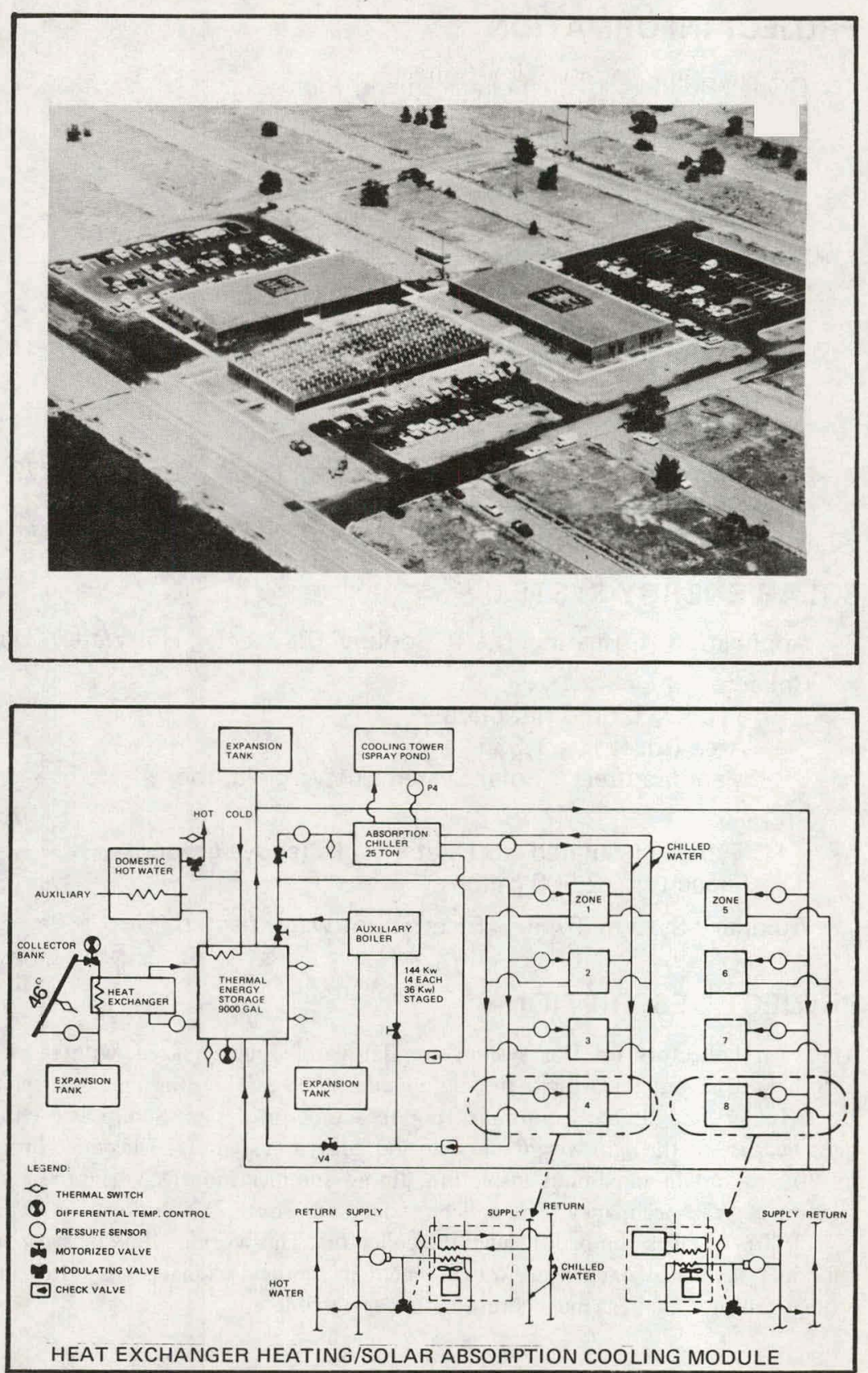


\section{PROJECT INFORMATION}

Owner/Builder: Bethany College

Contractor: InterTechnology Corporation/Solar Corporation of America Operational Date: September 1978

Total Estimated DOE Funds: $\$ \$ 156,820$

Building

Type: Conference center/multipurpose dining facility

Area: 41,200 sq. ft.

Location: Bethany, West Virginia

Latitude: $40.1^{\circ} \mathrm{N}$

Climatic Data

Degree Days

Avg. Temp. $\left({ }^{\circ} \mathrm{F}\right)$

Heating 5402

Avg. Insol. (Ly/d)

Winter 41.8

Winter 165

Cooling N/A

Summer 68.0

Summer 435

\section{SOLAR ENERGY SYSTEM}

Application Heating 33\% Cooling 0\% Hot Water $86 \%$

Collector

Type: Liquid flat-plate

Area (sq. ft.): 4,518

Manufacturer: InterTechnology Corporation/ Solar Corporation of America

Storage

Type: Insulated steel water tank (above ground)

Capacity: 6,500 gallons

Auxiliary System Type: Gas forced air/gas boiler

\section{PROJECT DESCRIPTION}

In addition to its regular academic program for residential undergraduates iin the liberal arts, Bethany College operates the Leadership Center as a separate, non profit, educational enterprise dedicated to developing and training the adult human resources of the tri-state region and to fostering the economic and community development of the region. The Center is a three-building complex composed of two existing buildings and one planned building scheduled for occupancy the fall of 1978. The proposed solar heating system is to be applied to the three buildings of the Center. As a combination new building/retrofit application, a unique demonstration is provided for the solar heating demonstration program. The collectors will be installed on the roof of the existing motel building. The solar heat will be used for space heating both the motel lobby and the adjacent new dining facility, and for preheating the domestic water and for all three buildings of the Center, thus reducing the consumption of electricity currently used for these purposes.
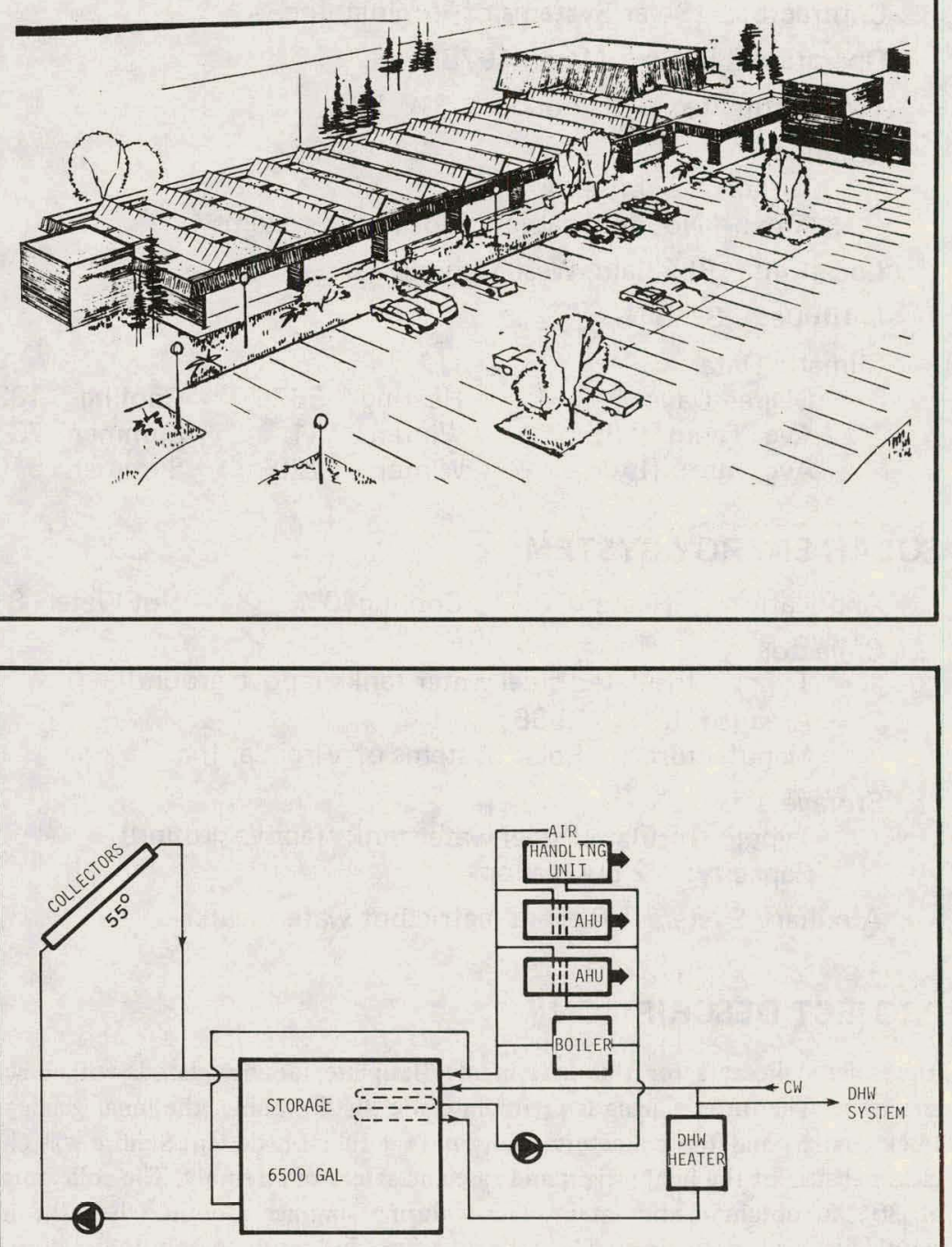

D = PUMP 


\section{PRUJECT INFORMATION}

Owner/Builder: Allen Management, Inc.

Contractor: Solar Systems of Virginia, Inc.

Operational Date: March 1978

Total Estimated DOE Funds: $\quad \$ 16,150$

Building

Type: Low rise motel

Area: Not applicable to hot water systems

Location: Bluefield, West Virginia

Latitude: $37^{\circ} 5^{\prime} \mathrm{N}$

Climatic Data

$\begin{array}{lllll}\text { Degree Days } & \text { Heating } & 5675 & \text { Cooling } & 1030 \\ \text { Avg. Temp. }\left({ }^{\circ} \mathrm{F}\right) & \text { Winter } & 41 & \text { Summer } & 73 \\ \text { Avg. Insol. (Ly/d) } & \text { Winter } & 220 & \text { Summer } & 510\end{array}$

\section{SOLAR ENERGY SYSTEM}

Application Heating $0 \%$

Collector

Type: Insulated steel water tanks (above ground)

Area (sq. ft.): 1,536

Manufacturer: Solar Systems of Virginia, Inc. Storage

Type: Insulated steel water tanks (above ground)

Capacity: 2,500 gallons

Auxiliary System Type: Electric hot water heater

\section{PROJECT DESCRIPTION}

The solar collectors for this system are flat-plate, double glazed, with black painted absorbers. The outer glazing is premium grade .040 " Sunlite, the inner glazing is 4-mils thick Tedlar, and the collectors incorporate a tube-fin design. Sunlite was chosen over glass because of the light weight and ease and safety of assembly. The collectors are tilted at $30^{\circ}$ to obtain maximum insolation during summer months when the motels are running at peak occupancy. The collectors face due south. A solution of $40 \%$ propylene glycol/60\% water is pumped through the collectors. This working fluid is transported to a tube and shell heat exchanger. Water heated in the heat exchanger is stored in vertical storage tank to obtain as much stratification as possible.
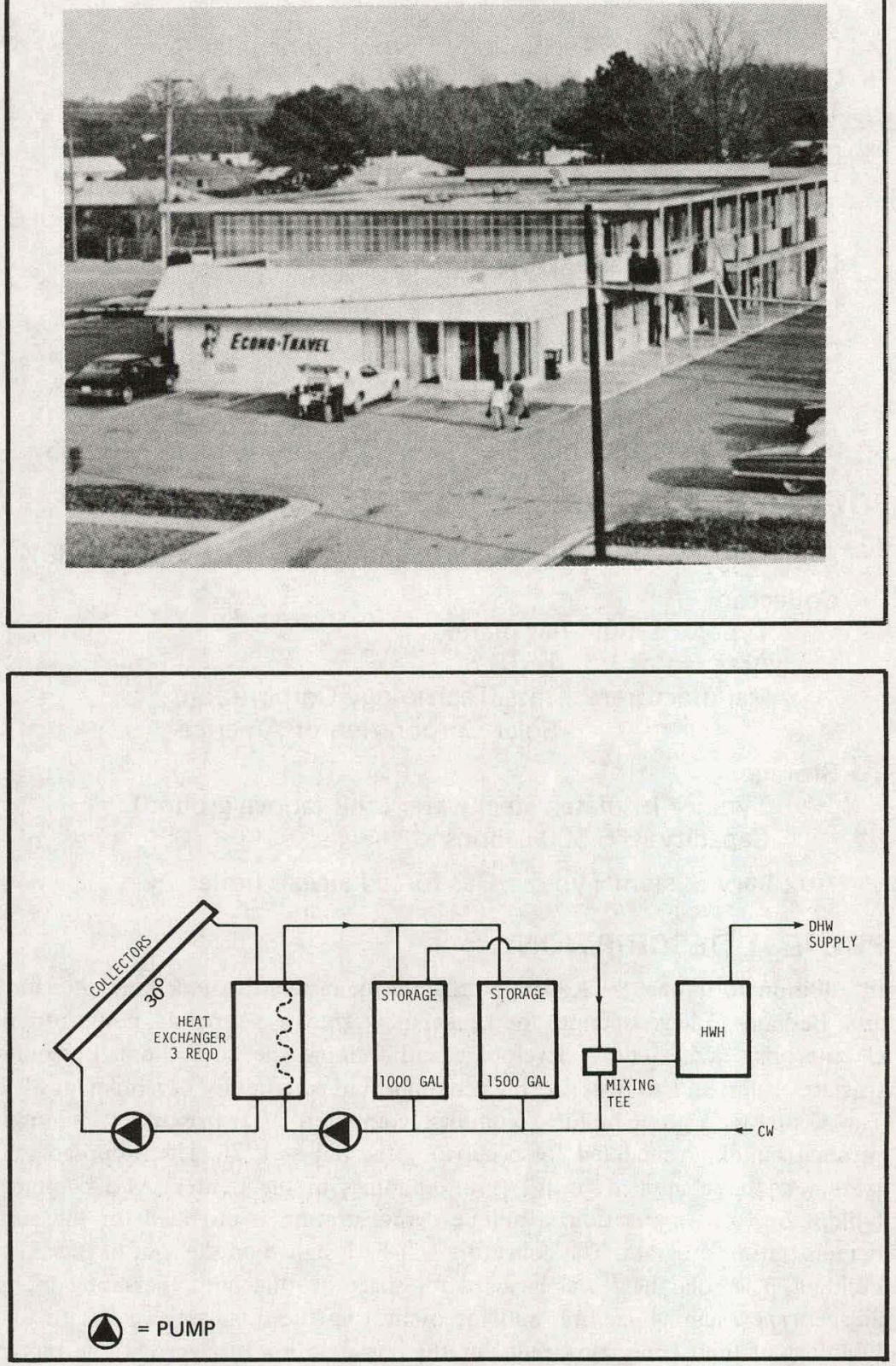


\section{PROJECT INFORMATION}

Owner/Builder: Jefferson County Board of Education

Contractor: Pickett, Siess, and Hook Associates

Operational Date: August 1978

Total Estimated DOE Funds: $\quad \$ 996,853$

Building

Type: School

Area: 50,600 sq. ft.

Location: Charles Town, West Virginia

Latitude: $38.4^{\circ} \mathrm{N}$

Climatic Data

$\begin{array}{lllll}\text { Degree Days } & \text { Heating } & 4590 & \text { Cooling } 1055 \\ \text { Avg. Temp. }\left({ }^{\circ} \mathrm{F}\right) & \text { Winter } & 46.8 & \text { Summer } & 72.0 \\ \text { Avg. } & \text { Winter } & 285 & \text { Summer } & 485\end{array}$

Avg. Insol. (Ly/d) Winter $285 \quad$ Summer 485

\section{SOLAR ENERGY SYSTEM}

Application Heating $85 \%$

\section{Cooling 51\%}

Hot Water $0 \%$

Collector

Type: Liquid flat-plate/reflector

Area (sq. ft.): $10,943 / 10,775$

Manufacturer: PPG Industries, Inc.

\section{Storage}

Type: Steel water tanks (above ground)

Capacity: 17,000 gallons

Auxiliary System Type: Oil fired boiler

\section{PROJECT DESCRIPTION}

This project is for the use of a solar energy system to provide heating, cooling, and hot water heating for the Page Jackson School, now being constructed in Jefferson County, West Virginia. The system will utilize flat-plate collectors, roof-top reflectors, two water storage tanks, a 100-ton absorption chiller, and a 100-ton conventional backup chiller. The roof will have several skylights which should appreciably reduce the need for electric lighting. The school has been designed for minimal energy utilization for heating and cooling requirements.
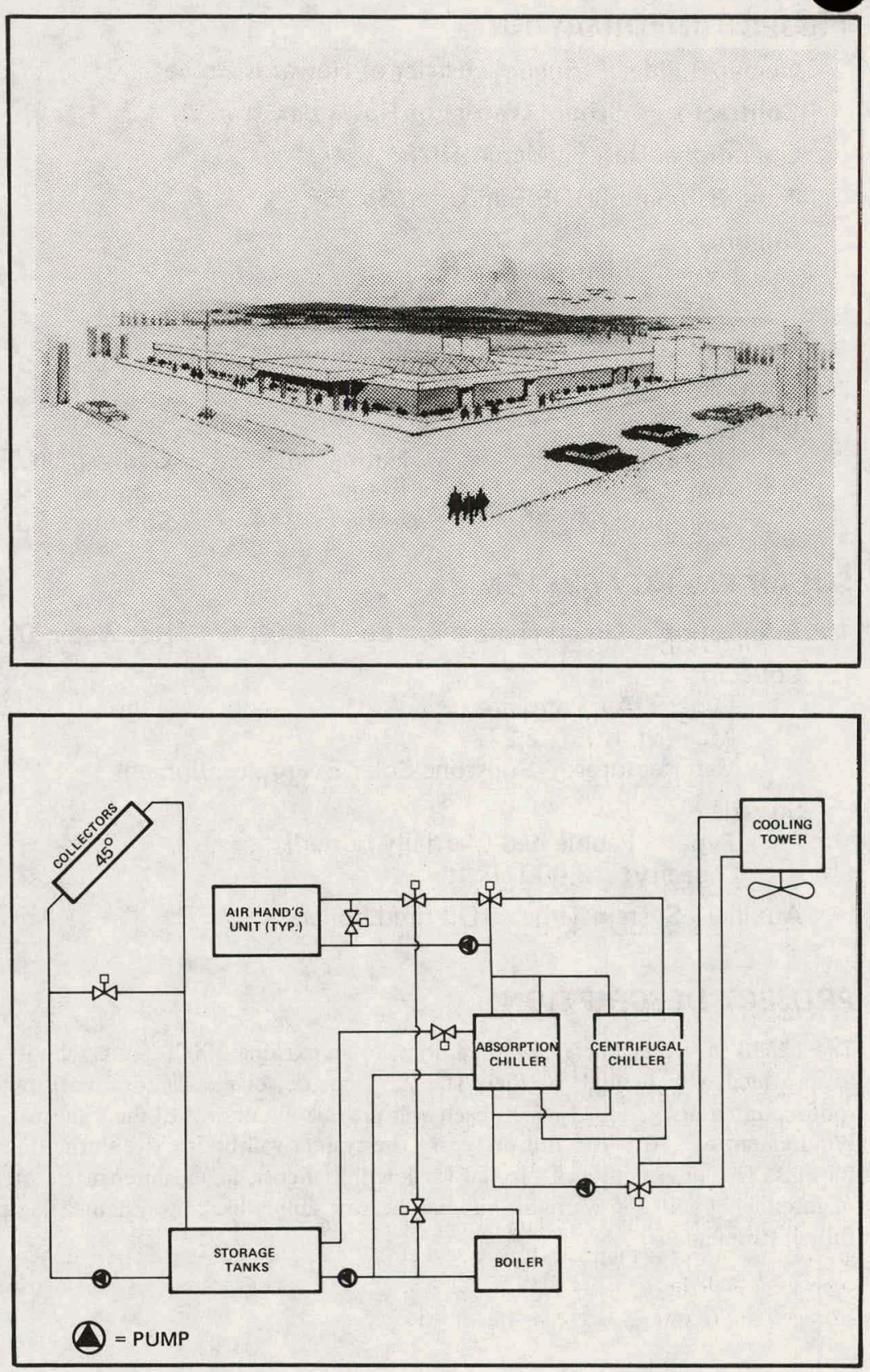


\section{PKOJECT INFORMATION}

Owner/Builder: School District of Howards Grove

Contractor: School District of Howards Grove

Operational Date: March 1978

Total Estimated DOE Funds; $\quad \$ 35,301$

Building

Type: Elementary school

Area: $\quad 12,330$ sq. $\mathrm{ft}$.

Location: Howards Grove, Wisconsin

Latitude: $43.5^{\circ} \mathrm{N}$

Climatic Data

$\begin{array}{lllll}\text { Degree Days } & \text { Heating } & 7360 & \text { Cooling } & \text { N/A } \\ \text { Avg. Temp. }\left({ }^{\circ} \mathrm{F}\right) & \text { Winter } & 21 & \text { Summer } & 70 \\ \text { Avg. Insol. (Ly/d) } & \text { Winter } & 114 & \text { Summer } & 534\end{array}$

\section{SOLAR ENERGY SYSTEM}

Application Heating 58\% Cooling $0 \%$ Hot Water $0 \%$

Collector

Type: Air flat-plate

Area (sq. ft.): 2,277

Manufacturer: Sunstone Solar Energy Equipment

Storage

Type: Pebble bed (partially buried)

Capacity: 3,000 cu. ft.

Auxiliary System Type: Oil fired boiler

\section{PROJECT DESCRIPTION}

The 12330 sq. ft., eight-classroom addition to an existing 30000 sq. ft. school could not be provided with natural gas fuel. The $2277 \mathrm{sq}$. ft. solar collector consisting of six roof-mounted arrays of 23 panels each will provide about $58 \%$ of the total space heating requirement of $650 \times 10^{6}$ Btu per year. The system will be inactive during the summer months. The air system was selected for low initial cost, low maintenance cost, and ease of interfacing with the warm air building heating supply back-up system. The site will be fully instrumented.
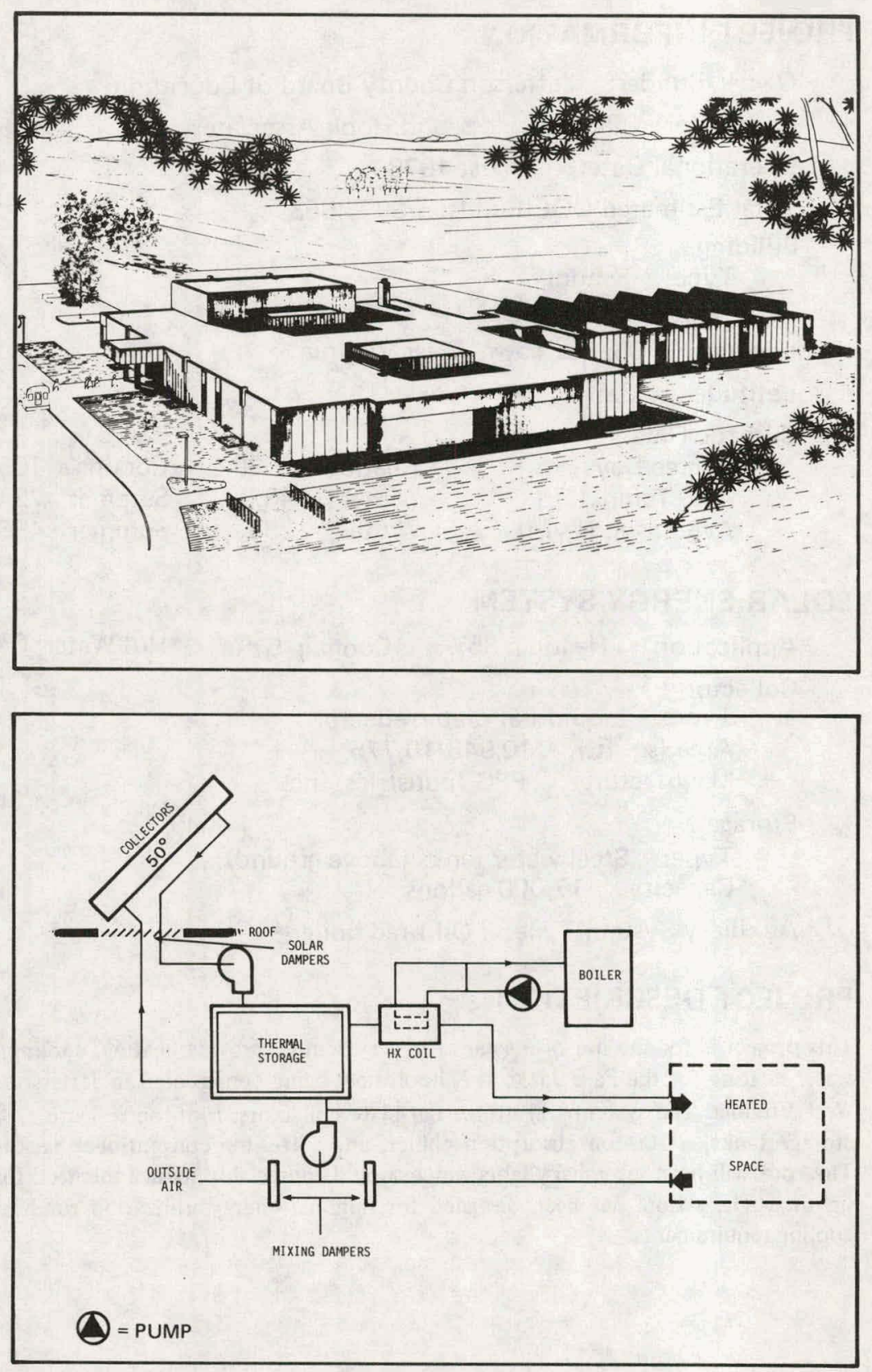


\section{PROJECT INFORMATION}

Owner/Builder: Dr. Walter A. Handzlik

Contractor: Zien Mechanical Contractor

Operational Date: June 1978

Total Estimated DOE Funds: $\$ 35,026$

Building

Type: Dental clinic

Area: 8,000 sq. ft. (total); 7,750 sq. ft. (cond.)

Location: West Bend, Wisconsin

Latitude: $42^{\circ} \mathrm{N}$

Climatic Data

$\begin{array}{lllll}\text { Degree Days } & \text { Heating } & 7444 & \text { Cooling } & 450 \\ \text { Avg. Temp. }\left({ }^{\circ} \mathrm{F}\right) & \text { Winter } & 26.8 & \text { Summer } & 66.2 \\ \text { Avg. Insol. (Ly/d) } & \text { Winter } & 258 & \text { Summer } & 390\end{array}$

\section{SOLAR ENERGY SYSTEM}

Application Heating 100\% Cooling $0 \%$ Hot Water $0 \%$

Collector

Type: Evacuated tubular

Area (sq. ft.): 1,000

Manufacturer: Owens-Illinois, Inc.

Storage

Type: Insulated concrete tank (underground)

Capacity: 4,000 galions

Auxiliary System Type: Electric water

\section{PROJECT DESCRIPTION}

This clinic is designed to minimize energy consumption. The north elevation, prone to cold winds and little sunlight, is one-story above grade with few windows. The south, east, and west elevations are two-stories above grade, and have windows to allow daytime solar heating. The collectors are mounted on the roof and are tilted $55^{\circ}$ to the horizontal. The storage tank is designed to provide enough heat in conjunction with the heat pumps to satisfy the demand for 24 hours when the outside temperature is $-10^{\circ} \mathrm{F}$ and the building is unoccupied. The auxiliary electric water heaters are sized to raise the tank temperature $100^{\circ} \mathrm{F}$ during a ten-hour nighttime period, which is enough heat to satisfy design conditions if no solar energy is available. The heat reclaim effected by the system serves two purposes: (1) by piping the heat pumps to a storage tank it is possible to store heat rejected during daytime cooling for use in nighttime heating; and, (2) by piping the heat pumps to a common loop, it is possible to transport energy from one side of the building to the other.
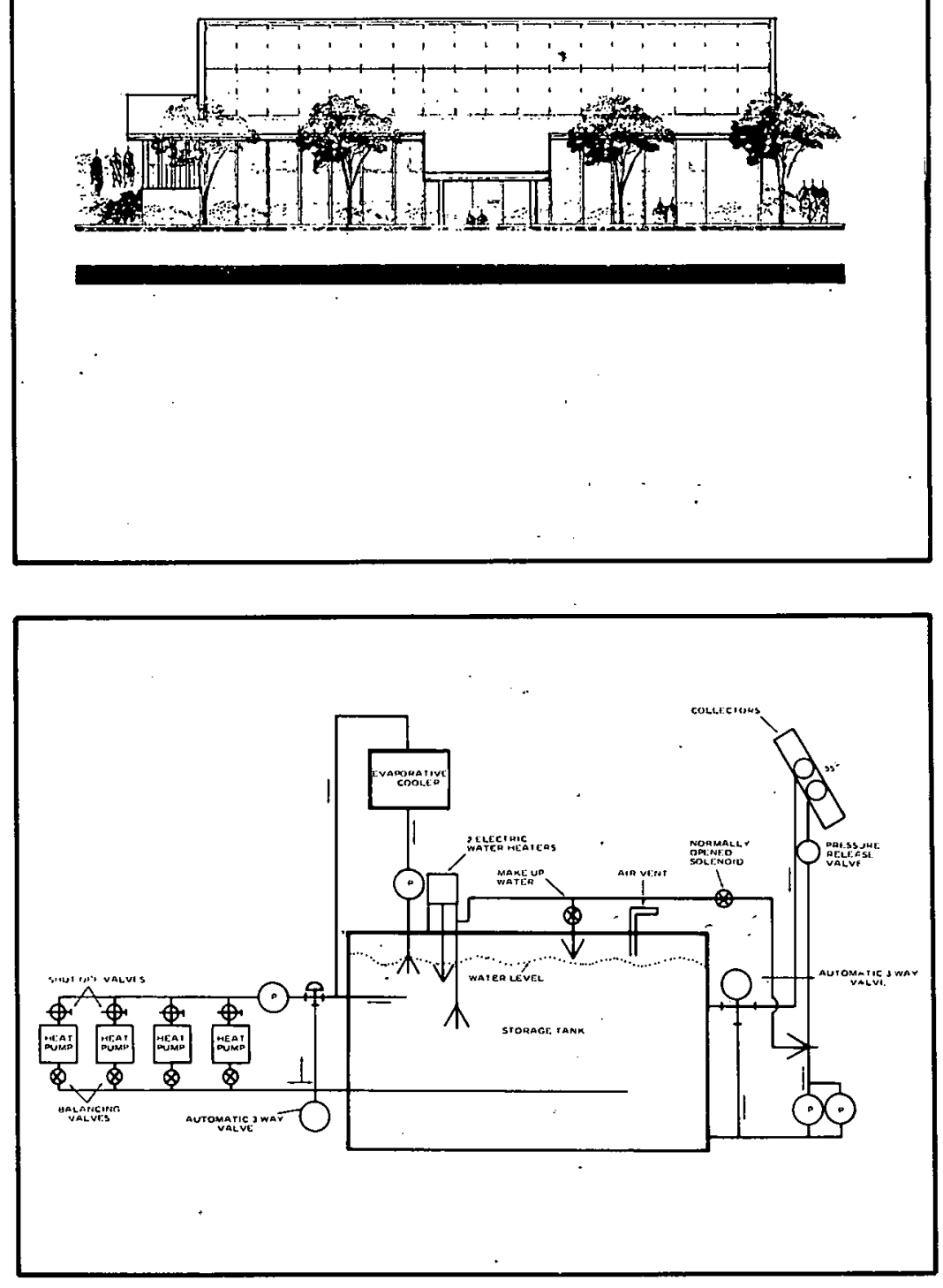


\section{PHOJECT INFORMATION}

Owner/Builder: Wyoming Rural Electric Association

Contractor: Marker Associates

Operational Date: April 1978

Total Estimated DOE Funds: $\quad \$ 40,283$

Building

Type: Office

Area: 9,030 sq. $\mathrm{ft}$.

Location: Casper, Wyoming

Latitude: $43^{\circ} \mathrm{N}$

Climatic Data

$\begin{array}{lllll}\text { Degree Days } & \text { Heating } & 6899 & \text { Cooling } & 1013 \\ \text { Avg. Temp. }\left({ }^{\circ} \mathrm{F}\right) & \text { Winter } & 35.8 & \text { Summer } & 83 \\ \text { Avg. Insol. (Ly/d) } & \text { Winter } & 132.8 & \text { Summer } & 581.5\end{array}$

\section{SOLAR ENERGY SYSTEM}

Application Heating 51\%

Collector

Type: Liquid flat-plate

Area (sq. ft.): $\mathbf{8 7 0}$

Manufacturer: Solargenics, Inc.

Storage

Type: Glass lined steel water tank (above ground)

Capacity: 1,520 gallons

Auxiliary System Type: Electric duct heater

\section{PROJECT DESCRIPTION}

This two-story structure is constructed of steel frame with panel curtain wall. Brick veneer is the exterior finish. The nonstructural panel curtain wall is a foam core plywood laminate. Expanded styrene is used as the core. The heating/cooling system is a roof top unit, dual duct, variable air volume system with a hot deck floor and a cold deck floor. The air conditioning cycle is provided with an economizer cycle mixing outside air with recirculated air. Twenty six collectors will be mounted on the scuth-facing, slanted wall of the structure at $62^{\circ}$ from horizontal. Heat will be transferred from the collectors to a heat exchanger by a circulating pump and a hot transfer fluid. Storage tank water is heated by a tank type heat exchanger immersed in the storage tank. Hot water in the storage tank will be pumped through a coil in the hot deck of the central air handling unit.
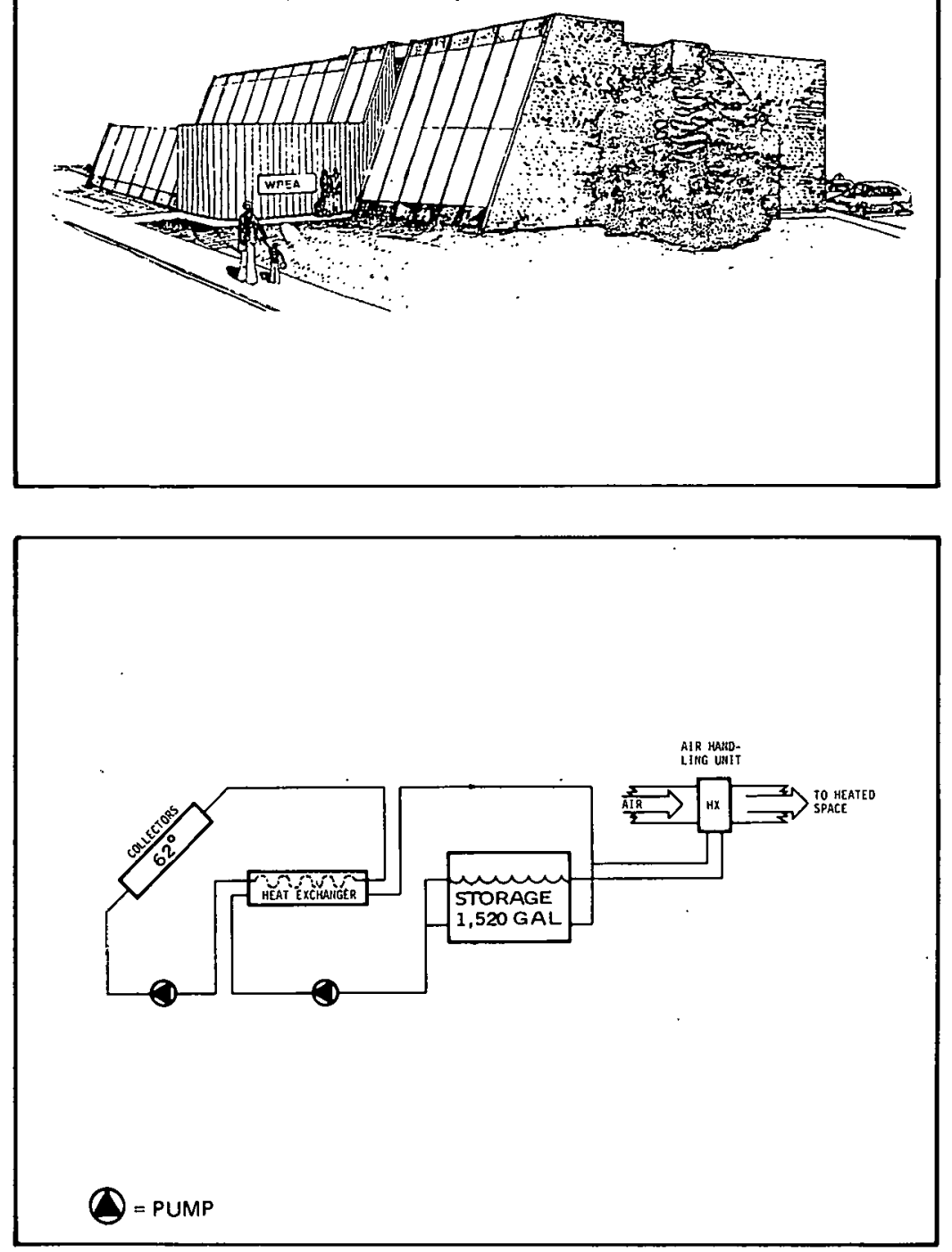


\section{SECTION II}

\section{COMMERCIAL DEMONSTRATION PROGRAM FEDERAL BUILDINGS}




\section{SECTION I COMMERCIAL DEMONSTRATION PROGRAM NON-FEDERAL BUILDINGS (CONTINUED)}

\begin{tabular}{|c|c|c|c|c|c|c|c|c|c|c|c|}
\hline \multirow[b]{2}{*}{ PAGE } & \multirow[b]{2}{*}{ STATE } & \multirow[b]{2}{*}{ LOCATION } & \multirow[b]{2}{*}{ OWNER/BUILDER } & \multirow[b]{2}{*}{$\begin{array}{l}\text { BUILDING } \\
\text { TYPE }\end{array}$} & \multirow{2}{*}{\multicolumn{2}{|c|}{$\begin{array}{l}\text { SOLAR } \\
\text { APPLICATION }\end{array}$}} & \multirow[b]{2}{*}{$\begin{array}{c}\text { SOLAR } \\
\text { MANUFACTURER }\end{array}$} & \multicolumn{4}{|c|}{$\begin{array}{l}\text { PROGRAM TYPE } \\
\text { HOT }\end{array}$} \\
\hline & & & & & & & & $\begin{array}{l}\mathrm{PON}^{*} \\
1\end{array}$ & $\begin{array}{l}\text { PON } \\
2\end{array}$ & $\begin{array}{c}\text { WATER } \\
\text { INITIATIVE }\end{array}$ & OTHER** \\
\hline 1.154 & & Farmers Branch & $\begin{array}{l}\text { Rodeway Inns of America \& R. V. } \\
\text { Develepment Cumpany }\end{array}$ & High Rise Honel & & HWW & General bleciric Cimpany & & & $x$ & \\
\hline 1.155 & & Sin Antunis & Lit Quinla Motur Inns. Inc. & Luw Rise Motel & & HW & Revere Copper \& Brass, like. & & & $x$ & \\
\hline 1.156 & & San Antonio, & Trinity University & Power Pliant & HC & $\mathrm{HW}$ & Northrup. Inc: & $x$ & ( & & \\
\hline 1.157 & & Taylor & John W. Thompsun & Ww Rise Mutci & & $\mathrm{HW}$ & Lennox industries. Inc. & & & $\mathrm{x}$ & \\
\hline 1.158 & & Texas Cily & La Quinta Molur Inns. Inc. & Low Rise Motcl & & HW & Raypak. Inc. & & & $\mathrm{x}$ & \\
\hline $1.15 y$ & & The Woodlands & $\begin{array}{l}\text { The Woodlands Commercial } \\
\text { Development Company }\end{array}$ & Low Rise Hotel & & HW & Sulir Energy Products. Ine. & & & $\mathrm{x}$ & \\
\hline 1.160 & & The Wirudlands & $\begin{array}{l}\text { The Woodlands Cominercial } \\
\text { Development Cumpany }\end{array}$ & Low Rise Hotel & & HW & Solar Energy Produets. Ine. & & & $\mathrm{x}$ & \\
\hline 1.161 & UTAH & Ogden & Young Ideas Consultanis & Light Manufacturing & H & & $\begin{array}{l}\text { Permaloy Corporation/Ysung } \\
\text { Ideas Consultants }\end{array}$ & & $\mathrm{x}$ & & \\
\hline 1.162 & & Salt Lake City & LaQuinta Motor Inns, Inc. & Low Rise Mutel & H & HW & Chamberlain Manufacturing Corporation & & $\mathrm{x}$ & & \\
\hline 1.163 & VERMONT & Rutland & The Rulland Group, Inc. & Office/Warehouse & $\mathrm{H}$ & & The Rutland Group, Inc: & & $\mathrm{x}$ & & \\
\hline 1.164 & & Woudstock & Woudstock Resort Corporation & Low Rise Hatel & & HW & Revere Copper \& Brass. Ime. & & & $\mathrm{x}$ & \\
\hline 1.165 & VIRGIN ISLANDS & Si. Juhn & Rockresorts, Inc. & $\begin{array}{l}\text { Duplex Coltages/ } \\
\text { Low Rise Hotel }\end{array}$ & & $\mathrm{HW}$ & Reverc Copper \& Brass, Inc. & & & $x$ & \\
\hline 1.166 & & S1. Thumas & American Motor Inns, Inc. & Hotel & C & & Northrup. Inc. & $\mathrm{x}$ & & & \\
\hline 1.167 & VIRGINIA & Alexandria & American Motor Inns, Inc. & High Rise Motor Inn & & $\mathrm{HW}$ & Sunworks. Inc. & & & $\mathrm{x}$ & \\
\hline 1.168 & & Charlottesville & Artington Associates, Inc. & Psychiatric Hospital & H & HW & Sunworks. Inc. & & $\mathrm{x}$ & & \\
\hline 1.169 & & Hampion & Alten Management, Inc. & Low Rise Motel & & HW & Solar Systems of Virginia, Inc. & & & $\mathrm{x}$ & \\
\hline 1.170 & & Leesiourg & Loudoun County School Board & Vocational School & & HW & Southwest Ener.Tech. Inc. & $x$ & & & \\
\hline 1.171 & & Lynchburg & Terrell E. Moseley, Inc. & office & H & HW & Terrell E. Moseley, Inc. & $x$ & & & \\
\hline 1.172 & & Portsmouth & Allen Management, Inc. & Low Rise Mutel & & HW & Solar Systems of Virginio. Inc. & & & $x$ & \\
\hline 1.173 & & Sandston & Allen Managemeni, Inc. & Low Rise Motel & & HW & Solar Systems of Virginia, Inc. & & & $\mathrm{x}$ & \\
\hline 1.174 & & Warrenton & Fauquier County & Classrooms & H & & InterTcchnology Solar Corporation & & & & $x$ \\
\hline 1.175 & & Woodbridge & Allen Management, Inc. & Low Rise Motel & & HW & Solar Systems of Virginia, Inc. & & & $x$ & \\
\hline 1.176 & WASHINGTON & Richland & $\begin{array}{l}\text { Development Dynamics of } \\
\text { Richland }\end{array}$ & Office & $\mathrm{HC}$ & HW & General Elcctric Company & $x$ & & & \\
\hline 1.177 & WEST VIRG'NIA & Bethany & Bethany Colliege & $\begin{array}{l}\text { Conference Center/Multi. } \\
\text { purpose Dixing Facility }\end{array}$ & $\mathrm{H}$ & HW & $\begin{array}{l}\text { InterTechnolugy Corporation/ } \\
\text { Solar Corporation of America }\end{array}$ & & $\mathrm{x}$ & & \\
\hline 1.178 & & Bluefield & Allen Management, Inc. & Low Rise Motel & & HW & Solar Systems of Virginia. Inc. & & & $x$ & \\
\hline 1.179 & & Charles Town & $\begin{array}{l}\text { Jefferson County Board } \\
\text { of Education }\end{array}$ & School & $\mathrm{HC}$ & & PPG Industries. Inc. & & & & $\mathrm{x}$ \\
\hline 1.180 & WISCONSIN & Howards Grove & School District of Howards Grove & Elementary Sthool & H & & Sunstone Solar Energy Equipment & & $x$ & s & \\
\hline 1.181 & & West Bend & Dr. Walter A. Handzlik & Dental Clinic & H & & Owens-IIlinois. Inc. & & $\mathrm{x}$ & 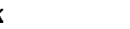 & \\
\hline 1.182 & WYOMINC & Casper & $\begin{array}{l}\text { Wyoming Rural Electric } \\
\text { Association }\end{array}$ & Office & H & & Solargenics, Inc. & & $x$ & s & \\
\hline & & $\begin{array}{l}Y: \\
- \text { Heating }\end{array}$ & C - Cooling & Hot Water & & & & & & & \\
\hline
\end{tabular}

*Program Opportunity Notice (PON) Projects administered by DOE

- Includes projects initiated by the National Science Foundation. 


\section{COMMERCIAL DEMONSTRATION PROGRAM}

FEDERAL BUILDINGS

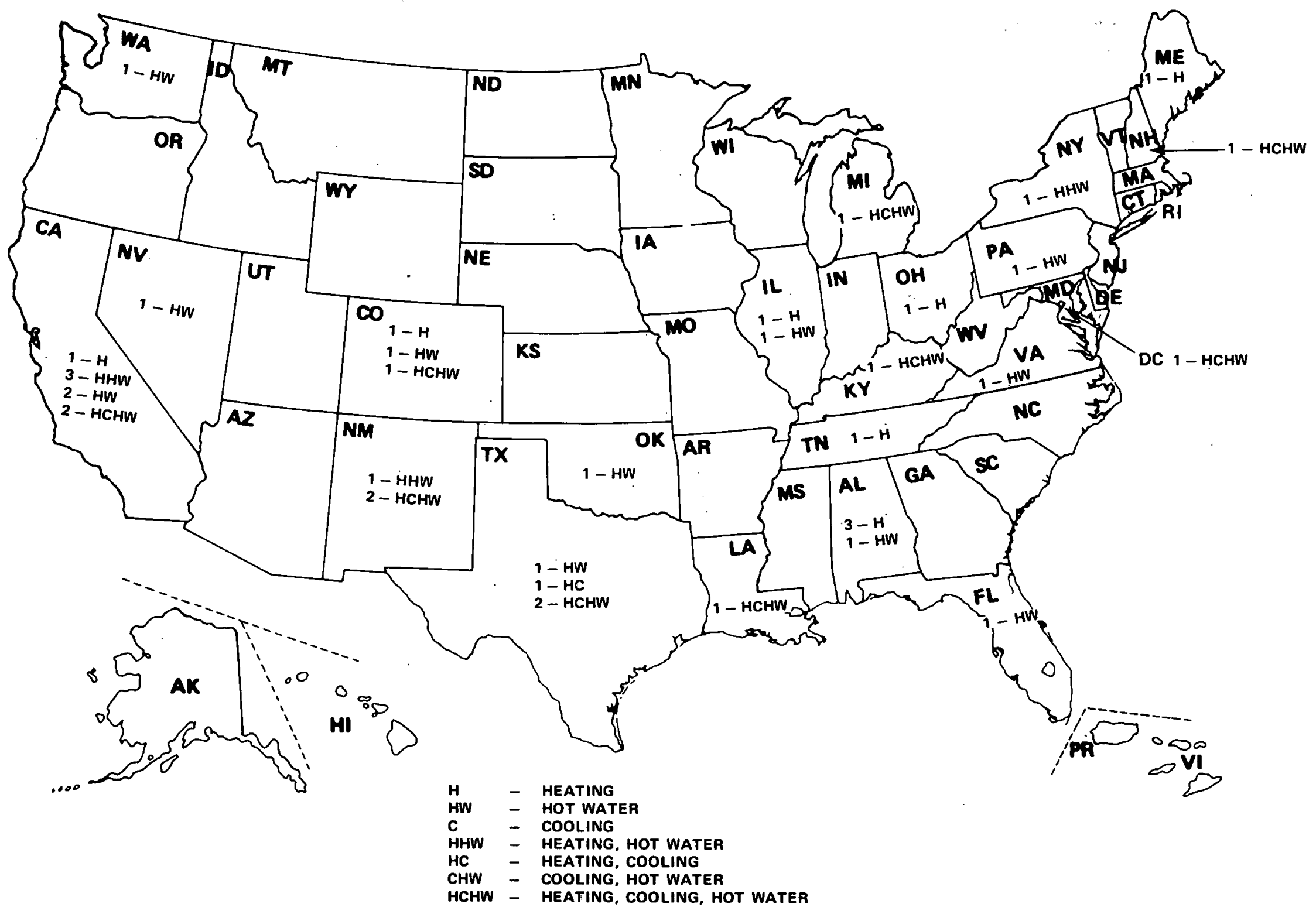




\section{SECTION II COMMERCIAL DEMONSTRATION PROGRAM FEDERAL BUILDINGS}

\begin{tabular}{|c|c|c|c|c|c|c|c|}
\hline PAGE & STATE & LOCATION & OWNER/BUILDER & $\begin{array}{l}\text { BUILDING } \\
\text { TYPE }\end{array}$ & $\begin{array}{r}\text { SOLA } \\
\text { APPLICA }\end{array}$ & AR & $\begin{array}{c}\text { SOLAR } \\
\text { MANUFACTURER }\end{array}$ \\
\hline II.I & ALABAMA & Huntsville & NASA Marshall Space Flight Center & Assembly Building & $\mathrm{H}$ & & Kalwall Corporation \\
\hline II- 2 & & Hur:tsville & N.ASA Marshall Space Flight Center & Laboratory & H & & To be Determined \\
\hline 11.3 & & Huritsville & N.ASA Marshall Space Flight Center & Laboratory & H & & Marshall Space Flight Center \\
\hline II. 4 & & Huntsville & NASA Marshall Space Flight Center & Office & & HW & To be Determined \\
\hline II-5 & CALIFORNIA & Adin & Dept. of Agriculture/Forest Service & Office & $\mathrm{H}$ & & To be Determined \\
\hline 11.6 & & Berkeley & $\begin{array}{l}\text { Dept. of Energy/Lawrence } \\
\text { Berkeley Laboratory }\end{array}$ & Office & $\mathrm{H}$ & $\mathrm{HW}$ & To be Determined \\
\hline II -7 & & Davis & $\begin{array}{l}\text { Dept. of Energy/University of } \\
\text { California }\end{array}$ & Laboratory & $\dot{\mathrm{H}}$ & HW & KTA Corporation \\
\hline II-8 & & Edwards & $\begin{array}{l}\text { NASA Dryden Flight Research } \\
\text { Center }\end{array}$ & Cafeteria & & HW & Lennox Industries, Inc. \\
\hline 11.9 & & Fresno & $\begin{array}{l}\text { Dept. of Agriculture/ } \\
\text { Forëst Service }\end{array}$ & Office/Laboratory & $\mathrm{H} \mathrm{C}$ & HW & To be Determined \\
\hline III.10 & & Livermore & $\begin{array}{l}\text { Department of Energy/Lawrence } \\
\text { Livermore Laboratory }\end{array}$ & Cafeteria & & HW & To be Determined \\
\hline 11.11 & & Moffett Field. & NASA Ames Research Center & Photographic Laboratory & & HW & To be Determined \\
\hline II -12 & & San Diego & Veterans Administration Hospital & Health Care Facility & H C & HW & To be Determined \\
\hline 11.13 & & San Francisco & $\begin{array}{l}\text { Dept. of Interior/Fish and } \\
\text { Wildlife Service }\end{array}$ & Visitors Center & H & HW & To be Determined \\
\hline [I. 14 & COLORADO & Boulder & U.S. Postal Service & Post Office & H C & HW & $\begin{array}{l}\text { Lennox Industries, Inc./ } \\
\text { Honeywell, Inc. }\end{array}$ \\
\hline II. 15 & & Denver & General Services Administration & Office & $\mathrm{H}$ & & To be Determined \\
\hline II. 16 & & Grand Junction & $\begin{array}{l}\text { Dept. of Energy/Grand Junction } \\
\text { Office }\end{array}$ & Cafeteria. & & $\mathrm{HW}$ & R.M Products \\
\hline II-17 & DIST.OF COLUMBIA & $\begin{array}{l}\text { Bolling Air Force } \\
\text { Base }\end{array}$ & $\begin{array}{l}\text { Dept. of Defense/Army and } \\
\text { Air Force Exchange Service }\end{array}$ & Exchange Shopping Center & $\mathrm{H} \mathrm{C}$ & HW & KTA Corporation \\
\hline II-18 & FLORIDA & Cape Canaveral & NASA Kennedy Space Center & Cafeteria & & $\mathrm{HW}$ & To be Determined \\
\hline II-19 & ILLINOIS & Argonne & $\begin{array}{l}\text { Dept. of Energy/Argonne National } \\
\text { Laboratory }\end{array}$ & Cafeteria & & HW & Chamberlain Manufacturing Corporation \\
\hline III-20 & & Batavia & $\begin{array}{l}\text { Dept. of Energy/Fermi National } \\
\text { Accelerator Laboratory }\end{array}$ & Industrial & $\mathrm{H}$ & & Fermi National Accelerator Laboratory \\
\hline II.21 & KENTUCKY & $\begin{array}{l}\text { Land Between the } \\
\text { Lakes }\end{array}$ & Tennessee Valley Authority & Visistors Center & $\mathrm{H} \mathrm{C}$ & HW & To be Determined \\
\hline II -22 & LOUISIANA & Ft. Polk & $\begin{array}{l}\text { Dept. of Defense/Army and } \\
\text { Air Force Exchange Service }\end{array}$ & Exchange Shopping Center & $\mathrm{H} \mathrm{C}$ & HW & General Electric Company \\
\hline II. 23 & MAINE & Hamlin & $\begin{array}{l}\text { Dept. of the Treasury/U.S. } \\
\text { Customs Service }\end{array}$ & U.S. Border Inspection Station & $\mathrm{H}$ & & Daystar Corporation \\
\hline II-24 & MICHIGAN & Saginaw & General Services Administration & Office & $\mathrm{H} \mathrm{C}$ & HW & Owens-Illinois, Inc. \\
\hline II-25 & NEVADA & Mercury & Dept. of Energy/Nevada Test Site & Fire Station & & $\mathrm{HW}$ & To be Determined \\
\hline II-26 & NEW HAMPSHIRE & Manchester & General Services Administration & Office & H C & HW & Multisource \\
\hline $11-27$ & NEW MEXICO & Bread Springs & $\begin{array}{l}\text { Dept. of Interior/Bureau of } \\
\text { Indian Affairs }\end{array}$ & School & H & HW & Gould, Inc./Sunworks, Inc. \\
\hline II-28 & & $\begin{array}{l}\text { Kirtland Air Force } \\
\text { Base }\end{array}$ & $\begin{array}{l}\text { Dept. of Defense/Army and Air } \\
\text { Force Exchange Service }\end{array}$ & Exchange Shopping Center & $\mathrm{H} \mathrm{C}$ & HW & Raypak, Inc. \\
\hline \multirow[t]{3}{*}{ II-29 } & & $\begin{array}{l}\text { Gila National For- } \\
\text { est, Mimbres }\end{array}$ & $\begin{array}{l}\text { Dept. of Agriculture/Forest } \\
\text { Service }\end{array}$ & Ranger Station & H C & HW & To be Determined \\
\hline & & Ranger District & & & & & \\
\hline & $\mathrm{H}-$ & & C - Cooling & HW - & - Họt $W_{s}$ & Vater & \\
\hline
\end{tabular}




\section{PROJECT INFORMATION}

Owner/Builder: NASA Marshall Space Flight Center

Contractor: To be determined

Operational Date: June 1978

Total Estimated DOE Funds: $\quad \$ 124,140$

\section{Building}

Type: Assembly building

Area: 85,000 sq. $\mathrm{ft}$.

Location: Huntsville, Alabama

Latitude: $34.8^{\circ} \mathrm{N}$

Climatic Data

$\begin{array}{lllll}\text { Degree Days } & \text { Heating } & 3070 & \text { Cooling } & 1808 \\ \text { Avg. Temp. }\left({ }^{\circ} \mathrm{F}\right) & \text { Winter } & 51.3 & \text { Summer } & 88.3 \\ \text { Avg. Insol. (Ly/d) } & \text { Winter } & 190 & \text { Summer } & 531\end{array}$

Avg. Insol. (Ly/d)

Winter 190

Summer 531

\section{SOLAR ENERGY SYSTEM}

Application Heating 35\% Cooling $0 \%$ Hot Water $0 \%$

Collector

Type: Vertical wall panels (passive)

Area (sq. ft.): $\quad 6,400$

Manufacturer: Kalwall Corporation

\section{Storage}

Type: None

Capacity: Not applicable

Auxiliary System Type: Oil fired boiler

\section{PROJECT DESCRIPTION}

This project will provide solar-aided heating of the Marshall Space Flight Center Assembly building, high bay area. The solar system will be a passive system with transparent collectors mounted in the walls and will supply part of the heating load. The existing air handling system will be modified to concentrate heating and cooling loads. The passive system will provide a significant energy saving due to a decreased lighting load.

\section{Photograph not available}

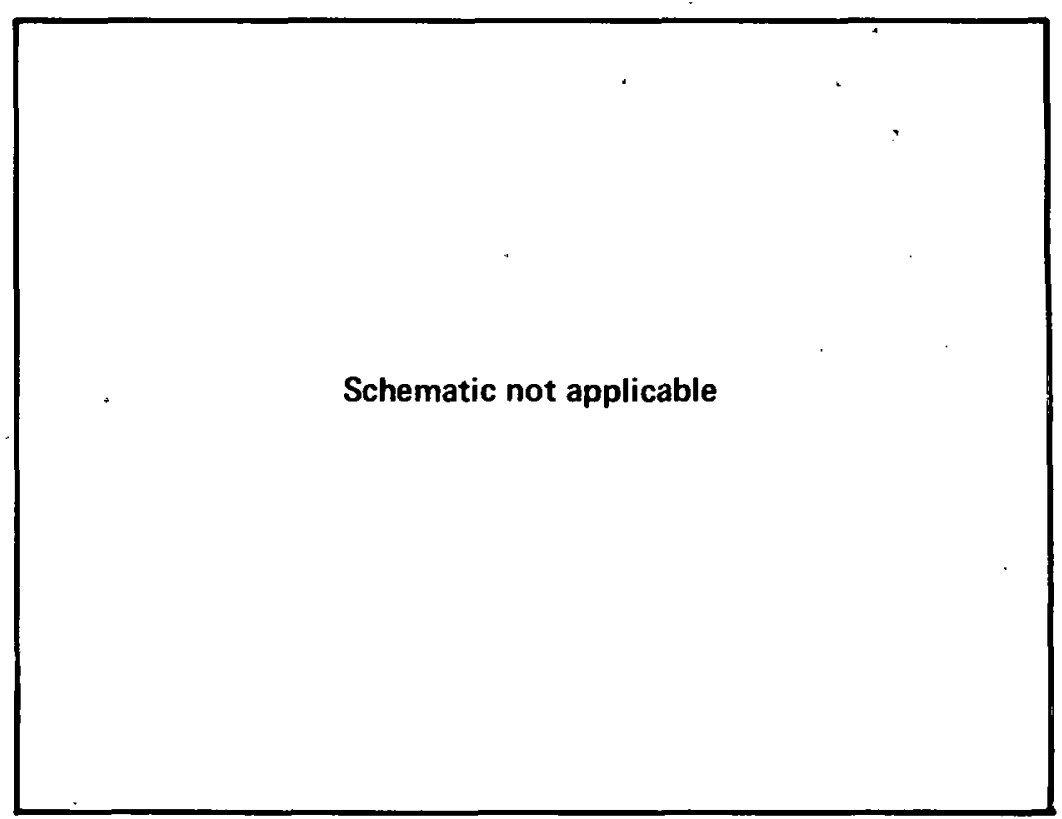




\section{PROJECT INFORMATION}

Owner/Builder: NASA Marshall Space Flight Center

: Contractor: To be determined

Operational Date: November 1978

Total Estimated DOE Funds: $\mathbf{\$ 2 4 4 , 0 0 0}$

Building

Type: Laboratory

Area: 285,882 sq. ft.

Location: Huntsville, Alabama

Latitude: $34.8^{\circ} \mathrm{N}$

Climatic Data

Degree Days

Avg. Temp. $\left({ }^{\circ} \mathrm{F}\right)$

Heating 3070

Winter 51.3

Cooling 1808

Avg. Insol. (Ly/d)

Winter 190

Summer 88.3

SOLAR ENERGY SYSTEM

Application Heating 20\% Cooling $0 \%$ Hot Water $0 \%$

Collector

Type: Liquid flat-plate

Area (sq. ft.): 2,400

Manufacturer: To be determined

Storage

Type: Water tank

Capacity: To be determined

Auxiliary System Type: Oil fired boiler

\section{PROJECT DESCRIPTION}

This project supplies heat to several electronic laboratories, instrumentation rooms, and computer rooms. The collectors will be roof mounted. The solar system will provide re-heat to computer areas in the summer and space heating to the high bay in the winter. Existing heating units will be modified to accommodate the solar system. Steam supplied by an oil fired boiler will provide system back-up.

\section{Photograph not available}

Schematic not available 


\section{PROJECT INFORMATION}

Owner/Builder: NASA Marshall Space Flight Center

Contractor: Marshall Space Flight Center

Operational Date: February 1978

Total Estimated DOE Funds: $\$ \$ 35,000$

Building

Type: Laboratory

Area: 1,200 sq. $\mathrm{ft}$.

Location: Huntsville, Alabama

Latitude: $34.8^{\circ} \mathrm{N}$

Climatic Data

$\begin{array}{lllll}\text { Degree Days } & \text { Heating } & 3070 & \text { Cooling } & 1808 \\ \text { Avg. Temp. }\left({ }^{\circ} \mathrm{F}\right) & \text { Winter } & 51.3 & \text { Summer } & 88.3 \\ \text { Avg. Insol. (Ly/d) } & \text { Winter } & 190 & \text { Summer } & 531\end{array}$

\section{SOLAR ENERGY SYSTEM}

Application Heating 100\% Cooling 0\% Hot Water $0 \%$

Collector

Type: Air flat-plate

Area (sq. ft.): $\quad 520$

Manufacturer: Marshall Space Flight Center

Storage

Type: Pebble bed

Capacity: $318 \mathrm{cu} . \mathrm{ft}$.

Auxiliary System Type: Electric

\section{PROJECT DESCRIPTION}

This project supplies heat to a facility used for the repair of solar collector panels at the Marshall Space Flight Center. The collectors have been designed by the Marshall Space Flight Center. The collector array is designed to allow experimentation with several types of air collectors. Air is used as the heat transfer medium. A $318 \mathrm{cu}$. ft. rock tank, with plenums above and below the rock storage, provides storage. An electric heater provides back-up. 


\section{PROJECT INFORMATION}

Owner/Builder: NASA Marshall Space Flight Center

Contractor: To be determined

Operational Date: September 1978

Total Estimated DOE Funds: $\$ \mathbf{2 2 8 , 0 0 0}$

Building

Type: Office

Area: 235,000

Location: Huntsville, Alabama

Latitude: $34.8^{\circ} \mathrm{N}$

Climatic Data

Avg. Insol. (Ly/d)

$\begin{array}{lllll}\text { Degree Days } & \text { Heating } & 3070 & \text { Cooling } & 1808 \\ \text { Avg. Temp. }\left({ }^{\circ} \mathrm{F}\right) & \text { Winter } & 51.3 & \text { Summer } & 88.3 \\ \text { Avg. Insol. (Ly/d) } & \text { Winter } & 190 & \text { Summer } & 531\end{array}$

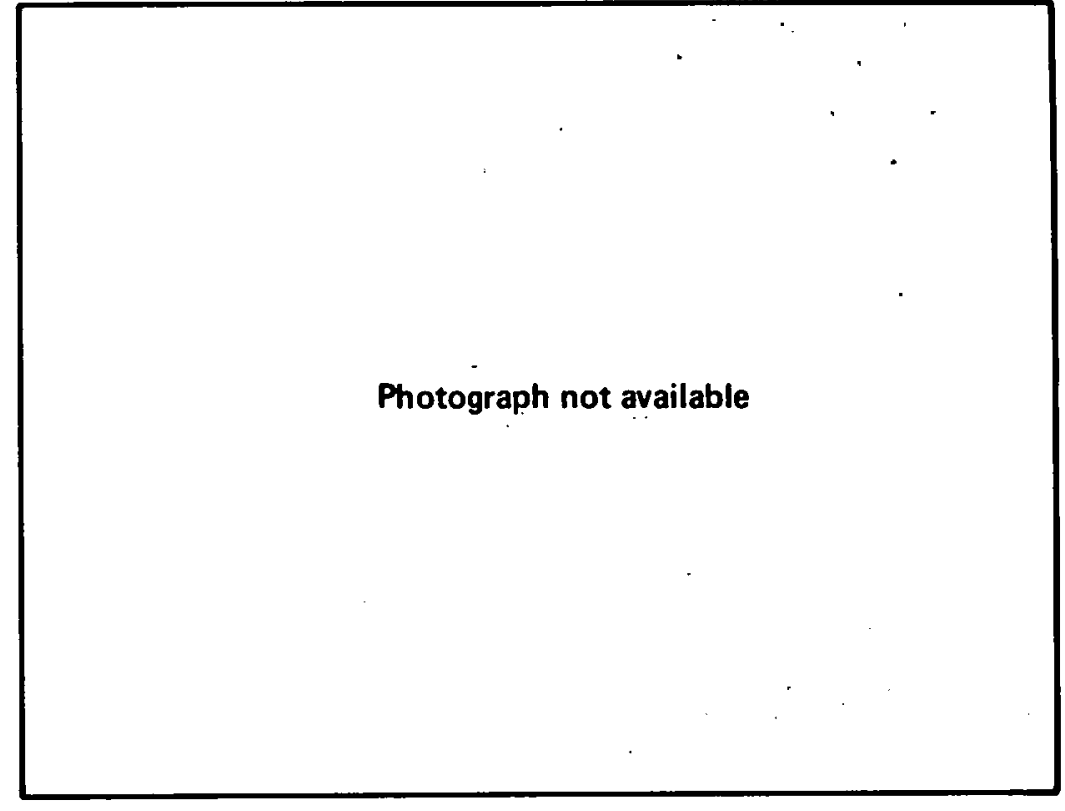

Collector

Type: Liquid flat-plate

Area (sq. ft.): 878

Manufacturer: To be determined

Storage

Type: Water tank

Capacity: 2,000 gallons

Auxiliary System Type: Electric boiler

\section{PROJECT DESCRIPTION}

This project will supply domestic hot water to two wings of the main office building of the Space Flight Center. The collector array will be located on the roof of the mezzanine adjoining the nine-story wings. Solar heated hot water is circulated to a 2000-gallon storage tank located in an equipment room located below the mezzanine. An electric boiler is used for back-up. Piping will be installed for future expansion to two sister buildings.

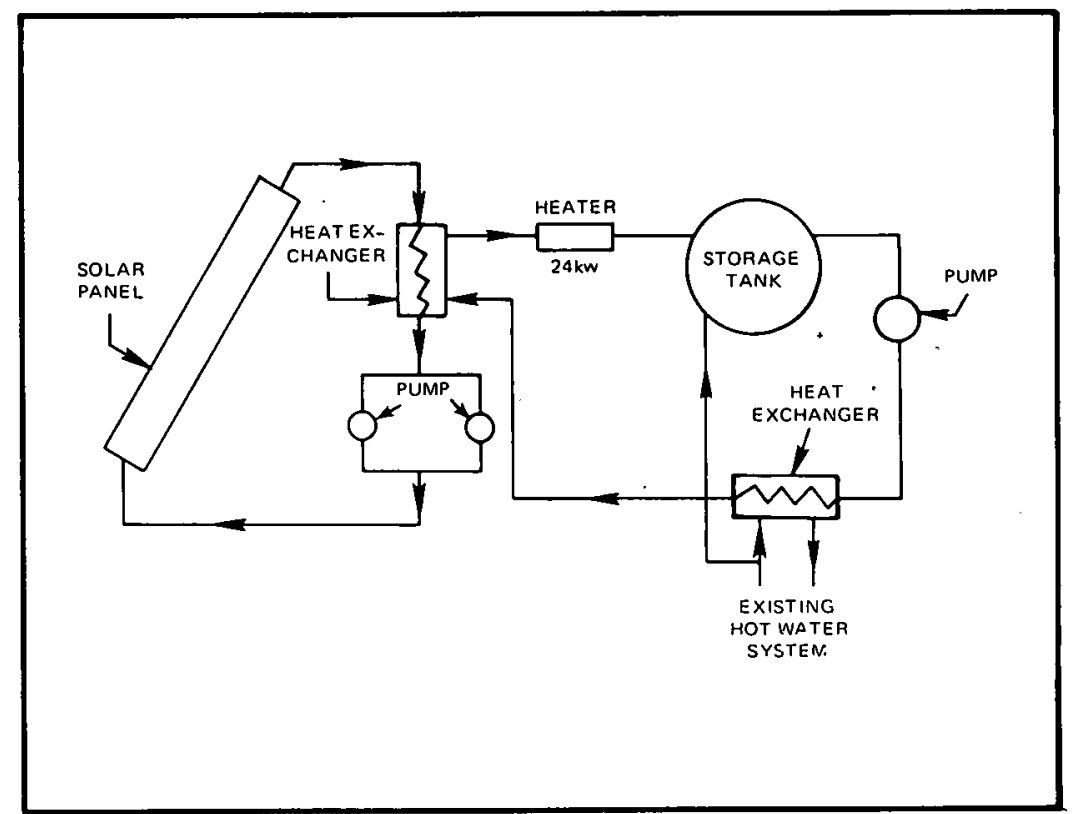




\section{PROJECT INFORMATION}

Owner/Builder: Dept. of Agriculture/Forest Service

Contractor: To be determined

Operational Date: May 1979

Total Estimated DOE Funds: $\quad \$ 16,800$

Building

Type: Office

Area: 2,362 sq. ft.

Location: Adin, California

Latitude: $41^{\circ} 12^{\prime} \mathrm{N}$

Climatic Data

$\begin{array}{lllll}\text { Degree Days } & \text { Heating } & 6620 & \text { Cooling } & 329 \\ \text { Avg. Temp. }\left({ }^{\circ} \mathrm{F}\right) & \text { Winter } & 31 & \text { Summer } & 70 \\ \text { Avg. Insol. (Ly/d) } & \text { Winter } & 172 & \text { Summer } & 637 .\end{array}$

Avg. Insol. (Ly/d)

Winter

172

\section{SOLAR ENERGY SYSTEM}

Application Heating 57\% Cooling $0 \%$ Hot Water $0 \%$

Collector

Type: Air flat-plate -

Area (sq. ft.): To be determined

Manufacturer: To be determined

Storage

Type: Rock bed

Capacity: To be determined

Auxiliary System Type:

\section{PROJECT DESCRIPTION}

This project is being designed to provide solar heating for an addition to an existing Forest Service district office. Air type collectors will be used with a rock-filled tank for heat storage.

Photograph not available

Schematic not available 


\section{PROJECT INFORMATION}

Owner/Builder: Dept. of Energy/Lawrence Berkeley Laboratory

Contractor: To be determined

Operational Date: June 1978

Total Estimated DOE Funds: $\$ 30,000$ (design); $\$ 131,000$ (construction) Building

Type: Office

Area: 88,000 sq. ft.

Location: Berkeley, California

Latitude: $38^{\circ} \mathrm{N}$

Climatic Data

Degree Days

Avg. Temp. $\left({ }^{\circ} \mathrm{F}\right)$

$\begin{array}{ll}\text { Heating } & 3163 \\ \text { Winter } & 56\end{array}$

Cooling 492

Avg. Insol. (Ly/d)

Summer 64

Summer 614

\section{SOLAR ENERGY SYSTEM}

Application Heating 30\%

\section{Collector}

Type: Liquid flat-plate

Area (sq. ft.): 1,250

Manufacturer: To be determined

Storage

Type: Water tank

Capacity: 2,000 gallons

Auxiliary System Type: Gas fired hot water boiler

\section{PROJECT DESCRIPTION}

This project involves the design and construction of a retrofitted solar heating system for a four-story office building (Bldg. 90) at Lawrence Berkeley Laboratory, California. The building, originally planned as a laboratory with $100 \%$ outside air, will be modified by a separate project to utilize recirculated air during heating. The solar system utilizes 1250 sq. ft. of flat-plate roof-mounted collectors and a 2000-gallon buried storage tank. A heat exchanger is used between the existing storage tank and the hot water heating system, because of low pressure limitations on the existing hot water boilers. Heating wate temperatures have been reduced by the inclusion of a three-way mixing valve to maximize solar energy utilization. Heating water is used for both building space and domestic hot water heating.
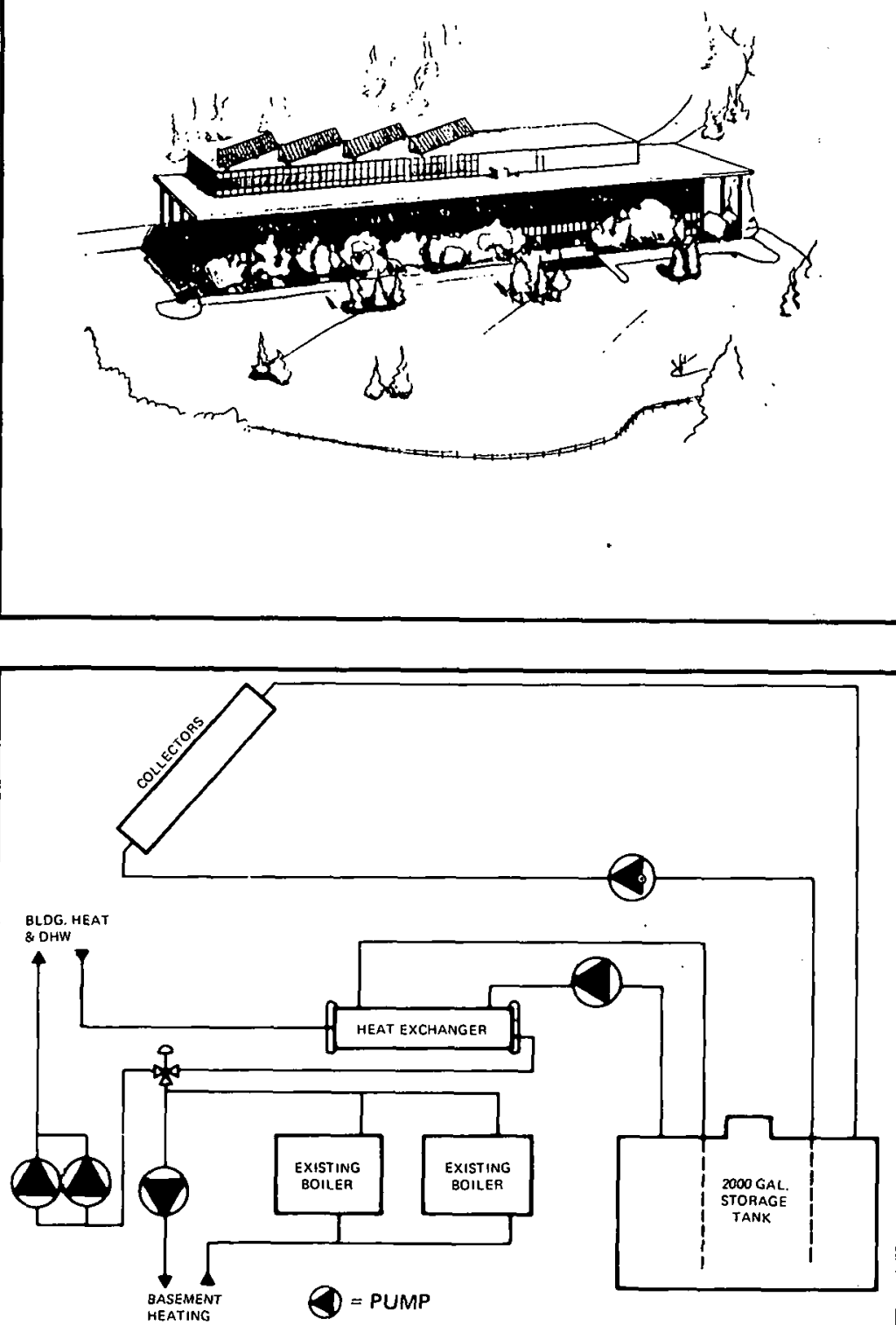


\section{PROJECT INFORMATION}

Owner/Builder: Dept. of Energy/University of California

Contractor: Construction Development Corporation

Operational Date: April 1978

Total Estimated DOE Funds: $\$ 10,000$ (design); $\$ 30,000$ (construction) Building

Type: Laboratory

Area: 4,200 sq. ft.

Location: Davis, California

Latitude: $38^{\circ} \mathrm{N}$

Climatic Data

Degree Days

Avg. Temp. $\left({ }^{\circ} \mathrm{F}\right)$

Avg. Insol. (Ly/d)

$\begin{array}{llll}\text { Heating } & 2502 & \text { Cooling } & 1798 \\ \text { Winter } & 54 & \text { Summer } & 71 \\ \text { Winter } & 175 & \text { Summer } & 711\end{array}$

\section{SOLAR ENERGY SYSTEM}

Application Heating $72 \%$

Collector

Type: Liquid flat-plate

Area (sq. ft.): 764

Manufacturer: KTA Corporation

\section{Storage}

Type: Water tank

Capacity: 1,200 gallons

Auxiliary System Type: Gas fired hot water boiler

\section{PROJECT DESCRIPTION}

The Tissue Culture Laboratory building will incorporate several energy conservation features. A four-foot roof overhang will protect the south wall from the summer sun and from the cold north wind. The roof will be sloped to accommodate the central mechanical system in the "attic space." The sloped roof will make it possible to instal the solar panels without additional panel framings. All building exhaust air, except that taken from laboratory exhaust hoods, will be ducted through the air-to-air heat exchanger in conjunction with outside air to the multizone unit. This will provide winter and summer tempering for the outside air with approximately $75 \%$ energy recovery Economizer dampers will be installed to bypass the heat exchanger to allow energy free cooling when atmospheric conditions are right. Controls will be arranged so that the building heating system has priority over solar heated water during the heating season.
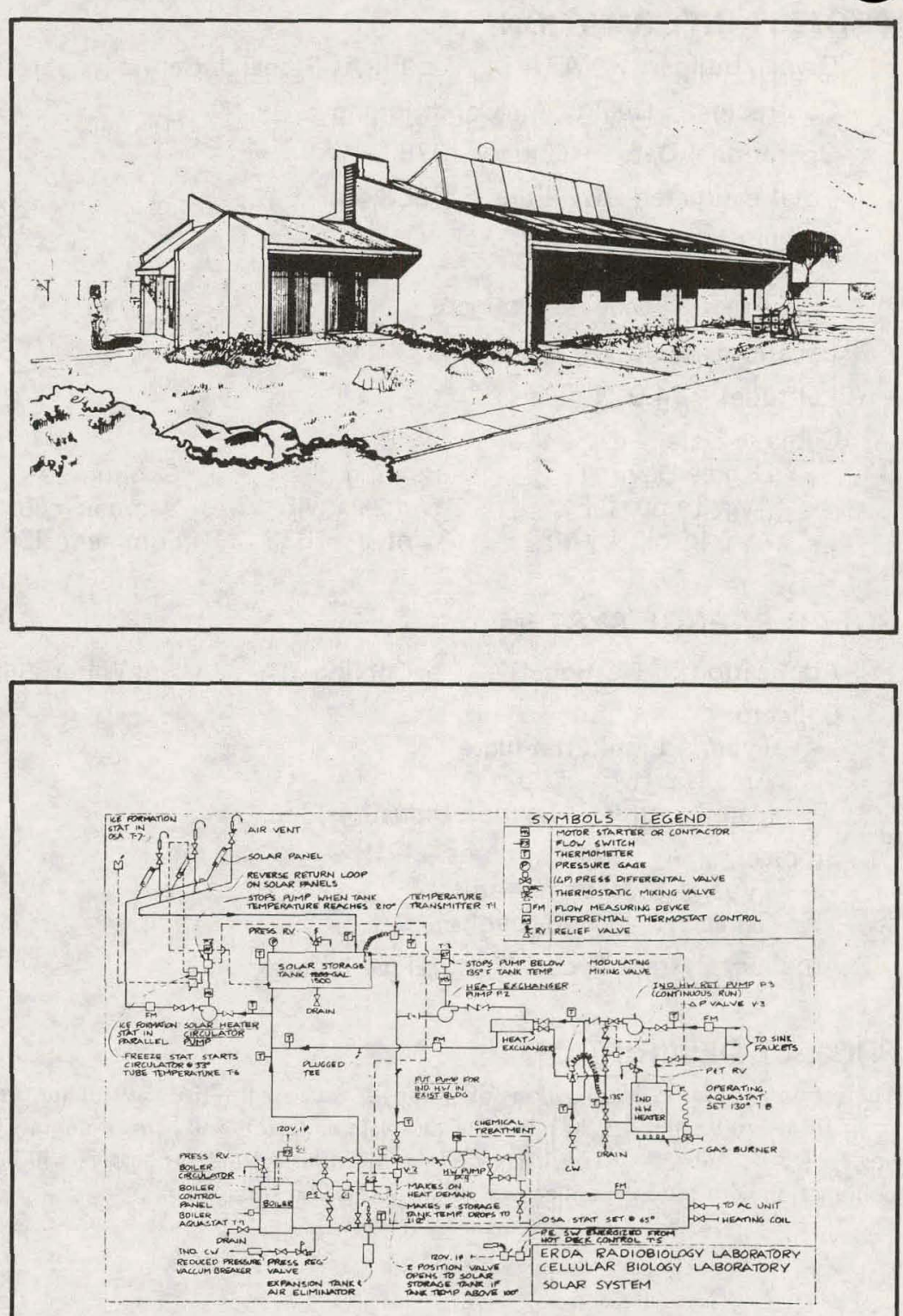


\section{PROJECT INFORMATION}

Owner/Builder: NASA Dryden Flight Research Center

Contractor: Quality Air Conditioning

Operational Date: January 1978

Total Estimated DOE Funds: $\$ 68,400$

Building

Type: Cafeteria

Area: To be determined

Location: Edwards, California

Latitude: $34.9^{\circ} \mathrm{N}$

Climatic Data

$\begin{array}{lllll}\text { Degree Days } & \text { Heating } & - & \text { Cooling } & - \\ \text { Avg. Temp. }\left({ }^{\circ} \mathrm{F}\right) & \text { Winter } & 46 & \text { Summer } & 80 \\ \text { Avg. Insol. (Ly/d) } & \text { Winter } & 633 & \text { Summer } & 900\end{array}$

\section{SOLAR ENERGY SYSTEM}

Application Heating $0 \%$

Collector

Type: Liquid flat-plate

Area (sq. ft.): 700

Manufacturer: Lennox Industries, Inc.

Storage

Type: Steel water tank

Capacity: 1,500 gallons

Auxiliary System Type: Natural gas boiler

\section{PROJECT DESCRIPTION}

The cafeteria requires 3000 gallons of water for each of the five days of the week. It is open from 6:00 a.m. to 3:30 p.m. The flat-plate collectors will be roof-mounted at a tilt angle of $30^{\circ}$. A back-up consisting of two 90-gallon natural gas heaters will be used in conjunction with the solar collectors and a 1500-gallon storage tank.
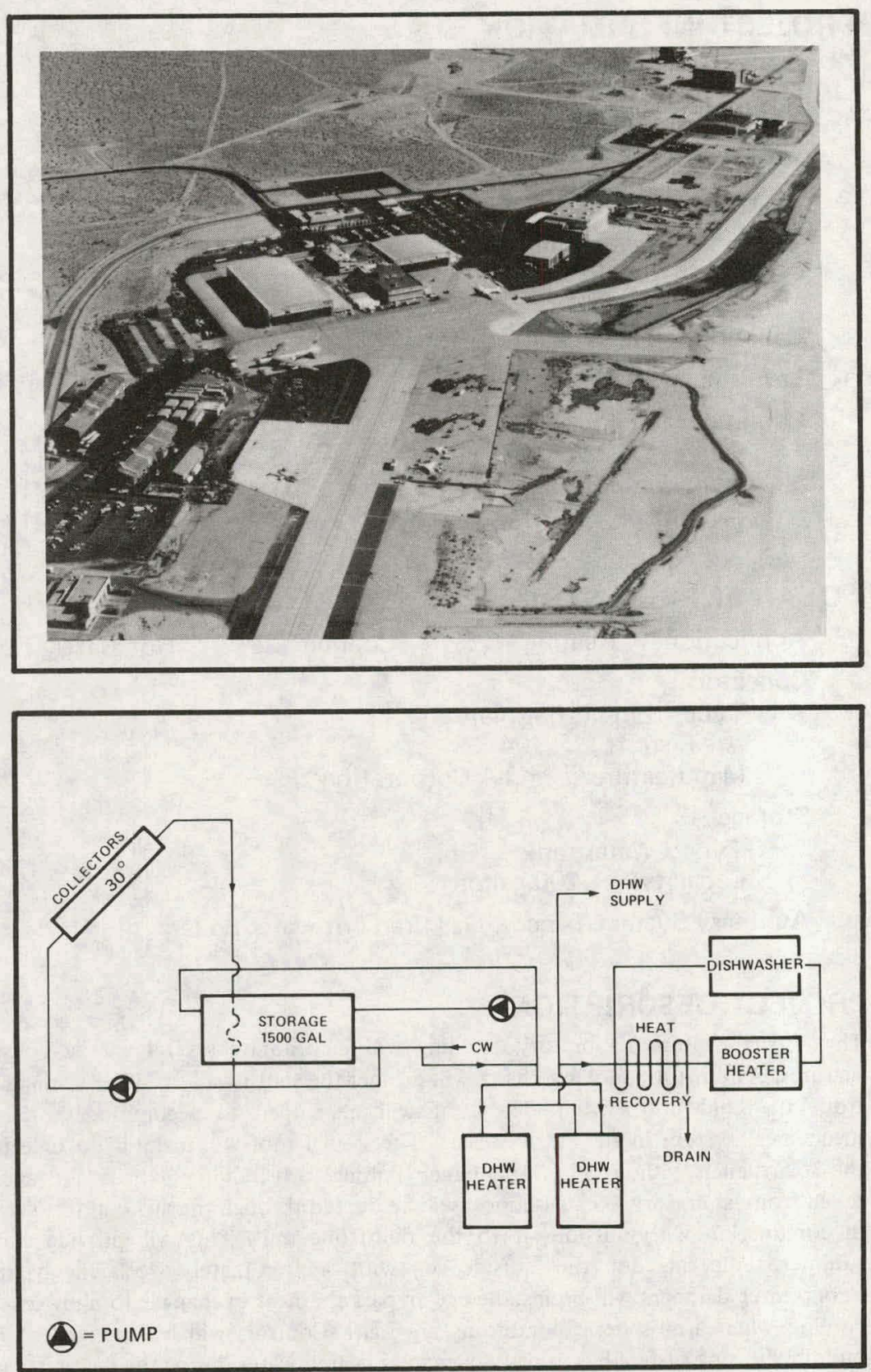


\section{PROJECT INFORMATION}

Owner/Builder: Dept. of Agriculture/Forest Service

Contractor: To be determined

Operational Date: December 1978

Total Estimated DOE Funds: $\quad \$ 82,400$

Building

Type: Office/laboratory

Area: 8,200 sq. ft. (total); 5,600 sq. ft. (cond.)

Location: Fresno, California

Latitude: $36^{\circ} 46^{\prime} \mathrm{N}$

Climatic Data

$\begin{array}{lllll}\text { Degree Days } & \text { Heating } & 2650 & \text { Cooling } & 1671 \\ \text { Avg. Temp. }\left({ }^{\circ} \mathrm{F}\right) & \text { Winter } & 53 & \text { Summer } & 75 \\ \text { Avg. Insol. }(\text { Ly/d) } & \text { Winter } & 211 & \text { Summer } & 668\end{array}$

\section{SOLAR ENERGY SYSTEM}

Application Heating 65\% Cooling $17.2 \%$ Hot Water $61.5 \%$

Collector

Type: Liquid flat-plate

Area (sq. ft.): 1,000

Manufacturer: To be determined

Storage

Type: Woter tank

Capacity: 2,000 gallons

Auxiliary System Type: Gas heating/electric cooling

\section{PROJECT DESCRIPTION}

This project is a laboratory and office building for U.S. Forest Service research. The solar system will be a solar atrium roof system. The system is designed to achieve a blending of pleasing architecture with the mechanical and other systems.
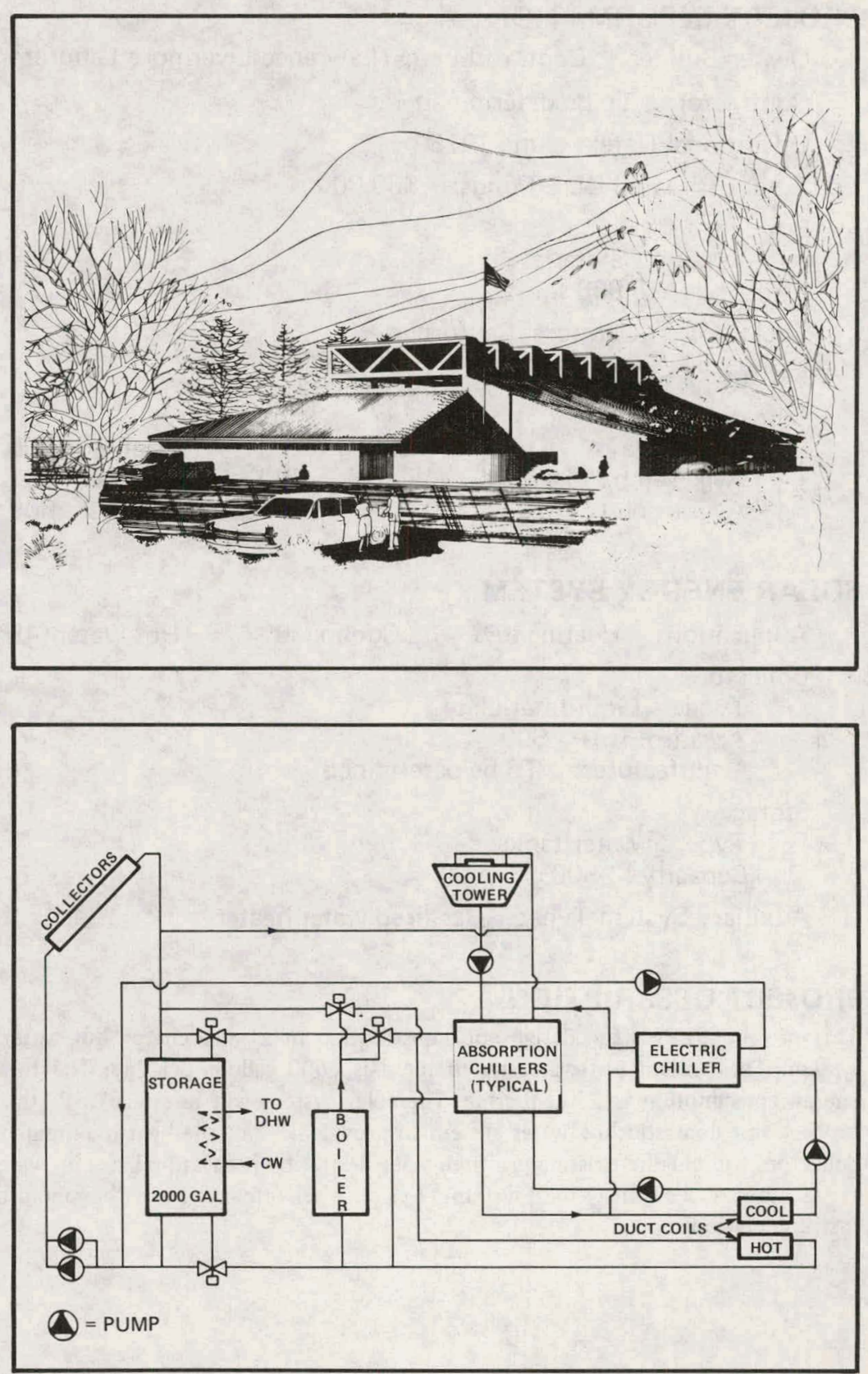


\section{PROJECT INFORMATION}

Owner/Builder: Dept. of Energy/Lawrence Livermore Laboratory

Contractor: To be determined

Operational Date: June 1978

Total Estimated DOE Funds: $\quad \$ 60,000$

Building

Type: Cafeteria

Area: 8,968 sq. ft.

Location: Livermore, California

Latitude: $37^{\circ} \mathrm{N}$

Climatic Data

Degree Days

Avg. Temp. $\left({ }^{\circ} \mathrm{F}\right)$

Avg. Insol. (Ly/d)

$\begin{array}{llll}\text { Heating } & 2881 & \text { Cooling } & 400 \\ \text { Winter } & 49 & \text { Summer } & 68 \\ \text { Winter } & 180 & \text { Summer } & 609\end{array}$

\section{SOLAR ENERGY SYSTEM}

Application Heating 0\%

Hot Water $45 \%$

Collector

Type: Liquid flat-plate

Area (sq. ft.): 500

Manufacturer: To be determined

Storage

Type: Water tanks

Capacity: 500 gallons

Auxiliary System Type: Gas fired water heater

\section{PROJECT DESCRIPTION}

This project involves the design and construction of a solar energy hot water heating system. The present hot water requirement is 1600 gallons per day. The total yearly energy consumption is 2500 therms. The solar system will interface with the existing process and domestic hot water system to provide $45 \%$ of the heat requirement. These collectors will aid the existing gas fired water heater by preheating make up water before it is introduced into the system. System performance will be monitored by instrumentation.
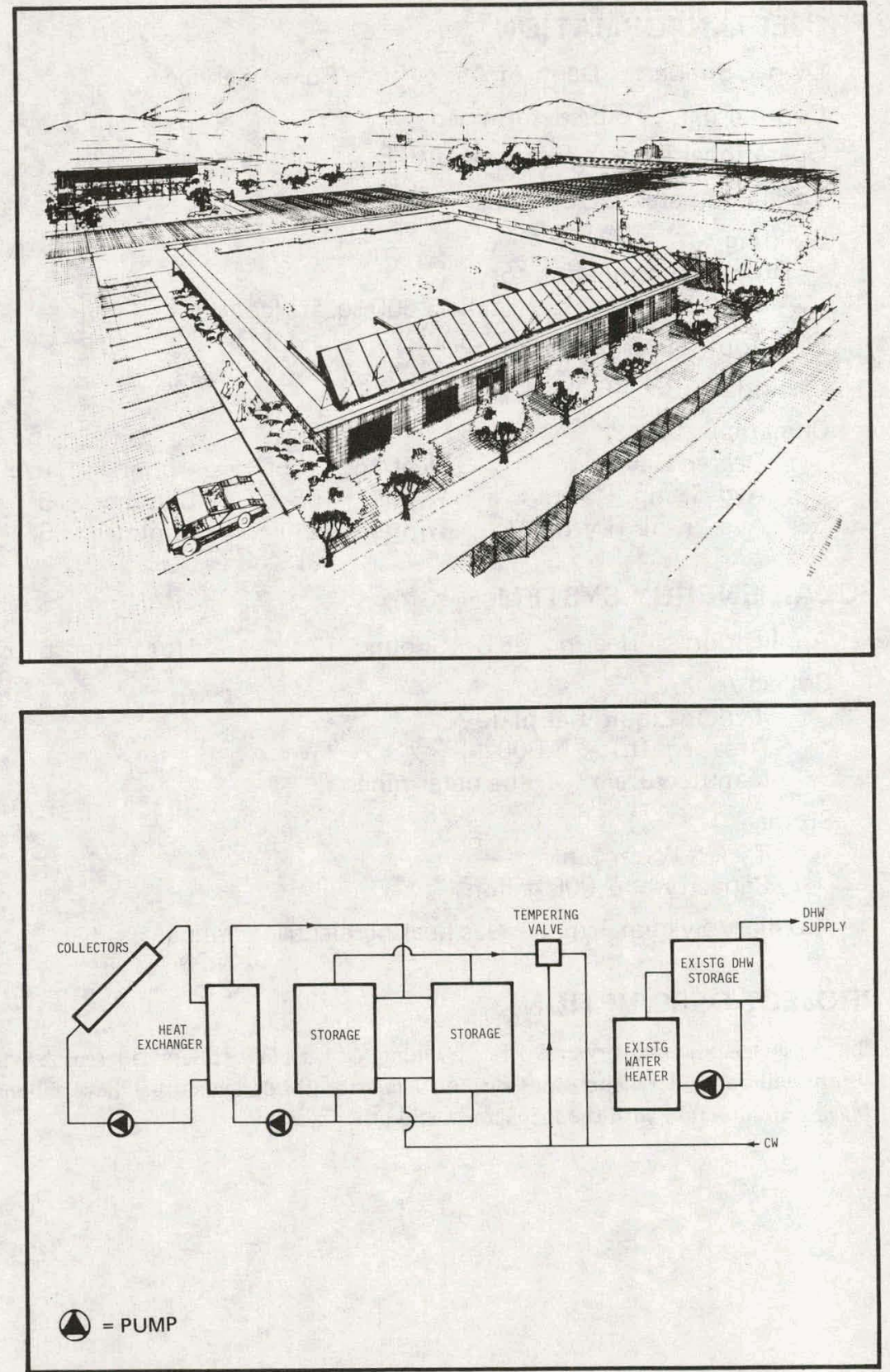


\section{PROJECT INFORMATION}

Owner/Builder: NASA Ames Research Center

Contractor: To be determined

Operational Date: June 1978

Total Estimated DOE Funds: $\quad \$ \mathbf{7 4 , 5 0 0}$

Building

Type: Photographic laboratory

Area: $8,000 \mathrm{sq} . \mathrm{ft}$.

Location: Moffett Field, California

Latitude: $37.7^{\circ} \mathrm{N}$

Climatic Data

Degree Days

Avg. Temp. $\left({ }^{\circ} \mathrm{F}\right)$

Avg. Insol. (Ly/d)

$\begin{array}{llll}\text { Heating } & 3001 & \text { Cooling } & 192 \\ \text { Winter } & 58 & \text { Summer } & 72 \\ \text { Winter } & 150 & \text { Summer } & 650\end{array}$

\section{SOLAR ENERGY SYSTEM}

Application Heating $0 \%$

Collector

Type: To be determined

Area (sq. ft.): 1,500

Manufacturer: To be determined

Storage

Type: Insulated steel water tank (in basement)

Capacity: 3,570 gallons

Auxiliary System Type: Gas fired boiler

\section{PROJECT DESCRIPTION}

This project is a retrofit to a thirty-year-old building at NASA Ames Research Center. The collector array placement is restricted to one-half of the building roof area due to existing mechanical equipment. Solar heated water will be used to supplement photographic process hot water. The auxiliary system is a gas fired boiler. A 3570-gallon insulated steel tank in the basement is used for hot water storage.
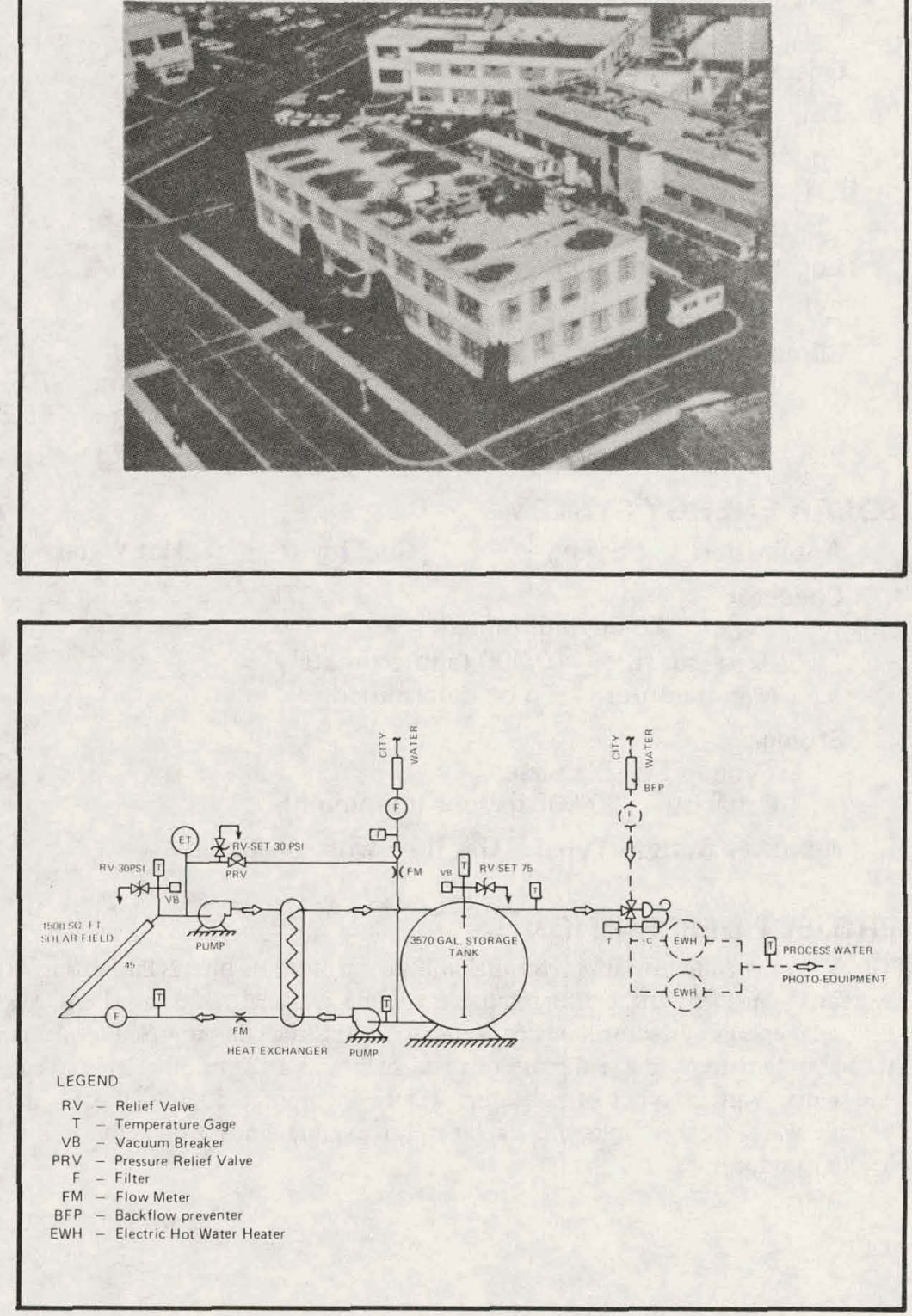


\section{PROJECT INFORMATION}

Owner/Builder: Veterans Administration/Veterans Administration Hospital

Contractor: To be determined

Operational Date: May 1979

Total Estimated DOE Funds: $\$ 290,000$

Building

Type: Health care facility

Area: 825,000 sq. ft.

Location: San Diego, California

Latitude: $32^{\circ} 52^{\prime} \mathrm{N}$

Climatic Data

Degree Days

Avg. Temp. $\left({ }^{\circ} \mathrm{F}\right)$

Heating 1300

Winter 58.2

Cooling 702

Avg. Insol. (Ly/d)

Winter 309

\section{SOLAR ENERGY SYSTEM}

Application Heating $\sqrt{ }$

\section{Cooling $\sqrt{ }$}

Hot Water $\sqrt{ }$

Collector

Type: To be determined

Area (sq. ft.): $\quad 10,000$ (approximately)

Manufacturer: To be determined

Storage

Type: Potable water

Capacity: 50,000 gallons (minimum)

Auxiliary System Type: Gas fired with oil standby

\section{PROJECT DESCRIPTION}

The Veterans Administration Hospital will be retrofitted with a solar heating and cooling system to augment the existing variable volume terminal reheating HVAC system. The new solar energy system will be connected to an existing computerized total energy monitoring system to optimize the use af fossil fuels and assist in other energy conservation endeavors. Various types of collectors will be incorporated into a flexible design using potable water storage tanks and a solar still to explore innovative methods of solar use at health care facilities.
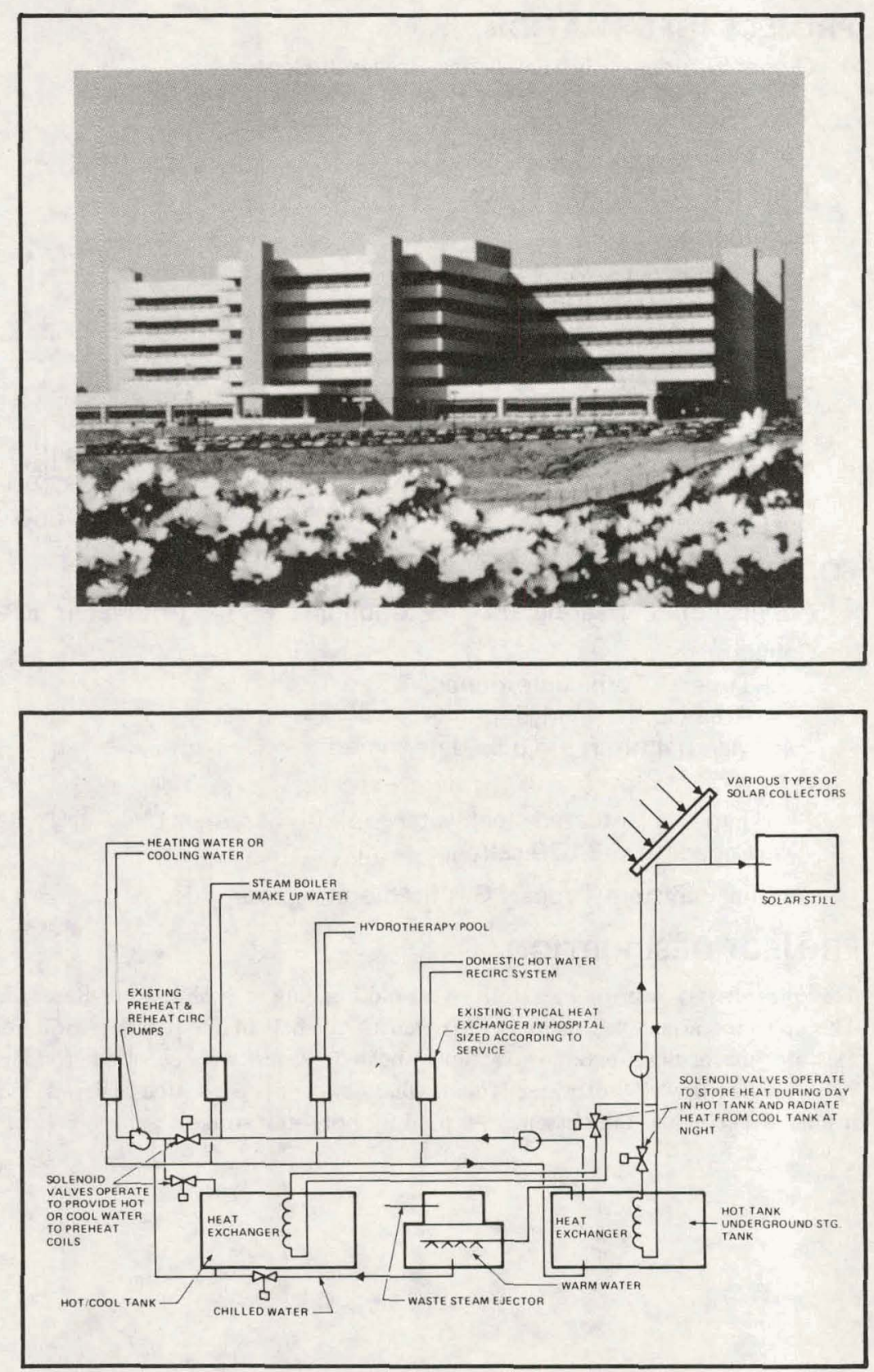


\section{PROJECT INFORMATION}

Owner/Builder: Dept. of Interior/Fish and Wildlife Service

Contractor: Frazier Construction Company

Operational Date: June 1979

Total Estimated DOE Funds: $\$ 33,000$

Building

Type: Visitors center

Area: 4,000 sq. $\mathrm{ft}$.

Location: San Francisco, California

Latitude: $37.5^{\circ} \mathrm{N}$

Climatic Data

Degree Days

Avg. Temp. $\left({ }^{\circ} \mathrm{F}\right)$

Heating 3320

Cooling

80

Avg. Insol. (Ly/d)

Winter 150

Summer 650

SOLAR ENERGY SYSTEM

Application Heating $50 \%$ Cooling $0 \%$ Hot Water $75 \%$

Collector

Type: Evacuated tubular

Area (sq. ft.): 480

Manufacturer: To be determined

Storage

Type: Insulated steel water tank (above ground)

Capacity: 1,400 gallons

Auxiliary System Type: Oil fired boiler

\section{PROJECT DESCRIPTION}

This project is a retrofit to an existing visitors center in the San Francisco National Refuge. The center has a wood frame structure and is mounted on pilings. The collector array will be roof-mounted and freeze protection will be provided by water circulation on cold nights. System back-up will be supplied by the existing oil fired boiler.

\section{Photograph not available}

Schematic not available 


\section{PROJECT INFORMATION}

Owner/Builder: U.S. Postal Service

Contractor: Honeywell, Inc.

Operational Date: August 1977

Total Estimated DOE Funds: $\quad \$ 399,000$

Building

Type: Post Office

Area: $\quad 30,000$ sq. ft. (total); 29,380 (cond.)

Location: Boulder, Colorado

Latitude: $40.0^{\circ} \mathrm{N}$

Climatic Data

$\begin{array}{lllll}\text { Degree Days } & \text { Heating } & 6276 & \text { Cooling } & 566 \\ \text { Avg. Temp. }\left({ }^{\circ} \mathrm{F}\right) & \text { Winter } & 42.5 & \text { Summer } & 69.3 \\ \text { Avg. Insol. (Ly/d) } & \text { Winter } & 383 & \text { Summer } & 624\end{array}$

Avg. Insol. (Ly/d) Winter $383 \quad$ Summer 624

\section{SOLAR ENERGY SYSTEM}

Application Heating 32\%

Collector

Type: Liquid flat-plate

Area (sq. ft.); 4,140

Manufacturer Lennox Industries, Inc.

Storage

Type: Water tank

Capacity: 6,000 gallons

Auxiliary System Type: Gas fired boiler, electric

\section{PROJECT DESCRIPTION}

A two-story U.S. Postal Service office building, constructed during the 1920's, was retrofitted with a solar energy system. This project is regarded as a prototype to demonstrate the technical and economic feasibility of retrofitting other similar facilities in the U.S. After initial testing, all systems will be operated by the Postal Service personnel normally assigned to building operation and maintenance. Emphasis was placed on making all component parts reliable and easily maintained. The contractor was required to document his methods of defining criteria for system design, his rationale for system, subsystem and component selection, and his design procedures
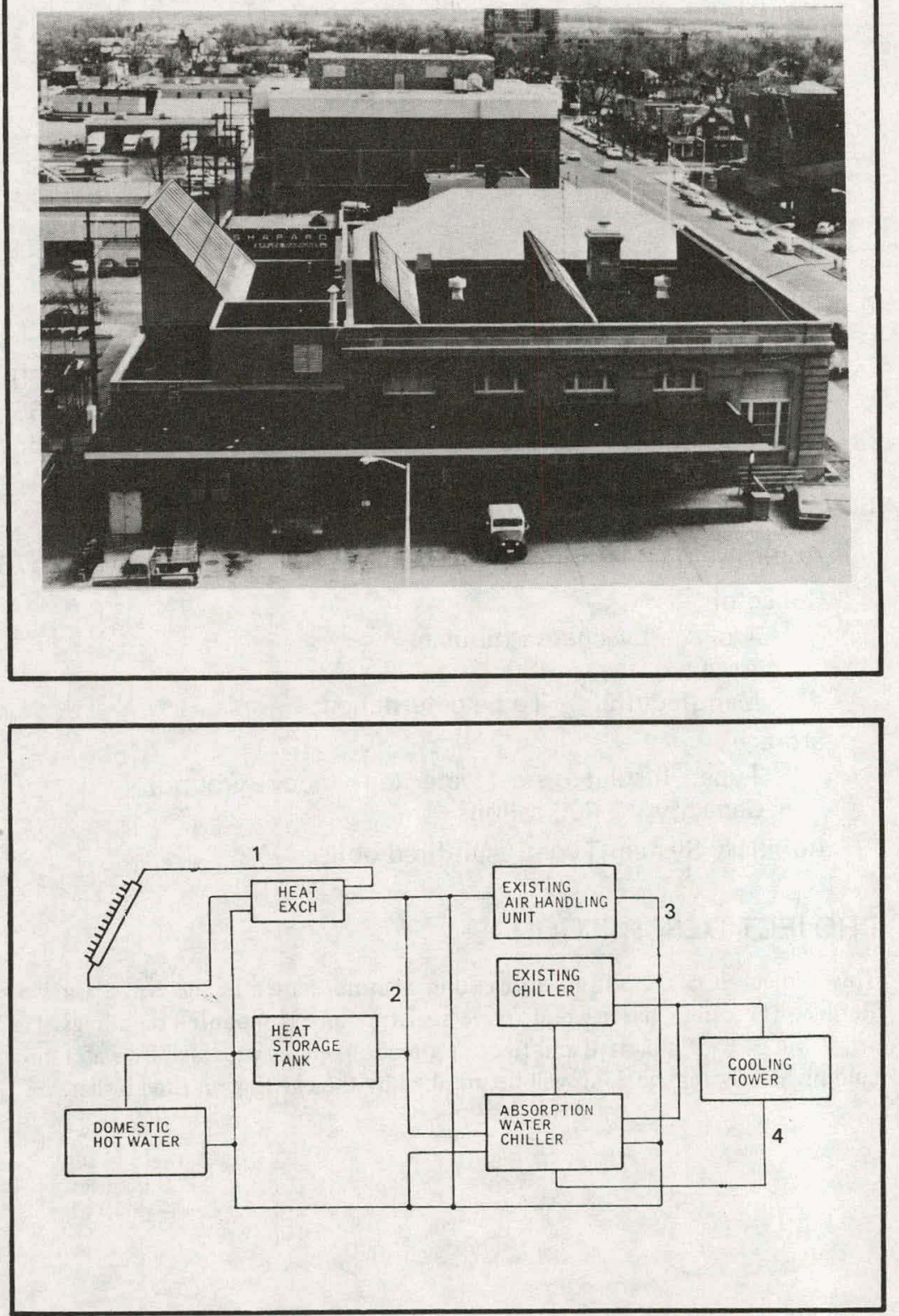


\section{PROJECT INFORMATION}

Owner/Builder: General Services Administration

Contractor: To be determined

Operational Date: December 1978

Total Estimated DOE Funds: $\$ 378,000$

Building

Type: Office

Area: 80,000 sq. ft.

Location: Denver, Colorado

Latitude: $39.5^{\circ} \mathrm{N}$

Climatic Data

Degree Days

Avg. Temp. $\left({ }^{\circ} \mathrm{F}\right)$

Avg. Insol. (Ly/d)

$\begin{array}{ll}\text { Heating } & 5505 \\ \text { Winter } & 37.6 \\ \text { Winter } & 264\end{array}$

Cooling 742

Summer 66

Summer 468

\section{SOLAR ENERGY SYSTEM}

Application Heating 65\%

Collector

Type: Liquid flat-plate

Area (sq. ft.): $\quad 10,000$

Manufacturer: To be determined

Storage

Type: Water tank

Capacity: $\quad 80,000$ gallons

Auxiliary System Type: Heat pump

\section{PROJECT DESCRIPTION}

Building 85 is a one-story concrete block building which has recently undergone major renovation to make it highly energy efficient. The solar collector and associated HVAC systems comprise a major element in the renovation of this building with the aim of conserving fossil fuels. The collectors which will interface with the building's mechanical system will provide source energy for heating and domestic hot water. The existing building system includes a solar domestic water heater. This solar heater may remain separate for the purpose of evaluating both a combined space heat/domestic water heating system and separate systems.
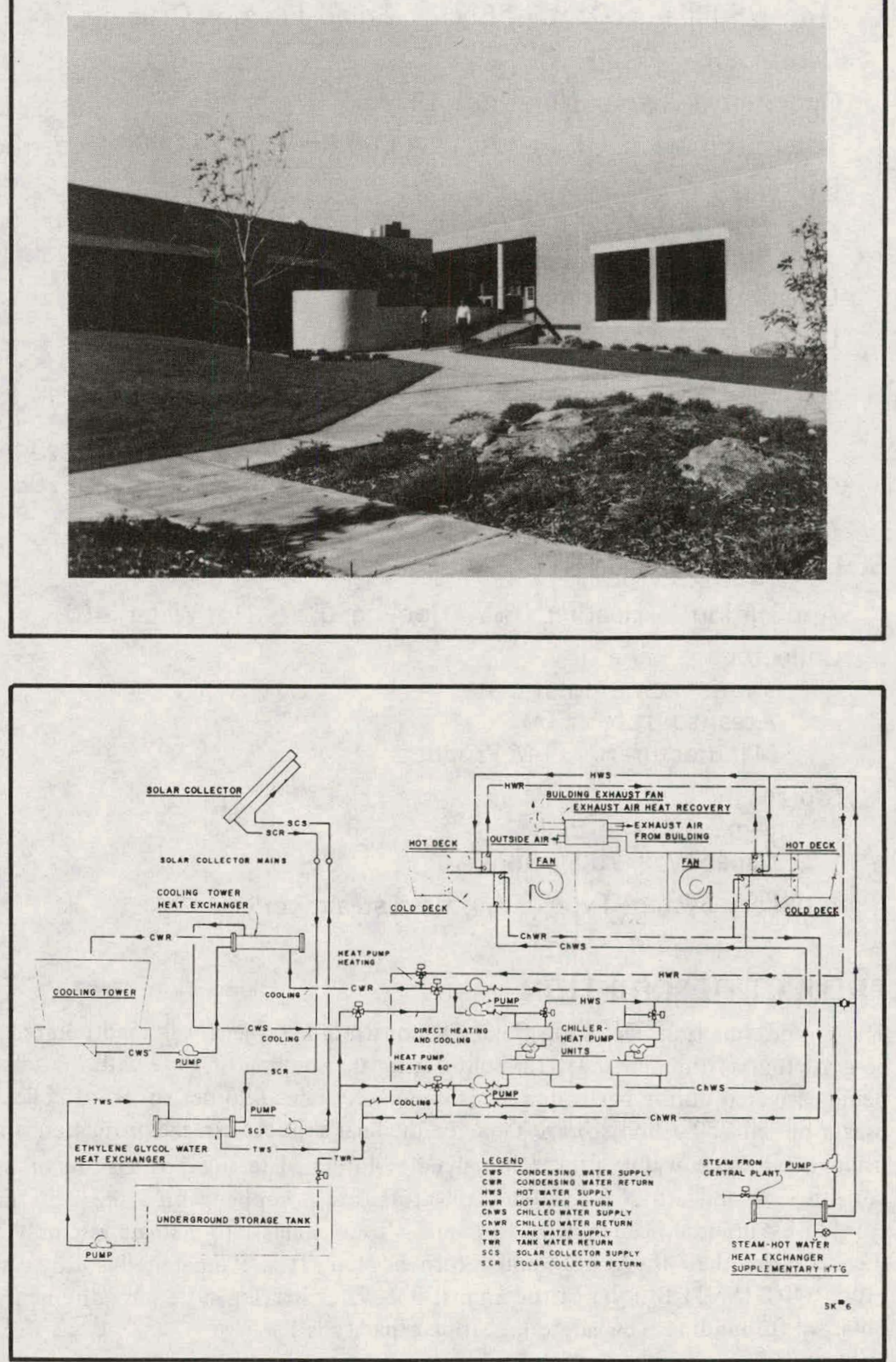


\section{PROJECT INFORMATION}

Owner/Builder: Dept. of Energy/Grand Junction Office

\section{Contractor: E.C. Huff}

\section{Operational Date: November 1977}

Total Estimated DOE Funds: $\$ 4,000$ (design); $\$ 44,000$ (construction) Building

Type: Cafeteria

Area: 3,000 sq. ft.

Location: Grand Junction, Colorado

Latitude: $39^{\circ} \mathrm{N}$

\section{Climatic Data}

$\begin{array}{llll}\text { Degree Days } & \text { Heating } & 5641 & \text { Cooling } 1545 \\ \text { Avg. Temp. }\left({ }^{\circ} \mathrm{F}\right) & \text { Winter } & 39 & \text { Summer } 73 \\ \text { Avg. Insol. (Ly/d) } & \text { Winter } & 227 & \text { Summer } 708\end{array}$

\section{SOLAR ENERGY SYSTEM}

\section{Application Heating 0\% Cooling $0 \%$ Hot Water $40 \%$}

\section{Collector}

Type: Liquid flat-plate

Area (sq. ft.): 500

Manufacturer: R-M Products

\section{Storage}

Type: Water tank

Capacity: 750 gallons

Auxiliary System Type: Gas fired steam boilers

\section{PROJECT DESCRIPTION}

The Grand Junction, Colorado Solar Demonstration project was incorporated into the construction of the new cafeteria built during the summer of 1977 with the solar system being activated during November. This system contains 496 net sq. ft. of collectors and uses a buried 750-gallon storage tank for the heat sink. Antifreeze protection is provided using a nontoxic water propylene glycol solution. The solar panels are of one piece construction and are $2^{\prime} \times 12^{\prime}$. The collector plate is copper with a single glazing and is covered by internal headers used to connect four panels into a single assembly, which is then connected to the supply and return headers. It is estimated that this system will supply $40 \%$ ( $88 \mathrm{M} \mathrm{Btu} / \mathrm{yr})$ of the annual hot water heating system requirements for this 3000 sq. $\mathrm{ft}$. building. The cafeteria seating capacity is 120 .
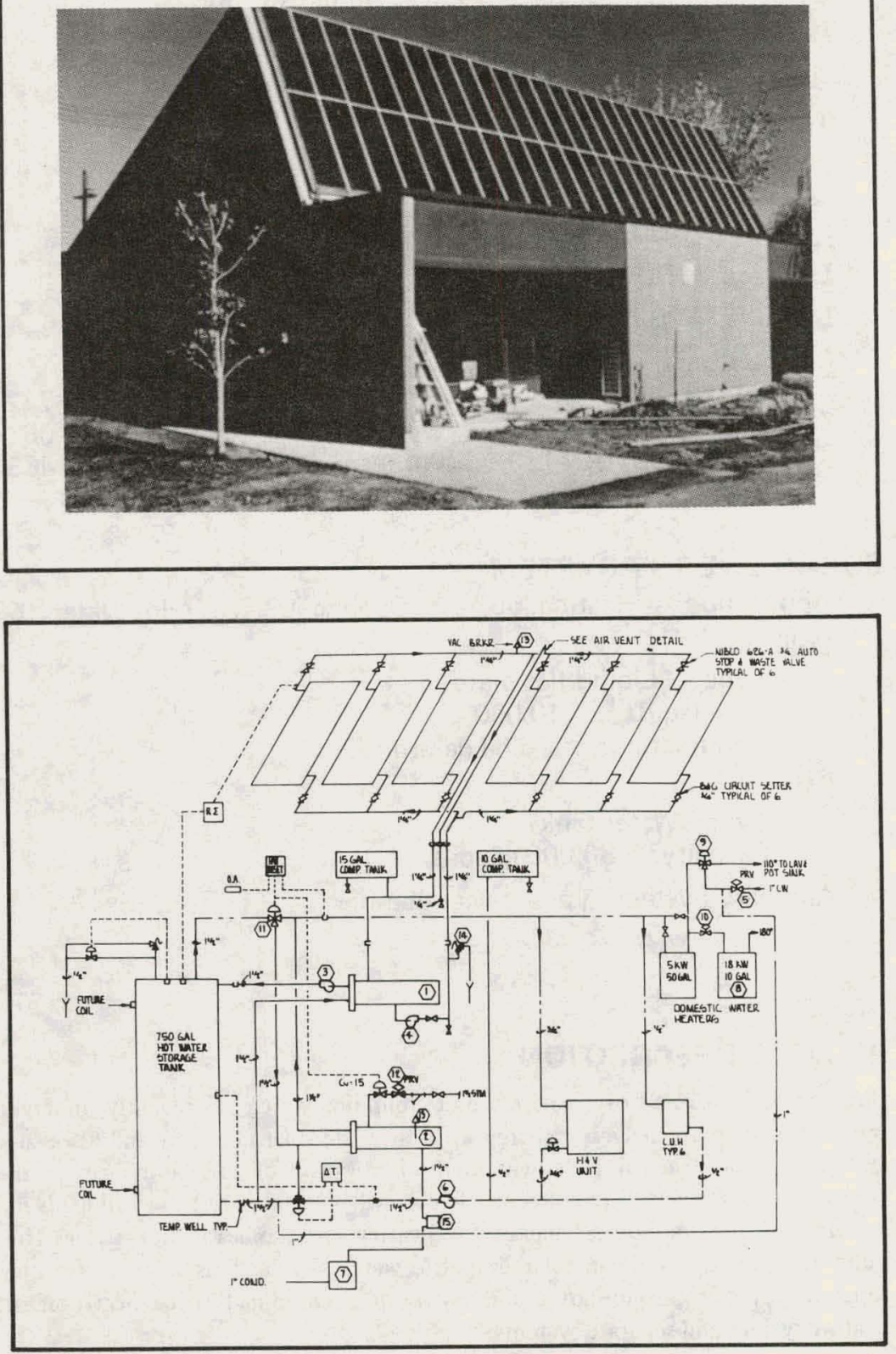


\section{PROJECT INFORMATION}

Owner/Builder: Dept. of DefenseßArmy and Air Force Exchange Service Contractor: To be determined

Operational Date: November 1978

Total Estimated DOE Funds: $\$ 500,000$

Building

Type: Exchange shopping center

Area: 73,457 sq. ft.

Location: Bolling Air Force Base, Washington, D.C.

Latitude: $38.5^{\circ} \mathrm{N}$

Climatic Data

$\begin{array}{lllll}\text { Degree Days } & \text { Heating } & 4224 & \text { Cooling } & 1659 \\ \text { Avg. Temp. }\left({ }^{\circ} \mathrm{F}\right) & \text { Winter } & 46 & \text { Summer } & 67 \\ \text { Avg. Insol. (Ly/d) } & \text { Winter } & 243 & \text { Summer } & 406\end{array}$

\section{SOLAR ENERGY SYSTEM}

Application Heating $88.7 \%$ Cooling $64.2 \%$ Hot Water $93 \%$

Collector

Type: Liquid glass tubular

Area (sq. ft.): 18,000

Manufacturer: KTA Corporation

Storage

Type: Water tank

Capacity: 150,000 gallons

Auxiliary System Type: Electric/high temperature hot water

\section{PROJECT DESCRIPTION}

This project involves the design and installation of a solar energy heating and cooling system for an Army exchange. The solar system will interface with the mechanical heating and cooling system planned for the facility. The mechanical system will be capable of meeting all of the facility's heating requirements. Data compiled in the project will be useful to those designing heating and cooling systems for private retail business. These projects utilize a concentrating collector and an off-peak mode operation. 


\section{PROJECT INFORMATION}

Owner/Builder: NASA Kennedy Space Center

Contractor: To be determined

Operational Date: May 1978

Total Estimated DOE Funds: $\quad \$ 88,360$

Building

Type: Cafeteria

Area: 8,000 sq. $\mathrm{ft}$.

Location: Cape Canaveral, Florida

Latitude: $28.3^{\circ} \mathrm{N}$

Climatic Data

$\begin{array}{lllll}\text { Degree Days } & \text { Heating } & 733 & \text { Cooling } & 3226 \\ \text { Avg. Temp. }\left({ }^{\circ} \mathrm{F}\right) & \text { Winter } & 61.1 & \text { Summer } & 81.1 \\ \text { Avg. Insol. (Ly/d) } & \text { Winter } & 349 & \text { Summer } & 532\end{array}$

\section{SOLAR ENERGY SYSTEM}

Application Heating $0 \%$ Cooling $0 \%$ Hot Water $80 \%$

Collector

Type: To be determined

Area (sq. ft.): 1,000

Manufacturer: To be determined

Storage

Type: Water tank

Capacity 1,500 gallons

Auxiliary System Type: Oil fired boiler

\section{PROJECT DESCRIPTION}

The solar system will be used to heat hot water for an office building cafeteria. The contractor will be selected in early 1978 . Collectors will be roof-mounted.
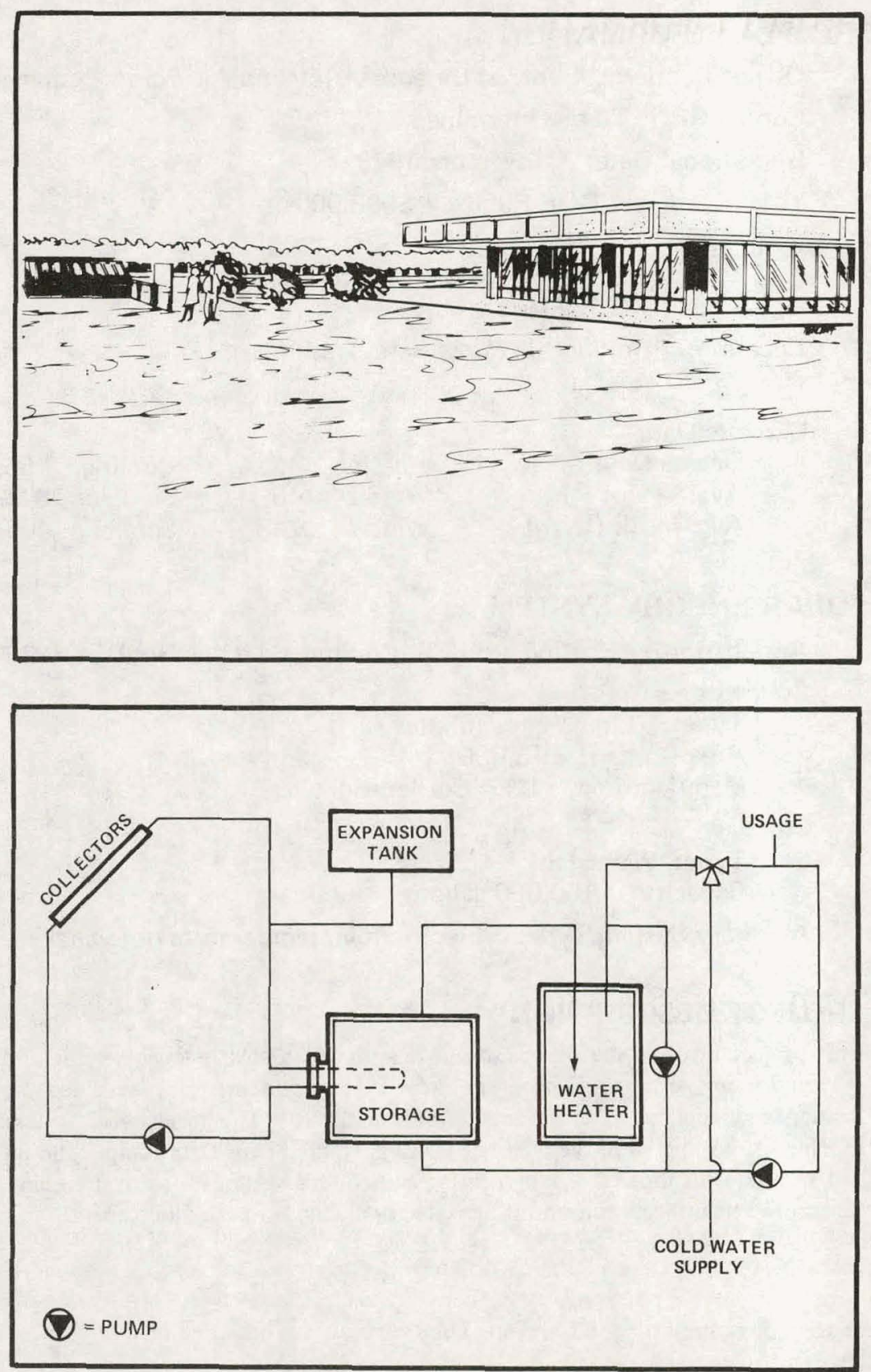


\section{PROJECT INFORMATION}

Owner/Builder: Dept. of Energy/Argonne National Laboratory

Contractor: Power Systems, Inc.

Operational Date: May 1978

Total Estimated DOE Funds: $\quad \$ 27,000$ (design); $\$ 101,000$ (construction) Building

Type: Cafeteria

Area: $\quad 34,000$ sq. ft.

Location: Argonne, Illinois

Latitude: $42^{\circ} \mathrm{N}$

Climatic Data

Degree Days
Avg. Temp. (
Avg. Insol. (Ly/d)

Heating 6600

Winter 36

\section{Cooling 1020 \\ Summer 71}

Summer 570

\section{SOLAR ENERGY SYSTEM}

Application Heating $0 \%$

Collector

Cooling $0 \% \quad$ Hot Water $64 \%$

Type: Liquid flat-plate

Area (sq. ft.): 1,500

Manufacturer: Chamberlain Manufacturing Corporation

Storage

Type: Insulated steel water tank (above ground)

Capacity: 2,000 gallons

Auxiliary System Type: Gas/oil fired steam boilers

\section{PROJECT DESCRIPTION}

The system is designed to provide preheating of the central cafeteria domestic hot water. The current daily usage of hot water in the cafeteria is 4000 gallons of $140^{\circ} \mathrm{F}$ water. When a demand for hot water occurs, water will be drawn from the storage tanks and pass through the conventional hot water heaters, which will maintain a $140^{\circ} \mathrm{F}$ discharge temperature to the cafeteria system. Heat will be transferred from the collectors whenever the collector temperature is $20^{\circ} \mathrm{F}$ higher than storage or during a demand period for hot water if the collector temperature is $20^{\circ} \mathrm{F}$ higher than the cold water entering the system. A double heat exchanger system with an intermediate water loop has been incorporated to provide double-wall protection between the collector glycol-water loop and the cafeteria domestic hot water system. The collectors are mounted on a steel and concrete support structure at grade level.
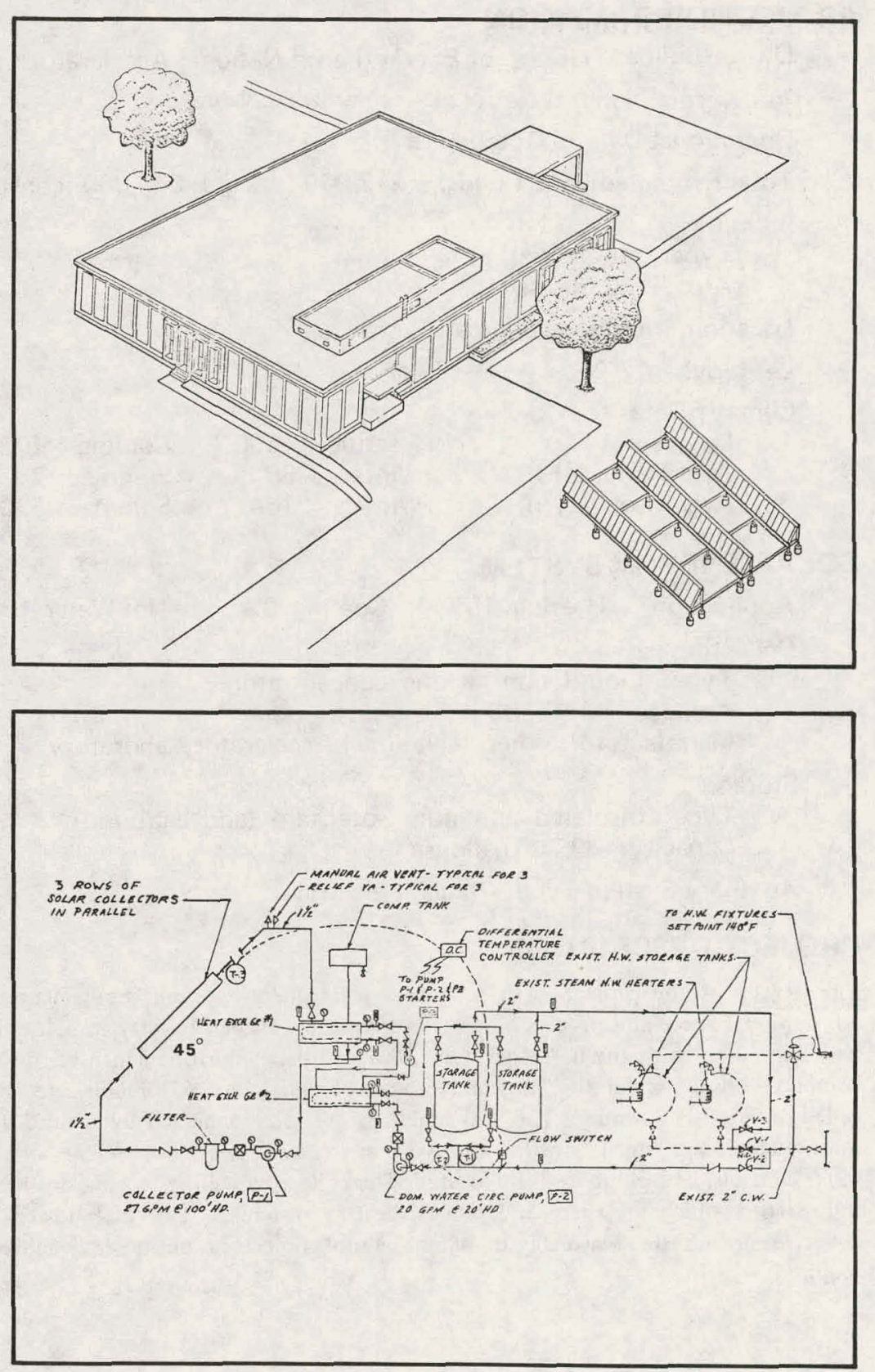


\section{PROJECT INFORMATION}

Owner/Builder: Dept. of Energy/Fermi National Accelerator Laboratory

Contractor: Fermi National Accelerator Laboratory

Operational Date: October 1978

Total Estimated DOE Funds: $\quad \$ 12,000$ (design); $\$ 48,000$ (construction)

Building

Type: Industrial

Area: 32,000 sq. ft.

Location: Batavia, Illinois

Latitude: $42^{\circ} \mathrm{N}$

Climatic Data

$\begin{array}{lllll}\text { Degree Days } & \text { Heating } & 6600 & \text { Cooling } & 1020 \\ \text { Avg. Temp. }\left({ }^{\circ} \mathrm{F}\right) & \text { Winter } & 36 & \text { Summer } & 71 \\ \text { Avg. Insol. (Ly/d) } & \text { Winter } & 164 & \text { Summer } & 570\end{array}$

\section{SOLAR ENERGY SYSTEM}

Application Heating $15 \%$ Cooling $0 \%$ Hot Water $0 \%$

\section{Collector}

Type: Liquid nontracking concentrator

Area (sq.ft.): $\quad 583$

Manufacturer: Fermi National Accelerator Laboratory

Storage

Type: Insulated aluminum water tank (above ground)

Capacity: 2,700 gallons

Auxiliary System Type: Radiant electric

\section{PROJECT DESCRIPTION}

The object of the project is to provide a solar energy system supplemental to the conventional space and process heatings at Fermilab's Magnet Facility complex. This will be achieved through the use of a unique, inverted panel mirror-augmented design. The complex considered for this project is a unit of two industrial prefabricated buildings called Industrials 1 and 2. The two buildings are interconnected by a third area, the midway building, which is office and work space. This is also where the solar storage tank, controls, and pumps will be located. The collectors will be located on the roof of Industrial 1 which the space and process heating systems will be in Industrial 2. The collectors are adjusted seasonally to match the sun's trajectory, but no daily adjustment is required.
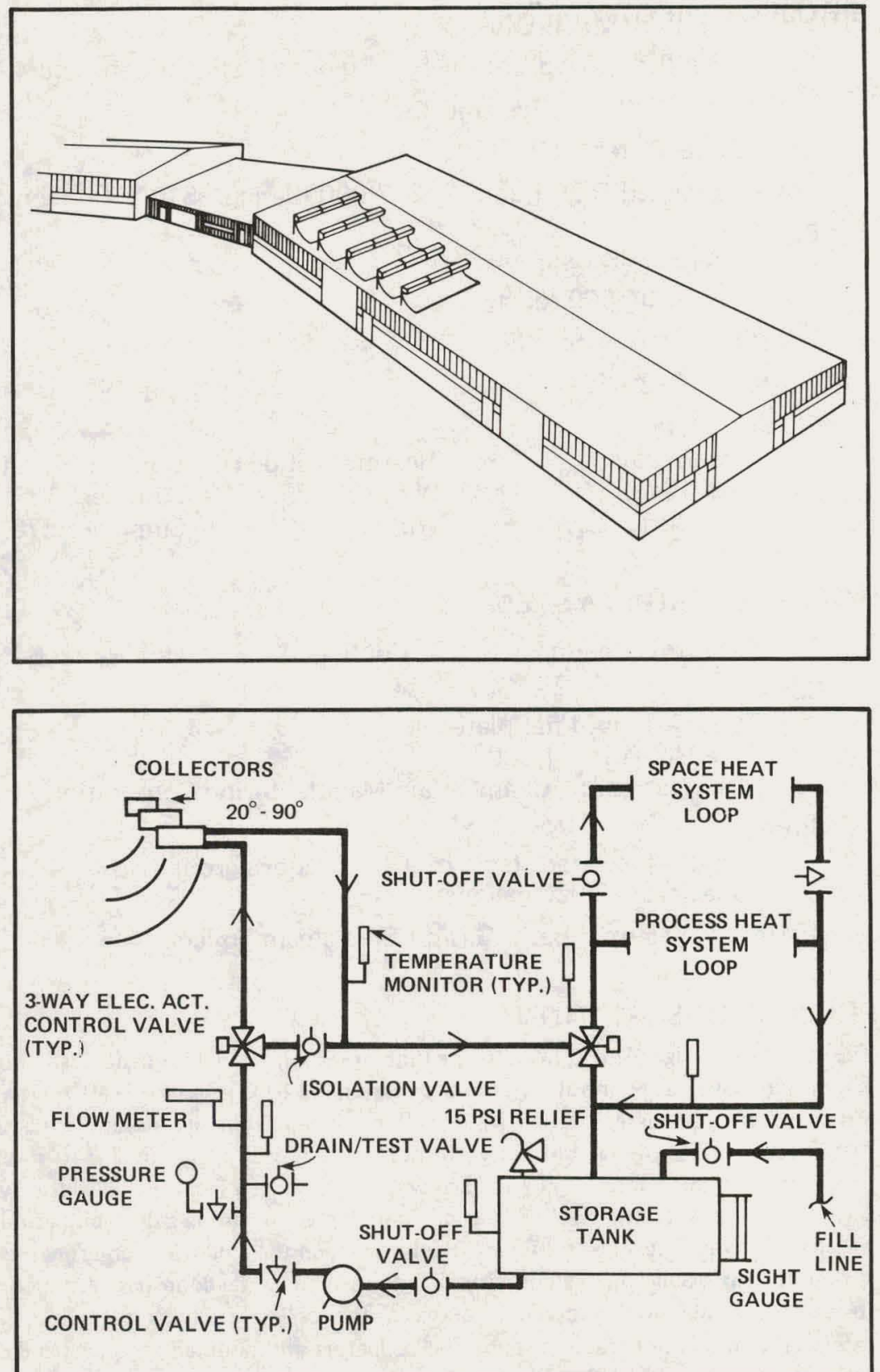


\section{PROJECT INFORMATION}

Owner/Builder: Tennessee Valley Authority

Contractor: Tennessee Valley Authority

Operational Date: May 1979

Total Estimated DOE Funds: $\quad \$ 170,000$

Building

Type: Visitors center

Area: $\quad 6,600$ sq. ft.

Location: Land Between The Lakes, Kentucky

Latitude: $37^{\circ} \mathrm{N}$

Climatic Data

Degree Days

Avg. Temp. $\left({ }^{\circ} \mathrm{F}\right)$

Avg. Insol. (Ly/d)

$\begin{array}{llll}\text { Heating } & 3578 & \text { Cooling } & 549 \\ \text { Winter } & 48.9 & \text { Summer } & 75.4 \\ \text { Winter } & 257 & \text { Summer } & 492\end{array}$

\section{SOLAR ENERGY SYSTEM}

Application Heating 87\%

Collector

Type: Liquid flat-plate

Area (sq. ft.): 2,000

Manufacturer: To be determined

Storage

Type: Insulated steel water tank (below ground)

Capacity: 6,000 gallons

Auxiliary System Type: Electric

\section{PROJECT DESCRIPTION}

The heating and air conditioning system for use in this facility will be a solar assisted heat pump system with provision for direct solar heating and cooling. This system will incorporate a solar assisted heat system for space heating and domestic hot water heating with a solar cooling system utilizing an absorption refrigeration unit. The major items of equipment will include the electric driven reciprocating chiller arranged for operation as a heat pump, the absorption chiller, the solar collectors, and storage tank. Auxiliary equipment will include pumps, heat exchangers, and an electric supplemental heating boiler. Plans for the system should be completed by February 1978; construction will begin in the spring of 1978, and the center will open in 1979. Because it will be installed in a visitor's center, the system will acquaint an estimated one million people each year with the benefits of solar systems.
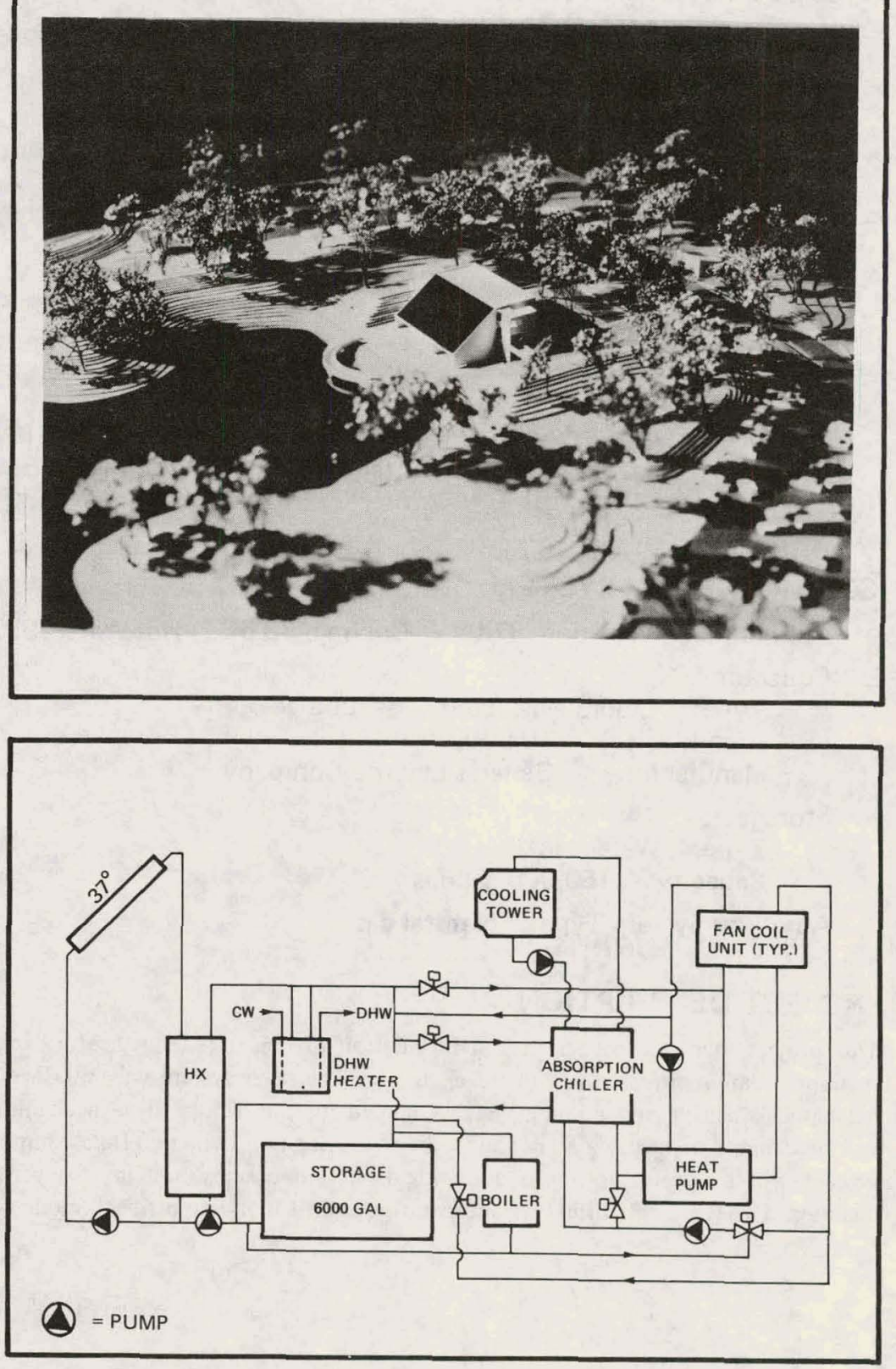


\section{PROJECT INFORMATION}

Owner/Builder: Dept. of Defense/Army and Air Force Exchange Service

Contractor: To be determined

Operational Date: October 1978

Total Estimated DOE Funds: $\$ 500,000$

Building

Type: Exchange shopping center

Area: 71,800 sq. $\mathrm{ft}$.

Location: Fort Polk, Louisiana

Latitude: $31^{\circ} \mathrm{N}$

Climatic Data

$\begin{array}{lllll}\text { Degree Days } & \text { Heating } & 1575 & \text { Cooling } & 3100 \\ \text { Avg. Temp. }\left({ }^{\circ} \mathrm{F}\right) & \text { Winter } & 54 & \text { Summer } & 75 \\ \text { Avg. Insol. (Ly/d) } & \text { Winter } & 311 & \text { Summer } & 480\end{array}$

\section{SOLAR ENERGY SYSTEM}

Application Heating $\mathbf{8 7 . 0 \%}$ Cooling $58.6 \%$ Hot Water $99 \%$

Collector

Type: Liquid evacuated glass tubular

Area (sq. ft. ): 10,000

Manufacturer: General Electric Company

\section{Storage}

Type: Water tank

Capacity: 150,000 gallons

Auxiliary System Type: Natural gas

\section{PROJECT DESCRIPTION}

This project involves the design and installation of a solar energy heating and cooling system for an Army and Air Force exchange. The solar system will interface with the mechanical heating and cooling system planned for the facility. The mechanical system will be capable of meeting all of the facility's heating requirements. Data compiled in the project will be useful to those designing heat and cooling systems for private retail business. These projects utilize a concentrating collector and an off-peak mode operation. 


\section{PROJECT INFORMATION}

Owner/Builder: Dept . of the Treasury/U.S. Customs Service

Contractor: Solar Assistance Inc .

Operational Date: February 1979

Total Estimated DOE Funds: $\quad \$ 40,572$

Building

Type: U.S. Border Inspection Station

Area: 1,400 sq. ft.

Location: Hamlin, Maine

Latitude: $47.0^{\circ} \mathrm{N}$

Climatic Data

Avg. Temp. $\left({ }^{\circ} \mathrm{F}\right)$

Avg. Insol. (Ly/d)

$\begin{array}{llll}\text { Heating } & 11,521 & \text { Cooling } & 0 \\ \text { Winter } & 13 & \text { Summer } & 62 \\ \text { Winter } & 157 & \text { Summer } & 476\end{array}$

\section{SOLAR ENERGY SYSTEM}

Application Heating $70 \%$

Collector

Type: Liquid flat-plate

Area (sq.ft.): 1,127

Manufacturer: Daystar Corporation

Storage

Type: Water/ethylene glycol

Capacity: 1,500 gallons

Auxiliary System Type: Forced air oil furnace

\section{PROJECT DESCRIPTION}

This project is a retrofit to an existing Border Inspection Station. The station is a onestory, brick veneered wood frame structure. The collector array will be located across the highway from the station. Solar heated water will be conducted underground in insulated piping to storage tanks located inside the building. Heat exchangers will transfer heat from the insulated storage tanks to the existing forced warm air duct system. Controls will automatically select the conventional heating system when the solar heating is insufficient.
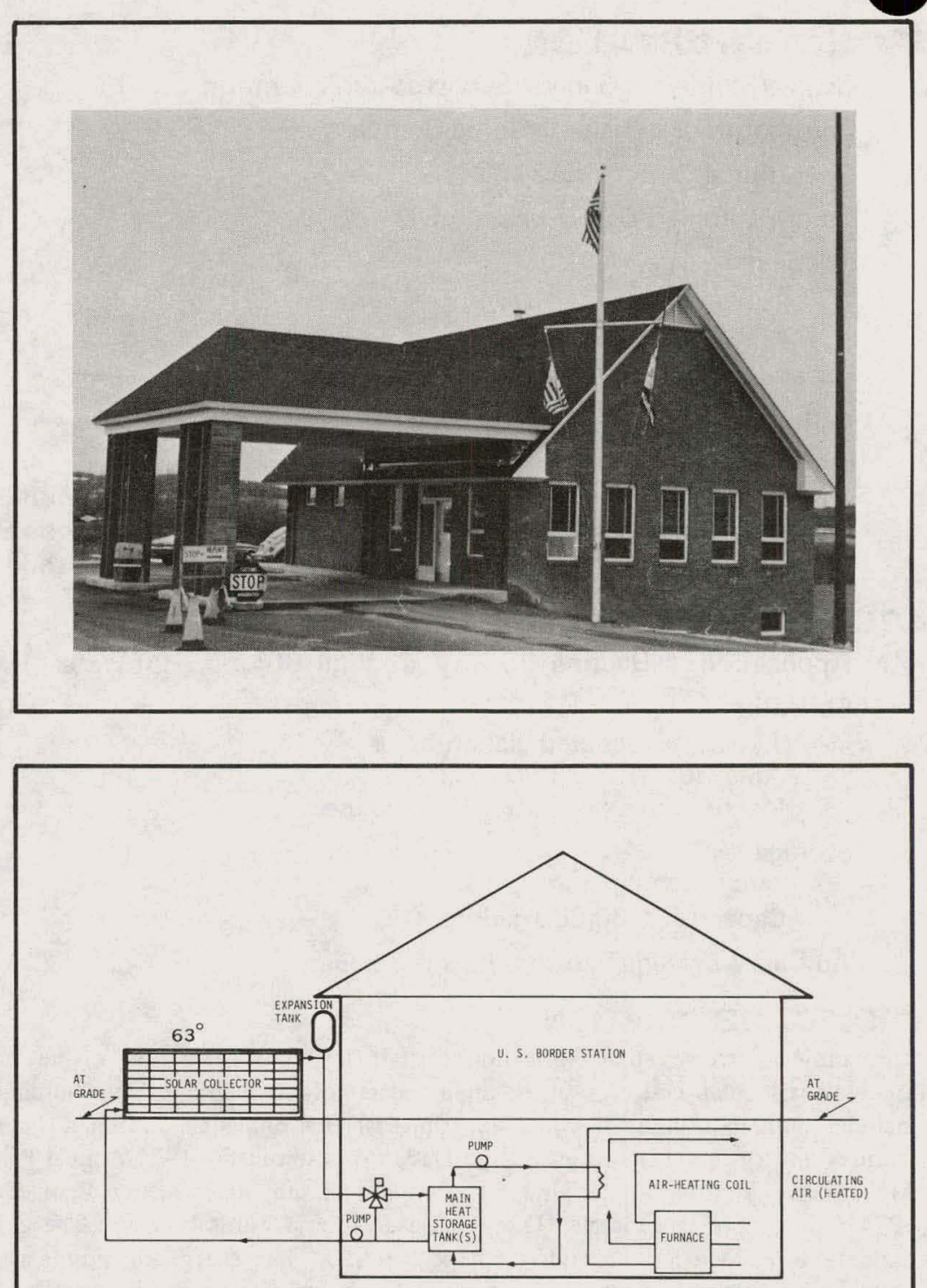

SCALE: NONE 


\section{PROJECT INFORMATION}

Owner/Builder: General Services Administration

Contractor: Gilbane Building Company

Operational Date: July 1977

Total Estimated DOE Funds: $\$ 471,000$

Building

Type: Office

Area: $\quad 59,500$ sq. ft.

Location: Saginaw, Michigan

Latitude: $43.4^{\circ} \mathrm{N}$

Climatic Data

Degree Days

Avg. Temp. $\left({ }^{\circ} \mathrm{F}\right)$

Heating 7420

Cooling 383

Avg. Insol. (Ly/d)

38.5

292

Summer 66.9

\section{SOLAR ENERGY SYSTEM}

Application Heating 60\%

Cooling $60 \%$

Hot Water $100 \%$

Collector

Type: Evacuated glass tubular

Area (sq. ft): 8,000

Manufacturer: Owens-IIlinois, Inc. Storage

Type: Water tank

Capacity: 30,000 gallons

Auxiliary System Type: Gas fired boiler

\section{PROJECT DESCRIPTION}

This project involves the fabrication, installation and evaluation of an advanced experimental solar collector array on a federal office building. The building design includes numerous innovative and experimental environmental and energy conserving features and systems. It was awarded a Design Citation in the 1974 Annual Progressive Architecture Awards Program and was a winner of the Governmental Category in the 1974 Owens-Corning Fiberglas Energy Conservation Awards Program. The completed building is expected to operate with $40 \%$ to $50 \%$ less energy than typical modern buildings of comparable size and subjected to similar climatic conditions. The building and the solar energy system will serve as a study model for facilities of its type, size, and location. Monitoring and evaluation of solar energy system performance is being carried out by the University of Michigan over a twelve-month period following initial building occupancy.
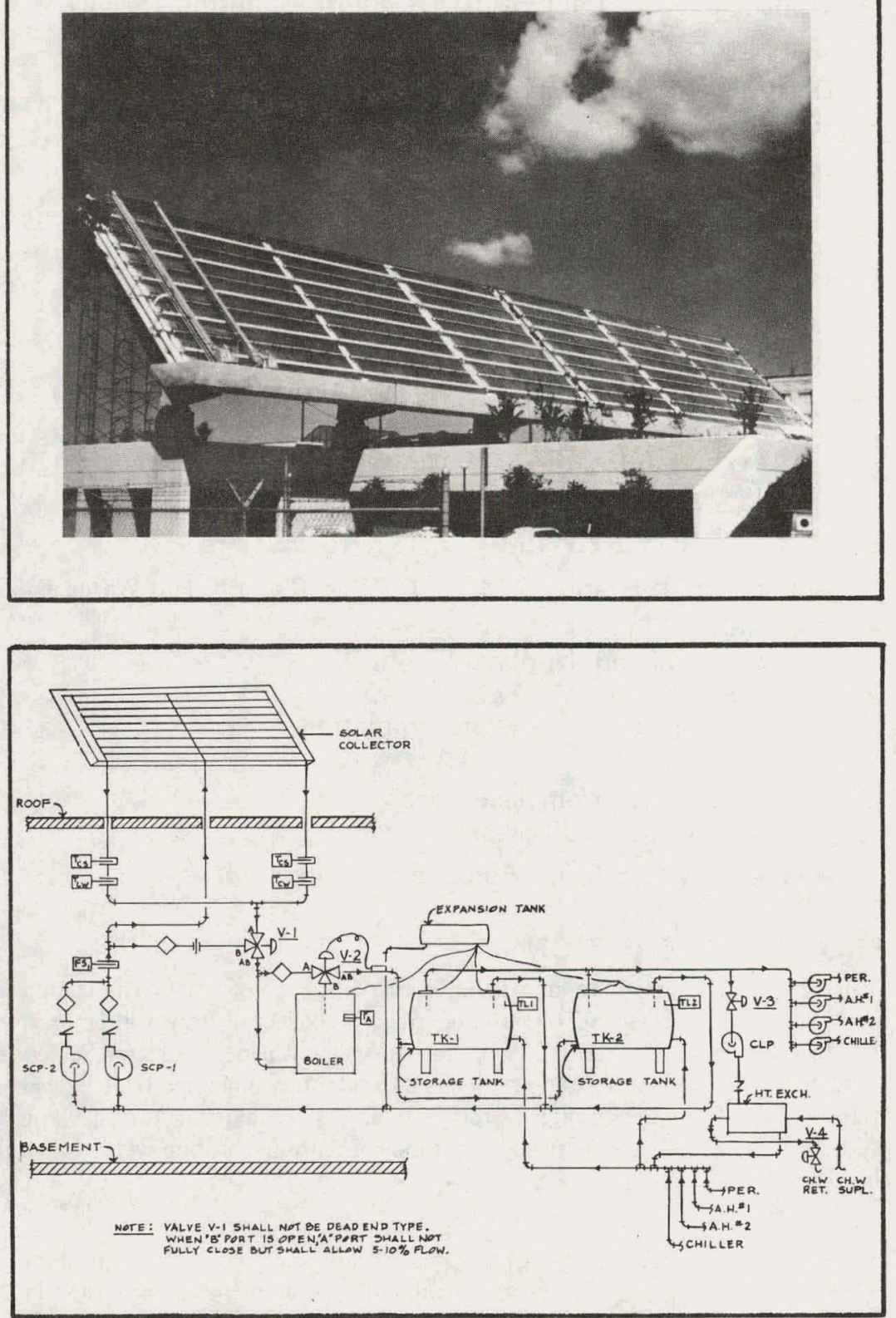


\section{PROJECT INFORMATION}

Owner/Builder: Dept. of Energy/Nevada Test Site

Contractor: To be determined

Operational Date: March 1978

Total Estimated DOE Funds: $\quad \$ 7,000$ (design); $\$ 26,000$ (construction) Building

Type: Fire station

Area: 10,000 sq. ft.

Location: Mercury, Nevada

Latitude: $36^{\circ} \mathrm{N}$

Climatic Data Degree Days

Avg. Temp. $\left({ }^{\circ} \mathrm{F}\right)$

Avg. Insol (Ly/d)

$\begin{array}{lll}\text { Heating } & 4600 & \text { Cooling } 2298 \\ \text { Winter } & 46 & \text { Summer } 72 \\ \text { Winter } & 277 & \text { Summer } 748\end{array}$

\section{SOLAR ENERGY SYSTEM}

Application Heating $0 \%$

Collector

Type: Liquid flat-plate

Area (sq. ft.): 200

Manufacturer: To be determined

\section{Storage}

Type: Water tank

Capacity: 328 gallons

Auxiliary System Type: Electric

\section{PROJECT DESCRIPTION}

The basic building service hot water system consists of a central electric water heater circulation loop, and circulation pump. The hot water system includes 200 sq. ft. of flat-plate solar collector panels; four, 82-gallon storage tanks with heat exchangers and circulating pumps; and associated piping and controls. The solar system liquid will be an antifreeze solution. The solar system will preheat the makeup water supplied to the basic building hot water system. The control system consists of one collector control sensor, one solar storage tank control sensor, and one differential thermostat controller for each storage tank/collector system. The two sensors provide signal inputs to the collector When the collector temperature is sufficiently above the tank temperature the controller will activate the circulating pump. The pump will continue to run until the temperature difference is reduced. The temperature controller shall have a three position selector switch, auto, off and on, for manual overrides of the system operation as described.
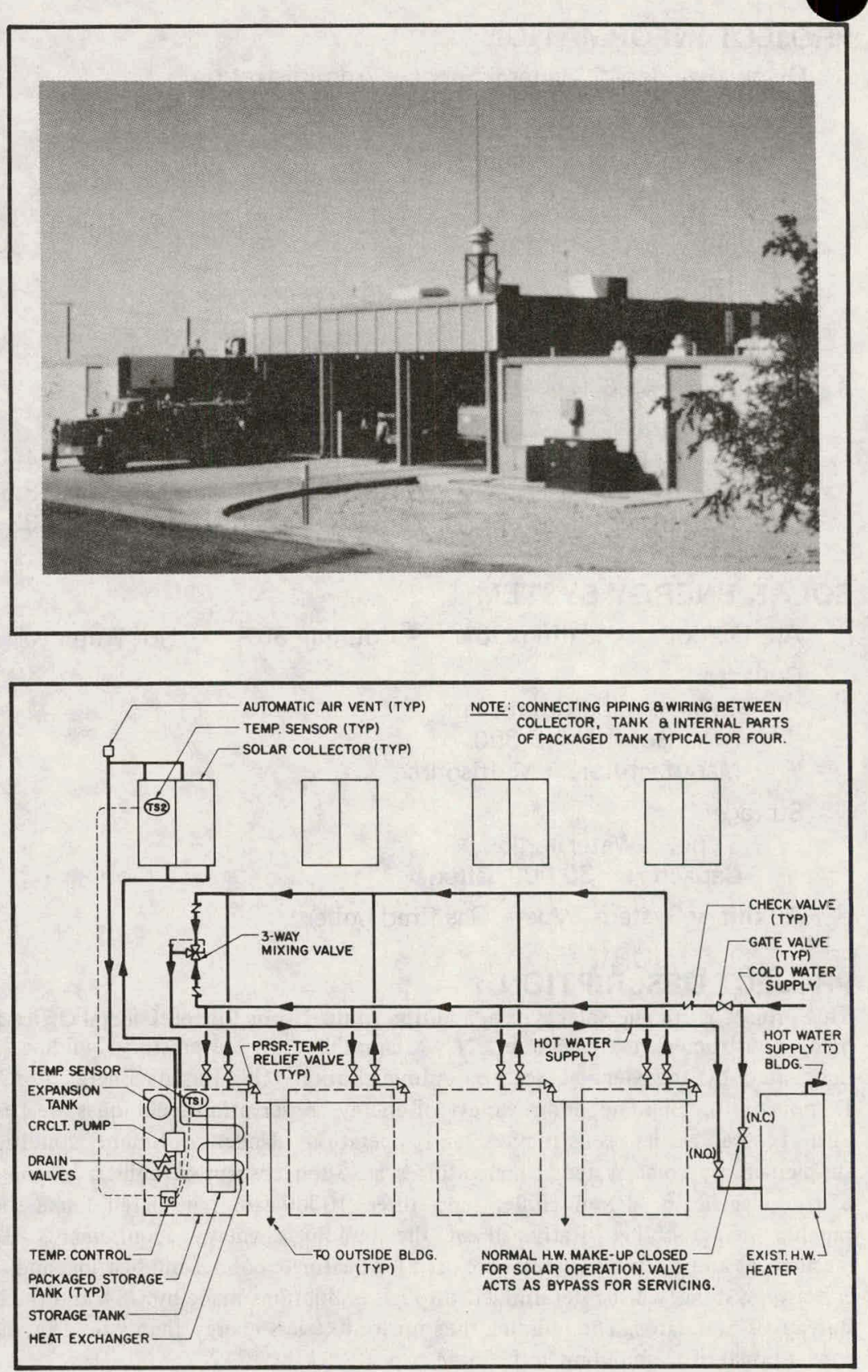


\section{PROJECT INFORMATION}

Owner/Builder:" General Services Administration

Contractor: Davidson Construction Co., Inc.

Operational Date: January 1977

Total Estimated DOE Funds: $\$ \$ 567,000$

Building

Type: Office

Area: 131,000 sq. ft. (total); 30,000 sq. ft. (cond.)

Location: Manchester, New Hampshire

Latitude: $43.0^{\circ} \mathrm{N}$

Climatic Data

$\begin{array}{lllll}\text { Degree Days } & \text { Heating } & 7360 & \text { Cooling } & 349 \\ \text { Avg. Temp. }\left({ }^{\circ} \mathrm{F}\right) & \text { Winter } & 38.5 & \text { Summer } & 68.5 \\ \text { Avg. Insol. (Ly/d) } & \text { Winter } & 266 & \text { Summer } & 488\end{array}$

Avg. Insol. (Ly/d) Winter 266 Summer 488

\section{SOLAR ENERGY SYSTEM}

Application Heating 30\%

Collector

Type: Liquid flat-plate

Area (sq. ft.): 3,800

Manufacturer: Multisource

Storage

Type: Water tank

Capacity: $\quad 30,000$ gallons

Auxiliary System Type: Gas fired boiler

\section{PROJECT DESCRIPTION}

This project is for the solar system addition to the Norris Cotton Federal Office Building being constructed in Manchester, New Hampshire. The seven-story building has been designated by the General Services Administration (GSA) as its Energy Conservation Demonstration Building, and a variety of energy conservation techniques are being used and tested in its construction and operation. Under optimum conditions the supplementary solar system which utilizes a 25 -ton absorption chiller, a conventional 65-ton electrically driven chiller, and three 10000-gallon insulated tanks should be capable of supplying nearly all of the building's energy requirements. Different mechanical and electrical systems are used for heating, cooling, and lighting; and the most effective systems will be determined through evaluations made by GSA and the National Bureau of Standards. The building uses up to $40 \%$ less energy than would be used by a conventional office building in the same area.
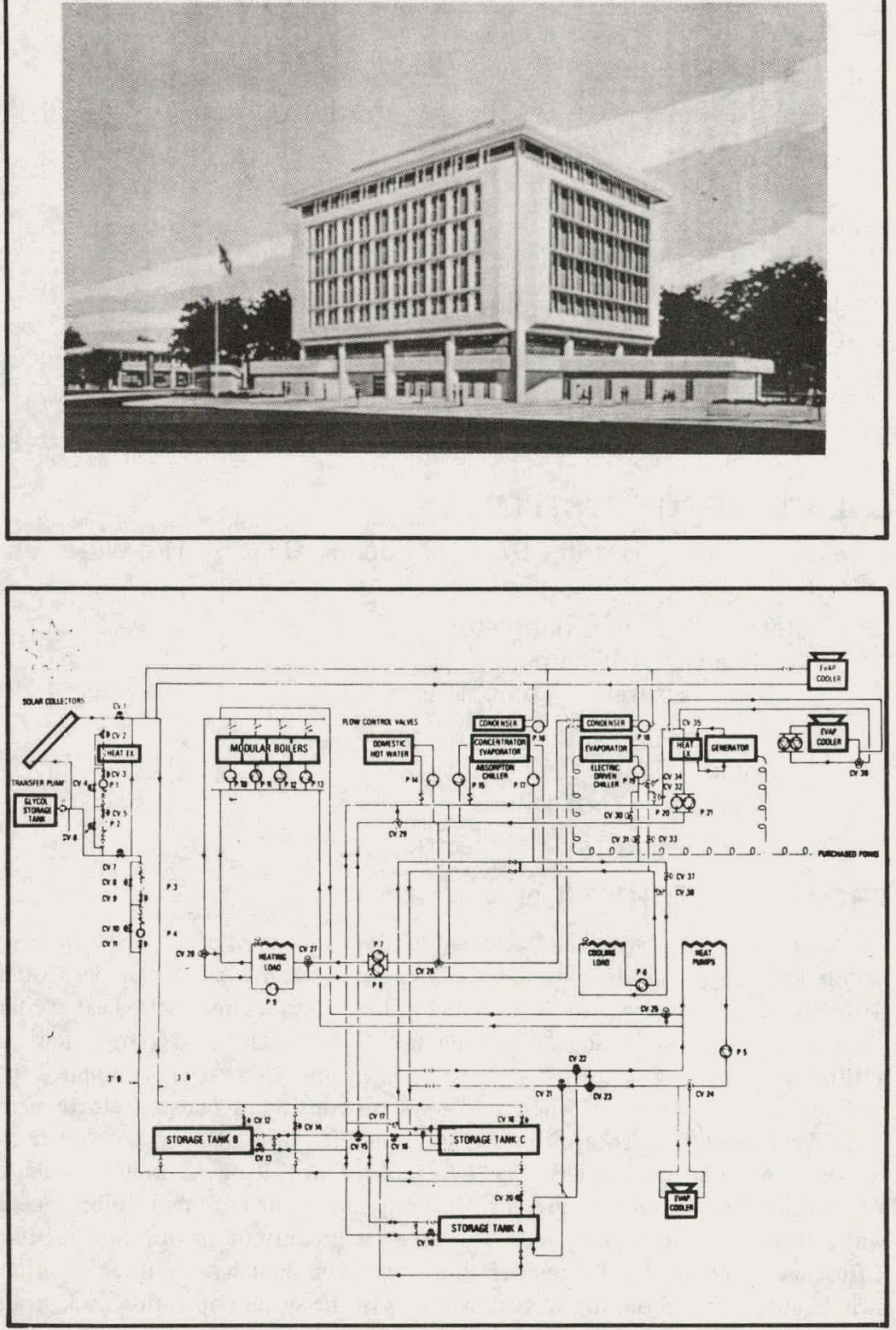


\section{PROJECT INFORMATION}

Owner/Builder: Dept. of Interior/Bureau of Indian Affairs

Contractor: Bureau of Indian Affairs, Branch of Facility Management Operational Date: February 1978

Total Estimated DOE Funds: $\$ 68,000$

Building

Type: School

Area: 8,852 sq. ft.

Location: Bread Springs, New Mexico

Latitude: $35^{\circ} \mathrm{N}$

Climatic Data

$\begin{array}{lllll}\text { Degree Days } & \text { Heating } & 6900 & \text { Cooling } & \text { N/A } \\ \text { Avg. Temp. }\left({ }^{\circ} \mathrm{F}\right) & \text { Winter } & 39 & \text { Summer } & 70 \\ \text { Avg. Insol. (Ly/d) } & \text { Winter } & 397 & \text { Summer } 681\end{array}$

\section{SOLAR ENERGY SYSTEM}

Application Heating $80 \%$

Cooling $0 \%$

Hot Water $20 \%$

Collector

Type: Concentrating/liquid flat-plate

Area (sq. ft.): $1,000 / 1,000$

Manufacturer: Gould, Inc./Sunworks, Inc.

Storage

Type: Water tank

Capacity: 38,000 gallons

Auxiliary System Type: Oil fired boiler

\section{PROJECT DESCRIPTION}

This project is a rural three-room Navajo school designed and constructed by Branch of Facility Management personnel. Two types of roof-mounted, drain-down collectors are used. The concentrating collectors are connected to an 1800-gallon pressurized storage tank. A three-way valve allows solar heated water to be circulated through existing baseboard heating elements. Solar heated hot water is also used to preheat domestic hot water before it is heated in the oil fired boiler. The flat-plate collectors provide an independent system to pump water into a shallow plastic, 20000-gallon tank. This tank is located under the floor of the north-facing classroom and provides radiative heat.
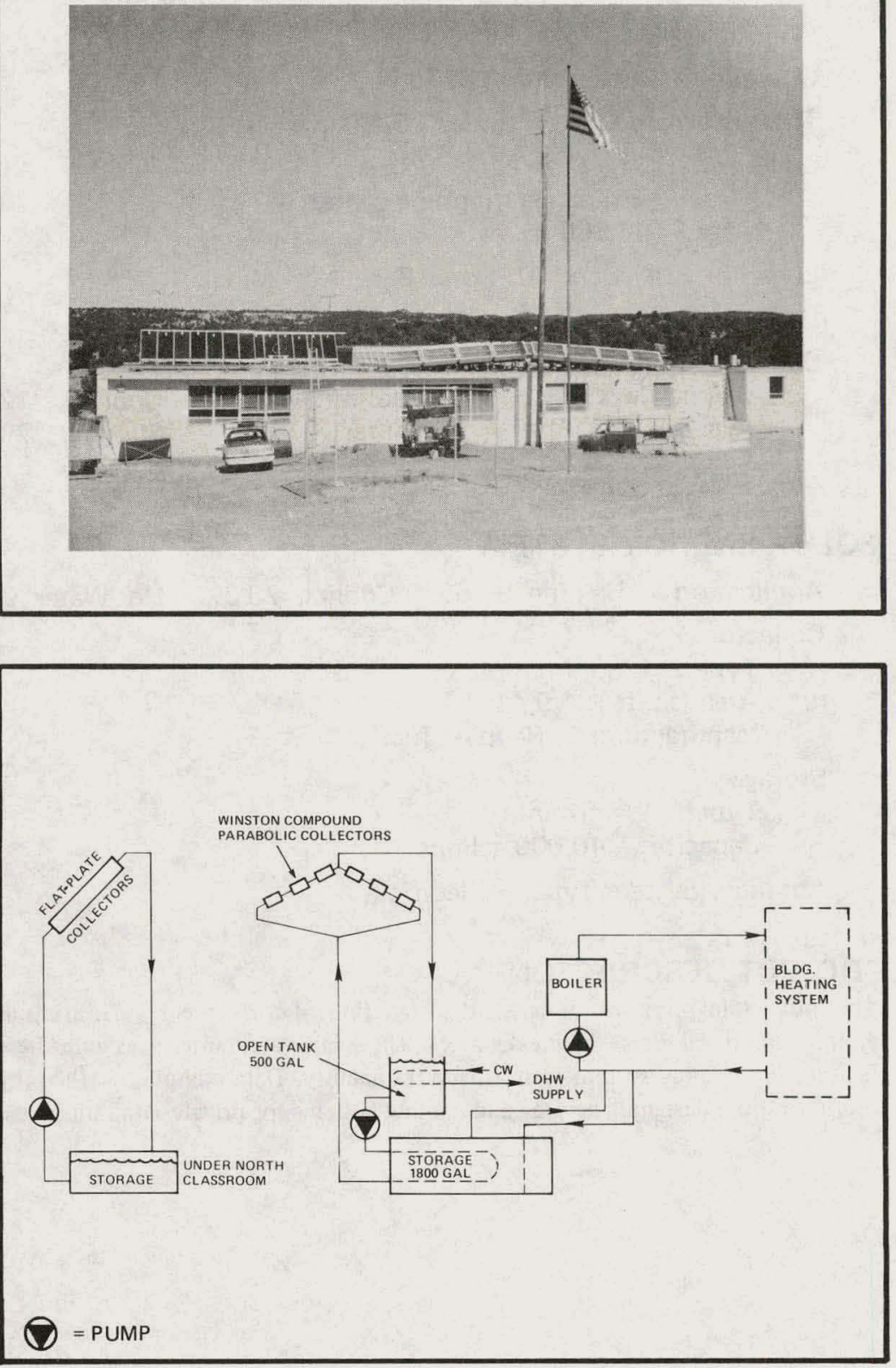


\section{PROJECT INFORMATION}

Owner/Builder: Dept. of Defense/Army and Air Force Exchange Service Contractor: Raypak, Inc.

Operational Date: July 1977

Total Estimated DOE Funds: $\$ 390,000$

Building

Type: Exchange shopping center

Area: 41,000 sq. ft.

Location: Kirtland Air Force Base, New Mexico

Latitude: $35^{\circ} \mathrm{N}$

Climatic Data

$\begin{array}{lllll}\text { Degree Days } & \text { Heating } & 4348 & \text { Cooling } & 1250 \\ \text { Avg. Temp. }\left({ }^{\circ} \mathrm{F}\right) & \text { Winter } & 45 & \text { Summer } & 79 \\ \text { Avg. Insol. (Ly/d) } & \text { Winter } & 405 & \text { Summer } & 618\end{array}$

\section{SOLAR ENERGY SYSTEM}

\author{
Application Heating $98.6 \%$ Cooling $78.3 \%$ Hot Water $98.6 \%$ \\ Collector \\ Type: Liquid flat-plate \\ Area (sq. ft.): 9,410 \\ Manufacturer: Raypak, Inc.

\section{Storage} \\ Type: Water tank \\ Capacity: $\quad 40,000$ gallons \\ Auxiliary System Type: Electric
}

\section{PROJECT DESCRIPTION}

This project involves the design and installation of a solar energy heating and cooling system for an Air Force base exchange. The solar system interfaces with the mechanical heating and cooling system planned for the facility. Data compiled in the project will be useful to those designing heating and cooling systems for private retail businesses.
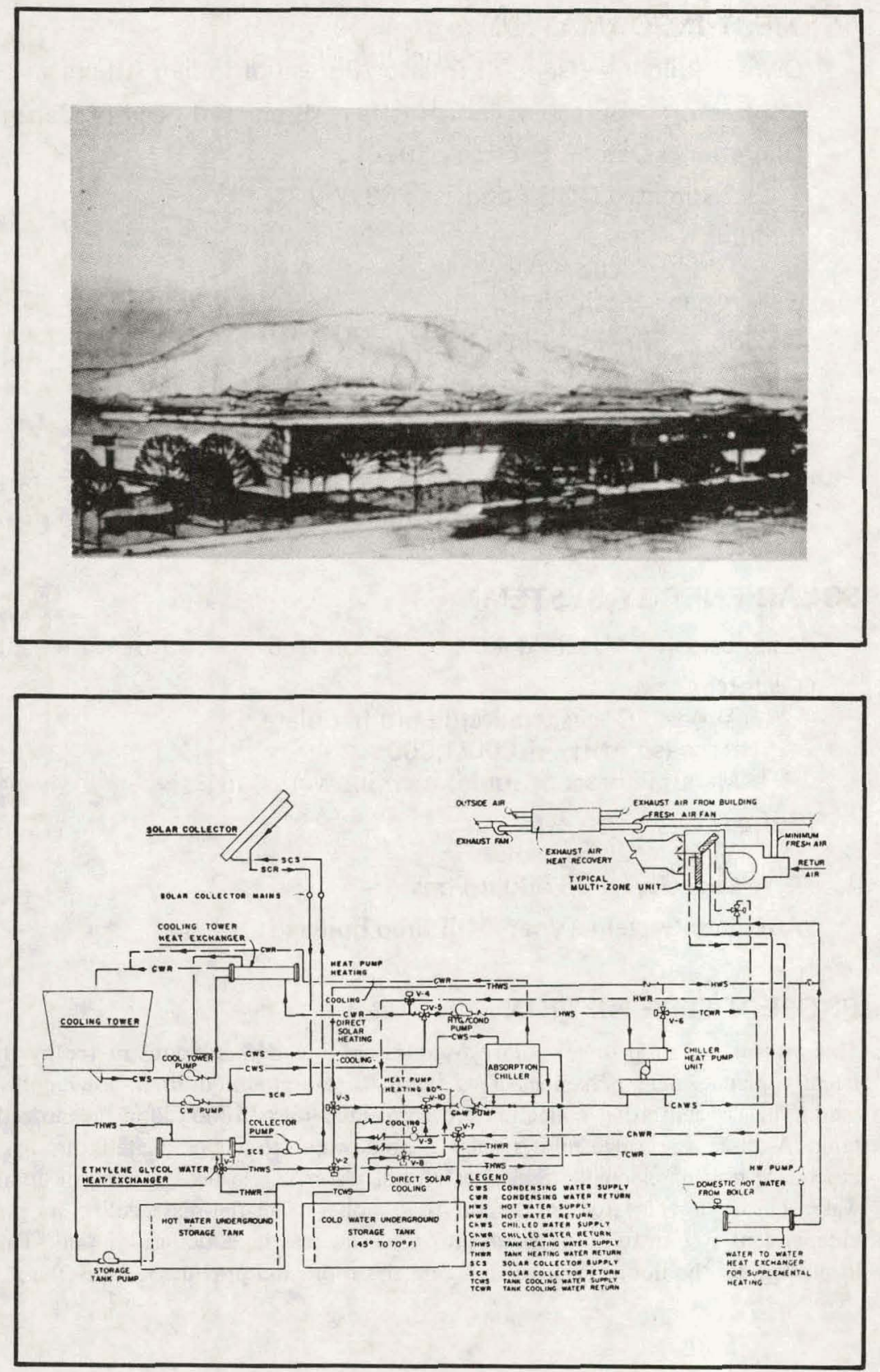


\section{PROJECT INFORMATION}

Owner/Builder: Dept. of Agriculture/Forest Service

Contractor: To be determined

Operational Date: November 1978

Total Estimated DOE Funds: $\$ 28,400$

Building

Type: Ranger station

Area: 2,560 sq. $\mathrm{ft}$.

Location: Gila National Forest, Mimbres Ranger District, New Mexico Latitude: $33^{\circ} \mathrm{N}$

Climatic Data

$\begin{array}{lllll}\text { Degree Days } & \text { Heating } & 4500 & \text { Cooling Very minor } \\ \text { Avg. Temp. }\left({ }^{\circ} \mathrm{F}\right) & \text { Winter } & 48 & \text { Summer } & 76 \\ \text { Avg. Insol. (Ly/d) } & \text { Winter } & 565.5 & \text { Summer } 680\end{array}$

\section{SOLAR ENERGY SYSTEM}

Application Heating $70 \%$ Cooling $25 \%$ Hot Water $20 \%$

Collector

Type: Liquid flat-plate

Area (sq. ft.): 1,038

Manufacturer: To be determined

Storage

Type: Water tank

Capacity: 5,000 gallons

Auxiliary System Type: Heat pump; electric boiler

\section{PROJECT DESCRIPTION}

This project is a new ranger station in the Gila National Forest in New Mexico. Single glazed, flat-plate trickle collectors will be used for the roof mounted solar array. Solar heated hot water will be circulated to three tanks where it will be mixed with auxiliary heated water for seasonal use. An air-to-air heat pump will provide auxiliary heating and cooling. Domestic hot water backup will be furnished by an electric boiler.

\section{Photograph not available}

Schematic not available 


\section{PROJECT INFORMATION}

Owner/Builder: Dept. of Energy/Brookhaven National Laboratory

Contractor: To be determined

Operational Date: April 1978

Total Estimated DOE Funds: $\$ 30,000$ (design); $\$ 170,000$ (construction) Building

Type: Animal quarantine

Area: 5,300 sq. ft.

Location: Upton, New York

Latitude: $40^{\circ} \mathrm{N}$

Climatic Data

$\begin{array}{lllll}\text { Degree Days } & \text { Heating } & 6204 & \text { Cooling } & 1079 \\ \text { Avg. Temp. }\left({ }^{\circ} \mathrm{F}\right) & \text { Winter } & 40 & \text { Summer } & 68 \\ \text { Avg. Insol. (Ly/d) } & \text { Winter } & 149 & \text { Summer } & 575\end{array}$

\section{SOLAR ENERGY SYSTEM}

Application Heating $40 \%$

Collector

Type: Liquid flat-plate

Area (sq. ft.): 3,000

Manufacturer: To be determined

\section{Storage}

Type: Water tank

Capacity: 6,000 gallons

Auxiliary System Type: Electric and propane

\section{PROJECT DESCRIPTION}

This project is a one-story, cement masonry structure. Newly acquired small mammals are housed in this building for observation prior to their transportation to medical research facilities. Large quantities of hot water, as well as steam, are used for washing and disinfecting cages, pens, stalls, and outdoor animal runs. This facility is totally air conditioned with two electrically energized, once-thru air conditioning systems. The solar system is designed to utilize the collected solar energy to meet heating, air preheating and building service hot water loads. A glycol/water mixture is used to transfer solar heat from the collectors to heat exchangers. Existing electric coils provide back-up for building heating and preheating; a propane hot water heater provides back-up for the building service hot water system.
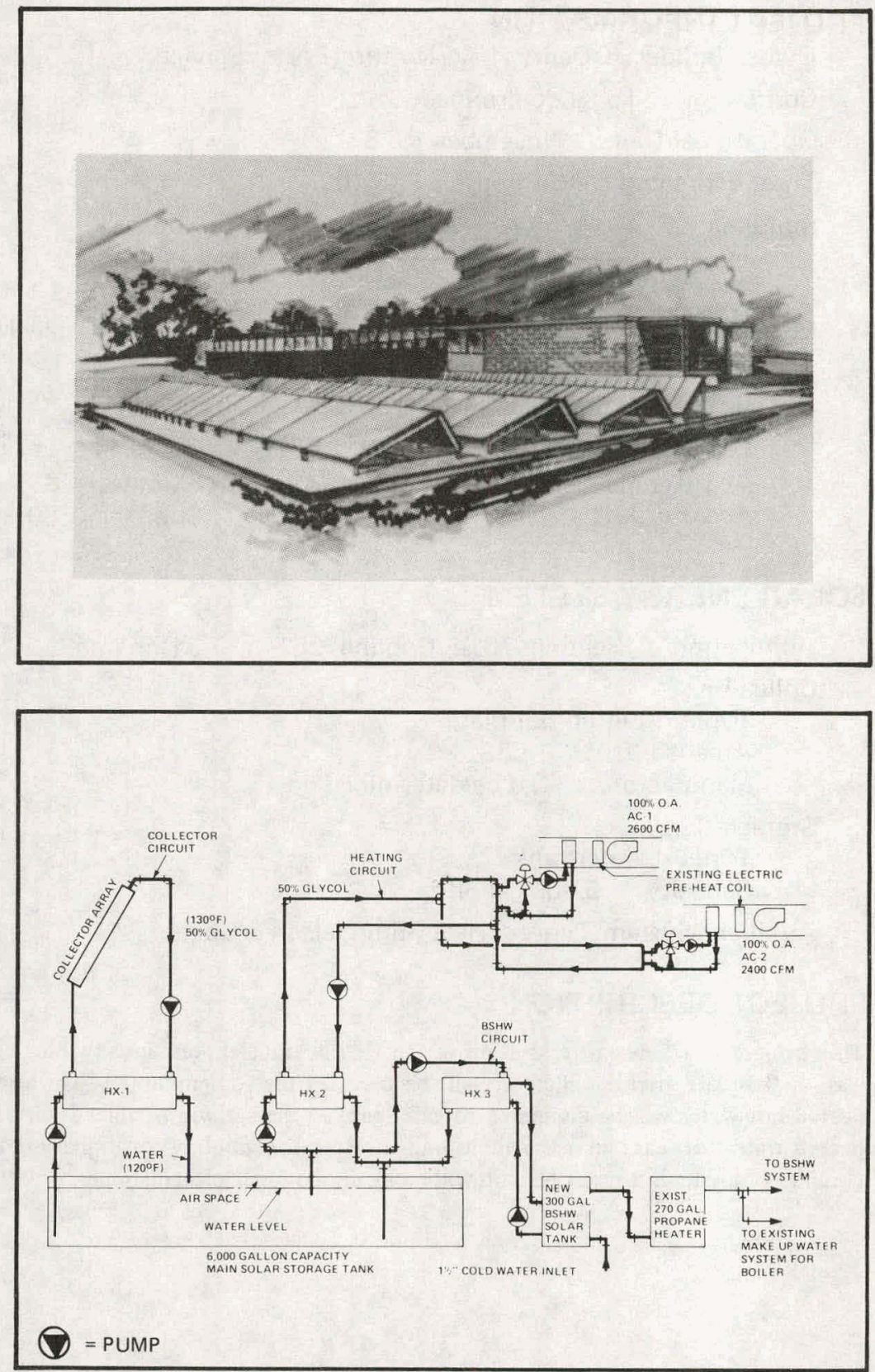


\section{PROJECT INFORMATION}

Owner/Builder: Dept. of Energy/Monsanto Research Corporation

Contractor: To be determined

Operational Date: July 1978

Total Estimated DOE Funds: $\$ 15,000$ (design); $\$ 105,000$ (construction)

Building

Type: Laboratory
Area: 6,300 sq. ft.

ocation: Miamisburg, Ohio

Latitude: $39^{\circ} \mathrm{N}$

Climatic Data

$\begin{array}{lllll}\text { Degree Days } & \text { Heating } & 5622 & \text { Cooling } 1483 \\ \text { Avg. Temp. }\left({ }^{\circ} \mathrm{F}\right) & \text { Winter } & 42 & \text { Summer } 71 \\ \text { Avg. Insol. (Ly/d) } & \text { Winter } & 128 & \text { Summer } 562\end{array}$

\section{SOLAR ENERGY SYSTEM}

Application Heating 53\% Cooling $0 \%$ Hot Water $0 \%$

Collector

Type: Liquid flat-plate

Area (sq. ft.): 2,000

Manufacturer: To be determined

Storage

Type: Water tank

Capacity: 2,000 gallons

Auxiliary System Type: Gas/oil fired steam boiler

\section{PROJECT DESCRIPTION}

This system provides year-round tempering for a laboratory building. During the heating season, the system provides heat for a ten-hour occupancy period using $60 \%$ outside and $40 \%$ recirculated reheat air. In the summer season, the system provides reheating from a constant cold deck temperature for humidity control. The solar system will interface with an existing system, a constant cold deck and a multizone, with a large amount of outside air for process usage. The solar collectors will be located on an adjoining hillside. An instrument system is contemplated to monitor system performance and to provide data for the evaluation of energy supplied.
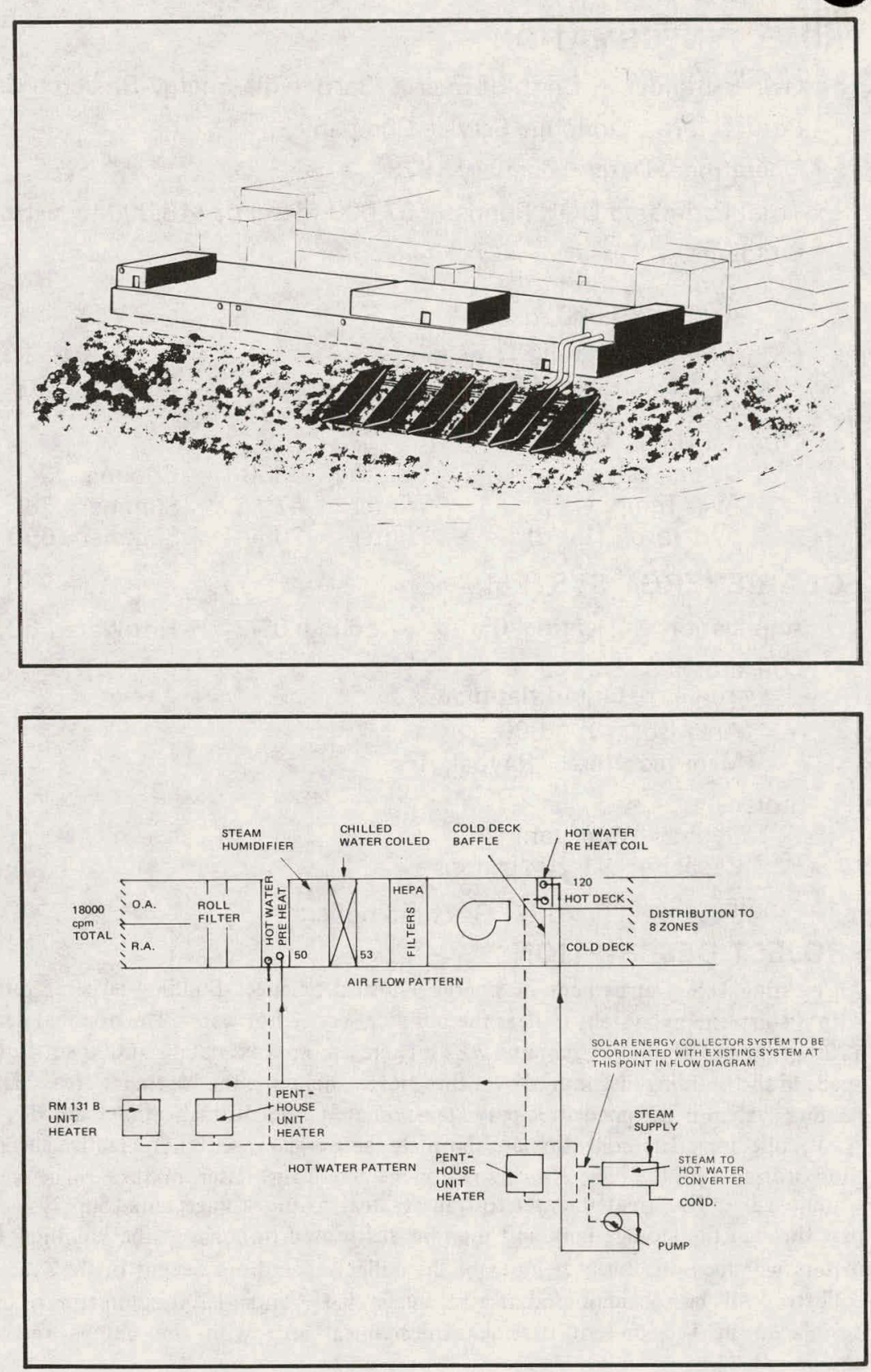


\section{PROJECT INFORMATION}

Owner/Builder: Dept. of Energy/Bartlesville Energy Research Center Contractor: Donohue Service Company

Operational Date: January 1978

Total Estimated DOE Funds: $\$ 7,000$ (design); $\$ 48,000$ (construction) Building

Type: Laboratory

Area: $\quad 50,000$ sq. ft.

Location: Bartlesville, Oklahoma

Latitude: $36^{\circ} \mathrm{N}$

Climatic Data

$\begin{array}{lllll}\text { Degree Days } & \text { Heating } & 3860 & \text { Cooling } & 2422 \\ \text { Avg. Temp. }\left({ }^{\circ} \mathrm{F}\right) & \text { Winter } & 47 & \text { Summer } & 78 \\ \text { Avg. Insol. (Ly/d) } & \text { Winter } & 205 & \text { Summer } & 600\end{array}$

\section{SOLAR ENERGY SYSTEM}

Application Heating $0 \%$ Cooling $0 \%$

Hot Water $60 \%$

Collector

Type: Liquid flat-plate

Area (sq. ft.): 600

Manufacturer: Raypak, Inc.

Storage

Type: Water tank

Capacity: 1,200 gallons

Auxiliary System Type: Gas fired boilers

\section{PROJECT DESCRIPTION}

An existing U.S. Department of Energy Physical Sciences Building is being retrofitted with a solar energy system to heat the building service hot water. The nominal demand is 1700 gallons of water per day at $120^{\circ} \mathrm{F}$. There are approximately $50000 \mathrm{sq}$. ft. of floor space in the building distributed over three levels including the basement area. The solar heating system is designed to supply approximately $60 \%$ of the heating load with 600 sq. ft. of collectors. The collectors are flat-plate, single glaze, with nonselective surface. The fluid utilized with the collectors is an ethylene glycol and water mixture. The secondary system will utilize treated water to transfer heat to the storage tank. Supply water will pass through the storage tank and then be distributed throughout the building. The Btu meters will measure the heat input of the collectors and net output of the system. The collectors will be roof-mounted at a tilt angle of $45^{\circ}$ and a 1200-gallon storage tank will be placed in the present basement mechanical area with the pumps and control equipment.
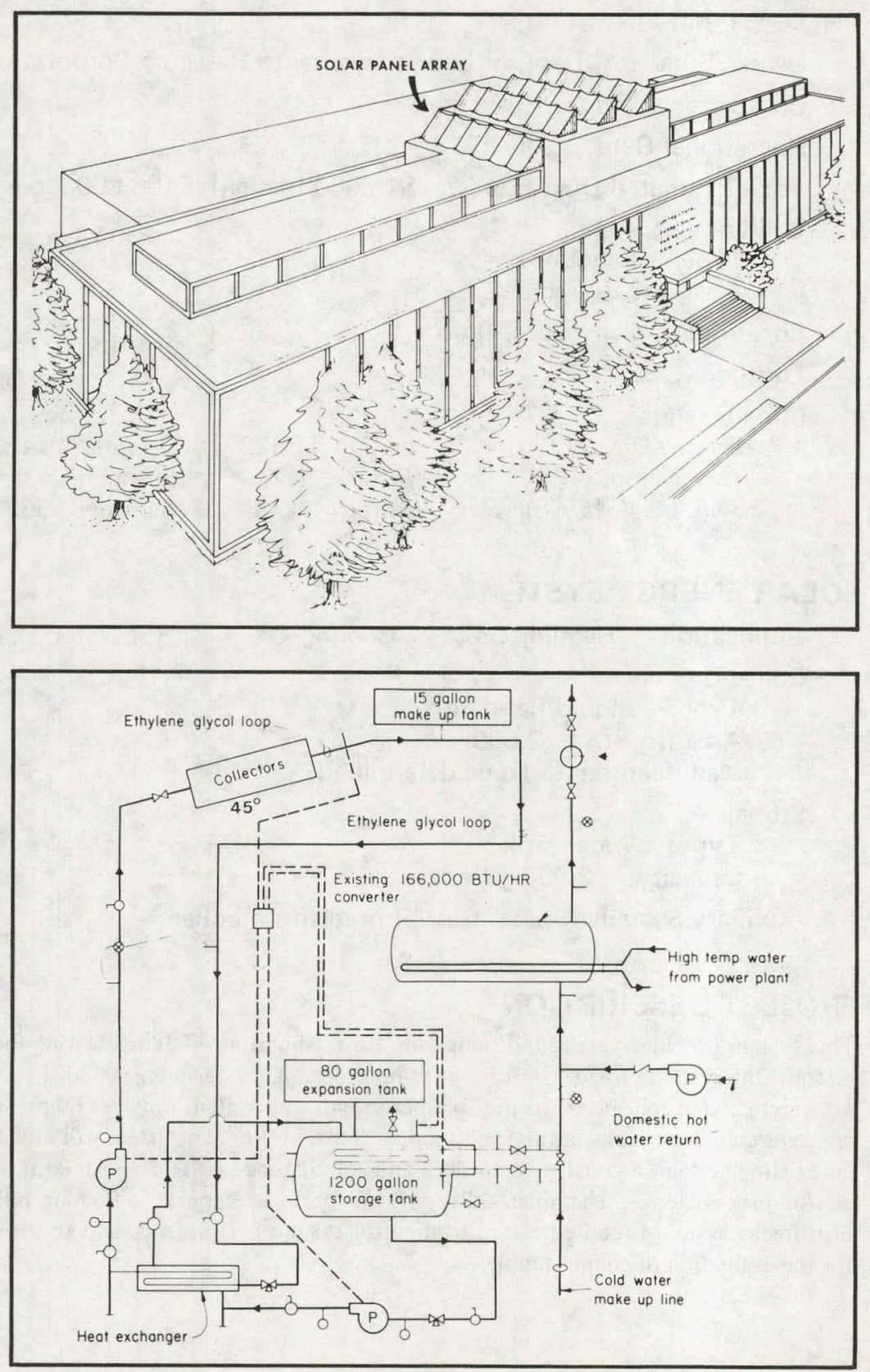


\section{PROJECT INFORMATION}

Owner/Builder: Dept. of Energy/Pittsburgh Energy Research Center Contractor: To be determined

Operational Date: June 1978

Total Estimated DOE Funds: $\quad \$ 80,000$

Building

Type: Office/laboratory

Area: 56,000 sq. ft.

Location: Bruceton, Pennsylvania

Latitude: $40^{\circ} \mathrm{N}$

Climatic Data

$\begin{array}{lllll}\text { Degree Days } & \text { Heating } & 5672 & \text { Cooling } & 953 \\ \text { Avg. Temp. }\left({ }^{\circ} \mathrm{F}\right) & \text { Winter } & 33 & \text { Summer } & 71 \\ \text { Avg. Insol. (Ly/d) } & \text { Winter } & 94 & \text { Summer } & 491\end{array}$

\section{SOLAR ENERGY SYSTEM}

Application Heating 0\%

Collector

Type: Concentrator/liquid flat-plate

Area (sq. ft.): $515 / 546$

Manufacturer: Northrup, Inc/Chamberlain Manufacturing Corporation

\section{Storage}

Type: Water tank

Capacity: 2,000 gallons

Auxiliary System Type: Oil fired steam boiler

\section{PROJECT DESCRIPTION}

This project provides for the design and installation of a solar energy system to provide hot water to one of the office-laboratory buildings at the Pittsburgh Energy Research Center facility of The Department of Energy. The solar system will include both flat-plate and concentrating collectors to serve as a basis for comparison of these two different systems in the Pittsburgh area. Data collected in this project will be useful to those designing systems for private as well as public use. The solar system will interface with the existing steam heating system which is capable of meeting all heating requirements to the buildings.
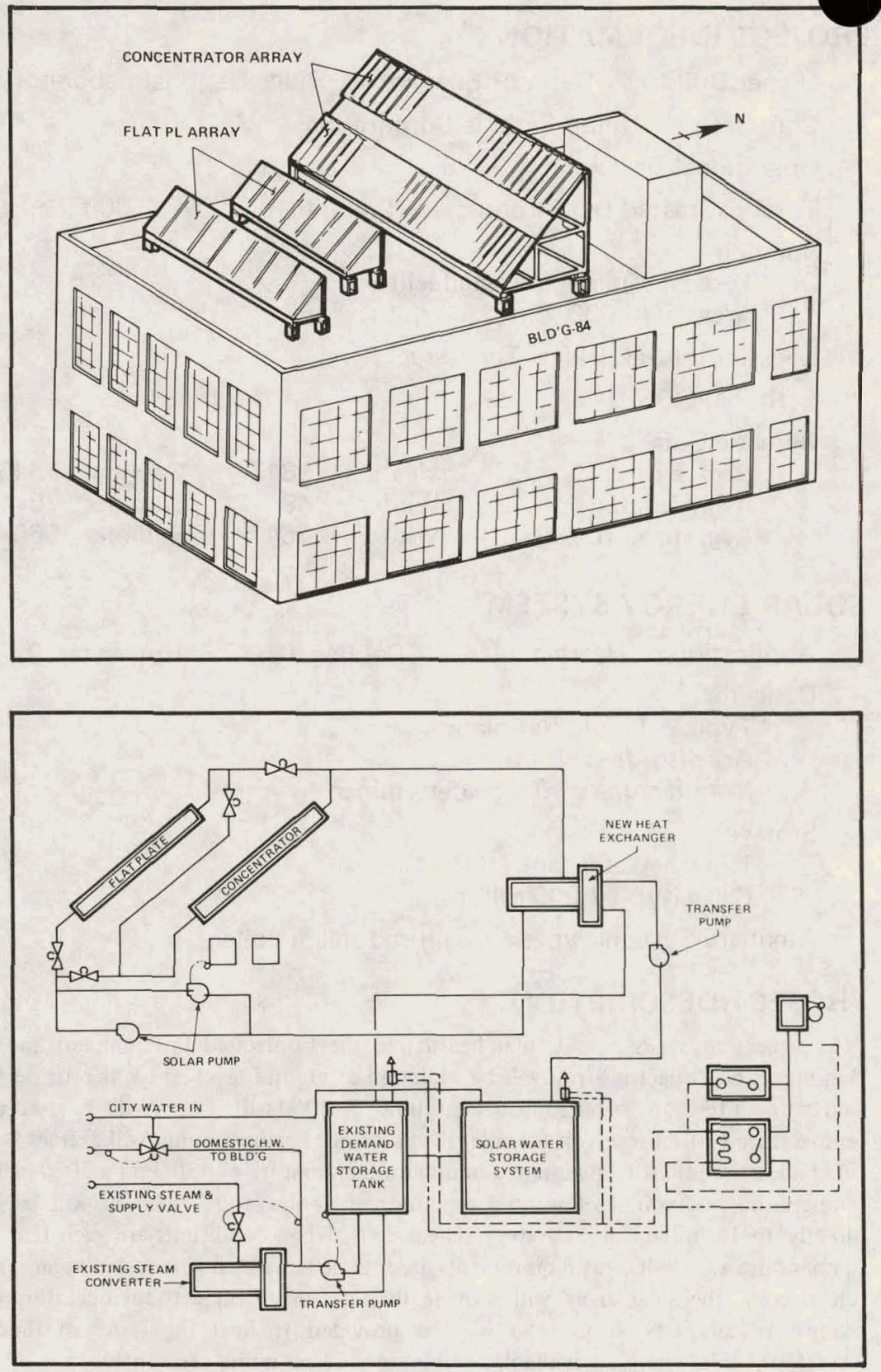


\section{PKUJECT INFORMATION}

Owner/Builder: Dept. of Energy/Oak Ridge National Laboratory

\section{Contractor: Union Carbide Corporation}

Operational Date: July 1978

Total Estimated DOE Funds: $\quad \$ 20,000$ (design); $\$ 100,000$ (construction) Building

Type: Animal holding facility

Area: 16,000 sq. ft.

Location: Oak Ridge, Tennessee

Latitude: $35^{\circ} \mathrm{N}$

Climatic Data

Degree Days

Avg. Temp. $\left({ }^{\circ} \mathrm{F}\right)$

Avg. Insol. (Ly/d)

$\begin{array}{llll}\text { Heating } & 3817 & \text { Cooling } & 1546 \\ \text { Winter } & 49 & \text { Summer } & 75 \\ \text { Winter } & 164 & \text { Summer } & 560\end{array}$

\section{SOLAR ENERGY SYSTEM}

Application Heating 50\%

Collector

\section{Cooling $0 \% \quad$ Hot Water $0 \%$}

Type: Liquid flat-plate

Area (sq. ft.): 500

Manufacturer: To be determined

Storage

Type: Water tank

Capacity: 7,000 gallons

Auxiliary System Type: Coal fired steam boiler

\section{PROJECT DESCRIPTION}

This project provides partial solar heating to the Controlled Environment and Animal Building. The collector array will be mounted at ground level and will provide the heat source for a ten-ton, water-source heat pump. A 4000 -gallon tank will be used as a low temperature $\left(90^{\circ} \mathrm{F}\right)$ reservoir for solar heat storage. The heat pump will extract heat from this tank as required to maintain a minimum temperature of $130^{\circ} \mathrm{F}$ in a 3000 -gallon high temperature reservoir. Hot water from the high temperature reservoir will be pumped directly to 12 individual laboratory reheat coils. When conditions are such that the low temperature reservoir heat requirements are satisfied and heat is required in any of the 12 reheat coils, the solar array will provide the necessary heat without operating the heat pump. An auxiliary steam coil will be provided to heat the water at times when insufficient solar energy is available to operate the heat pump efficiently.
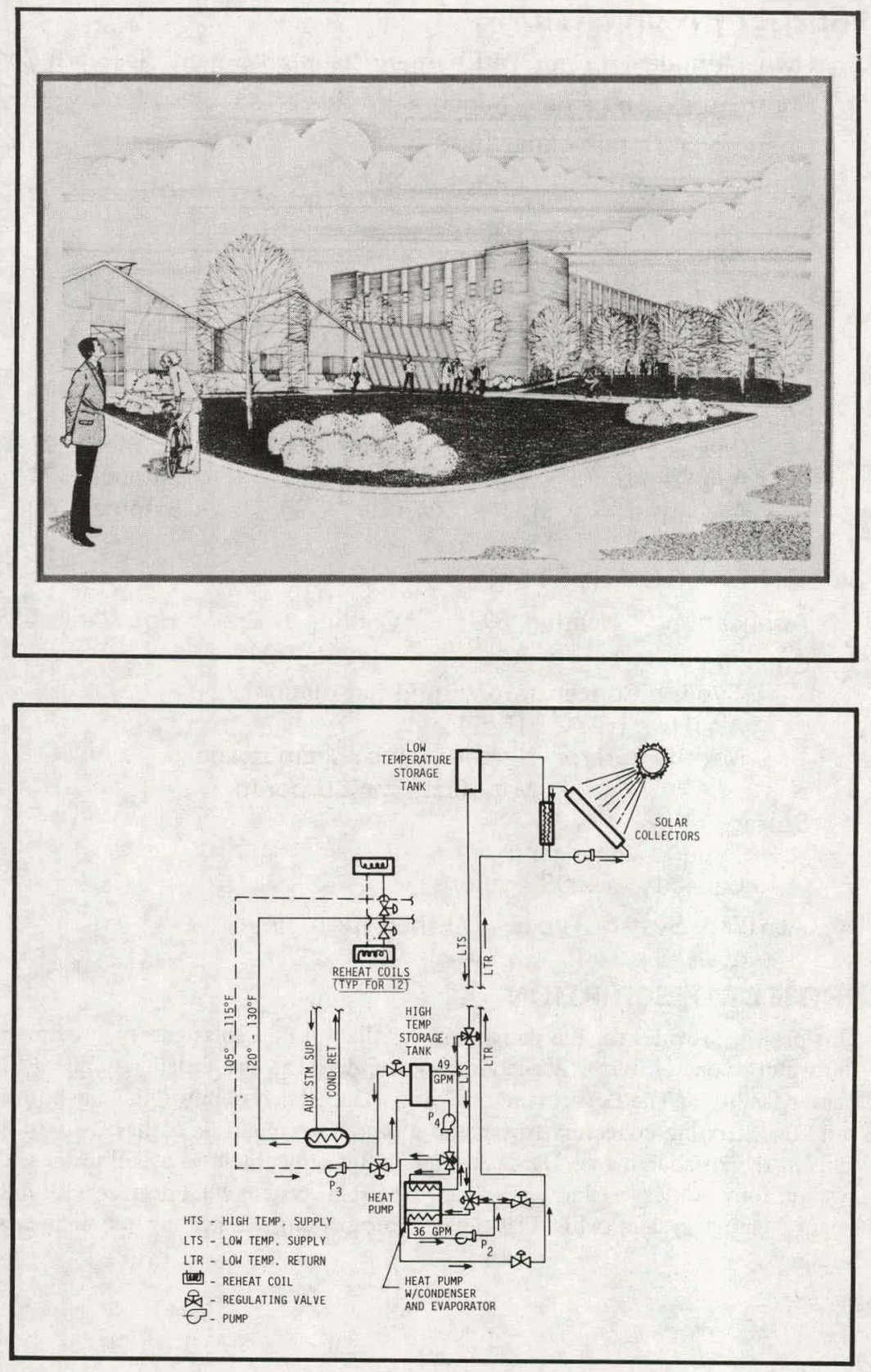


\section{PROJECT INFORMATION}

Owner/Builder: Dept. of Justice/General Services Administration/ Bureau of Prisons

Contractor: Wattinger Co., Inc.

Operational Date: August 1978

Total Estimated DOE Funds: $\$ \mathbf{8 0 0 , 0 0 0}$

Building

Type: Youth correctional facility

Area: 175,546 sq. ft.

Location: Bastrop; Texas

Latitude: $30.1^{\circ} \mathrm{N}$

Climatic Data

Degree Days

Avg. Temp. $\left({ }^{\circ} \mathrm{F}\right)$

Heating 1711

Cooling 2788

Avg. Insol. (Ly/d)

Winter 59.1

Summer 84.4

Winter 333 Summer 553

\section{SOLAR ENERGY SYSTEM}

Application Heating 57\%

Hot Water $70 \%$

Collector

Type: Liquid flat-plate

Area (sq. ft.): 25,000

Manufacturer: Cole Solar Systems

\section{Storage}

Type: Water tank

Capacity: $\quad 40,000$ gallons

Auxiliary System Type: Gas fired boilers

\section{PROJECT DESCRIPTION}

The Federal Youth Center will provide correctional treatment programs for 500 youthful offenders. The facility consists of youth housing units, administration offices, prison industries, academic and vocational training, a clinic, recreation, and support services similar to a small community. The Youth Center is small enough to make the application of solar energy feasible, but large enough to provide valid documentation of the costs, problems, advantages, limitations, and requirements of solar collection and delivery systems. This "campus type" facility is unique for a solar demonstration project. The operation of this controlled community is a microcosmic reflection of the energy needs of an entire city.
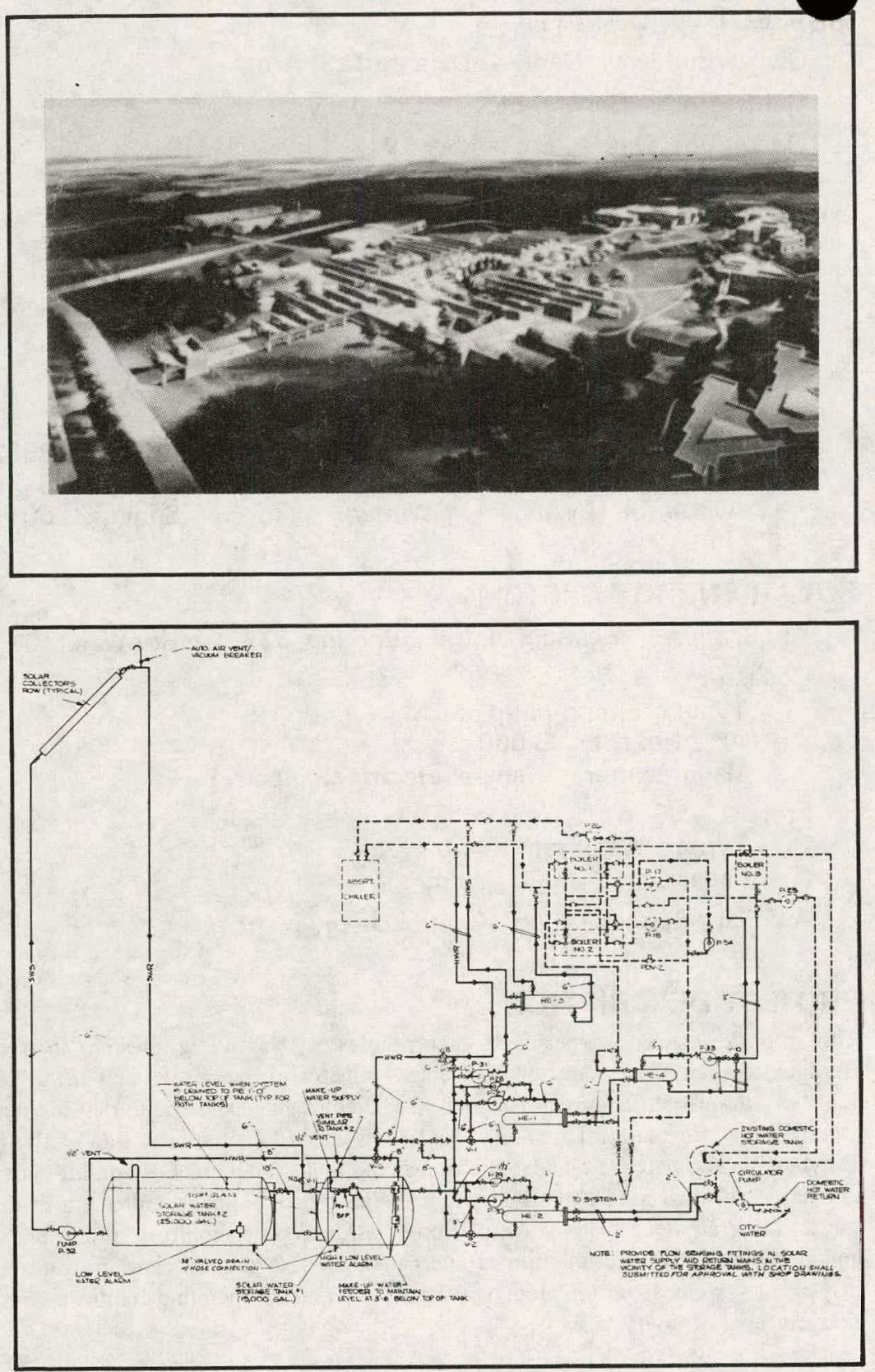


\section{...JJECT INFORMATION}

Owner/Builder: Dept. of Defense/U.S. Army

Contractor: General Electric Company

Operational Date: September 1977

Total Estimated DOE Funds: $\quad \$ 588,000$

Building

Type: Office/classrooms

Area: 12,200 sq. ft.

Location: Fort Hood, Texas

Latitude: $31.1^{\circ} \mathrm{N}$

Climatic Data

$\begin{array}{lllll}\text { Degree Days } & \text { Heating } & 1950 & \text { Cooling } & 2802 \\ \text { Avg. Temp. }\left({ }^{\circ} \mathrm{F}\right) & \text { Winter } & 49 & \text { Summer } & 83 \\ \text { Avg. Insol. (Ly/d) } & \text { Winter } & 285 & \text { Summer } & 501\end{array}$

Avg. Insol. (Ly/d)

Winter 285

\section{SOLAR ENERGY SYSTEM}

Application Heating 98\%

Collector

Type: Liquid flat-plate

Area (sq. ft.): 6,000

Manufacturer: General Electric Company

\section{Storage}

Type: Water tank

Capacity: 12,000 gallons

Auxiliary System Type: Central energy plant

\section{PROJECT DESCRIPTION}

This proof-of-concept experiment incorporates a solar energy system in a battalion headquarters and classroom building. Solar collectors are mounted at a tilt of $20^{\circ}$ above the roof on a structural grid and aligned with the building axis. The buried thermal energy storage tank and the system cooling tower are located on the west side of the building. Ethylene glycol/water is circulated through the collector loop. For cooling, hot water is circulated through a 100-ton absorption chiller which supplies chilled water to coils in the building air duct system. An instrumentation system monitors system performance and provides data for evaluation of energy supplied. A display panel provides a graphic display of system operation along with direct readout of operating conditions and system temperatures.
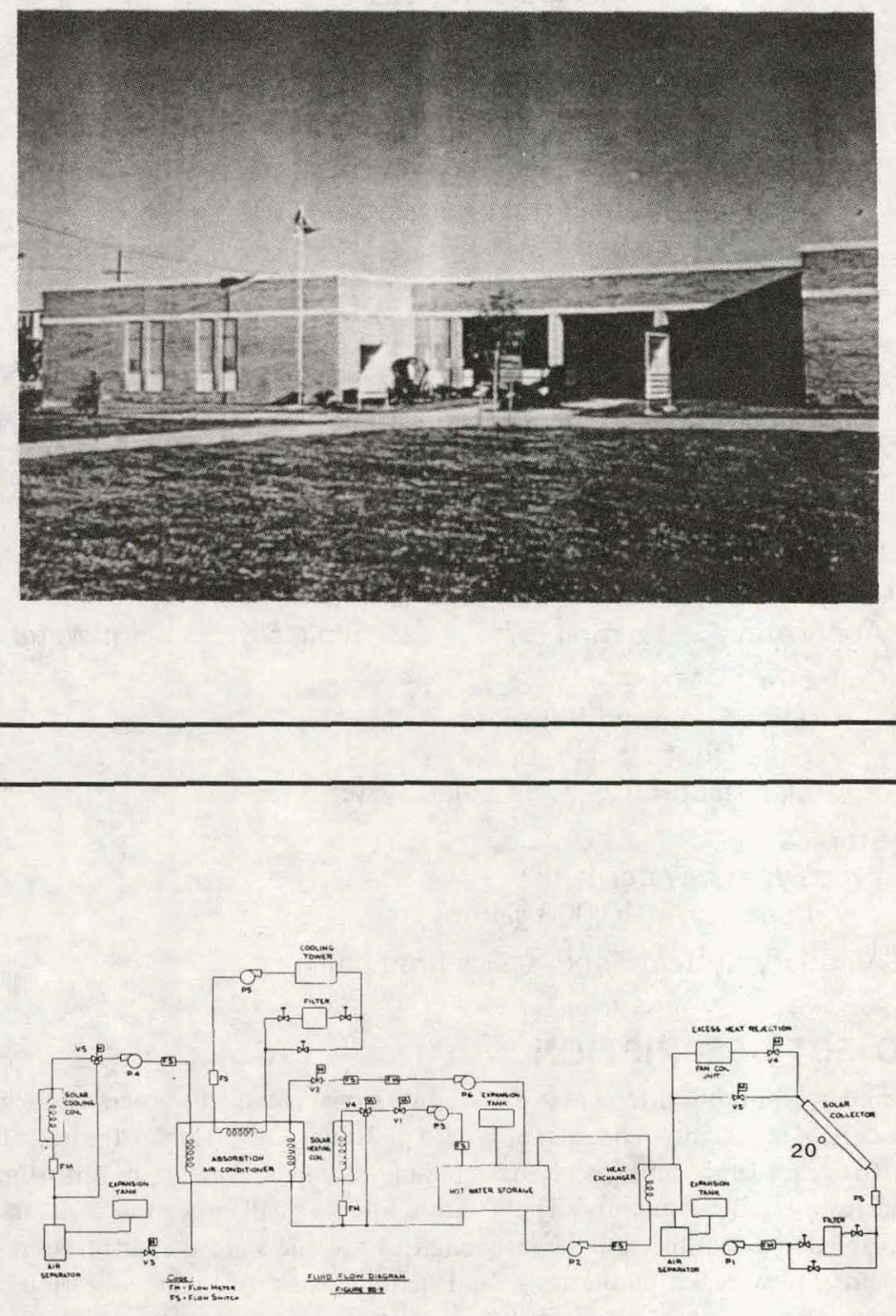


\section{PROJECT INFORMATION}

Owner/Builder: NASA Johnson Space Center

Contractor: Charles G. Heyne and Company

Operational Date: December 1977

Total Estimated DOE Funds: $\$ 18,500$ (design); $\$ 318,500$ (construction) Building

Type: Computer center

Area: 89,334 sq. $\mathrm{ft}$.

Location: Houston, Texas

Latitude: $30^{\circ} \mathrm{N}$

Climatic Data

$$
\begin{aligned}
& \text { Degree Days } \\
& \text { Avg. Temp. }\left({ }^{\circ} \mathrm{F}\right)
\end{aligned}
$$

Avg. Insol. (Ly/d)

$\begin{array}{ll}\text { Heating } & 1396 \\ \text { Winter } & 33 \\ \text { Winter } & 250\end{array}$

Cooling $\cdot 2656$

Summer 96

Summer 618

\section{SOLAR ENERGY SYSTEM}

Application Heating 0\% Cooling 0\%

Hot Water $20 \%$

Collector

Type: Liquid flat-plate

Area (sq. ft.): 5,657

Manufacturer: Southwestern Sheetmetal Works, Inc.

\section{Storage}

Type: None

Capacity: Not applicable

Auxiliary System Type: Steam

\section{PROJECT DESCRIPTION}

This system is designed to provide hot water to the Mission Control Computer Center air conditioning system. The collectors are mounted above the roof and have black painted absorbers and single glazing of tempered white crystal. The existing hot water system is a closed loop using a steam-to-water heat exchanger with solar heated water used to preheat water. The energy generated by the solar system is less than the minimum amount required so that a storage tank is not required. A manual drain-down is provided for freeze protection.
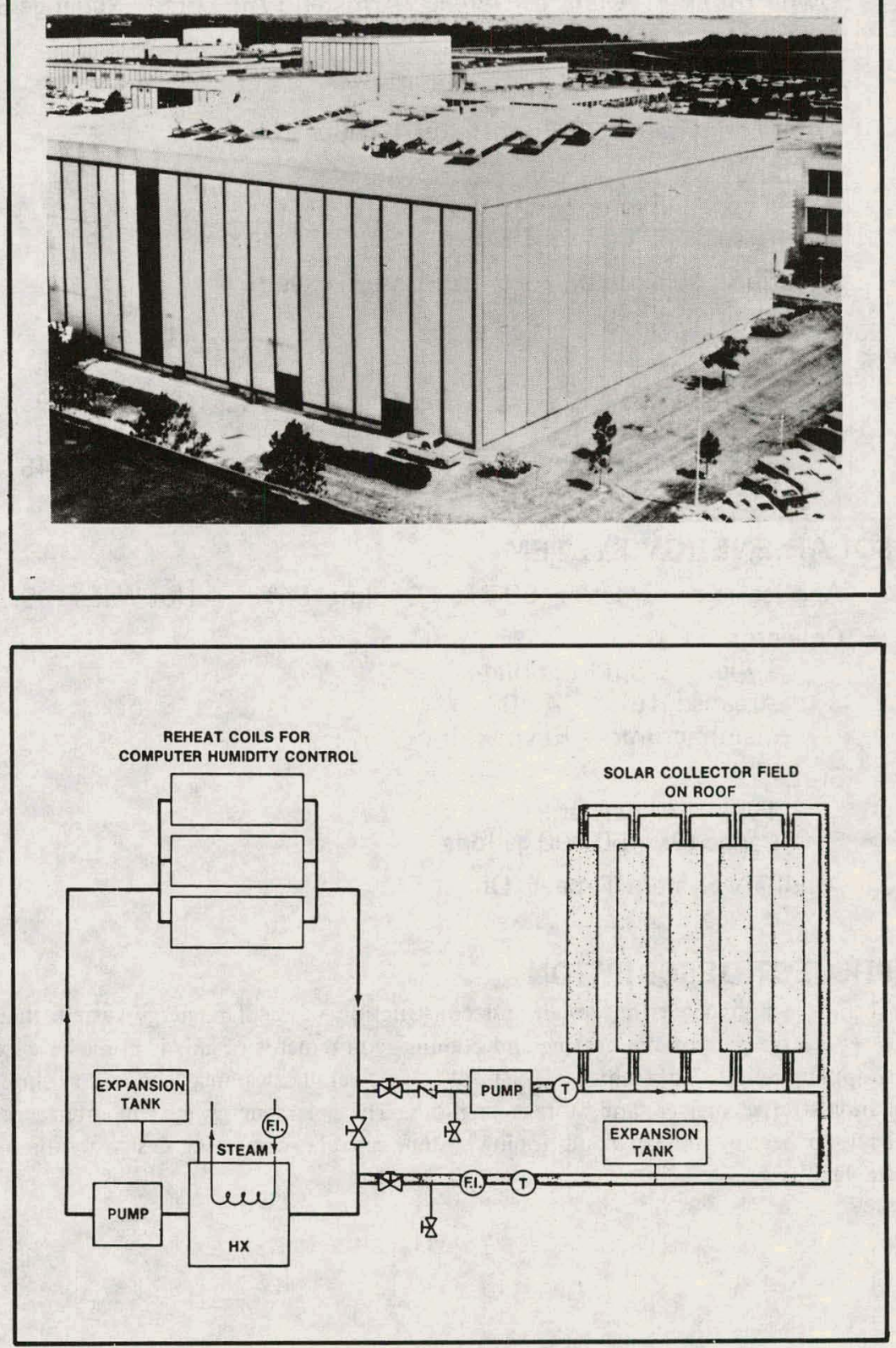


\section{JJECT INFORMATION}

Owner/Builder: Dept. of Defense/Army and Air Force Exchange Service

Contractor: Raypak, Inc.

Operational Date: October 1977

Total Estimated DOE Funds: $\$ 510,000$

Building

Type: Exchange shopping center

Area: $62,000 \mathrm{sq} . \mathrm{ft}$.

Location: Randolph Air Force Base, Texas

Latitude: $29.5^{\circ} \mathrm{N}$

Climatic Data

$\begin{array}{lllll}\text { Degree Days } & \text { Heating } & 1546 & \text { Cooling } & 2990 \\ \left.\text { Avg. Temp. ( }{ }^{\circ} \mathrm{F}\right) & \text { Winter } & 60 & \text { Summer } & 78 \\ \text { Avg. Insol. (Ly/d) } & \text { Winter } & 340 & \text { Summer } & 545\end{array}$

\section{SOLAR ENERGY SYSTEM}

Application Heating $99.7 \%$ Cooling $64 \%$ Hot Water $99.7 \%$

Collector

Type: Liquid flat-plate

Area (sq. ft.): $\quad 14,700$

Manufacturer: Raypak, Inc.

Storage

Type: Water tank

Capacity: 50,000 gallons

Auxiliary System Type: Oil

\section{PROJECT DESCRIPTION}

The project involved the design and construction of a solar energy system that would meet a large part of the heating and cooling requirements of an Air Force base exchange shopping center. The center consists of a large retail sales area, concession shops, mall, administrative offices, and storage facilities. The solar energy system interfaces with a back-up heating and air conditioning system capable of meeting design requirements of the facility.
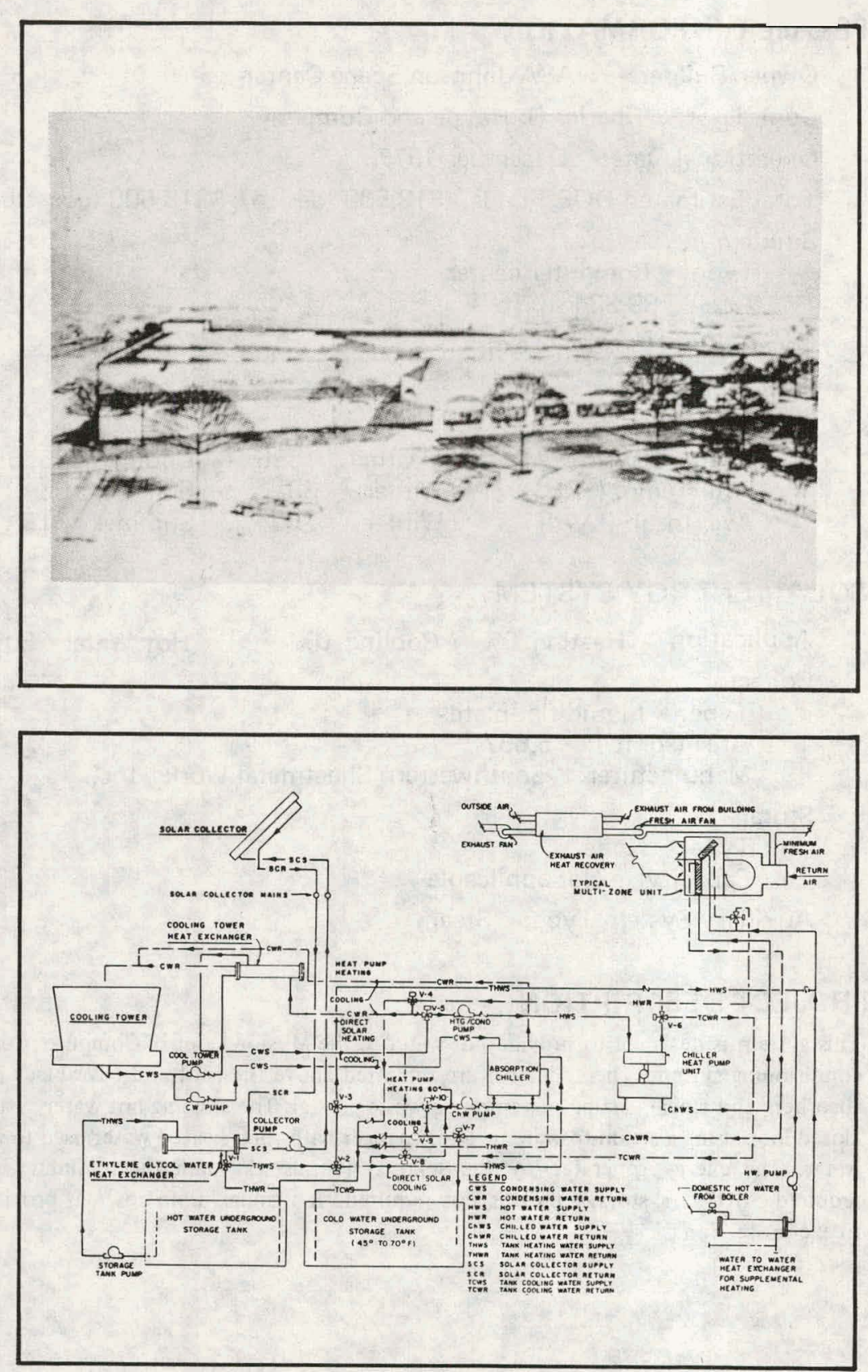
Owner/Builder: NASA Langley Research Center

Contractor: To be determined

Operational Date: October 1978

Total Estimated DOE Funds: $\quad \$ 260,000$

Building

Type: Photographic laboratory

Area: 12,000 sq. ft.

Location: Hampton, Virginia

Latitude: $36^{\circ} \mathrm{N}$

Climatic Data

$\begin{array}{lllll}\text { Degree Days } & \text { Heating } & 3285 & \text { Cooling } & 1744 \\ \text { Avg. Temp. }\left({ }^{\circ} \mathrm{F}\right) & \text { Winter } & 41 & \text { Summer } & 73 \\ \text { Avg. Insol. }(\text { Ly/d) } & \text { Winter } & 200 & \text { Summer } & 552\end{array}$

\section{SOLAR ENERGY SYSTEM}

Application Heating $0 \%$ Cooling $0 \%$ Hot Water $70 \%$

Collector

Type: Evacuated tubular

Area (sq. ft.): 3,000

Manufacturer: To be determined

\section{Storage}

Type: Insulated steel water tank (above ground)

Capacity: 6,000 gallons

Auxiliary System Type: Electric

\section{PROJECT DESCRIPTION}

This solar project will provide solar heating of process water for an existing NASA photographic laboratory. Evacuated tubular collectors mounted on wood supports will be used for the solar array. Ethylene glycol will be used for freeze protection. Backup will be provided by existing electric heating elements.

\section{Photograph not available}

\section{Schematic not available}




\section{IJECT INFORMATION}

Owner/Builder: Dept. of Energy/Hanford Works

Contractor: To be determined

Operational Date: November 1978

Total Estimated DOE Funds: $\quad \$ 12,000$ (design); $\$ 78,000$ (construction)

Building

Type: Laboratory

Area: $\quad 35 ; 000$ sq. $\mathrm{ft}$.

Location: Richland, Washington

Latitude: $46^{\circ} \mathrm{N}$

Climatic Data

$\begin{array}{lllll}\text { Degree Days } & \text { Heating } & 5267 & \text { Cooling } & 46 \\ \text { Avg. Temp. }\left({ }^{\circ} \mathrm{F}\right) & \text { Winter } & 43 & \text { Summer } & 74 \\ \text { Avg. Insol. (Ly/d) } & \text { Winter } & 118 & \text { Summer } & 633\end{array}$

\section{SOLAR ENERGY SYSTEM}

Application Heating $0 \%$

Collector

Type: Liquid flat-plate

Area (sq. ft.): 800

Manufacturer: To be determined

Storage

Type: Water tank

Capacity: 1,500 gallons

Auxiliary System Type: Steam

\section{PROJECT DESCRIPTION}

The system will supply domestic hot water for the cafeteria and office areas of the High Temperature Sodium Facility. The solar energy will be collected by $800 \mathrm{sq}$. ft. of flat-plate solar collectors mounted on the roof of the south office wing. Water will be circulated through the collectors to transfer the energy to a 1500 -gallon storage tank located in the equipment room beneath the lobby. The storage tank will store energy for peak demand periods and for use during cloudy days. About $70 \%$ of the building's domestic hot water requirements will be supplied by the solar collector system. The remainder will be supplied by the existing steam heated hot water system.
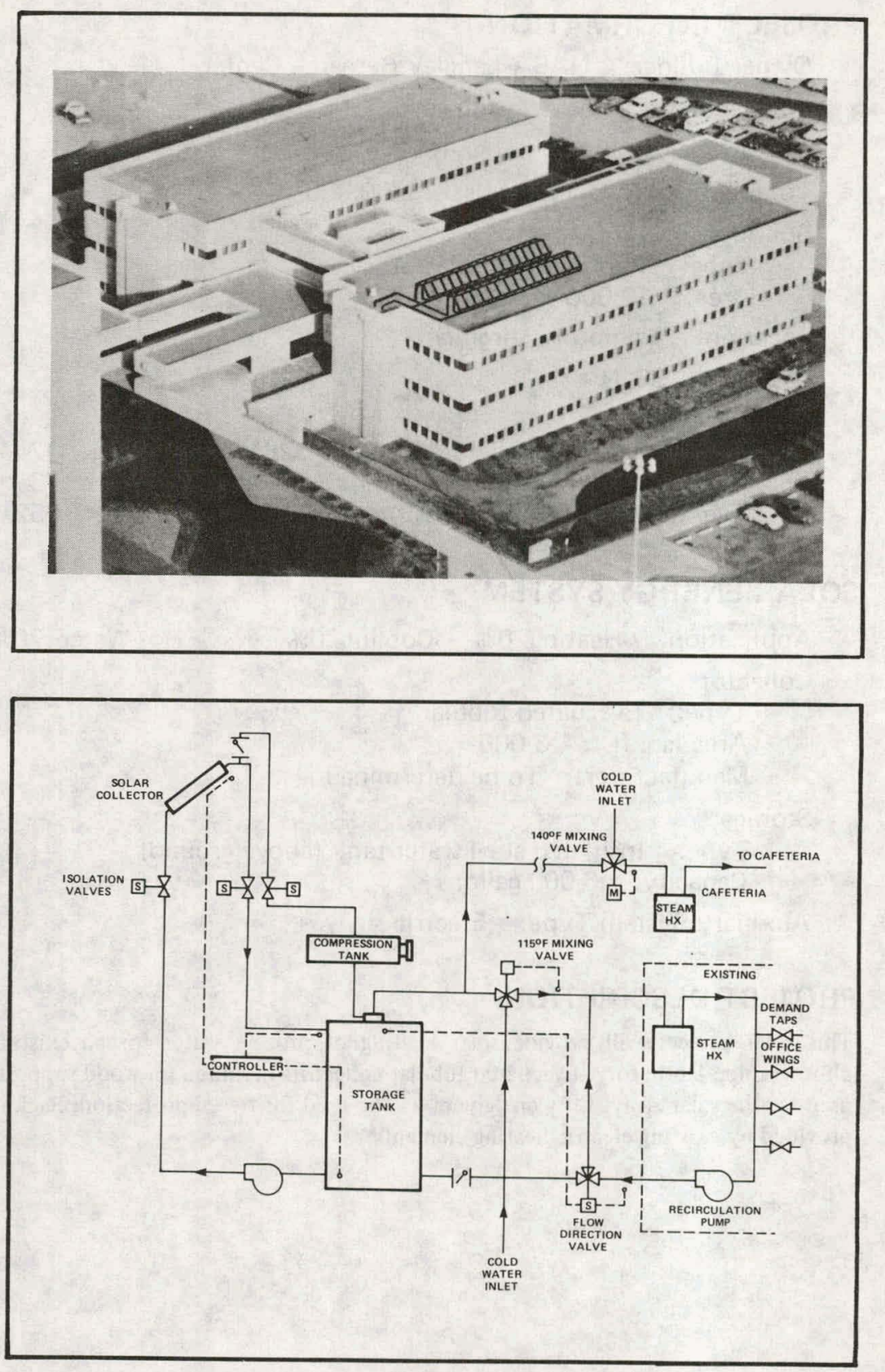


\section{SECTION II COMMERCIAL DEMONSTRATION PROGRAM FEDERAL BUILDINGS (CONTINUED)}

\begin{tabular}{|c|c|c|c|c|c|c|c|}
\hline PAGE & STATE & LOCATION & OWNER/BUILDER & $\begin{array}{l}\text { BUILDING } \\
\text { TYPE }\end{array}$ & $\begin{aligned} \text { SOI } \\
\text { APPLIO }\end{aligned}$ & AR & $\begin{array}{l}\text { SOLAR } \\
\text { MANUFACTIIRER }\end{array}$ \\
\hline $11 \cdot 30$ & NEW YORK & Upton & $\begin{array}{l}\text { Dept. of Energy/Brookhaven } \\
\text { National Laboratory }\end{array}$ & Animal Quarantine & $\mathrm{H}$ & HW & To be Determined \\
\hline II.3I & $\mathrm{OHIO}$ & Miamisburg & $\begin{array}{l}\text { Dept. of Energy/Monsanto Research } \\
\text { Corporation }\end{array}$ & Laboratory & $\mathrm{H}$ & & To be Determined \\
\hline II. 32 & OKLAHOMA & Bartlesville & $\begin{array}{l}\text { Dept. of Energy/Bartlesville Energy } \\
\text { Research Center }\end{array}$ & Laboratory & & $H W$ & Raypak, Inc. \\
\hline II! 33 & PENNSYLVANIA & Bruceton & $\begin{array}{l}\text { Dept, of Energy/Pittsburgh Energy } \\
\text { Research Center }\end{array}$ & Office/Laboratory & & $\mathrm{HW}$ & $\begin{array}{l}\text { Northrup, Inc./Chamberlain } \\
\text { Manufacturing Corporation }\end{array}$ \\
\hline II. 34 & TENNESSEE & Oak Ridge & $\begin{array}{l}\text { Dept. of Energy/Oak Ridge } \\
\text { National Laboratory }\end{array}$ & Animal Holding Facility & H & & To be Determined \\
\hline 11. 35 & TEXAS & Bastrop & $\begin{array}{l}\text { Dept. of Justice/General Services } \\
\text { Administration/Bureau of Prisons }\end{array}$ & Youth Correctional Facility & H C & $H W$ & Cole Solar Systems \\
\hline II. 36 & & Ft. Hood & Dept. of Defense/U.S. Army & Office/Classrooms & H C & & General Electric Company \\
\hline 11.-37 & & Houston & NASA Johnson Space Center & Computer Center & & $\mathrm{HW}$ & Southwestern Sheet Metal Works, In \\
\hline III-38 & & $\begin{array}{r}\text { Randolph Air } \\
\text { Force Base }\end{array}$ & $\begin{array}{l}\text { Dept. of Defense/Army and Air } \\
\text { Force Exciange Service }\end{array}$ & Exchange Shopping Center & $\mathrm{HC}$ & $\mathrm{HW}$ & Raypak, Inc. \\
\hline .11 .39 & VIRGINIA & Hampton & NASA Langley Research Center & Photographic Laboratory & & HW & To be Determined \\
\hline II. 40 & WASHINGTON & Richland & Dept. of Energy/Hanford Works & Laboratory & & HW & To be Determined \\
\hline
\end{tabular}




\section{THIS PAGE WAS INTENTIONALLY \\ LEFT BLANK}




\section{SECTION III}

RESIDENTIAL DEMONSTRATION PROGRAM FEDERAL BUILDINGS 


\section{RESIDENTIAL DEMONSTRATION PROGRAM FEDERAL BUILDINGS}

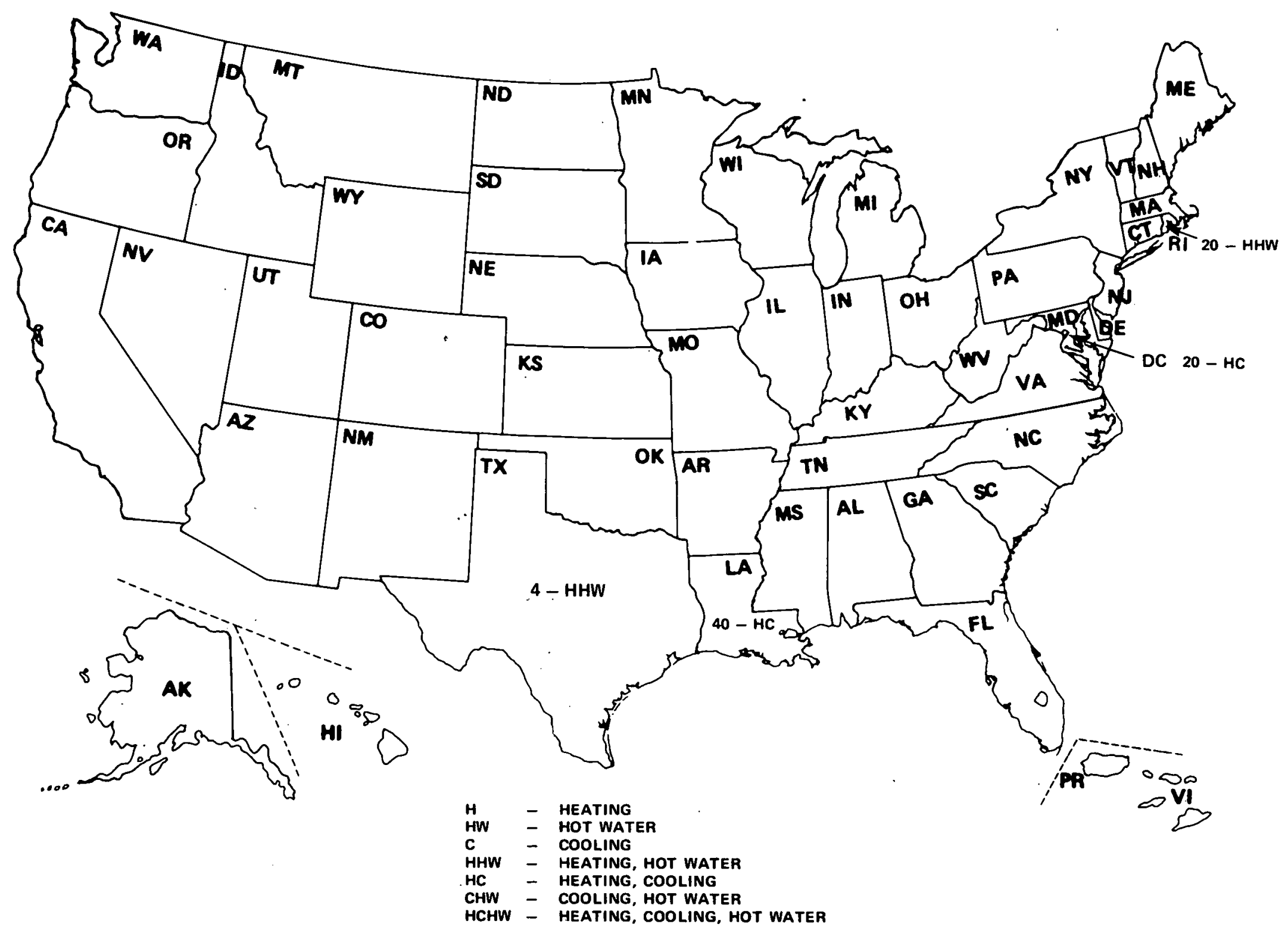

III-i 
SECTION III RESIDENTIAL DEMONSTRATION PROGRAM FEDERAL BUILDINGS

\begin{tabular}{|c|c|c|c|c|c|c|c|c|}
\hline PAGE & STATE & LOCATION & OWNER/BUILDER & $\begin{array}{l}\text { BUILDING } \\
\text { TYPE }\end{array}$ & $\begin{array}{l}\text { NUMBER } \\
\text { OF UNITS }\end{array}$ & \multicolumn{2}{|c|}{$\begin{array}{c}\text { SOLAR } \\
\text { APPLICATION }\end{array}$} & $\begin{array}{c}\text { SOLAR } \\
\text { MANUFACTURER }\end{array}$ \\
\hline $111 \cdot .1$ & DIST. OF CDLUMBIA & $\begin{array}{l}\text { Belling Ai: Force } \\
\text { Busse }\end{array}$ & Depl. of [telense/U.S. Air Force & MF & 20 & \multicolumn{2}{|c|}{$\mathrm{HC}$} & Owens-Illinois. Inc. \\
\hline III.2 & LOUISIANA & FI. Pilk & Dept. of Delense/U.S. Army & SFA & 40 & \multicolumn{2}{|c|}{$\mathrm{HC}$} & Tolbe Determined \\
\hline III-3 & RHODE ISLAND & $\begin{array}{l}\text { Newport Yaval } \\
\text { Siation }\end{array}$ & Dept, of Defense/U.S. Navy & SFA & 20 & H & HW & Iloneywell. Inc. \\
\hline 11114 & TEXAS & $\begin{array}{l}\text { She pard Air } \\
\text { Force Base }\end{array}$ & Depi. of Defense/U.S. Air Force & SFA & 1 & H & IIW & Honeywell. Inc. \\
\hline III-5 & & $\begin{array}{l}\text { Sheppara Air } \\
\text { Force Base }\end{array}$ & Dep1. or Defense/U.S. Air Force & SFA & 1 & H & HW & Sunworks. Inc. \\
\hline III-6 & & $\begin{array}{l}\text { Sle ppard Air } \\
\text { Force Base }\end{array}$ & Dept. of Detense/U.S. Air Force & $S F A$ & 1 & H & INW & General Electric Company \\
\hline IIII.7 & & $\begin{array}{l}\text { Sleppard Air } \\
\text { Force Base }\end{array}$ & Dep:. or De ense/U.S. Air Force & SFA & 1 & $\mathrm{H}$ & $\mathrm{HW}$ & General Electric Company \\
\hline \multicolumn{9}{|c|}{ Additional projects being implemented: } \\
\hline & ARIZONA & $\begin{array}{l}\text { Davis-Muntlanm } \\
\text { Air } \bar{F} \text { orce Base }\end{array}$ & Dept. of Defense/U.S. Air Force & SFD & 1 & H & HW & Daystar Corporation \\
\hline & IDAHO & $\begin{array}{l}\text { M. Home Air } \\
\text { Forse Base }\end{array}$ & Dept, or Defense/U.S. Air Force & SFD & 1 & 11 & IIW & Ametek, Ins. \\
\hline & KANSAS & Fort Riley & Dept. of De Fense/U.S. Arny & MF & 8 & \multirow{4}{*}{11} & II & To he Delermined \\
\hline & KENTUCKY & Forl Campbell & Depi. of Defense/U.S. Army & SFD & 1 & & HW & To be Determined \\
\hline & LOUISIANA & $\begin{array}{c}\text { New Orleans } \\
\text { Naral Base }\end{array}$ & Depi. of Defense/U.S. Navy & MF & 12 & & HW & To be Determined \\
\hline & MARYLAND & $\begin{array}{l}\text { U.S. Naval } \\
\text { Academy }\end{array}$ & Depi. of Defense/U.S. Navy & $\mathrm{MF}$ & 16 & & IIW & To be Determined \\
\hline & NORTH CAROLINA & Fort Bragg & Depl of 'Defense/U.S. Army' & SFD & 1 & \multirow[t]{2}{*}{ H } & & To be Determined \\
\hline & VIRGINIA & Forl Meyer & Lept. of Defense/U.S. Arniy & $\mathrm{MF}$ & 120 & & IIW & Sunworks. luc. \\
\hline
\end{tabular}




\section{PROJECT INFORMATION}

Owner/Builder: Dept. of Defense/U.S. Air Force

Contractor: To be determined

Operational Date: January 1979

Total Estimated DOE Funds: $\quad \$ 330,000$

Building

Type: Four two-story multiple dwellings (20 units)

Area: 1,150 sq. ft. (each unit); 23;000 sq. ft. (total)

Location: Bolling Air Force Base, Washington, D.C.

Latitude: $39^{\circ} \mathrm{N}$

Climatic Data

$\begin{array}{lllll}\text { Degree Days } & \text { Heating } & 4211 & \text { Cooling } & 1499 \\ \text { Avg. Temp. }\left({ }^{\circ} \mathrm{F}\right) & \text { Winter } & 44 & \text { Summer } & 69 \\ \text { Avg. Insol. (Ly/d) } & \text { Winter } & 262 & \text { Summer } & 450\end{array}$

Avg. Insol. (Ly/d) Winter 262 Summer 450

\section{SOLAR ENERGY SYSTEM}

Application Heating 60\% Cooling 60\% .. Hot Water $0 \%$

Collector

Type: Evacuated tubular

Area (sq. ft.): 4,500 sq. ft.

Manufacturer: Owens-Illinois, Inc.

Storage

Type: Water tank

Capacity: To be determined

Auxiliary System Type: Heat pump

\section{PROJECT DESCRIPTION}

This project will provide solar-assisted heating and cooling to twenty residential projects in four two-story buildings. Solar energy will be used to boost heat pumps installed in each unit. All residential units will be supported from a centrally located collector field. 


\section{PROJECT INFORMATION}

Owner/Builder: Dept. of Defense/U.S. Army

Contractor: To be determined

Operational Date: May 1979

Total Estimated DOE Funds: $\quad \$ 660,000$

Building

Type: Townhouses (40 units)

Area: 1,350 sq. ft. (each unit); 54,280 sq. ft. (total)

Location: Fort Polk, Louisiana

Latitude: $31^{\circ} \mathrm{N}$

Climatic Data

$\begin{array}{lllll}\text { Degree Days } & \text { Heating } & 1927 & \text { Cooling } & 3175 \\ \text { Avg. Temp. }\left({ }^{\circ} \mathrm{F}\right) & \text { Winter } & 54 & \text { Summer } & 79 \\ \text { Avg. Insol. (Ly/d) } & \text { Winter } & 311 & \text { Summer } & 480\end{array}$

\section{SOLAR ENERGY SYSTEM}

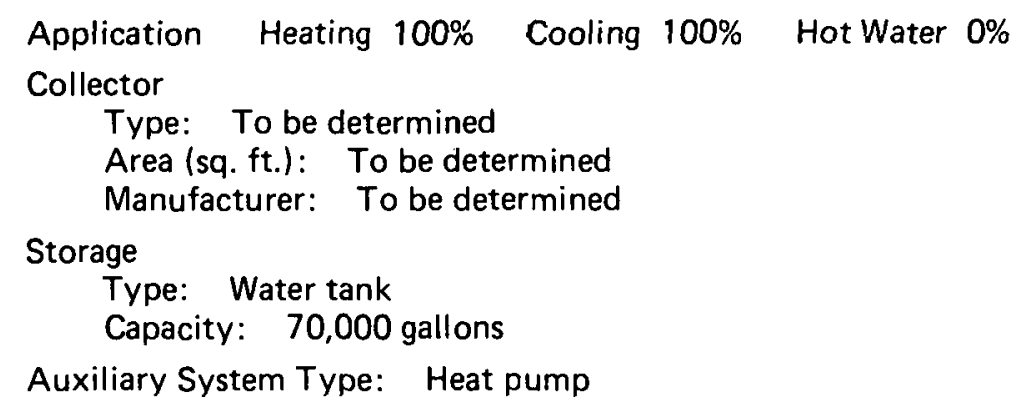

\section{PROJECT DESCRIPTION}

This project consists of forty townhouses at Fort Polk for base housing. All forty units will be supported from a centrally locaied collector field. Solar energy collected will be used to boost heat pumps installed in each townhouse.

\section{Photograph not available}

Schematic not available 


\section{PROJECT INFORMATION}

Owner/Builder: Dept. of Defense/U.S. Navy

Contractor: To be determined

Operational Date: September 1978

Total Estimated ERDA Funds: $\$ 330,000$

Building

Type: Two-story duplexes (20 units)

Area: 1,191 sq. ft. (each unit); 23,820 sq. ft. (total)

Location: Newport Naval Station, Rhode Island

Latitude: $41^{\circ} \mathrm{N}$

Climatic Data

$\begin{array}{lllll}\text { Degree Days } & \text { Heating } & 5972 & \text { Cooling } & 532 \\ \text { Avg. Temp. }\left({ }^{\circ} \mathrm{F}\right) & \text { Winter } & 38 & \text { Summer } & 68 \\ \text { Avg. Insol. (Ly/d) } & \text { Winter } & 332 & \text { Summer } & 408\end{array}$

\section{SOLAR ENERGY SYSTEM}

Application Heating $60 \%$ Cooling $0 \%$ Hot Water $90 \%$

Collector

Type: Liquid flat-plate

Area (sq. ft.): $\quad 6,990$

Manufacturer: Honeywell, Inc. Storage

Type: Water tank

Capacity: 13,000 gallons

Auxiliary System Type: Heat pump

\section{PROJECT DESCRIPTION}

This project will provide solar-assisted heating and domestic hot water to twenty units at the Newport Naval Station. All units will be supported from a centrally located collected field. 


\section{PROJECT INFORMATION}

Owner/Builder: Dept. of Defense/U.S. Air Force

Contractor: To be determined

Operational Date: April 1977

Total Estimated DOE Funds: To be determined

Building

Type: Single family attached

Area: 1,534 sq. ft.

Location: Sheppard Air Force Base, Texas

Latitude: $34^{\circ} \mathrm{N}$

Climatic Data

$\begin{array}{lllll}\text { Degree Days } & \text { Heating } & 3009 & \text { Cooling } & 2000 \\ \text { Avg. Temp. }\left({ }^{\circ} \mathrm{F}\right) & \text { Winter } & 48 & \text { Summer } & 76 \\ \text { Avg. Insol. (Ly/d) } & \text { Winter } & 324 & \text { Summer } & 528\end{array}$

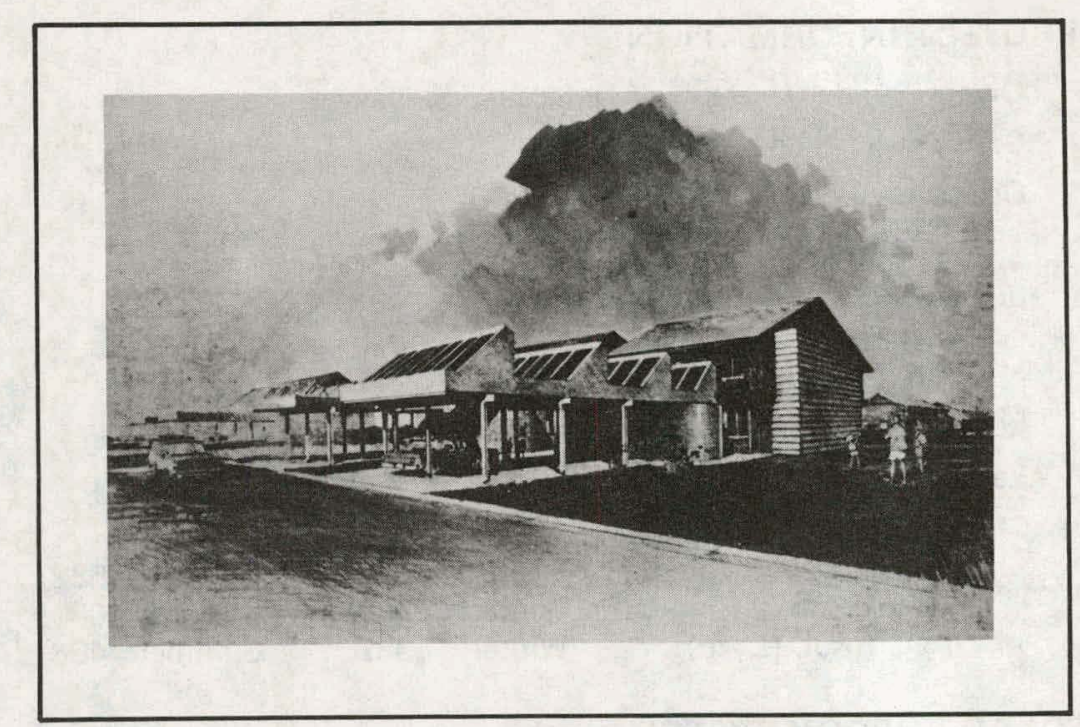

\section{SOLAR ENERGY SYSTEM}

Application Heating 69\% Cooling 0\% Hot Water $85 \%$

Collector

Type: Liquid flat-plate

Area (sq. ft.): 288

Manufacturer: Honeywell, Inc.

Storage

Type: Water tank

Capacity: 113 sq. ft.

Auxiliary System Tvpe: Gas furnace with humidifier

\section{PROJECT DESCRIPTION}

Objective(s): To compare fixed and tiltable collectors and to demonstrate a carport installation.

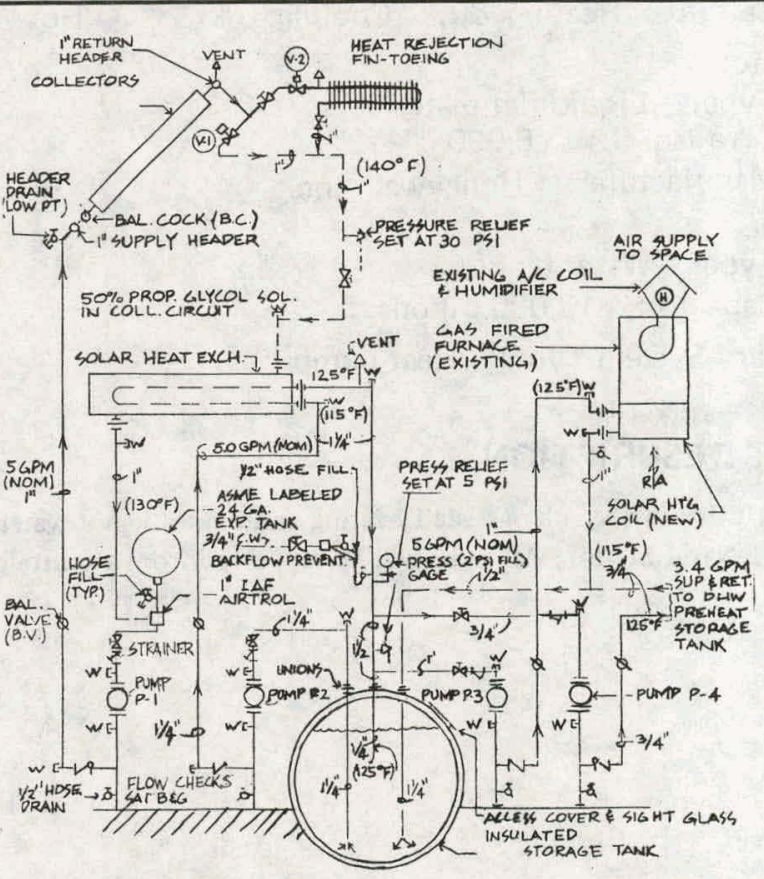




\section{PROJECT INFORMATION}

Owner/Builder: Dept. of Defense/U.S. Air Force

Contractor: To be determined

Operational Date: April 1977

Total Estimated DOE Funds: To be determined

Building

Type: Single family attached

Area: 1,534 sq. ft.

Location: Sheppard Air Force Base, Texas

Latitude: $34^{\circ} \mathrm{N}$

Climatic Data

Degree Days

Avg. Temp. $\left({ }^{\circ} \mathrm{F}\right)$

Avg. Insol. (Ly/d)

$\begin{array}{ll}\text { Heating } & 3009 \\ \text { Winter } & 48 \\ \text { Winter } & 324\end{array}$

Cooling 2000

Summer 76

\section{SOLAR ENERGY SYSTEM}

Application Heating 63\%

Collector

Type: Liquid flat-plate

Area (sq. ft. ): 336

Manufacturer: Sunworks, Inc.

Storage

Type: Water tank

Capacity: 113 sq. ft.

Auxiliary System Type: Gas furnace with humidifier

\section{PROJECT DESCRIPTION}

Objective(s): To compare fixed and tiltable collectors and to demonstrate a carport installation.

Hot Water $80 \%$
Summer 528
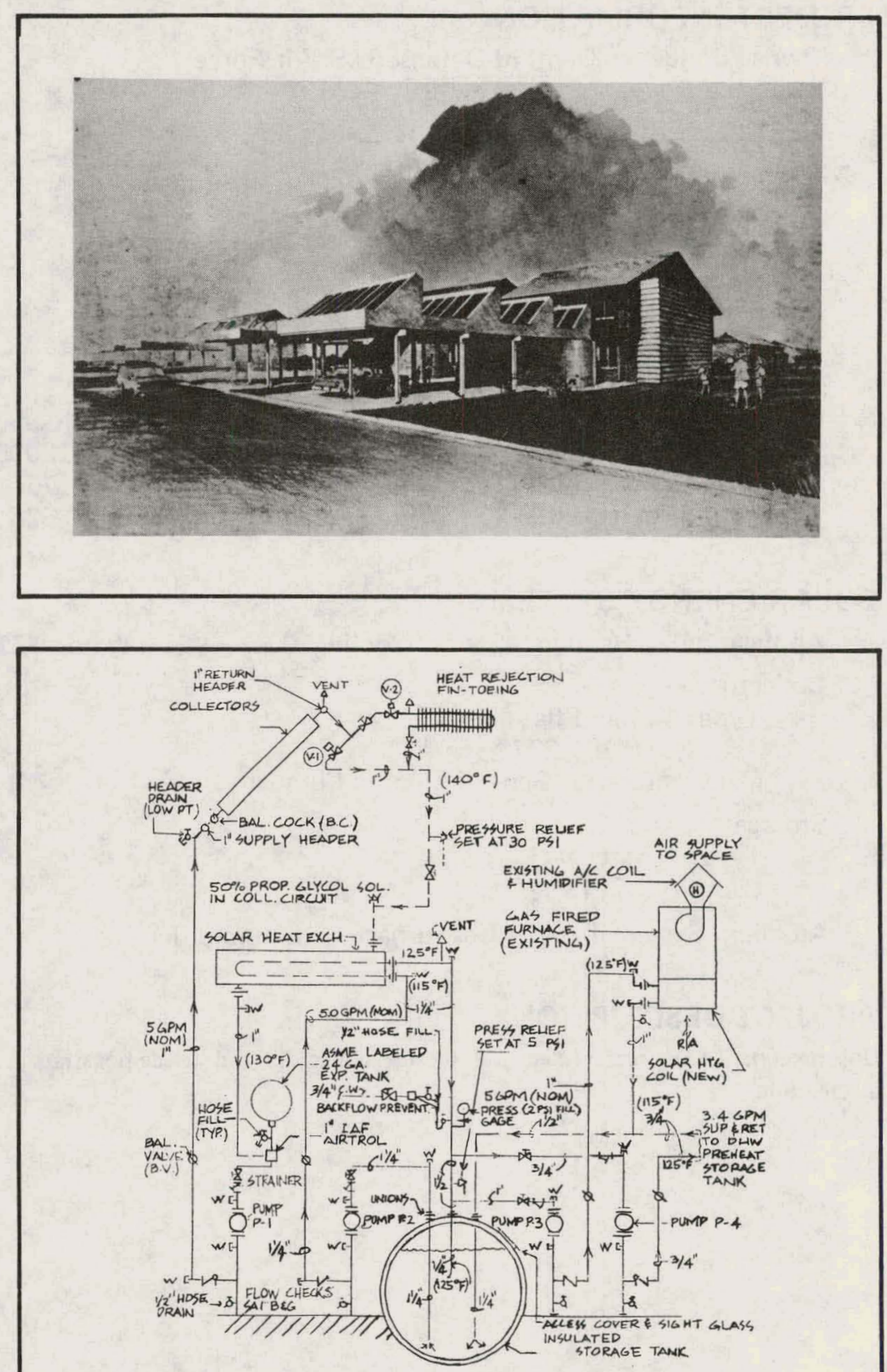


\section{PROJECT INFORMATION}

Owner/Builder: Dept. of Defense/U.S. Air Force

Contractor: To be determined

Operational Date: April 1977

Total Estimated DOE Funds: To be determined

Building

Type: Single family attached

Area: 1,534 sq. ft.

Location: Sheppard Air Force Base, Texas

Latitude: $34^{\circ} \mathrm{N}$

Climatic Data

$\begin{array}{lllll}\text { Degree Days } & \text { Heating } & 3009 & \text { Cooling } 2000 \\ \text { Avg. Temp. }\left({ }^{\circ} \mathrm{F}\right) & \text { Winter } & 48 & \text { Summer } & 76 \\ \text { Avg. Insol. (Ly/d) } & \text { Winter } & 324 & \text { Summer } & 528\end{array}$

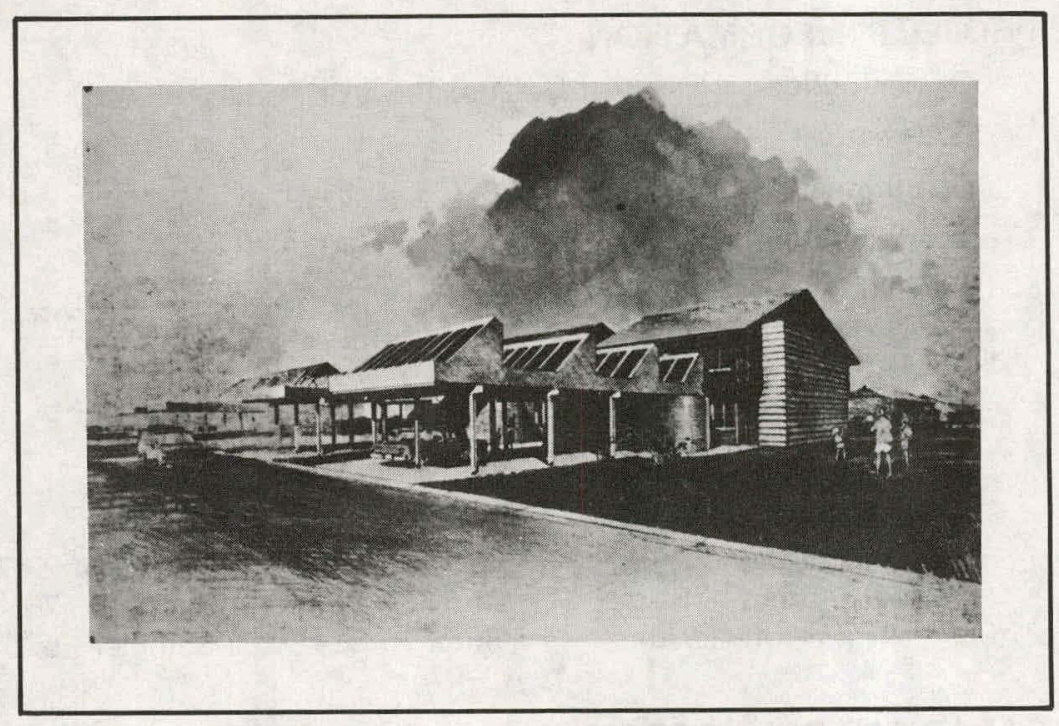

\section{SOLAR ENERGY SYSTEM}

\section{Application Heating 48\% \\ Cooling $0 \%$ \\ Hot Water $75 \%$}

Collector

Type: Liquid flat-plate

Area (sq. ft.): 227

Manufacturer: General Electric Company

Storage

Type: Water tank

Capacity: 113 sq. $\mathrm{ft}$.

Auxiliary System Type: Gas furnace with humidifier

\section{PROJECT DESCRIPTION}

Objective(s): To compare fixed and tiltable collectors and to demonstrate a carport installation.

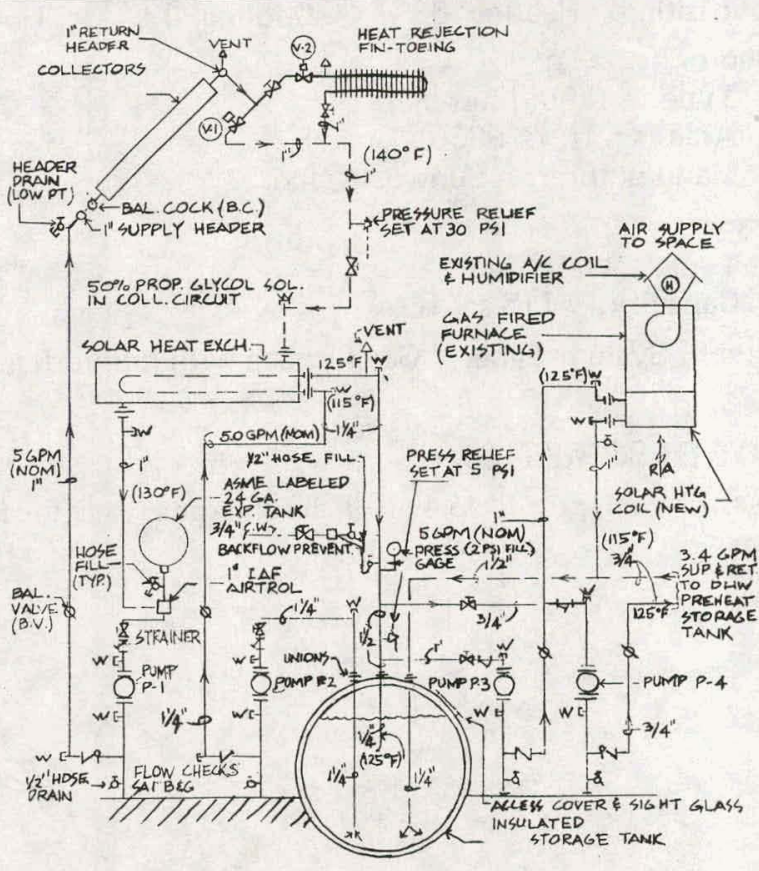




\section{PROJECT INFORMATION}

Owner/Builder: Dept. of Defense/U.S. Air Force Contractor: To be determined Jperational Date: April 1977

Total Estimated DOE Funds: To be determined Building

Type: Single family attached

Area: 1,534 sq. $\mathrm{ft}$.

Location: Sheppard Air Force Base, Texas

Latitude: $34^{\circ} \mathrm{N}$

Climatic Data

$\begin{array}{lllll}\text { Degree Days } & \text { Heating } & 3009 & \text { Cooling } & 2000 \\ \text { Avg. Temp. }\left({ }^{\circ} \mathrm{F}\right) & \text { Winter } & 48 & \text { Summer } & 76 \\ \text { Avg. Insol. (Ly/d) } & \text { Winter } & 324 & \text { Summer } & 528\end{array}$

\section{SOLAR ENERGY SYSTEM}

Application Heating 59\%

Collector

Type: Liquid flat-plate

Area (sq. ft.): 151

Manufacturer: General Electric Company Storage

Type: Water tank

Capacity: 113 sq. ft.

Auxiliary System Type: Gas furnace with humidifier

\section{PROJECT DESCRIPTION}

Objective(s): To compare fixed and tiltable collectors and to demonstrate a carport installation.

Hot Water $75 \%$
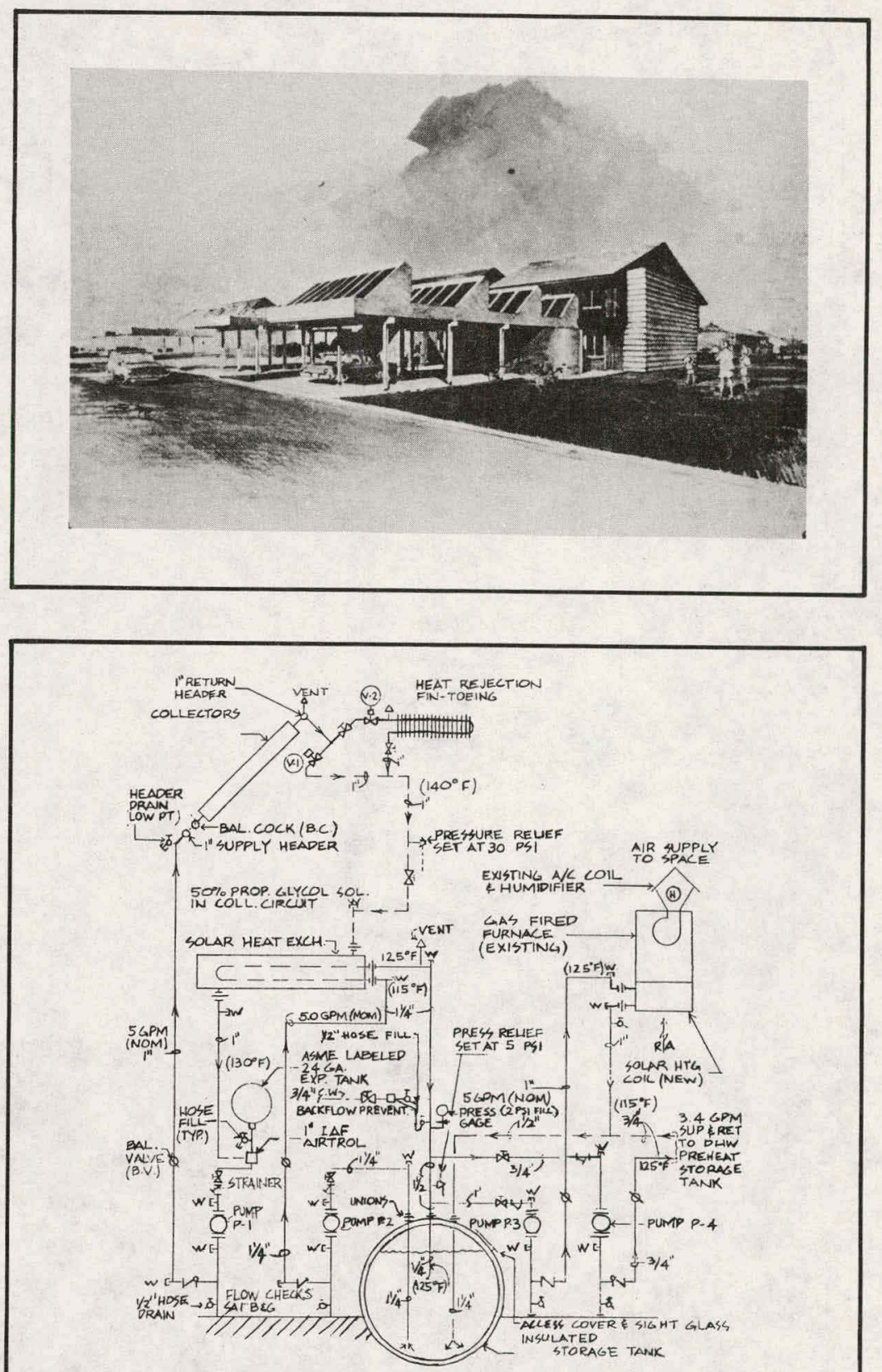


\section{THIS PAGE WAS INTENTIONALLY LEFT BLANK}




\section{SECTION IV}

\section{RESIDENTIAL DEMONSTRATION PROGRAM NON-FEDERAL BUILDINGS}




\section{RESIDENTIAL DEMONSTRATION PROGRAM}

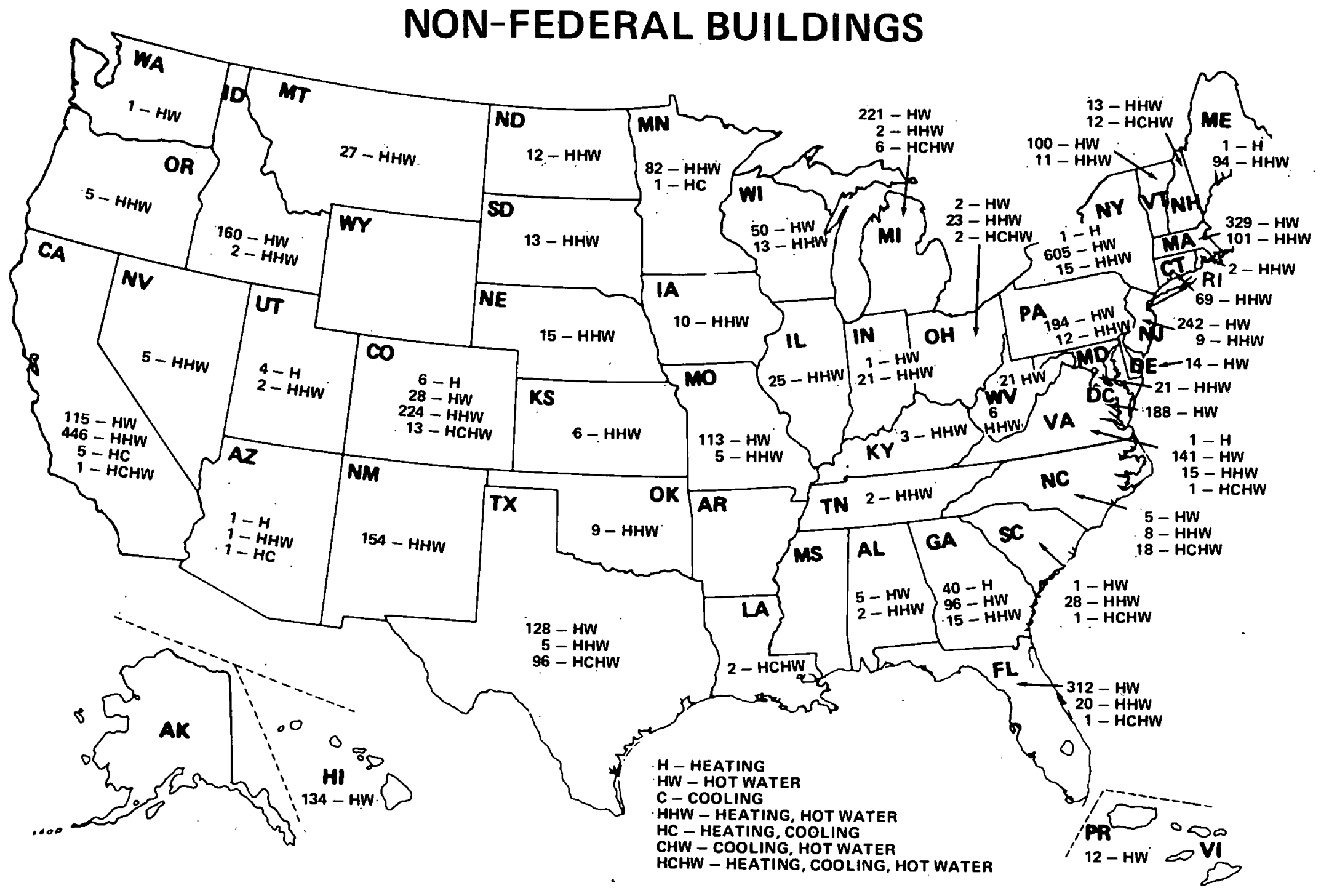




\section{SECTION IV RESIDENTIAL DEMONSTRATION PROGRAM NON-FEDERAL BUILDINGS}

STATE

LOCATION

ALABAMA

CALIFORNIA

Huntsville
Madison
Mobile
Pima Co.
Prescott
Yavapai
Bodega Bay
Camarillo
Davis
Davis
Davis
Donner
Escondido
Hemet
Manchester
Mission Viejo
Mission Viejo
Mission Viejo
Monterey
Palo Alto
Prairie Creek
Ramona
San Bernadino
San Diego
San Diego
Santa Clara
Santa Monica
Santa Monica
Santa Rosa
Selma
Sonoma
Trabuco Canyon

\section{OWNER/BUILDER}

Chester West, Inc.

Housing Development Co.

Edsel, Inc.

Bobrick Construction $\mathrm{Co}$

BUILDING NUMBER SOLAR TYPE OF UNITS APPLICATION

Hullco Construction Co.

Ray L. Hasse

Sun House Des. \& Environ. Des.

Leisure Technology of Calif., Inc.

Michael N. Corbett

John DeLapp Design \& Const.

Living Systems \& Jonathan Hamond

Calif. Energy Res. Conserv. \& Dev. Comm.

Ortiz \& Reill Developers

Blue Skies Radiant Homes

Mendocino Coast Properties

Mission Viejo Co.

Mission Viejo Co.

Mission Viejo Co.

MAR-MAC Development, Inc.

Colorado Park Housing Corp.

Calif. Energy Res. Conserv. \& Dev. Comm.

San Diego Estates \& Gas \& Elec. Co.

SFD
SFA
SFD
SFD
SFD
SFD
SFD
SFD
MF
SFD
SFD
SFA
SFD
SFD
SFD
SFD
SFD
SFD
SFD
MF
SFD
SFD
SFD
SFD
MF
SFD
SFD
MF
MF
SFD
SFD
SFD

San Bernadino W. Side Comm. Dev. Co.

Calif. Energy Res. Conserv. \& Dev. Comm. SFD

Facilities Development Company

H HW

HW

H HW

$\mathrm{H} \mathrm{C}$

$\mathrm{H}$

H HW

H HW

HW

HW

H HW

H C HW

HW

H HW

H HW

H HW

HW

HW

HW

H HW

HW

H HW

$\mathrm{H} \quad \mathrm{HW}$

H HW

HW

HW

H HW

Calif. Energy Res Conserv. \& Dev. Comm.

L \& S Operating Co.

Montecito Pines - A Ltd. Partnership

Self-Help Enterprises

Calif. Energy Res. Conserv. \& Dev. Comm. SFD

Creative Real Estate Develop., Inc.

SFD
SOLAR

MANUFACTURER

KEY:

SFD - Single Family Detached $\quad$ SFA - Single Family Attached $\quad$ MF - Multifamily 


\section{SECTION IV RESIDENTIAL DEMONSTRATION PROGRAM NON-FEDERAL BUILDINGS (CONTINUED)}

STATE

LOCATION

Aurora

Aurora

Aurora

Aurora

Aurora

Boulder

Boulder

Boulder

Boulder

Boulder

Boulder

Canon City

Colorado Springs

Denver

Denver

Denver

Evergreen

Fort Collins

Fort Collins

Fort Collins

Ft. Lupton

Granada

Granby

Longmont

Pueblo

Silverthorne

Silverthorne

Westminster

Westminster

Westminster

\section{OWNER/BUILDER}

Gutrich Development Co., Inc.

Mission Viejo Co.

Mission Viejo Co.

Mission Viejo Co.

Perl-Mack Enterprises.Co.

Ervin J. Bell

University of Colorado

Douglas E. Myers

Robert C. Naumann

Stonebraker Investments

Wonderland Hill Development Co.

United Construction of Colorado

Colorado Springs Urban Renewal Eff.

Brothers Redevelopment, Inc.

Denver Housing Authority

Witkin Homes, Inc.

David L. Vickerman, Inc.

ECO-ERA, Inc.

Solar Engineering Constr. Co.

Sunland Realty, Inc.

Colo. Rural Hsg. Dev. Corp.

Colo. Rural Hsg. Dev. Corp.

Grand County Fuel \& Supply, Inc.

Colorado Sunworks Partnership

City of Pueblo, Co.

JMC Co. \& Charles Schiffer Assoc.

JMC Co. \& Charles Schiffer Assoc.

Waverly Homes, Inc.

Waverly Homes, Inc.

Waverly Homes, Inc.

Perl-Mack Enterprises Co., Inc. PMT

\section{BUILDING NUMBER SOLAR TYPE \\ OF UNITS APPLICATION}

SFD
SFD
SFD
SFD
SFD
SFD
MF
SFD
SFA
MF
SFA
SFD
MF
SFD
MF
SFD
SFD
SFD
SFD
SFD
SFD
SFD
SFD
SFD
SFD
SFD
SFA
SFD
SFD
SFD
SFD

SOLAR MANUFACTURER

KEY:

SFD - Single Family Detached

SFA - Single Family Attached

MF - Multifamily

$\mathrm{H}$ - Heating

C - Cooling

HW - Hot Water 


\section{SECTION IV RESIDENTIAL DEMONSTRATION PROGRAM NON-FEDERAL BUILDINGS (CONTINUED)}

\section{STATE}

\section{LOCATION}

Cheshire

Hamden

New Haven

Tolland

Unionville

DELAWARE

DIST. OF COLUMBIA

FLORIDA

SFD - Single Family Detached

Wilmington

Washington, D.C.

Dade Co.

Dade Co.

Daytona Beach

Gainesville

Gainesville

Gretna

Hialeah

Kissimmee

St. Petersburg

Winter Springs

Clarkston

Dacula

Dalton

Decatur

De Kalb Co.

Lawrenceville

Macon

Marietta

Marietta

Marietta

Shenandoah

HAWAII

Swainsboro

Ewa Beach

Honolulu

Honolulu

Kaneohe
OWNER/BUILDER

J. Capone Construction Co.

Utility Electrical Contractors

Frank Chapman

The Madrid Corporation

William Francini

Bestfield Builders

Forest City Dillon, Inc.

The Babcock Co.

The Babcock Co.

Embry-Riddle Aeronautical Univ.

Matt D. Cannon

Univ. of Florida, Hsg. Div.

Town Council, City of Gretna

Hialeah Housing Authority

Kissimmee Court Apartments

Florida Gas Co.

F. E. Fortenberry \& Sons, Inc

Winford Lindsay

Dalton Housing Authority

Harbor Oaks Apartments

Hooker/Barnes

Fairview Bldrs/Winford Lindsay

Kenilworth Manor, Inc.

Christopher David Assoc., Inc.

Christopher David Assoc., Inc.

Christopher David Assoc., Inc.

Glanton/Russel (Peachtrees Homes)

Unified Development, Inc.

Finance Realty Company Ltd.

Diamond Head Alii Corp.

Hei Wai Wong

A-Frame Industries
City of Petersburg, Florida

FA - Single Family Attached

\section{BUILDING NUMBER SOLAR TYPE \\ OF UNITS APPLICATION}

$\begin{array}{lllll}\text { SFA } & 10 & \text { H } & \text { HW } & \text { Sunworks, Inc. } \\ \text { MF } & 52 & \text { H } & \text { HW } & \text { Sunworks, Inc. }\end{array}$

$\begin{array}{llll}\text { MF } & 52 & \text { H } & \text { HW }\end{array}$

$\mathrm{MF}$

SFD

SFD

SFA

MF

SFD

SFA

MF

MF

MF

SFD

SFD

MF

MF

SFD

SFD

SFD

SFD

MF

SFD

SFD

MF

SFD

SFD

SFD

SFD

SFD

SFA

MF

MF

SFD
H HW

H HW

H HW

HW

HW

HW

HW

HW

H HW

HW

H HW

HW

HW

HW

$\mathrm{H} \mathrm{C}$ HW

$\mathrm{H}$ HW

H HW

HW

H

H HW

H HW

HW

HW

HW

HW

H HW

H HW

HW

HW

HW

HW
SOLAR

Sunworks, Inc.

Solar Energy Struct. Inc.

Daystar Corp.

Daystar Corp.

Revere

Lennox Industries

Capitol Solar Heat, Inc.

Capitol Solar Heat, Inc.

Gulf Thermal Corp.

Gulf Thermal Corp.

Union $\mathrm{Co}$.

General Electric

Solar Products, Inc./Sun Tank, Inc Aztec Solar Co.

Gulf Thermal Corp.

Chamberlain Manufacturing Corp.

Scientific-Atlanta, Inc.

Revere

Solar Development, Inc.

Scientific-Atlanta, Inc.

Revere

Revere

Revere

Solaron Corp.

Daystar Corp.

Sunworks, Inc.

Revere

Revere

Miromit American Heliothermal

Raypak, Inc

Raypak, Inc.

Sunsource Pacific

MF - Multifamily 


\section{SECTION IV RESIDENTIAL DEMONSTRATION PROGRAM NON-FEDERAL BUILDINGS (CONTINUED)}

\section{STATE LOCATION $\quad$ OWNER/BUILDER}

\section{BUILDING NUMBER SOLAR TYPE OF UNITS APPLICATION}

SOLAR

$\begin{array}{llll}\text { HAWAII } & \text { Waipahu } & \text { Hawaii Housing Authority } & \text { MF } \\ \text { IDAHO } & \text { Pocatello } & \text { Idaho State University } & \text { MF } \\ & \text { Pocatello } & \text { TAS Development \& Construction } & \text { SFD } \\ \text { ILLINOIS } & \text { Rexburg } & \text { Cascade Construction Ltd. } & \text { SFD } \\ & \text { Kingston } & \text { Sungate Construction Co. } & \text { SFD } \\ & \text { Lake Forest } & \text { Robert M. Roloson Architect } & \text { SFD } \\ \text { INDIANA } & \text { Roselle } & \text { Foundation for the Handicapped } & \text { MF } \\ & \text { Vernon Hills } & \text { United Development Co. } & \text { SFA } \\ & \text { Batesville } & \text { Steinkamp and Company } & \text { SFD } \\ & \text { Fort Wayne } & \text { Graber Homes, Inc. } & \text { SFD } \\ & \text { Fountaintown } & \text { R\&R Builders, Inc. } & \text { SFD } \\ & \text { Greenwood } & \text { Ron Smith Custom Builder, Inc. } & \text { SFD } \\ & \text { Indianapolis } & \text { Historic Landmarks Fdn. of Ind. } & \text { SFD } \\ & \text { Liberty } & \text { Miles-Richmond, Inc. } & \text { SFD } \\ & \text { Muncie } & \text { Vernon O. Freeman } & \text { SFD } \\ & \text { Newburgh } & \text { Trica Corporation } & \text { SFA } \\ & \text { Peru } & \text { W. J. Leffel Construction } & \text { SFD } \\ \text { IOWA } & \text { Terre Haute } & \text { Stan Peebles \& Company } & \text { SFD } \\ & \text { Western Greenwood Moulder Corp. } & \text { SFD } \\ \text { KANSAS } & \text { Glenwood } & \text { Glenwood Hsg., Inc. } & \text { MF } \\ & \text { West Des Moines } & \text { Spence-Urban \& Associates } & \text { SFD } \\ & \text { DeSoto } & \text { Ed Thomas \& Associates } & \text { SFD } \\ & \text { Paola } & \text { Ed Thomas \& Associates } & \text { SFD } \\ & \text { Shawnee } & \text { John C. Byram } & \text { SFD } \\ \text { KENTUCKY } & \text { Stillwell } & \text { Du-Mac Investment Company } & \text { SFD } \\ & \text { Lexington } & \text { Philip Sims } & \text { SFA } \\ \text { LOUISIANA } & \text { Lexington } & \text { Whitman \& Associates, Inc. } & \text { SFD } \\ \text { MAINE } & \text { Baton Rouge } & \text { E. Baton Rouge Parish Hsg. Auth. } & \text { SFA } \\ & \text { Harpswell } & \text { AIDCO Maine Corp. } & \text { SFD } \\ & \text { Lewiston } & \text { Parkan Constr. Co. } & \text { MF } \\ & \text { Perry } & \text { Pleasant Point Hsg. Authority } & \text { SFD } \\ & \text { Perry } & \text { Pleasant Point Passamaquoddy Reserv. } & \text { SFD } \\ & & & \end{array}$

KEY: 


\section{SECTION IV RESIDENTIAL DEMONSTRATION PROGRAM NON-FEDERAL BUILDINGS (CONTINUED)}

STATE

\section{LOCATION}

\section{OWNER/BUILDER}

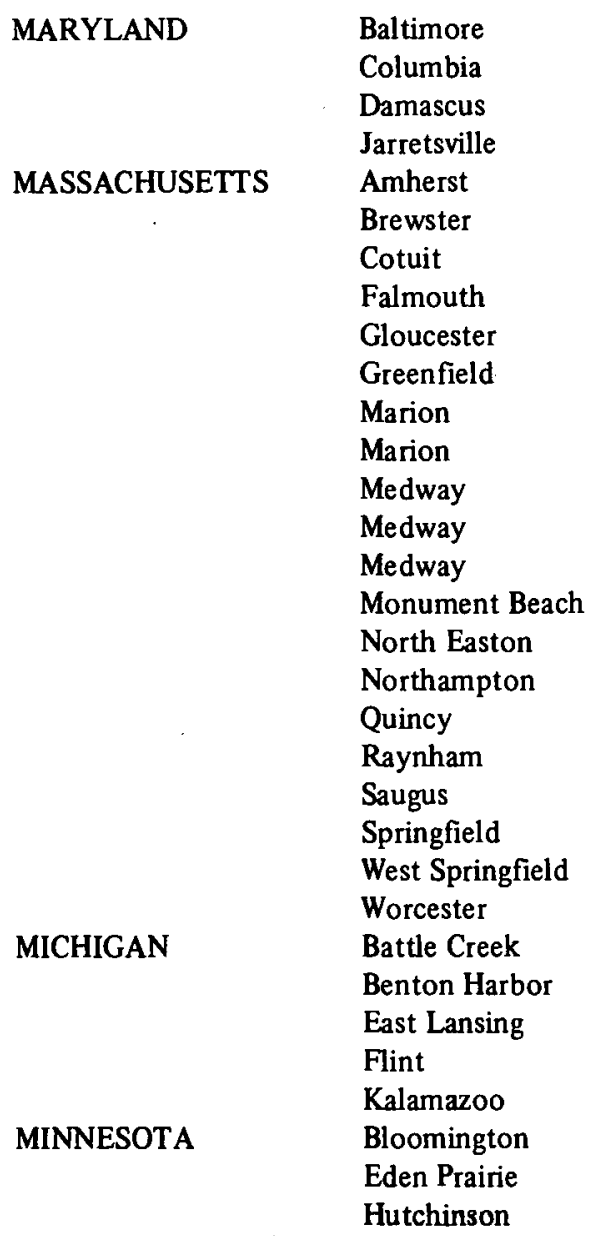

Centennial Dev. \& Bldg. Corp.

J. D. Evans

Damascus Land Corporation

Duerbeck Building Corporation

Plantation Valley Homes, Inc.

Corcoran Mullins Jennison, Inc.

R. L. Seaberg Assoc.

Laura L. Baker

Gloucester Hsg. Authority

Greenfield Housing Authority

Indian Cove Associates

Town of Marion

Saddle Hill Trust

Saddle Hill Trust

Saddle Hill Trust

Sandman Realty Co.

Friends' Community Development

Exec. Office of Commun. \& Devel.

Hancock House Realty Trust

Raynham Housing Authority

John M. Corcoran \& Co.

Landgraf Associates, Inc.

Joseph Real Estate \& Devel. Co.

Worcester Polytech Institute

Battle Creek Hsg. Commission

Sanford \& Son Builders

Sam Eyde Const. Co.

City of Flint/Dept. of Comm. Dev.

Willow Creek II Partnership

Marvin H. Anderson Constr. Co.

Houston Construction, Inc.

Professional Builders, Inc.

\section{BUILDING NUMBER SOLAR TYPE \\ OF UNITS APPLICATION}

SFA
SFD
SFD
SFD
SFD
SFA
SFA
SFA
MF
MF
SFD
SFD
SFD
SFD
SFD
SFD
MF
SFD
MF
MF
MF
SFD
SFD
MF
MF
SFD
SFD
SFA
MF
SFD
SFD
SFD

KEY:

SFD - Single Family Detached

SFA - Single Family Attached

MF - Multifamily
SOLAR

MANUFACTURER 


\section{SECTION IV RESIDENTIAL DEMONSTRATION PROGRAM NON-FEDERAL BUILDINGS (CONTINUED)}

STATE

\section{LOCATION}

Maple Grove

Minneapois

Minnetonka

New Brighten

MISSOURI

Barnhart

Gladstone

Gladstone

Gladstone

Richmond

St. Louis

MONTANA

Tomaro Oaks

Bigfork

Browning

Cut Bank

Harlen

Kalispell

Lame Deer

NEBRASKA

NEVADA

NEW HAMPSHIRE

Callaway

Plattsmouth

Reno

East Derry

Harrisville

Keene

Nashua

New Ipswich

North Conway

North Conway

NEW JERSEY

Blackwood

Dover

Hoboken

Newark

\section{OWNER/BUILDER}

Gridley Construction, Inc.

Creek Associates

Hobmar Homes, Inc.

Gridley Construction Co.

Parkton Development Co.

Bond Construction $\mathrm{Co}$.

Bond Construction $\mathrm{Co}$.

Bond Construction Co.

Ed Thomas \& Associates

Pantheon Corp.

Oscar P. Wren, Jr.

Design Construction Associates

The Blackfeet Tribe

Blackfeet Indian Tribe

Fort Belknap Indian Community

Sun Spec

Northern Cheyenne Ind. Hsg. Auth.

Callaway Housing Corporation

Peterson Construction Co.

Quadro, Inc.

Frontier Development Co.

Fletcher Myers, Inc.

Total Environmental Action, Inc.

Style Craft Homes, Inc.

First Fidelity Service Corp.

Barrett Mountain

Forest Park Village, Inc.

Kearsarge Building Co., Inc.

Korman Corp.

Dover Housing Authority

Jefferson Adams Rehab. Co.

Ferry Street Group NJ Sch. of Arch.

\section{BUILDING TYPE}

\section{NUMBER}

SFD

MF

SFD

SFD

SFD

SFD

SFD

SFD

MF

SFD

SFD

SFD

MF

SFD

SFD

SFD

MF

SFD

SFA

SFD

SFD

SFD

SFD

SFD

SFD

MF

SFA

SFD

MF

MF

MF

1
77
1
1
1
1
1
1
1
112
1
1
5
10
5
1
5
8
1
6
5
1
1
1
3
2
172
1

SOLAR

MANUFACTURER

KEY:

SFD - Single Family Detached

SFA - Single Family Attached

MF - Multifamily

H - Heating

C-Cooling

HW - Hot Water 


\section{SECTION IV RESIDENTIAL DEMONSTRATION PROGRAM NON-FEDERAL BUILDINGS (CONTINUED)}

STATE

LOCATION

Old Bridge

S. Brunswick Twp

NEW MEXICO

NORTH CAROLINA

Albuquerque

Albuquerque

Santa Fe

Santa Fe

Santa Fe

Santa Fe

Santa $\mathrm{Fe}$

Santa $\mathrm{Fe}$

Santa Teresa

Bedford

Bronx

Brooklyn

Chester

Forest Hills

Hamburg

La Grangeville

Long Island

Malta

New York

New York

New York

New York

New York

New York

Pomona

Columbus

Durham

Fayetteville

\section{OWNER/BUILDER}

Housing Authority of the City of Newark

Jespa Enterprises

Raritan Valley Comm. Dev. Fndn.

Albuquerque Western Solar Indus.

Homes by Marilynn

Sandia Homes, Inc.

Communico

Public Svc. Co. of New Mexico

Schepps Construction Co.

Stanley Associates

Stanley Associates

Wayne Nichols - Communico

Lambert \& Winston, Inc.

D.W.S. Holdings, Inc.

Peoples Development Corp.

Sunset Park Redev. Committee, Inc.

Suntech Homes, Inc.

Lefrak Organization, Inc.

Innovative Building Systems, Inc.

Solar Structures, Inc.

Pinewood Manor, Inc.

Stewart-Teele-Mitchell Const.

Bedford Stuyvesant Restor. Corp.

Lefrak Organization, Inc.

Mountbatten Equities

South Bronx Community Hsg. Corp.

South Bronx Community Hsg. Corp.

924 West End Ave., Inc.

Pomona Heights, Inc.

Morgan Chapel Enterprises

Durham Housing Authority

L\&O Investments, Inc.

\section{BUILDING NUMBER SOLAR TYPE OF UNITS APPLICATION}

SOLAR

\section{MANUFACTURER}

6
1
8
101
2
1
1
25
1
1
1
1
20
6
28
4
1
207
1
1
1
1
10
96
188
4
4
68
1
2
18
1

H HW

H HW

HW

H HW

H HW

H HW

H HW

H HW

H HW

$\mathrm{H} \quad \mathrm{HW}$

H HW

H HW

H HW

H HW

HW

HW

H HW

HW

H HW

$\mathrm{H} \quad \mathrm{HW}$

$\mathrm{H}$

H HW

HW

HW

HW

HW

H HW

HW

H HW

H HW

H C HW

H HW
Sunworks, Inc.

Sunworks, Inc.

State Industries

Albuquerque Western Solar Ind.

Revere

Solaron Corp.

Homemade

Solar Seven Industry, Inc.

Northrup, Inc.

Solar Seven Industry, Inc.

Solaron Corp.

Local Greenhouse

Solaron Corp.

KTA Corp.

Sun Harvester Corp.

Sunworks, Inc.

Solar Shelter

Sunworks, Inc.

PPG Industries

Revere

Sunenergy Power Ltd.

Lennox Industries

Grumman/Energy Systems, Inc.

Sunworks, Inc.

Grumman/Energy Systems, Inc.

Sunworks, Inc.

Sunworks, Inc.

Daystar Corp.

KTA Corp.

Helio Thermics, Inc.

Owens-Illinois, Inc

Solaron Corp.

KEY:

SFD - Single Family Detached $\quad$ SFA - Single Family Attached $\quad$ MF - Multifamily

H - Heating

C - Cooling

HW - Hot Water 


\section{SECTION IV RESIDENTIAL DEMONSTRATION PROGRAM NON-FEDERAL BUILDINGS (CONTINUED)}

STATE

\section{LOCATION}

Pinehurst

Pineville

Pittsboro

Winston-Salem

NORTH DAKOTA

$\mathrm{OHIO}$

\begin{tabular}{|c|c|c|}
\hline \multirow{3}{*}{ OKLAHOMA } & Troy & Caprice Builders, Inc. \\
\hline & Norman & Moore-Norman Vo-Tech. Fndn., Inc. \\
\hline & Okmulgee & Creek National Hsg. Authority \\
\hline \multirow{5}{*}{ OREGON } & Tulsa & Connors Construction Co., Inc. \\
\hline & Ashland & Larry Barr \& Lance Pugh - Partners \\
\hline & Ashland & Vincent L. Oredson \\
\hline & Coos Bay & Twin City Builders, Inc. \\
\hline & Stayton & Landura Corporation \\
\hline \multirow[t]{7}{*}{ PENNSYLVANIA } & Bryn Mawr & William Felton, Inc. \\
\hline & Havertown & Hollow Run Associates \\
\hline & Mechanicsburg & United Methodist Homes for Aging \\
\hline & Milford Township & Regent Valley Builders, Inc. \\
\hline & N. Franklin Twp. & Walnut Ridge, Inc. \\
\hline & $\begin{array}{l}\text { Northampton Twp. } \\
\text { Penn Valley }\end{array}$ & $\begin{array}{l}\text { Gigliotti Corp. } \\
\text { William Felton Inc }\end{array}$ \\
\hline & & \\
\hline
\end{tabular}

Habitat 2000, Inc.

Beatrice Mongeau

GLS Construction Co.

Liberty Estates Developers

Bryant \& Others Homes by Stan-Jim, Inc.

Canton

Columbus

Columbus

Columbus

Columbus

Fairfield

Findlay

Loveland

Marietta

Alpha Construction Co.

D. C. Winslow Construction Co.

Davidson-Phillips, Inc.

Davidson-Phillips, Inc.

Davidson-Phillips, Inc.

Universal Home Builders

Boyle \& Schey Builders

Lucke \& Strassel Builders

Sims Brothers Builders, Inc.

First Piqua Corporation

Volpini \& Sorice Builders

\section{BUILDING NUMBER SOLAR TYPE \\ NUMBER}

Page Associates, Inc.

SFD

SFD

SFA

SFD

SFA

SFD

SFD

SFD

SFD

SFD

SFD

SFD

SFD

SFD

SFD

SFD

SFD

SFA

SFD

SFD

SFD

SFD

SFD

SFD

SFD

SFD

MF

MF

SFD

SFD

SFD

SFD
1 H HW

$\mathrm{H}$ HW

H HW

HW

H HW

H HW

H $\mathrm{HW}$

HW

HW

H C HW

$\mathrm{H} \quad \mathrm{HW}$

H HW

H HW

$\mathrm{H} \quad \mathrm{HW}$

H HW

H HW

H HW

$\mathrm{H}$ HW

H HW

H HW

H HW

H HW

$\mathrm{H}$ HW

H HW

H HW

H HW

HW

HW

H HW

$\mathrm{H}$ HW

H HW

H HW
SOLAR

MANUFACTURER
Helio Thermics, Inc.

Revere

Revere

Energy Converters

Solaron Corp.

Solar Energy Products Co.

Solar Energy Products Co.

Sunworks, Inc.

Raypak, Inc.

General Electric Co.

Sun Stone

Sunworks, Inc.

Solaron Corp.

Revere

Solaron Corp.

Revere

Solar Energy Products Co.

Revere

Sunworks, Inc.

Raypak, Inc.

Solaron Corp.

Reynolds Metals Co.

Sunwater Co.

Revere

Sunworks, Inc.

Solaron Corp.

Heliotherm

Lennox Industries

Daystar Corp.

Kalwall Corp.

Daystar Corp.

Solaron Corp.

KEY:

SFD - Single Family Detached

SFA - Single Family Attached

MF - Multifamily

H - Heating

C- Cooling

HW - Hot Water 


\section{SECTION IV RESIDENTIAL DEMONSTRATION PROGRAM NON-FEDERAL BUILDINGS (CONTINUED)}

\section{STATE}

\section{LOCATION}

Philadelphia

Philadelphia

Philadelphia

Pittsburgh

Towamencin Twp.

West Grove

PUERTO RICO

RHODE ISLAND

SOUTH CAROLINA

Rio Piedros

Jamestown

Newport

Columbia

Greenville

Greenville

Greenville

Hilton Head Isl.

St. Matthews

Summerville

Summerville

SOUTH DAKOTA

TENNESSEE

TEXAS

Sioux Fälls

Memphis

Memphis

Austin

Austin

Austin

Carrollton

Corsicana

Dallas

Lago Vista

Lubbock

Lubbock

San Antonio

San Antonio

\section{BUILDING NUMBER SOLAR TYPE}

\section{OWNER/BUILDER}

Drexel University

The Fumo, Manfredi Partnership

University of Pennsylvania

Contemporary Import \& Export Co.

$\begin{array}{lr}\text { MF } & 5 \\ \text { MF } & 9 \\ \text { SFA } & 1 \\ \text { SFA } & 4 \\ \text { SFD } & 1 \\ \text { SFD } & 1 \\ \text { MF } & 12 \\ \text { SFD } & 1 \\ \text { SFD } & 1 \\ \text { SFD } & 4 \\ \text { SFD } & 3 \\ \text { SFD } & 6 \\ \text { SFD } & 1 \\ \text { SFD } & 2 \\ \text { SFA } & 12 \\ \text { SFD } & 1 \\ \text { SFD } & 1 \\ \text { SFA } & 9 \\ \text { SFA } & 4 \\ \text { SFD } & 1 \\ \text { SFD } & 1 \\ \text { SFD } & 1 \\ \text { MF } & 80 \\ \text { MF } & 12 \\ \text { SFD } & 1 \\ \text { MF } & 25 \\ \text { SFD } & 2 \\ \text { SFA } & 3 \\ \text { SFD } & 1 \\ \text { SFD } & 1 \\ \text { MF } & 100 \\ \text { SFD } & 3\end{array}$

SOLAR

\section{MANUFACTURER}

PPG Industries

Sunearth, Inc.

PPH \& Intl. Environ. Corp.

Daystar Corp.

Daystar Corp.

Revere

Solar Devices, Inc.

Christopher Shipp Productions

Puerto Rico Urban Renewal \& Hsg. Corp.

M. F. Smith Associates

Church-Community Corp.

Solar Homes, Inc.

Homemade

Olin Brass

Cambridge Development Group, Inc.

Croville Property Assoc. II

Gulf Thermal Corp.

Helio Thermics, Inc.

Helio Thermics, Inc.

Helio Thermics, Inc.

Solar Development Associates

Phillips Kauric Adams \& Branham

Everett A. Knight Agency

Everett A. Knight Agency

Harney Lumber Company

Environmental Contact, Inc.

Acropolis Joint Venture

Rainey Bros. Construction Co., Inc.

Carl Morris Custom Builder

College Houses

University of Texas/Austin

Brad Popkin, Inc.

Navarro College

W. Brown Custom Builders

Starr Homes

Gordon Deering

Gordon Deering, Jr.

Housing Authority San Antonio

San Antonio Ranch, Ltd.
$\mathrm{H} H W$

$\mathrm{H}$. HW

$\mathrm{H} \quad \mathrm{HW}$

H HW

HW

$\mathrm{H} \quad \mathrm{HW}$

$\mathrm{H} \quad \mathrm{HW}$

$\mathrm{H}$ HW

$\mathrm{H} \quad \mathrm{HW}$

$\mathrm{H}$ HW

$\mathrm{H} \mathrm{C}$ HW

$\mathrm{H} \mathrm{C}$ HW

H HW

HW

H . HW

HW

H C HW

H HW

HW

H C HW
Sunworks, Inc.

Revere

Solaron Corp.

Solaron Corp.

Miromit American Heliothermal

National Energy Corp.

Solaron Corp.

Solaron Corp.

Cole Solar Systems, Inc.

Northrup, Inc.

Northrup, Inc.

Northrup, Inc.

Northrup, Inc.

Sun Source

Solargenics

Owens-Illinois, Inc.

Solaron Corp.

Sunworks, Inc.

Honeywell/Lennox

KEY: 


\section{SECTION IV RESIDENTIAL DEMONSTRATION PROGRAM NON-FEDERAL BUILDINGS (CONTINUED)}

\section{STATE}

LOCATION

UTAH

VERMONT

VIRGINIA

WASHINGTON

WEST VIRGINIA

WISCONSIN

Granger
Logan
Salt Lake City
Stansbury Park
Brookline
Burlington
Waitsfield
Berryville
Dumfries
Fairfax Co.
Falls Church
Lynchburg
Vienna
Virginia Beach
Williamsburg
Seattle
Clarksburg
Inwood
Baraboo
Eldorado
Sheboygan
Milwaukee
Milwaukee
Osceola
Racine
Rice Lake
Summit Meadows
Winneconne

\section{OWNER/BUILDER}

\section{IPK Corporation}

Villatek

Tios Corporation

Terracor, Utah

Grassy Brook Village, Inc.

Cathedral Square Corporation

Greenmoss Builders, Inc.

Ritter Buildings, Inc.

J\&J Construction, Inc.

Strawbridge Square Assoc.

Barcroft Hills Council-Co-Owners

Solar Structures

The Yeonas Company

Sir Galahad Co.

S. M. Nichols Builder, Inc.

Washington Natural Gas Co.

City of Clarksburg

Middle Creek Investment Corp.

J. A. Verthein Construction Co.

Robert J. Zimmerman

Theodore A. Kuck

University of Wisconsin-Milwaukee

Zien Mechanical Contractors

Nelson-Lewis Construction $\mathrm{Co}$

Lincoln Lutheran Racine Wisc., Inc.

William C. Burdick

Friedman, Rosen, Zien

Family Homes United, Inc.

\section{BUILDING NUMBER SOLAR \\ TYPE OF UNITS APPLICATION}

\section{SFD}

SFD

SFD

SFD

SFA

MF

SFD

SFD

SFA

SFA

MF

SFD

SFD

SFD

SFD

SFD

MF

SFD

SFD

SFD

SFD

SFD

SFD

SFD

MF

SFD

SFD

SFD

3
1
1
1
10
100
1
1
1
12
140
1
1
1
1
1
21
6
1
1
1
1
1
1
50
1
1
5

SOLAR

MANUFACTURER 